\title{
Reginald McKenna
}




\section{British Politics and Society}

Peter Catterall, Series Editor

The Making of Channel 4

Edited by Peter Catterall

Managing Domestic Dissent in First World War Britain

Brock Millman

Reforming the Constitution

Debates in Twentieth Century Britain

Edited by Peter Catterall, Wolfram

Kaiser and Ulrike Walton-Jordan

Pessimism and British War Policy, 1916-1918

Brock Millman

Amateurs and Professionals in Post-War British Sport

Edited by Adrian Smith and Dilwyn Porter

\section{A Life of Sir John Eldon Gorst}

Disraeli's Awkward Disciple

Archie Hunter

Conservative Party Attitudes to

Jews 1900-1950

Harry Defries

\section{Poor Health}

Social Inequality before and after the

Black Report

Edited by Virginia Berridge and Stuart Blume
Mass Conservatism

The Conservatives and the Public since the 1880s

Edited by Stuart Ball and Ian Holliday

Defining British Citizenship

Empire, Commonwealth and Modern

Britain

Rieko Karatani

Television Policies of the Labour

Party 1951-2001

Des Freedman

Creating the National Health Service Aneurin Bevan and the Medical Lords

Marvin Rintala

A Social History of Milton Keynes

Middle England/Edge City

Mark Clapson

Scottish Nationalism and the Idea of Europe

Concepts of Europe and the Nation

Atsuko Ichijo

The Royal Navy in the Falklands

Conflict and the Gulf War

Culture and Strategy

Alastair Finlan

The Labour Party in Opposition 1970-1974

Patrick Bell 
The Civil Service Commission

1855-1991

A Bureau Biography

Richard A. Chapman

Popular Newspapers, the Labour Party and British Politics

James Thomas

In the Midst of Events

The Foreign Office Diaries and Papers

of Kenneth Younger, February 1950

October 1951

Edited by Geoffrey Warner

\section{Strangers, Aliens and Asians}

Huguenots, Jews and Bangladeshis in Spitalfields 1666-2000

Anne J. Kershen

Conscription in Britain 1939-1964

The Militarization of a Generation

Roger Broad

\section{German Migrants in Post-War}

\section{Britain}

An Enemy Embrace

Inge Weber-Newth and Johannes-

Dieter Steinert

The Labour Governments 19641970

Edited by Peter Dorey

Government, the Railways and the Modernization of Britain

Beeching's Last Trains

Charles Loft

Britain, America and the War Debt

\section{Controversy}

The Economic Diplomacy of an

Unspecial Relationship 1917-1941

Robert Self

\section{Reginald McKenna}

Financier among Statesmen, 18631916

Martin Farr 



\section{Reginald McKenna}

Financier among Statesmen, 1863-1916

\section{Martin Farr}

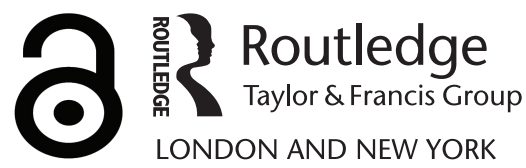


First published 2008 by Routledge

Published 2017 by Routledge

2 Park Square, Milton Park, Abingdon, Oxon OX14 4RN

711 Third Avenue, New York, NY 10017, USA

Routledge is an imprint of the Taylor \& Francis Group, an informa business

\section{Copyright @ 92008 Martin Farr}

The Open Access version of this book, available at www.tandfebooks.com, has been made available under a Creative Commons Attribution-Non Commercial-No Derivatives 4.0 license.

Library of Congress Cataloging in Publication Data A catalog record has been requested.

Typeset in 10 point Sabon Roman by IBT Global.

ISBN 13: 978-0-415-54309-5 (pbk)

ISBN 13: 978-0-7146-5047-0 (hbk) 
To Mum and Dad 



\section{Contents}

Abbreviations $\quad \mathrm{xi}$

Preface xiii

Acknowledgments $\quad \mathrm{xv}$

Selective Family Trees xix

Chronology xxi

$\begin{array}{ll}\text { Introduction } & 1\end{array}$

1 Beginnings, July 1863 to July 1895

2 Opposition Backbencher, August 1895 to December 1905

3 Financial Secretary to the Treasury; President of the Board of Education, December 1905 to April 1908

4 First Lord of the Admiralty, April 1908 to October 1911

5 Home Secretary, October 1911 to May 1915

6 Chancellor of the Exchequer, May 1915 to December $1916 \quad 285$

Bibliography 341

Index 359 



\section{Abbreviations}

CMcK: Cecilia McKenna

DMcK: $\quad$ David McKenna

HHA: H. H. Asquith

MA: Margot Asquith

MMcK: $\quad$ Michael McKenna

PJ: $\quad$ Pamela Jekyll

PMcK: $\quad$ Pamela McKenna

RMcK: $\quad$ Reginald McKenna

RMcK: $\quad$ Stephen McKenna, Reginald McKenna 1863-1943: A Memoir, 1948

SMcK: $\quad$ Stephen McKenna 



\section{Preface}

I am sure no one would want to read [a biography] more than a quarter of a century after Reggie's departure from the political stage. ${ }^{1}$

In the overgrown field of modern British political biography, Reginald McKenna has managed to avoid attention. The only author to have written a book about him, his nephew Stephen McKenna, recalled: '[M]y uncle's attitude to a biography of himself was one of completely passive, dumb indifference. He did not help, he would not hinder.' ${ }^{2}$ The sudden reversal in McKenna's reputation marked by these volumes-Stephen's book being notionally a memoir but essentially an homage to both a man and an era-is due in part merely to the passing of time. A historian was always likely to alight on one of the most significant and intriguing public figures of the first half of the twentieth century. It did not help, however, that, unusually for a senior politician, the public figure never made any public comment about his parliamentary life during his lengthy post-parliamentary career. Nor did it help that the putative subject appeared to have left few private papers, without which considered research would be problematic.

This Life was made possible by the newly discovered archive and has been constituted largely from manuscript sources. It is concerned with a person and based in the main on the evidence of individuals. After the introduction, only primary material, the thoughts of the subject himself, or of those who knew him, appear in the text. The use made of McKenna's own thoughts and writing is unprecedented, as, in most instances, they were unavailable. The cooperation of McKenna's surviving son not only made the project feasible, it also provided the author with most of the information about the

Where no location or archive has been cited, the document referred to was part of the uncatalogued McKenna papers, which were in the author's possession from 1999 to 2005, when they were deposited with the rest of the McKenna papers at the Churchill Archives Centre, Churchill College Cambridge.

Unless otherwise stated, all books were published in London.

1. SMcK to Vincent Baddeley, 23 June 1944.

2. RMcK, xi. 
private and personal traits and activities of his subject. It was a privilege for a biographer to be able to commune-albeit at one remove-with his subject of a century before. It was also a proximity that risked the desired scholarly distance; indeed, such prolonged and inescapable captivity has perhaps produced something of a Stockholm syndrome on the part of the author.

This Life is intended to provide a full biography of the man. This volume is concerned with the first-the parliamentary-half of his public career. It is intended to be a volume of record, rather than a political study. It aims, as will the subsequent volume, to chronicle McKenna's life as he lived it, rather than necessarily to highlight his subsequent historical significance, or necessarily to engage significantly with ongoing historical debates. This is more of a perhaps somewhat old-fashioned two-volume Life and Letters of the like of which many of McKenna's peers were subject, an undertaking that can provide for further, more imaginative interpretation. Curiously, with Stephen's book, such an evaluation came first. 


\section{Acknowledgments}

I am grateful to the staff of the libraries and archives where I have conducted research: the Modern Records Centre, University of Warwick; Bodleian Library, Oxford; British Library, London; House of Lords Records Office, London; Churchill Archives Centre, Cambridge; National Archives, Kew; Cambridge University Library; National Library of Scotland, Edinburgh; Oriental and India Office Collection, London; University of Adelaide Library; Hertfordshire County Record Office, Hertford; Royal Archives, Windsor; British Library of Political and Economic Science, London; Durham University Library; Liddell Hart Centre, Kings College London University, London; Royal Naval Museum, Portsmouth; National Library of Wales, Aberystwyth; Birmingham University Library; Glasgow University Library; Trinity College, Cambridge; Bank of England Archive, London; Newcastle University Library; University of Manchester Library; Labour History Centre, Manchester; HSBC Head Office, London; and Trinity Hall, Cambridge. I owe particular thanks to Pamela Clark at the Royal Archives, and to Andrew Riley at Churchill.

I am grateful to the family and estate of Reginald McKenna for permission to quote from family papers and to reproduce family photographs. Material from the Royal Archives is reproduced with the gracious permission of Her Majesty Queen Elizabeth II. I am grateful to the trustees of the National Library of Scotland, Edinburgh, for permission to quote from material in their possession, and to the Rt Hon Earl Haig as holder of his father's copyright; to the National Library of Wales, Aberystwyth, for permission to quote from the Herbert Lewis papers; to the Royal Naval Museum, Portsmouth, to quote from the George King Hall papers; to Lord Selborne for permission to quote from the Selborne papers; to Special Collections at Birmingham University, for permission to quote from the Oliver Lodge papers; to the British Library for permission to quote from the Balfour, Burns, CampbellBannerman, Cave, Cecil, Dilke, Evans Thomas, Gladstone, Grant, Hamilton, and Jellicoe papers; to $\mathrm{Mr}$ Christopher Osborn for permission to quote from the Margot Asquith papers; to Mrs Nancy McLaren for permission to quote from the McLaren papers; to Alexander Murray for permission to quote from the Gilbert Murray papers; to the Hon Mrs E. A. Gascoigne for 
permission to quote from the Harcourt papers; to the Earl of Crawford and Balcarres for permission to quote from the Crawford papers; to the trustees of the Liddell Hart Centre for Military Archives for permission to quote from the Robertson and Liddell Hart papers; to the Bodleian Library for permission to quote from the H. H. Asquith, McKinnon Wood, and Simon papers; to Cambridge University Library for permission to quote from the Hardinge and Crewe papers; to the Asia Pacific and Africa Collections of the British Library for permission to quote from the Curzon, Reading, and Charles Roberts papers; from Trinity College, Cambridge, for permission to quote from the Montagu papers; to the director and librarian, the John Rylands University Library, the University of Manchester, for permission to quote from the C. P. Scott papers; to Glasgow University Special Collections for permission to quote from the Alexander MacCallum Scott; to King's College Cambridge for permission to quote from the Keynes papers; to the University of Warwick Modern Records Centre for permission to quote from the C. P. Allen papers; to HSBC Group Archives for permission to quote from the Midland Bank papers; to the Churchill Archives Centre, Churchill College Cambridge, for permission to quote from the Hankey, Fisher, Esher, Stead, Bull, and Hurd papers; to Little, Brown, for permission to quote from the Churchill papers; to the Special Collections and Archives librarian, Robinson Library, Newcastle University, for permission to quote from the Runciman papers; to the Parliamentary Archives for permission to quote from the Bonar Law, Lloyd George, Stansgate, Samuel, Wargrave, Beaverbrook, and Strachey papers. It will be seen that I have tried to be thorough in these matters; I apologise for any permissions that should have been obtained and have not, and will gladly rectify matters in any subsequent edition and the subsequent volume.

Professor Hew Strachan, my doctoral supervisor at the University of Glasgow, bears original responsibility, having extracted the germ of a thesis-on McKenna's chancellorship and British strategy in the First World War-from the list of historical events that interested me and that passed for a $\mathrm{PhD}$ research proposal in 1993.

I made contact with Reginald McKenna's his surviving son soon after I began my research. David McKenna was delighted that biographical inquiry was finally being directed to his father, and was wholly encouraging from the outset. Later, when the missing papers were discovered, he offered unlimited and unrestricted access. His kindness and trust made this book possible, and his friendship made it more than merely a professional undertaking. My visits to David and his wife Cela in Cornwall-and London-were a source of great pleasure, as well as of great productivity. It is to my abiding regret that both died in 2003 and, owing to my own procrastination, were not able to see the fruits of our collaboration. The support and assistance of the family was unaffected, however, through David and Cela's daughters, Miranda, Primrose, and Sophia, and their sons-in-law, Christopher Arnander and John 
Villiers. The family were generous with their support and comments on the project and the manuscript during its protracted course, without making any editorial demands. I'm very grateful to all of them.

What has often felt like a very long, lonely endeavour was in fact more a very long, team effort. A number of friends and colleagues read all or most of the text-or tried to-and for their attention I thank Professor Bob Moore, Professor Patrick Salmon, Professor David Saunders, Professor Philip Williamson, Dr Cameron Hazlehurst, and Dr Andrew Kaye, as well as Professor Neil Daglish and Professor Andrew Lambert, who read individual chapters. Many people have provided advice and assistance in other ways. In this category I should like to thank Lady Helen Asquith, Professor Trevor Wilson, Professor Peter Clarke, Mr Colin Clifford, Dr Robert Colley, Lady Henniker, and Lord Henniker, another generous patron who could unfortunately not see this day. Pamela Mason and Vanessa Badham Thornhill suffered in their own ways for the cause.

I am grateful to Andrew Humphrys, originally at Frank Cass, and Terry McCague, at Routledge, for their patience, and, more recently, to Max Novick, at Taylor \& Francis, in New York, for his help.

Professor Salmon, when head of History at Newcastle University, provided the author with a job, which was a relief, but which served further to delay the book, owing to the propensity of the author to be distracted. The passing of generations saw the burden move to the shoulders of Professor Jeremy Boulton, who made delivery easier, before inducing it. Professor Saunders applied forceps. The result was twins.

Most importantly, I thank my parents, Jen and Don, to whom the book is dedicated, and who will be as relieved as the author that the deed is finally done or at least the first part of it. 



\section{Selective Family Trees}

Michael McKenna m. Mary Plunkett Cregan

Sir Joseph Neale McKenna [5 others]

William Columban McKenna

(1815-1887)<smiles>C=CC</smiles>

m. Esther Louise Howell

Helen, m. John O'Connell

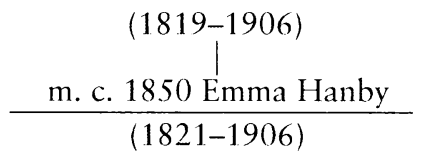

$$
(1821-1906)
$$$$
\text { Helen, m. John } \mathrm{O}^{\mathrm{C}} \mathrm{connell}
$$

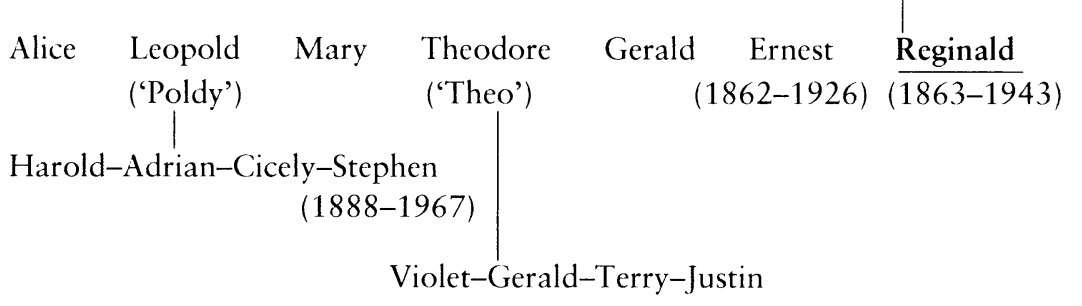

Edward Jekyll m. Julia Hammersley

Caroline Edward Arthur Frederick Gertrude Herbert Walter (1843-1932) (1846-1932) m. 1881 Agnes Graham ('Aggie') (1860-1937)
Francis Barbara ('Bar')
(1887-1973)
m. 1911 Francis McLaren
1866-1917
m. 1921 Bernard Freyberg ('Ber')
1889-1963





\section{Chronology}

1863 Born, Bayswater, London, 6 July

1870 Afton House College, Chiswick

1871 School in St Malo, Brittany

1872 School in Ebersdorf, Bavaria

$1878 \quad$ King's College School, Strand

1882 Scholar, Trinity Hall, Cambridge

1884 Member, Inner Temple, 26 January

1885 Senior Optime, Mathematics

1887 Rowed in winning Cambridge boat, 26 March

1887 Called to the Bar, Inner Temple, 17 November

[1889 Pamela Margaret Jekyll born, Chelsea, 10 March]

1892 Unsuccessfully contested Clapham, 4 July

1895 Successfully contested North Monmouthshire, 20 July

1905 Financial secretary to the Treasury, 12 December

1907 President of the Board of Education, 23 January

1907 Privy Councillor, 11 February

1908 First lord of the Admiralty, 12 April

1908 Married Pamela Margaret Jekyll, 3 June

1910 Michael McKenna born, 31 January

1911 David McKenna born, 16 February

1911 Home secretary, 23 October

1915 Chancellor of the Exchequer, 27 May

1916 Resigns from government, 5 December 



\section{Introduction}

Nobody is directed by his will to select from his papers or to prepare them for publication or to deposit them in the British Museum for fifty years or to deposit them unread. He would not write his own life-Why should he? - and apparently he did not contemplate that others-Why should they? - might feel that his life ought to be written.

One of the most insubstantial figures of the first half of the twentieth century.

-Roy Jenkins, Baldwin ${ }^{2}$

In the National Portrait Gallery, London, hangs Sir James Guthrie's imagined ensemble 'Statesmen of the Great War'. Assembled beneath Nike, the winged goddess of victory, the leaders of the Imperial war effort reflect on final glory, hard won. It is a heroic representation, but not one composed wholly of victors. The preference of $\mathrm{H}$. H. Asquith, Sir Edward Grey, and Field Marshal Lord Kitchener recalled a time before success, as it would latterly be defined. Reginald McKenna was not included. Guthrie, unaware of how the period would come to be written, had painted with prescience. McKenna was not present when the war was won; worse, was a figure associated with the recalcitrant vested interests of party when victory had been in doubt and government wracked by indecision. The then chancellor of the Exchequer, unlike his prime minister, the foreign secretary, and the secretary of state for war, was to receive accommodation from neither portraitist nor historian.

Perhaps it was just as well. McKenna would have sullied Guthrie's neoRomantic contrivance. He was not a man to stir the imagination, nor did he rue the fact. It was often said of Kitchener that his reputation suffered because he did not live to write his memoirs; McKenna had the longevity but not the inclination. Kitchener had at least been a poster; McKenna refused to

1. $R M c K, 4$.

2. Roy Jenkins, Baldwin (1987), 181. 


\section{Introduction}

exorcise the printed ghosts of past participants, even if he had been inclined to: 'my pen doesn't help me', he wrote. ${ }^{1}$ Interviews were similarly spurned, as was any public, postfactual, justification: 'I do not wish to appear in the light of a mauvais coucheur'. ${ }^{2}$ In this regard, talent corresponded with temperament: 'Personal advertisement is always in bad taste and is to be avoided', he told his son. ${ }^{3}$ Concessions were rare and begrudged. Josiah Wedgwood, prosopographist and historian of Parliament, sent questionnaires to parliamentarians past and present with the object of compiling a comprehensive record. In July 1936, he reached McKenna. 'I hope you will enjoy filling up the enclosed and amplifying for posterity. I am getting really splendid results', he enthused. 'I have not enjoyed filling up the enclosed', McKenna replied, 'because I am not greatly concerned about the interest which posterity is likely to take in me'. ${ }^{5}$ Posterity responded in kind.

Yet by the time of his death, Reginald McKenna had been first lord of the Admiralty, home secretary, chancellor of the Exchequer, and chairman of the largest bank in the world for over twenty years. As a minister, he had been one of the men closest to the premier, H. H. Asquith, throughout one of the longest premierships in history. Through a profound personal and political dispute with David Lloyd George, McKenna found himself out of office, and then out of Parliament. He thereafter managed something quite unusual in establishing himself in a new and distinct career, and one where his significance may actually have been greater. As chairman of Midland Bank, he was a pivotal figure in international financial affairs and the political debates about economic policy throughout the 1920s and 1930s. Throughout his life, moreover, he was at the centre of a diverse and talented family that was fully part of Britain's artistic and cultural life.

McKenna's nevertheless remained one of the last leading Liberal lives left unwritten. It was long thought by some with good reason; indeed, that he was 'deservedly obscure'. ${ }^{6}$ McKenna was very seldom prominent in writing of his period, as if his own modesty was his testament. ${ }^{7}$ The prevailing historiography regarding McKenna was created by three related factors: circumstantial, personal, and material. Firstly, Westminster's being a brighter flame than that of the City, McKenna's displacement from government and his move to banking meant that his subsequent influence was not matched by his profile. The discretion more common in financiers than in statesmen meant that those who had prevailed politically wrote the history of

1. RMcK to Walter Runciman, 5 May 1908, Runciman papers, 21/91.

2. RMcK to Lord Beaverbrook, 24 March 1927, Beaverbrook papers, C234; RMcK to Cecil Harmsworth, 26 June 1923 [copy].

3. RMcK to DMcK, 14 October 1924.

4. Josiah Wedgwood to RMcK, 29 July 1936.

5. RMcK to Josiah Wedgwood, 5 August 1936 [copy].

6. David Cannadine, 'Writer and Biographer', in Roy Jenkins: a Retrospective, ed. Andrew Adonis and Keith Thomas (Oxford, 2004), 271-306, 298.

7. Lord Vansittart, The Mist Procession (1958), 163-64. 
the politics without contradiction from him. The second factor-McKenna's personality-was more important even than his station. 'I am a bad hand at photographs and autobiography', was his understated observation. ${ }^{1}$ Stephen McKenna remembered his uncle's 'almost completely inhuman' lack of interest in his own history.

In the interests of accuracy he would occasionally and for a very few moments reopen a closed chapter; but his manner was discouraging to any that tried to draw him and only an intenser, more frozen quality of silence discriminated between the subjects that he was not interested to discuss and the subjects that he refused to discuss. ${ }^{2}$

Yet McKenna's own, almost chronic, personal diffidence was something many who only knew him from his public profile would have found difficult to believe.

The final factor was material. In 1966, Jock Colville wrote to his friend, and McKenna's son, David McKenna. Colville, who had been private secretary to Winston Churchill during the Second World War, enquired in his capacity as trustee of the newly formed Archive Centre at Churchill College Cambridge whether David's father's papers might be deposited there as part of the collection of 'the original papers of Statesmen and Men of War', and be housed with those of McKenna's colleagues, such as Hankey, Esher, and Jellicoe. Moreover, 'Unless Randolph changes his mind', Colville wrote, 'all Winston's papers will eventually find their home at the College, and indeed, a specially fireproof room has been attached to the library. ${ }^{3}$ David agreed.

From the search room at Churchill College the 'McKenna papers' were regularly consulted since the Archives Centre opened in July 1973. The collection was, however, far from extensive. Abiding puzzlement had been felt by historians who had arrived with Stephen McKenna's claim that the papers were 'nearly complete as any one could wish'. ${ }^{4}$ The collection was nearly complete only for McKenna's period at the Admiralty, with a smattering from his time as home secretary and chancellor of the Exchequer, and nothing at all from McKenna's existence before 1908 or after 1918. When his nephew wrote of 'other boxes, big and small, packed with letters, drafts and copies unindexed and even unsorted, which have certainly never been published and which probably never again saw the light of day after the lock snapped on them', historians had assumed it an exaggeration, or, worse,

1. RMcK to J. L. Garvin, 28 May 1908, McKenna papers, 3/13/4a.

2. RMcK, 118-19.

3. John Colville to DMcK, 21 March 1966.

4. $R M c K$, xi.

5. Ibid. 
that they had been destroyed. ${ }^{1}$ The archivist at Churchill noted, 'it seems unlikely any other papers have survived'. ${ }^{2}$ The standard guide to ministerial papers concluded: "McKenna's son, Mr David McKenna has advised that there are no other papers in the family possession. Attempts to trace papers that may have been in Stephen McKenna's possession have been unsuccessful." "' Yet, as Stephen recognised, 'To destroy would have betrayed almost as much interest as to assemble'. ${ }^{4}$

When McKenna died, in his flat above Midland Bank's branch at 70 Pall Mall in September 1943, he indeed left other boxes, big and small. In October, his friend Lord Beaverbrook visited his widow Pamela and suggested that, lest it be overshadowed by his second career as a financier, her husband's career as a statesman should be chronicled. She considered potential biographers. The financial journalist Paul Einzig suggested an 'independent personal appreciation of his career', ${ }^{5}$ but not a formal political biography. For that, Pamela first considered G. M. Trevelyan, who had recently completed a life of one of her husband's closest political friends, Edward Grey. ${ }^{6}$ She decided on Stephen, who was not only family, but also the author of over forty books, including an autobiography. ${ }^{7}$ David told his wife Cela,

Stephen wrote me a very nice letter about a memoir; Pamela had just mentioned the possibility of his doing one of Reggie, but then things were cut short. Stephen was very practical and set out the possibilities, either a rather personal historical essay, or a conventional biography. I favour the former, for Reggie left no papers or letters, and the latter type is apt to be so dull. Stephen said he would like to try his hand at the former. I do not know what you feel, but I am rather in favour of it. ${ }^{8}$

The 'personal historical essay' had to wait two years until the end of the war; the other type David mentioned rather longer.

1. Neil Daglish, Education Policy-Making in England and Wales (1996), x, 338 n.22.

2. Original introduction to the McKenna papers, Churchill College, Cambridge; DMcK to John Colville, 5 September 1966 [copy]; J. T. Killen to DMcK, 11 July 1968; M. A. Hoskin to DMcK, 20 July 1972.

3. Cameron Hazlehurst, Sally Whitehead, and Christine Woodland, eds., A Guide to the Papers of British Cabinet Ministers (1996), 248. The most determined of enquirers, Dr Hazlehurst, was told three times: 7 October 1966, 29 June 1972, 3 July 1993.

4. $\mathrm{RMcK}$, in $R M c K$, xi.

5. Paul Einzig to PMcK, 15 September 1943; Paul Einzig to PMcK, 17 September 1943.

6. G. M. Trevelyan, Grey of Fallodon (1937).

7. Stephen McKenna, While I Remember (1921).

8. DMcK to CMcK, 3 December 1943. The author is grateful to Mrs Miranda Villiers for this reference. 
Faced with the 'jungle' of papers that were waiting in the basement of 70 Pall Mall in 1946, Stephen used, and quoted extensively from, only those boxes dealing with ministerial matters, and in particular those of the Admiralty. ${ }^{1}$ Stephen returned the papers he used to David, who subsequently took them-and the papers Stephen did not consult - to his country residence in Cornwall. In the 1950)s, Professor Arthur Marder of the University of Hawaii corresponded with David about the papers quoted by Stephen in the book during Marder's research into the pre-1914 Royal Navy. ${ }^{2}$ In 1956, Marder consulted them in Cornwall. The papers subsequently quoted in Marder's work were the papers requested by Colville ten years later, and which were deposited in Cambridge, constituting the 'McKenna papers' as cited regularly thereafter. In 1983, David deposited further documents, relating to the Beresford inquiry with the college. ${ }^{3}$ In 1988, McKenna's papers held by Midland Bank were released to scholars, dealing in the main as they did with impersonal business matters from the second, less well known, half of his career. The main body of personal papers remained, forgotten, in Cornwall. As David put it in 1972: 'It is just conceivable that I might still have a few oddments left over in other places. ${ }^{4}$

The present author found them, covered in dust and silverfish, on a succession of trips to Cornwall in the late 1990s. Among several noteworthy correspondences was that between $\mathrm{H}$. H. Asquith and Pamela McKenna. Volumes of letters from Asquith to his half a dozen or so close female friends-there was no male equivalent—had been appearing periodically for some time, but it was not widely known that Asquith similarly corresponded with McKenna's wife. ${ }^{5}$ Another colleague's wife, Hilda Runciman, said that Margot's publishers offered her husband $\$ 10,000$ for the rights to his diaries, which he accepted. Unfortunately, Asquith never kept a diary. 'The best record of his daily life were the letters he constantly wrote to whichever of his various ladies happened to be his favourite of the moment',

1. SMcK to Vincent Baddeley, 23 June 1944; SMcK to PMcK, 6 September 1943; SMcK to CMcK, 2 November 1943; SMcK to Vincent Baddeley, 19 June 1943; SMcK to CMcK, 17 January 1945.

2. Arthur Marder to DMcK, 16 December 1953; DMcK to Arthur Marder, 23 December 1953 [copy]; Arthur Marder to DMcK, 24 February 1956: Arthur Marder, From the Dreadnought to Scapa Flow: The Royal Navy in the Fisher Era, 1904-1919, 5 vols. (1961-70), 4:ix; Arthur Marder (ed.), Fear God and Dread Nought, The Correspondence of Admiral of the Fleet Lord Fisher of Kilverstone, 3 vols. (1952-59), 1:10.

3. Marion Stewart to DMcK, 6 January 1983.

4. DMcK to M. A. Hoskin, 21 July 1972 [copy].

5. Desmond MacCarthy, ed., Letters to a Friend, 2 vols. (1933); Michael Brock and Eleanor Brock, eds., HHA Letters to Venetia Stanley (Oxford, 1982); HHA's letters to Venetia Stanley's sister, Sylvia Henley have most closely been utilised by George Cassar, Asquith as War Leader (1994). 
Hilda wrote. 'He therefore had to write and ask them for his letters ... But they refused!'1

The correspondence revealed that the 'McKennae', as he called them, were even closer to Asquith than had hitherto been thought. It is not clear how widely known was the extent of the Asquith-McKenna letters. Beaverbrook asked to see them as he completed his Politicians and the War, in 1928, and his biographer mistakenly claimed that the correspondence had begun after Asquith stopped writing to Venetia Stanley in May $1915 .^{2}$ In fact, Asquith continued those epistles to Venetia's sister Sylvia Henleyhis letters to Pamela were more personal and less political in tone. After Asquith's death, Pamela appeared to have offered only to Beaverbrook those letters relevant to his interest in the December crisis of 1916. 'I'm so sorry not to have more. Aren't I a thin and broken reed!'3 Beaverbrook was more than satisfied with the letters. 'Asquith's are as interesting as any I've read. And that is saying very much'. ${ }^{4}$

When it appeared in 1948, Reginald McKenna 1863-1943: A Memoir did not purport to be anything more. Stephen wrote little about his uncle's early life, or, indeed, on the seventy years when he was not a minister. It was clearly not the work of an academic historian: it is effortlessly readable. The matriarch serves as a plot device. ${ }^{5}$ The book has large sections of impressionistic Edwardian political history and quotations transcribed from the memoirs of the day. Here and there, ten years of parliamentary life pass in a paragraph, as can pages before its nominal subject makes an appearance. Perhaps it was a reflection of its subject's significance that even in a memoir of him he could successfully be marginalised. Reginald McKenna is, in fact, both little more than a political study, and much more than anyone else has attempted, and it does convey the nature of the man the author knew well for nearly fifty years. Most importantly, for present purposes, the portrait of the man that emerges is consonant with the accounts and recollections of others who encountered him.

Consequently, Reginald McKenna is employed here as a primary source. There are perils in depending too much on a memoir by a writer of fiction, particularly one for whom a life could be described through one central

1. Hilda Runciman, diary, 13/14 November 1930 Runciman papers, add/6/(ii). Hilda Harrisson did not refuse, and was rewarded with $£ 2000$ on publication of the MacCarthy editions.

2. A. J. P. Taylor, Beaverbrook (1972), 103; Lord Beaverbrook, Politicians and the War 1914-1916 (1928).

3. PMcK to Beaverbrook, 5 July [1928], Beaverbrook papers, BBK/G/2/17.

4. Lord Beaverbrook to PMcK, 8 July 1928. PMcK had sent Beaverbrook two letters to her from HHA (of 3 December 1916 and 6 December 1916), and one from Fisher (of 8 December 1916): PMcK to Lord Beaverbrook, 5 July [1928], Beaverbrook papers, BBK/G/2/17.

5. Miranda Villiers to the author, 8 January 2003. 
event, to and from which all else was deemed to flow. McKenna's period as first lord of the Admiralty stood for his nephew, as it did for most of those who knew or know about him, as the office of his greatest influence and achievement. Therefore, Reginald McKenna is a paean to five years at the centre of a lifetime. Stephen wrote the book in the period of shock after the Second World War, the unsuccessful avoidance of which had preoccupied a generation. McKenna, as first lord of the Admiralty, was in this conception an example of how war should have been averted.

The posterity with which McKenna was unconcerned but which has defined him has therefore been effectively determined by others. McKenna's own reticence was symptomatic of his comparative failure as a politician. As a banker, where he delighted in supporting radical issues and consistently advocated an unorthodox and progressive approach to economic policy, he flourished away from the attention of the yellow press, but embraced the culture of circumspection that characterized the City of London. He seldom wrote a letter containing a disclosure without appending an attendant disclaimer. He refused interviews in the same way that he refused publishers, though he was persuaded to issue a collection of his addresses in the interests of educating the public in matters of monetary policy. ${ }^{1}$ The resultant negligible profile encouraged suspicions that he was negligible. It had been asserted, pointedly, that McKenna was offered no peerage. ${ }^{2}$ One view had it that he wanted to remain free to accept the Exchequer whenever it was offered; yet neither was he offered a knighthood. McKenna in fact refused each, and all other, honours, reluctant as he was to acquire either the publicity or the personal or political indebtedness from accepting patronage. It was a testament to his profile—or what authors may have imagined it should have been-that so many writers erroneously bestowed titles upon him. ${ }^{3}$ They too, perhaps, expected McKenna to join in retirement Viscounts Runciman, Simon, Samuel, Grey, Haldane, Harcourt, Long, Bridgeman, Buckmaster, Crewe, Norwich, Snowden, Gladstone, Addison, Bledisloe, Bracken, Lee, Davidson, Horne, Templewood, Jellicoe, Stansgate, and Waverley; or Earls Asquith, Baldwin, Balfour, and Lloyd George, although not, ironically given their antipathy, Joseph Chamberlain. At least one source has him alive decades after his demise, and two confuse him with his nephew. ${ }^{4}$

1. Reginald McKenna, Post War Banking Policy (1928).

2. Jenkins, Baldwin, 181; Roy Jenkins, Chancellors (1998), 190.

3. DMcK, in conversation with the author, 16 November 1998; RMcK to PMcK, 23 October 1927. Examples of a confused profile are too numerous to mention; the most common concern name ('MacKenna'), education (usually 'King's College London University'), title (usually 'Sir Reginald', but, very occasionally, 'Lord McKenna'), and offspring (between none and three [misinformation that originally confused the present author]).

4. George Wigg papers, 4/26, 4/105; J. R. Clynes, Memoirs, 2 vols. 1937; Austen Chamberlain, Down the Years, [1935]. 
McKenna's profile was made no more distinct by autobiographical silence. Lloyd George, his bete noire, got by with a million words of autobiography in six volumes covering four years, ${ }^{1}$ but his de facto memoir is nearer fifty volumes. The number of accounts during Lloyd George's life was surpassed by those after his death, supplemented by memoirs of public figures prominent through their relationship with him; acolytes adding fond remembrance. ${ }^{2}$ His own, published, correspondence completed the picture. ${ }^{3}$ It was one way in which the war was still fought in the peace. Matters reached the point when even Lloyd George was brushed by circumspection, worried that there might be 'too many digs at McKenna', in his War Memoirs, and that 'it was psychologically unwise to dig at McKenna too much', as his military adviser Basil Liddell Hart recorded. 'My diary note of this incident ends: "we shall see"'. ${ }^{4}$ It was McKenna's further misfortune that most of those to whom he was closest in public life, notably Keynes, Runciman, Jellicoe, and Bonar Law, chose not to write their memoirs or were prevented from so doing. ${ }^{5}$ The recollections of those allies which did eventually arrive were leached of interest by infirmity or distance. ${ }^{6}$

The wealth of primary and semi-primary material was duly absorbed into the secondary literature, most vividly in the 1960s and 1970s when the other personal and institutional papers of Edwardian Britain were openedincluding the 'McKenna papers'. First World War scholarship then began in earnest, and McKenna's significance began to be appreciated. ${ }^{7}$ Even so, the pattern reemerged, and forty-odd years of accumulated interpretation still

1. David Lloyd George, War Memoirs, 6 vols. (1933-36).

2. Christopher Addison, Politics from Within (1929), Four and Half Years (1934); Leopold Amery, My Political Life, 2 vols. (1953); Lord Beaverbrook, Politicians and the War; Men and Power 1917-1918 (1963); William George, My Brother and I (1958); Basil Liddell Hart, The Memoirs of Captain Liddell Hart, 2 vols., (1965); Kennedy Jones, Fleet Street and Downing Street (1919), Arthur Murray, Master and Brother (1945); Charles à Court Repington, Vestigia (1919); Frances Lloyd George, The Years that are Past (1967); Winston S. Churchill, The World Crisis, 5 vols. (1923-27).

3. Most notably A. J. P. Taylor, ed., Lloyd George: A Diary by Frances Stevenson (1971); but also A. J. P. Taylor, ed., My Darling Pussy: The Letters of Lloyd George and Frances Stevenson (1973); K. O. Morgan, ed., Lloyd George Family Letters (1973).

4. Liddell Hart, Memoirs, 1:361; Lloyd George to Liddell Hart, 4 April 1929, Liddell Hart papers, 1/450/1/2.

5. J. M. Keynes, Essays in Biography, ed. Geoffrey Keynes (1957), reflects RMcK's own attitudes to Asquith, Lloyd George, and Bonar Law, without any comment on RMcK himself. Keynes did so on RMcK's death: 'Mr R. McKenna: An Appreciation', Times, 15 September 1943.

6. H. H. Asquith, Memories and Reflections, 2 vols. (1928), Fifty Years of Parliament, 2 vols. (1926); Edward Grey, Twenty-Five Years, 3 vols. (1928); Herbert Samuel, Memoirs (1945); John Simon, Retrospect.

7. As may be seen in the incidence in requests to DMcK to consult the papers: $1960-65,2 ; 1965-70,28 ; 1970-75,30 ; 1975-80,15 ; 1980-85,6$. 
shaped perceptions, as did the recurrent use of the usual sources by the most notable practitioners. When he was mentioned at all, McKenna was usually the most frigid of frockcoats, ${ }^{1}$ and many historians directed their investigations to illuminating further the means of success of those who succeeded. ${ }^{2}$

Writings on the economics of the war suffered from a distinct but related problem. Just as McKenna's principal opponent wound up on a plinth, so his adviser and friend became almost as venerated. Most of McKenna's work as chancellor-and much of it as a banker-has been presented as being really from the pen of J. M. Keynes, and, at its worst, McKenna as chancellor has been presented as the simian accompanist to Keynes's organ-grinder, if even that, with the two being effectively contracted to 'Keynes' ${ }^{3}$ For some, the relationship between a minister and his civil servants is evidently shrouded in mystery; for McKenna it was part of the cycle of neglect and perhaps even misfortune: his assistant himself became one of the key figures of the century.

The principal published versions of events from which secondary judgements were drawn were diaries. Yet in their edited form, the diaries themselves misrepresented. By the time the journals of George Riddell, of the News of the World, C. P. Scott, of the Manchester Guardian, and, of a

1. A small, but telling, example concerned the diplomat Lord Hardinge. In 1917, after McKenna had left office, Hardinge complained to the British Ambassador in Petrograd, Sir George Buchanan, that when chancellor, McKenna's parsimony had threatened Russia's war effort. The mail was intercepted by the German navy and published in the Frankfurter Zeitung. John Dillon, the Irish Nationalist MP, read the letter in the Commons to embarrass the government. The letter was factually inaccurate, so McKenna assumed it was a forgery (RMcK to Captain E. N. Bennett, 27 February, 1917, [copy]), but Hardinge soon wrote to apologise and to claim that he had been misrepresented (Hardinge to RMcK, 6 March 1917); RMcK assured him that no offence had been caused, but offered some factual clarifications. (RMcK to Hardinge, 7 March 1917, Hardinge papers, 30/37). In his memoirs, Hardinge recalled, 'McKenna did not mind a bit, but wrote to me sheets to prove he was not a pedant' (Hardinge, Old Diplomacy (1947), 212). He was half-right: RMcK's reply occupied a single sheet and was shorter than Hardinge's unsolicited apology.

2. The key text in this regard was that of A. J. P. Taylor: 'Politics in the First World War', Raleigh Lecture on History, 1959, Proceedings of the British Academy 45 (1959): 67-95. With reference to his chancellorship, two are typical: Robert E. Bunselmeyer, The Cost of the War, 1914-1919 (Hamden, 1975); Samuel Hurwitz, State Intervention in Great Britain, 1914-1919 (New York, 1949). The former included one reference to $\mathrm{RMcK}$, the latter manages to place its single reference in parenthesis. More recently, Niall Ferguson, The Pity of War (1998), otherwise almost maniacally revisionist, effectively omits $\mathrm{RMcK}$ as a feature of war finance.

3. For example, Charles H. Hession, John Maynard Keynes (New York, 1984); Seymour E. Harris, John Maynard Keynes (New York, 1955); N. H. Dimsdale, 'Keynes and the Finance of the First World War', in Essays on Maynard Keynes, ed. Milo Keynes (Cambridge, 1975), 142-61; John Anthony Hemery, 'The Emergence of Treasury Influence in British Foreign Policy, 1914-1921' (PhD thesis, University of Cambridge, 1988). Even by this standard, A. P. Thirlwell, ed., Keynes as Policy Adviser (1982), is remiss. 


\section{Introduction}

fashion, Sir Almeric Fitzroy, of the Privy Council, as well as Viscount Esher and Maurice Hankey, of the Committee of Imperial Defence, were published, the war had been won, and the predominance in the popular mind of Lloyd George was assured. ${ }^{1}$ As publishing ventures, diaries and papers were edited to respond to public preoccupations, rather than to challenge them. ${ }^{2}$ Manuscript sources often bore little resemblance to their better-known published versions, and writers have found, perhaps to their own surprise, the prominence with which McKenna appears in the gloom of a search room in contrast to the warmth of a bookshop. ${ }^{3}$ One multivolume biographer of Lloyd George, consulting the original manuscripts of previously published diarists, found himself faced with 'the transcending importance of the ghostly figure in early Georgian Liberal politics, Reginald McKenna'. ${ }^{4}$

It followed from the memoir literature and the initial historiography that McKenna's significance was insufficiently emphasised and understood, or even traduced. ${ }^{5}$ Some historians were conscious of the oversight. 'One of the chief victims of the destruction of Liberalism in British politics', commented one of McKenna in 1957.'Persistently underrated partly because his gifts, illuminated by no great powers of imagination nor by high flights of eloquence, infuriated the "brilliant" men and the old-fashioned "traditionalists". 6

While no one has looked at McKenna's career as a whole-and only one other historian is known to have even expressed an interest in writing a

1. George Riddell, Lord Riddell's War Diary, 1914-1918 [1933]; George Riddell, More Pages from My Diary, 1908-1914 (1934); J. M. McEwen, ed., The Riddell Diaries, 1908-1932 (1986); Trevor Wilson, ed., The Political Diaries of C. P. Scott, 1911-1928 (1970); Sir Almeric Fitzroy, Memoirs, 2 vols. [1925]; Maurice Brett, ed., Journals and Letters of Reginald, Viscount Esher (1934-38); Stephen Roskill, Hankey: Man of Secrets, 3 vols. (1970-74).

2. Robert Rhodes James, ed., Memoirs of a Conservative: J. C. C. Davidson's Memoirs and Papers, 1910-37 (1969); Keith Wilson, ed., The Rasp of War: The Letters of H. A. Gwynne to the Countess Bathurst, 1914-18 (1988); John Vincent, ed., The Crawford Papers: The Journals of David Lindsay Twenty-seventh Earl of Crawford and Tenth Earl of Balcarres 1871-1940, During the Years 1892 to 1940 (Manchester, 1984); Philip Williamson, (ed., The Modernisation of Conservative Politics: Diaries and Letters of William Bridgeman, 1904-1935 (1988); George Boyce, ed., The Crisis of British Unionism: Lord Selborne's Domestic Political Papers, 18851922 (1987). The most notable exception was Charles à Court Repington, The First World War 1914-18, 2 vols. (1920).

3. Professor Peter Clarke, in conversation with the author, 11 July 1997; Lord Skidelsky, in correspondence with the author, 1997-98.

4. Bentley Brinkerhoff Gilbert, David Lloyd George: A Political Life, 2 vols. (1987-92).

5. Rather than mention the much more numerous examples of omission, only those scholars who have made a contribution to RMcK historiography-and have provided the initial context for the present author's research-are included below.

6. Roger Fulford, Votes for Women: The Story of a Struggle (1957), 262. Fulford had reviewed $R M c K$, in The Times Literary Supplement, 19 June 1948, 339. 
biography ${ }^{1}$ - sections of his political life have been illuminated by scholarship. ${ }^{2}$ There is understandably little on his first period at the Treasury that concerns him as financial secretary. At the Board of Education he has usually been presented, not unfairly, as another in a conveyor-belt of middle-ranking Cabinet ministers to be offered to an insatiable religious controversy. ${ }^{3}$ McKenna's work at the Admiralty has been by far the subject of the greatest scrutiny. While he was alive, he was happy to speak to naval historians, particularly when, as with Reginald Bacon, they were acquaintances who were both of the service themselves and concerned with sympathetic accounts of McKenna's friends, most notably Fisher and Jellicoe. ${ }^{4}$ After his death, in the wake of Marder and the deposit of his Admiralty papers in Cambridge, McKenna's role has been assessed primarily in terms of the relationship between Liberalism and navalism, ${ }^{5}$ maritime rights, ${ }^{6}$ and Fisher. ${ }^{7}$ Assisted

1. A. J. A. Morris to DMcK, n.d. 1984. An MA thesis, entitled'Reginald McKenna: The Pre to War Years, a Political Biography', was written by Sam H. Jenike, of the University of Cincinnati, in 1968. McKenna's entry in the Dictionary of National Biography was revised, and replaced Stephen's entry in the original, though it was largely based on it; D. M. Cregier, 'Reginald McKenna', in Oxford Dictionary of National Biography, eds. H. C. G. Matthew and Brian Harrison (Oxford, 2004); Stephen McKenna, 'Reginald McKenna', in The Dictionary of National Biography 1941-1950, eds. L. G. Wickham Legg and E. T. Williams (1959).

2. The historian who came closest to a balanced appreciation of RMcK was perhaps Stephen Koss: 'Destruction'; Lord Haldane: Scapegoat for Liberalism (New York, 1969); Fleet Street Radical: A. G. G. Gardner and the Daily News (1973); Nonconformity in Modern British Politics (1975); Asquith (1976); The Rise and Fall of the Political Press in Britain, 2 vols. (1981-84). There have also been contributions from the present author: 'A Compelling Case for Voluntarism: Britain's Alternative Strategy, 1915-1916', War in History 9 (2002): 279-306; 'Clann MacKenna's Edwardian Exile', Sydney Series in Celtic Studies 8 (2005): 207-24; 'Squiff', 'Lliar George', and 'the McKennae': The Unpersuasive Politics of Personality in the Asquith Coalition, 1915-16', in Making Reputations: Power, Persuasion and the Individual in Modern British Politics, eds. Richard Gottlieb and Julie Toye (2005), 29-42; 'Left, Right: The Forward March of Liberals Halted', Journal of Liberal History 47 (2005): 30-35.

3. Neil Daglish, Education Policy-Making; 'A "Difficult and Somewhat Thankless Task": Politics, Religion, and the Education Bill of 1908', Journal of Educational Administration and History 31 (1999): 19-35; see also Benjamin Sacks, The Religious Issue in the State Schools of England and Wales, 1902-1914 (Albuquerque, 1961).

4. Admiral Sir R. H. Bacon, The Life of Lord Fisher of Kilverstone, 2 vols. (1929); The Life of John Rushworth, Earl Jellicoe (1936).

5. Bernard Semmel, Liberalism and Naval Strategy: Ideology, Interest and Sea Power During the Pax Britannica (1986); Avner Offer, The First World War, An Agrarian Interpretation (Oxford, 1989).

6. John W. Coogan, The End of Neutrality-The United States, Britain, and Maritime Rights, 1899-1915 (Ithaca, 1981).

7. Nicholas A. Lambert, Sir John Fisher's Naval Revolution (Columbia, 1999); also Samuel R. Williamson, Jr., The Politics of Grand Strategy-Britain and France Prepare for War, 1904-1914 (Cambridge, MA, 1969). 


\section{Introduction}

on his part by the availability of papers, this is the area of McKenna's public career which has enjoyed the most scrutiny. ${ }^{1}$

His work at the Home Office tends to fall into the spheres of interest of those concerned with distinct areas of what was even then a department with a broad remit. Thus Wales, ${ }^{2}$ women, ${ }^{3}$ and the distinct but related hysterias of the pre- and early stages of the First World War. ${ }^{4}$ McKenna's involvement in politics during the war has been assessed on a large scale, ${ }^{5}$ and, more pointedly, in the journal literature. ${ }^{6}$ More specifically, his work as chancellor has been assessed in the context of Britain's relations with the United States, France, and Russia, ${ }^{7}$ and the connection has been made with the interwar period. ${ }^{8}$

If there is a thematic arc to McKenna's first career, it concerned the nature of Britain's involvement in a European war. His involvement in strategic

1. Cate Haste, Keep the Home Fires Burning (1977), 17, though he has still managed to be misrepresented as a Liberal Imperialist.

2. K. O. Morgan, Wales in British Politics, 1868-1922 (Cardiff, 1980).

3. Brian Harrison, Separate Spheres: The Opposition to Women's Suffrage in Britain (1978).

4. David French, 'Spy Fever in Britain, 1900-1915', Historical Journal 21 (1978): 355-70; J. C. Bird, Control of Enemy Aliens in Great Britain, 1914-1918 (New York, 1986); Panikos Panayi, The Enemy in Our Midst: Germans in Britain During the First World War (New York, 1991); A. J. A. Morris, The Scaremongers: The Advocacy of War and Rearmament, 1896-1914 (1984).

5. Cameron Hazlehurst, Politicians at War: July 1914 to May 1915: A Prologue to the Triumph of Lloyd George (1971); John Turner, British Politics and the Great War: Coalition and Conflict, 1915-1918 (1992); George Cassar, Asquith as War Leader (1994).

6. R. J. Q. Adams, 'Asquith's Choice: The May Coalition and the Coming of Conscription, 1915-1916', Journal of British Studies 25 (1986): 243-63; Michael Fry, 'Political Change in Britain, August 1914 to December 1916: Lloyd George Replaces Asquith: The Issues Underlying the Drama', Historical Journal 31 (1988): 609-27; Richard Murphy, 'Walter Long, The Unionist Ministers, and the Formation of Lloyd George's Government in December 1916', Historical Journal 29 (1986): 736-45; J. M. McEwen, 'The Press and the Fall of Asquith', Historical Journal 21 (1978): 863-83; J. M. McEwen, 'The Struggle for Mastery in Britain: Lloyd George versus Asquith, December 1916', Journal of British Studies 18 (1978): 131-56; Martin Pugh, 'Asquith, Bonar Law, and the First Coalition', Historical Joumal 17 (1974): 813-36; Edward David, 'The Liberal Party Divided, 1916-1918', Historical Journal 13 (1970): 509-33; Peter Fraser, 'British War Policy and the Crisis of Liberalism in May 1915, Journal of Modern History 54 (1982): 1-26; Stephen Koss, 'The Destruction of Britain's Last Liberal Government', Journal of Modern History 40 (1968): 257-77.

7. Kathleen Burk, Britain, America, and the Sinew's of War, 1914-1918 (1985); Martin Horn, Britain, France, and the Financing of the First World War (Montreal, 2002); Keith Neilson, Strategy and Supply: The Anglo-Russian Alliance, 1914-17 (1984). See also Martin Farr, 'Reginald McKenna as Chancellor of the Exchequer, 1915-1916' (PhD thesis, University of Glasgow, 1998).

8. Robert Skidelsky, John Maynard Keynes, 3 vols. (1983-2000). Also D. E. Moggridge, Maynard Keynes: An Economist's Biography (1992). 
thinking, which began at the Admiralty in 1908, where he could shape policy, continued intermittently through the Home Office, where he was confined to domestic considerations, and then found its most notable expression at the Treasury, where he applied his approach most forcefully. His period as chancellor is the top of that arc, the climax of this volume, and the climax of his ministerial career. It was the only office for which he had ever harboured ambition, but he received it at a time when it was marginalised, certainly when compared to the period immediately before the war. That marginalisation has been reflected in the literature, with notable exceptions. ${ }^{1}$ The dominant political thread was the fate of Liberalism. It was more as a partisan than as a theorist that McKenna has been explored, which is why he barely features in the literature of Liberalism but is well considered in that of party. ${ }^{2}$

The two central personal relationships of McKenna's parliamentary career were those with Asquith and Lloyd George, the one bringing that parliamentary career to realisation, the other bringing it to an end. Biography has been disparaged for emphasising the personal over the political, but it is impossible adequately to assess the functioning of government from 1905 to 1916 without close reference to Cabinet relations in general, and those of its three chancellors of the Exchequer in particular. Yet, other than in passing, few have explored the dynamics of those relationships. ${ }^{3}$

Some traditions have remained hard to shift: in a centenary article on the 1906 government, he is not even mentioned, ${ }^{4}$ while another study has Ramsay MacDonald as a more significant actor. ${ }^{5}$ The revision offered by the present Life is primarily therefore through illumination. McKenna will certainly be seen as a more rounded character than before; he may also be seen to be altogether more progressive than he has appeared hitherto. Recognition of his progressivist interventionism ${ }^{6}$ is less prominent than the preponderant views that McKenna was of a more reactionary disposition. ${ }^{7}$

The historical misrepresentation that endured because of McKenna's own silence and his rivals' triumphalism, and which was then reinforced by

1. David French, British Economic and Strategic Planning 1905-1915 (1982); David French, British Strategy and War Aims (1986); Hew Strachan, The First World War (Oxford, 2001).

2. Trevor Wilson, The Dounfall of the Liberal Party, 1914-1935 (1966); Michael Bentley, The Liberal Mind, 1914-1929 (1977).

3. Peter Clarke, A Question of Leadership (1991); Gilbert, Lloyd George, 2 vols.

4. Lawrence Goldman, 'The General Election of 1906', Oxford Dictionary of National Biography, online ed. (Oxford University Press, May 2006).

5. For Colin Cross, The Liberals in Power, 1905-1914 (1963). The best history of the government remains Peter Rowland, The Last Liberal Governments, 2 vols. (1968-71).

6. R. Page Arnot, South Wales Miners: A History of the South Wales Mining Federation, 1898-1914 (1967), 341-42, 349-50.

7. Paul Addison, Churchill on the Home Front, 1900-1955 (1992), 52. 
the imprints of new travellers on old routes, has gradually reached the point where a better-informed sense of the man has emerged. No one outside the family, however, had thought to deal with him exclusively, an omission underlined, and perhaps explained, by the apparent absence of more than a few folios of private and political papers.

The chronicle of McKenna's life thus made possible provides the opportunity to assess his significance and his uniqueness. Much depended on good fortune. He came from a background uncommon in a politician of the time, and about which patronising comments were made throughout his career; a background about which he was never embarrassed but was always conscious. He excelled at school, but still required a scholarship to reach university, and always felt uncultured. Motivated by the social deprivation of south London he decided to pursue a political career, but could only do so through the sponsorship of two of his brothers. Theo and Ernest's financial support is for that reason the single most important consideration in his public career. The patronage of one noted parliamentarian, Sir Charles Dilke, provided him with a constituency, and the actions of another, Joseph Chamberlain, provided him with a cause, and it was the issue of free trade, and the inexactitude of protectionists, that helped him make his name. It followed that when the Liberals won the 1906 general election, he was an obvious candidate for a ministerial position, as financial secretary to the Treasury. He had again been fortunate in that his chief, H. H. Asquith, soon became prime minister.

Crucially, Asquith was soon more than merely a colleague. He had always appreciated McKenna's competence as a minister and came to value his company as friend. Asquith introduced McKenna to a quite different society than he was used to-and from which he had always felt excluded-and in so doing introduced him to his future wife, who soon became the most important feature of his life. Asquith also promoted him as first lord of the Admiralty, when that Admiralty ran the largest navy in the world. Three and a half years later, and to McKenna's profound disenchantment, Asquith elevated him to the office of home secretary, and, three and a half years after that, further promotion to the office of chancellor of the Exchequer. Only the reorganisation of the government in December 1916 brought McKenna's-and Asquith's-ministerial career to an end.

There was for McKenna therefore an unusually long and prominent period in high office, and one which was marked by an unusually close relationship with the prime minister. Many suspected at the time and subsequently that the former owed itself to the latter. McKenna was probably the most consistently unpopular minister during a long and controversial ministry. Unlike some colleagues, McKenna had no personal following within the party or in the country. Yet, in May 1915, when the prime minister had the opportunity, and, many claimed, the necessity, to divest himself of such an encumbrance, he not only retained but promoted his most divisive colleague. 
McKenna's competence was one factor. Even given the professional platitudes of the day, it is clear that he was uncommonly popular with his civil servants-to the point of devotion-and certainly in contrast to his predecessor and successors in each office. His appeal in Whitehall was in great contrast to appreciation of him outside. McKenna was untouched by any semblance of creativity or eloquence, and yet the unusually febrile nature of Edwardian politics, and the growth of an increasingly mass democracy and mass media, placed greater emphasis on those politicians at the highest level to be able to inspire, or at least to engage. McKenna's ambivalence was rendered into hostility when he witnessed the demotic language and behaviour of colleagues, and particularly of Lloyd George and Churchill. Close in Opposition, with the divergent interests of government office McKenna broke from them in so irreconcilable a way as ultimately to break his own political career.

This would be interesting enough were it not for the small fact that McKenna's parliamentary years-as a financier among statesmen-constitute only half of his public life. Alone amongst any comparable figure, McKenna went on to create a second, distinct, and in many ways more significant career. In 1917, in the nether world of unofficial parliamentary opposition during wartime, he was appointed a director of Midland Bank, and, in 1919, after he had lost his parliamentary seat, he was made its chairman. McKenna remained in charge until 1943, during most of which time it was the largest bank in the world. McKenna was as much chief executive as chairman, and throughout the interwar period only Montagu Norman, the governor of the Bank of England, was a more prominent financial authority. McKenna was offered the Exchequer several times by different prime ministers, and was considered a nonparty prime minister of a government of trustees himself. The second part of his career-as a statesman among financiers-will be the subject of the concluding volume of this Life.

McKenna was much happier as a financier than as a statesman. It was not, simply, a matter of remuneration, though money remained an abiding concern. Nor was it, merely, one of lifestyle; he had married late, but thereafter had a deeply happy and rewarding family life with a wife and two boys all widely regarded as being uncommonly gifted. It was most significantly because he could educate and influence the public, and policymakers, on matters he felt were of fundamental importance, and about which he felt he was right, intellectual self-confidence being a constant throughout both careers. Much of the interwar period was spent in successfully convincing the public and policy makers about a more enlightened national economic policy. Though he attracted criticism-indeed, enjoyed his profile relative to those of other bank chairmen-he never experienced the ad hominem abuse he had as a minister, or the crises of confidence that defined his worst periods. His political career was marked at the same time by achievement and great personal cost, and is the subject of this volume. 
It is through Reginald McKenna's succession of increasingly important ministerial posts, his divisive personality, his ambiguous political identity, and his possibly inadvertent role in the downfall of the longest serving prime minister to that point that he is important; it is his background, wife, family, and his developed patronage of the arts and of architecture that make him interesting.

There is therefore a task, which is to describe a life, and there is a challenge, which is to convey the nature of a person. The challenge is the greater when the person's reputation contradicts his nature. McKenna is generally held to be dry and passionless; yet he was regarded by his peers as both provocative and courageous. He seemed to retain the focus required by the Bar, his original day job: to pursue relentlessly the matter at hand, which, when resolved, was no longer a matter of any concern, and about which one could not therefore be required to express anything but indifference. Positivist rather than poet, McKenna was far removed from any study in lyricism. In a companion piece to 'Statesmen of the Great War', Guthrie might have painted McKenna and the other defeatists, whey-faced, fretfully poring over actuarial data in a stark Whitehall chamber.

Given the accumulation of misrepresentation, it is the author's intention as far as possible to let Reginald McKenna speak for himself. The emphasis is therefore on character more than context. ${ }^{1}$ The most obvious criticism, at the time and subsequently, was that he lacked imagination. Whether related or not, he certainly lacked personal self-confidence, yet he was widely thought of as arrogant. Indeed, his modesty was, by the standards of statesmen, chronic. McKenna did not like politics-a problem for a politician-and yet near the end of his life, after over two decades at the apex of international finance, when asked his occupation, he replied, simply, 'Privy Councillor'. Nevertheless, he chose to die a commoner, without membership of any order of chivalry or a single honorary degree to his name. McKenna's own predisposition appeared readily to be assumed by others. His reputation rested on his silence, leaving the voices of his critics, in the apparent absence of biographical evidence, to speak on his behalf. McKenna was traduced to conform to the self-justification of some and the preconceptions of others. Often as not, it was through the absence of interest. He always adopted the more prosaic interpretation of events, or did so on those occasions when he could be induced to comment at all. Without a memoir, or, as it was thought, an archive, in filling lacunae one could only speculate. Speculation was not something with which McKenna tended to concern himself; reflection was even rarer. A Life, particularly one as long as this, is the last thing he would have wanted.

1. For this reason, it may be found that some material relating to McKenna's private life is used outside of the strict chronological sequence that has been applied to his public career; one of few artistic liberties taken here. 


\section{Beginnings, July 1863 to July 1895}

What assurance have I that I shall ever have opportunity to use this politically much instructed but inferior wit of mine? At four and twenty, without a penny, I study Burke to learn the art of statesmanship. Ye Gods, what assurance!

-McKenna, diary $1887^{1}$

\section{ANCESTORS}

Reginald McKenna was born in Bayswater, London, on 6 July 1863, of an Irish family. The Clann Mhic Chionaoith was descended from Colla da Chrioch. ${ }^{2}$ Tradition suggested they originated from the southern Uí Neill, who moved to Meath and the east midlands of Ireland, but belonged to the territory of Truagh, in south Ulster, northern County Monaghan. The Clann may have been descended from Brian Ború, or Ollam Fodlah, ${ }^{3}$ or from the fearsome 'MacKenna of Truagh' whose deer-hunting expedition led them from Meath into Monaghan, or perhaps from the Firbolgs, the native Neolithic race driven into the mountains by the Gaels. ${ }^{4}$ Another story had it that the MacKennas had a feud with the O'Donnells, lured them into a hunting expedition, and then massacred them. The MacKennas ran home yelling 'Faustina Venatio', ${ }^{5}$ which subsequently became the family motto. From the

1. RMcK, diary, 14 July 1887.

2. John O'Hart, Irish Pedigrees (Dublin, 1881), 669. For much advice and corrections of fact and interpretation concerning the Irish ancestry of RMcK, the author is grateful to Mr Vincent Mac Niocaill, Mr James Quain, Mr Gerry McKenna, and Mr Patrick Mac Cionnaith for their assistance. A more detailed synthesis may be found in the present author's 'Clann MacKenna's Edwardian Exile', Sydney Series in Celtic Studies 8 (2005): 207-24.

3. RMcK to SMcK, 8 April 1941; Edward MacLysaght, Irish Families (Dublin, 1957), 197; Dr DáithíO hÓgáin to Gerry McKenna, 8 October 2003.

4. Shane Leslie, The End of a Chapter (1929), 1, 165; Shane Leslie, Long Shadows [1966], 5.

5. 'Good hunting'. 
eighth century the clann settled and lived in Truagh, in the words of another descendant, 'more or less turbulently ever afterwards'.

Those fables did not take account of migration, perhaps the Clann's dominant narrative. As one member put it, 'Clann Mackenna in its dispersal carried the best of its blood into foreign lands up to the twentieth century'; ${ }^{2}$ they were 'a dispersed people sent in slavery to Barbados, in chains to Australia, in famine to America'. ${ }^{3}$ They also prospered. John McKenna became General Juan McKenna in the Chilean Army before perishing in a duel at Buenos Aires in 1814, but not before, as Vicũna McKenna, he was hailed, with Bernardo O'Higgins, as father of the country in its struggle against the Spanish. There was even a Don Juan McKenna, about whose exploits unfortunately little is known. ${ }^{4}$ The clann ancestry remained a source of fascination for those so fascinated, though Stephen McKenna thought that any Irishman who may 'want to take his lineage back to the year of Bosworth Field, had better-like other men-invent it: nobody will be any the wiser.' He was at one with his uncle Reggie, who remained resolutely unconcerned with the more arcane aspects of his genealogy; he was a man who appeared to regard all aspects of genealogy as arcane. ${ }^{6}$ It enabled him to be sanguine in the face of profiles claiming that he was Irish, his mother French, or his father Governor of Santiago. ${ }^{7}$

No McKenna rose to a position of power between the first half of the seventeenth century and the first half of the nineteenth century, though several McKennas redressed that thereafter. In addition to the success of Reggie and his brothers Theodore and Ernest, three Stephens became noted writers; a Patrick was an active associate of the revolutionary republicans Wolfe Tone and Napper Tandy, while Reggie's own grandmother, Mary Plunkett Gregan, was a collateral descendant of Oliver Plunkett, the last Roman Catholic martyr to die in England, being hung, drawn and quartered in 1861, and canonized a hundred and fourteen years later. ${ }^{8}$ Virginia McKenna later proved that while some were sent in chains, others were born free.

Notwithstanding his lack of interest in his own heritage, there were some portents for Reggie from within the clann. Through the patronage of Daniel O'Connell, 'The Liberator', his uncle Joseph was placed in charge of the

1. SMcK to RMcK, 14 December 1932.

2. Ella Mackenna Mietziner, in The Mackennas of Truagh, ed. C. Eugene Swezey III, privately printed, 2nd ed. (1977), 52.

3. 'Clann MacKenna' motto, Mabel McKenna to Marquess of Linlithgow, 30 July 1950 .

4. McKenna papers, $1 / 1$.

5. SMcK to RMcK, 5 April 1941.

6. RMcK to ['SD'], n.d. [1927], [copy]; Eoin O'Mahony to RMcK, 29 March 1941; RMcK to SMcK, 3 April 1941; SMcK to RMcK, 5 April 1941; RMcK to Eoin O’Mahony, 7 April 1941; RMcK to SMcK, 7 April 1941.

7. Herbert N. Casson, Boston News Bureau [1923]; Echo, 29 June 1892.

8. Guy Collis to DMcK, 20 September 1990. 
National Bank of Ireland; so pervasive was O'Connell's patronage that his grandson Daniel married one of Sir Joseph's daughters, Helen, and Reggie retained O'Connell cousins throughout his life. After serving as Chairman of the National Bank, and receiving a knighthood in 1867, Sir Joseph stood for Parliament, being returned in 1873 first for Youghal, defeating O'Connell's opponent, the Home Ruler Isaac Butt, and then for South Monaghan from 1885 to 1892 . As an MP, Sir Joseph was something of a nuisance to his parliamentary allies, the Liberal Party, and was a supporter of Butt's eventual successor as leader of the Home Rule League, Charles Stewart Parnell. Sir Joseph made his special interest greater equality for Irish taxpayers, lobbying the Prime Minister William Gladstone to that end. ${ }^{1}$ The tardiness with which Sir Joseph felt British governments treated the issue became a source of regular and indignant public statements and, towards the end of his career, he condemned Gladstone, the act of Union, and the general financial oppression of the Irish people. ${ }^{2}$ Such straitened circumstances were not always apparent. At Ardoginna House, County Waterford, which had been part of the Plan of Campaign for rent reductions in the aftermath of the Irish Land League's Boycott, Sir Joseph and Lady McKenna hosted great parties, with the avenue of fir trees lit by five hundred torches. ${ }^{3}$

\section{FAMILY}

A few months after the birth of Joseph, his first son, in 1819, Michacl McKenna, Reggie's grandfather, left for the United States with his family. En route, another son was born, and so was baptised William Columban, though his birthplace was registered as Pennsylvania. On their return to Dublin, the father continued his seed business, while, in 1838, Columban moved to England, where such London patronage as O'Connell could command provided for another member of the clan. ${ }^{4}$ Columban was appointed as a surveyor of taxes in 1845, and though the Board of Stamps and Taxes was one of the first departments to select by competitive examination, it

1. Sir Joseph Neale McKenna to W. E. Gladstone, 27 May 1871, W. E. Gladstone papers, 44430/269.

2. Sir Joseph Neale McKenna, Imperial Taxation: The Case of Ireland Plainly Stated for the Information of the English People and of Those Others Whom it May Concern, 1883; The Irish Land Question Where the Requisite Funds for Its Solution are to be Found Without Trenching on or Imperilling the Proceeds of British Taxes the Question Considered and Answered in Connection with Mr Gladstone's Taxation of Ireland from 1853 to the Present Time, n.d.

3. The author is grateful to Dr Carole O'Reilly for these references.

4. For much of what follows regarding William Columban McKenna, the author is grateful to Dr Robert Colley for sharing his research. 


\section{Reginald McKenna}

still required nomination. ${ }^{1}$ With the reinstatement of income tax in 1842, his position was a significant one, as there were only 140 surveyors in England and Wales. Promotion was steady: by 1845 , Columban had qualified as assistant surveyor, and by 1848 became district surveyor in King's Lynn, followed, in 1852, by Bristol, Stoke upon Trent, and, in 1859, Sheffield. Around 1850, he married Emma Hanby, from Broughton, Lancashire, a descendant of John Foxe, author of the sixteenth-century Book of Martyrs. ${ }^{2}$

William Columban had done well for himself, and the couple lived with Emma's mother, Sarah, two servants and five children, at Carleton Place, Eccesall, Sheffield. ${ }^{3}$ But, for an apparently impulsive man, the pairing with bureaucracy was unlikely to last very long. While in Sheffield, in 1859, he discovered significant tax arrears in the accounts of the South Yorkshire Railway Company and, in attempting to pursue the monies, found arrayed against him local landowners and industrialists who had flourished through the laxity of the earlier surveying regime. ${ }^{4}$ The links between the interests of the Railway Company in Sheffield and the elected representatives of the area in Westminster were such that Columban was encouraged not to pursue the matter, which he summarily did by the principled act of resigning. The immediate effect was the jeopardising of his family's station and standard of living.

When his first born had died in infancy, William Columban had taken 'revenge on Omnipotence' by renouncing Catholicism. ${ }^{5}$ On 10 May 1866, omnipotence struck again, and with greater effect. The family had moved to London, where William had found work on the stock exchange with the London clearing house Overend Gurney. The firm, described by Walter Bagehot as 'the model instance of all evil in business', ${ }^{6}$ collapsed, and left the family without savings or investments, and brought a dramatic change to its standard of living. Without a covenanted term at the Inland Revenue and a civil service pension, Columban was forced to forage for employment, but still managed to help raise a fighting fund for the impecunious radical atheist MP Charles Bradlaugh, and, on reading of the Turkish massacre of Bulgars in 1876, had to be restrained from leaving on a mission to the Balkans. ${ }^{7}$

The size of the family accentuated the effect of Columban's misfortunes. There were nine children, of whom Reggie was the youngest; two died in

1. Robert Colley, 'The Shoreditch Tax Frauds: A Study of the Relationship Between the State and Civil Society in 1860', Historical Research 78 (2005): 540-62.

2. Times, 12 April 1937. She was also the godmother of Mary Lardner to Clarke, née Augusta, d. 1950. Mary Lardner to Clarke to RMcK, April [1908].

3. 1861 England census, National Archives, PRO/RG9/3468114/17/543137.

4. Dr Robert Colley to the author, 30 July 1999; Colley, 'Railways'.

5. $R M c K, 36$.

6. Walter Bagehot, Lombard Street: A Description of the Money Market, 5th ed. (1873), 273.

7. $R M c K, 36,27$. 
infancy, and the survivors were Alice, Leopold, Mary, Theodore, Gerald, Ernest, and Reggie. The number and age range ensured that few of the children had anything more than their parentage in common, and with the exception of the two youngest, Reggie and Ernest, none stayed particularly close. ${ }^{1}$ Their birthplaces marking their father's peripatetic existence, Alice and Leopold were born in King's Lynn, Theo was born in Bristol, Gerald, and Mary were born in Stoke, Ernest in Sheffield, with Reggie finally in London. Leopold became an accountant, and had four children, one of whom was Stephen, the future memoirist of Poldy's youngest brother. Gerald, who was close to Reggie in childhood, died relatively young. By some recollections the brightest of all the children, Gerald had conducted a spectacularly successful career on the Stock Exchange, until his sudden death.

Much closer was brother Theo. Theodore became a solicitor in 1882 , specialising in patents and trademarks. He set up his own practice three years later as McKenna and Co., which was based in London and went on to span three centuries, latterly as Cameron McKenna. Other than conspicuous professional success, the most obvious connection between Reggie and Theo was physical: despite the difference in age, they appeared to be identical twins. Such was their similarity that Reggie occasionally impersonated his brother on business during high summer when Theo was off on one of his long holidays. They had little else in common. Theo married twice, and he and his much younger second wife Ethel were noted 'first nighters' around town, their evenings beginning at Portland Place-subsequently Bryanston Square-and ending at their table at the Ivy. Ethel was the daughter of the eminent surgeon Morell Mackenzie, who, infamously, failed to operate on the throat cancer of the Kaiser's father, Frederick III, in 1887, which meant, among other things, that a twenty-seven year wait resulted in a ninety-nine day reign. Mackenzie responded to subsequent accusations of professional indiscretion by writing a book about the episode, for which he was censured by the Royal College of Surgeons. In the years before his political career would do so, Ethel helped introduce Reggie into the ambit of court politics and international affairs. Theo's most striking achievement was fictional: as the inspiration for Cosmo Forsyte, in John Galsworthy's saga. Another lurid achievement was quite real, and also made it into print. Dining with Theo at Bryanston Square one evening, the novelist and family friend Arnold Bennett noticed of his host that 'one or two skins had burnt off. He could scarcely talk, or eat. His tongue shrivelled and hard. He was all black'. ${ }^{3}$ Theo had fallen asleep under his violet-ray lamp, could not leave his house for a month, and appeared in The Lancet as a case study.

1. Sister K. N. McKenna to DMcK, 23 March 1972.

2. Ella Dixon, As I Knew Them [1930], 90; Michaela Reid, Ask Sir James (1987), 261-66.

3. Arnold Bennett, diary, 7 February 1925, in The Journals of Arnold Bennett, Volume III, 1921-1928, ed. Newman Flower (1933), 74. 


\section{Reginald McKenna}

For all Reggie's and Theo's similitude, it was Ernest, as Stephen put it, who was Reggie's 'twin-brother in everything but years'. ${ }^{1}$ A year younger, Ernest was, and remained, Reggie's closest male companion, and his only male intimate. Clever, and, by most accounts, indolent, Ernest married his first cousin, a widow, Agatha Gibson. As with Reggie and Theo, Ernest had a facility with figures, and not long after Gerald had made his fortune, Ernest too made money on the Stock Exchange in their uncle Michael's office. Unlike Gerald, for whom the choice was denied, Ernest came to the conclusion that he had in fact made enough money, and retired at the age of thirty-four to a life divided between the Reform Club, Villa McKenna on the English Channel, Villa Urie on the French Riviera, and wherever Reggie happened to be living at the time. 'A delightful fellow', one of Reggie's closest friends thought, 'with the kindest possible face. ${ }^{3}$ Portly, musical, and wise, Ernest served as the counterpart to his much more rigorous, sensitised, and logical younger brother. Each would call on the other when his own natural gifts needed to be supplemented, and Ernest's early retirement allowed him to apply himself full time to his role as Mycroft Holmes to Reggie's Sherlock.

What characterised the younger brothers was that, without inherited wealth or influence, Gerald, Ernest, and Reggie were dependent upon their talents. They were all sharp-witted, high-spirited, and combative, in conversation as well as in argument. Emma had learnt to have a Bible, Shakespeare, and a dictionary to hand when a dispute between the three of them required adjudication. The boys were boisterous, with Reggie tending to be picked on as the youngest. Perhaps for that reason he was also the closest to his mother of any of the children. She delighted that, at a fairground, the infant Reggie beat the resident mathematical genius in a high-speed mental arithmetic challenge. Reggie's closeness to his mother was the dominant feature of the first quarter of his life.

By 1871 , Columban and the elder children had moved to 2 Cheyne Walk, Chelsea. ${ }^{4}$ Due to the effects of the Overend Gurney collapse, however, 'little Em' had taken the three youngest to France, where she had been educated. Villa McKenna was in Etrêtat, in Normandy, a small fishermen's village that was 'jealously guarded by the few families who frequented it, and which remained the favourite holiday-place of a chosen band of intellectuals ${ }^{5}$ including at that time Gustave Corbet and Claude Monet. From its shores, into the strong currents of the English Channel the young Reggie grew into a powerful swimmer and acquired what would be a lifelong love of the sea.

1. $R M C K, 29$.

2. DMcK to Arthur Marder, 2 June 1955 [copy].

3. Walter Runciman to Hilda Runciman, 24 July 1906, Runciman papers, $303 / 1$.

4. 1871 England census, National Archives, PRO/RG10/75/60/56/824580.

5. Times, 17 August 1921. 
Meanwhile, at Field Court, Grey's Inn, Poldy and Theo, with their father, earned enough to send weekly remittances to France. Reggie wrote shortly after of Poldy:

I have perfect confidence in his sense of fairness, and I can never forget that his labour supported the whole family of us in our times of need. He never failed to send us 3 youngest ones our weekly pocket money out of his own pocket, when troubles were sufficient to make him forget and money was scare enough to make $8 \mathrm{~d}$ a week a consideration. ${ }^{1}$

Years after all his siblings were dead, Reggie could start the lightest discussion of family business with the words 'I can support no course of action that in any way affects adversely any of Leopold's children'.2

The remittances meant that Reggie had probably the most comfortable childhood of all, yet money was always a priority, and often a preoccupation, for the youngest of the family. Reggie's attitudes about wealth and status were, and remained, closely linked. When a friend spoke 'about the old English families evidently with great respect for them, I am afraid I am not much inclined that way', Reggie confessed:

To be rich is something, but to merely belong to a family who have lived in such and such a place for 500 years, what is it? Provided a man is well bred and has sufficient money to support him in comfort he is in quite as good a position as the bluest blooded man in the world has. ${ }^{3}$

'I like staying with rich people', he said many years later. 'If they've made their money, I want to know how they've made it. If they've inherited it, I want to know how they've kept it'. ${ }^{4}$

\section{SCHOOLING}

Aged seven, Reggie went to Afton House College in Chiswick, with Gerald and Ernest. ${ }^{5}$ From there, in 1871, Reggie went to school at St. Malo, in France, until he was eleven, and thence, with Ernest, at Ebersdorf near Bamberg, in Germany, until he was fourteen. Though it served to strengthen the relationship of the two youngest brothers, it was an isolated upbringing. Half a century later Reggie admitted, 'I do not think that I have met a single

1. RMcK, diary, 24 October [1888].

2. RMcK, in $R M c K, 26$.

3. RMcK, diary, 17 January 1884.

4. RMcK, in $R M c K, 49$.

5. 1871 England census, National Archives, PRO RG10/1321/4/2/828268. 


\section{Reginald McKenna}

one of my school-fellows since I left'. ${ }^{1}$ They did not make many friends, but appealed to their teachers. 'Ernest and Reginald are the only scholars who think', thought their master, Bruder August Freytag. ${ }^{2}$ On reflection, in retirement, he concluded that 'both McKennas were, in forty-five years of office, my most diligent and obedient pupils. ${ }^{3}$ Fluency in French and German rather than in Latin and Greek would prove significant, as indications of both outlook and upbringing, more modern than classical. As Lord Claud Hamilton, the Unionist MP, later put it,

Balfour knew no French; Lord Grey speaks French disgraceful on the lips of a Foreign Secretary; Mr Asquith's French is excessively bad; $\mathrm{Mr}$ Runciman speaks fair French, and Mr McKenna speaks fluent conversational though not colloquial French-but then McKenna never went to any of our great public schools. ${ }^{4}$

Private enterprise provided the possibility of some stability to family life back in England, but, since it depended on Reggie's father, it was still capricious. William Columban for several years had been a director of the Stubbs Mercantile Agency, part of the Trade Auxiliary Company. Three men formed the company in 1866, and remained its directors: Columban, Vickers, and Chadwick. In January 1872, after Columban had bought the shares of the others, they claimed that they nevertheless remained directors of the firm. Not only would they not withdraw from the company offices in Gresham Street when requested, they decided to lock Columban out of the building. Columban went off, and returned with crowbars and some Irish labourers who proceeded to break open the doors, take over the offices, and throw Vickers and Chadwick out. ${ }^{5}$ The trio were subsequently called before the Lord Mayor of London for censure. Columban went on to sue Vickers and Chadwick, and prevailed, his case helping to advance the governing of joint stock companies where, as the judge Sir Richard Malians put it, 'violence and disorganization' prevailed. ${ }^{6}$

Family fortunes had recovered sufficiently by 1878 for William to move to 6 Ravensbourne Park, Catford Bridge, Lewisham, and take on two more young servants. ${ }^{7}$ Alice and Poldy had moved out, and with the improved family finances, Reggie returned to London to complete his secondary

1. RMcK to August Freytag, 22 December 1922 [copy]; RMcK to John Marriott, 5 March 1929 [copy].

2. August Freytag to RMcK, 11 July 1926.

3. Bruder Freytag to RMcK, 9 November 1922. The author is grateful to Professor Tim Kirk for the translation.

4. Hamilton, in Vagaries of a Vagabond by George Gray (1930), 20.

5. 1-2 July 1873, Trade Auxiliary Company v. Vickers, V.C.M. 16.

6. Sir Richard Malins, 1, 2 July 1873, Trade Auxiliary Company v. Vickers, V.C.M. $16,305$.

7. 1881 England census, National Archives, PRO/RG11/735/117/10/1341171. 
education. In the spring term of 1878, he joined 589 other boys at King's College School. ${ }^{1}$ King's College had been founded by Royal Charter in 1829 to offer general education to the sons of the middle classes destined for commercial careers; the School was established at the same time, two decades before the great expansion in public schools, as the junior department to the College. Though it moved to Wimbledon Common a few years after he left, when Reggie was there it was also physically subservient, being housed in 'gloomy vaults' beneath the College where pupils spent their days, as one master put it, in the 'congestion of the infernal regions.' With a cramped central location, poor endowments, few scholarships, and high fees, the school reached a nadir in 1885 when a boy was bullied to death, prompting the intervention of the home secretary, Sir William Harcourt. Nor did the school do much more than Ebersdorf in adding to the leading personnel of state and society: as an adult, Reggie seldom came across a fellow inmate of 'the doomed dungeons of the Strand'.

Academically, however, King's College School was perhaps the best in the country. It emphasised mathematics, modern languages, and natural sciences, and though most students would leave at the age of sixteen, the rest were expected to go up, literally, to the senior department_- King's College, University of London-or to Oxford or Cambridge. Having started to take exams set by the Examination Boards of Oxford and Cambridge in 1873, by 1881 the school's results were better than those of any other apart from Eton, which gained one more certificate with twice as many pupils. In this environment, Reggie flourished. By the end of 1878 he had won the Lower Third Classics, French, and the Middle School Greek prizes; the following year he won the Middle and Upper Fourth, and Lower Fifth, Maths, and Upper School French prizes; in 1880 the Lower and Middle Sixth Maths, and Upper School French prizes; in 1881 the Upper Sixth Maths and Upper School French prizes, and a Freake Exhibition in Maths; and in the summer term of his final year, the King's College School Maths Scholarship, and an exhibition at Trinity Hall, Cambridge. ${ }^{4}$ Of the seven candidates for exhibition in 1882, Reggie comfortably came top, and the admissions tutor 'Agreed to offer to Mackenna $£ 40 .{ }^{5}$ Without a scholarship, McKenna's place would have been in doubt; he was, however, too old to be awarded the scholarship. For his future career, Reginald McKenna owed much to his Headmaster, the Reverend Dr Thomas Henry Stokoe, who raised the upper age limit from eighteen to nineteen to allow it to be awarded to a pupil, 'though he

1. F. J. C. Hearnshaw, The Centenary History of King's College, London, 18281928 (1929), 326-27; Frank Miles and Graeme Cranch, Kings College School, The First 1.50 Years (1979), 129.

2. Hearnshaw, King's, 153.

3. Ibid., 373; RMcK to John Marriott, 5 March 1929 [copy].

4. King's College School Register, vol. 2, 1985.

5. Trinity Hall, tutorial records, vol. 80 . 
has exceeded the specified limit of age. It is, I am assured, a matter of some importance to him, and no other eligible candidate would be excluded by such arrangement. ${ }^{1}$

\section{CAMBRIDGE}

Trinity Hall was a small Cambridge college, socially conservative, politically liberal, and religiously dissenting. It had a reputation for producing rowers and lawyers, and Reginald McKenna duly became a rower and a lawyer. Behind an eighteenth-century façade, the Court, and the Screens, stood an Elizabethan library and buildings that originated in the fourteenth century. There were, architecturally, more impressive colleges, but it was probably impressive enough for a small, balding scholarship boy with eczema, alopecia, and a stammer. He also had severe money worries, and perhaps consequently a preference for applied over pure mathematics, and little confidence even in that. Reggie went up at Michaelmas 1882. 'Practice has done a little for me, but I am certain now I am not any good for mathematics,' the prizewinner wrote. 'I am beginning to be more than doubtful about my capabilities'. ${ }^{2}$

One of the most pronounced of Reggie's many pronounced characteristics as an adult was a disinclination to self-analysis. It was contrary to appearance. As Stephen put it, 'Seriousness dwelt so near to solemnity that his head at any age seemed older than the shoulders that supported it'. ${ }^{3}$ While an undergraduate, however, Reggie kept a diary that constitutes the only evidence of his thoughts at the time, and helps facilitate a coherent account of his personal and intellectual development. From the outset, the diary was a very self-conscious expression of self-consciousness. 'A diary is a great undertaking,' the twenty-year-old wrote. 'I am afraid I shall be very awkward at writing my day's experiences at first'. ${ }^{4}$

The most prominent private feature of his reflections, and another not to survive into adulthood, was religion. More than many colleges, Trinity Hall indulged nonconformity. Most of his college friends, including Sidney Swann, Percy Stanley, and Donald Tait, became ministers. In adulthood, Reggie was never regarded even as a man of faith. ${ }^{5}$ Nominally a Congregationalist, as an adult he professed agnosticism. He attended church only occasionally, and then for his enjoyment of Old Testament stories told by

1. Stokoe, in Miles Kings, 129.

2. RMcK, diary, 17 January 1884.

3. $R M c K, 166$.

4. RMcK, diary, 15 January 1884.

5. DMcK, in conversation with the author; HHA to Sir John Simon, 26 June 1915, Simon papers, 51, 76; 'I am a member of the Church of England who habitually takes advantage of the Toleration Act', Daily Graphic, 29 December 1912. 
a favourite preacher and family friend, Canon James Hannay, at Mells in Somerset. Nor could the Catholicism of the clann explain the evangelical nature of the conversion Reggie experienced as an undergraduate.

I believe in God who worketh in all things. I believe Jesus Christ to be one with God; for so he declared himself, and I believe his testimony to be true. I believe that in June $1884 \mathrm{I}$ had a spiritual experience unknown to me before. It was as a revelation of the truth of God and of Jesus Christ; passing all certainty that might come from reasoning; all sufficing in itself, and giving peace to my spirit, such as I had never known before, nor ever since in the same degree. I live in the hope that God will repeat this revelation of Himself within me and that he will give me strength to throw aside the bondage of my flesh, that I may follow with pure heart and single mind the guidance of the spirit. ${ }^{1}$

Yet even such expressive faith was riven with doubt, and fear of failure.

Always the one question revolved over and over again. The uneasy consciousness that I am not serving God as I should, the longing to live or rather be able to live wholly for the spirit, the eager desire for truth absolute and undoubted, real living burning faith, all these fill my soul. And yet I am not prompted to action; a physical apathy creeps over me when I try to face these thoughts sternly and make my actions agree with what they would teach. I act in a groove and think out of it. And yet thank God I always feel at bottom enough of love, faith and hope to give me peace again when I am most jarred. ${ }^{2}$

As with his academic self-reproach, 'I find now to my shame that the task which I proposed to myself six months ago of learning what Christ has told me is very little advanced. Pray God His Will be done with me. ${ }^{3}$ Consequently, 'To-day I start anew with one settled purpose. I hope by daily noting in here to bolster up a determination never too strong in respect of my purpose.'

It was the beginning of what he referred to constantly as his 'oath', and which came to define a somewhat puritan university experience.

What folly there is in taking an oath on a matter of personal conduct no one has occasion to know more than I. Yet once again I have bound all my future action by an oath spoken under a state of mind produced by the circumstances of the moment. This all I can say in defence, that to act according to my oath, whether I had taken it or not, should be my

1. RMcK, diary, 3 September 1885.

2. RMcK, diary, 5 August 1885.

3. Ibid., 30 November 1884. 
best endeavour, and the fact of having sorrow may add sufficient weight to one side of the balance to keep it always depressed. A determination, except with men of an exceptionally strong character, lasts only as long as the conditions which gave birth to the determination remain fresh. Nothing is more difficult than to recall a state of mind, which is foreign to the usual character, and is the outcome of exceptional circumstances. It is the same with our physical sensations. Who when labouring in a midsummer heat can recall the sensation of winter's cold? Or who, risen from the table, can reproduce a mental picture of the so oft repeated sensation of hunger? Our mental states attune themselves naturally to the touch of our momentary surrounding conditions; it is the office of "principle" and "morality" to free us from this physical dependence, and to train us to suppress some emotions and to foster others. Teachers of religions inculcate the habitual use of prayer, whereby a devotional state of mind may become our daily companion. In praying we constantly endeavour to recall the highest feelings of reverence we have ever known; true, our surroundings at the moment may not be such as of themselves to induce in the smallest degree such a state of mind, yet by constant effort we learn in some sort to reproduce former impressions, whereto we are helped by the conscious exclusion of other thoughts, and the necessary self-abstraction. To a man earnest in prayer, reverence, with its companions humility and love, becomes a habit, and herein lies the overwhelming virtue of prayer. I think prayer, then, to be an effort to recall the noblest state of mind. ${ }^{1}$

Reggie's 'oath' provided routine and practice to a life that could already be characterised by such disciplines, and would continue to be.

While a head of thick curly brown hair would not long survive early adulthood, and a countenance that could appear impassive when not supercilious would, young Reggie's most obvious source of inhibition was not physical but vocal. He had a bad stammer, 'and he was resolved to conquer this', a friend recruited to help recalled. ${ }^{2}$ One challenge he set himself was debating at the Cambridge Union, but the most important was his routine of reading the writings of Edmund Burke aloud for several minutes every morning. Burke's oratorical fashion being ideal for recitation, the choice was functional, rather than political, and Reggie maintained the practice throughout his life, perhaps as much through routine as through fear of regressing. ${ }^{3} \mathrm{He}$ was so satisfied with the method that he later recommended it to the Duke of York, who, as George VI, had less apparent success.

1. Ibid., 13 July 1887.

2. J. B. Atkins, Incidents and Reflections (1947), 59-62.

3. Viola Tree, Can I Help You? (1937), 82. 
The additional concern, which he could do less about, his brothers' largesse notwithstanding, was financial. 'I settled up my account', he wrote at the beginning of 1884, 'and found the outlook not at all promising'. ${ }^{1}$ Money worries encouraged his obsession with self-improvement, which he pursued intellectually through apparently painful autodidacticism. 'Only five and a half hours work', he confessed one Saturday. ${ }^{2}$ The following Tuesday

I read The Mill on the Floss most of the day. What a great recollection George Eliot has of the feelings of her childhood. I think she and Disraeli are about the only two authors I know who could appreciate the passion, the suffering, the love and the ambition of childhood. I know I myself do not feel personally, I mean, my feelings and sensibilities are not nearly so acute now as they were two or three years ago. My ambition too is not so fanciful and exalted as it was before, though it is strong enough now to supply myself. The strong passions and deep suffering of a child like Maggie, with a vivid imagination and a great amount of affection, are very drawn. I can feel for her in my memory of childhood. Tom's character too is very well drawn, I can feel a touch of him well too within myself. I do not know how it is, but in every well drawn character no matter of whom, the greatest hero or the lowest villain, the brave genius or the most contemptible sneak, I can see some of myself. Human nature is many sided. Eight hours work. The best so far. ${ }^{3}$

As aware as he was of the merits of logic and the pursuit of verifiable truths-and critical of those who did not-Reggie was conscious of the limitations mathematics imposed on him, but also of its effects as a stimulant to wider learning. 'Hard work ... is good, not for the improvement in mathematics itself but for the taste it gives one for other work. I never feel so inclined to sit down and read a stiff book on any subject whatever as I do after a couple of hours of maths' ${ }^{4}$ Certainly, a couple of hours of maths did not appear to make him feel any less uncultured, or under-read. With Eliot, his private reading at the time included Samuel Butler, Carlyle's Sartor Resartus, Darwin, much Dickens, Froude's English in Ireland, Reid's Life of Forster, Ruskin's Sesame and Lilies, and Thackeray's History of Henry Esmond; Buckle's History of Civilisation, Macaulay's Essays, and Bunyan's Pilgrim's Progress were three books that 'influenced my thought as well as interested me'.

1. RMcK, diary, 15 January 1884.

2. Ibid., 17 January 1884.

3. Ibid., 21 January 1884.

4. Ibid., 16 January 1884.

5. RMcK to R. T. Hopkins, 19 February 1926 [copy]. 
More than the routine of declaration or of prayer, competitiveness provided the most important counterpoint to Reggie's diffidence. Through the same methods as he had applied to his intellectual development, he made himself into an athlete. Reggie's dedication, even at school, one friend recalled, ensured football teams always sought the slight youth, and he was an accomplished gymnast. ${ }^{1}$ He had gone to Cambridge knowing nothing of billiards, but started playing once there and within two years had won the university cue. ${ }^{2}$ He similarly excelled at chess and bridge, but, with the coast of Brittany so prominent in his upbringing, Reggie was a wet, rather than a dry, sportsman. Whether in the water, diving or in races at Lambeth Baths, or on it, in any form of boat, it was and remained his favourite environment, offering ample scope for the physical bravery for which he became renowned. ${ }^{3}$ More profoundly, the requirements of rowing helped shape Reggie's life. He spoke later of what being a successful oarsman required: 'how much endurance, how much physical pain, how much attention, obedience, and discipline'. ${ }^{4}$ He practiced on a rowing dummy he installed in his room, ${ }^{5}$ and within a year had appeared in the college first boat. What most impressed observers was his watermanship, his control of the balance of the boat. John Atkins thought it 'consummate ... Reggie McKenna, who was a lightweight, was unerring in every instinct of balance, and could forestall his partner's clumsiness ... The cleanness of his running headers was a sight.' ${ }^{\prime}$

Reggie's greater distinction was, however, as a coach. Henry Bond, a fellow and future master of the college, remarked how Reggie 'thought out the whole theory of rowing afresh for himself', and in so doing became the most successful coach Trinity Hall College had ever had. ${ }^{7}$ He felt that the essence of the act should be to use the strongest muscles, which were the legs, rather than the arms, which merely guided the blades in the water. In instructing crews to forget their arms, he contradicted the orthodoxy, which dictated that both arms and legs were to be used as forces for propulsion. Thus, Reggie became renowned as a theorist and an early proponent of the long slide, and his Trinity Hall crews were known, like their coach, as being light, but very precise. The success of the Hall crews in the 1880s and 1890s advertised the method. The coach's approach became conventional, if not his manner: several generations of rowers experienced him on horseback, trotting along the towpath shouting directions as to the exact position of an

1. John Marriott to RMcK, 28 February 1929.

2. Yorkshire Evening Post, 6 September 1943.

3. Philip Bright to RMcK, 13 April 1908; Sidney Swann to RMcK, 26 September 1927 [citing a contemporary letter].

4. Westminster Gazette, 8 June 1907.

5. Lord Beaverbrook, Success (1922), 46-47.

6. Atkins, Incidents, 60.

7. Henry Bond, A History of the Trinity Hall Boat Club (Cambridge, 1930) 85. 
outstretched shoulder, or that the oar of one unfortunate missed the beginning, washed out at the finish, and had nothing to speak of in between. ${ }^{1}$

\section{INNER TEMPLE}

To religion and rowing as an undergraduate, Reggie added the more pressing requirement of a profession. Given his family background, his aptitude, and his education, a career in the City was the obvious one, and one that Theo, Gerald, and Ernest, not to mention William Columban's muscular presence, would have facilitated. However, at Cambridge McKenna decided on training to be a barrister. Selecting the Inner Temple, McKenna paid his fee and deposit, and submitted his references, from G. Elion, barrister of the Middle Temple, and Thomas Bucknill, barrister of the Inner Temple. The Inn admitted McKenna as a member on 26 January $1884 .^{2}$ Described in the admissions register as 'aged 19, of Trinity Hall, Cambridge, the fifth son of William Columban McKenna of 2 Sheffield Terrace, Kensington, in the County of Middlesex, gentleman', there is almost no evidence as to his motives or his process, but some evidence that they were at least consistent.

I have eaten two law dinners this week. This is my first term, so I am only now just beginning to be a barrister. The dinners are not impressive enough, neither are they social. The original purpose of forming a friendship amongst barristers of the same standing has died out entirely; we were all as much strangers when we left as we were when we went in. The whole thing is a farce, and I do not see any way of rendering it more reasonable. ${ }^{3}$

Though the public dimension was disagreeable, he excelled at the private requirements. 'I hope I am more thorough in all work. I think I am, but it will not do to be confident till the end of term', Reggie wrote in his first autumn. Yet it was something to which he warmed.

My work is to my taste, what it never was before. It has been added unto me, and I thank God for it. The old Adam has been breaking out as strong as ever this term. But there is no great point gained. The fears are more perceptible than they used to be. When they are recognised they may be uprooted, till then they must reign supreme. Self-knowledge is

1. J. M. Furniss to RMcK, 12 December 1943, Midland Bank papers, 192.069; Addison McLeod to PMcK, 16 September 1943; Sir Edgar Waterlow to RMcK, 22 January 1943, Midland Bank papers, 192.069.

2. The author is grateful to Dr Clare Rider and Mr Adrian Blunt, of the Inner Temple, for information regarding RMcK's training as a barrister.

3. RMcK, diary, 29 January 1884. 


\section{Reginald McKenna}

what I want, not the knowledge or rather want of knowledge which self love allows me, but the true revelation of myself to myself by God. Hasty intolerance of what I dislike, without a careful consideration if the dislike is justifiable ... is what I very much require. ${ }^{1}$

The adult was recognisable in the undergraduate. Self-conscious of what he felt were limitations in ability and background, he sought to compensate for them by industry and competitiveness. The talents he possessed tended to be those regarded as respectable rather than inspiring, and that was how they remained. He was straightforward, without conspicuous charm, and with no interest in currying favour: 'what a base tool flattery is. Heaven preserve one from using it. A little amusement might be pardonable, but nothing beyond that.' ${ }^{2}$ His development had been marked, and marked as much by those elements that would play no further part in his life as by those that would.

'It is certain that rowing claimed a greater share of his time than did mathematics', Henry Bond recalled, 'and a still greater share of his thoughts.' Consequently, McKenna graduated, in 1885, a senior optime rather than a wrangler, to his subsequent regret. ${ }^{4}$ Yet he had not been diverted from his essential preoccupation. Whether the subject was mathematics, billiards, chess, bridge, or rowing, for him the attraction of an activity was in the precision of process, in the exactness of the conception and realisation of a complex undertaking. It helped explain his later, practical, interest in architecture. He demonstrated it in those areas of his life where he worked and, less often, where he played. He took his pleasure as much in appreciating the skills of musicians and artists as he did in the music or the art itself. Even late in life, as his nephew noted, he brightened at the chance to inquire of another's activities, 'he would pour forth a searching stream of questions on construction and composition'.5

He wanted to know how an artist planned his composition and how an author plotted the scenario of a novel. This boyish eagerness to master a new subject sometimes surprised and always delighted those who had expected to find him solemnly playing a careworn statesman or grave financier in private life. ${ }^{6}$

Though never one ostentatiously interested in children, Reggie liked to interrogate young men as to their hopes and ambitions. It was a quality

1. Ibid., 9 October 1884 .

2. Ibid., 22 January 1884.

3. Bond, Trinity, 85 .

4. Westminster Gazette, 8 June 1907.

5. $R M c K, 164$.

6. Ibid., 49. 
that did not contradict the observation-or criticism-throughout his life that Reginald McKenna was deficient in imagination. What he did was take vicarious pleasure in the inspiration and ambition of others, at the same time as 'inducing a feeling of non-personal excellence' himself. ${ }^{1}$

\section{7}

1887 was 'the Annus Mirabilis of Trinity Hall rowing', ${ }^{2}$ as it was for Reggie more generally. He spent ten days with the team at Devonport in training, being coached from the bows of a passenger steamer with the result that 'we certainly could hear nothing of what the coach said', ${ }^{3}$ but 'when we moved to Henley we were all in first rate conditions and spirits. ${ }^{4}$ Reggie duly rowed in the crew that went Head, and was bow in the crew that won the Grand at Henley, where he coached the Hall eights that won the Challenge Cup and the Ladies Plate, and himself rowed bow in the winning Steward's Four. The rowing that year centred on the annual boat race with Oxford. After weeks of twice-daily practice, often in snowfall, and with early morning runs around Hyde Park, on 26 March, Reggie took his place as Cambridge's ten-stone seven pounds bow in the university eight. Followed by a fleet of vessels, including four steamers, one for the umpire, one for each university, and one for the press, and in front of the largest crowd for many years, Cambridge took a slight early lead, which it maintained, until a late rally from Oxford, which resulted in its No 7 breaking his oar and thereafter literally going through the motions. Cambridge won by three-and-a-half lengths. Turning back to land at the Ship pub, the Cambridge boat narrowly avoided collision with a flotilla that had surged from its moorings for a closer view of the victors. ${ }^{5}$

1887 was the year of a more confident and ambitious voice. 'Great change has come over me in the last two years, more than I should have recognized but for the occasional entries in this book', ${ }^{6}$ and incessant admonition 'Daily to work at improving my capabilities, and still at 24 , without money, to be doing nothing to provide for myself, is to build high upon hopes'. ${ }^{7}$ Reggie's reflections became less overtly religious and more about the likely lessons of life: he went beyond reflection, into speculation:

1. DMcK, in conversation with the author, 10 April 1996.

2. Viscount Maugham, At the End of the Day (1954), 36; Atkins, Incidents, 60.

3. RMcK to Henry Bond, 17 June 1929.

4. RMcK, in Bond, Trinity, 69.

5. Times, 28 March 1887.

6. RMcK, diary, 13 July 1887.

7. Ibid., 14 July 1887. 
According to our novelists to live in a magic expectancy of something turning up is the characteristic of do-nothings, Micawber, Jack Raikes. But the belief in a personal good fortune, a fairy sprite watching over us and awaiting only the best opportunity to shower gifts upon us, is common to all. True this sprite is mischievous, and chides us in this present moment of time, but she (or is it a he) is still hovering over us, and will one day descend and nestle with us. Experience never teaches us, that for 99 people out of 100 this fortune is a myth, and that in very great probability humdrum will be our lot in life; and for this best of reasons that we don't want to be taught. The pleasure of this kind of imagination does not lie in the actual expectancy, but in a vague excitement, not unlike in a small degree what is felt before starting for a holiday. No one, not a fool, defines even to his most secret self a probable path for his good fairy, but in moments of weariness he can fall back upon vague possibilities and find there a spring wherein his flagging energies may take a cooling draught. Only let him not drink deep. The cordial is as seductive as wine, and like wine bears no excess. ${ }^{1}$

He also placed himself in a social context, in such as way as would have later, political, significance:

Today I have said 'Independence of character is my great aim'. 'It will make you hard', replied the girls. But wherefore? Surely a man loses no little of sympathy for others, because he refuses to let himself be blown about by every fleeting breath of opinion. Let action be founded upon principle, and let who shall care for another's hasty judgement. But it is not so much in the grand matters of life that independence is necessary. On a trying occasion a man is brought face to face with himself, he speaks and acts for himself, the unconscious influence of others is swept aside. It is in the every day trifles that a man is most moored by the gregarious instinct; his private judgement is asleep, while his spring of action is what is expected of him. Let a man but preserve his independence and what will be expected of him will be what he does. He will lead, not follow. He will be a reasoning, rational creature, not one of a flock following the bellwether. Whose attempts to please all will become ridiculous in his pliance. If you always agree with your neighbour, and honestly, too, in your desire to please, you will not only lose the power of true discrimination, but your neighbour himself will not continue to take pleasure in your agreement; for he will recognise your judgement to be colourless. 
Be amiable, but not servile; tolerant, but not dependent. Let the amiability spring from feeling, not merely from manner, but let it be joined to self-respect. ${ }^{1}$

1887 was the year his father died. It was the year his mother returned to France permanently. 1887 was also the year, on 17 November, after four years of study culminating in the Council of Legal Education's bar exam, that Reggie was called to the Bar. He served his pupillage from 1888 to 1894 at 1, Dr Johnson's Buildings, Temple, E.C. McKenna's first case was in 1888, and his last in $1895 .^{2}$ In his diary, his legal activities pass virtually without mention. Just as Theodore specialised as a solicitor in patents, so the cases with which his youngest brother was concerned tended to be commercial, concerning disputes between individuals and companies, particularly over company law, trademarks, and copyright. Word went round between businesses of his abilities, and with that came recommendations that were both 'Flattering and profitable.' ${ }^{3}$

Notwithstanding his father's experience of joint stock companies, Reggie's own need for greater financial independence gave him the idea of becoming a director of Stubbs and Co. Stubbs was still associated with the Trade Auxiliary Company, and the family retained four-elevenths of the shares. As ever, Ernest supported his younger brother, but 'Leopold is apparently quite upset at my suggestion', which in turn upset Reggie: 'I must make Poldy understand that nothing is further from me than a wish to make myself disagreeable to him. ${ }^{4}$ In the end, Reggie stayed at the Bar. His ambivalence ensured, however, that he did not feel that the law was in any way his calling, and he did not take silk. Family connections were mutually beneficial, with most of the cases having Theo's firm as the solicitor. ${ }^{5}$ A Queen's Counsel led McKenna in each case. They included Robert Finlay, the future lord chancellor, and Unionist MP for Inverness Burghs; Herbert Cozens-Hardy, the future master of the rolls, and Liberal MP for North Norfolk; and John Moulton, future lord of appeal, who in 1885 was elected Liberal MP for Clapham. While money may have inclined Reggie to follow his brothers into the City, his environment increasingly suggested Westminster.

1. Ibid., 18 July 1887.

2. 25-28 January 1889: Cate v Devon and Exeter Constitutional Newspaper Company, 40 Ch.D. 500; 4, 5 December 1889: Starey v Chilworth Gunpowder Company, 24 Q.B.D. 90; 27 April 1891: Salaman v Warner, [1891] 1 Q.B. 734; 26 July 1892: in re Henry Clay and Bock and Company, [1892] 3 Ch. 549.

3. RMcK, diary, 3 October 1888.

4. Ibid., 24 October 1888 .

5. 21 December 1888, 6 February 1889: Trade Auxiliary Company v Middlesborough and District Tradesmen's Protection Association, 40 Ch.D. 425. 


\section{CLAPHAM}

During his legal training and then practice, McKenna increasingly became interested in politics. He experienced a political conversion less dramatic but more profound than the youthful evangelism of college; it appeared to supplant faith. The nature of his religious experience, his general awkwardness and self-consciousness, and the reasons for these characteristics suggested a Liberal more than a Conservative temperament. He was further encouraged by the dominance throughout his youth of Gladstone, who, through his efforts to bring Home Rule to Ireland, became McKenna's political hero. By the late 1880s, however, the circumstances for a Liberal were less propitious. The years of great Liberal ministries that marked his childhood and university days had passed. Gladstone's abortive third administration had just fallen, his abortive fourth was still to come, and something close to Unionist hegemony under Salisbury was in place. Sir William Harcourt had been home secretary and chancellor of the exchequer, with Rosebery foreign secretary and soon to be short-lived prime minister. On the radical wing of Liberalism, Sir Charles Dilke and Joseph Chamberlain offered both inspiration and division. The party had modernised democracy, but its most important reform, Home Rule for Ireland, proved the most controversial, and split the party. Chamberlain departed in 1886, taking other Liberal Unionists with him. It was in that context, and through that opening, that McKenna entered party politics.

Dilke and Chamberlain became central figures in McKenna's developing political consciousness, as, respectively, mentor and idol. Yet, just as his youthful religiosity bore little relation to the mature man, so his initial political concerns were social-housing, benefit societies, and social insurancerather than financial. That his reputation and greater facility rested with the latter ought not to disguise the essential inspiration, which was evident from his earliest campaigning. His religious faith appeared to draw him towards issues that were at that time largely in the purview of charity. On the issue of government benefit societies, McKenna worked in the late 1880s with the Reverend William Lewery Blackley, vicar of St James the Less, Westminster, director of the Clergy Mutual Insurance Company, and another emigrant Irishman. Blackley had come to prominence as an advocate of social insurance, and had in part inspired the creation of a House of Commons Select Committee in 1857, which eventually retreated from the issue because of its compulsory character. McKenna campaigned with him against landlordism, and for social insurance, to combat pauperism. ${ }^{1}$ McKenna related to those issues with which he was then closest, living as he was in an insalubrious quarter of South London. To advance its concerns through parliament, McKenna joined an active group of radicals, nonconformists, and feminists,

1. Times, 16 October 1885, 29 October 1885, 26 July 1902. 
including the Baptist minister Dr John Clifford, and the philanthropist Sophia Fry. In July 1887, McKenna canvassed for Edmund Routledge, son of the great publisher, in the North Paddington by-election, before heading south to campaign for James Hill. 'To-day I canvass in Brixton. This makes the third day at it. Nearly all Tories; semi-detached, shabby genteels, with a live Marquis [of Carmarthen] for their candidate. ${ }^{1}$ Routledge and Hill both lost.

McKenna's Clapham years saw the first and fullest expression of his social radicalism. Given that his political reputation was ultimately made in financial affairs, and that he was never inclined to speak more widely than an issue required, McKenna was never personally associated with the social reform that so animated many of his future colleagues. Yet his programme, such as it was, was a radical one that frequently overlapped with those of the trade union and labour organisations with which many Liberals chose, or were required, to cooperate. McKenna's compassion was as manifest at the outset as it was latent subsequently, and it grew, though the measures to which it gave rise had to be practicable-and affordable, which was less of a preoccupation for some future colleagues. With this prosaic concern with cost, McKenna managed to create a reputation for coldness. He read the 1888 parliamentary report on National Provident Insurance, and, on grounds of both efficacy and effect, felt insurance of superannuation pay preferable to insurance against sickness. In it he discovered

startling statistics as to number of people in Great Britain over 60 who die in the workhouse, estimated at $45 \%$. So that for nearly every one of us over 60 who dies in his home, there is another who does so in the workhouse. Rightly or wrongly the workhouse is looked upon as disgraceful. What a painful close to a life of toil. No help against it except by the thrift of the workers. A compulsory thrift in early youth [...] would go far towards inculcating a spirit of thrift in later life. The knowledge that every working man and woman would hold, that he or she had by their industry secured their old age against want without charitable or state help, would increase this self-respect and lead them to further efforts of thrift. Difficulty lies in registration, and finding suitable punishment for breach of compulsion. How are the vagrants, idle and homeless to be brought to account? I must look into the German 'Book' system. ${ }^{2}$

The pioneering of centralized social policy from 1880 that paralleled the unification of the German state became a model for the later New Liberal intervention into that of Britain. Such diverse and imaginative initiatives became the essence of Edwardian Liberalism, and characterised the so-called

1. RMcK, diary, 15 July 1887.

2. Ibid., 2 October 1888. 
'heavenly twins' that were David Lloyd George and Winston Churchill. ${ }^{1}$ McKenna was always regarded as more traditional and less receptive; his attitude towards what the state could do being constrained by more orthodox notions of revenue and expenditure. Certainly, his conception may have been less impassioned than those of his future colleagues, but it was also earlier:

Great difficulty in detecting and preventing malingering. The fact of its being the state that would be cheated renders the idea of cheating not only not disgraceful but even arguable to certain kinds of people, and there would be no inducement amongst such persons to report each other in cases of malingering. Whereas in private friendly societies, each man having a more recognisable interest and share in the general funds, it is more obvious to his interest to expose the frauds of his fellowmembers. We must have a higher level of political knowledge and a purer honesty before we eradicate the idea that the state purse is an inexhaustible treasure, and it is the duty of each of us to get as much from it as we can. ${ }^{2}$

Finance remained Reggie's most pressing preoccupation, and it was a personal as much as a political concern. Reggie continually tried to obtain financial means for a political career through various arrangements with Leopold and Ernest, in an effort to secure half as secure a foothold as either brother had. Even the necessary induction into clubland suffered through his limited means and relatively humble station. 'Called on the secretary of the Pall Mall Club with reference to the Whip for $£ 10$ from every member,' he wrote in October 1888. 'Am to lay my case before the committee, whose misconduct in allowing the debts to accumulate I consider is very gross. Trust they will redeem it by letting me off.' ${ }^{3}$

Throughout his pupillage-which counted for politics as much as law-it was in religion, and, particularly, in prayer, that Reggie found guidance, and, more important to an increasingly practical man, example.

Though I hold that to pray for a material object or for a new ability, such as the ability to speak Chinese, is to waste one's time, yet as the attitude of prayer necessitates earnest supplication and earnest contemplation, the desire for and the constant and concentrated contemplation of the thing we require, it follows that to pray for a quality, be it patience, or humility or dignity, is to come near attaining that quality according to the degree of the capacity of the person praying for making a true estimate of the nature of the quality. In prayer we consciously set

1. Earl of Swinton, Sixty Years of Power (1966), 40.

2. RMck, diary, 3 October 1888.

3. Ibid., 8 October 1888 . 
before ourselves a model for our conduct. We ascribe to this model first one and then another of the qualities we wish to acquire or strengthen with in ourselves and we consciously imitate what we believe would be the conduct of the model we have chosen under any conditions in which we may be placed. What we at first do consciously we at length by force of habit come to do unconsciously, and we have then acquired a new quality. It is with our mental as with our physical abilities. ${ }^{1}$

'In learning any new exercise of the fingers or of the body each motion is at first made consciously. Later after frequent repetition the motions become a habit, and increased dexterity accompanies the greater unconsciousness', he wrote. Reggie had come to see in ritual a form of practice that made developments possible. 'It is not long before the process of thought accompanying each motion becomes quicker and quicker until it leaves no impression upon the consciousness, making ultimately the various motions quite unconscious. ${ }^{2}$ With that, he saw the model to adopt.

I remember in his life and letters that Darwin speaks of the great difficulty he always had of expressing himself in writing, and that the only method by which he could accomplish his work sufficiently rapidly was to write rapidly without any regard to style expressing his thoughts in the very words and form in which they were clothed in his mind and subsequently correcting what he had written. The result was certainly an excellent plain speaking clear thinking style without ornament or elaboration, but I doubt whether it would have been as good as it is if Darwin had not previously laboured hard though as he thought ineffectually to acquire a style. The conscious process of thought ... had nevertheless given a habit to the mind, which let its impress upon Darwin's style. And moreover Darwin was such a plain speaking clear thinking man that his ordinary mode of expression, unconscious of manner, of elaboration, must have been an excellent style; but for most of us who are not clear thinking and therefore not plain speaking the natural manner of expression means an incomplete jumble. ${ }^{3}$

Parliamentary politics might not therefore have suggested itself as vocation, but, for all his local involvements, Parliament became McKenna's clear object. The most auspicious association a prospective Liberal politician could make, and join, was the Eighty Club, successor to the Grey Club, and established explicitly to help the party repeat the triumph of the general election of 1880 through ideas and organisation. By 1887, however, a political split had affected the club in much the same way as it had the

1. Ibid., 3 September 1888.

2. Ibid., 4 September 1888.

3. Ibid. 
party. Chamberlain had taken many Liberals with him, but the travails of the club, and of the party, were also an opportunity, since the mass resignation of Chamberlainite Liberal Unionists meant vacancies, and aspirant politicians soon filled them up. McKenna became one of a membership of 310, of whom 44 were MPs, including John Morley, whose closeness to and then distance from Chamberlain well reflected that of many radicals. McKenna joined, proposed by Morley, and, on 13 December 1887, attended the Eighty Club dinner at Willis's Rooms, St James. Lord Granville was the main guest, and the party included Sir Charles Dilke, Sir William Harcourt, Charles Mallet, Sir William Henry Wills, and two new Liberal MPs, H. H. Asquith and R. B. Haldane, who had also met through it. While it was certainly true that they met 'undivided by any difference of opinion as to any object of Liberal policy,' the strident claims that they had repaired the losses and that the club had returned to 1885 levels of participation and enthusiasm were less convincing. ${ }^{1}$

In contrast to Theo, McKenna had, and retained, a dislike of evening events in general, and of great balls and dinners in particular. He attended few of the Eighty Club's social functions, but, on 11 March 1890, seconded the vote of thanks at the club's annual dinner, with Augustine Birrell, another Trinity Hall and Inner Temple Liberal, in the chair, and with Ernest, a new life member, in the audience. There, and at the National Liberal Club, Ernest made a point of introducing his brother to individuals of note; in Nice, he had met another young barrister politician, called Rufus Isaacs. ${ }^{2}$

By then living at 10 Clarence Terrace, Regents Park, McKenna decided to make Clapham, which his old Queen's Council John Moulton had lost a year after he had won it in the 1886 general election, his target. McKenna's plan of action was:

Quietly to make myself known, but without enthusiasm. If I were to raise an enthusiasm, I have not got enough at my back to keep it up, and it would die down like the froth of ginger beer. I shan't draw the cork till the election. Now just efficient visitings and meetings to ensure getting in the subscriptions for the association. ${ }^{3}$

The same preoccupations that had beset the undergraduate and trainee barrister also affected the politician. In October 1888, McKenna delivered a 'speech at opening of Battersea library. Poor' ${ }^{4}$ Friends told him that he spoke too quickly, so he rehearsed his speeches with a stopwatch. ${ }^{5}$ At the Clapham Parliament, established two years earlier as one of several debating

1. Times, 14 December 1887.

2. Rufus Isaacs to PMcK, 6 June 1915.

3. RMcK, diary, 11 October 1888.

4. Ibid., 25 October [1888].

5. Beaverbrook, Success, 47. 
chambers around the country, he thought he was 'moderately good only. Too declamatory. The practice of learning the peroration by heart hampers me rather at present. ${ }^{1}$ McKenna nevertheless sufficiently impressed a selection subcommittee that month for it to select him as the Liberal candidate for Clapham at the next general election. ${ }^{2}$ There were obstacles to overcome. The constituency straddled Wandsworth and was essentially middle class, with concentrated areas of working-class men. Unionist agents were well practiced, and the Liberal 'organization very bad. Volunteers don't work.' McKenna set himself to 'improve it next year', ${ }^{4}$ but immediately set upon mobilising men and measures. To that end, and perhaps mindful of the residence qualification, McKenna even subsidised his electors when they could not pay their rent, at the risk of his own exploitation. One, John Davis, borrowed 30/-. 'Doubted his faith, but not confidently, so lent him the money with good grace. If he is an impostor, is sure to return to so easy a victim.'

By the time Salisbury had called the election for June 1892, he had also personally chosen McKenna's opponent. Percy Thornton was a local man whose family were prominent in the area, and who was supported by Conservative, Unionist, and Liberal Unionist associations. ${ }^{6}$ For McKenna, 'the Gladstonians and the Labour League are cooperating', ${ }^{7}$ with the result that both Gladstone and the labour candidate in neighbouring Battersea-John Burns-went to campaign for him. They joined the second progressive assemblage of which McKenna was part, which this time included the Reverend James Guinness Rogers, of Clapham Congregationalist Church, the factory inspector May Abraham, and Dilke's niece, the trades Unionist and social campaigner Gertrude Tuckwell. ${ }^{8}$ Memories of John Moulton's success six years earlier encouraged party workers, and the Daily News reported that the Radical candidate 'is fighting with great energy, and with most encouraging prospects of success. The seat is one which ought to be won back to the Liberal party; if this can be done Mr McKenna will certainly do it."

Problems remained. 'Great difficulty had been found in securing committee rooms,' the Daily News reported of the McKenna campaign, 'as the landlord class were boycotting the Liberal party. ${ }^{10}$ There was also, went the Echo, the perennial issue of localism, and the lack of it in the Radical candidate:

1. RMcK, diary, 23 October [1888].

2. N. E. Jarrett to RMcK, 28 May 1915.

3. RMcK, diary, 4 October 1888.

4. Ibid., 1 October 1888.

5. Ibid., 2 October 1888.

6. Thornton, 'Battersea \& Clapham', 177-80; Times, 11 March 1891, 22 June 1892, 9 January 1918.

7. Echo, 8 June 1892.

8. RMcK to Dilke, 7 July 1892, Dilke papers, $43915 / 75$.

9. Daily News, 30 June 1892.

10. Ibid., 11 June 1892. 
He has diligently cultivated the constituency for a long time, and not without results. The fighting Liberals of Clapham are very sanguine of victory, all the more so because of their brilliant success at the Council poll. If they had selected a local candidate, they might perhaps have had better justification for their hopes. ${ }^{1}$

The contest was 'remarkable for the excessive amount of zeal the supporters of the rival candidates have displayed,' reported the Echo. 'During the past few weeks the candidates have sent out vast quantities of election literature, and their mural appeals for support have been so numerous that portions of the constituency have become veritable pictorial records of political progress of the past six years.' ${ }^{2}$ Both candidates used 'a small army of cyclists ... who have paraded the constituency, their machines ornamented with a profusion of party bills and posters'; Thornton had carriages too, where McKenna had none, but did possess 'exceedingly energetic workers.' So energetic were they that Thornton complained that his rallies were interrupted by 'ruffians who appear to be hired for the purpose of breaking up the meetings'. ${ }^{4}$ McKenna was forced publicly to reprimand his supporters: 'If you have an objection to the principles you hear enunciated thereat, you should wait quietly till the end of the proceedings, and then vote against the resolution, but on no account make any disturbance'. ${ }^{5}$

Imbued with-or at least espousing - the mission of the Clapham Parliament, McKenna called for 'home rule for London' and claimed that those who opposed it for Ireland opposed democracy for England. ${ }^{6}$ Thornton imported Ulster clergymen to spread scare stories about Ireland, and claimed that McKenna 'is now in alliance both with Socialists and extreme Radicals'. ' Labour support was critical, and McKenna advocated trades union legislation most regularly, taxation of ground landlords, one man one vote, and a vote for every man with three months qualification. Burns, campaigning on his own behalf in neighbouring Battersea, held joint meetings with McKenna on the borders of their constituencies for gas and rail workers whose shifts had just finished. 'The candidate was surrounded by about two hundred men and lads, who were described by Mr M'Kenna as being mostly non-electors. ${ }^{8}$ McKenna ridiculed Thornton's claim to be a friend of the working man, to which a Thornton supporter responded, with more accuracy than the Radical candidate would have wished, 'M'Kenna's knowledge of working men has probably been mainly derived from such experience as

1. Echo, 29 June 1892.

2. Ibid., 6 July 1892 .

3. Ibid.

4. 'J.', Times, 29 June 1892.

5. RMcK, 23 June 1892, attrib. H. Smith, Times, 30 June 1892.

6. Pall Mall Gazette, 24 June 1892; Daily News, 1 July 1892.

7. Echo, 6 July 1892.

8. 'J.', The Times, 29 June 1892. 
could be acquired at the Radical Club, ${ }^{11}$ or from the Progressive Dinners he attended with Burns. ${ }^{2}$

On the eve of polling, the Pall Mall Gazette raised the possibility of an upset.

Mr McKenna's supporters are hopeful as to the result. He has been before the constituency for more than four years and is exceedingly popular among the electorate. The meetings that have been held during the past few weeks have exceeded in enthusiasm anything of the kind that has been seen in Clapham before. ${ }^{3}$

'Vote for McKenna!' ran a notice in the Daily Graphic. 'The contest is likely to be so close that not a vote can be dispensed with. Carriages should be sent to 741 a Wandsworth Road. The Liberals are hard at work this morning, but need all the help they can get.' ${ }^{4}$ Polling day was 6 July 1892 . The weather was fine, with the Liberal committee rooms the centre of great activity, and the subject of several visits from the candidate. ${ }^{56}$

As a result of Parnell's lurid divorce case, what had been expected to be a large Liberal majority eighteen months before had been reduced to one of only forty seats. McKenna was exhausted but defiant in defeat.

My brother has been with me through the whole fight, and has kept up my energy and spirits so high that I have worked far harder and better than I ever believed myself capable of, but I have known for the last ten days that the struggle was desperate. A number of nonconformists voted against me on Home Rule; the whole of the Church Party through the district visitors were intensely active, and for most of all the new quarter of Clapham, built during the last five or six years, was almost solid against me. Those last number about 2000-pure type of villa voters. The workmen of Battersea were splendid, polling to the last man, and my own supporters did their utmost. ${ }^{7}$

1. Ibid.

2. John Burns, diary, 14 March 1892, Burns papers, 46312.

3. Pall Mall Gazette, 30 June 1892.

4. Daily Graphic, 6 July 1892.

5. Daily News, 7 July 1892.

6. 1892 general election, Clapham, 6 July 1892.

\begin{tabular}{lrl}
\hline Total electors & 12,124 & Share \\
Percy Thornton (C) & 5170 & $53.3 \%$ \\
R. McKenna (R) & 4526 & $46.7 \%$ \\
Conservative majority & 644 & $6.6 \%$ \\
\hline
\end{tabular}

7. RMcK to Dilke, 7 July 1892, Dilke papers, 43915/75-76. 
In Clapham, the Unionist majority had increased; Burns was elected; and McKenna was in need of patronage. He found it in another Trinity Hall rowing lawyer.

Sir Charles Dilke, although only just in his fifties, was already an exfuture prime minister. One of the most prominent Liberals of the late Victorian period, Dilke pressed the radical case in Gladstone's governments, often alongside Joseph Chamberlain, with such effectiveness that Disraeli, for one, predicted his rise to the premiership. Then, in 1886, Dilke lost his seat in the general election and his ministerial career in a divorce case. While he may have missed office, he still practised the exercise of patronage by befriending young politicians. Dilke and McKenna first met through college contacts and became better acquainted in Clapham. McKenna duly became one of Dilke's 'young men', and was, for several years, despite their differences, devoted to him: they were 'years during which he was far more to me than any friend I had'. ${ }^{1}$

Dilke had decided to return to politics in 1891 , and had been elected to the Commons that July. McKenna had campaigned with him on Dilke's successful campaign, and Dilke's election made McKenna's defeat at Clapham worse. The victor commiserated, with the effect that

Your telegram quite broke me down. Till then I had taken any beating like a man, but that brought home to me in a very moving way all that I had lost. I had hoped so much to be always near you in the House, and to go on learning from you-I don't mean information, but patience, and judgement and steadfastness as I have during the years of affectionate friendship you have given me. ${ }^{2}$

McKenna became a regular guest at Docket Eddy, Dilke's house on the Thames, where rowing and more general coaching were practised. Behind Dockett Eddy, on the large Chertsey Mead, McKenna took another Dilke protégé, John Atkins, in another attempt finally to resolve an abiding concern.

Rides had been cut through this jungle. McKenna's idea was that he should read from a book while I stood at varying distances from him in one of the rides, and could tell him how his voice was carrying. The book he chose was a selection of Browning's poems. He was six years senior to me at Cambridge, but we both belonged to the era of devotion to Browning ... he showed no trace of hesitation in his speech, but he certainly showed no trace of whatever precautions he was taking... He concentrated on keeping his voice up for the last word or 2 [of a

1. RMcK to Gertrude Tuckwell, 27 January 1911, Dilke papers, 43967/164.

2. RMcK to Dilke, 7 July 1892 , Dilke papers, $43915 / 75$. 
sentence], and the difficulty was to do this without falling into unnaturalness which he hated...1

While McKenna refined his pre-parliamentary techniques, Dilke and his close colleagues, inspired both by their own radicalism and by their need to contain the rise of the Labour Party, worked to create a pressure group charged with radicalising the Liberal Party. To that end, Dilke's befriending of McKenna served his wider interests. Having been bloodied by the contest at Clapham, and with the support of a leading, if independent-minded, Liberal, McKenna's goal,was a safe constituency - the usual reward for a candidate who had fought a lost cause in an earlier election. In a demonstration of concentrated political patronage, it was to be the seat adjacent to that of the Forest of Dean, the MP for which was Sir Charles Dilke.

\section{NORTH MONMOUTHSHIRE}

The constituency of North Monmouthshire was on the border of south Wales and England, and the issue of whether it was in fact Wales or England exercised some at the time. ${ }^{2}$ It 'was entirely industrial, mainly mining, with a fair sprinkling of steel-workers, tin-plate workers, and railwaymen', as McKenna described it. 'Although it is a county constituency, it is more like a borough than an ordinary county division. Nearly the whole of the electorate is contained in a valley not more than two or three miles wide and twelve miles long. ${ }^{3}$ Pontypool, Blaenavon, and Aberyschan were the main mining towns, and Abergavenny was at the centre of its agricultural interests.

It was also a safe Liberal seat. North Monmouthshire's MP since 1885 had been Thomas Philips Price, a local man and another Inner Temple lawyer. Price announced that he would not contest the next election, and the constituency association had been anxious to secure Dilke as their candidate to succeed him. ${ }^{4}$ With his election for the Forest of Dean, the association was forced to draw up a shortlist of four candidates in the summer of 1893 , which included, through Dilke's agency, McKenna. Among those contesting the nomination were Sir William-Henry Wills, the tobacco magnate, who had lost Coventry in 1886, and Sir Horace Davey, a former solicitor general, who had lost Stockton-on-Tees in 1892. If they did not provide enough of a challenge, McKenna was concerned that his quest might be further jeopardised by his prospective colleagues regarding him as an English

1. Atkins, Incidents, 59-62.

2. Letters, Times, 8 February 1892, 26 October 1892, 18 May 1894, 22 May 1894.

3. RMcK to Geoffrey Howard, 16 April 1919.

4. Stephen Gwynn and Gertrude Tuckwell, The Life of the Right Honourable Sir Charles W. Dilke, 2 vols. (1917), 2:289. 
carpetbagger. 'It is now asserted that Mr Gwilyan James, of Merthyr, who is not regularly before the association, is the nominee of the Welsh party in Parliament', McKenna wrote to Thomas Ellis, the Liberal chief whip. 'As far as I can learn this statement is being widely [distributed]. Is it fair for me to ask if there is any truth in it? Needless to say it very much prejudices the chances of the other candidates."

With Guinness Rogers writing to the nonconformist interests in the seat, and Dilke supporting McKenna with the local association, it did not matter. In August 1893, after a meeting at the constituency headquarters in Blaenavon, the Liberal association for North Monmouthshire adopted McKenna as their candidate. He had overcome much better qualified opponents, and recognising the circumstances, devoted himself to campaigning, and established the model for all of those that were to follow. The candidate was assisted by his agent, Lewis Davies, and accompanied regularly by Theo, who managed his campaign finances, ${ }^{2}$ and constantly by Ernest, who drove the candidate everywhere. Through the last months of the Parliament, McKenna addressed seventy meetings in the constituency. Dilke joined him at one while Parliament was still sitting, something, he told the crowd, he would only do for a friend. ${ }^{3}$

Having suffered for its small majority and large ambition, the government was without drive or direction. In March 1894, Gladstone finally retired, ostensibly over naval spending, and Rosebery became prime minister. The government fell in June 1895, and an election was called for the following month. McKenna's own radicalism, and the constituency's nonconformity, defined the campaign. Returning from a brief holiday in Scotland, McKenna spoke at his first rally on 12 June, where he called for disestablishment of the Church of England in Wales, supported crofters against landowners, and attacked the Unionist bill against alien immigration. He went on to support the Armenian treaty, and in his election address called for Home Rule, the abolition of the House of Lords' veto, pro-labour legislation, including an Eight Hours Bill, and, perhaps with his brothers in mind, publicly funded election expenses and payment of MPs. The Liberal march, 'Hark, the Liberal call is sounding', heralded each appearance, which concluded with more singing.

By the beginning of July, the South Wales Argus offered an assessment, which marked the changes the candidate had imposed on himself.

Mr McKenna is a remarkably eloquent speaker; he has a very pleasant address; he is gentlemanly in his demeanour, alike to friend and opponent and has a winning way. As a politician, he has studied earnestly and zealously to make himself acquainted with the actual needs of the

1. RMcK to [Thomas] Ellis, 9 August 1893, Herbert Gladstone papers, 46022/80.

2. Theodore McKenna to RMcK, 7 July 1910.

3. Pontypool Free Press, 21 June 1895. 
people ... It is predicted of him that when he enters Parliament-and there seems to be no doubt about his election-he will make his mark, and some day occupy a high position in the Government of the country ... From his earliest days he has aspired to take part in public affairs, and his education has been mainly directed to secure that object. ${ }^{1}$

His Unionist challenger was Ellis Hume-Williams, another Trinity Hall lawyer. While he had no more local connections than did his opponent, HumeWilliams served to emphasise the fact by bussing in London barristers and Irish Unionists. ${ }^{2}$ In contrast, and to some effect, McKenna praised the constituency's 'ardent and advanced liberalism', ${ }^{3}$ with the result that the press thought a late rally of his at Abergavenny 'the most enthusiastic political meeting that had ever been held in the town. ${ }^{3}$ With one meeting in mind, Hume-Williams recalled the excitement of the campaign:

Special trains were run from all over Monmouthshire, the hall was crammed, all my supporters sat solidly on one side and all $\mathrm{Mr} \mathrm{Mc}$ Kenna's solidly on the other, while the police hovered everywhere. After it was over all Mr McKenna's supporters said it was pitiful to hear me, and they supposed I should leave the constituency; and all my supporters said they really felt sorry for Mr McKenna, it was awful to see a man get such a beating; whereupon they all returned to their homes and worked for their respective candidates as before. In a few days the constituency was covered with posters, in which each party accused the other of unfair behaviour at the debate, but as the posters were all printed in the colours of one party or the other, no one bothered to read them. The whole thing was an expensive nuisance which did no possible good to anybody, and I have never consented to take part in another. ${ }^{5}$

The night before the poll, Hume-Williams's first meeting, at Blaenavon, was broken up after a fight broke out. At the following meeting at Pontypool, the audience yelled throughout, so he gave a passionate gesticulatory address so effectively that no one realised he was only mouthing the words.

1. South Wales Argus, 2 July 1895.

2. Ibid.

3. Ibid., 5 July 1895.

4. Ibid., 11 July 1895.

5. Sir Ellis Hume-Williams, The World, the House, and the Bar (1930), 11-12. 
Polling day was 20 July 1895 . Torrential rain threatened everyone's predictions. McKenna and Ernest went to the count, held in 'blue' Abergavenny, but which had been invaded by radicals from 'red' Blaenavon. ${ }^{1}$

After the declaration, the new member attempted to address his constituents from a window of the town hall overlooking the market, but such were the taunts from Unionists-'change for Clapham Junction'2- that he had to retire. Hume-Williams took to the same window, but was shouted down by the radicals. McKenna's supporters then carried McKenna on their shoulders to the Angel Hotel, where another attempt to speak had to be abandoned. ${ }^{3}$

Sir William-Henry Wills took East Bristol, and Sir Horace Davey took a peerage. Though the radical majority had been almost halved from the 1892 vote, McKenna had won North Monmouthshire; while Percy Thornton's majority at Clapham had more than doubled. Reginald McKenna, member of Parliament for North Monmouthshire, was thirty-two. As a former constituent wrote years later, 'One could scarcely anticipate that such great results could ensue from that little gathering we had in your house after the meeting in Blaenavon'. ${ }^{4}$ McKenna's parliamentary career had begun, and it began in debt. 'You said when I saw you at the House that it was only a trifle you had done for me', he told Dilke.

That is not a view I take of it. No doubt I am a very fine fellow, but I think the sudden burst of popularity in Monmouthshire requires explanation other than my merits. With the exception of Guinness Rogers' letters, it is you who provided me with every recommendation I received; you prompted every action; and through your friends I have secured the seat. I am glad to owe it to you. ${ }^{5}$

1. General election, Monmouthshire, North, 20 July 1895.

\begin{tabular}{lrl}
\hline Total electors & 11,674 & Share \\
R. McKenna (R) & 4965 & $54.2 \%$ \\
W. E. Hume-Williams (C) & 4203 & $45.8 \%$ \\
Radical majority & 762 & $8.4 \%$ \\
\hline
\end{tabular}

2. Pontypool Free Press, 26 July 1895.

3. South Wales Argus, 22 July 1895.

4. RMcK, 2 September 1895, in H. M. Davies to RMcK, 15 April 1908.

5. RMcK to Dilke, 2 September 1893, Dilke papers, 43915/117-18. 


\section{Opposition Backbencher, August 1895 to December 1905}

I am for fighting them, indeed the only part of my speeches which interests me is that which is devoted to attacking their pretensions.

-McKenna, $1905^{1}$

\section{LIBERALS}

Unlike his uncle Joseph, who had left in 1892-and who had no apparent effect on his nephew's career-McKenna reached the House of Commons on his second, rather than his fourth, attempt. His impact was less immediate. The electors of North, unlike those of West, Monmouthshire, had sent to Westminster a novice rather than an established figure. They had, however, contributed in their way to a broader cultural revolution. In the years before what became known as New Liberalism, there were new Liberals: professional politicians, having served as professional others, who would run a department of state as they might a limited company. McKenna arrived at Westminster in the late summer of 1895 as another middle class professional in the late Victorian Commons' social-and, soon, political-transformation. ${ }^{2}$ Lawyers were the largest single profession, though McKenna was rare in turning away from the bar and devoting himself wholly to political business: his last case had been in March $1895 .^{3}$ In contrast with many of the other new arrivals, however, he was rootless, with a cosmopolitan background and no grounding in church or business or region; immediately after the election, he repaired to his mother's home in Etrêtat, with Ernest.

1. RMcK to Runciman, 5 October 1905, Runciman papers, 13(5)/2.

2. Roger Fulford, Votes for Women: The Story of a Struggle (1957), 262; Wilhelm Guttsman, The British Political Elite (1963), 190-2; John Thomas, The House of Commons, 1906-1911. An Analysis of Its Economic and Social Character (Cardiff, 1958), 22-27.

3. 5, 6 March 1895, 3 April 1895, 3, 5, 6, 8, 12 July 1895: Hickman v Berens, [1895] 2 Ch. 638. 
Liberals had remained unreconciled to Joseph Chamberlain's secessionist Liberal Unionists, and the result of the general election demonstrated the effects. Yet both the split in the movement and the duration of the electionit was held between 13 July and 7 August-ultimately benefitted McKenna. Harcourt, the chancellor of the Exchequer, had lost his seat at Derby on 14 July. Four days later, he was offered another, West Monmouthshire, the idea being that of a friend in the eastern adjoining constituency, the Forest of Dean. Sir Charles Dilke's latest act of patronage meant that McKenna, in the northern adjoining seat, had opportunity to come to Harcourt's attention by travelling south to help with his campaign to return to Westminster. McKenna had already become friends with Harcourt's only surviving son Lewis-'Loulou'-who was so close to his father that he had foregone university to serve as his private secretary, a role he had occupied for nearly twenty years. By the time Parliament met, not only was Harcourt, another Inner Temple lawyer, close to Dilke and McKenna in more than one sense, he was also, after Rosebery's resignation in October 1896, leader of the Liberal Party.

However exalted McKenna's company may have been, his first decade as a member of Parliament was spent in opposition. More than many periods out of office, it was one of genuine renewal. The radicals in the new Liberal opposition recognised their shared concerns and were united in collaboration against the government on the backbenches inside the Palace of Westminster, and in dining groups outside. ${ }^{1}$ Real Liberal leadership in the Commons increasingly passed to the backbenchers, where the new men attacked the government with vigour, unencumbered as they were with the responsibilities of the front bench, where the likes of $\mathrm{H}$. H. Asquith and John Morley sat and opposed, officially. ${ }^{2}$ From whichever benches, opposition encouraged the shift of generations, and most of the men with whom McKenna would work for the next twenty years in parliamentary Liberalism were already present. John Burns, who had campaigned with McKenna in Clapham, had been in Parliament for three years as a Labour representative, but found himself moving closer to Liberals who were themselves taking on the mantle of working-class concerns; Walter Runciman arrived in a by-election in 1899; Lewis Harcourt was elected five years later; Augustine Birrell had been there since 1889; Charles Hobhouse since 1892, but lost his seat in 1895 , to return five years later. Edward Grey and Richard Haldane had already been MPs for ten years.

1. RMcK to Runciman, 3 October 1905, Runciman papers, 13(5)/1; Lloyd George to Churchill, 5 December 1905, Churchill papers, CHAR 2/23/48; Lord Shaw, Letters to Isabel (1921), 266.

2. J. A. Spender, The Life of Sir Henry Campbell-Bannerman, GCB, 2 vols. (1923), 2:81. 
Of the most recent additions, David Lloyd George was already the most notable and had been in the Commons for five years. McKenna and Lloyd George had superficially a great deal in common. They were born of the 'Celtic fringe' seven months apart. Both had been elected as Liberal MPs for Welsh constituencies in the 1890s. The two became associates in opposition, radicals of note, respectively making their names defending Boers and attacking tariffs. Both became ministers at the same time. Both retained something of the outsider: McKenna's Irish roots and foreign education, Lloyd George's Welsh language and partial education. ${ }^{1}$ From the outset, McKenna supported the more established man. In February 1898, he nominated Lloyd George as leader of the Welsh Radical MPs, though Lloyd George in turn made way for Alfred Thomas. ${ }^{2}$ Even without the nominal leadership, Lloyd George was the dominant figure in Welsh politics and the personification of Welsh Liberalism. It was the beginning of the relationship that would come to define-and to determine-McKenna's political life.

\section{DILKE}

McKenna's and Dilke's companionship outside the Commons immediately became a partnership inside it. McKenna later described his early parliamentary career as being 'in opposition for 10 years in constant attendance at House of Commons and gaining great advantage from the friendship and guidance of Sir Charles Dilke whose exactitude in thought and business methods was a model he laid himself to follow. ${ }^{3}$ Dilke was already McKenna's patron, became his dominant influence, and served to develop the natural inclinations of his protégé into his standard practice. McKenna's approach throughout his life had always been to master a challenge, whether it was speaking, rowing, the law, or parliament. McKenna told Dilke's biographer "What Dilke did was impress upon me the importance of a thorough understanding of the procedure and the business of the House of Commons. ${ }^{4}$ With an experienced teacher in Dilke, not only were McKenna's methods, but also his causes, determined. Finance and public administration were the focus for his first years in Parliament. This combination of the methodological and the personal lent common currency to the notion that Dilke 'fed' his young charge on a diet of Blue Books, the statistical digests published by the Government. So reliable was the pairing that to the minds of some observers it suggested a different sort of coupling. To McKenna's subsequent disapproval, Punch depicted him as blacked-up Man Friday to

\footnotetext{
1. Haldane papers, 5923/17.

2. Times, 16 February 1898; E. T. Raymond, Mr Lloyd George (1922), 51.

3. 'Reggie's own notes dictated to me [PMcK] on his early years', c. 1943.

4. RMcK to Stephen Gwynn, 26 December 1913, Dilke papers, 43967/ 324.
} 
Dilke's Crusoe, following his master with a pile of Blue Books balanced on his head.

There were many interests shared by the constituents of North Monmouthshire and of the Forest of Dean. The most notable were nonconformity and labour issues. McKenna had already developed his sensitivities to working-class politics in Clapham alongside John Burns, and had spent the summer of 1895 engrossed in Henry Traill's newly published six-volume Social England. In Parliament, McKenna made himself part of Dilke's attempts to respond to the demands of labour through the offices of Liberalism. For his part, Dilke was, if not resurrecting his political career, certainly reestablishing himself as a parliamentarian. Alongside Dilke as a secondary veteran radical patron was Sir Henry Labouchere, an associate of Sir Joseph Neale McKenna, who had first been elected to Parliament when Reginald McKenna was three years old. Labouchere had established himself as a radical politician and editor, and one widely distrusted. For the time being, therefore, McKenna's parliamentary lodestars were both elderly and disgraced. Sir Henry Lucy, the parliamentary journalist, observed the trio from the reporters' gallery: 'The two sat together on the front bench below the gangway, the quarter made famous by memory of Randolph Churchill and the Fourth Party. Labby had the corner seat, Dilke on his left, with Reginald McKenna next'. ${ }^{1}$ The Fourth Party had been a small grouping of Unionist MPs which harassed the 1880 Liberal Government, and its own leadership, but in so doing energised wider Unionist opposition. Sitting below the gangway implied licence, and the Liberals of 1895 were much like the Unionists of 1880 . The emulation was unspoken but obvious.

On their arrival, and in some cases, return, to Parliament, on the opposition benches a number of the younger, more radical, less patient, MPs sought to explain their defeat and propose future success through reorganisation. On his reelection in 1892, Dilke had resurrected the old Radical Club, renamed as the Radical Committee, which was regarded by some as the Independent Radical Party, and which sought to counteract the threat of the Independent Labour Party by reinvigorating Liberalism. When McKenna entered Parliament three years later, the Liberals' losses reinforced the need for action. The Radical Committee manifesto proclaimed: 'It has been resolved to form a distinctive advanced radical section in Parliament', and as such was signed by Dilke, Labouchere, eleven other MPs, Lloyd George, and McKenna. ${ }^{2}$ They met in committee rooms in the House of Commons to promote an advanced radical agenda that included abolition of the House of Lords, disestablishment and disendowment of state churches, payment for MPs, and support for the Eight Hours Bill. It sought greater autonomy for the National Liberal Federation from Liberal Central Office, and for the

1. Henry Lucy, Sixty Years in the Wilderness (1912), 72.

2. Henry Lucy, Later Peeps at Parliament from Bebind the Speaker's Chair (1905), 411, 429-30. 
nations of the United Kingdom from Westminster through 'Home Rule All Round'. ${ }^{1}$ By advancing a programme at odds with that of the parliamentary leadership, the opposition's need for unity had therefore immediately produced faction, and one centred on a divisive figure. Where the old radicals had their debating societies and clubs, the new radicals, even with old leaders, were conspiratorial, and without popular following." The leadership alone convinced Sir Henry Campbell-Bannerman that 'the ludicrous cabal' could not be effective. ${ }^{3}$

Parliamentary Liberalism in opposition was at first fractious, and the intemperate leadership of Sir William Harcourt. McKenna's early parliamentary interventions were almost appropriately disparate. They were at least consistent in nature: the antagonisation of ministers on matters of both procedure and principle. Whatever the actual issue, McKenna's concern was the financial probity of government policy. His maiden speech concerned France and the Mekong. ${ }^{4}$ Having hitherto demonstrated little interest in, enthusiasm for, or knowledge of, international relations, over the subsequent weeks, he proceeded to burrow a furrow that connected Siam, Sudan, Uganda, Matabeleland, Abyssinia, Mekong, Korea, and South Africa. A common theme to his international interventions was the rights of small nations. McKenna spoke both as the representative of a Welsh constituency and as the son of a man who had campaigned against the Turks for their oppression of the Bulgarians. In 1897, Britain's support for Turkey obstructed Crete's efforts to transfer from Ottoman rule to that of the Kingdom of Greece. In April, McKenna attacked George Curzon, under secretary of state for foreign affairs, for the government supporting an imperial power over a minority. Having received a request from an admiral in Crete for reinforcements, the government had sent only Scottish and Welsh troops. McKenna asked why troops from Wales had been sent, to which Curzon responded by asking why troops from Wales should not be sent; 'Because the work they are asked to do is wholly repugnant to the feelings of the Welsh people.' ${ }^{5}$

Less imperially minded than many in the Commons, for McKenna trade was the looser but more enduring connection between the empire and the condition of the people. Beyond that, its appeal as an issue was twofold: it allowed him to deal with the measurable and the quantifiable; and it offered him the scope to reveal the shortcomings of adversaries who were less empirically minded, irrespective of where they sat in the chamber. Thus McKenna opposed the prohibition of foreign prison-made goods, less on

1. Times, 7 March 1896.

2. Guttsman, Political Elite, 190 .

3. Campbell-Bannerman to D. H. Saunders, 24 March 1896, Campbell-Bannerman papers, 52517/102.

4. RMcK, Parliamentary Debates, 20 August 1895, 366.

5. RMcK, Parliamentary Debates, 1 April 1897, 285. 
grounds of principle, than because he objected to 'pettifogging' restrictions; ${ }^{1}$ he deplored spending money on Irish harbours because there was no authority in the Imperial Defence Act to do so; he advocated the employment of women by the state because they were more productive in certain tasks than were men. ${ }^{2}$

Elsewhere, McKenna sought to balance the patriotic and the progressive by pressing for the awarding of Diamond Jubilee medals to policemen ${ }^{3}$ and supporting the superannuation of teachers. ${ }^{4}$ In respect of funds for voluntary schools, he promoted the controversial notion of relating their size to what they were supposed to achieve rather than to what would command assent. ${ }^{5}$ McKenna felt that 'the Roman Catholic would not send his child to a board school at all; the Roman Catholics had made sacrifices out of all proportion to the sacrifices made by the Church of England', and, consequently, he supported an amendment designed to give voluntary Catholic schools financial support. ${ }^{6}$

McKenna's associations had been on the radical wing of the party, and, as the MP for an industrial constituency, he made much of industrial relations and the lot of working people. Concern to mitigate the severity of depressions led him to move an amendment to the Agricultural Land Rating Bill over the decline in land values, and, with Lloyd George, to attack the government for its ignorance. ${ }^{7}$ When he backed the workers over the abolition of fines in the Truck Bill, which concerned the wages of servants, since the workers were not paid until their fines were deducted, he was criticised for not understanding the need of discipline in the workplace. ${ }^{8}$ To McKenna, however, the Truck Bill assumed that a workman was 'not a free party to the contract, and if he was not a free party to a contract he was equally not a free party in his acquiescence or consent to any deduction which was made in his wages'. ${ }^{9}$

With Dilke and the former and future Labour MP Keir Hardie, McKenna supported the Coal Mine Regulation Bill, which prevented any miner under the age of eighteen from working more than eight hours a day and which, as the 'Eight Hour Act', became a keystone of labour electoral appeal. They also moved an amendment to promote the representation of workmen without their having to offer security, and advocated state imposition of safety

1. Ibid., 13 July $1897,76-77$.

2. Ibid., 29 July $1898,515$.

3. Ibid., 18 June $1897,368$.

4. Ibid., 13 February 1896, 238; 16 April 1896, 1120; 17 June 1897, 325.

5. Ibid., 1 March 1897, 1353, 1366, 1370, 1390-91, 1406.

6. Ibid., 9 March 1897, 339.

7. Ibid., 14 May 1896, 1354-56; 21 May 1896, 92-132.

8. Ibid., 4 May 1896, 52.

9. Ibid., 30 July $1896,1085$. 
rules in mines as the only way to avoid preventable accidents. ${ }^{1}$ McKenna campaigned for increases in compensation for the incapacitated, improvements in factory conditions, and the exemption of illegitimate children from benefits. ${ }^{2} \mathrm{He}$ called for inspection of vivisection workshops, ${ }^{3}$ advocated an end to female post office clerks working before 5:00 a.m., ${ }^{4}$ and demanded that the home secretary deal with incidents of lead poisoning. ${ }^{5}$ McKenna felt the Workmen (Compensation for Accidents) Bill would deny workers' rights and limit their benefits by offering 'new defences to an employer in the case of every accident', and, recalling his work with Reverend William Lewery Blackley in Clapham, he moved an amendment 'on the ground that its tendency undoubtedly would be to make insurance universal.' ${ }^{6}$

McKenna and Dilke cooperated on the Working Men's Dwellings Bill in 1896, described by the latter as 'the first social egg laid by the Tory democracy,7 and McKenna seconded Dilke's amendment that state purchase of dwellings for the working classes should vest the freehold in a public body, and not in the individual. McKenna maintained that the bill could encourage working-class speculation, and thereby leave the working man stranded in the event of a downturn in trade, with the result that he could not keep up his payments; for that reason, his money would be better off in a savings bank. ${ }^{8}$ As an illustration of Dilke's efforts to outflank the labour movement, the bill foreshadowed the motives and methods of the New Liberalism of ten years later. McKenna claimed it was 'as important to the working-classes of Great Britain as the Evicted Tenants' Bill was to the people of Ireland.'

McKenna also spoke on the widening of the franchise, by supporting Dilke's bill to establish a single franchise 'and to remove the disabilities of Women'. ${ }^{10}$ In the debate on the Diamond Jubilee Queen's speech of 1897, he called for a simplification of election laws as a means of reforming the constitution. The Liberal Party, he said, had moved five bills between 1868 and 1875 that had been thwarted in the House of Lords, prejudicing radical or even progressive legislation. Britain's electoral laws, McKenna claimed, were a 'mass of absurdities and anomalies', ${ }^{11}$ and he supported Dilke's bill to abolish the property qualification to voting. ${ }^{12}$ Over the Local Government

1. Coal Mines Regulation Act (1887) Amendment (No. 2) Bill, Parliamentary Debates, 27 July 1896, 740-41, 746, 755.

2. RMcK, Parliamentary Debates, 2 June 1897, 119; 11 July 1898, 464; 2 June $1897,141$.

3. Ibid., 18 June 1897, 413.

4. Ibid., 10 May 1897,98 .

5. Ibid., 24 May 1897, 1134.

6. Ibid., 24 May 1897, 1208.

7. Dilke, Parliamentary Debates, 4 April 1896, 142-43.

8. RMcK, Parliamentary Debates, 8 April 1898, 1019-23.

9. Ibid., 25 February 1896, 1096.

10. RMcK, Parliamentary Debates, 22 January 1897, 304.

11. Ibid., 26 January $1897,561$.

12. Ibid., 28 April 1897, 1191-93. 
(Ireland) Bill, and especially the grant offered to Irish landlords, McKenna joined with Lloyd George, and proposed 'that the whole of that grant shall be paid to the tenants, and none of it to the landlords. ${ }^{1}$ In a speech his uncle Joseph could have delivered, McKenna claimed that that which went to the landlords tended to be spent in Britain, and that which went to the tenants stayed in Ireland: 'Pay the whole of this money into Irish pockets'. Throughout the debate McKenna was the most prominent and vociferous member opposing the rights of landlords. 'It is not a case of robbing Peter to pay Paul; it is robbing Lazarus to pay Dives'. ${ }^{4}$

McKenna's Clapham experiences still dominated his parliamentary activities: Social England was more important to him than Greater Britain; the two became one through the Aborigines' Protection Society (APS). McKenna's involvement in aboriginal affairs was as much about his interest in the 'condition of the people' as it was about imperial matters; it too had been cultivated in Clapham, as had been the antislavery movement itself. Soon after his election, McKenna joined the APS, a body formed to promote the interests of the indigenous races of the British Empire. ${ }^{5}$ Membership was drawn largely from the left of the party, and included Dilke, Birrell, Burns, Morley, Herbert Samuel, C. P. Scott, and Alfred Emmott, as well as, in Keir Hardie and Ramsay MacDonald, nonparliamentary Labour support. At the sixtieth annual meeting of the APS, on 20 April 1898, McKenna seconded a resolution from the socialist journalist Alfred Fletcher 'protesting against the arbitrary and wrongful treatment' to which natives of British South Africa were subjected. ${ }^{6}$ It was an indication of the progressive nature of the organisation both that he was seconded by a woman, Eliza Orme, and that 'there was a very small attendance'. ${ }^{7}$

The APS exercised most of its influence through the comments of MPs in the chamber of the House of Commons. The forum provided opportunities to attack the colonial secretary, Chamberlain, and the idea of grants-in-aid to already established colonies; the priority of which was clearly imperial in purpose rather than merely the outlay of relief. 'The Negro, although a man and a brother, I admit, may not be the very finest specimen of a citizen', McKenna had to concede, but should nevertheless still be well treated. 'If popularity is not sought, then governance by despotism is required, and is clearly less desirable', to which the cultivation of minor agricultural industries, such as the stripping of tobacco leaves, should be encouraged. ${ }^{8}$

1. Ibid., 17 May $1898,1596$.

2. Ibid., 1600.

3. Ibid., 13 July 1898,808 .

4. Ibid., 14 July $1898,969$.

5. The author is grateful to Dr Tony Bryan for information concerning the Aborigines' Protection Society.

6. Aborigines' Protection Society Yearbook (1889), 395.

7. Times, 22 April 1898.

8. RMcK, Parliamentary Debates, 14 March 1898, 1584. 
When Dilke moved an amendment to secure equitable treatment of African natives, McKenna told Curzon that 'The evils complained of could only be remedied by a public enquiry. ${ }^{1}$ McKenna had long criticised the treatment of Zulus, and on the British South Africa Company, accused the foreign office of financial imprecision. ${ }^{2} \mathrm{He}$ disapproved of Sir Arthur Hardinge, consul general in Zanzibar for his reluctance to oppose slavery, and attacked the government for funding him to hand over fugitive slaves to their masters. ${ }^{3}$ The notion that slavery was over 'is romance-it is not the fact. It ought to be, but it is not'. ${ }^{4}$

McKenna's interventions increasingly came to centre on the financial provisions of proposed legislation. Contrary to the impression of critics, they went beyond accountancy, because his approach to government was not just one of cost, but of intention. He felt that motives needed to take account of their probable effects. On the Military Works Bill, he discerned confused motives that would produce confused practices. ${ }^{5}$ McKenna's radicalism was pronounced, but defined absolutely by its practicability: his refusal to employ rhetoric limited the extent to which it could be anything else. That did not mean his opposition lacked ambition. He made it his object to target the two dominant figures on the government benches: Chamberlain and Balfour. Chamberlain had made himself the most prominent feature of McKenna's horizon. His leaving the Liberal Party provided McKenna with both an opportunity, in that it led to vacancies, and a lesson, insofar as it demonstrated the importance of party, while the policy he came famously to adopt provided McKenna with a cause. Over Home Rule there was already a significant policy difference, with McKenna strongly for and Chamberlain strongly against, but it was the issue that would bring about the cleavage between Chamberlain and his latest colleagues over which McKenna was most exercised: tariff reform. McKenna's attacks on Joseph Chamberlain throughout the second half of his decade in opposition made his name in the Commons, and, with his leadership of the Free Trade Union, raised his profile in the country. Free trade offered McKenna his second, and more enduring, evangelical experience and he dedicated himself to the efficient operation of the Free Trade Union, and was impatient of its increasing bureaucracy. He wanted the kind of guerrilla campaigns outside Parliament that he practiced inside it. ${ }^{6}$ Where some of his colleagues saw free trade as a means to an end, McKenna was attracted to the policy as much for its own sake.

1. Ibid., 2 April $1897,447$.

2. Ibid., 28 December 1896, 1416.

3. Ibid., 24 June $1897,523$.

4. Ibid., 10 February $1898,302-3,310$.

5. Ibid., 18 February $1897,749-50 ; 22$ February $1897,936-37$.

6. RMcK to Gladstone, 14 January 1904, Herbert Gladstone papers, 46061/ 119-22. 
In that they were essentially critical, McKenna's practices were suited to opposition; in that they concerned detail and entailed confrontation, the practices became his norm. In this sphere, the Gladstonian and the New Liberal could converge on the principle of retrenchment in public administration. Thus, McKenna attacked the government over poor accounting on the Ugandan railway, ${ }^{1}$ clashed with the first lord of the admiralty over parliamentary scrutiny of estimates, and demanded checks on what he regarded as War Office extravagance. ${ }^{2}$ When the government responded by taking away Friday motions, McKenna told Balfour 'if the whirligig of time brought its revenges, the right hon. Gentleman would have only himself to blame'. ${ }^{3}$

\section{BACKBENCHER}

Balfour had retaliated in a way calculated to injure. Whether with Dilke or Labouchere, who 'occupy the old quarters of the Fourth Party, and alternately lead Mr McKenna', ${ }^{4}$ as Henry Lucy had it or with Lloyd George, the pair being for Harold Spender the 'able and brilliant freelances under the gangway, ${ }^{5}$ McKenna had become a prominent practitioner of parliamentary guerrilla tactics, disrupting divisions and claiming breaches of procedure to the ends of making the operation of Parliament impossible. ${ }^{6}$ One consequence was the animus of Unionist MPs who adopted the similarly obstructive tactic of shouting him down. ${ }^{7}$ It was an early example of McKenna's apparent imperturbability, and a tendency almost to seek to arouse hostility in his opponents. McKenna was 'one of that group called in a flippant moment, "the leather-lunged young barristers of the Liberal Party", wrote Charles King, Henry Lucy's replacement at the Daily Express. 'He harangued a thousand multitudes. He had helped to obstruct the House of Commons on a hundred nights.'

'What struck me most about his work in the House was the enormous trouble he took to become complete master of his subject', James Lowther, Speaker of the Commons, recalled. 'He never seemed to be seeking for instruction or guidance elsewhere than from himself'. ${ }^{9}$ Preparation, or indeed, ability, was not in question. As with many lawyer politicians, McKenna found difficulty not in presenting a case or in refuting a criticism,

1. RMcK, Parliamentary Debates, 18 February 1897, 951-52.

2. Ibid., 22 February $1897,946-47$.

3. Ibid., 25 February 1896, 1096.

4. Lucy, April 1901, Later, 411.

5. Harold Spender, Herbert Henry Asquith (1915), 86.

6. RMcK, Parliamentary Debates, 21 May 1896, 150, 182.

7. Ibid., 351-54.

8. Charles King, The Asquith Parliament (1906-1909): A Popular History of Its Men and Its Measures (1910), 44.

9. Viscount Ullswater to PMcK, 12 September 1943. 
but in carrying a large and often diverse audience with him. A gift for clarity and concision did not extend to a talent for persuasion. This was, throughout his parliamentary career, the principal grounds for his causing problems in the chamber, and, indeed, elsewhere. He 'made something of a name in this parliament', wrote Charles King, as 'a hard-necked wasp of debate'. ${ }^{1}$

Even at his junior station, McKenna appeared older than he was. 'Though in fact a kindly and genial being, his manner', one observer noted, 'was apt to be donnish'. ${ }^{2}$ Manner did not necessarily equate with policy, but some politicians could succeed in blurring the distinction. McKenna never did. He tended both to disdain thought processes that were not as rigorous as were his own, and to disapprove of conduct which was not his own, indeed, to view with suspicion even those who entertained differences of opinion. Stephen noted how 'critics detected a kindred tendency to associate economic heresy and political libertinism with intellectual collapse or original sin'. ${ }^{3}$ The difficulty arose because McKenna did not disguise his reaction. 'I know my fault and I always make up my mind not to be drawn. The other side know it too. Someone gets up and attacks. Then I forget all my good resolutions and enter into an argument. ${ }^{34}$

'Some careless debaters, whose arguments were in inverse proportion to the strength of their lungs', a contemporary noted, 'did not at all like the merciless way in which Mr McKenna handled their speeches and he has a reputation on the Conservative side for being a prickly person to meet in debate. ${ }^{5}$ It followed that, as Stephen admitted, 'he was more respected than liked in the House'.

He was so self-contained that he seemed uninterested in human beings, beginning with himself ... By limiting his intellectual curiosity to what could be ascertained and proved, McKenna created for himself a legend of aloofness, if not of inhumanity. ${ }^{6}$

'This is all due to his manner', George Riddell, proprietor of the News of the World, felt.

He is very kind hearted and will do more for his friends than most people. He also has a great sense of justice that often leads him to occupy positions that the public do not understand. His mind always works along mathematical lines. He does not appreciate fully that human

1. King, Parliament, 44.

2. Times, 7 September 1943.

3. $R M c K, 178$.

4. Riddell, diary, 20 November 1914, Riddell papers, 62974.

5. Westminster Gazette, 18 June 1907.

6. $R M c K, 164$. 
affairs are not like a problem in Euclid and that people do not like to be proved in the wrong in respect of their favourite prejudices. ${ }^{1}$

If Ernest McKenna was the Mycroft to Reginald's Sherlock, then Watson's description of Holmes in The Greek Interpreter was apposite: 'an isolated phenomenon, a brain without a heart, as deficient in human sympathy as he was pre-eminent in intelligence'. ${ }^{2}$ What most irritated onlookers was that he appeared to know it. 'Reginald McKenna', Charles King concluded, 'was a man of considerable debating ability, no end of energy, and abounding confidence in Reginald McKenna., ${ }^{3}$ It was nevertheless the self-conscious confidence of one 'too matter-of-fact and prosaic to be an artist'. ${ }^{4}$

McKenna was described in the press as 'one of the most industrious members of the House of Commons'. ${ }^{5}$ He was spirited, critical, deeply unpopular with government members, and, if not necessarily correspondingly popular with his own side, in committee work at least, his talents had opportunity to be applied positively. McKenna's association with so divisive a figure as Dilke risked his marginalisation. Campbell-Bannerman maintained Dilke 'has no following but three in the party (Dalziel, young Allen, and McKenna) - the party will have none of him'.${ }^{6}$ His self-imposed exile had been overlooked, but McKenna appeared to want to remain on the margin. At the beginning of 1898, McKenna's third year as an MP, Harcourt offered him the post of his parliamentary private secretary. McKenna declined.

I do not feel equally sure that he would not prefer someone with fewer ties and predilections than I have. I am a member of the Advanced Radical Section, and although that group contains no member who is not completely loyal to Sir William, still occasions have arisen when they could not accept Front Bench decisions made for Front Bench reasons. I have also since I have been a member, perhaps somewhat conspicuously, habitually taken a seat on the front bench below the gangway, which is an outward sign of freedom-for what it may be worth-I should not like to relinquish. ${ }^{7}$

McKenna's attitude was reflective of radical opinion, which increasingly became vocally dissatisfied with Harcourt's leadership. With a newly married

1. Riddell, diary, 20 November 1914, Riddell papers, 62974.

2. Arthur Conan Doyle, The Memoirs of Sherlock Holmes (1894), 174.

3. King, Parliament, 44.

4. RMcK, in Pontypool Free Press, 28 September 1900.

5. Anon. newspaper, [c December 1905].

6. Campbell-Bannerman to D. H. Saunders, 24 March 1896, Campbell-Bannerman papers, 52517/104-105.

7. RMcK to Sir William Harcourt, 10 February 1898, Harcourt papers, 436/22. 
and distracted Loulou no longer constantly managing his father's interests, Harcourt felt it necessary to resign.

In the succession, Dilke favoured the erstwhile Liberal home secretary H. H. Asquith over Campbell-Bannerman, promoting the view that at least the younger Asquith was a radical-Campbell-Bannerman being little better than a Tory, and certainly no more aggressive than Harcourt had been. Robert William Perks-The 'Member for Nonconformists' - had begun agitating through his Nonconformist Parliamentary Committee. 'I cannot see any reason why you should not help to prevent the choice of C.B.', McKenna urged Dilke.

Your political action on the only matter on which C. B. has spoken so far as I know during opposition, i.e. war office, thoroughly justifies you. My idea of the leader is one who may be expected to be wise enough to work with you, if Perks kicks, then so much the better; let him do it at once and get it over while we are in opposition. The great thing to establish to my mind is that when Perks kicks, nobody is hurt. A sensible leader would give him the occasion by identifying you with the first opposition bench. ${ }^{1}$

Campbell-Bannerman was, nevertheless, promoted to the leadership, at a meeting in the Reform Club in February 1899, by virtue of what McKenna regarded as his defect: his age. ${ }^{2}$

1899 brought two other significant events: the South African War and McKenna's appointment as chairman of the Police and Sanitary Committee of the House of Commons. Of the two, it was the war that ultimately proved more momentous, and provided another opportunity for Liberals to turn on each other. McKenna did not contribute to the general disorder. He was not a liberal imperialist, like Asquith or Haldane, nor a Little Englander, like Harcourt, nor a pro-Boer, like Lloyd George or Campbell-Bannerman. McKenna's interest in the war was focussed more on inefficiencies in its prosecution than in inconsistencies in the claimed merits of the conflict. As much went for his efforts at encouraging an early conclusion, and on 7 February 1900, he supported the government, Campbell-Bannerman, and Asquith in rejecting John Redmond's call to end the war by recognising the independence of the Orange Free State and the Transvaal. ${ }^{3}$

McKenna's main activity during the early part of the war was to attack the government over fraudulent contracts for cordite. He was appointed, in July 1900, to a War Office Contracts Select Committee 'to consider and

1. RMcK to Dilke, 23 December 1898, Dilke papers, $43916 / 103$.

2. José Harris and Cameron Hazlehurst, 'Campbell-Bannerman as Prime Minister', History 55 (1970): 360-83.

3. RMcK, Parliamentary Debates, 7 February 1900, 895. 
report upon allegations of Fraud and Irregularity in connection with War Office Contracts during the last Twelve Months', to which end whistleblowers were encouraged. McKenna successfully drew attention to his task by summarily implicating Chamberlain in profiteering. He introduced to the committee the question of cordite contracts awarded to Kynoch's, the chairman of which happened to be Arthur Chamberlain, Joseph's brother. The committee reported in August and considered a number of cases of firms placed on the ineligible list, and cordite contracts, where bribes had been accepted. Whilst exonerating from all blame those implicated, the committee did recommend more rigorous inspection, and that any firm offering the slightest gratuity to any officer in connection with a government contract should be struck off the list. It also felt, moreover, that Parliament should extend the Public Bodies Corrupt Practices Act, 1889, to the government service. ${ }^{1}$ McKenna moved his own amendments to the report, which the committee rejected and he therefore told The Times that 'though the committee attached no moral blame to these gentlemen, it cannot be said that they rejected the conclusion that something improper had been done'. ${ }^{2}$

McKenna made fresh enemies, including Chamberlain's auxiliariesJoseph Powell Williams, Financial Secretary at the War Office, attacked him for making 'scandalous and untrue' ${ }^{3}$ charges-charges, moreover, which had been fed to him by a rival contractor. Sir Edward Grey distanced himself from the accusations, though Lloyd George pursued the matter in the Commons, which caused Austen Chamberlain to defend his own involvement in another firm, Hoskins. McKenna did not admit defeat, but did admit to Campbell-Bannerman:

Many people have spoken to me of the opportunity which the cordite enquiry offers for an attack on Chamberlain. I know the evidence, and I have not been able to argue with them. I think a strong case can be made out against Powell Williams, but an attempt to include Chamberlain would only afford a means of escape to that one of the culprits against whom the facts ought to be brought home. ${ }^{4}$

McKenna maintained to Campbell-Bannerman that "Chamberlain is more vulnerable through his satellites than in himself. Perhaps it is only a question of the order of attack. ${ }^{5} \mathrm{~A}$ month later he returned to the issue, and revealed that Joseph and Austen Chamberlain both had shares in a Birming-

1. Report from the Select Committee on War Office Contracts, Sessional Paper 313, HMSO, 1900.

2. Times, 18 October 1900.

3. Joseph Powell Williams, ibid., 3 October 1900.

4. RMcK to Campbell-Bannerman, 25 October 1900, Campbell-Bannerman papers, $41235 / 274$.

5. RMcK to Campbell-Bannerman, 1 November 1900, ibid., 41236/3; RMcK to Runciman, 28 November 1905, Runciman papers, 11/57. 
ham Trust, an investment body with assets in 'Tubes', a company which happened to be chaired by Arthur Chamberlain, and which in turn supplied boilers to the Admiralty. ${ }^{1}$ Nothing but the suspicion of impropriety came of it, which was sufficient, as further damage had been done to illustrious reputations, but McKenna and the Chamberlains appeared to be pursuing a personal vendetta. ${ }^{2}$

\section{GENERAL ELECTION}

With the electorate enthused by belligerency, and the parliamentary opposition divided, the government went to the country, confident in the outcome of a 'khaki' election. McKenna's address to his electors, on 26 September 1900 , acknowledged the colour of the campaign by centring on military reform. Drawing on his cordite investigations, he demanded that 'root-andbranch reform of the War Office, and of the organisation of the Army, is imperatively needed'. He also managed to combine the issue with more general social provision by referring to the resolution he had carried through the Commons, which 'urged the extension of the Workingmen's Compensation Act, with appropriate modifications to Soldiers and Sailors killed or wounded in their country's service'. It was the government's responsibility that 'nothing has been done, and, where private charity does not reach them, the widows and orphans of our brave fighters are left to no better fate than the Workhouse and the stigma of pauperism. ${ }^{3}$

In the new age of mass democracy, the third Marquess of Salisbury went to the country, and Sir John de Fonblanque Pennefather, Bart., went to the working men of North Monmouthshire. The candidate was 'selected' rather than 'adopted', which, with claims that the election had been called to exploit both an old register and 'what remains of the war fever', leant a bitter air to proceedings. ${ }^{4}$ Pennefather was a wealthy man who had made a single speech in the previous year in the constituency, and who hoped that by 'showering golden rays' on the clubs and charities of Abergavenny he could unseat the candidate of radicals and labour. ${ }^{5}$ The perceived inadequacies of the Unionist candidate gave heart and focus to a local campaign that did not mirror the national effort. The singing and the glee parties that preceded and closed McKenna's meetings could not disguise the fact that the election had been called on government terms, and that was how it was fought.

1. RMcK, Parliamentary Debates, 10 December 1900, 445-46, 454-56; Times, 29 November 1900. See G. R. Searle, Corruption in British Politics, 1895-1930 (Oxford, 1987), 52-65.

2. Parliamentary Debates, 23 May 1901, 1035-42.

3. RMcK, 26 September 1900 , electoral statement.

4. RMcK, speech at Blaenavon, 13 September 1900, Pontypool Free Press, 21 September 1900.

5. RMcK, speech at Pontypool, 21 September 1900, ibid., 28 September 1900. 


\section{Reginald McKenna}

Nevertheless, McKenna spoke out; of the 'courage and tenacity' of the Boer people, and of the chauvinism of the Tory press 'was unworthy of the best tradition of the British people', who 'were now able to recognise something of the love of their country which had been displayed by the Boers' However, they were 'bound to carry out the war to a successful conclusion.' His support for the objective of the war meant that McKenna could concentrate on the inefficiencies in its prosecution. He called for compulsory arbitration in labour disputes, the taxation of mining profits for local purposes, 'perfect freedom and equality in religious matters' regarding both the established church and the issue of church schools, and further assaults on the Chamberlains' insider-dealing. ${ }^{2}$ He called on British soldiers to be the equal of German soldiers, and British schoolchildren to be the equal of German schoolchildren. ${ }^{3}$

Polling day was 10 October 1900. ${ }^{4}$ Thousands waited outside Abergavenny Corn Exchange for the result. After rumours that Pennefather had won by four votes, McKenna's reelection with an increased majority was announced, and he was carried shoulder high to his hotel. With supporters replacing the horses of his carriage, McKenna led a procession of several hundred supporters and vehicles, torch-bearers and bands, from the count to the towns and villages of the constituency, and in the process running over two pedestrians. ${ }^{5}$ After attracting some 'decayed vegetables' from a few persons 'who felt their defeat more keenly than others', as the Pontypool Free Press put it, the procession reached Pontenewydd, where, 'never in the memory of its oldest inhabitants have such vast numbers of people assembled in its usually quiet streets'. ${ }^{6}$ McKenna 'gazed in an expression of amazement' at the numbers. ${ }^{7}$ The strength of the reception demonstrated how welcome had been the victory. The government had also been reelected with an increased majority. It had been the model 'khaki election'. 'I hope you are pleased with the way in which gallant little Wales behaved at the election',

1. RMcK, speech at Blaenavon, 13 September 1900, ibid., 21 September 1900.

2. RMcK, speech at Upper Cwmbran, 12 September 1900, ibid., 21 September 1900 .

3. RMcK, speech at Blaenavon, 23 September 1900, ibid., 28 September 1900.

4. General election, Monmouthshire, North, 10 October 1900.

\begin{tabular}{lrl}
\hline Total electors & 11,159 & Share \\
R. McKenna (L) & 5139 & $57.9 \%$ \\
De F. Pennefather (U) & 3740 & $42.1 \%$ \\
Liberal majority & 1399 & $15.8 \%$ \\
\hline
\end{tabular}

5. Pontypool Free Press, 12 October 1900.

6. Ibid., 19 October 1900.

7. Ibid., 19 September 1900. 
McKenna told Campbell-Bannerman, offering the smallest of gratifications after the rout the party had suffered nationally. ${ }^{1}$

\section{'CB'}

Although even further from power, in his second Parliament, and notwithstanding his misgivings McKenna paid more attention to his second party leader than he had to his first. Having sought to retain distance from Harcourt, McKenna did all he could to be on good terms with Campbell-Bannerman. ${ }^{2}$ Privately, McKenna, in common with most of his parliamentary generation, regarded Campbell-Bannerman's leadership as being insufficiently vigorous. As if aware of this, Campbell-Bannerman was keen therefore to harness McKenna's still relatively youthful aggression, and McKenna was keen that his own efforts should count for more. To each end, McKenna wrote both constructive and flattering letters, and accepted an invitation to stay with the Campbell-Bannermans at Belmont Castle, Meigle, in Perthshire, in November 1900.

McKenna's behaviour towards Campbell-Bannerman's likely successor-to whom he had originally been receptive-appeared anything but self-serving. On 14 June 1901, Campbell-Bannerman formally, and infamously, came out publicly against the Boer War. At a dinner of the National Reform Union, he concluded his speech by condemning the government and its 'methods of barbarism. ${ }^{3}$ It was an offensive remark that opened up a new front in the war. On 20 June, H. H. Asquith publicly repudiated his leader's comments. To celebrate and endorse that event, the City Liberal Club had planned another dinner, for 19 July, to which McKenna had been invited. He decided to boycott it, and wrote a letter to Asquith on 28 June on behalf of forty Liberal MPs, explaining that they would be unable to join him at what they regarded as a sectarian occasion.

Recognising the consistent efforts you have made to promote unity, we are concerned lest occasion should be given for emphasising the differences which unfortunately exist amongst us-differences which ought not to deter us from working cordially together both in criticising the failure of the Government to carry on the war successfully, and in dealing with the settlement of South African hereafter. ${ }^{4}$

1. RMcK to Campbell-Bannerman, 25 October 1900, Campbell-Bannerman papers, 41235/274.

2. RMcK to Campbell-Bannerman, 6 December 1900, ibid.,41236/52.

3. Campbell-Bannerman, 14 June 1901, Times, 15 June 1901.

4. RMcK to HHA, n.d. The first draft of the letter sent to Asquith on 28 June 1901, Asquith papers, 10/6-5; RMcK to HHA, n.d., Asquith papers, 10/7. 
'My hope, on the contrary, was and is to take advantage of the proposed dinner for another purpose', Asquith replied.

Liberals who share the views which I have lately restated about the war are supposed, in some quarters upon both sides, to be in the early stages of a process of political evolution. Having differed with some of our friends upon one question, we are told that before long we shall be found to be in general agreement with our opponents. This is an illusion which in my opinion cannot be too promptly or effectually dispelled. ${ }^{1}$

Asquith refused Campbell-Bannerman's request to postpone the event; ${ }^{2}$ Asquith was inclined towards the Marquess of Rosebery over both the leadership and the war, whereas McKenna, for all his doubts, and on grounds of party unity more than the war itself, continued to side with CampbellBannerman.

The result of McKenna's balancing act over the war was an amendment, tabled with Frederick Cawley, to the King's Speech at the start of the 1902 session.

The House, while prepared to support all proper measures for the effective prosecution of the war ... is of the opinion that the course pursued by your majesty's ministers, and their attitude with regard to a settlement, have not conduced to the early termination of the war and established a durable peace. ${ }^{3}$

By adopting Chesterfield's policy of the sword and the olive branch, it was dismissed by Balfour to much laughter as 'a many coloured amendment', ${ }^{4}$ and it had the opposite effect to that intended, with both Chamberlain and Lloyd George attacking it from opposite directions. The measure may well have originated from the front bench, ${ }^{5}$ but McKenna might have learnt a lesson about the premium in wartime of clear advocacy, of whichever direction. He was much more comfortable alleging widespread corruption in horse purchases. ${ }^{6}$

The fraying of parliamentary associations continued with that of the Radical Party. Henry Lucy observed from the press gallery, 'The new Party gradually dissolved leaving not a wrack behind, unless we cluster under that word Sir Charles Dilke, Mr Labouchere, and Mr McKenna."7 It was

1. HHA to RMcK and C. E. Hobhouse, 29 June 1901; Times, 2 July 1901.

2. Stephen Koss, Asquith (1976) 54-5.

3. RMcK, 20 January 1902, Parliamentary Debates, 330-35.

4. Balfour, 22 January 1902, Times, 23 January 1902.

5. Spender, Life of Sir Henry Campbell-Bannerman, ii. 23.

6. Parliamentary Debates, 18 March 1902, 359-63.

7. Lucy, Later, 429. 
as clear to McKenna as it was to others, however, that neither Dilke nor Labby pointed much to a ministerial future. In his 1900 election campaign McKenna had ridiculed much of the Conservative party in Parliament as obeisant 'lobby trotters'; $;$ if he had not decided to ape them, he appeared to recognise the merits of discipline, though he was still happy to call into question the procedural probity of the government and the speaker, at the risk of suspension. ${ }^{2}$

With his closer proximity to the leadership, McKenna appeared to moderate his radicalism. Queen Victoria's death, in January 1901, provided the occasion for a parliamentary reconsideration of the Civil List and the expenditure of the royal household. Dilke and Labouchere had long been proponents of dramatic retrenchment of the court. In March, the Commons appointed a Civil List Select Committee, which included as members Balfour, Harcourt, Campbell-Bannerman, Labouchere, and McKenna. It was the most prominent position McKenna had so far occupied, and one that brought together the past and the present and the possible future of his parliamentary career. McKenna's conduct on the committee suggested both disagreement between radicals and 'extreme radicals', ${ }^{3}$ and his closer alignment with a 'front bench' disposition. McKenna wrote to his leader with his proposed amendment to the Civil List:

The settlement of a Civil List affords the proper opportunity for a thorough reconsideration of Royal expenditure and the committee are of the opinion that an enquiry should be made into the duties and emoluments of all employments in the Royal Household with a view to determining the extent to which the change of the Civil List might be lessened without impairing the appropriate provision for the comfort of the sovereign and the splendour of the court.

'I shall of course vote against Labouchere's report, but it seemed to me desirable to express the regard for economy which I feel. ${ }^{4}$ Labouchere alone voted for his version of the report, which concerned the kind of issue on which he may once have expected McKenna to join him.

With effective parliamentary opposition on their part limited by their numbers, the Liberals' main opportunity lay in the complacency of the Unionists, of whom only 172 were present to support the chancellor, Sir Michael Hicks Beach, against McKenna's amendment to the budget proposing to lay a quarter of the new coal duty on royalty owners. The amendment

1. RMcK, speech at Blaenavon, 13 September 1900, Pontypool Free Press, 21 September 1900.

2. RMcK, 13 February 1902, Parliamentary Debates, 1360-63.

3. Times, 19 February 1901.

4. RMcK to Campbell-Bannerman, 27 March 1901, Campbell-Bannerman papers, 41236/102. 
went down to defeat by only twenty-eight votes. McKenna was criticised, in a leading article in The Times, for attempting to utilise a means of revenue to reform the social system-and attack the owners of landed property: 'unfair from every point of view except that of persons in favour of a social revolution in regard to land'.

Harcourt had recently said 'we are all socialists now', ${ }^{2}$ and McKenna's political concerns remained as much those of labour as they were of Liberalism. Dilke chaired the select committee on income tax, which also included Trevelyan, Hicks Beech, and Keir Hardie, as well as McKenna. ${ }^{3}$ It investigated 'the practicability of graduating the Income Tax and of differentiating, for the purposes of the Tax, between Permanent and Precarious incomes.' It advocated the compulsory declaration of net income, accepted super-tax in principle, and to continue the existing abatement to $£ 1,000$. McKenna opposed the factory and workshops bill, and claimed that it withdrew from women and children many of the safeguards built up in the previous thirty years, and with Hardie, supported the extension of the workman's compensation act to seaman-one legislative initiative that could not be connected with constituency self-interest. When he laid the foundation stone at Pontypool hospital made possible by the landowner, an annual grant from an industrialist, a donation from the Chamber of Trade, and contributions of 7000 workmen, McKenna applauded the cooperation of labour and capital. ${ }^{4}$

Given his constituency, McKenna was indeed effectively a labour representative in Parliament, and associated himself closely with those of his colleagues who sought to minimise the difference between labour and liberal. McKenna's waging of the class war, such as it was, combined with the Taff Vale judgement, where a South Wales railway company succeeded in rendering a trades union liable for damages in the event of industrial action, and thereby effectively denying labouring people the right to strike. The Liberal leadership was ambivalent about reversing the measure, but the Radical Committee was determined to fight the legislation. The issue became the focus of more general cooperation and association between socialists and radicals. On 5 February 1902, Dilke presided at a meeting of the parliamentary committee of the Trades Union Congress and five sympathetic MPs, including McKenna and John Burns. They subsequently resolved that the Radical Club, Labour MPs, and the parliamentary committee of the Trades Union Congress would work together on matters concerning labour. ${ }^{5}$

1. Times, 26 June 1901.

2. Times, 20 May 1890 .

3. Report from the Select Committee on Income Tax, November 1906, Sessional Paper 365, HMSO, 1906.

4. Pontypool Free Press, 8 August 1902.

5. Times, 19 June 1902. 
It was in the 1902 session that Balfour introduced an issue over which he and McKenna would clash, and which would embroil McKenna for several years. The subject was education, which was fraught with divisive potential, because there was a religiously defined dual system. One type of elementary school-'provided' or 'nonvoluntary schools'-was funded by the rates by school boards; the other-'nonprovided', or 'voluntary schools'-was funded by voluntary agencies, usually churches, and therefore usually Anglican. In the growing urban areas, where there was inadequate provision of voluntary denominational schools, the 1870 Education Act had established nondenominational state schools, organised by districts, administered by boards, and paid for from the rates. While the bill made provision for religious teaching, board schools were required to be nondenominational, which appealed to nonconformists, as did the fact that they could elect the board, and meanwhile voluntary, particularly Anglican, provision was undermined. While that was agreeable to radicals, it was not to conservatives. Balfour's 1902 Education Bill proposed the abolition of the school boards and the handing of power to local education authorities (LEAs), which could establish new secondary and technical schools and develop elementary provision. Denominational schools were to be integrated into the state system, and would be paid for by mandatory taxation-the rates. Nonconformists were therefore expected to pay rates that would then be used for the financing of Anglican education, which was in any case rarely demanded by workingclass parents. Even more pointedly, in Wales nonconformists were effectively being required to pay for the Church of England.

Balfour's commitment to sectarian teaching-his provision that LEAs were required to give rate-aid to voluntary schools-had aroused the interests that the Liberal Party represented, and gave scope for ambitious young Liberals, particularly those based in Wales, to arouse it further. McKenna acted with Samuel Evans and Lloyd George, which tightened the Welsh party in Parliament, and supported the Baptist minister Dr John Clifford, who organised a national passive resistance movement in the country, by which 170 were imprisoned for nonpayment of rates. At Westminster, McKenna moved an amendment to clause seven of the bill, proposing that if there were no other schools within three miles, nonprovided, or church, schools should be considered provided. ${ }^{1}$ He demanded that local authorities 'have sole control over the expenditure of all money publicly provided'. ${ }^{2}$ Balfour's measure had established the basic structure for education in England and Wales, but at the cost of animating the government's opponents, at a time when the government was suffering setbacks. It meant that in addition to involvement in the strategic interests of the Liberal Party and its constituents, McKenna fully occupied himself in the tactics of distracting and inconveniencing the government. As the Westminster Gazette put it, McKenna

1. RMcK, Parliamentary Debates, 22 July 1902, 916.

2. Ibid., 17 October 1902, 172. 
had "earned the reputation of an all-round man who could safely "put up" to find the weak spot in the Government's armour, and as a vigilant sharpshooter below the gangway he was invaluable to the Liberal Whips'. ${ }^{1}$

\section{PERSONAL}

Midway through his period in opposition, Reggie had reached middle age without office, or family. He had moved from Clarence Terrace to live with his sister Mary at 123 Sloane Street. Other than Ernest and Theo, his closest friends were his political allies, in particular H. W. Massingham of the Daily News, J. A. Spender of the Westminster Gazette, and Lloyd George. Spender and Lloyd George holidayed with Reggie and Ernest at Etrêtat in September 1902. At the end of year they headed south, where much of the parliamentary classes could be found wintering on the Riviera. Where the popular imagination had them in the casinos of Monte Carlo, they would more often be found walking in the mountains around Mentone or Beaulieu, or in Roquebrune itself where Ernest had purchased land in 1901 and built a villa, overlooking the Nice golf links. As well as Lloyd George and Spender, Sir Robert Hudson, and Charles Russell would join the brothers McKenna. ${ }^{2}$ Reggie's regular sojourns to his French villa were another practice he shared with Dilke.

In a parliamentary working environment dominated by the stout and hirsute, Reggie stood apart. Slight and completely bald, 'when he was sitting he looked as if he must be a very tall man; when he stood up he became short, so disproportionately long was his body in relation to his legs', doubly curious from the rowing proponent of the 'long slide. ${ }^{3}$ Charles King may have been influenced by his manner when he described 'a man who sat and stood as though a poker ran up his spine into the crown of his head and kept him from bending. ${ }^{4}$ However rigid he may have appeared, Reggie remained physically very active. As he did when he was a barrister, Reggie swam regularly in the Serpentine in Hyde Park, the only place in London, it was said, where one could make a long straight dive from the shore. He was one of the last members of the Parliamentary Cycle Union; ${ }^{5}$ he was also one of the last members of the parliamentary bachelors' union.

Of Reggie's contemporaries, Crewe had a wife at the age of twenty-two, Grey at twenty-three, Asquith and Lloyd George were married at twenty-five, Loulou and Simon at twenty-six, Samuel, Seely, and Massingham at twentyseven, Hobhouse and Runciman at twenty-eight; only Churchill waited

1. Westminster Gazette, 8 June 1907.

2. J. A. Spender, Sir Robert Hudson, A Memoir (1930), 104-5.

3. Francis Meynell, My Lives (1971), 68.

4. King, Parliament, 44.

5. A. C. Forster Boulton, Adventures, Travels and Politics (1939), 144. 
until his thirties. In 1903, Reggie was forty. The delay could be ascribed in part to McKenna's general effect on women being similar to that which he had on men. First reactions were often unfavourable, as the female family Asquith demonstrated. ${ }^{1}$ Though Cynthia admitted, 'I really like him', it was because 'he appeals to the fraction of me which loves Dickens'. ${ }^{2}$ Elizabeth meant it as a compliment when she said 'his faults are all on the surface.' Even when he tried to be friendly, as Violet put it, Reggie's 'table-talk and linksbadinage do his brains an injustice-he is a different man when he talks shop'. ${ }^{4}$ It was perhaps for that reason that he was attracted to politically active women. In 1903, Reggie became involved with the twenty-three-yearold Ivy Gladys Pretious. A protégé of the positivist Frederic Harrison, Ivy was personal secretary to Emily Hobhouse when Reggie met her. A year later, she was secretary of the executive committee of the Free Trade Union, before working in the Women's Free Trade Union, a repository of Unionists and antisuffragists. ${ }^{5}$ She became one of the most prominent and best-paid women in Edwardian Britain. ${ }^{6}$

It was a public courting of two public figures, and Reggie was not alone in his intent. Ivy had already been jilted by Albert Napier, proposed to by the Irish Nationalist MP Tom Kettle, and as a single woman in Edwardian Britain attracted the attentions of both Lloyd George and Bertrand Russell. ${ }^{7}$ Maladroit in such matters, Reggie was scorned by one who was not. 'She is in the gravest danger from a man who is simply a blackguard', Russell warned Lucy Donnelly in September 1904. McKenna 'has a great influence over her by means of his ability and strength of will ... [but] she will not let me speak to him'. ${ }^{8}$ The irony of Bertrand Russell defending the honour of a young woman from a blackguard went without apparent notice. Ultimately, Ivy married Charles Tennyson, whose mother, reinforcing a sense of a selfreplicating political elite, went on to marry Augustine Birrell.

1. HHA to Sylvia Henley, 13 August 1915, Asquith papers, 542/2/31.

2. Cynthia Asquith, 11 May 1916, in Lady Cynthia Asquith, Diaries, 191.5-1918 (1968), 164.

3. Elizabeth Asquith to Lloyd George, 2 July 1912, in Riddell, diary, Riddell papers, 62971.

4. Violet Asquith to Edwin Montagu, 9 March 1908, in Lantern Slides, Diaries and Letters of Violet Asquith, eds. Mark Bonham Carter and Mark Pottle (1996), 145 .

5. Cameron Hazlehurst and Christine Woodland, eds., A Liberal Chronicle: Journal and Papers of J. A. Pease, 1st Lord Gainford, 1908-10 (1995), 248; RMcK to Crook, 16 December 1904, Crook papers, 384/236.

6. Anthony Howe, Free Trade and Liberal England, 1846-1946 (Oxford, 1997), 260; Hallam Tennyson, The Haunted Mind, An Autobiography (1984), 7; Martha S. Vogeler, Frederic Harrison, The Vocations of a Positivist (Oxford, 1984), 250.

7. Hazlehurst and Woodland, A Liberal Chronicle, 248.

8. Bertrand Russell to Lucy Donnelly, 19 September 1904, in The Selected Letters of Bertrand Russell, Volume I: The Private Years, 1882-1914, ed. Nicholas Griffin (1992), 282. 


\section{Reginald McKenna}

For the time being, continuing bachelorhood did not matter to Reggie. Far from providing another Don Juan McKenna to the family, Reggie's only real female devotion remained to his mother. As long as Em was alive, there appeared to be little room for any other woman. 'I have only known 2 men who really loved \& love their mothers', Asquith's second wife Margot thought. 'Haldane \& McKenna-boys sometimes do but they seldom keep it up. Haldane writes every day to his mother. McKenna never married but gave up his life to his mother'. ${ }^{1}$ Marital matters would have to wait until the maternal spell had been broken. Lady Crawford met the McKennas at a party at T. P. O'Connor's, where 'the two brothers were so genial and somebody spoke to one ... of their devotion to their mother. 'A good son is sure to be a good husband'.2

\section{FREE TRADE}

Unsettled by his contortions over the South African war, McKenna was probably grateful that its inconclusive passing in May 1902 provided for more doctrinal preoccupations, and one in particular. Free trade was an issue that was both logical and measurable, and one that was central to his raison d'être as a politician and to his essence as a Liberal. His whole conception of civilisation, as he would not have put it, could be said to have been economic, yet free trade was more than an economic policy. From free trade flowed freedom of the seas, natural law, and progress: 'truth', as he liked to put it. Free trade meant cooperation between nations, and cooperation between nations discouraged conflicts and wars. Free trade overcame borders, and where borders could be overcome, so could differences. Free trade was a counsel of peace; it also offered further opportunity for twitting Balfour and Chamberlain.

With Chamberlain's latest dramatic initiative, the issue of free trade suddenly became the central question in politics. Smarting from the damage to imperial pride constituted by the war, on 15 May 1903 he set out to divide his second party by declaring publicly for a tariff wall around the empire. Having failed to convince Balfour, Chamberlain resigned from the Cabinet on 16 September. On 2 October, Balfour came out for protection. Having freed himself from his most ardent protectionist, the prime minister then shed his most inveterate free traders. Chamberlain's announcement for protection had split the Unionists in a similar way as his announcement for Home Rule had the Liberals twenty years earlier. Just as, in 1886, Chamberlain's action seventeen years later had provided McKenna with the opportunity to rise

1. MA, diary, April 1909, MA papers, d.3207/217.

2. Emily Crawford to Agnes Jekyll, 22 April 1908. The author is grateful to Mrs Primrose Arnander for this reference. 
within the counsels of his party, so his 1903 action provided McKenna with the opportunity to move from opposition and into government.

In the vanguard of Liberal opposition to any plans for tariff reform was the Free Trade Union (FTU). Inaugurated in July 1903 and based at 8 Victoria Street, Westminster, the FTU was formed 'with the sole purpose of meeting the dangers with which the country is threatened by Mr Chamberlain's fiscal proposals,' as expressed by the simultaneous Tariff Reform League. ${ }^{1}$ Indeed, it managed to draw back to the party Liberal Unionists for whom free trade was more important than Home Rule. Under the supervision of Herbert Gladstone, the chief whip, the executive committee of twenty-two included Birrell, Loulou, Runciman, and Charles Hobhouse, with George Whiteley helping to fund the union as honorary treasurer. As honorary secretary, and assisted by Leonard Hobhouse, McKenna directed the union's work. ${ }^{2}$ His office made him central to the cause with which he would be most closely associated. Despite the broad implications of the issue, it gave a precise focus to his political activism, accelerating his shift from social to fiscal conflict. The ends were the same, but the emphasis henceforth was on means. While free trade focussed McKenna's efforts, it also served to broaden his outlook; where the APS was a matter of duty, the FTU was a mission.

The cause of free trade required research. Intellectual rigour had always characterised McKenna's work, and he felt there was no such rigour in the practice of protectionists. McKenna had soon immersed himself in what Spender called his 'indefatigable and well equipped research laboratory', ${ }^{3}$ of blue books, official reports, and correspondence. The cause also required publicity and the Unionist MP Winston Churchill conceived a small private committee of six or seven MPs to coordinate the free trade press of the country, and included in it himself, Grey, Burns, and McKenna. ${ }^{4}$ Where Chamberlain received consistent support in the press from J. L. Garvinand his Fortnightly Review-McKenna's journalistic supporter of mutual choice was Spender-and his Westminster Gazette. After one provocative article by Garvin, Spender was charged with replying in the next issue. McKenna offered to help write the piece, and in the ten days available, the two went through the trade records for the previous thirty years. They jointly wrote the resulting article, but McKenna refused a byline or any public credit. Through McKenna's adherence to statistical evidence, and the

1. Times, 18 July 1903.

2. Sir Charles Mallet, Herbert Gladstone: A Memoir (1932), 197.

3. J. A. Spender, Life, Journalism and Politics, 2 vols. (1927), 2:111.

4. Winston Churchill to Earl of Rosebery, 17 November 1903, in Winston S. Churchill, vol. 2, Companion I: Documents, 1901-1907, ed. Randolph Churchill (1969), 252. 
selva selvaggia of the official records, Spender claimed to have found it an invaluable journalistic experience. ${ }^{1}$

Free trade also meant campaigning. McKenna preferred to be in the laboratory. 'The man is not born-at any rate, I don't know him-who can be glad at the prospect of public meetings,' McKenna confessed to Walter Runciman in 1902. 'From September 29th to October 11 I have ten with my people, not to mention a big demonstration with Asquith on October 30th and two or three more meetings to be squeezed in this session. ${ }^{2}$ The pleasure he took in platform performance had changed little in the twenty years since he began in Clapham-and nor had his aptitude for it. His aversion to the protectionists and tariff reformers was in large part one of method, of the demagoguery their cause presupposed, and which to him they duly delivered. It might almost have been in deliberate contrast that, as one observer noted, McKenna was 'not a popular platform speaker, lacking a generous sense of humour, and having a rather dry delivery, as well as a pontifical manner'. ${ }^{3}$

Nevertheless, McKenna proselytised on platforms, in Parliament, and in the letters page of The Times. The qualities that rendered him unpersuasive on platforms worked to his advantage in print-and in the Commons, where he offered detailed correction of falsehoods or the amplification of mistakes on the part of his opponents. The method usually produced the desired reaction. In October 1903, he got into a row over the consequences for German-Russian trade of the tariff war between the two countries, and, by implication, for other countries that indulged in economic nationalism. ${ }^{4}$ In January 1904, after Chamberlain had claimed at the Guildhall that German prosperity was due to its erection of tariffs, he used Chamberlain's own evidence to prove exactly the opposite. Chamberlain employed 1890 as the beginning of the protectionist period, whereas it was near the close; 'Judged by any test, it will be found that the German people have prospered far more under the reduced tariffs', McKenna concluded, 'and their experience has abundantly justified the belief that social prosperity is promoted by a reduction of tariffs'. ${ }^{5}$ That claim prompted the independent Irish Nationalist MP Moreton Frewen to claim that 'their very wells of truth are poisoned' by McKenna about whose cause the public was being 'wilfully misled'. ${ }^{6}$ McKenna responded to the accusations with recourse to a combination of blue books and his antagonist's misunderstanding: 'I impute nothing worse

1. Spender, Journalism, i:111.

2. RMcK to Runciman, 9 September 1902, Runciman papers, 6/(6)/29; F. H. Lambert to Churchill, 23 April 1904, Churchill papers, CHAR 2/17/36.

3. Birmingham Mail, 6 September 1943.

4. RMcK, Times, 29 October 1903.

5. RMcK, Times, 22 January 1904.

6. Times, 23 January 1904. 
to $\mathrm{Mr}$ Frewen than that he has been furiously carried away by his protectionist ardour.'

Free trade helped cement McKenna's most enduring friendships. ${ }^{2}$ Spender recalled, 'Many of the hours that I would most wish to live over again have been spent with McKenna and his brother, Ernest'. ${ }^{3}$ Spender was a year older than McKenna, and had been editor of the Westminster Gazette since 1896. Most weekday evenings, McKenna would finish at the Commons and go with Ernest to Spender's flat at 45 Sloane Street, where they would sit into the small hours. 'Hundreds of times I have sat down to write leading articles with the memory of our overnight talks in my mind', Spender recalled. ${ }^{4}$ McKenna was the source of Westminster gossip that found expression as 'The Diary of Greville Minor' in the Westminster Gazette, and which, through its nominally fictitious diarist, allowed for the type of bold but unsubstantiated assertion that could take no other form. ${ }^{5}$ Greville Minor's diary was a chronicle of concerted opposition, mischievous and aggressive, in which McKenna appeared to take the form of Burndale to Spender's Greville; both being preoccupied with Chamberlain and Balfour, together and separately, and how the imperspicuous latter 'contrived to turn his fence into a pedestal'. ${ }^{6}$

McKenna's friendship with $\mathrm{H}$. W. Massingham, subsequently editor of The Nation, also developed through the Free Trade Union, as did that with C. P. Scott, who was editor of the Manchester Guardian, and for the first eleven years of McKenna's parliamentary career also a Liberal MP. Yet what served in this period as an advantage would in time reveal a limitation: just as McKenna appeared to be interested only in women who were interested in politics, so he was drawn to journalists because they were free trade Liberals. The disadvantage was that while the Unionist press was one of massmarket newspapers with large proprietors, the Liberal press had smaller circulations but larger editors, who regarded themselves as the equals of the politicians. McKenna was not as reticent as some of his other colleagues in dealing with the press, but he still displayed an instinctive aversion to courting opinion, an aversion that contrasted with those who were more forthcoming and were in time to prove ascendant.

Just as free trade provided McKenna with his closest journalistic friend, so it also led to his closest parliamentary association. Walter Runciman was seven years younger than McKenna, and had been an MP since 1899. He came from an only slightly more gilded background than had McKenna, and

1. RMcK, Times, 25 January 1903.

2. RMcK to Runciman, 14 October 1905 , Runciman papers, 11/43.

3. J. A. Spender, Life, Journalism and Politics, 2 vols. (1927), i:165.

4. Ibid.

5. Ibid., 1:113.

6. 'Greville Minor', diary, 8 July 1903, in A Modern Journal: Being the Diary of Greville Minor for the Year of Agitation, 1903-1904, by J. A. Spender (1904), 3. 
was a teetotaller and Wesleyan Methodist. McKenna and Runciman became a pairing referred to historiographically almost to the point of hyphenation, and were similarly distrusted as sectional partisans early in the Commons. ${ }^{1}$

In contrast, when Lloyd George visited McKenna at Blaenavon in the summer of 1903, nearly 2,000 people met them, and the inevitable Templar Band escorted them to the hall. That evening marked the height of their friendship. McKenna announced, The Times reported, that

Mr Lloyd George had been the leader of a great fight on behalf of the popular rights and of religious equality; he had, metaphorically, $\mathrm{Mr}$ Chamberlain dead on the floor of the House of Commons (loud laughter and cheers). He was the stamp of the man they needed ... [Lloyd George] paid a tribute to the active services of Mr McKenna, remarking that it was said that there were some people that they must not go tigerhunting with, and there were some that he would not go rat-catching with (loud laughter), but with Mr McKenna as a colleague he would face any action. There was no man in the House who had made greater strides in recent years (cheers) ... ${ }^{2}$

The following April, McKenna acted as intermediary for the crossing of the floor of another Unionist MP alienated by Balfour's support for protection. In May, Winston Churchill became a Liberal MP. ${ }^{3}$

McKenna continued as a member of the Aborigines Protection Society, and following the appropriation of land in central Africa by European companies, signed a memorial to the Inter-Parliamentary Union conference in Vienna in August 1903. The petition brought 'the cruel and devastating treatment of natives' by the Belgian regime to its attention. It proposed 'that there should be complete freedom of trade for all nations, without matters being allowed therein, and that its indigenous population should be watched over and preserved, and their moral and material conditions of existence improved', by referral to the Hague Tribunal. ${ }^{4}$

May 1904 encouraged another generational shift, when McKenna cultivated another scandal with a Chamberlain, this time Austen, son of Joseph, and the chancellor of the Exchequer. The unprepossessing subject was stripped and unstripped tobacco. The affair was a model example of McKenna's parliamentary priorities and practice; indeed, for one anonymous portraitist, the key one.

1. See Jonathan Wallace, 'The Political Career of Walter Runciman, 1st Viscount Runciman of Doxford' (PhD thesis, University of Newcastle, 1995).

2. South Wales Daily News, 5 June 1903.

3. William Finnemore to RMcK, 2 December 1903, Churchill papers, CHAR2/10/6; J. Moore Bayley to Churchill, 7 December 1903, Churchill papers, CHAR 2/10/7-9.

4. Times, 2 October 1903. 
I remember his first great score, when from the backbenches he shook the whole fabric of Mr Austen Chamberlain's first Budget on the question of unstripped tobacco. What unstripped tobacco is I do not know; neither, I suppose, did the majority of members. But McKenna knew all about it; and that is just his characteristic. ${ }^{1}$

Stripped tobacco was tobacco leaf stripped from the stalk by aboriginal women and children, a process undertaken where the tobacco was grown. Chamberlain had sought to protect the tobacco stripping industry in clause two of his finance bill, which sanctioned an increased duty of three pence on stripped tobacco. Without implying any filial devotion, McKenna claimed the duty violated the government's stated policy of free trade. ${ }^{2}$ The duty would imperil the Aboriginal stripped tobacco industry, but produce no more than a dozen jobs in the United Kingdom. It would pass on the costs to the already poorly paid retail tobacconists, having the ultimate effect of reducing revenue to the Exchequer through diminished consumption. It appeared a measure more of ideological provocation than fiscal practicability, and that was how it was treated. Even the Wholesale Tobacconists' Protection Association opposed it. ${ }^{3}$

As honorary secretary of the Free Trade Union, McKenna could have had no better issue on which to assail both the men and the measure. McKenna made the matter even more pointed when, two years after accusing Joseph Chamberlain of profiteering, he accused Austen Chamberlain of insider dealing. He told the Commons that the immediate effect of the tax-before any revenue to the Exchequer was received-was to transfer around $£ 300,000$ from the owners of stocks of stripped tobacco to the owners of stocks of unstripped tobacco. He therefore wanted to know who had advised the chancellor, after insinuating that it had been his father's Tariff Commission and a tobacco merchant who would make a profit through the increased duty. ${ }^{4}$ The exchanges were bitter, Austen Chamberlain describing McKenna's speech 'happily of a kind to which we are not accustomed to listen in this House', and one which 'reflects discredit on the maker rather than on the persons at whom it is aimed.' In the Commons on 5 May, McKenna called on Chamberlain to appoint a select committee 'to ascertain whether an exceptionally large import of unstripped tobacco in March was to be ascribed to foreknowledge on the importers' part of the contents of the budget'. ${ }^{6}$ Balfour, the prime minister, answered, refused, and accused

1. Illustrated Sunday Herald, 18 April 1915 [Enc. HHA to PMcK, 28 June 1915].

2. RMcK, Parliamentary Debates, 3 May 1904, 291-95.

3. Times, 23 April 1904.

4. RMcK, Parliamentary Debates, 3 May 1904, 296-99.

5. Austen Chamberlain, Parliamentary Debates, 3 May 1904, 299.

6. RMcK, Times, 6 May 1904. 
McKenna of impugning the honour of a member of the government. ${ }^{1}$ In the following uproar, McKenna was prevented from replying. CampbellBannerman rose to his defence and demanded that Balfour withdraw his comments. Balfour refused. The press reported that Balfour would reply publicly to McKenna's claims at a meeting of the Primrose League at the Albert Hall the following day, but, as he left for the meeting, he was handed a letter from McKenna. 'The Board of Trade Returns raise a prima-facie case for the inquiry', McKenna maintained, but also claimed that his speech had been misreported: certain journalists 'have enjoyed a carnival of calumny against me for the last few days' and 'though I did not say anything against the honour of the Chancellor of the Exchequer, I meant it'. ${ }^{2}$

Rather than reply in the Albert Hall, Balfour replied in The Times, accepting the clarification, but recognising that McKenna's language 'could not fail somewhat to obscure the benevolent intentions which, as I gather, really underlay your remarks'. ${ }^{3}$ McKenna went on to move an amendment to relieve stripped tobacco from the proposed additional duty of 3 pence per pound. The chancellor conceded a rebate of 1.5 pence to importers with stripped tobacco in bond, but also pointed out that less unstripped tobacco had actually been imported than in the previous year. McKenna's behaviour caused Sir Almeric Fitzroy, clerk of the Privy Council, to muse that 'it is curious what unexpected assistance is given to the Government by the ill-judged malice of a certain type of politician'. ${ }^{4}$ McKenna was left to comment how 'it was remarkable that a member of Mr Chamberlain's commission correctly anticipated what the budget proposals were going to be.'

McKenna aroused similar reactions in a certain type of prelate with the resurgence of the education controversy in 1904. With Lloyd George, he led what was described as the 'Welsh revolt', when largely nonconformist or Liberal county councils refused to implement the 1902 Act because it gave rate support to church schools. The bishop of St. David's accused Welsh liberals of brandishing education as a political weapon to the ends of their ultimate objective: disestablishment of the Church of Wales. Attempts by the church to point to division in the no-rate campaign-when three counties failed to fulfil their obligations under the act and found themselves in default-roused McKenna in the Reform Club to thunder in the pages of The Times, 'In relation to the Defaulting Authorities Act and the Education Act there is no Ulster in Wales.'

1. Balfour, Parliamentary Debates, 5 May 1904, 545-46.

2. RMcK, 6 May 1904, Times, 9 May 1904.

3. Times, 10 May 1904.

4. Sir Almeric Fitzroy, Memoirs, 2 vols. [1925], 1:202; RMcK, Parliamentary Debates, 10 December 1900, 454-58; Illustrated Sunday Herald, 18 April 1915; See G. R. Searle, Corruption in British Politics, 1895-1930 (Oxford, 1987), 56-59.

5. New York Times, 4 May 1904.

6. RMcK, 1 November 1904, Times, 3 November 1904. 


\section{THE FALL}

With the passing of the war that had divided it, the fiscal and education policies of the government served to unite the Liberal Party. Confidence was growing across the parliamentary opposition. 'Shall we defeat the Government?' McKenna asked Runciman. 'The country is with us and we may make our opposition as determined as we like." Lord Craigmyle remembered the 'jollity of those days', of dinners at the Café Royal with McKenna, Lloyd George, and Churchill. ${ }^{2}$ Frances Balfour lunched with the three at J. A. Spender's one afternoon, the memory of which 'seems to me still to fill the air with the sound of laughter'. ${ }^{3}$

Their confidence was well founded. With signs that the government was faltering, McKenna increased his campaigning, with by-elections a particular priority. ${ }^{4}$ The Free Trade Union necessitated meetings in such numbers that he had to turn them down. 'The spirit is willing,' he told the Methodist journalist William Crook, 'and the flesh is pretty tough, but there are limits on the strain it will bear.' The role of a campaigning backbencher did not appeal in the way it might have ten years before. From mid-November to Christmas 1905 , McKenna addressed thirty meetings. 'I find the strain unusually exhausting', he told Runciman from Pontypool.

Perhaps I am getting old, I know you think so-but I have made the pleasanter explanation to myself that every topic has become painfully threadbare, and the audiences like myself have exhausted their expressive powers of indignation. There is no opposition here. Occasional meetings of Labour are heard, but the I.L.P. gentlemen won't do me the favour of coming to my meetings and working us up with a little controversy. ${ }^{6}$

McKenna's devotion developed into a self-confidence that displayed itself in public with his contradictions of Chamberlain's latest pronouncement, followed by a protracted correspondence in the public prints with his satellites. ${ }^{7}$ It was justified by wider indications of the relative strength

1. RMcK to Runciman, 9 September 1902 , Runciman papers, $6 /(6) / 29$; RMcK to Dilke, 19 October 1905, Dilke papers, 43918/129.

2. Lord Craigmyle, Letters to Isabel (1936), 262; Pelham Warner, Long Innings (1951), 67; Ralph Nevill, ed., The Life and Letters of Lady Dorothy Nevill (1919), 172.

3. Lady Frances Balfour, Ne Obliviscaris: Dinna Forget, 2 vols. (1930), ii:406.

4. RMcK to Herbert Gladstone, 6 January 1905, Herbert Gladstone papers, 46062/70; 13 January 1905, 46062/76.

5. RMcK to William Crook, 22 April 1905, Crook papers, 385/50.

6. RMcK to Runciman, 5 October 1905 , Runciman papers, 13(5)/2.

7. Times, 3 February 1905; 'Examiner', Times, 6 February 1905; RMcK, Times, 8 February 1905. RMcK, Times, 10 February 1905. 
of the parties. By-election results were encouraging for the Liberals, which not even McKenna's pontifical manner could dampen. In March 1904, he addressed a sparsely attended meeting of the Free Food Union at Wimborne on behalf of the Liberal candidate in the Dorset East by-election, but still contributed to the success of the candidate in a formerly Unionist seat. It was one of eighteen such successes since Balfour had become prime minister. The government had been weakened, and the opposition both inside and outside Parliament had exacerbated its problems.

'He had been one of the hornets of opposition'. The journalist Charles King noted, 'Reginald McKenna, David Lloyd George, and Winston Churchill were a wicked trio of wasps in the latter years of Mr Balfour's premiership.' Parliamentary attrition took the form, in March 1905, of the trio calling on A. G. Gardiner to publish division lists in the Daily News as a way of bringing about an end to pairing with government MPs during divisions. ${ }^{2}$ McKenna and Lloyd George had also been developing the tactic of calling snap divisions in the chamber, as on the 1904 Supplementary Estimates, when McKenna's motion saw the government majority reduced to twentyfour. The result was firmer government whipping, and the further testing of its patience and resources. More constructively, in 1905 McKenna was member of the Committee of Selection, which appointed committees for private bills and members of standing committees. That spring he returned to military affairs, with attacks on the War Office and naval yards. ${ }^{3}$ McKenna began the autumn in Wales addressing apparently endless meetings. 'I am getting a little worn', he told Runciman. 'It is expected of me to speak in every district and of the electors to come and listen, and when it is over we are all very glad and go to our homes with a sense of duty done. ${ }^{4}$

With the end of 1905, and Balfour and the Unionists about to resign office, the issue arose of whether the Liberals should take office prior to a general election, and so be without a parliamentary majority. Accepting the challenge would serve either to demonstrate their seriousness and ability or cause disintegration through the varied weaknesses that only a mandate could assuage. 'I don't fear Joe; nor Rosebery. If A. J. B. resigns I think C-B should form his government. Refusal is too dangerous,' McKenna told Runciman on 28 November. ${ }^{5}$ Yet he had misgivings.

Be at hand, you say, in case you are wanted; but I am not sure that being wanted is not more to be dreaded than desired. So much depends on the men who are to control our future policy. If the men I believe in get responsible work in which their opinions and energies have fair

1. King, Parliament, 44.

2. RMcK to Gardiner, 2 March 1905, Gardiner papers, 1/6a.

3. RMcK, Parliamentary Debates, 26 June 1905, 185-88.

4. RMcK to Runciman, 3 October 1905, Runciman papers, 13(5)/1.

5. RMcK to Runciman, 28 November 1905 , Runciman papers, 11/57. 
scope, I too would be willing enough to serve. You, for one, I am glad to think are safe, but I fear that C-B may be overwhelmed by the time-old claims of veterans, who in their salad days had never much of the living faith necessary for constructive work, and whose minds are now stiff and whose energies are exhausted. I find the hopes of the Liberal Party running so high and I have a great dread of disappointing them. If all the younger men were involved in the disappointment, we should find ourselves without defence, face to face with rampant Labourism. ${ }^{1}$

McKenna stirred himself three days later to write to his chief. 'This letter has three merits: it is legible, brief, and needs no answer', McKenna informed Campbell-Bannerman.

Your self-constituted advisers in the press urge you in the event of $\mathrm{Mr}$ Balfour's resignation not to form a government before dissolution. At my meetings, last week and this, in different parts of the country, I have expressed the opinion that this is a matter on which your judgement is a great deal better than that of your advisers, and I have found myself on every occasion in perfect agreement with my audiences. It has indeed seemed to me that the tacticians, whether they are right or wrong in their conclusion, have considered the question too much from the point of view of alleged party interests, and too little from that of the general public, and, in so doing, have committed one of Mr Balfour's 'clever stupidnesses'. If a new government is not formed until next March, the session of 1906 will be entirely lost for financial and almost entirely for legislative purposes. Yet I think the public are really anxious for some economy in expenditure and for certain legislative reforms without waiting till $1907 .^{2}$

Forty-eight hours after Campbell-Bannerman received the job application, Balfour 'resigned his post, notwithstanding the fact that he still retained the support of a majority of upwards of 70 in the House of Commons', and, McKenna told his constituents, 'his resignation was an admission, by something much stronger than words, that, in the divided condition of the Conservative Party on the Fiscal Question, a Conservative Government cannot be kept in being. The only alternative is a Liberal Government. ${ }^{3}$ On 5 December, Campbell-Bannerman accepted Edward VII's invitation to form an administration.

1. Ibid.; Alan Clark, ed., A Good Innings: The Private Papers of Viscount Lee of Fareham (1974), 314-15.

2. RMcK to Campbell-Bannerman, 1 December 1905, Campbell-Bannerman papers, $41238 / 118$.

3. RMcK, January 1906, election statement. 


\section{Financial Secretary to the Treasury; President of the Board of Education, December 1905 to April 1908}

Mankind was inclined to do too little rather than too much.

-McKenna, $1907^{1}$

\section{OFFICE}

Power had an immediate and heady effect. 'Why are you not in London?' McKenna asked Runciman, after the results had been announced, on 7 December. 'George, Winston, Jack Seely and I are having the best time in our lives. We lunch and dine together and make merry; tomorrow we die." The day after the morrow, 'Late this afternoon I was summoned by C. B. and offered the post of Financial Secretary to the Treasury', McKenna told Sir Charles Dilke two days later. 'I accepted. ${ }^{3}$ The government front bench was later described by the newly elected Labour MP and future Chancellor Philip Snowden as 'the ablest I have known in my parliamentary career', ${ }_{4}$ and by a contemporary civil servant as 'the most able and brilliant in British history'. ${ }^{5}$ McKenna had been appointed effective deputy to the chancellor of the Exchequer. The chancellor, effective deputy prime minister, and heir apparent, was H. H. Asquith. The financial secretaryship was the closest ministerial position to actual membership of the Cabinet, and the occupant was entitled to attend meetings of the full Cabinet. McKenna owed his promotion, observers felt, to his performance as an opposition backbencher in general, and his work over cordite and tobacco in particular. For that reason, the Liberal MP Sir John Moulton pronounced it 'the most brilliant

1. RMcK, speech at Nelson, 9 October 1907, Times, 10 October 1907.

2. RMcK to Walter Runciman, 7 December 1905, Runciman papers, 11/59; RMcK to Runciman, 3 October 1905, Runciman papers, 13(5)/1; J. E. B. Seely, Adventure (1930), 142, 156.

3. RMcK to Sir Charles Dilke, 9 December 1905, Dilke papers, 43918/139.

4. Philip Snowden, An Autobiography, 2 vols. (1934), 1:126.

5. Arthur Salter, Personality in Politics: Studies of Contemporary Statesmen (1947), 113. 
appointment that has been made yet'. 'It is indeed the post for which I had expressed a preference when questioned by Loulou Harcourt immediately after Balfour's resignation', McKenna told Dilke. 'I can repeat my letter to you of this morning expressing now when my own wishes have been fulfilled. ${ }^{2}$

Seely had been left out - and there was a more notable omission, with the promotion of the disciple over his master. 'I am sick at heart' McKenna told an excluded Dilke, 'at not being able to write a different account of the nominations to War Office and Colonies', which went to Haldane and Elgin, respectively. ${ }^{3}$

When I first got into the House I wrote to you that I was glad to owe it to you. I have never changed my feeling, and barren though the statement is, I would willingly stand aside now and wait my turn to see you in one of the great posts. What adds to my personal pain is the thought of the unjust wanton waste of the best administrative powers in the country. ${ }^{4}$

Some claimed that Dilke regarded McKenna's appointment 'in some measure a compensation for his own exclusion'. 5 The regret may have been sincere, but the omission also provided an opportunity. McKenna felt, he later told George Riddell, 'that he was compelled to break with Dilke as he wished to absorb all his time and to dominate his life more than he thought desirable'. ${ }^{6}$ Moreover, Campbell-Bannerman had appointed McKenna as financial secretary to the Treasury, and, Dilke confessed, 'I do not understand banking and money'?

Dilke and Labby's exclusion meant that, of the radical party of 1895 , only two signatories ever made it to the Cabinet table, and the most prominent of those was far from an automatic selection. 'George has not been sent for yet, but according to the information received he may get a message from C-B tomorrow', McKenna told Runciman. 'I think hitches are all over; if so, $\mathrm{C}-\mathrm{B}$ will go ahead early in the next week. ${ }^{8}$ Sir Henry Campbell-Bannerman was not thought to like David Lloyd George. ${ }^{9}$ McKenna helped persuade

1. Mary Fletcher Moulton to Agnes Jekyll, 23 March 1908.

2. RMcK to Dilke, 9 December 1905 , Dilke papers, 43918/139-40; RMcK to Dilke, 20 December 1905, ibid., 43918/148.

3. RMcK to Dilke, 9 December 1905, ibid., 43918/138.

4. Ibid., 43918/139-40; RMcK to Dilke, 20 December 1905, ibid., 43918/148.

5. Illustrated Sunday Herald, 18 April 1915. [Enclosed in HHA to PMcK, 28 June 1915.]

6. George Riddell, diary, 23 September 1913, Riddell papers, 62973.

7. Dilke to Sidney Webb, 8 August 1906 , Passfield papers, II/4/C/3/177.

8. RMcK to Runciman, 7 December 1905 , Runciman papers, 11/59.

9. Oscar Browning, Memories of Later Years (1923), 45. 
the prime minister to include him in the government. 'Responsibility will improve him'. ${ }^{1}$

Despite McKenna's obvious interest and qualification for the post, the appointment almost immediately occasioned the ministry's first rumours of intrigue. Churchill later claimed 'I stood out of his way when he wanted the Financial Secretaryship to the Treasury and took a lower post', as Elgin's deputy. ${ }^{2}$ In fact, Churchill chose to be under-secretary of state for the colonies rather than financial secretary; Campbell-Bannerman had from the outset reserved the two near-Cabinet posts for the two men, and was prepared to let each choose. ${ }^{3}$ Each duly chose the office closest to his interests. McKenna later claimed that, though he assisted Lloyd George's elevation to the Cabinet, Lloyd George had tried to prevent him from attending its meetings. ${ }^{4}$ The ease with which McKenna moved into the Treasury was not doubted, however. Robert Chalmers was assistant secretary, while Sir Edward Hamilton was joint permanent secretary. He described McKenna as 'a very clever secretary, who is very anxious to learn'. ${ }^{5}$ Such comfort gave rise to suspicions. McKenna 'didn't seem to have much idea what to do, or to have much initiative capacity', thought Sir Michael Hicks Beach, a former chancellor of the Exchequer. ${ }^{6}$

\section{GENERAL ELECTION}

Although in office, the government was without a mandate, and the necessary general election was one about which McKenna was not overly confident. ${ }^{7}$ Everything depended on the election, and, in addition to the education controversy, on the salience of the free trade cause to which McKenna had devoted himself. 'Given a good majority we ought to have a full programme for 1906', McKenna told Dilke, 'but education will of necessity take so much time that I expect there will not be much left for anything else except trades disputes'. 8

Though North Monmouthshire was clearly a mining and labour constituency, 'so great is the popularity' of the Liberal incumbent, the Manchester

1. Riddell, diary, 30 September 1913, Riddell papers, 62973; though there were other reasons: Winston Churchill to Cecil, 1 January 1904, in Winston S. Churchill, vol. 2, Companion I: Documents, 1901-1907, ed. Randolph Churchill, 284.

2. Churchill to John Morley, 23 December 1909 [copy], Churchill papers, CHAR 2/39/121.

3. J. A. Spender, Life, Journalism and Politics, 2 vols. (1927), 1:162.

4. B. Nicholas to RMcK, 29 March 1922. RMcK declined the remark on threat of libel, RMcK to Nicholas, 31 October 1922 [copy].

5. Sir Edward Hamilton, diary, 29 December 1905, Hamilton papers, 48683.

6. Sir Michael Hicks Beach, in David Kynaston, The Chancellor of the Exchequer (Lavenham, 1980), 37.

7. RMcK to Charles Allen, 29 December 1905, Allen papers, 118/9.

8. RMcK to Dilke, 20 December 1905, Dilke papers, 43918/148. 
Guardian observed, 'that the South Wales Miners' Federation recognised months ago that it would be hopeless to run a labour candidate against him.. ${ }^{1}$ Further to highlight the growing distance, McKenna had actively opposed the nomination of a Labour man in the adjoining seat of Monmouth Burghs, as it might impair the chances of the sitting Liberal, Lewis Haslam. 'This courageous action on the part of Mr M'Kenna,' the Manchester Guardian reported, 'so far from involving him in disfavour with the North Monmouth miners, has secured for him a still wider and heartier support of the colliers of the division'. ${ }^{2}$ For the South Wales Daily Press 'there are no more loyal supporters of Mr McKenna than the Labour Party'. ${ }^{3}$

On 16 December, Campbell-Bannerman announced the dissolution of Parliament, and called a general election for January 1906. McKenna's election address solicited his gentlemen electors to the support of a government committed to:

Education and Temperance reform on the basis of Popular Control, Economy in Expenditure, Taxation of Ground Values, amendment of the Trades Union laws, the discontinuance of the introduction of Chinese Labour into the Transvaal, and the maintenance of our existing system of free trade.

He concluded pointedly, and perhaps confusingly, that:

I shall do my utmost to secure retrenchment in the late extravagant expenditure, with a view both to the remission of existing burdensome taxes upon the people and to the provision of the funds necessary for carrying out the Social Reforms which are urgently needed. ${ }^{4}$

Owing to his duties at the Treasury, and since, as the Pontypool Free Press put it, "no one regarded it as within the bounds of possibility that $\mathrm{Mr}$ McKenna could be defeated', ${ }^{5}$ he did not campaign fully in the constituency. He visited at weekends, driven around by Ernest or Theo. 'This will not be a great disadvantage,' the Manchester Guardian reported, 'for it was only a few weeks before the nominations that the Unionists found a champion in Admiral Sir Charles Campbell, who before was unknown in the division. ${ }^{6}$ Having been determined to contest the election, if only, as they thought, to keep McKenna there during the campaign, the Unionists had been unable to find a contestant after the ignominious fate of Pennefather six years before.

1. Manchester Guardian, 22 January 1906; Times, 21 April 1915.

2. Manchester Guardian, 22 January 1906; Times, 21 April 1915.

3. South Wales Daily Press, 19 January 1906.

4. RMcK, January 1906, election statement.

5. Pontypool Free Press, 26 January 1906.

6. Manchester Guardian, 22 January 1906. 
They eventually had to settle upon a man who, although a KCMG, CB, and with a DSO, and whatever his other merits, was 'no politician, and not least among the humours of the contest has been the manner in which he has avoided the inconvenient queries of hecklers who have worried him at every meeting.' ${ }^{1}$ Already at a number of disadvantages, Admiral Campbell decided to accuse McKenna of contravening the Ballot Act, and then proceeded to describe his potential electors as 'fatheads' and 'blockheads'. 2 A decidedly peculiar campaign continued with the active support of the local coal magnate Leonard Llewelyn, who chaired a Campbell rally when the candidate "was received with great booing, the audience then struck up the refrain "Vote boys, vote for $\mathrm{R}$ McKenna", the Admiral keeping time, and concluding with a hornpipe'. 3

Polling day was 22 January, and McKenna was re-elected. With the highest turnout for nearly twenty years, McKenna had achieved the highest share of the vote since North Monmouthshire became a single member constituency in 1885.4 Nationally, the electorate provided the largest progressive, or even radical, majority for eighty years. There were 400 Liberal MPs in the new parliament, supported by a further 113 Labour and Irish members. The Unionist presence in the Commons had been reduced to 157 seats.

The government expressed the depth of its mandate with a host of proposals, including arms reductions and the reform of the 1902 Education Act, which was entrusted to Augustine Birrell. The breadth of the government's interests, however, betokened future limitations. The political and social pressures in Westminster and the country at large had encouraged the creation of programmatic groups within the party, of which McKenna's own-the Free Trade Union-was the most significant. The work of the union was not over with the election of a Liberal government, and the paralytic stroke suffered by Joseph Chamberlain in July 1906 had removed only its most prominent antagonist.

The party's success in the election provided for radicalism, but for all his associations and conduct in opposition, McKenna was later to be accused of being one of the Liberals least enamoured of fiscal reform in the period. Hobhouse felt that but for McKenna and, Runciman, the Cabinet was

1. Ibid., 22 January 1906.

2. South Wales Daily Press, 9 January 1906.

3. Ibid., 20 January 1906.

4. General election, Monmouthshire, North, 22 January 1906.

\begin{tabular}{lrl}
\hline Total electors & 13,411 & Share \\
R. McKenna (L) & 7730 & $71.0 \%$ \\
Rear Admiral Campbell (C) & 3155 & $29.0 \%$ \\
Liberal majority & 4575 & $42.0 \%$ \\
\hline
\end{tabular}


impelled by the belief that 'you can, and ought to, buy political gratitude by largesse to this and that class of people." ${ }^{1}$ The accusation went on that true radicalism had to wait for the chancellorship of Lloyd George, and that even Asquith's moderate reforming instincts were further constrained by McKenna's want of imagination and purpose. The financial secretary was certainly concerned about the relationship between fiscal responsibility and social reform, more than perhaps would have been a 'classical' Gladstonian, or classic New Liberal. Certainly, he acted as a moderating influence on measures regarded as insufficiently radical for much of the party, but which still tested the temperament and machinery of the Treasury.

Yet McKenna had originally gone into politics to deal with poverty through social reform, and the attitude of North Monmouthshire labour attested to his effectiveness. While most senior Cabinet ministers abstained, McKenna voted with Labour, Lloyd George, and Churchill, on $30 \mathrm{March}$, to support the second reading of the Trades Disputes Bill, which sought to reverse the Taff Vale judgement and protect trade unions against actions by employers. Beatrice Webb, social campaigner and member of Royal Commission on Poor Law and Unemployment, welcomed the appointment to the Treasury of her 'friendly acquaintance', ${ }^{2}$ and was soon convinced that he was 'a genuine reformer', albeit 'of the ordinary kind. ${ }^{3}$

\section{THE TREASURY}

It was the Treasury that the government saw as responsible for its principal policy measures and its popularity, both in terms of sustaining Liberal support and attracting that of labour. In their year together at the Treasury, which saw the delivery of one budget and the preparation for another, Asquith instituted progressive reform of the fiscal system. Under the two, the new government's Exchequer could be defined as traditionally Liberal, being preoccupied with safeguarding free trade, curbing expenditure, and reducing debt, yet sufficiently 'New' Liberal to be charged with a positive and progressive social and economic function. Thus, its fiscal agenda was to increase, graduate, and differentiate taxes.

Against what was by any measure a progressive agenda were the political constraints and likely obstructionism of an unreformed House of Lords and a largely unreconstructed Treasury. For these reasons, as well as by later standards, the measures were cautious, and required the financial secretary to

1. Charles Hobhouse, diary, 30 June 1910, in Inside Asquith's Cabinet: From the Diaries of Charles Hobbouse, ed. Edward David (1977), 94.

2. Beatrice Webb, 15 December [1905], in The Diary of Beatrice Webb, vol. 3, 1905-1924: The Power to Alter Things, eds. Norman Mackenzie and Jeanne Norman (1984), 20.

3. Webb, diary, 22 February [1906], Webb diary, 25/116. 
serve as a bridge between the ministerial and civil service concerns. Anxious and doubtful as he was in many respects, McKenna was increasingly confident in matters of fiscal policy. For all his apparent orthodoxy, he was not above the attractions of expediency, and one proposal, for financing expenditure by delaying payments on the national debt, prompted Sir Edward Hamilton to tell McKenna that 'the doctrine of suspending the sinking fund is a very immoral one." More conventionally, McKenna and Hamilton both resisted the introduction of supertax and the land tax, which left income tax as the central progressive policy measure. Asquith was determined to apply fiscal redistribution, the prospect and consequences of which concerned the permanent secretary, as they did the financial secretary.

Their first budget, in April 1906, had to be delivered only four months after taking office. The most notable feature, given the subsequent reputation of the Liberal governments, was of controlling public expenditure. Asquith announced a ceiling at around $£ 150$ million. ${ }^{2}$ While it marked an increase, it also served as a limit, and one to which the government would be held. Otherwise, with the view to their fiscal principles, the budget reduced the tax on tea, abolished the tax on coal, and increased the tax on death (as death duties). It also reduced the expenditure on the navy.

Their focus for the second budget was more directly on 'differentiation' between earned and unearned income, since, as a progressive measure, it would avoid a general increase in rates of income tax. Asquith was keener on differentiation and progression than were his civil servants, with McKenna serving as a moderating intermediate body. ${ }^{3}$ McKenna had already consulted Dilke on the matter, and the chancellor established a select committee with Dilke as chairman to investigate the possibility of graduating income tax at the point of collection. ${ }^{4}$ During its deliberations, it became clear that Dilke favoured something quite different to the rest of the committee, and McKenna interceded. 5 Dilke was unmoved, and stood against the rest of the committee, which concluded in July 1907 that differentiation was possible, and advocated a supertax above $£ 5,000$ a year, to Hamilton's disquiet and McKenna's scepticism. The financial secretary felt that a high tax on a small section would be counterproductive through evasion, and that relative to the national income the largest incomes were not especially prominent, though he was not averse in principle. 'So far as it is desirable to diminish or break up large fortunes,' McKenna told Asquith in December 1906, 'I share in this respect the views of the supporters of a super-tax [though] I think the

1. Sir Edward Hamilton to RMcK, 19 June 1906, Churchill papers, CHAR 2/26/66-67.

2. Roy Jenkins, Chancellors (1998), 160.

3. Bruce K. Murray, The People's Budget 1909-10: Lloyd George and Liberal Politics (Oxford, 1980), 98-99.

4. RMcK to Dilke, 27 April 1906, Dilke papers, 43919/54.

5. RMcK to Dilke, 29 October 1906, ibid., 43919/95-96; RMcK to Dilke, 21 October 1906, ibid., $43919 / 94$. 
object is far better obtainable through the death duties than by means of the income tax'. ${ }^{1}$ Asquith reassured Hamilton that 'I am not wedded - or even engaged - to the supertax, and I quite share your respect for McKenna's judgement in these matters'.

In respect of differentiation, McKenna's caution had more to do with the attendant dislocations of the measure than with any aversion to raising revenue. Income tax was already more progressively levied in Britain than it was in Germany, the national model for many of the government's social reforms. The income tax rate in 1905 was one shilling in the pound. No tax was paid at all on annual incomes of less than $£ 150$, and income tax rose only to a maximum of 5 percent on incomes of $£ 750$. That meant that someone earning $£ 750$ was paying the same proportion of income tax as someone earning $£ 20,000$. There were political, as well as fiscal, reasons why this was undesirable, as McKenna told Asquith:

In its present incidence the income tax falls hardest on persons earning incomes between $£ 700$ and $£ 2,000$ or $£ 3,000$ a year, and it is the resistance of these persons which stands most in the way of raising it when the Exchequer has to be replenished. The class of persons earning incomes between $£ 700$ and $£ 2,000$ to $£ 3,000$ a year are formidable as a body by their influence on public opinion ... By giving them the relief to which they have a claim the tax is rendered far more elastic. ${ }^{3}$

The class of persons would be less likely to reward Liberal indulgence of working-class voters, McKenna contended, than it would be simply to vote Unionist. The case could therefore be made that the relief of middle-income groups would produce a higher general level of taxation. ${ }^{4}$ The issue was that of earned and unearned income for the purposes of income tax. Asquith's second budget of April 1907 duly differentiated income, by abating the charge on earned incomes under $£ 2,000$, while admitting that the introduction of graduation was beyond the tax administration. ${ }^{5}$ Two years later, Lloyd George applied the principle, by exempting that class from increases in income tax, and introduced the supertax. ${ }^{6}$

The 1907 budget was more than usually controversial in its extension of taxation and in its treatment of income tax as a permanent tax. The differences between Asquith and McKenna were clear, both in form and in substance. Where, The Times felt, the chancellor sought to apply taxation

1. RMcK to HHA, 17 December 1906, Treasury papers, T172/22.

2. HHA to Sir Edward Hamilton, 20 March 1907, Hamilton papers, 48614/30.

3. RMcK to HHA, 17 December 1906, Treasury papers, T172/22.

4. Martin Daunton, Trusting Leviathan: The Politics of Taxation in Britain, 1799-1914 (Cambridge, 2001), 335.

5. HHA, Parliamentary Debates, 18 April 1907, 1203.

6. Lloyd George, Parliamentary Debates, 29 April 1909, 506-14. 
as an anaesthetic, the financial secretary 'is above all blandishments. Strong and nasty seems to be his recipe for taxation' ${ }^{1}$ McKenna was increasingly regarded as an extremist even in an extreme government. 'In an ideal system he thought nothing would be better than to have our whole taxation raised through income-tax and death duties; we should then get rid of all burdens upon trade from which we now suffered-the whole machinery of customs. But that was the ideal.'2 He would certainly rather extend direct taxation than have any extension of indirect taxation, indeed, 'if it were possible, [I] would gladly see all indirect taxation done away with'. ${ }^{3}$ One Unionist condemned the "views unorthodox enough to make the late Mr Gladstone and Lord Goschen rise from their graves-of Mr Reginald McKenna'. ${ }^{4}$ In the debate on the budget, Austen Chamberlain confessed he had 'never heard a more amazing statement from a Minister'.

In attracting opposition scorn, McKenna served a useful function to his chief. After their cool relations in opposition, McKenna and Asquith developed an effective professional relationship that assumed a social dimension. Nine years McKenna's senior in both age and parliamentary experience, Asquith served as the latest in his line of patrons. The two were quite unalike; the one was self-assured, humorous, cultured, and happy at leisure; the other self-conscious, and self-consciously narrow, both intellectually and socially. The pairing was unpredictably successful. Broadly motivated by instincts that were liberal and legalist rather than radical, they were clearly at one in their forensic dissection of Unionist measures. With golf and bridge, politics ensured a close affinity. In politics, with Asquith's instinct allied to McKenna's industry, they well complemented each other. McKenna became a regular guest at Asquith's town house in Cavendish Square, and later at the Wharf, Sutton Courtenay, Oxfordshire, Asquith's own Docket Eddy, where McKenna's prowess in bridge was as useful as that in rowing had once been, and became a great asset in the seemingly endless rubbers that took place. It meant that the relationship went beyond politics. 'I have been living a life of stillness and idleness', Asquith told Runciman during one weekend at the Wharf, 'and even with McKenna, who has been here for a few days, I have carefully eschewed politics'. ${ }^{6}$ That summer Margot had been telling her friends of 'Mr McKenna, my new and very dear friend'.?

1. Times, 3 July 1907.

2. RMcK, Parliamentary Debates, 2 July 1907, 559.

3. Ibid., 558 .

4. Letters, Times, 11 November 1907.

5. Austen Chamberlain, Parliamentary Debates, 2 July 1907, 559.

6. HHA to Runciman, 1 October 1907 , Runciman papers, 131/302.

7. MA to D. D. Lyttleton, 30 June 1907 , Chandos papers, 5/1. The author is grateful to $\mathrm{Mr}$ Colin Clifford for this reference. MA to Ettie Desborough, 29 June 1907, Desborough papers, D/Erv C1/19; HHA to MA, 27 June 1907, MA papers, c.6690/115-16; HHA to MA, 18 January 1908, MA papers, c.6690/145-46. HHA to MA, 6 November 1907, MA papers, c.6690/133-34. 


\section{PROMOTION}

The Government had been experiencing its first setbacks, particularly over the predictable issue of education. Birrell's April 1906 Education Bill had been resisted in the Commons and blocked by a variety of interests in the Lords, demonstrating that in its efforts to redress nonconformist grievances about the 1902 Education Act, the government's reforms would prove to be as controversial as they had been for the Unionists. At the same time, McKenna had established his ministerial persona. He had demonstrated both his general competence and his specific expertise. Its appeal was another matter. The Treasury being a department, according to its present chief, that was both 'angular and pedantic', ${ }^{1}$ it followed that 'I like what I have seen of McKenna', Hamilton noted. 'An able secretary.' At the same time, from the press gallery, Charles King dismissed McKenna as 'a glib Treasury spadeworker.' 'An able accountant and there it ends', sniffed Balfour. ${ }^{4}$ Nevertheless, the usually critical Times observed that he has 'undoubtedly increased his Parliamentary reputation'. ${ }^{5}$ McKenna enjoyed his work, which he could do well so long as mastery of detail was more important than mastery of the Commons. The permanent secretary at the Treasury, Sir George Murray, claimed McKenna's as 'one of the best heads and hearts I have come across in a very long official life, ${ }^{6}$ and told the prime minister that he "was the best of all recent holders of his present place'?

As McKenna was increasingly to find, however, ministerial office was better suited to the dynamic of advancement than he wished. His evident success and pleasure as financial secretary ensured his removal. The office was seen as the obvious anteroom to the Cabinet, and that development, predicted in the press, ${ }^{8}$ took a little over a year. The occasion was provided by Bryce's decision to resign as chief secretary for Ireland, in order to succeed as ambassador to the United States, and by Birrell's wretched experience at the Board of Education. The two competing candidates to replace Birrell were, once again, McKenna and Churchill. Campbell-Bannerman, once again, consulted Morley. The secretary of state for India thought Churchill 'unfit

1. HHA to Sir Edward Hamilton, 27 September 1907, Hamilton papers, $48614 / 42$.

2. Hamilton, diary, 26 February 1906, in The Diary of Sir Edward Walter Hamilton, 1885-1906, ed. Dudley Bahlman (Hull, 1993), 461.

3. Charles King, The Asquith Parliament (1906-1909): A Popular History of Its Men and Its Measures (1910), 44.

4. A. J. Balfour to Riddell, 31 October 1908, Balfour papers, 62969.

5. Times, 24 January 1907.

6. Sir George Murray to RMcK, 10 February 1907, McKenna papers, 2/1/2.

7. Sir George Murray, quoted by Campbell-Bannerman to Birrell, 25 December 1906, in CB: A Life of Sir Henry Campbell-Bannerman, by John Wilson (1973), 589; Henry Roseveare, The Treasury: The Evolution of a British Institution (1969), 199, 231.

8. Times, 19 January 1907. 


\section{Reginald McKenna}

and even unthinkable' for Education, but that McKenna 'is evidently clever, industrious, hardy, and conciliatory." Birrell also offered his opinion.

RMcK is a nonconformist, sits for a Welsh seat, has knowledge of the situation, enjoys the confidence of the Treasury, is a good organiser and man of Business. From the official point of view I can think of nobody near half so good. I recognise the truth of what you say about his lack of standing in the public eye. He would get this, and be a cinder in the eye of the Church of England if he went to the Board of Education. ${ }^{2}$

'My story shall be short', the prime minister consequently wrote to McKenna on 12 January 1907.

Birrell succeeds Bryce in Ireland. I want you to come into the Cabinet as President of the Education Board. I can assure you that your acceptance of the duty and responsibilities attached to that position will please all your colleagues, except the Treasury people who will deplore your departure. It will give in a special degree satisfaction to myself for I shall be greatly fortified by your presence in the Cabinet, and at the head of an office of particular difficulty just now. Please keep this sweet till the Royal pleasure is taken. ${ }^{3}$

The chancellor of the Exchequer did deplore his departure. ${ }^{4}$ The permanent secretary was almost in tears. 'It is not always out of the fullness of the heart that the mouth speaks, but I have never yet parted with an official chief with so much upset as I feel on saying goodbye to you.' Murray had joined the civil service in 1873. 'It has been a constant pleasure to be associated with you; and I do not think that anybody else will ever occupy quite the same position as you have done."

Campbell-Bannerman explained he had promoted McKenna because he 'had nearly all the qualities - in fact all save notoriety, and that is better absent' ${ }^{6}$ Asquith, whether as a means of retaining him or as a recognition of his limitations, maintained McKenna had 'inferior claims' to the promotion than Churchill, who remained outside the Cabinet for over a year. ${ }^{7}$ Once again, there appeared to have been some collusion. Morley told the

1. Morley to Campbell-Bannerman, 1 January 1907, Campbell-Bannerman papers, 41223/207-8. See Robin S. Betts, 'Winston Churchill and the Presidency of the Board of Education, 1906-7', History of Education 15 (1986): 89-93.

2. Birrell to Campbell-Bannerman, 28 December 1906, 52518/186.

3. Campbell-Bannerman to RMcK, 12 January 1907.

4. Morley to Campbell-Bannerman, 9 January 1907, Campbell-Bannerman papers, $41223 / 216$.

5. Sir George Murray to RMcK, 10 February 1907, McKenna papers, 2/1/2.

6. Campbell-Bannerman to HHA, 5 January 1907, Asquith papers, 20/222-23.

7. HHA to MA, 1 March 1908, MA papers, c.6690/153-54. 
prime minister 'He and $\mathrm{McK}$, I think, must have had some conversation, in which each supported the claims of the other to Cabinet. I told him I did not know what your decision would be'. ${ }^{1}$ The prime minister explained to the king. 'The Treasury people say [McKenna] is by far the most efficient Secretary to the Treasury they have had in recent years. He is popular, a good debater, industrious: and not committed any way on the education controversy beyond the degree in which every MP is now committed.'

Though he accepted, McKenna was almost as ambivalent about promotion by Campbell-Bannerman as he had been by that of Harcourt. ${ }^{3} \mathrm{He}$ admitted to Dilke that, though it was a personal promotion, and as such could not really be resisted, 'even that does not remove my sorrow at leaving the Treasury'. ${ }^{4}$ Not only, therefore, did Asquith think McKenna should not have gone, McKenna himself did not want to go. Even publicly, McKenna announced his 'genuine regret', ${ }^{5}$ and told Loulou he could conceive of 'other arrangements which would have personally pleased me better-giving friends what they would take better advantage of than I and leaving me to my beloved Treasury'. ${ }^{6}$ Squaring the contradiction of his not wanting to leave the Treasury at the same time as accepting promotion, it crossed more than one mind that McKenna might be the logical successor to Asquith himself. Even though, perhaps in comparison to the current occupant, the chancellor's wife thought McKenna 'lacks distinction \& has not much authority', 7 by remaining at the Treasury and eventually being promoted as chancellor she admitted 'McKenna wd be far more valuable ultimately in that position'. 'McKenna would be safe and sober, hard working, conciliatory having a strong claim from years of useful work in opposition', her husband, considering the candidates with Birrell, thought, 'but he has small personal prestige and has no standing in the public eye."

In the immediate future, with Birrell evidently regarding the pacification of Ireland a more appealing prospect than the organisation of elementary schools, McKenna admitted to an old college friend, 'I have a tough task before me. ${ }^{10}$ Catholic interest was immediately mobilised by the archbishop of Westminster, and by the Marquess of Ripon inside the Cabinet. 'I do

1. Morley to Campbell-Bannerman, 3 January 1907, Campbell-Bannerman papers, $41223 / 209$.

2. Campbell-Bannerman to Knollys, 12 January 1907, Royal Archives, RA VIC/ R 28/2; Churchill to Elgin, 10 January 1907, in Companion, ii:1, 612-13.

3. RMcK to Campbell-Bannerman, 14 January 1907, Campbell-Bannerman papers, 41239/199.

4. RMcK to Dilke, 28 January 1907, Dilke papers, 43919/173.

5. Times, 5 February 1907.

6. RMcK to Harcourt, 28 January 1907 , Harcourt papers, 439/143.

7. MA, diary, 18 April 1907, MA papers, d.3206/10.

8. MA, diary, 18 April 1907, MA papers, d.3206/10.

9. Campbell-Bannerman to Birrell, 25 December 1907, in CB, Wilson, 590.

10. RMcK to C. J. Bristowe, 13 February 1907. 
not as yet know what his views on the education question may be, but I like much what I have seen of him. ${ }^{1}$ Having been regarded as one of their own by Hamilton and Chalmers at the Treasury, McKenna had to face in Sir Robert Morant a quite different permanent secretary. 'Whether he carries guns enough to keep Morant in order, you know best', Morley told Campbell-Bannerman. ${ }^{2}$ The prime minister obliged, asking, even before royal pleasure could be taken, that McKenna 'communicate with Morant at the Edu. Office-he is gasping for you for some very urgent matters.' 3

\section{JEKYLLISATION}

Ostentatious recognition of Reggie's progress in public life came on 19 February 1907 , with his invitation to St. James's Palace and the King's Levée. Reggie additionally had a new profile to go with his new status. His otherwise unprepossessing facial features appeared in advertisements as a man about town, one apparently benefiting from a reduced duty on stripped tobacco: "Connoisseurs who smoke and recommend "De Reszke" Cigarettes: Rt. Hon. Reginald McKenna, Lord Winterton, Sir Gilbert Parker', his partners in pleasure being a Unionist and a novelist, each perhaps being better suited to such advertisement than was a Cabinet minister.

He did not enjoy the ostentation, any more than he did the Commons. If, as most observers maintained, the House did not like Reggie, Reggie reciprocated. He resented its noise and intrusions, as well as its clubbishness, avoiding functions and dinners whenever possible, and, when he could not, 'I pleaded pressure of work and was the first to go. ${ }^{34}$ His preference was for the small and informal gatherings, as was that of the Asquiths, but even there, the Asquiths' new and very dear friend was still recognisably the gauche diarist of twenty years earlier. At one dinner, when conversation went on to books, Margot 'noticed McKenna was humbler \& wiser than usual as he felt literature was not his strong point.' Socially, as well as culturally, Reggie was continually given cause for doubts. Tories mocked him, and, although he was a member of the Reform Club, Brooks admitted him only after the discounting of two black balls. ${ }^{6}$ Esher thought him 'a common fellow'. 'Margot despaired to Balfour of his 'conduct', by which she

1. Ripon to Archbishop of Westminster, 25 January 1907 [copy], Ripon papers, $43545 / 102$.

2. Morley to Campbell-Bannerman, 1 January 1907, Campbell-Bannerman papers, 41223/207-8.

3. Campbell-Bannerman to RMcK, 17 January 1907.

4. RMcK to PMcK, 16 March 1908.

5. MA, diary, 10 April 1908, MA papers, d.3206/59.

6. Eighty Club papers, d. 2009/35; Philip Ziegler and Desmond Seward, Brooks's: A Social History (1991), 74.

7. Viscount Esher to Balfour, 16 August 1910, Balfour papers, 49719/153. 
meant 'the jarring social errors McKenna makes'. ${ }^{1}$ Even Charles Hobhouse, a friendly colleague, thought 'he attempts bonhomie but is not sufficiently of a gentleman for it to be successful'. 'I think he has goodwill', Beatrice Webb thought, albeit 'of a somewhat common sort.'

The occasional female free trader excepted, Reggie apparently met few unmarried women. When he was in London, he was working; when he was not in London he was in France with his mother. Emma McKenna spent her summers at her villa at Etrêtat in Brittany, in the north, and her winters at Ernest's at Roquebrune, Cap Martin in the south. Each autumn Reggie and Ernest accompanied her on her migration. In October 1906, Reggie wrote to Dilke, from Hotel Champs des Élysées, Mâcon.

My mother is seriously ill. On our usual journey, from Etrêtat to the south we had rested at Paris for a few days and for a week at Dijon, and my brother and I hoped to reach Roquebrune without mishap, but on starting from Dijon she had a heart attack. We left the train at the first station, Macon, and have now been here ten days. Neither our own doctor from England nor an excellent local doctor ventures any definite opinion on the future. She has much uneasiness of body but not pain. She is scarcely conscious of her surroundings though she recognises my brother and me. So long as she remains in her present condition I shall stay with her. ${ }^{4}$

Asquith told Margot, 'McKenna is stranded in the middle of France with his old mother, who I fear is dying. ${ }^{5}$ Emma McKenna, eighty-five, died on 11 December 1906 in Mâcon-at the Hôtel Terminus.

Where Emma now provided the latitude for her son's personal development, the Asquiths offered the opportunity. Apparently unconcerned by his philistinism, the Asquiths took him to temples of high intellectualism and moral purpose; namely Munstead, near Godalming in Surrey, and Mells, near Frome in Somerset. Munstead was the home of the Jekylls, and Mells was the home of the Horners. ${ }^{6}$ At Munstead Wood was Gertrude Jekyll, the leading garden designer and plantswoman, and at Munstead House were her brother Herbert, his wife Agnes, and their children Francis, Barbara, and Pamela; a family of respectable gentlefolk who practised arts and crafts

1. MA to Balfour, 16 March 1915, Balfour papers, 49794/146.

2. Hobhouse, diary, 13 August 1912, 121; Shane Leslie, Mark Sykes: His Life and Letters (1923), 230-31.

3. Webb, diary, 18 July [1907], 26/88.

4. RMcK to Dilke, 21 October 1906, Dilke papers, $43919 / 94$.

5. HHA to MA, 23 October 1906, MA papers, c.6690/84.

6. The author is particularly grateful to Mrs Primrose Arnander for her corrections and clarifications of a number of points related to the Jekylls and Horners, and for her comments on this section. 
of many descriptions. At Mells Park were Aggie's sister Frances Horner, her husband Sir John, and their four children; an old landed family that patronised the arts, and of which 'little Jack Horner, sat in his corner', was only the most well known. Munstead and Mells were households dominated by women - the worldly Aggie and the romantic Frances-and where unconventional lifestyles rubbed at the edges of social conventions. Munstead and Mells were at the centre of a social and political network; the main difference between the two houses was their proximity to London; the more distant Mells being 'divinely peaceful and quiet', for Pamela; 'ideal from my point of view as nothing happens and we do embroidery and go for walks and bed early and it is so much more like real country than Munstead. No telephones or motors full of people suddenly appearing.'

Sir Herbert Jekyll had been a soldier, was a civil servant, but had wanted to be an artist and an architect; Agnes-Aggie-was the youngest child of William Graham, the defining spirit of Munstead, Liberal MP, pre-Raphaelite patron, and friend of Gladstone and Bright, Hogg and Muir Mackenzie and of the Mellands, into which Asquith himself had married in 1894. Herbert and Aggie married in 1881, their pairing fusing further politics and the arts, with friends including Philip Burne-Jones, Hilaire Belloc, Arnold Bennett, and the wider associations of both Bloomsbury and the Souls. ${ }^{2}$ Aggie dominated: for Lytton Strachey, "Whenever she appeared life was enhanced-intensified.' ${ }^{3}$ Herbert's brother Walter was briefly a priest, then philosopher and gardener, who before moving to Jamaica allowed his name to be used by his friend Robert Louis Stevenson, as a character in a novel on which Stevenson was working in 1886 , the other protagonist being a $\mathrm{Mr}$ Hyde.

After a spell in Gibraltar, Sir Herbert went to Dublin as private secretary to the Earl of Carnarvon, with the family living in the Vice-Regal grounds of Phoenix Park in the aftermath of the infamous murders of 1882. At around the time Reggie was first elected to Parliament, Sir Herbert had returned to Dublin as private secretary to Lord Crewe, and was effectively governor during Crewe's lengthy absences. 'The society was brilliant', Aggie recalled, and was centred on the Bar, the military, Trinity College, and the Gaelic group. ${ }^{4}$ W. B. Yeats, A. E. Russell, Sarah Purser, Henry Irving, Ellen Terry, Jan Paderewski, John Morley, and Thomas Hardy were guests, and Sir Herbert, soon to be a member of Clann MacKenna, saw 'no reason why Donegal,

1. PMcK to RMcK, n.d; Viscountess Milner, My Picture Gallery 1886-1901 (1951), 112-17.

2. Roderick Gradidge, Edwin Lutyens: Architect Laureate (1981), 26-27, 74-75; Frances Horner, Time Remembered (1933), passim.

3. Lytton Strachey, in Agnes Jekyll, Ne Oublie, eds. Barbara Freyberg and Pamela McKenna [1937], iii.

4. Jekyll, Ne Oublie, $\mathrm{x}$. 
Mayo, Galway, Clare, Kerry, and Cork should not become the playground of England'. ${ }^{\prime}$

Sir Herbert then became commissioner of the British section of the Paris International Exhibition in 1900, where he designed the British pavilion with the architect Edwin Lutyens-Ned-a friend and collaborator of Gertrude. It was in partnership with Gertrude that Ned produced much of his greatest work. They had met in 1889, the year Gertrude's niece Pamela was born, and Gertrude commissioned him to build Munstead Wood six years later; a Lutyens house and a Jekyll garden became something of an Edwardian idyll. ${ }^{2}$

Of the Jekyll children, Francis, known as Timmy, was a successful scholarship boy at Eton and Balliol, who wrote what for some time remained the best book on his aunt Gertrude, and found himself in court circles through his friend and flatmate Alan Lascelles. Apparently selfish and irresponsible, Timmy became a depressive, drifted for years, his social and financial isolation being compounded by his homosexuality, and the attendant blackmail of the period. ${ }^{3}$ The middle child, Barbara, known as Bar, was much the most spirited and worldly; the youngest Jekyll was born in Lennox Gardens, Chelsea, on 10 March 1889. Sensitive and spiritual, from a young age Pamela read and transcribed romantic poetry, a habit she maintained throughout her life; deeply musical, she composed music and later performed as a concert pianist.

Bar and Pamela were very close, popular, and precocious. As early as 1900, when their father was in Paris, the two the society press noted "came out here, not as young ladies, but children long before they appeared in London'. ${ }^{4}$ The youngest made a particularly strong impression. 'I remember her as a charming child engaged with her no less winsome sister in handing flowers to your guests at those never to be forgotten receptions at the British House in the 1900 Exhibition', ${ }^{5}$ Lady Crawford told Aggie. Jekyll women had long practiced the role of political hostess, and the two youngest, one journal put it, 'are both very popular in the clever and artistic set of young ladies who form rather an important côterie in the society of the day'. 6 The

1. Herbert Jekyll to Algernon West, 25 July 1893, in Private Diaries of the Rt. Hon. Sir Algernon West, G.C.B., ed. Horace Hutchinson (1922), 178; Lady Cynthia Colville, Crowded Life (1963), 36.

2. Jane Ridley, 'Architect for the Metropolis', City Journal, Spring 1998.

3. Paul Freyberg to DMcK, 22 December 1992; Paul Freyberg to Michael Tooley, 20 November 1992.

4. Truth, May 1908.

5. Emily Crawford to Agnes Jekyll, 22 April 1908. The author is grateful to Mrs Primrose Arnander for this letter; see Gertrude Jekyll: Essays on the Life of a Working Amateur, eds. M. J. Tooley and P. Arnander, (Witton-le-Wear, 1995), 37-40; Edwin Lutyens to Emily, 6 August 1899, in The Letters of Edwin Lutyens to His Wife Lady Emily, eds. Jane Ridley and Clayre Percy, (1988), 73.

6. World, 1 April 1908. 
Jekyll daughters were beautiful, spirited, and independent-minded, as captured in oil by Sir Philip Burne-Jones and John Singer Sargent, and in print by Truth:

There is nothing immature about [Pamela] except her age, for she is not only exceptionally intelligent, but has been thoroughly well educated. She studied music under Leonard Borwick, and is a brilliant pianist. Her knowledge of literature, too, is remarkably wide in scope, and there are very few books of note with which she is not familiar. She has been reared in the midst of a political and scientific atmosphere, and, young as she is, she is quite at home and happy in the company of much older men and leaders of their kind, who find in her a responsive companion. ${ }^{1}$

There was one in particular. At Munstead and Mells, Asquith could indulge his self-confessed 'weakness for the companionship of clever and attractive women'. ${ }^{2}$ It was to Aggie, 'as an old friend, I had confided that I had fallen in love', ${ }^{3}$ to Frances Horner that he became especially close after the death of his first wife in 1891, and to her daughter Katharine that his eldest son Raymond was married, in 1907. The Asquiths loved Munstead and stayed there for a time before they acquired the Wharf as their country residence; so long, that Aggie wondered if they would ever leave. ${ }^{4} \mathrm{~A}$ visit to Munstead during the early years of Liberal government would find Pamela and Bar playing in the garden, and planting roses for Gertrude, who organised the cat's tea party in 1898, with invitations, and a cream and herring-based menu printed. 'Munstead was an abode of the Arts as well as of creature comforts', Cynthia Asquith recalled. 'Music, talk, reading aloud, all flourished there, and Lady Jekyll's two talented daughters, Bar and Pamela, conspired with their mother to keep their guests as happy and amused as they were comfortable.' There was also the pressing issue of trade policy. 'Munstead seems to be opening its doors to the chiefs of the Liberal Party', Timmy complained, 'and the air thick as ever with Zollverein talk'. ${ }^{6}$

At the same time as Reggie joined the Cabinet, he became part of a wellestablished social network and met the Jekylls. After working at the Paris exhibition in 1900, Sir Herbert returned home, dividing his time between

1. Queen, c. 11 June 1911.

2. HHA to Venetia Stanley, [March 1915], in Letters, 471.

3. HHA to PJ, 28 October 1907.

4. DMcK to Ivry Freyberg, 1 November 1998 [copy]; Ivry Freyberg to DMcK, 2 November 1998; Algernon West, diary, 8 June 1893, Diaries, 173; HHA to MA, 9 December 1901, MA papers, c.6689/148-49; Horner, Time Remembered, 166-76; Violet Asquith to PMcK, 15 October 1903; HHA to MA, 14 December 1904, MA papers, c.6689/266.

5. Cynthia Asquith, Remember and be Glad (1952), 190-1.

6. Francis Jekyll to Barbara Jekyll, 15 July 1903. 
summers at Munstead and winters at 3 Green Street, Park Lane. There, Haldane and Birrell were regular visitors, as were the Asquiths, who returned the invitations at Cavendish Square. Violet Asquith and Pamela Jekyll had been correspondents since at least 1901, the subject of their juvenile letters being as much about politics as persons, and the subject was frequently Violet's father, who had himself been writing to Pamela since she was sixteen. ${ }^{1}$ By 1907 , their correspondence became a regular, and often a daily, event. She drew a diagram for him depicting his heart as divided between 'Viola [Tree], Dorothy [Beresford], Lilian [Tennant], Venetia [Stanley], and me'. ${ }^{2}$ Venetia, whom Asquith described to Pamela as 'a bold and mendacious hussy', ${ }^{3}$ was the main competitor, though Pamela mocked her 'tepid' 'predecessors' ${ }^{4}$ Asquith protested,

The merchant, to secure his treasure,

Conveys it in a borrowed name;

$\mathrm{V}$ _ $\mathrm{t}$ _ia ${ }^{(a)}$ seemed to grace my measure, But $P_{\text {___ a }}{ }^{\text {'s }}{ }^{(b)}$ my real flame..$^{5}$

It was for that reason that 'I confess my soul rather shrivelled within me when I was invited to outline a campaign of match-making for you. ${ }^{6}$ Rather than having to identify a bachelor, the challenge for Asquith was as much a question of exclusion. As well as Asquith, Pamela was the subject of, at the very least, epistolatory attention from others, including Lieutenant Sir General Ian Hamilton, Edwin Montagu, Hilaire Belloc, and Arnold Bennett. ${ }^{7}$ As Aggie put it, 'It was then that Reggie swam into our ken, and carried off Pamela'. ${ }^{8}$ By that time, Reggie had moved from Sloane Street to 2 Whitehall Court. ${ }^{9}$ The first record of his dining at the Jekylls was 28 November 1907. The Jekylls then spent the 1907-08 winter at Monte Carlo, with Reggie and Ernest nearby at Roquebrune, where Ernest's keyboard wizardry offered another affinity with the Jekylls. Regular contact on their return meant that by February 1908, Asquith could describe his younger colleague as being 'completely Jekyllised'. ${ }^{10}$

1. Violet Asquith to PJ, 17 October 1901; HHA to PJ, 'autumn' [1907].

2. PJ to HHA, January 1908 , in Letters to Venetia Stanley, 1.

3. HHA to PJ, 7 November 1907.

4. HHA to PJ, 17 December 1907.

5. '(Notes) (a) name of young woman-easily managed in verse. (b) name of another young woman; quite unmanageable in verse.' HHA to PJ, n.d.

6. HHA to PJ, 2 December 1907.

7. DMcK, in conversation with the author; S. D. Waley to DMcK, 27 January 1960 .

8. Jekyll, Ne Oublie, xi.

9. McKenna papers, $1 / 2$.

10. HHA to Violet Asquith, 17 February 1908, in Lantern Slides, Diaries and Letters of Violet Asquith, eds. Mark Bonham Carter and Mark Pottle (1996), 143. 
Having introduced the two, Asquith seemed at first reluctant to accept the consequences, namely the pairing of his junior with his 'favourite BlueEye.' Asquith mocked Pamela for her infatuation with 'Reggie', and the ever-present Ernest, with 'his infernal piano. I seem already to discern with a prophetic ear the distinct jingle of a prolonged duet.' ${ }^{2}$ It was not that 'I am such a goth about music', ${ }^{3}$ just that Asquith was grateful when 'the baleful figure of Ernest had not yet appeared on the stage with his damnable instrument'. ${ }^{4}$ It meant that 'HHA' and Pamela when together were constantly attended by her suitor and his lieutenants. Asquith admitted to her 'I curse the Spenders and McKennas (tho' poor Ernest is, so far, not to blame: I rather dread his sinister activity in the near future)'. ${ }^{5}$

However incongruous it may have appeared to observers, Reggie and Pamela had come together to form a mutually delighted pair. Even Asquith admitted to her, on the eve of her eighteenth birthday,

There is a tone of diffused, equable, satisfied enjoyment about your last letter which ought to fill me with unselfish, sympathetic happiness, and so it does, up to a point. I love you to be happy, and to get the most out of every week of life-and I don't the least mind you facing the hazards of the roulette table. XVIII is a lucky number-at least so I think: but you won't be able to claim it for long. I felt sure, tho' I pretended a dread of Ernest, that Reggie would hold his own. Voilà l'ennemi! ${ }^{6}$

So it was that Reggie, the man whose angularity derived from his selfconsciousness, came to find himself the object of the affection of a beautiful and cultured young woman, with a background characterised by the features and advantages that his own had lacked. Through Pamela Jekyll, it could be seen that, as Stephen certainly saw it, "underneath a somewhat aggressive self-confidence he was sensitive, emotional and fundamentally shy'. ${ }^{7}$ As well as being politically informed and interested, one quality Pamela possessed which appealed greatly to Reggie, was, as he said after their first meeting, 'a mind like a trap': closing swiftly and surely on each new fact as it was presented. ${ }^{8}$ It was a rare congruence in their personalities, since Pamela was as expressive and spiritual as Reggie was restrained and logical; she beautiful and elegant, he bald and with bad skin. She was also less than half his age. Dilke had predicted that, because of her, Reggie would start to grow

1. HHA to PJ, 7 October 1907.

2. HHA to PJ, 17 December 1907.

3. HHA to PJ, 15-16 October 1907.

4. HHA to PJ, 28 December 1907.

5. HHA to PJ, 14 December 1907.

6. HHA to PJ, 6 January 1908.

7. SMcK, 'RMcK', 20.

8. RMcK, in $R M c K, 49$. 
younger, ${ }^{1}$ and his Man Friday duly declared, slipping into the appropriate idiom, that 'without her the world is one great fish face'.

\section{EDUCATION}

The Board of Education was a department that had been in existence for only seven years, and which was thought of as an authority of superintendence, rather than, as one permanent secretary put it, of "categorical imperatives. ${ }^{3}$ That was not how it had been under the Liberal government. At least nominally, both as a Congregationalist and as a Welsh MP, McKenna was expected to be attuned to the interests of two particularly fractious parts of the 1906 Liberal coalition. Yet where Lloyd George railed to great and dramatic effect against the injustice of the $1902 \mathrm{Act}$, and exploited his own sectional background to that end, McKenna's preoccupation was more, as he told Churchill, with the act's consequent 'administrative chaos' ${ }^{4} \mathrm{He}$ also wanted to create a national system of education, free from religious tests for teachers and with popular control of elementary schools. 'Education preoccupied and baffled Parliament throughout the session', Alfred Edwards, bishop of St. Asaph, recalled. ${ }^{5}$ At the centre was the president of the board, of whom the prime minister could announce 'this is one man contra mundum'. 6

On 2 February McKenna, having resigned his seat, as MPs promoted to the Cabinet-and thereby taking up an office of profit under the Crownwere required to do, was re-elected unopposed in a by-election in North Monmouthshire, and nine days later was sworn of the Privy Council, as Cabinet ministers were required, and adopted the only title he would ever use: 'Right Honourable'. Sir Robert Morant, meanwhile, wanted 'a hard and careful worker and a brainy handler of Parliament." He was therefore halfsatisfied, as he told Beatrice Webb.

He is, as you have probably found, neither large, nor wide, nor imaginative, but essentially Treasury, financial, statistical, mechanical. He has no interest whatever in education, nor in educational organisation and development. I fancy his only real interest is to become Chancellor of

1. $R M c K, 47$.

2. RMcK to PJ, n.d.

3. Selby-Bigge, in The Board of Education, by Sir Lewis Amherst Selby-Bigge (1927), preface.

4. RMcK to Churchill, 2 March 1908, Churchill papers, CHAR 2/38/5-6.

5. Alfred George Edwards, Archbishop of Wales, Memories (1927), 204.

6. Times, 22 July 1907.

7. Morant to Ponsonby, n.d., in David Lloyd George: A Political Life, by Bentley Brinkerhoff Gilbert, 2 vols. (1987-1992), $i: 301$. 
the Exchequer as quickly as possible, and certainly to get quit of Education as speedily as possible!

The immediate precedents for the president were not encouraging, inside or outside Parliament, and he was inclined to admit as much. Whereas Lloyd George 'had to deal with men of business', McKenna told one public meeting, he "had to deal with gentlemen of religion.' ${ }^{2}$ The recent history, at least in part, as Morant's successor Amherst Selby-Bigge put it, had been relentless 'denominational, inter-denominational, anti-denominational and secularist controversy'. ${ }^{3}$ Only a year into its life, the government's agenda of reform for education - of reducing class sizes, improving teacher training, expanding the inspectorate, increasing teachers' superannuation-had been obstructed by denominational interests. Rather than the Lords, it was nonconformists, who above all resented paying rates which subsidised Church of England schools, and wanted public control extended over all schools. Just as nonconformist support had helped bring the Liberals to power, so nonconformist disaffection risked undermining it. ${ }^{4}$ The determination of the Church of England to defend the 1902 Act ensured further difficulties.

The decline of nonconformist, or Free Church, activism brought obvious electoral considerations, and, not unconnected, philosophical ones. The Liberal coalition risked fraying from the moment of its greatest achievement, the landslide 1906 election victory; indeed, that success granted licence for increasingly disparate interest groups while encouraging intransigence in the upper house. Unionist opposition to the Liberal programme had hitherto been pragmatic. The untroubled passage of the Trade Disputes Bill was evidence that in some areas, such as that concerning the burgeoning labour movement, resistance was nominal. Where the essence of the state was called into question, however, as over religion or finance, a stand would be made. What Liberals-most liberals-thought to be a fair compromise between divergent interests, was to Conservatives-most conservatives-an act of vandalism: an attack on the constitution through the covert disestablishment of the Church of England.

Birrell's Education (England and Wales) Bill, had proposed the transfer of all nonprovided schools to LEAs. To those schools, basic facilities-bible reading-for special religious instruction on two mornings a week would be provided. Extended facilities-denominational education-would apply to schools in urban areas when four-fifths of parents voted for them. As an effort to balance denominational and secular interests, it resulted in

1. Sir Robert Morant to Webb, n.d., Passfield papers, II/4/C/3/236; A. H. Acland to Crewe, 17 September 1916, Crewe papers, C1.

2. RMcK, speech at Goole, Times, 8 November 1907.

3. Selby-Bigge, Education, 222.

4. See Noel Richards, 'The Education Bill of 1906 and the Decline of Political Nonconformity', Journal of Ecclesiastical History 23 (1972): 49-63. 
Unionists proclaiming an assault on the Church of England, and, by virtue of its position, the state. The House of Lords filleted the bill to take account of Anglicans' annoyance that they could not teach as they wished in their own schools and, in a spirit of denominational ecumenicism, the Catholics joined them. ${ }^{1}$ Birrell was shocked at the far from passive resistance of the Unionists in Parliament. ${ }^{2}$ Campbell-Bannerman considered a dissolution, but did not want another election within a year, and not over an issue which, while important, was not one central to the primary purpose of the ministry, and certainly not one around which to rally the country. ${ }^{3}$ Another cause would have to be found on which to challenge the Lords. Birrell's bill was withdrawn as, a month later, was Birrell.

A climactic standoff with the Lords had only been postponed. In the meantime, sufficient opposition existed both inside and outside Parliament to make life as difficult for the new president of the Board of Education as it had for the old. Perhaps by way of consolation, the National Liberal Club gave a dinner in his honour on 18 February 1907, at which Birrell professed to be uncertain whether the event was a funeral or a wake. Linley Sambourne, Tenniel's successor as chief cartoonist of Punch, drew Birrell and McKenna as the Princes in the Tower, feathers in caps, leotards cocked, facing an imposing and unidentified shadow descending the stairs.

\section{'LITTLE CONTROVERSIAL BILL'}

McKenna's main objective was to bring all voluntary schools under public control. The grounds being, predictably, financial: the state's assuming of the burden of education implied, for at least one, some sense of authority over it.

The system of national education was established on a basis of national grants given by the House of Commons, and as those grants exceeded every other form of contribution to the costs of education, it was only proper that the authority which alone could control the grants should settle the conditions on which they should be made ... any national system to be lasting should be based upon the broadest foundations of mutual consideration and fair concession. They were bound to adhere to those principles of public control of public money and no religious tests upon the appointment of civil servants, which were an integral part of Liberal policy in dealing with education. ${ }^{4}$

1. See John Cashman, 'The 1906 Education Bill: Catholic Peers and Irish Nationalists', Recusant History 18 (1987): 422-39.

2. Augustine Birrell, Things Past Redress (1937), 191-92.

3. Master of Elibank, diary, 23 April 1912, Elibank papers, 8814/81.

4. RMcK, 4 February 1907, address in Pontypool. 


\section{Reginald McKenna}

On 26 February 1907, a little over a month after taking over, McKenna was ready to present his first attempt to resolve religious grievances, and in particular address the cause of the passive resistors he had championed in opposition. He nevertheless intended his 'little controversial bill' to be a palliative, as well as a temporary measure until a wider settlement was possible. ${ }^{1}$ The Special Religious Instruction Bill was a one-clause measure, introduced under the ten-minute rule, to 'make provision for relieving the local education authority of the cost of giving special religious instruction in schools not provided by the authority'. ${ }^{2}$ The bill was designed to transfer the cost of denominational education from the LEA to managers of nonprovided schools. McKenna estimated the cost at one-fifteenth of teachers' salaries, which would be repaid to the authority. ${ }^{3}$ Only basic, nondenominational, teaching - bible study - would be funded from the rates. 'A gratuitous teacher would of course repay to the manager the amount paid by them,' McKenna told Ripon. ${ }^{4}$ The President intended the bill to occupy no more than half a day for its second reading, with another day in committee. ${ }^{5}$

Unionists were not impressed, but did not oppose its first reading. ${ }^{6}$ As they were perfectly aware, they did not need to. While Local Education Authorities were pleased with it, and indeed asked for it to be extended to cover vacation schools, ${ }^{7}$ nonconformists dismissed it as merely an expedient, quite inadequate in dealing with the larger issue, and all too representative of the lukewarm nature of Liberals' commitment to their cause now they were in government. Catholic opposition, led by the Duke of Norfolk, and including Irish members, expressed itself in Westminster, though John Redmond at least recognised that Catholics were paying the price for their interference with the 1906 bill. $^{8}$ The archbishop of Westminster's concern was that the bill would 'prevent the Teachers in the non-provided schools from giving religious instruction." McKenna denied this. 'I deal only with the question of who is to pay for it', he told the Marquess of Ripon. 'A case of gratuitous instruction by the teacher is not contemplated or provided for under the Bill; nor would it well be so, if, as the memorandum recommends, a fixed

1. RMcK, speech at Marlow, 1 March 1907.

2. Times, 28 February 1907.

3. RMcK privately admitted that one-tenth was in fact sufficient. RMcK to Ripon, 23 February 1907, Ripon papers, 43640/66; Ripon to Archbishop of Westminster, 25 February 1907 [copy], ibid., 43545/106.

4. RMcK to Ripon, 23 February 1907, ibid., 43640/66; Ripon to Archbishop of Westminster, 25 February 1907 [copy], ibid., 43545/106.

5. RMcK, 14 February 1907, 'One Clause Bill', cabinet papers, CAB37/87/15.

6. RMcK, Parliamentary Debates, 26 February 1907, 1453-56.

7. Interview with Mr McKenna, 4 June 1907, Manchester Education committee, Churchill papers, CHAR 4/1519-22.

8. Letters, Times, 28 February 1907; Times, 2 March 1907; Times, 9 March 1907.

9. Ripon to RMcK, 23 February 1907 [copy], Ripon papers, 43640/64. 
deduction is to be made'. ${ }^{1}$ Further passive resistance was threatened, this time from the High Church party. McKenna was unrepentant. 'The obligation of maintaining denominational schools first imposed on the rates by the Act of 1902 was a rock of offence to thousands and tens of thousands of our fellow-citizens'. ${ }^{2}$ At the conference of the National Union of Teachers in April, when one delegate denounced it as as bad a bill as had ever been introduced, since it would satisfy neither nonconformist nor Anglican, another shouted from the floor, 'what will?'3 After further weeks of protest, throughout the country, the bill, which had indeed been both little and controversial, was abandoned on 3 June, with a view to 'a more comprehensive measure' in $1908 .^{4}$

\section{MINISTER}

'Of the younger men in the Liberal Party none has risen more rapidly or more thoroughly earned his high promotion', the admittedly parti pris Westminster Gazette maintained. 'In his first year of office he gained the reputation of being one of the best Secretaries to the Treasury that that Department had ever known, and as a courageous administrator he was clearly marked out for the difficult place that he has since filled.' ${ }^{5}$ It was a sympathetic assessment, and did not recognise the limitations that others less closely concerned discerned. 'McKenna has an infinite capacity for taking pains, which they say is akin to genius', thought Viscount Sandhurst, 'though I don't suppose McKenna is accused of this' ${ }^{6}$

In place of the casual ridicule and ad hominem criticism he had become used to, in his first year as a Cabinet minister McKenna had for the first time been the subject of concerted hostility in the press. ${ }^{7}$ Given the nature of the issue, the hostility was from both sides. Most notably William Robertson Nicoll, the leading Free Church journalist, attacked McKenna unremittingly in the pages of the British Weekly. Sir John Sykes, assistant secretary to the board, thought the description of McKenna as nothing more than a 'party politician' one of 'serious injustice'. ${ }^{8}$ Viscount Greenwood thought that 'no other minister ever tackled a Church question with more courage

1. RMcK to Ripon, 23 February 1907, Ripon papers, 43640/66; Ripon to Archbishop of Westminster, 25 February 1907 [copy], Ripon papers, 43545/106.

2. RMcK, speech at Marlow, 1 March 1907.

3. Times, 4 April 1907.

4. RMcK to J. M. Bartlett, 7 July 1907, Times, 10 July 1907; Spender, CampbellBannerman, 339.

5. Westminster Gazette, 30 March 1908.

6. Viscount Sandhurst, From Day to Day, 2 vols. (1928-29), i:340.

7. RMcK to Runciman, 30 September 1907 , Runciman papers, $17 / 36$.

8. J. C. G. Sykes to PMcK, 7 September 1943. 
and knowledge-and abuse!'” The effects were noticeable. Beatrice Webb thought him a changed man: 'office has hardened him-developed both capacity and cynicism'. ${ }^{2}$

McKenna would always have Spender's Westminster Gazette to rely on, and it ran a profile of him as one the 'Men of the Moment'. The president of the Board of Education 'is the Benjamin of the Cabinet', who has 'always looked wiser than his years.'

He proved adept in answering difficult questions, and the skilful way in which he handled his oar at the Treasury marked him out as spare man for the cabinet. He has not reached perhaps quite the height of his ambition, but he has gone much further than he dared to hope [in 1892] ... he is withal modest, and knows his own limitations as well as his friends know his good qualities. He is thus never likely to swamp his boat from lack of skill or precaution, and if he suits his feather to wind and tide, he will row a brave strong stroke through the stormy reach in the river of politics that faces him. ${ }^{3}$

His early experiences set the pattern and reputation for his ministerial career as a whole. 'McKenna had always puzzled the House', Stephen later wrote of the Commons, 'and the House did not like being puzzled.' ${ }^{4}$ F. E. Smith recalled

when I first entered Parliament in 1906, he was, on the whole, one of the most unpopular Ministers in the eyes of the rank and file of the Conservative Party. His manner was precise and irritating. And in the eyes of men who did not know how much charm and geniality he possessed in private life, he seemed jejune in his conceptions; and rather small in their presentation. ${ }^{5}$

MPs called him 'the rasper', Charles King wrote, 'from his way of scraping the nerves of his political opponents'; ${ }^{6}$ and not just his opponents. Fitzroy found himself preoccupied, to an unusual extent, with the newly appointed 'McKenna, who is not the most reticent of ministers'.'

Where, in the face of often fanatical sectional interests Birrell suffered from being too reasonable, McKenna risked suffering from appearing too unyielding. While he was as unpopular as he was unhappy, he did nothing

1. Viscount Greenwood to PMcK, 6 July 1943.

2. Webb, diary, 18 July [1907], Webb diaries, 26/86.

3. Westminster Gazette, 8 June 1907.

4. $R M c K, 164$.

5. Birkenhead, Sunday Times, 1 June 1923.

6. King, Parliament, 44.

7. Fitzroy, diary, 20 August 1907, in Memoirs, by Sir Almeric Fitzroy, 2 vols. [1925], 1:330. 
to help himself. Though his duties entailed no responsibility for trade, McKenna could not resist making often gratuitous provocations when ostensibly addressing something quite unrelated. ${ }^{1}$ In one address he compared his proposals for schools reform with 'the wild-cat schemes of tariff reform, under which everybody was to be made richer by increasing the taxation of everybody'. ${ }^{2}$ Next to him, Lloyd George was regarded as moderate. ${ }^{3}$

\section{ADMINISTRATIVE PROVISIONS}

McKenna's damnosa hereditas may have been elementary education, but it was secondary and even tertiary provision that engaged him more, with the scope they offered for scientific advance, both of subject and method. ${ }^{4}$ In February 1907, he announced the grant of a charter for a major technological institute, to rival those of Germany, to be built in London on land used for the 1851 exhibition, and on 13 July, he presided at the first meeting of the governing body of the Imperial College. ${ }^{5}$ McKenna wanted further to promote secondary education in Britain in the way it was advanced in the United States and Germany, and scientific physical training in the way it was in Sweden. 'He has been bold enough to tell an audience of British parents that it is not, after all, a waste of time to give so much attention to football, cricket, and rowing', the Westminster Gazette averred, 'for these very sports involve the strictest discipline to which a young man can be subjected.' 6 McKenna declared his support for raising the school leaving age, and abolishing 'half-time' attendance, at the same time as recognising the limits of public opinion; while any such proposal would complicate his impending bill, he would support one of a private member. ${ }^{7}$

Such concerns made McKenna despair that far too much of his time 'was occupied with controversial questions. The Board of Education seemed to be the cockpit for rival denominations to continue the fight which had been going on down through the centuries'. ${ }^{8}$ It was not just a reaction against the criticism he had suffered, but an exasperation with sectional interests when a much large object was in view. It was his objective, he told one public meeting, that "Any child, however poor or humble, if able to take advantage of the educational facilities which were offered to him, should have the fullest opportunity of getting the best education it was possible to provide. ${ }^{9}$ When

1. RMcK, speech at Goole, Times, 8 November 1907.

2. RMcK, Times, 11 November 1907.

3. Letters, Times, 11 November 1907.

4. RMcK to Oliver Lodge, 5 March 1907, Lodge papers, OL 26.

5. Times, 13 July 1907.

6. Westminster Gazette, 8 June 1907.

7. Times, 6 November 1907.

8. RMcK, speech at Newport, 16 November 1907, Times, 18 November 1907.

9. RMcK, speech at Goole, The Times, 8 November 1907. 
he could, he expedited it. Birrell had introduced the Education (Provision for Meals) Act, and in that pastoral category fell McKenna's Administrative Provisions Bill. In 1907, the medical inspection and treatment of schoolchildren-like their feeding-was a contentious issue. The British Medical Association had asked each of McKenna's three predecessors to provide for it, and, as Morant put it, the present president was 'anxious on many grounds' for the measure to be drafted into a bill. ${ }^{1}$

McKenna introduced his Education (Administrative Provisions) Bill on 5 March 1907. It would empower LEAs 'to make such arrangements as may be sanctioned by the Board of Education for attending to the health and physical condition of children in Public elementary Schools. ${ }^{2}$ It introduced a schools medical service, which provided systematised medical examination for schoolchildren, with the treatment of minor ailments. There would be an annual report sent each year to the chief medical officer, with a medical bureau established in the Board of Education. ${ }^{3}$ The measure also organised games for schoolchildren. In attempting compulsorily to improve the condition of the people, McKenna's proposals followed closely those of the physical deterioration committee, charged with improving the condition of the people in the light of the South African war, and, pointing to the tensions within liberalism, aroused concern from more traditional Liberals at the accretion of powers to the president. ${ }^{4}$ Yet demands that had been advocated for years by the Fabians, and taken up by the Labour Party, were introduced by McKenna, debated for two hours supported by the Unionists, and passed at 2 a.m. the following day. Within a fortnight, McKenna said 'I expect the Municipal Reformers will be quite out of favour.' The bill certainly 'does not make my position easier,' the Marquess of Ripon complained. ${ }^{6}$

The bill additionally provided for a Teachers' Registration Council, another attempt to provide a coherent and comprehensive register of all teachers in both elementary and secondary schools, after the failure of previous schemes during the previous decade, which were subsequently found to be compromised by a teacher's registration being only voluntary. The regulations also imposed a conscience clause on training colleges and secondary schools, prevented the foundation of new denominational training colleges, and banned denominational teaching in schools, unless specifically

1. Morant to Provis, 19 February 1907; Morant to Macnamara, 19 February 1907, ED 24/128. See Bentley Brinkerhoff Gilbert, The Evolution of National Insurance in Britain, the Origins of the Welfare State (1973), 127-43.

2. Times, 6 March 1907.

3. The Liberal backbencher Walter Rea had introduced a Private Member's Bill of similar measures eleven days earlier, but a compact between RMcK and Balfour over the extent to which LEAs funded the inspections crowded it out. Daglish, Education, 379-81.

4. Ripon to Crewe, 14 June 1907, Ripon papers, 43552/156.

5. RMcK to Lady Dorothy Nevill, 5 March 1907, Garber papers.

6. Ripon to Crewe, 30 May 1907 [copy], Ripon papers, 43552/152. 
requested by parents. Moreover, prospective students could not be rejected on religious grounds, and current students would be freed from compulsory religious attendance. ${ }^{1}$ Since 95 per cent of their funds came from the Exchequer; so, McKenna maintained, the taxpayer should say how they were run. ${ }^{2}$ Thus teacher training colleges were required to modify their trust deeds so as to admit students from other denominations, as well as those without denomination. However, rather than announce his proposals at the dispatch box, he remained seated on the front bench and let the Opposition begin the debate. ${ }^{3}$ He did so, he said after protests, to save time and because he had explained the government's policy in March, which only provoked more complaints, though the archbishop of Canterbury was notably conciliatory. ${ }^{4}$

In another clause, which became the basis of the 1907 Secondary Schools Regulations, McKenna encouraged the building of more secondary schools by a two-tier system of grants: $£ 5$ per pupil would be given to schools that did not offer religious tests and offered at least a quarter of their places free to pupils from elementary schools, and only the old grant of $£ 2$ per pupil would be paid to those schools that did not. ${ }^{5}$ Raising the grant to $£ 5$ per pupil offered an incentive. It was a move that was as much to do with redressing the balance of provision made by voluntary and denominational agencies and that of the LEA. He also empowered LEAs compulsorily to acquire land for the purpose of building more secondary schools. McKenna used the overriding authority of the Appropriation Act, reviving a practice which had been expressively prohibited by the 1870 Act. ${ }^{6}$ At the same time, McKenna compounded the controversial nature of the measure by the even more controversial nature of its passage: 'It must be admitted that [my] device of including the additional grants in the estimates passed en bloc without a special Bill was, however ingenious, hardly constitutional."

In addition to the inducements for LEAs to build more schools, the most important of the board's regulations required that in all fee-paying schools in receipt of grant, 25 per cent of admissions each year were to be free for children from elementary schools. McKenna's elementary code and secondary school regulations for 1907 would further expand the secondary sector which should, McKenna said, 'be open to children of all classes. The educational ladder which was supposed to enable the child, fitted to receive the education, to rise from the bottom to the top of the educational edifice had

1. National Register (1907), 1:187.

2. RMcK, speech at Goole, Times, 8 November 1907.

3. Balfour, Parliamentary Debates, 11 July 1907, 65-67.

4. Randall Davidson to RMcK, 10 July 1907, McKenna papers, 2/1/5.

5. RMcK, Parliamentary Debates, 15 May 1907, 1052-55.

6. Bigge, Education, 84.

7. 'Reggie's own notes dictated to me [Pamela McKenna] on his early years', n.d. [c. 1943]. 
been much more talked about than realized'. ${ }^{1}$ Attainment tests at elementary school would select the pupils who would receive the scholarships.

Balfour attacked McKenna and the regulations for being both unjust and unconstitutional and for contravening the $1870 \mathrm{Act}$, and that he 'proposed to fine people for holding certain religious opinions' for the first time since the seventeenth century. ${ }^{2}$ McKenna offered no concessions, despite large and lengthy representations that he received at No. 10 with the prime minister. The Anglican delegation led by the archbishop of Canterbury was followed a few days later by the Catholic delegation led by the archbishop of Westminster, and that by a smaller and more appreciative, though still critical, Free Church delegation on 2 August, to which the prime minister professed the government's intention to pursue such matters on 'a larger scale'. ${ }^{3}$

Measures on a larger scale would not necessarily produce opposition on a larger scale. McKenna's regulations had caused as much discontent as a full bill, but where a bill would have brought parliamentary censure before abandonment, the regulations only produced opposition when their implications were realised after implementation in the country. Public meetings and letters to various editors revealed opposition, but not obstruction. The longer term effect may have been more damaging, both for the minister and the ministry. What The Times described as a 'study in politics and in public morals', Balfour described as a 'study in misgovernment': ${ }^{4}$ McKenna had sought to do through administration what he could not do by legislation.

When faced with opposition, McKenna threatened to enforce the 1905 Local Authority Default Act-a Unionist measure to enforce the 1902 Act and ensure the funding of Anglican schools in Wales, known locally as the 'Coercion of Wales Act'-against the Merionethshire County Council. Cases were brought around the country, such as the 'Swansea School Scandal', where the Local Education Authority withheld the salaries of teachers in a church school, and where McKenna refused to carry out the recommendations of his own public enquiry. ${ }^{5}$ By fining those who did not comply, and increasing the grant to those who did, McKenna was held to have replaced government by Parliament with government by decree, and Aristotle and Dante were invoked to warn of the threat to the rule of law. ${ }^{6}$ The Board of Education had brought a climactic constitutional crisis closer. The bill was passed on 1 August 1907.

1. RMcK, speech at Newport, 16 November 1907; Times, 18 November 1907.

2. Balfour, Parliamentary Debates, 11 July 1907, 70.

3. Times, 3 August 1907.

4. Times, 10 December 1907.

5. Parliamentary Debates, 5 February 1908, 938.

6. Times, 11 January 1908. 


\section{SOCIAL REFORM}

His period at the Board of Education saw McKenna's most prolonged exposure to, and involvement with, social reform, the culmination of a process begun in Clapham ten years earlier. On 27 April 1907, Beatrice Webb went 'for a friendly chat with McKenna' to 'ventilate the handing over of the children to the education authority' for medical provision. This was one measure that came up against McKenna's financial sensitivities: his 'Treasury Mind'. 'He was taken aback by the notion-feared it would mean additional expense. Wanted to know whether the Commission as a whole would take that view'. ${ }^{1}$ She urged him to appoint George Newman, with whom Beatrice had worked on the Poor Law Commission, as the chief medical officer charged with setting up the School Medical Service. Notwithstanding his concerns, McKenna 'said he intended to appoint Newman as he heard "nothing but good of him". ${ }^{2}$ The Webbs were satisfied with the president of the Board. 'He impressed Sidney with the rapidity of his mind and both of us with his hard businesslike tone.'

Imbued with the post-Boer War notions of national efficiency and the role of education in promoting 'all those qualities which John Bull affects much to admire in the Continental soldier,' ${ }^{34}$ McKenna, in turn, was much impressed by Beatrice's proposals on poor law reform, which included the school-age Poor Law children being taken under the supervision of LEAs. ${ }^{5}$ His only concern, and it was one more consonant with his previous office than with his current post, was the extent of the increase in expenditure the measures would necessitate. Those more concerned with issues of personal liberty were incensed by McKenna's measures, but combined with the Care Committees established in 1906, the proposals served as part of the early foundations of the National Health Service.

One reform that was urgently needed, and certainly urgently demanded by labour interests, was that of old age pensions. On 27 February 1906, the Trades Union Congress sent a parliamentary deputation to visit Asquith and McKenna, and, on 14 March, after speeches of support from Asquith and John Burns, the Commons unanimously passed a resolution for provision to be made out of public funds. ${ }^{6}$ The concerns of cost preoccupied the chancellor just as much as they did his financial secretary. 'Universal' came to mean different things to different people. Primed by Spender, for whom it was a

1. Webb, diary, 27 April [1907], Webb papers, 25/72-73.

2. Webb, diary, 18 July [1907], Webb papers, $26 / 88$.

3. Ibid.

4. Westminster Gazette, 8 June 1907.

5. RMcK to Webb, 19 February 1908 , Passfield papers, II/4/D/1; RMcK to Webb, 19 December 1908, Passfield papers, II/4/D/1/5; RMcK to Webb, 2 May 1905, Passfield papers, II/4/C/1/238. The proposals were not novel, having been part of the 1895 Report on Metropolitan Poor Law Schools.

6. Times, 15 March 1906. 


\section{Reginald McKenna}

subject of special interest, McKenna helped prepare the paper presented to Cabinet in December 1906. The King's Speech at the opening of parliament in February 1907 contained no reference, much less a commitment, to the measure, but in his second budget in April 1907, Asquith promised as much in $1908 .^{1}$

Charged with drafting the bill, McKenna went to Beatrice Webb and 'asked me what we proposed about old-age pensions', she recorded. 'He was up to his neck in that question.' She said they had not considered it because they thought it would be settled for them. 'I gathered from him that the Government plan is a non-contributory scheme-something between the New Zealand and Danish plan', which left the question of how to limit the number of applicants to the sum they were prepared to put down. She thought Parliament would ridicule any age below sixty-five. 'Could they make character a test?', McKenna asked. Beatrice thought the population too dense to use anything but criminal convictions. 'Then he suggested some proof of destitution-inability to earn', prompting Beatrice to suggest the New Zealand limit of income. 'How were they to discover whether a person was fit to live outside of an institution?', which Beatrice was adamant must be an issue for the public health authority. He took that point. 'The worst of all your proposals, Mrs Webb, is that though each one seems excellent, they all mean more expenditure. And where are we to get the money?'2

Three months later McKenna dined alone with the Webbs.

The scheme he thrashed out with us was universal non-contributory pensions to all over 65 with less than 10s. a week from property, with a sliding scale of 5/ upwards, income under 5/ not to be taken into account. No disqualification from pauperism present or future-some contribution from the rates on account of potential paupers. To be administered evidently by a stipendiary. ${ }^{3}$

McKenna calculated that such a scheme would cost the Exchequer between $£ 7$ million and $£ 10$ million a year. In November, the proposals went to a Cabinet committee chaired by Asquith, and including McKenna, Burns, and Lloyd George. Asquith's commitment, as announced in his final budget of 7 May 1908, diluted the proposals to a noncontributory pension of 5 shillings per week to individuals over seventy whose income was less than 10 shillings. Married couples would receive 8 shillings 9 pence. Lloyd George's Bill of 2 June 1908 did not deliver the McKenna-Webb proposals in all particulars, the proposal for a noncontributory pension financed by general taxation was innovative in that it specified central and direct, rather than local and indirect, provision.

1. HHA, Parliamentary Debates, 18 April 1907, 1191.

2. Webb, diary, 27 April [1907], Webb papers, 25/72-73.

3. Ibid., 18 July $1907,25 / 87$. 
However progressive the measures may have been, McKenna's enduring Treasury perspective ensured scepticism from his labour opposition in the country, where party competition complemented that which he wanted to encourage on the playing field. It was in the nature of the New Liberal agenda that McKenna came under increasing scrutiny in his constituency by the growing influence of the Labour Party. He prevaricated when questioned on his voting against Keir Hardie's amendment to include illegitimate children as beneficiaries in the Workmen's Compensation Act, and the Independent Labour Party (ILP) harried him on the matter. ${ }^{1}$ The ILP assistant secretary, W. Raddeford, thought 'Mr McKenna's opposition is all the more remarkable when one knows that even Campbell-Bannerman, Asquith, Birrell, Gladstone ... Haldane, Shaw, Sinclair and numerous other Liberals, supported the labour amendment', and few of those could be regarded as on the left wing of the party. 'I am glad to say that not the least instructive work of the Labour men in their constituencies is the publication of the reactionary votes of their representatives...'2

Just as he saw its role in improving 'Social England', McKenna also saw education as the way of redressing what was becoming an increasingly potent issue. 'The best way to secure votes for women', he said, 'was to increase the area of education'. ${ }^{3}$ A significant minority disagreed. Pamela was in the ladies' gallery of the House of Commons for the vote on the Woman's Suffrage Bill.

Majority in favour of the Bill and large majority against its going into Committee upstairs, tantamount to killing then and there and a really cowardly way of treating it. $\mathrm{R}$ voted consistently against it both times. Walking back up Whitehall we were pursued by a shrieking Suffragette who was kept from us by a sturdy detective. ${ }^{4}$

McKenna's first experience of the manifestations of the cause was when he addressed a Free Trade Union meeting at Brighton on 11 November 1907. Within moments of his speaking, a woman interrupted him and said, 'Mr Chairman, I rise to protest against the Government refusing to give women the right to vote'. As The Times reported it, 'uproar followed, in which the lady was ejected, while on the organ was played "Down with Protection".'5 After three more interruptions, 'McKenna said this was most disturbing, and almost in despair resumed his seat'. After two more interruptions pro-

1. Frederick Harding to W. Raddeford, 3 November 1907, Labour papers, I.P.GC.21/161/1-5; W. Raddeford to Frederick Harding, 6 November 1907, Labour papers, LP.GC.21/162.

2. W. Raddeford to Frederick Harding, 11 November 1907, Labour papers, LP.GC.21/164.

3. RMcK, speech at Brighton, 11 November 1907.

4. PMcK, diary, 12 July 1910.

5. Times, 12 November 1907. 
duced violent ejections, some men in the audience attacked the stewards. 'The latter retaliated, and almost at the foot of the platform something in the nature of small free fight ensued'. ${ }^{1}$

Late in 1907, McKenna was involved for the first time in what would be a career-defining issue and the focus of the government's divided priorities of retrenchment, reform, and national security: naval estimates and the implications of the Dreadnought programme. Due to the length of time it took to produce a warship, the Admiralty budget was called its estimates, and, uniquely was presented a year ahead of the government budget of which it would be a part. The government's policy from 1906 to 1908 was to apply savings in military and naval expenditure, as well as any surplus in taxation revenues, to liquidate debts, rather than service the debt, and to make provision for increased social spending. Tax revenue had fallen in 1908, with receipts driven down by a depression, and for 1909 there was little prospect of change. ${ }^{2}$ For that reason, when presented with the first lord of the Admiralty's 1908-09 estimates, McKenna, Lloyd George, Burns, and Harcourt offered united opposition to the proposals. On 4 February 1908, Cabinet unanimously decided to reduce Tweedmouth's estimates by $£ 1,340,000$, so as to bring them below the figures for the previous year. The prime minister charged a committee, made up of McKenna, Lloyd George, and Harcourt, with putting the resolution into effect. ${ }^{3}$ Admiral Sir John Fisher, the first sea lord, having offered $£ 750,000$ to reach his 'irreducible minimum', was told that his leading rival, Lord Charles Beresford, who sought his post, as an inducement offered $£ 2,000,000$ of reductions. Fisher refused to compromise, at which point, the prime minister intervened, maintaining the naval estimates, and lopping $£ 300,000$ off Haldane's budget for the War Office. ${ }^{4}$ The committee continued its work, and while Fisher had prevailed, Beresford had reason to think he had an ally in McKenna.

\section{COLLEAGUES}

McKenna's accession to the Cabinet transformed his relations with colleagues. From an essentially departmental existence at the Treasury, he now found himself daily meeting, and engaging with, the same eighteen men, and seeking through them to resolve the major issues of his brief. The collectivising and galvanising effects of opposition bore little relationship to the problems of office. The personal traits that had become liabilities in the chamber of the House of Commons risked being amplified in their effect

1. Ibid.

2. Sumida, Strategy, 187.

3. Esher, diary, 7 February 1908, Esher papers, 2/11/70.

4. Runciman to Churchill, 13 December 1907, Churchill papers, CHAR 2/30/9295; Esher, diary, 7 February 1908, Esher papers, 2/11/75. 
at the more rarefied executive level. When she met McKenna with several other ministers, Beatrice Webb detected an 'aloofness from his colleagues and absorption in his own career'.

It was when they sat at the Cabinet table as president of the Board of Education and president of the Board of Trade, respectively, that relations between McKenna and Lloyd George began to deteriorate. It was no longer possible to disguise or avoid the effect of differences in personal and political practice, and each came to dislike and then resent not just their practical implications, but also the type of person each represented. In policy terms, the problem remained McKenna's animating concern. Lloyd George's ambivalence about free trade meant that if he were ever appointed chancellor, McKenna thought, "he would be a very unsound one. Of course you disagree with us,' McKenna told Balfour at a dinner in 1907, 'but you can understand our principles. Lloyd George doesn't understand them and we can't make him.' ${ }^{2}$ In part he blamed Lloyd George's 'defective education ... details were beyond [his] comprehension', ${ }^{3}$ as would be the notion that details ought to have prominence in public affairs. Lloyd George's disregard for facts, to the ends as he saw it of bigger truths, was antithetical and almost heretical for his colleague. As Stephen put it, 'a mind that saw everything in pictures, clashed with one which saw everything in figures; emotion was brought down to earth daily by calculation. ${ }^{4}$

Both McKenna and Lloyd George thought the disposition and practices of the other reflected wider and disagreeable concerns; their view of politics reflected the man. Lloyd George could similarly disparage the likes of Runciman, who was at least personally inoffensive, while recognising in Churchill another man larger than his office. McKenna suspected that Lloyd George's rhetoric and cult of personality constituted ends as much as means. Lloyd George, his own nature implicit in the simile, said that McKenna and Churchill were "like trees in a forest. Churchill like the oak ... gave warning before crashing. McKenna ... the elm, the branch falls without notice. ${ }^{5}$

Already, even a sympathetic, if frustrated, partisan like Spender could see the problem, certainly as far as the coherence of the government was concerned.

McKenna was the perfect administrative man, bringing a cool mathematical judgement to bear on the affairs of the Department of Government; and about most of them exasperatingly right. There is nothing

1. Webb, diary, 3 May [1907], Webb, Diary, 72.

2. RMcK to Balfour, May 1907, in Politics from Inside, an Epistolary Chronicle, by Austen Chamberlain (1936), 86.

3. RMcK, in 'The Cabinet, the Admiralty, and the Perceptions Governing the Formation of British Naval Policy, 1909, 1921-1922, 1927-1936', by Phillips Payson O'Brien (PhD thesis, University of Cambridge, 1992), 72.

4. SMcK, 'RMcK', 14.

5. Lord Beaverbrook, The Decline and Fall of Lloyd George (1963), 34. 
that irritates impressionist politicians more than to have such a man at their elbow in cabinet, and for years McKenna played this part to Lloyd George ... If they had been rolled into one, McKenna's cool judgement and political rectitude, [and] Lloyd George's impetuousness and eloquence, an incomparable statesman would have resulted. ${ }^{1}$

For McKenna, as for Churchill, the power of personality was the root of other people's reactions. It was difficult for many of them to see beyond it. For Margot Asquith-generally sympathetic to McKenna- What is charming and amusing like Lloyd George, not what is ... ugly and loyal like McKenna is preferred'. ${ }^{2}$ It made Violet Asquith 'perfectly sick' to hear McKenna criticise Lloyd George. 'His soul is worthy of the dark cottage, bald, battered, eczema-ridden and decayed in which it is lodged!"3

The oak and the elm also grew at different rates, and one was always the more prominent. On one occasion McKenna and Churchill jointly addressed a Liberal meeting at Wimborne. The Times carried Churchill's speech almost verbatim, McKenna's in two sentences. ${ }^{4}$ Perhaps because he had been a colleague for much less time than had Lloyd George, Churchill had developed good relations with McKenna, from his move across the floor of the Commons onwards. While McKenna was critical of method, he was realistic as to its effect. 'I do not conceal my opinion', he told Churchill over the Small Holdings Bill that Loulou was directing, 'that your pressure there would be of much greater advantage than his or mine'.

One of the ways in which office began to fray relations between Liberals was in the role and use made of the press. Where Lloyd George appeared natural, McKenna, as ever, was faltering and had to apply himself with determination. Another reason Lloyd George excelled was that, like Churchill, he provided better copy. Perhaps in response, McKenna began the habit of talking to journalists, but, while Lloyd George had soon successfully cultivated C. P. Scott, of the Manchester Guardian, Robert Donald, of the Daily Chronicle, and George Riddell, of the News of the World-a numerous and politically diverse group-McKenna only really had one pressman, and even that was held against him. When Campbell-Bannerman had discussed McKenna's promotion to the Cabinet with Morley, the latter thought, 'Of his probable figure as an element in Cabinet-as what you would call a sound element-I should be a trifle dubious. His ally, friend, and inspirer in general is Spender. ${ }^{6}$ Though McKenna had moved from the department

1. J. A. Spender, Life, Journalism and Politics, 2 vols. (1927), 1:164-65.

2. MA to Violet Tree, n.d., Tree papers, 59895.

3. Violet Asquith to Venetia Stanley, 15 October 1909, in Diaries, 187.

4. Times, 7 August 1906.

5. RMcK to Churchill, 27 March 1907, Churchill papers, CHAR2/29/65.

6. Morley to Campbell-Bannerman, 1 January 1907, Campbell-Bannerman papers, 41223/207-8. 
that most exercised Spender, the two remained close, and it was a closeness that concerned McKenna's older colleagues. On one occasion, Loreburn, the lord chancellor, went to McKenna's room at the Commons, and on finding him discussing Cabinet business with Spender, 'said it was monstrous that I, a mere journalist, should know things that were unknown to him', Spender recalled. ${ }^{1}$ The relationships between Cabinet ministers and journalists became more of an issue as the ministry went on.

The largest figure in McKenna's political life, and almost as significant in his personal affairs, remained the chancellor of the Exchequer. His apparently effortless superiority in all areas of parliamentary affairs, combined with his appreciation of McKenna's qualities, meant that the younger man could simply sit back and enjoy them. During the debate on the King's Speech, Balfour 'treated me yesterday to a mild session of j'accuse', McKenna told Pamela, when Asquith, substituting for Campbell-Bannerman, replied

in an absolutely flawless explanation of some very technical matters to which he had given no more than a few moments consideration while we listened to A. J. B. He warms my heart. "He delighteth not in the strength of a horse; he taketh not pleasure in the legs of a man"; but I may delight in superb brains. ${ }^{2}$

The qualities McKenna could see in Asquith, as well as the growing problems besetting the government, made it increasingly apparent that McKenna's original misgivings about Campbell-Bannerman were being realised, and those about Asquith revised. A change of leadership was already in mind. 'You must let your Cabinet take some of your meetings off your shoulders. The House of Commons would not forgive us for allowing our chief to overstrain himself', McKenna told Campbell-Bannerman, two days after the prime minister's third heart attack in a year. ${ }^{3}$

\section{BIG CONTROVERSIAL BILL}

McKenna explained to one public meeting that three classes of person were the root of all his troubles: 'the educational enthusiast, the religious zealot, and the ratepayer.'4 Those classes of person would determine the success of McKenna's major piece of legislation at the Board of Education, one he would have been justified in calling his 'big controversial bill'. Its gestation

1. Spender, Journalism, 1:241.

2. RMcK to Agnes Jekyll, 30 January 1908. (Prayer Book, 147:10.)

3. RMcK to Campbell-Bannerman, 15 November 1907, Campbell-Bannerman papers, 41240/157; RMcK to Arthur Ponsonby, 26 October 1907, Ponsonby papers, c. 655 .

4. RMcK, speech, 9 May 1907, Times, 10 May 1907. 


\section{Reginald McKenna}

was unusually long. On 18 July 1907, he met the Webbs and 'adumbrated his Education Bill of next session which he means to pass!'

All denominational schools to depend on a three-quarter parents' majority, and then to be supported wholly by the Government grant and voluntary contributions; on the other hand, to be emancipated from local control. Cowper-Temple religion to be swept away, and in its stead, hymns, prayers, and Bible reading-difficult to understand exactly what he meant. ${ }^{1}$

He meant that the Cowper-Temple amendment to the 1870 Education Act, which ensured interdenominational education in board schools, would be replaced merely by religious instruction.

On 19 August, after more work, McKenna presented his plans to Cabinet. ${ }^{2}$ His intention was to draft the measure with a view to the government's ultimate objective for education: no distinction between state schools, and every school would be wholly run by an LEA. McKenna also needed to heed what was feasible given the present volatile circumstances, which meant that the best way of effecting that change would be to increase, rather than to reduce, the gap in the current dual system. If voluntary schools in single school areas would transfer to the LEA, the remaining voluntary schools could 'contract out', only receive the Exchequer grant, and be free from LEA control.

On 6 September 1908, McKenna gave 'a definite pledge of a Bill next year embodying the fundamental principles upon which the Liberal party asked for the support of the electorate'. ${ }^{3}$ On 18 November, he presented the draft bill to Cabinet. His main goal remained a uniform public elementary system of rate-maintained schools without religious tests for teachers. ${ }^{4}$ John Burns thought he made his case 'clearly and bravely', but noticed that Lloyd George was 'hostile to McKenna, who has a difficult task and deserved kinder treatment', and warned that with contracting-out inserted, the bill would be heading 'straight for the rocks'. ${ }^{5}$ Contracting out was now central to McKenna's conception of allowing strictly denominational schools to continue with a grant only by 'going off the rates'. Dr. John Clifford's support for the measure helped it overcome Cabinet hesitation, and McKenna could proceed, though, Burns felt, Campbell-Bannerman was 'rather bored

1. Webb diary, 18 July [1907], Webb papers, $26 / 87$.

2. RMcK, 'Suggestions for an Education Bill', 19 August 1907, cabinet papers, CAB37/89/78.

3. RMcK, 7 September 1907, Times, 9 September 1907.

4. RMcK, 14 November 1907, 'Draft of an Education Bill', cabinet papers, CAB37/90/95.

5. John Burns, diary, 18 November 1907, Burns papers, 46325. 
at the futility of attempting to reconcile education with sectarian claims and sacerdotal domination'. ${ }^{1}$

Crewe told the Marquess of Ripon that McKenna 'seemed confident that he would get all sections at any rate to acquiesce in his proposals, which seemed a sanguine view.'2 McKenna's insistence on allowing denominational schools a grant if they went off the rates, Crewe went on, 'though the educational objections are patent, offers perhaps the clearest way out of the wood. ${ }^{3}$ The connexion between public funding and public control was an issue through many of McKenna's initiatives, and if that meant the marginalisation of the Church, he did not recoil from stating as much. Edwin Montagu wrote to him that 'I am frightened of anything that would lead to the identification of the Liberal Party with secularism', but McKenna professed himself to be against secularising education. ${ }^{4} \mathrm{With}$ the opponents to his measure unwittingly facilitating that end, he nevertheless appeared to enjoy baiting prelates as much as he did protectionists, evidently regarding each as equally antediluvian in belief and imprecise in practice. If McKenna had not been secularising education, education appeared to be going some way to secularising him. 'I suppose the Bishops have treated me according to their lights; as they stood high in the ecclesiastical hierarchy I must assume that those lights were very bright'. ${ }^{5}$ Church of England bishops sat in the House of Lords, which revealed an additional agenda, in the context of the government and the constitutional settlement. He told Beatrice Webb

that he hoped the Lords would throw the Bill out because if they did the Liberals would come back to power. If they passed it, there would be nothing to bind Liberal and Labour together. But I am not sure he did not express his hope to impress me with the impolicy of throwing out the Education Bill. ${ }^{6}$

Another complication came from within the Board of Education itself. After the relationship he enjoyed with his civil servants at the Treasury, McKenna found that of Education altogether less congenial. The reason was singular and personal, in the form of Sir Robert Morant. As a measure of conciliation to Welsh nonconformists for the dropping of McKenna's first bill, and expressly against the wishes of Morant, McKenna created a Welsh department of the board, for issues 'not necessarily coincident with those

1. Ibid.

2. Crewe to Ripon, 21 October 1907, Ripon papers, 43552/183.

3. Ibid.

4. Montagu to RMcK, 27 September 1907, in Edwin Montagu-a Memoir and an Account of His Visit to India, ed. S. D. Waley (1964), 21-22.

5. RMcK, speech at Goole, Times, 8 November 1907.

6. Webb diary, 18 July [1907], Webb papers, 26/87-88. 
of English education'. ${ }^{1}$ Essentially a separate inspectorate, but with its own permanent secretary, the creation of the department served to appease Lloyd George and marginalise Morant. Through his 1907 Grant Regulations, some Liberals criticised McKenna for helping to turn the Education Office into one of the great spending departments, which needed as much scrutiny as McKenna used to maintain did the War Office. Morant agreed. In seeking to gain greater public control, the Liberal MP John Massie claimed, McKenna offered 'a fresh bribe in order to tempt some of these schools to admit some public control and some check upon their sectarian propaganda.'2

'I am writing this with Morant and Murray sitting by and talking hard', McKenna wrote to Pamela. 'I have to give them an ear and an occasional word, but they don't deserve more as they are worrying about a matter I have made up my mind about long ago. ${ }^{3}$ Morant had indeed begun to complain that McKenna no longer consulted him. ${ }^{4}$ Yet his civil servants had always tended to revere McKenna, and Morant had a reputation as a difficult colleague. ${ }^{5}$ Though relations had never been good, substantial differences between them had arisen during the Administrative Provisions Bill, when McKenna put the concerns of the National Union of Teachers above those of his permanent secretary, and over the appointment of Newman as chief medical officer. ${ }^{6}$ Morant made little effort to disguise his feelings. In August 1907, during preparations for McKenna's principal legislative proposal, the president of the Board of Education heard that his permanent secretary had described McKenna to a dining party at the Reform Club 'as being an "utterly colourless person who did not count", and specifically, and particularly, as "merely Asquith's jackal"'?

\section{PERSONAL}

Strained professional relations only served to highlight how happy Reggie's personal life had become. 'I have known Pamela a little over a year', he told Dilke. 'The wise would say that she is much too young for me-she is only nineteen-but I don't despair of making her happy. ${ }^{, 8}$ The arithmetic had

1. Selby-Bigge, in Bigge, Education, 72; RMcK, 25 February 1907, Parliamentary Debates, 1258; National Register (1943); Morant to Ponsonby, n.d., in Gilbert, Lloyd George, 1:301.

2. John Massie, Times, 18 June 1907.

3. RMcK to PJ, 26 February 1908.

4. Morant to Thring, 25 January 1908, in Daglish, Education, 320.

5. Andrew McFadyean, Recollected in Tranquillity (1964), 47; Fitzroy, Memoirs, 1:231; Daglish, Education, 320, though cf. Bernard Allen, Sir Robert Morant-A Great Public Servant (1934), passim.

6. Daglish, Education, 385-86, 419.

7. J. H. [indecipherable] to RMcK, 28 August 1907, McKenna papers, 2/1/6.

8. RMcK to Dilke, 28 March 1908, Dilke papers, 43920/65-6. 
occurred to others. 'I think it impossible to find a straighter better man than McKenna; he has a splendid nature and an excellent brain I should be quite happy if he married one of my children', Margot told Aggie. 'Of course the difference of age is a little too great but can any one have every thing?' Aggie also consulted Birrell. 'The Age Question does not press on me. You cannot calculate on so much life as being anybody's due. If you can look forward to 25 years happiness, it is more than you are entitled to.'2

'After thrilling expectantly over every taxy and handsome which has patronised Green Street I am going to bed (not disappointed)', Pamela wrote to him, before a spelling class. 'I won't ever withdraw anything because it would rob me of the joy of your persuadings. ${ }^{3}$ They were persuasive, and within four months of their first meeting, in March 1908, Reggie proposed; Pamela accepted. Perhaps because of the age question, there was initial reluctance to make the matter public. 'I don't think you and Pamela will be able to keep it a secret', Margot told him; 'you both have too many friends'. ${ }^{4}$ Pamela's were scornful of his age, and his 'spots, spats, speckles $\&$ tricot tights'. ${ }^{5}$ The reaction was otherwise positive. 'I love Mr McKenna: his friendship and intimacy with Henry and myself is an enormous pleasure,' Margot told Aggie. ${ }^{6}$ Everything was relative, Ian Hamilton told Pamela. 'To me McKenna is hard and self-centred; to you I am quite prepared to believe, he is gentle and thoughtful." 'You know you have my blessing', Asquith told her, but,

I don't pretend not to have watched the making up of your mind with anxiety and some doubts. The issues are so tremendous, and 'wise' as you are, you are young ... It was on this ground (and never on any other) that at first, and indeed, for a long time, I hoped that the brain-storms might subside into a different sort of calm. But, I believe, indeed I am sure, that you have done the right thing, and have I not always held up to you as the most 'frustrating' of all sins 'the unlit lamp and the ungirt loin'? .. There are great things in front of you both, and in facing them you take with you dearest Pamela a large part of the heart of your loving and devoted, HHA. ${ }^{8}$

1. MA to Agnes Jekyll, 19 March 1908; Morley to Agnes Jekyll, 23 March 1908.

2. Birrell to Agnes Jekyll, 3 April 1908.

3. PJ to RMcK, n.d.

4. MA to RMcK, 18 March 1908, in Jane Brown, Lutyens and the Edwardians: An English Architect and his Clients (1996), 130-1. 146.

5. Violet Asquith to Ettie Desborough, 21 March 1908, Violet Asquith, Diaries,

6. MA to Agnes Jekyll, 19 March 1908.

7. Ian Hamilton to PJ, 10 January 1908, 2 January 1908.

8. HHA to PMcK, 19 March 1908. 


\section{Reginald McKenna}

'I have not had from the first the faintest doubt of my own love,' Reggie told Margot, 'but you will not be surprised at my saying that I have been very anxious for Pamela's sake on the score of years, and I could not help feeling that our friends would share this anxiety. Your and the Chancellor's kindness relieves me.'1

Having had his proposal accepted with alacrity, and his person accepted without equivocation by his fiancée's family, Reggie did not seem to be able to accept his good fortune. "While Cabinet was going on I made a start to write to you, but I was distracted by the talk and had not got beyond half a page when I was brought up suddenly by a question as to my opinion from the Chancellor,' he wrote from Cabinet, illustrating the closeness of the private and the public, later that month.

The subject of my meditation has been that I am not worthy of you. I will tell you why, and you shall be the judge; I know you will agree with me. It is just this. When I think of the political future of changes of government and of what my own position may or may not be, try as I will I cannot bring it home to myself that you really don't mind and that you would wish me to be indifferent to personal consequences. I know that it is so and that you would not be the least bit disappointed either in me or in life because steering the right course did not bring us into a comfortable harbour; I know this of you as an unshakeable fact, but it is my mind that knows and I can't get it into my blood. I feel timid and cautious about the future, and that is why I am unworthy of you. You have given me the fullest bravest confidence. I can only accept it up to the measure of my own powers. My mind knows and understands all about it, but it takes time for me to teach my unconscious thought that it is really true and that Pamela takes me for better or for worse and gives me her heart in payment of my love. Dearest, bear with me and love me for I have nothing left now in the world but only you. ${ }^{3}$

So wrote Bertrand Russell's 'blackguard'. 'Now you could break my life and everything that I am or might be', he wrote to her from the House of Commons.

I was fussing. Is it very absurd that a man of 44 with serious responsibilities, who according to all accounts has no guiding principles in life but violent hostility to a great state church and the satisfaction of his predatory instincts in the spoliation of her property, should be at the mercy of a girl (I won't describe her) who will be 19 tomorrow. It is

1. RMcK to MA, 21 March 1908, MA papers, c.6679/93.

2. Lutyens to Emily, 3 May 1908, in The Letters of Edwin Lutyens to His Wife Lady Emily, eds. Jane Ridley and Clayre Percy (1988), 152.

3. RMcK to PJ, 18 March 1908. 
nothing more complicated than this that I love her with all my heart and soul and always shall. ${ }^{1}$

'Pamela said to me', Venetia told Violet, 'that what she was waiting and longing for was for someone to write and say she was the only person he wanted to marry.' 'I have thought or talked of you all day', 'R' duly told 'Pamlet'. 'I reflected upon the joys of the HONEY moon (the large letters signify its quality, the small its length).' ${ }^{3}$ She wrote to him-about wedding presents-from the classroom. 'I shall tap at the school window I hope fairly early this afternoon-certainly before six', wrote the president of the Board of Education. 'Till then, dearest, keep me in mind' ${ }^{4}$

\section{DENOUEMENT}

McKenna did not help his case. By the end of the month, he was quite distracted, and his fiancée forced to writing in his diary that he should 'Stop neglecting Pamela'. ${ }^{5}$ The culmination of McKenna's period at the Board of Education had arrived. 'The great stumbling block to reform was the House of Lords,' McKenna told a public meeting at Goole, 'and that question must now be settled.' ${ }^{6}$ John Clifford wanted to use the bill to force the issue, but government reluctance mirrored that of the parliamentary opposition. During the King's Speech debate, in February 1908, McKenna came under concerted attack for what was held to be the general partisanship of his presidency. 'I sat long hours on the bench pretending to listen to absurd attacks on me', McKenna wrote to Pamela. 'Alfred Lyttelton's joining in annoyed me as it seemed to make all the ridiculous nonsense more personal. I saw the Arch[bishop of Canterbury] this afternoon and found him anxious to repudiate the attacks made by his friends. ${ }^{8}$ While the occasion for constitutional confrontation was getting closer as McKenna finalised his controversial bill, his stridency was for public consumption. Burns, to whom McKenna turned for advice, found him distracted, ${ }^{9}$ and with three days to go, McKenna had met Robert Perks, the leading Free Church MP,

1. RMcK to PJ, 9 March 1908.

2. Venetia Stanley to Violet Asquith, 14 April 1908, in Violet Asquith, Diaries, 153.

3. RMcK to PJ, n.d.

4. RMcK to PJ, 16 March 1908.

5. PJ, RMcK, diary, 29 March 1908; RMcK to Dilke, 28 March 1908, Dilke papers, 43920/65-66.

6. RMcK, speech at Goole, Times, 8 November 1907.

7. Parliamentary Debates, 5 February 1908, 884-964.

8. RMcK to PJ, 6 February 1908.

9. Burns, diary, 24 January 1908, Burns papers, 46326; ibid, 21 November 1907, 46325 . 


\section{Reginald McKenna}

and 'begged' him, Perks claimed, 'almost with tears in his eyes not to oppose his Education Bill "especially in the present crisis in our party". ${ }^{1}$ When that failed to move Perks, McKenna warned him that the party would resent any obstructive opposition. 'Of course I expect to receive full and even bitter criticism but no easy and generally acceptable solution is possible.'2 To another leading actor, McKenna tried flattery. 'A recent Prime Minister has been known to avow that there was no more powerful factor in creating and guiding opinion than your articles', McKenna told Robertson Nicoll. 'In the case I refer to, perhaps the exact words used may have been 'misguiding public opinion'; but I need hardly say that I recognise not only the power but the permanent value of your organ'. ${ }^{3}$

McKenna introduced his Elementary Education (England and Wales) Bill, the first leading government measure of the session, to a packed Commons on 24 February 1908, almost a year to the day after his first attempt. Clause one proposed that LEAs would be given control of all rate-aided schools; clause two, that LEAs would be given control over nonprovided schools in single-school areas, which could offer denominational teaching outside of school hours. The remaining nonprovided schools could contract out. It took the simple approach of making council schools the only schools receiving rate aid, and the only schools where children could be compelled to attend. Single school parishes would have only council schools, but denominations would be given the chance to teach their faith. For the loss of rate aid, nonprovided schools were given an increased Exchequer grant to cover maintenance.

As with his 1907 Grant Regulations, McKenna sought to use financial levers to effect social change, with an addition of $£ 1.4$ million to government expenditure. While the bill maintained the principle of denominational education, it required any school receiving rate aid to come under local authority control. In return for becoming part of the national system, sectarian schools in single-school areas could offer extracurricular denominational teaching three times a week, paid for by the denomination, and taught by denominational teachers. Denominational schools in urban areas-but not in single-school rural areas-could 'contract out' of the national system and receive Exchequer grants of 47 shillings per head, though not rate aid. To give the board greater latitude in reorganising grants, the proposals would repeal the Free Education Act of 1891 and allow boards to supplement grants by charging fees, thereby returning affairs to the pre-1902 system. 'If a school is to privately manage and to have its teachers privately appointed it cannot expect to have all its expenses privately paid', McKenna

1. Perks to Rosebery, 21 February 1908, Rosebery papers, 10053/68.

2. RMcK to C. J. Bristowe, 25 February 1908.

3. RMcK to William Robertson Nicoll, 27 February 1908, in Letters of Principal James Denney to W. Robertson Nicoll, 1893-1917, by James Denney [1920], 196-97. 
told Churchill. 'I venture to say that if Balfour had proposed 47s in 1902 instead of his own Bill the Voluntary Schools would have definitely preferred the larger grant with the complete freedom which I now offer'. 'The fact is the two Churches of England and Rome have been so fed and fostered that they have lost sight of the fact that their creed is hateful to at least $1 / 2$ of the electorate'. ${ }^{2}$

McKenna's attempt at breaking the dual system and the Anglican monopoly in rural areas with a scattered population and a single school was a more calculated attack on denominational schools than that of Birrell. 'The Bill attacks the main points of controversy by methods different to those in the Bill of 1906,' as the chief whip, Herbert Gladstone put it, 'and endeavours to cut cleanly through rather than to go round them. ${ }^{3}$ It would compulsorily transfer 8,000 schools to the local authority. Voluntary schools were invited to transfer their schools to local authorities, but while facilities would be provided for denominational teaching, it would only be extracurricular. If a voluntary school was the only one in the district, managers could receive a government grant per child to 'contract out', to private control, such teaching. Despite his rhetoric and his brandishing of olive branches, the measure was destructive: contracted out schools might be excluded from scholarship schemes and municipal provision, with the contention that LEA powers were potentially circumscribed and fee-paying reintroduced as a means of seeking to undermine denominational schools. ${ }^{4}$

One LEA representative present thought it provided 'clear main principle which we have not had yet', ${ }^{5}$ while John Clifford, the leader of passive resistance, also present, felt 'the speech had strong conviction, impressive directness and a massive sense of responsibility'. ${ }^{6}$ The Chapels thought it too generous to the Churches, the Churches simply rejected it. Nonconformists wished it had gone further, as they would still be paying for denominational schools, and so Perks initially condemned it, but Clifford managed to convince him otherwise. While he did not think it marked a settlement, the Reverend James Guinness Rogers, who had campaigned for McKenna in Clapham, thought it 'not the Dissenting settlement, but Churchmen and Dissenters must both learn a give and take policy', ${ }^{7}$ as did the Free Church

1. RMcK to Churchill, 2 March 1908, Churchill papers, CHAR 2/38/5-6.

2. Birrell to McKenna, 25 February [1908], McKenna papers, 2/1/9.

3. Gladstone to Edward VII, 24 February 1908, Royal Archives, RA VIC/R $37 / 96$.

4. J. Scott Lidgett, Reminiscences [1928], 61-62; Peter Gordon, Richard Aldrich, and Dennis Dean, Education and Policy in England in the Twentieth Century (1991), 19.

5. 'Charlie' to RMcK, 26 February 1908 , McKenna papers, 2/1/10.

6. Clifford, n.d., in Dr John Clifford, C. H, Life, Letters and Reminiscences, by Sir James Marchant (1924), 129.

7. J. Guinness Rogers to RMcK, 2.5 February 1908, McKenna papers, 2/1/7. 


\section{Reginald McKenna}

Council Education Committee, and the London Congregational Union. ${ }^{1}$ The bishop of St. Asaph thought it, when compared to the Birrell bill, 'less complicated and less exasperating. ${ }^{2}$ One Liberal MP told McKenna 'I never listened to a more lucid, business like speech', a compliment that revealed part of the problem. ${ }^{3}$

There was no such balanced reaction from the parliamentary opposition, which regarded the bill an arbitrary restriction on one denomination by the proxies of another; as, in fact, the opposite of what it professed: that it was a sectarian measure. Balfour condemned 'the violence of your religious prejudice', and denounced it as not an olive branch but a sword, F. E. Smith ridiculed the concessions on the grounds of inequality, while Lord Robert Cecil and Lord Edward Talbot practised the kind of tactics that had brought McKenna and Lloyd George to infamy ten years before. At the same time, McKenna was preoccupied with controversies he had thought were over: his 1907 grant regulations had been the subject of parliamentary censure. A whole morning was taken up by 'a discussion with Crewe on what he is to say this afternoon when my misdeeds are brought under review in the House of Lords', ${ }^{4}$ and most of the afternoon was taken up with the debate, in which Crewe offered a less than emphatic defence. ${ }^{5}$

Anglicans and Catholics were bitterly opposed to measures that would make them outcasts from the national system. In ending the rate aid for voluntary schools at the same time as granting greater state subsidies, McKenna had particularly antagonised Catholics, on whose discontent was blamed the Liberals' by-election loss in Peckham on 24 March. ${ }^{6}$ Anglicans protested, most forcibly through the Committee for Church Defence, and through the archbishop of Canterbury personally.? The leading Welsh churchman, Alfred Edwards, bishop of St Asaph, encouraged by Lloyd George, offered conciliation to the parliamentary deadlock by offering alternative legislation in the Lords. 'The position of the Government in regard to their own educational proposal', The Times pronounced, 'is now regarded on all hands as one of embarrassment. ${ }^{\prime 9}$

Edwards drafted the bill as an interdenominational substitute to the denominational and undenominational attrition, based on the principles of his 1904 bill to overcome the 'Welsh revolt'. He gave it to Lloyd George,

1. London Congregational Union resolution, 14 April 1908, Runciman papers, 21/29; Daglish, Education, 321.

2. Alfred George Edwards, Archbishop of Wales, Memories (1927), 205.

3. John Edward Ellis to RMcK, 24 February 1908, McKenna papers, 2/1/8.

4. RMcK to PJ, 23 March 1908; Parliamentary Debates, 23 March 1908, $1005-46$.

5. Parliamentary Debates, 23 March 1908, 1005-46.

6. Times, 25 March 1908, 26 March 1908.

7. Randall Davidson to RMcK, 10 March 1908, ED24/14.

8. Lord Bishop of St Asaph, Parliamentary Debates, 30 March 1908, 3-16.

9. Times, 19 March 1908. 
who passed it to McKenna. The bishop and president met on 11 March. McKenna told Edwards,

I should welcome the Bill as an expression of the views of the Church of England for dealing with the Church of England schools. Your Bill has the great merit of recognising only one type of private elementary school. ... I am prepared to accept the freedom of the teacher ... I can quite easily incorporate its main provisions in my Bill. ${ }^{1}$

Seven days later, he went to the other place to listen to Edwards introduce the bill. 'Mr McKenna, who listened to the Bishop from the steps of the Throne, seemed well pleased with his statement', the Westminster Gazette reported. 'Indeed, a vision of the Bishop, with his white wings, as Cupid aiming his arrow at Mr McKenna, crossed the mind of at least one spectator' and at least one cartoonist. ${ }^{2}$

The St. Asaph bill modified that of McKenna by allowing denominational facilities within school hours if parents so wished a compromise, which duly won the support of the archbishop of Canterbury, in the Lords, but not of the leader of the opposition, in the Commons, nor of Catholics, who objected to it more than they did to McKenna's bill. The Daily Telegraph referred to 'the furtive vindictiveness which is the quintessence of McKennaism'. 'As a specimen of class legislation of unscrupulous rapacity,' pronounced the bishop of Manchester, 'the bill will no doubt deserve a place in historical archives by the side of racks, thumbscrews, boots, and other engines of torture'. ${ }^{4}$

\section{A NEW CHIEF}

His heart condition having deteriorated further over the winter, on 3 April 1908, Sir Henry Campbell-Bannerman tendered his resignation to the king. ${ }^{5}$ Rather than returning to London, Edward VII had summoned Asquith to Biarritz, and McKenna and Pamela saw the Chancellor off from Charing Cross Station as he boarded the Continental boat train. ${ }^{6}$ Two days later, the king appointed Asquith his prime minister. Immediately on his return, an episode took place that could subsequently be seen to characterise the relations between Asquith, McKenna, Lloyd George, and Churchill over

1. RMcK, 11 March 1908, in Edwards, Memories, 206.

2. Westminster Gazette, 31 March 1908.

3. Daily Telegraph, April 1908, in Westminster Gazette, 5 March 1908.

4. Bishop of Manchester, attrib., Times, 10 March 1908; J. A. Spender, Great Britain and Commonwealth, 1886-193.5 (1936), 326.

5. He died on 22 April.

6. Daily News, 7 April 1908. 


\section{Reginald McKenna}

the next eight years. The reconstruction of the ministry had already been outlined accurately in Robert Donald's Daily Chronicle, four days before the official announcement, to the Asquiths' irritation. In another portentous episode, Margot suspected Lloyd George, prompting Churchill to say that 'he feared I had been prejudiced by McKenna who certainly does not like L. George'. ${ }^{1}$ McKenna maintained his story, Margot told Churchill, ${ }^{2}$ who went to Asquith, ${ }^{3}$ and in all likelihood told Lloyd George, whose defence was that the story had appeared in The Times the day before. He did not say who had briefed George Buckle. ${ }^{4}$

The changeover from Campbell-Bannerman to Asquith had obvious implications. The most apparent was that the new prime minister could not fail to be more active. For McKenna, though promotion could have been expected, it marked the passing of an opportunity. Dilke told McKenna that Asquith and Campbell-Bannerman had discussed the handover of power, and the inevitable reshuffle, at the prime minister's deathbed. 'When C-B "woke-up" on that Thursday, you were the one subject on which he agreed with Asquith, who of course wanted you at the Exchequer." Asquith had first wanted to retain the office of chancellor of the Exchequer while prime minister, as Gladstone had done. Then he intended McKenna to take the post to continue his work on pensions and income tax. Perhaps with a premonition that the continuance of those measures would be a political as much as a financial matter, Asquith instead appointed Lloyd George. To the weight of intuition on the prime minister's part, Lloyd George provided the threat of resignation if he was not appointed. ${ }^{6}$ Morley, a keen observer of Cabinet appointments, felt Lloyd George had 'put a pistol to Asquith's head and asked for the Ch. of the Ex. with a threat of resignation', ${ }^{7}$ ensuring, in Fitzroy's words, the prime minister's 'surrender to Lloyd George as Chancellor of the Exchequer when McKenna was his own choice'. ${ }^{8}$ Lloyd George would have accepted Morley, who turned it down, but not McKenna, whose elevation would both reflect adversely on Lloyd George's own station, and, he felt, undermine his social programme. ${ }^{9}$ Lloyd George thus managed that he, rather than McKenna-who was Lloyd George's junior in both status

1. MA, 7 April 1908, diary, MA papers, d.3206/53-54.

2. MA to Churchill, 10 April 1908, in Winston S. Churchill, vol. 2, Companion II: Documents, 1907-1911, ed. Randolph Churchill (1969), 771-72.

3. Churchill to HHA, 10 April 1908, Companion, ii:2, 772.

4. Lloyd George to HHA, 11 April 1908, Companion, ii:2, 773.

5. Dilke to RMcK, 'Easter Day 1908', McKenna papers, 3/13/4b; London letter, Birmingham Post, 7 September 1943.

6. Birrell, Things Past Redress, 245-46.

7. Esher, diary, 10 April 1908, Esher papers, 2/11/108; Beatrice Webb, diary, 18, 20 April 1908, in The Diary of Beatrice Webb, vol. 3, 1905-1924, eds. Norman Mackenzie and Jeanne Norman (1984), 91.

8. Fitzroy, diary, 6 April 1910, Fitzroy, Memoirs, $i: 400-1$.

9. E. T. Raymond, Mr Lloyd George (1922), 103-4, 111. 
and experience-should succeed to the Exchequer. With Grey secure at the Foreign Office, Lloyd George wanted the next most prestigious department himself. His position in the party, and in the country, was much more prominent than that of McKenna, a fact which, with Lloyd George's threatened resignation, concluded the matter.

With Herbert Gladstone remaining at the Home Office, the highest ranked office available after the Exchequer was first lord of the Admiralty, and it became the subject of the latest horse-trading between McKenna and Churchill. McKenna, Churchill claimed, 'offered when the Government was reformed to ask the Prime Minister to let me go to the Admiralty instead of him'. ${ }^{1}$ Others claimed that Churchill turned it down to take Lloyd George's old job as president of the Board of Trade. ${ }^{2}$ Alongside the obvious promotion it offered, a little more than a year after the previous one, the position of first lord of the Admiralty involved an official residence, at the beginning of the Mall. McKenna's little flat in Whitehall Court offered little comparable attraction, any more than did further wrestling with the bishop of $\mathrm{St}$ Asaph. Battered at the Board of Education, Reginald McKenna left the most belligerent department in government at the time, formally to be granted a martial role, uniform, and state apartments as first lord of the Admiralty.

It was not an obvious appointment, but McKenna managed to reconcile himself to it.

It appears he has a yacht, the Enchantress, over 2000 tons, at his disposal, and under the excuse of inspecting battleships he can take a cruise whenever he likes. Of course he would be suitably accompanied. There is a fine suite of cabins and a piano. Since I have heard this I have renounced the disinterested attitude I have hitherto posed in. The baser part of my nature has come to the top, and I mean to fight with teeth and claws for the right to take my darling on as many cruises as I like on a 2000 ton yacht. She enjoys yachting and I shall soon get over the trifling ills of the rolling main. ${ }^{3}$

Freedom of the seas also meant freedom more generally. 'Many congratulations on your promotion and on your escape from the terrors of the Education Department', Harold Cox told McKenna. ${ }^{4}$ 'My hearty congratulations to you. I am delighted you have got a job worthy of you', Kaiser von Courtauld wrote from Berlin. 'I hope after Easter I shall be able to get you and

1. Churchill to Morley, 23 December 1909 [copy], Churchill papers, CHAR 2/39/121.

2. Nicholas A. Lambert, Sir John Fisher's Naval Revolution (Columbia, 1999), 141.

3. RMcK to PJ, 23 March 1908.

4. Harold Cox to RMcK, 12 April 1908. 
Ernest to come and splice the mainbrace (as I suppose you will call it) to celebrate the event.' ${ }^{1}$

There remained, after the celebration, the Education Bill, for which McKenna had retained responsibility, even though he had been replaced as president of the Board of Education by his closest ministerial friend. As it had with so much else of the government's programme, the House of Lords moved to block the measure. Despite the number of incensed parties, neither the Liberal Party inside Westminster, nor its Free Church interests outside, was sufficiently enthusiastic to defend the measure. An alternative bill, by the name of Asaph, and an alternative president, by the name of Runciman, further confused already confusing matters, and nonconformist and Unionist pressure continued unabated. McKenna had promised the Reverend John Scott Lidgett, editor of the Methodist Times, that he would reconsider the contracting out arrangements. ${ }^{2}$ On 11 April, the archbishop of Canterbury called, and distracted by the light offered by St. Asaph, was more opposed than ever to McKenna's bill. ${ }^{3}$

At the same time, McKenna had upset Morant again. When McKenna had introduced the bill, Morant criticised the way he 'airily' promised millions of pounds of extra expenditure, but not extra expenditure by the Exchequer, which had the effect of alarming county councils who feared they would have to find more money from the rates. McKenna's bill pledged to increase the existing education grants by $£ 1,400,000$, which, he told local authority delegations that had rushed to the Board of Education, would be sufficient to fund the rising costs. ${ }^{4}$ It was an uncharacteristically cavalier gesture, which could only be explained by his commitment to the measures he had worked out with the Webbs. The failure to support the expansion actually came from the first architect of the welfare state, Lloyd George, who told the relevant parties on 18 March.

McKenna moved the second reading on 18 May, and said that a compromise between his bill, which had the support of nonconformists, and the St. Asaph bill, which had the support of Anglicans, should be possible, which was not how high churchmen, Catholics, or Unionists saw it. ${ }^{5}$ Or the electorate. Since McKenna had introduced the bill, the Liberals had lost three parliamentary seats to Labour, and nine to the Unionists in by-elections, an 'an outburst of hostility' which the Birmingham Post thought 'brought home to the Government the conviction that it is bad political business for

1. Kaiser von Courtauld to RMcK, 13 April 1908.

2. J. Scott Lidgett, My Guided Life (1936), 193.

3. ED 24/153.

4. Margaret Hammer, "The Building of the Nation's Health": The Life and Work of George Newman to 1921' (PhD thesis, University of Cambridge, 1995), 96-99, 141.

5. G. K. A. Bell, Randall Davidson, Archbishop of Canterbury, 2 vols. (1935), 1:531-32. 
them to continue in the policy of extinction.' ${ }^{1}$ The government had to aim for fairness if it intended disturbing the existing state of things, but 'for the sake of an artificial uniformity the McKenna Bill violates them all'. ${ }^{2}$ By now, where some were 'sick of attempts to satisfy all the Churches by compromises, which ex hypothesi must satisfy none', ${ }^{3}$ the various indignations of a packed house had been replaced by the general uninterest of a sparsely attended chamber. Suspicion that McKenna had welcomed the Asaph bill as a way of withdrawing his own without blame falling on the government was reinforced when debate on the bill was suspended on 7 December 1908. ${ }^{4}$ The next, fourth—and last—bill would be that of Runciman. ${ }^{5}$ Bishop Edwards was relieved to have so unsympathetic a minister moving on: 'he treated the whole business like a liquidation' ${ }^{6}$ McKenna's presidency of the Board of Education was over. 'I most heartily loathed it."

1. Birmingham Post, 18 May 1908.

2. Ibid.

3. James Denney to William Robertson Nicoll, 3 April 1908, Nicoll, Letters, 114.

4. Times, 25 March 1908, 28 March 1908.

5. Daily Graphic, May 1908.

6. Edwards, Memories, 294.

7. RMcK, 19 April 1917, Parliamentary Debates, 1915. 


\section{Reginald McKenna}

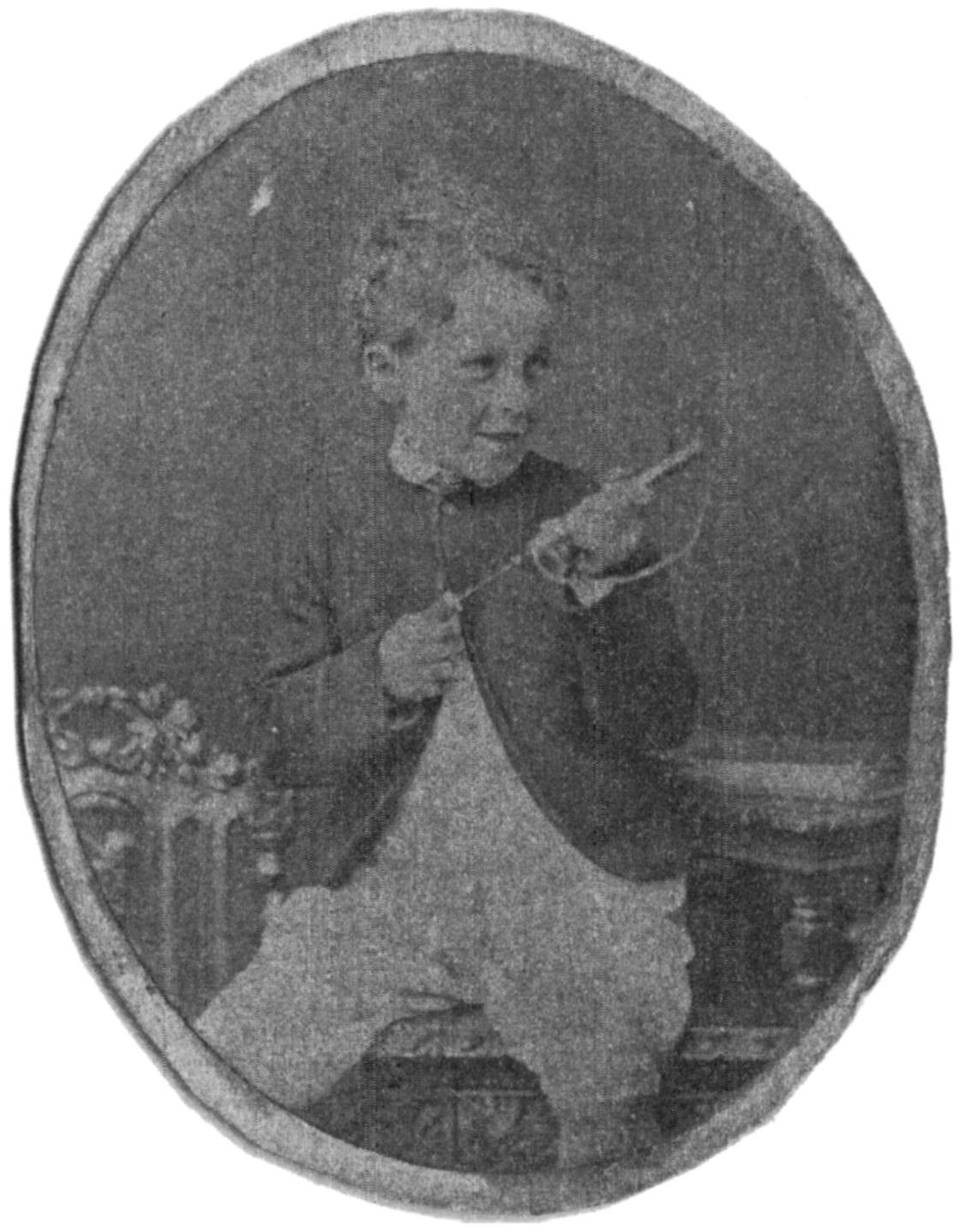

Figure 1.1 Young Reggie, hirsute and belligerent; only one quality would endure, circa 1870 . 


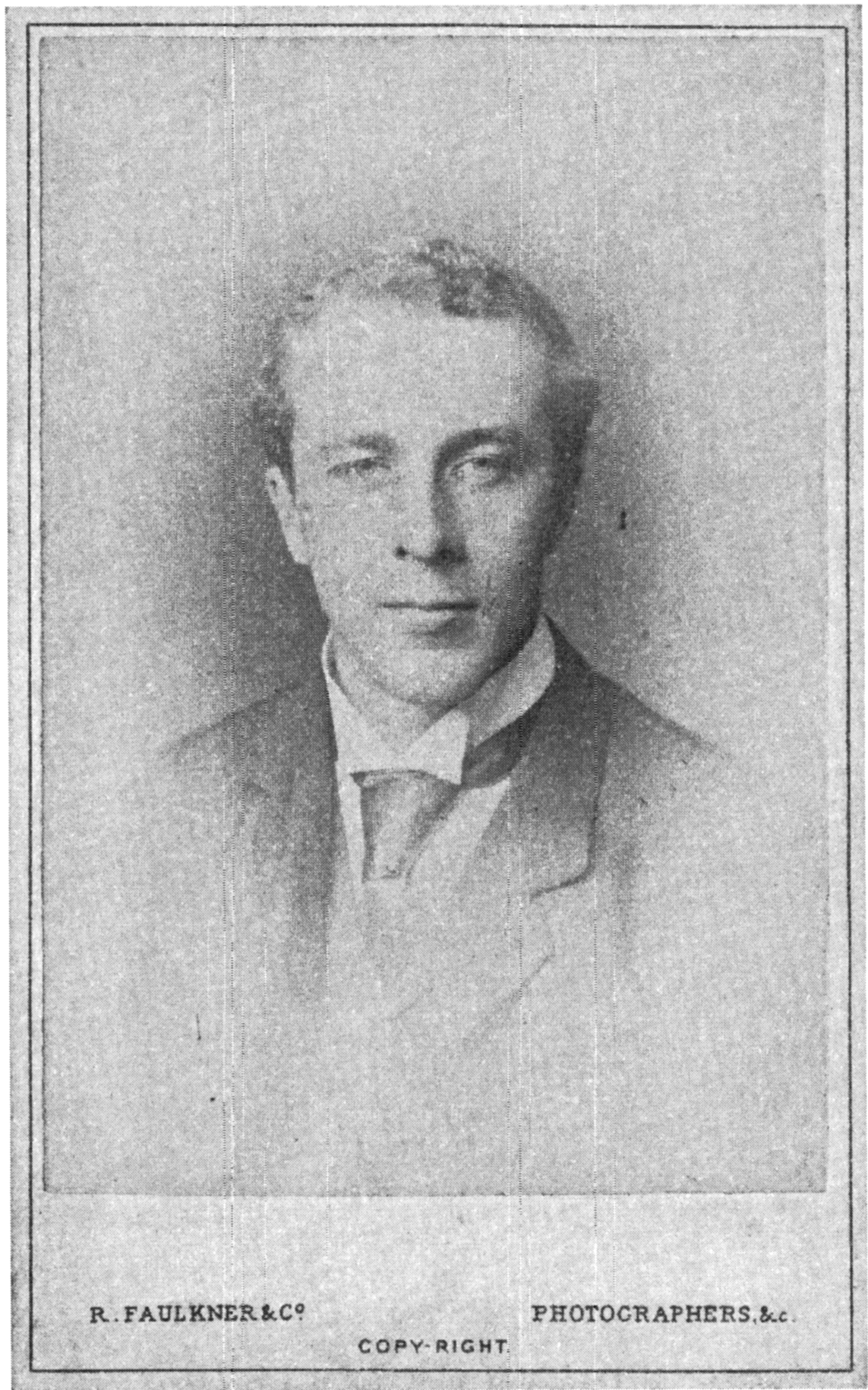

Figure 1.2 The Trinity Hall scholarship boy, circa 1884. 


\section{Reginald McKenna}

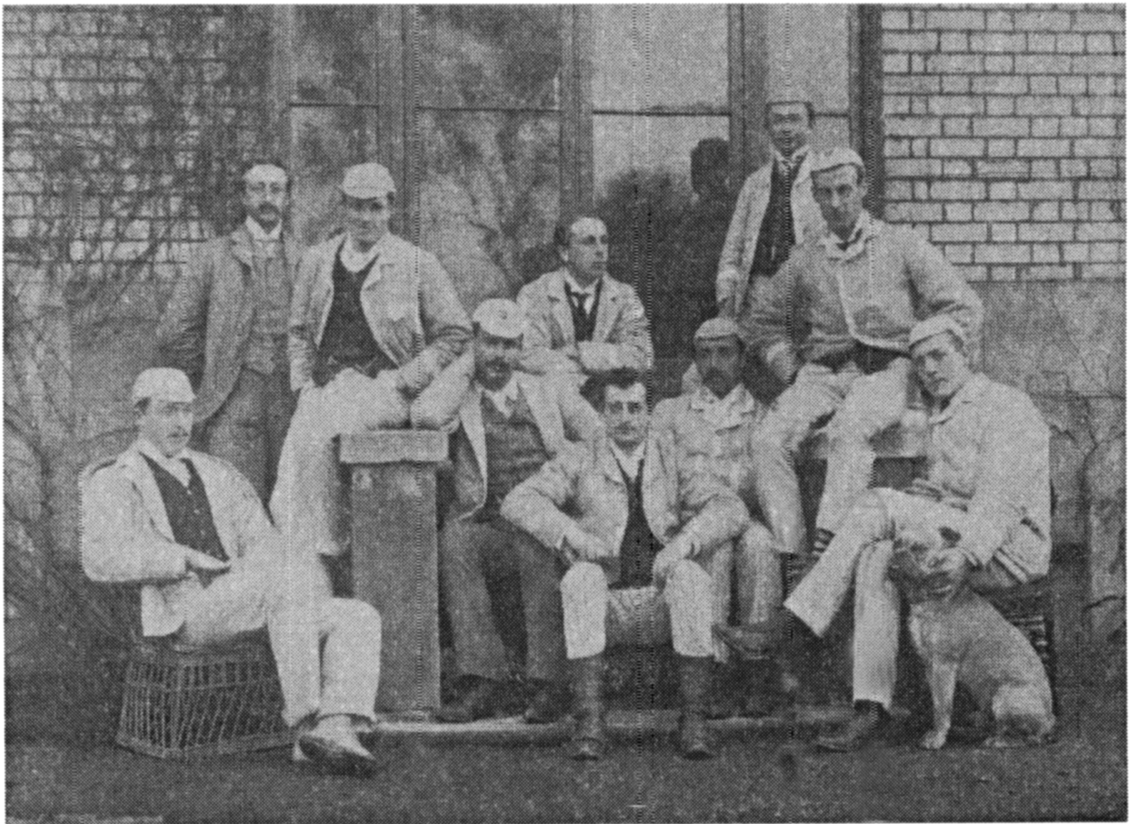

Figure 1.3 Sitting slightly apart, with the Cambridge crew, circa 1887.

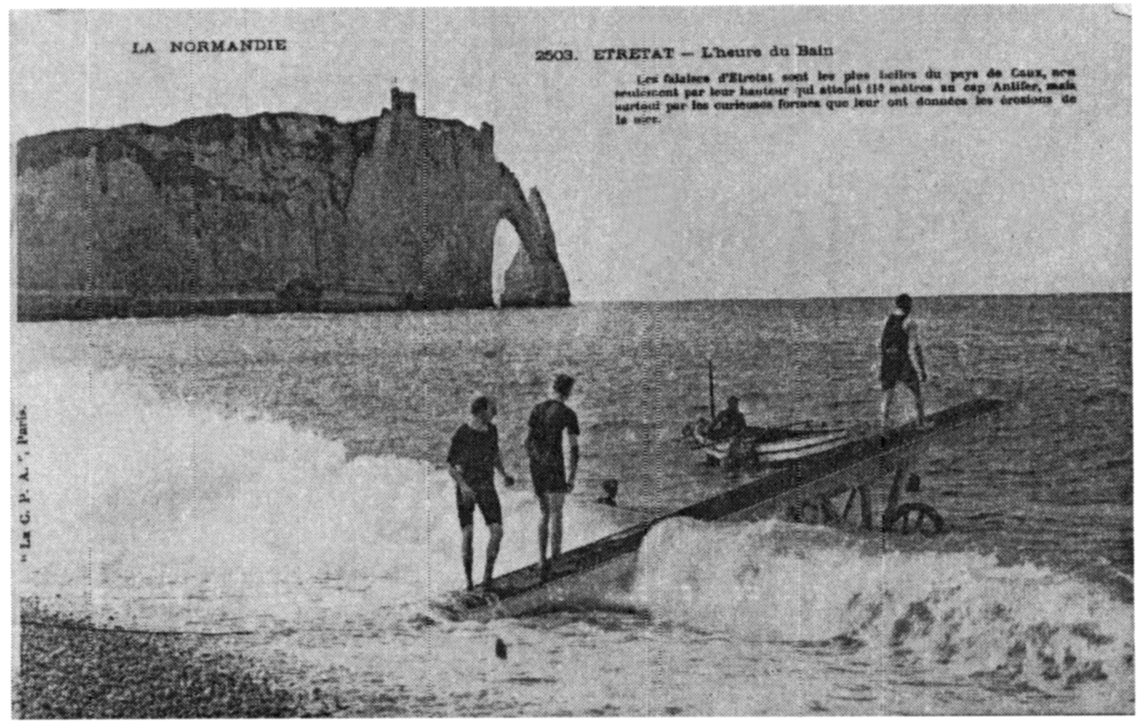

Figure 2.1 Hydrophile and Francophile: Reggie, left near Villa McKenna, Etrêtat, circa 1900. 


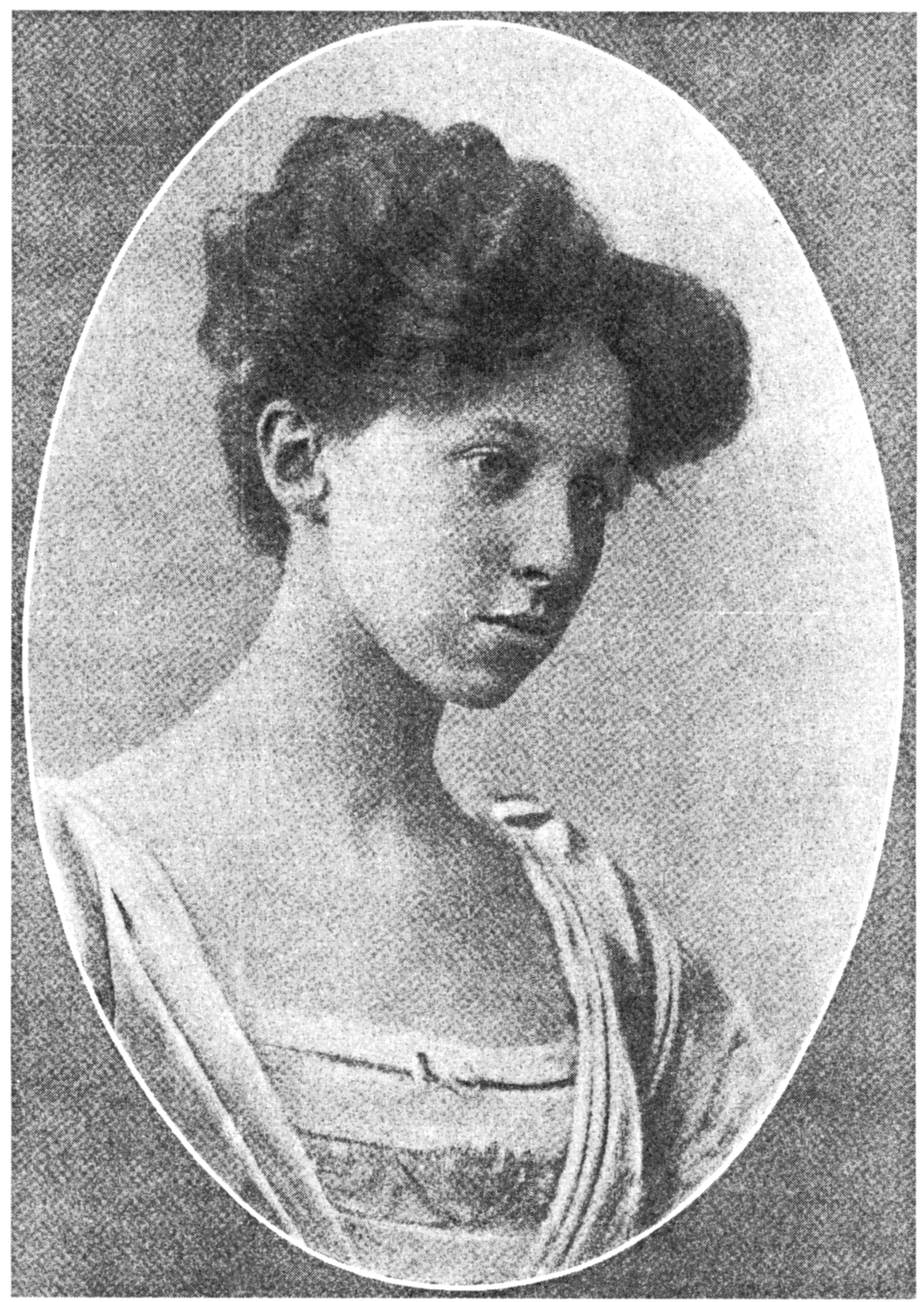

Figure 3.1 Pamela. 


\section{Reginald McKenna}

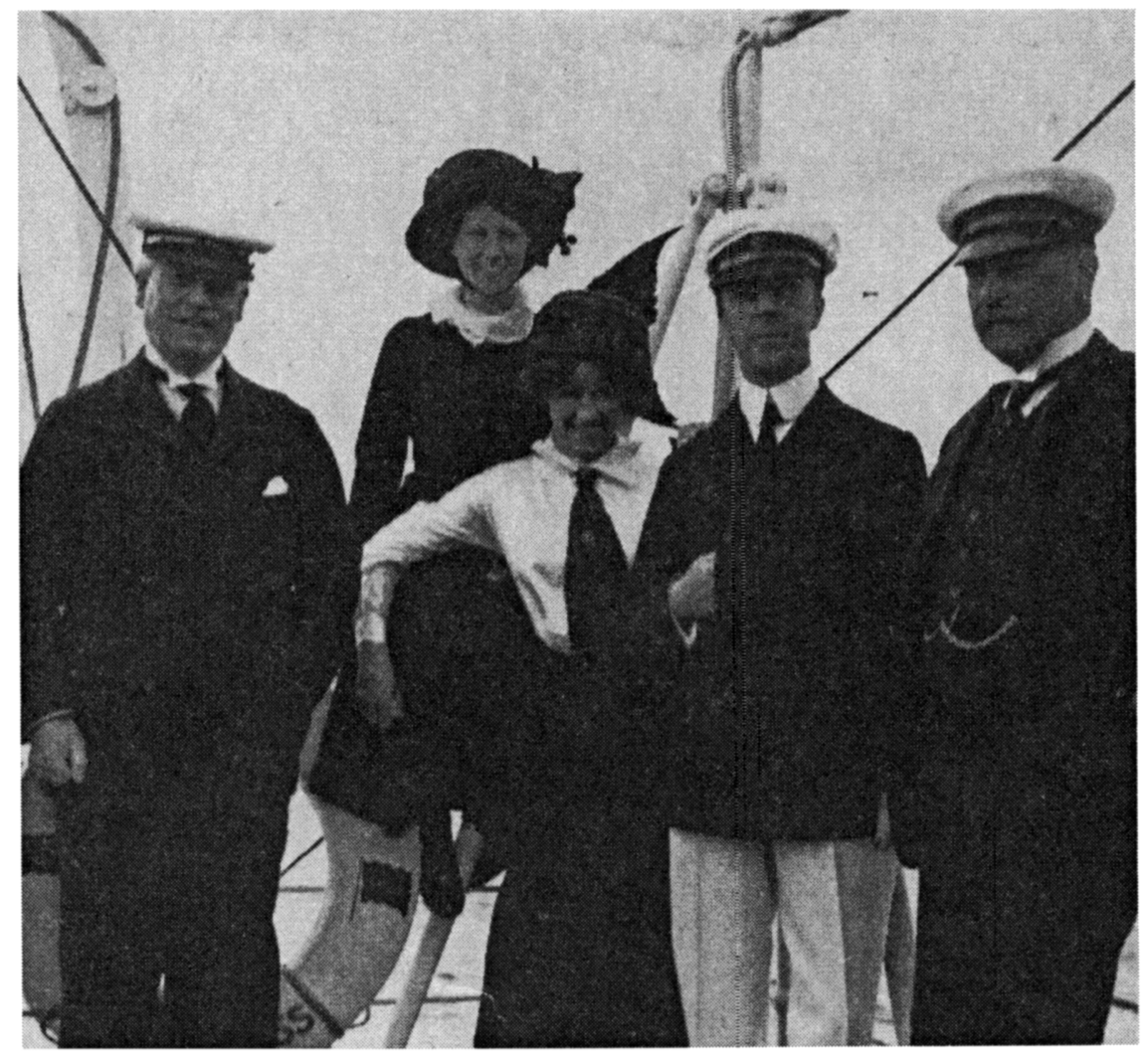

Figure 3.2 The happiest days: Asquith, Pamela, Barbara, Reggie, Ernest, and the Enchantress: circa 1910. 


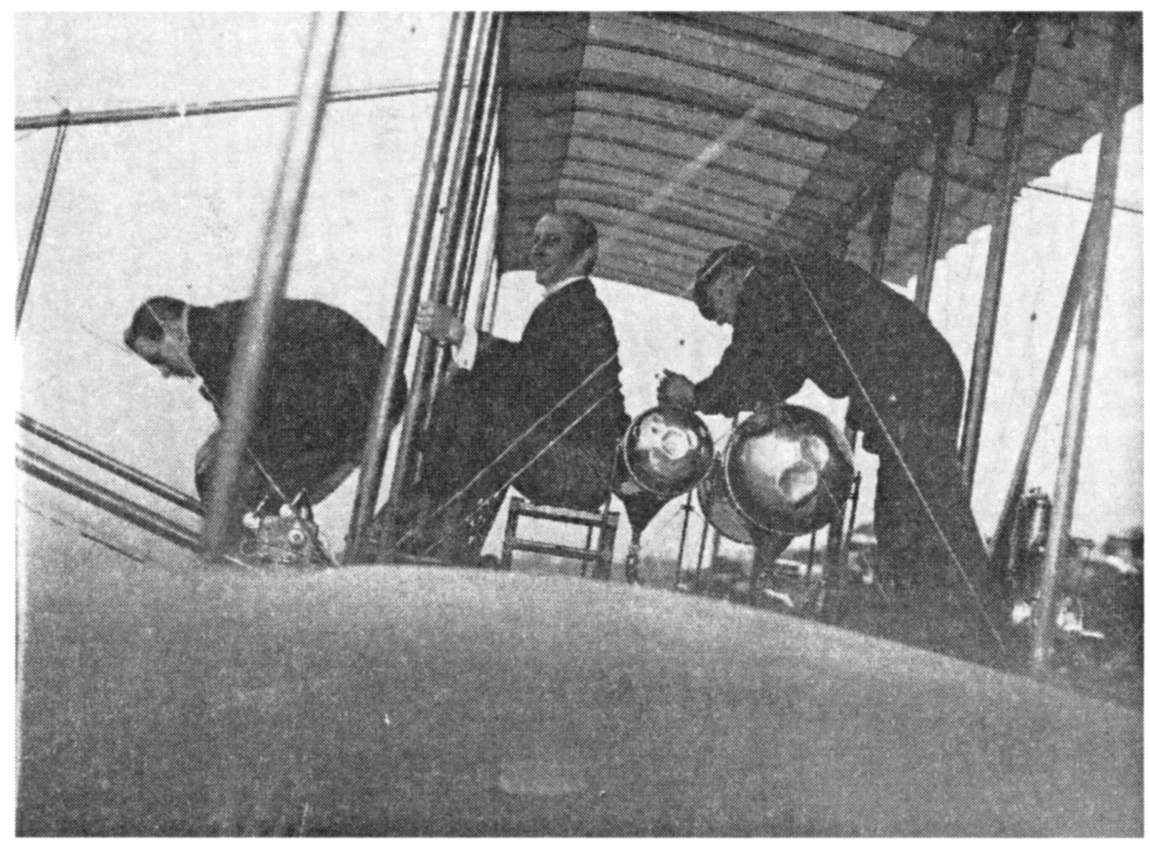

Figure 4.1 'Courage, of which . . . he is a shining example.' Hendon, 12 May 1911: the first minister to fly. 


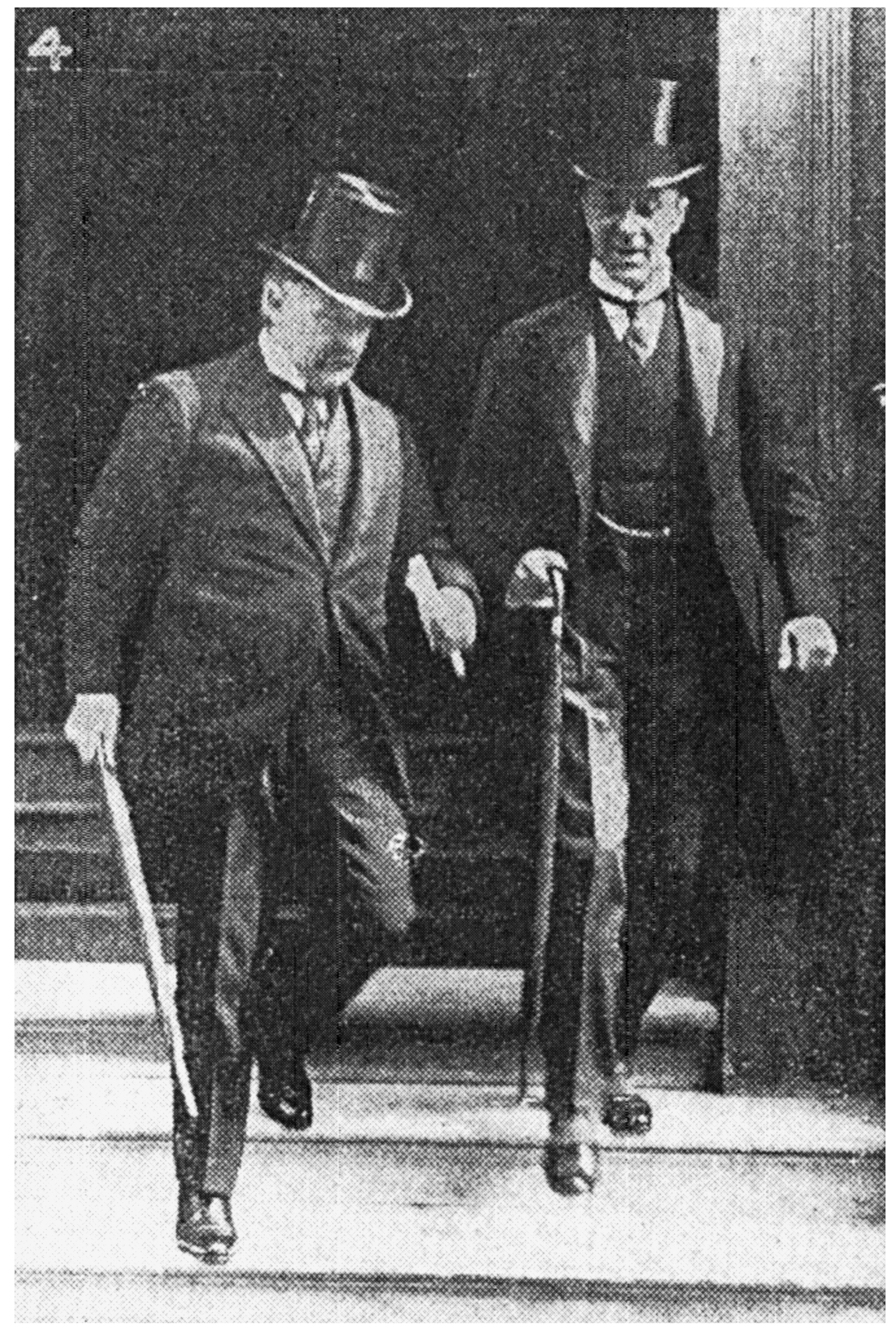

Figutre 4.2 I.loyd George and McKenna, 1 August 1912, an infrequent, but usually poisonous, pairing. 


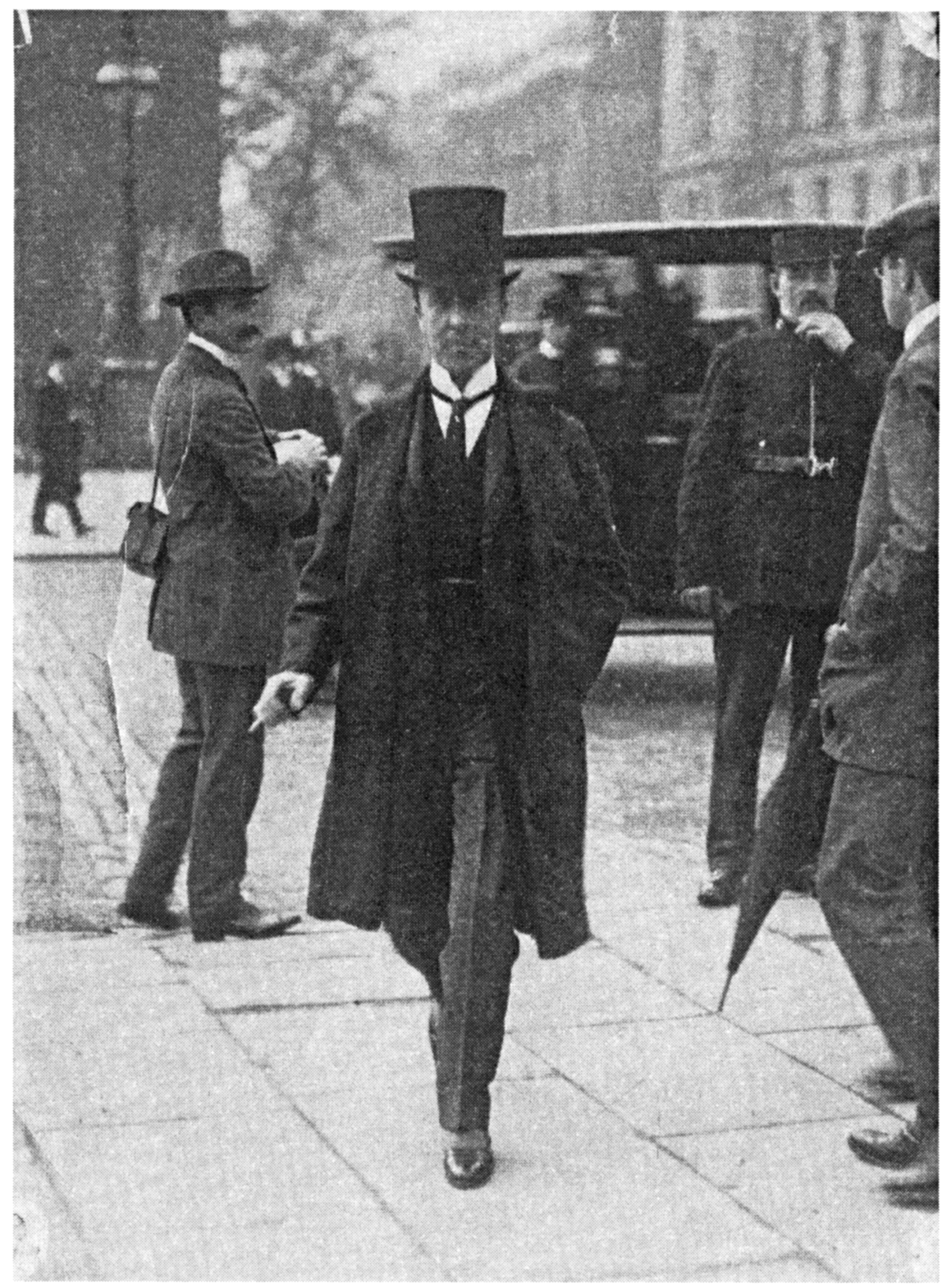

Figure 5.1 The home secretary, attracting the attention of the law, circa 1913. 


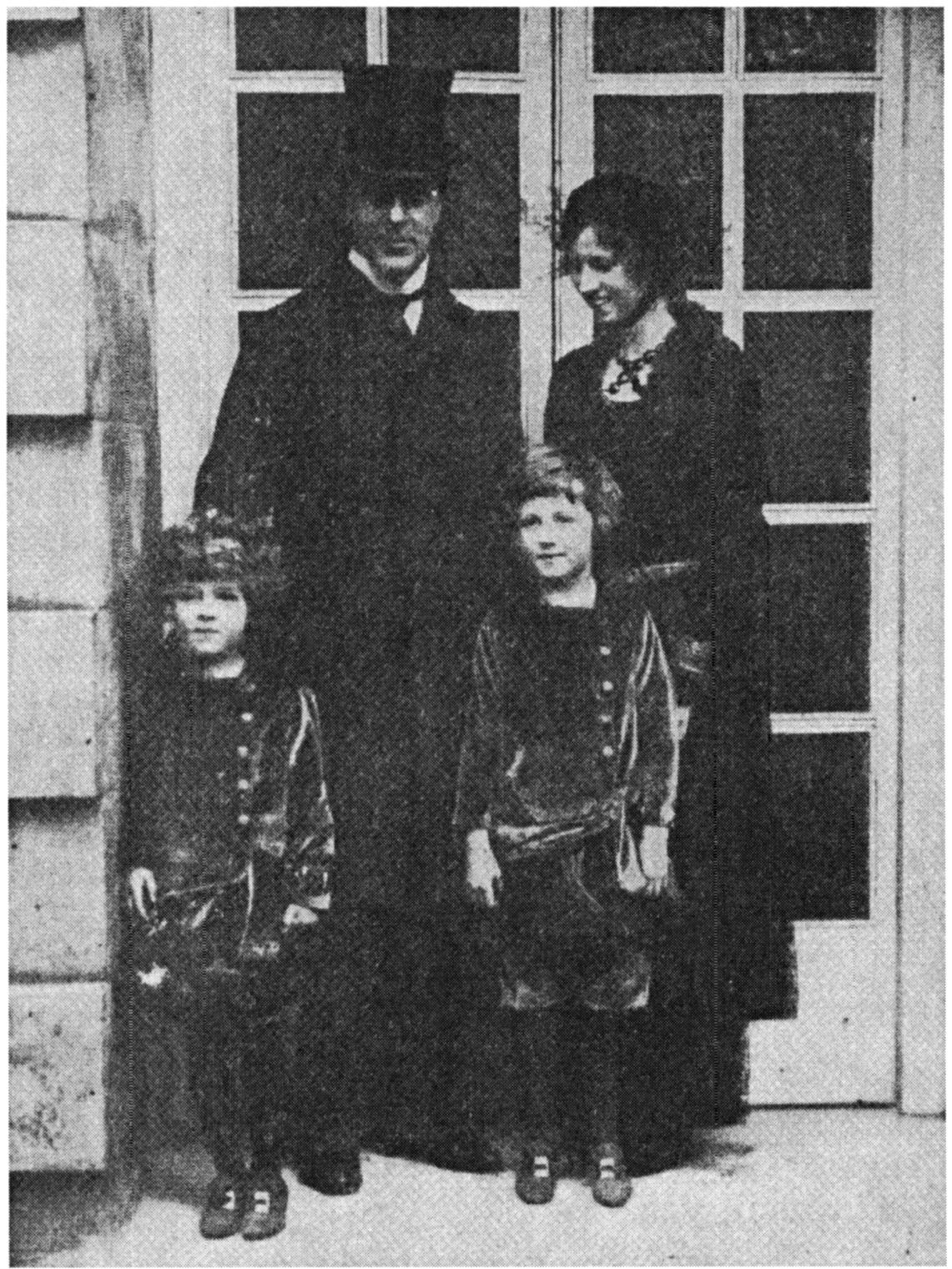

Figure 6.1 A Liberal affair: the McKennae at the wedding of Maurice Bonham Carter and Violet Asquith, Pamela's childhood friend, 30 November 1915. David in front of his father, and Michael in front of his mother. 


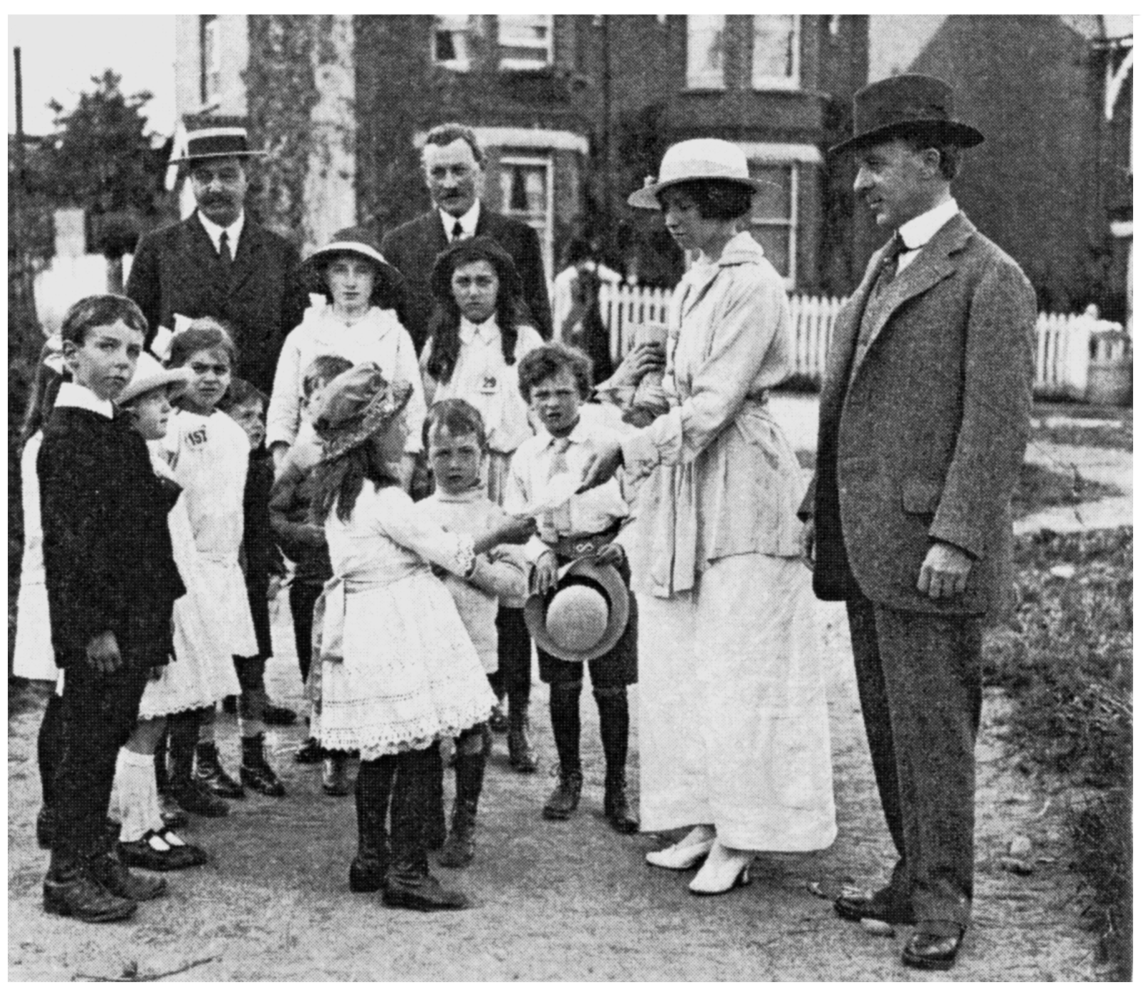

Figure 6.2 The chancellor and Mrs McKenna distributing savings books to encourage juvenile thrift, 1915-16. 


\section{First Lord of the Admiralty, April 1908 to October 1911}

How can we reason with rumour or argue with a shriek?

-McKenna, 1910

\section{AGENDA}

If, as The Times thought, the survival of the British Empire depended on both school power and sea power, ${ }^{2}$ a president of the Board of Education was a more than suitable candidate to be first lord of the Admiralty. That was not, however, either the reason for the promotion, or how it was received. With the Treasury providing the new prime minister, and constituting the spiritual home of the new first lord, the expectation in the service was that 'retrenchment' had prevailed. Complaints therefore that the government's reforming agenda had been distracted by the estimates of Lord Tweedmouth, Campbell-Bannerman's first lord of the Admiralty, would now be resolved to the satisfaction of most Liberals. ${ }^{3}$ Of all the appointments in the new ministry, 'that of Mr Reginald McKenna to the Admiralty is very much the worst', thought The Globe, imbued with its Britannic preoccupations, through his 'being a strong adherent of that disastrous policy of a Little Navy.' ${ }^{4}$ The shadow cast by Gladstone was a long one. Those Liberals such as McKenna, whose natural inclination was for economy over spending, retained their appeal in a government whose leading figures, such as Lloyd George, did not feel constrained by such precepts when they did recognise them. So parsimonious was the new first lord feared to be that Crewe felt it necessary to go off and pacify the king's private secretary. ${ }^{5}$ When a Liberal

1. RMcK, 4 January 1910 , election address.

2. Times, 6 January 1903 .

3. Sir Archibald Hurd, Who Goes There? [1942], 88; RMcK to Dilke, 17 April 1908 , Dilke papers, $43920 / 72$.

4. Globe, 13 April 1908; but cf. Lord Spencer to Viscount Althorp, 15 April 1908, in The Red Earl: The Papers of the Fifth Earl Spencer 1835-1910, vol. 2, 1885-1910, ed. Peter Gordon (Northampton, 1986), 360.

5. Knollys to Edward VII, 26 March 1908, Royal Archives, RA VIC/X 5/1. 
MP congratulated McKenna on the promotion, it was because 'I hope it means that we shall spend less on our armaments, and have more for our social reforms.' "The first sea lord, Admiral Sir John-'Jacky'-Fisher, had a nightmare: 'Mr Gladstone stood by me last night. Mr McKenna was by his side'. ${ }^{2}$

Retrenchment was only one tenet of Liberalism. When Viscount Esher pronounced McKenna 'exactly the type Mr Gladstone would have chosen', 3 it was not because of his parsimony. 'I am to be in every sense Minister for the Navy', McKenna told J. L. Garvin. 'I am as stiff as Mr Cobden himself in my desire to maintain the unconditional supremacy of the navy'. ${ }^{4}$ In a private note on 'Naval supremacy and the unity of maritime effort', he attempted to reconcile the priorities of the government with those that had first brought him to politics.

Slums and insanitary dwellings are a disgrace to civilisation but that is no reason for denying their existence. And so war and threats of war disgrace our humanity but that is no reason for shutting our eyes to the danger. In the last five years by the happy issue of their measures the Government have confounded the Conservatives, delighted the Liberals, and exasperated the Socialists. ${ }^{5}$

After the unfortunate experience of Tweedmouth, Margot Asquith believed, 'The Admiralty just now wants a 1 st rate man $\&$ a very straight strong character. McKenna seems to me a good appointment'. ${ }^{6}$ With a view to wider strategic considerations between a navalist and a continentalist approach to war in Europe, some discerned a counterweight to the ascendancy of the army on the Committee of Imperial Defence. ${ }^{7}$ It was the beginning of what imperialists and patriots called 'the Naval Awakening.,

Liberalism and navalism could also be said to more than complement each other, particularly for a Liberal for whom free trade was the lodestar. It was a common presumption that, given his reputation and record, McKenna was an 'economist'. It would have been more accurate to say he was an empiricist. F. E. Smith, like most Unionists dismissive of a ministry 'drugged

1. Frederic Mackarness to RMcK, 13 April 1908.

2. Lord Fisher, Memories (1919), 41.

3. Esher to Spender, 8 August 1910, in Journals and Letters of Reginald, Viscount Esher, vol. 3, 1910-1915, ed. Oliver Esher (1938), 13.

4. RMcK to Garvin, 28 May 1908, McKenna papers, 3/13/4a.

5. RMcK, diary, 1911, memoranda.

6. MA, diary, 11 April 1908, MA papers, d. 3206/62.

7. 'Have you read this week's "Nation?"', Esher asked RMcK. 'It indicates, what some people have always suspected, that the attack on the Army would be followed (at a decent interval) by an attack on the navy estimates!!' Esher to RMcK, Esher papers, F182.

8. Frank Fox, Ramparts of Empire. (1910), 252. 
by the deadly influence of pacifism', thought McKenna's principal ability, and eventual achievement, was to apply 'his cold and passionless mind in the first place to a conclusion upon the merits of the Admiralty claim.' ${ }^{1}$ The claim, as ever, was for more money. In time, the reliable 'economist' before his move to Admiralty House thereafter emerged as the leading 'expansionist'. ${ }^{2}$ After the scandal of the 'Tweedmouth letter', when McKenna's predecessor had revealed future naval expenditure to the Kaiser, ${ }^{3}$ informed observers felt McKenna had been given license to increase spending. ${ }^{4}$ Fitzroy felt that McKenna, with 'his grasp of financial detail and a great deal of natural tenacity, [was] on strong ground'. ${ }^{5}$

At the Admiralty, McKenna had three main policy concerns. The first concerned the rights of neutrals at sea, an issue which was doubly significant in the general sense of the Royal Navy being the world's largest and thus having an interest in any aspect of maritime law, particularly if, in the event of a European war, Britain were neutral. The second concern was the eternal service department question of expenditure, specifically directed at the expansion of the fleet by a government elected to increase social spending. The third was the Admiralty's involvement in determining the precise nature of Britain's continental commitment: the conditions and extent of British action in the event of war in Europe. It surprised few that the position of first lord of the Admiralty was available because Tweedmouth had suffered a nervous breakdown.

Consequently, McKenna had to press concerns that to many appeared militaristic. The attractions of the office of first lord were seductive, and seduction, as so often, proved to be at the expense of chastity. The Irish Nationalist MP John Dillon publicly accused McKenna of yielding to influences to which a Liberal ought not to yield, while Bertrand Russell told the internationalist and peace campaigner Gilbert Murray that McKenna was responsible for the First World War. ${ }^{6}$ Indeed, for Archibald Hurd, naval correspondent of the Daily Telegraph, 'The critical phase in the Anglo-German struggle for sea supremacy opened in 1908, when Mr Reginald McKenna became First Lord of the Admiralty, with Fisher as First Sea Lord'?

The contradiction between what was expected and what was delivered by a politician in government could always be ascribed simply to 'ministeri-

1. Birkenhead, Sunday Times, 1 June 1923.

2. Vide, RMcK to Harcourt, 28 November 1907, Harcourt papers, 439/236.

3. Morning Post, 30 October 1914.

4. Charles à Court Repington, Vestigia (1919), 292.

5. Fitzroy, diary, 21 December 1908, in Sir Almeric Fitzroy, Memoirs, 2 vols. (1925), i:370.

6. Dillon, F. S. Lyons, John Dillon: A Biography (1968), 322; Bertrand Russell to Gilbert Murray, n.d. November 1915, in The Collected Papers of Bertrand Russell, vol. 13, ed. Richard Rempel (1988), 209, 263-64.

7. Hurd, Who Goes There?, 88. 
alismus' or 'departmentalitis': the advocacy of the interests of a minister's current department, irrespective of any broader philosophical or doctrinal concerns. As an explanation, the interpretation reinforced the notion of McKenna as being little more than an executive bureaucrat-or a spokesman ${ }^{1}$ - and as such antagonised ministers of a more original and inventive disposition-two in particular. More legitimately, it could be explained by the nature of Britain's international position at the end of the Edwardian era. Strategic conception and provision were based around that which had provided for British paramountcy: free trade based on maritime supremacy. Prosperity and empire had been attained and ensured by global naval mastery, as policymakers in Berlin and Washington were well aware, and the efforts of the former to emulate it framed McKenna's first lordship. To add piquancy, through his earlier actions as a minister, McKenna had in part created the conditions he inherited. His naval concerns hitherto had been most avowedly those of cost: the financial balance had to be struck between an expansion of provision, both naval and social, and consideration to electorates, which were ever more attentive, and to financial communities. The decisions taken were never therefore those of maritime strategy alone, as perhaps in the conception of previous Liberal governments. Industrial society forced strategy to embrace all elements of industrial society, from food to elections.

The Edwardian age marked a signal development in British policy. Put broadly, it saw the shift from tactics to strategy on the part of the Royal Navy. The change stemmed from an implicit recognition that, as in other areas of the national interest, what had once been an absolute-British naval strength-was now relative, and required greater attention as to its policy of best advantage. There was something of a division between Atlanticists and Continentalists, which expressed itself in more localised tensions: between radicals and the army, where the army involved a continental commitment and the threat of conscription; between radicals and the navy, where the navy squeezed a budget intent on dealing with social reform; and between the navy and the army, over their near-statutory schism.

Liberals had a natural interest in the navy. Free trade and the freedom of trade were regarded as both peaceful and encouraging of peace, as were accepted standards of maritime law. Similarly, naval strength was conceived of as acting as a deterrent, which, in the unlikely event of its failing, would ensure, as it were, a war of hunger rather than of blood through application of a blockade of the continent, while keeping Britain's essential trade routes open. Such a method of fighting the war would also discourage conscription and ensure that manpower be used to maintain Britain's industrial and trading concerns, which were dependent on freedom of the seas. Britain

1. A. Temple Patterson, Jellicoe-A Biography (1969), 41; Walter Long, 16 November 1912, in Politics from Inside, an Epistolary Chronicle, by Austen Chamberlain (1936), 492. 
would henceforth not need to intervene in a continental war, as had been its habitual preference. At the time of his appointment, McKenna intended his reference to Cobden to invoke Britain's natural strengths and national interests. As with that of Gladstone, Cobden's outlook of free trade on free seas was irenical, since the cost of war would act as an incentive for preserving peace. It was a popular notion at the time. Norman Angell, in The Great Illusion, and Ivan Bloch, in Is War Now Impossible? highlighted what they held to be the economic disutility of military conflict. ${ }^{1}$

The context for McKenna's conduct as first lord was at least as much personal as it was intellectual. 'The British empire,' the copy of Sir Charles Dilke's Imperial Defence, which the author gave to him in January 1897, attested, 'is the possession of the sea'. ${ }^{2}$ McKenna had learnt as a schoolboy in France and Germany that a French war of revenge and a German preventative war were ever-present threats to European peace. ${ }^{3}$ Admirers urged McKenna to apply Angellism and 'checkmate the action that is brewing and pending on the other side of the North Sea', ${ }^{4}$ but Angell had already favourably influenced two men-Hankey and Fisher-with whom McKenna was to work closely. It also happened to be the case that Bloch's British publicist was the journalist W. T. Stead, who was a friend of Fisher, and became an acquaintance of McKenna, while Angell was of a Liberal circle that included the journalists J. A. Hobson and F. W. Hirst. ${ }^{5}$

In terms of his departmental colleagues, McKenna returned to warm personal relations after his wretched experience at Education. With one, admittedly spectacular, exception, McKenna overcame initial misgivings and became a popular chief. He was organised and decisive, listened to his administrators, and treated them well, as he always had. The specific appeal McKenna held for those at the Admiralty was that he assumed sole responsibility in policy at the same time as demonstrating noninterference in operational matters. ${ }^{6}$ It was so popular that in no other post, Treasury included, did McKenna enjoy such harmonious relations with his colleagues, several of whom became among his closest friends. McKenna's first private secretary was Charles Madden, who was close to John Jellicoe, and his second was

1. I. S. Bloch, Is War Now Impossible?, 1899; Norman Angell, The Great Illusion: A Study of the Relation of Military Power to National Advantage (1913).

2. Sir Charles Wentworth Dilke and Spenser Wilkinson, Imperial Defence (1892), 42.

3. SMcK, 'Reginald McKenna 1863-1943', A Preprint of the Life Written for the Dictionary of National Biography, 1941-1950, Aspley Guise (1946), 7.

4. Sir George Holmes to RMcK, 13 April 1908.

5. Avner Offer, The First World War, An Agrarian Interpretation (Oxford, 1989), 250; J. D. B. Miller, Norman Angell and the Futility of War: Peace and the Public Mind (1986), 5-7; Hankey papers, 7/6/2; Fisher to Hankey, 11 June 1910, Hankey papers, $5 / 2 \mathrm{a} / 4$.

6. Arthur Marder, From the Dreadnought to Scapa Flow: The Royal Navy in the Fisher Era, 1904-1919, 5 vols. (1961-70), ii:269. 
Ernest Troubridge. ${ }^{1}$ There was an immediate and abiding affinity with Jellicoe, while one of McKenna's private secretaries, Vincent Baddeley, became, as 'Vinbad the Sailor', a family confidant.

McKenna's most significant relationship, however, was superficially quite incongruous. It appeared less so to Asquith, who told Fisher,' 'I know you and McKenna fought over the Navy Estimates, but I am sure he will get on with you.'2 At first, Fisher's rival Lord Charles Beresford, recalling McKenna's economising in February, told Sir Robert Hudson that McKenna's appointment meant Fisher's retirement had been brought closer, something Fisher himself raised with McKenna; ${ }^{3}$ in fact, after meeting his new chief, Fisher was relieved. 'Asquith and McKenna both fought me to the last gasp when C.B. was PM. But in consequence they afterwards became my staunchest friends." As Archibald Hurd put it, McKenna and Fisher 'worked together with a cordiality and loyalty, and even affection, which was probably never equalled in the Admiralty. ${ }^{6}$ McKenna thought Fisher 'a lovable man'; ${ }^{7}$ Fisher said that, of the five first lords under whom he served, McKenna was the best. ' 'He is A1! The best First Lord we've ever had!'9 The relationship lent itself to the representation of a mercurial demagogue with an impressionable technocrat in his thrall, even though Fisher appeared to have had that effect on most people. ${ }^{10}$ Fisher wrote to McKenna on a scale unequalled by any other colleague or acquaintance in McKenna's life. ${ }^{11}$ Indeed, McKenna's relationship with Fisher was widely held as being emblematic of his time at the Admiralty: to contemporaries, of accommodation-that McKenna was yielding on principle; and to historians, of limitation-that his wit seldom ran beyond his brief.

1. Troubridge's wife was an intimate of Marguerite Radclyffe-Hall.

2. HHA, attrib., Fisher to Edward VII, 11 April 1908, in Fear God and Dread Nought, The Correspondence of Admiral of the Fleet Lord Fisher of Kilverstone, vol. 2, Years of Power, 1904-1914, ed. Arthur Marder (1956), 172.

3. Fisher to RMcK, 28 October 1908, McKenna papers, 6/1/2; J. A. Spender, Sir Robert Hudson, A Memoir (1930), 103.

4. Fisher to HHA, 27 October 1909, Asquith papers, c.6690/204. Another way of putting it was that Fisher had inveigled McKenna: Morris, Scaremongers, 166.

5. Fisher to Hankey, 21 September 1911, Hankey papers, 5/2a/26.

6. Hurd, Who Goes There?, 92; Marder, Dreadnought, 329; Admiral Sir R. H. Bacon, The Life of Lord Fisher of Kilverstone, 2 vols. (1929), passim.

7. RMcK to Reginald Bacon, 28 October 1929.

8. Fisher to Hankey, 13 April 1911, Hankey papers, 5/2a/13. The others were the Earl of Selborne, Earl Cawdor, Lord Tweedmouth, and Winston Churchill; Bacon, Fisher, ii:104, 136.

9. Fisher to Evan Thomas, [29 July 1910], Evan Thomas papers, 52404/93.

10. Sir Frederick Ponsonby, Recollections of Three Reigns (1951), 130-1; E. T. Raymond, Portraits of the New Century (1928), 254.

11. McKenna papers, $6 / 1-12,3 / 4$. 
At 2 o'clock on Wednesday 3 June 1908, Reggie married Pamela Margaret Jekyll at St Margaret's Church, Westminster. The age disparity was obvious enough without the Sunday Times, among other papers, claiming her as 'sweet seventeen'. The three witnesses were the groom's brother as best man, the bride's father, and the prime minister. Bar was bridesmaid, and the prime minister's son Anthony and the architect Edwin Lutyens's boy Robert were the pages. The day before, Charles Masterman went through the same ceremony, at the risk of alarming confusion. 'POLITICIANS MARRIED', as Reynolds News put it, 'MR MASTERMAN AND MR McKENNA WEDDED'.

'Not since the wedding of the Premier at St. George's, Hanover Square, some fourteen years ago, has so much public interest been excited by a political marriage', the Westminster Gazette announced. ${ }^{1}$ There were over 700 present, a great total that was the greater, the press noticed, for the fact that it was also Derby day. It was also, the papers pointedly observed, testament to the wide popularity of the Jekylls. Reggie's attending colleagues included Dilke, Burns, in his blue reefer suit, Gladstone, Loulou, Churchill, Runciman, Herbert Samuel, Pease, Seely, Lyttelton, Lloyd George, Wedgwood Benn - the McKennas' 'dear Benntig'2 - and Haldane, Pamela's 'Mr Pugey'. ${ }^{3}$ Even Sir Robert Morant was invited, the list evidently having been drawn up when he was still the groom's permanent secretary. Pamela's friend May Harrison performed a Bach air for solo violin as the duo signed the register. The weather was fine. The king sent a telegram.

The reception took place at 22 Grosvenor Square, near Green Street, where additional guests included Lord Northcliffe, Muir McKenzie, St. Loe Strachey, and J. M. Barrie. There were over 500 presents, and dozens of silver candlesticks, hatpins, combs, and pots. The Asquiths gave the newlyweds the works of Shakespeare; the Webbs, the collected works of Bernard Shaw; Birrell, the collected works of Birrell; Vinbad offered a print of Whitehall; Dilke brought a vase. Mrs David and Mrs Drew both sent Morley's Life of Gladstone; Pease sent Morley's essays; Morley did not appear to have sent anything. In the afternoon, the couple departed for their honeymoon, which they spent on the Thames and at Hurley House, near Marlow, which belonged to Reggie's brother Theo. Reggie told his mother in law,

I have had only one thing to say and I am not sure that this one thing is not better expressed by an unwillingness to write than in any other way. All day Pam and I do things together and to sit down and write is to do things separately, and it makes a break and it seems like a loss. I am very very happy, and there is an end of it. ${ }^{4}$

1. Westminster Gazette, 4 June 1908.

2. RMcK to PMcK, 2 March 1910.

3. PMcK to Vincent Baddeley, n.d. [c. 1912].

4. RMcK to Agnes Jekyll, 11 June 1908. 
Pamela accounted for her husband's first week of marriage in his diary. Wednesday 3: 'The Halter'; Thursday 4: 'Hurley chafing'; Friday 5: 'settling down'; Saturday 6: 'philosophical resignation'; Sunday 7: 'Consolation in golf'; Monday 8: 'Triumph of golf over married life'. 'The bride consoled herself with her bridesmaid's wedding present-a Persian kitten, called Dreadnought.

\section{ESTIMATES: PART I}

Jacky Fisher's wedding present to his new chief was a large silver magnifying glass. The day before the wedding, McKenna chaired the first meeting of the estimates committee to determine the Admiralty's 1909 shipbuilding programme and its claim on the Exchequer. It began the story that became the defining episode of his public life. In many respects merely another demoralising struggle against more numerous antagonists, time lent it greater value. The particular circumstances helped to explain the apparent inconsistency of his position. In 1908, McKenna had sought to restrict the Admiralty programme and succeeded; in 1909, he proposed a dramatic increase in shipbuilding and succeeded once more, but only after dividing the Cabinet and the country and resigning from the government. The positions, as presenting, suggested 'departmentalitis' of a most virulent strain. What had happened in the intervening period was the expansion of the German navy, unfortunately for the government, at the same time as the expansion of the British state. As chancellor of the Exchequer, Lloyd George would be required to pay for both at the same time. The 1909 naval estimates at the same time as the dramatic expansion in domestic welfare provision produced a crisis within the Cabinet and a crisis within Parliament.

When Austen Chamberlain had introduced the notion of 'acceleration' to naval construction, he added a threatening dimension to the obvious development of Germany. ${ }^{2}$ That German shipbuilding capacity was increasing gave great cause for concern; British naval policy had been for some time that its fleet should be larger than the next two combined, however imprecise and impractical McKenna admitted that measure as being. ${ }^{3}$ The introduction, in 1906, of the Dreadnought class battleship, to the development of which Fisher had been central, rendered previous classes obsolete but elevated concerns as to Britain's ability to maintain a more general big ship superiority over Germany. While Britain possessed forty-three battleships to Germany's twenty-two, the ability of the Germans to match the British dreadnought fleet became a great concern. Germany had laid down,

1. PMcK, RMcK, diary, 3-8 June 1908.

2. Austen Chamberlain, 3 March 1908, Times, 4 March 1908.

3. [RMcK] to HHA, May 1909, in Publications of the Naval Record Society, vol. $131,754-55$. 


\section{0}

Reginald McKenna

or intended to lay down, enough vessels to ensure that it had thirteen dreadnoughts by 1912, by which time Britain would only have twelve. The question for the Liberal government was how many ships to build in each of the following years. The Admiralty, advocating a two-keel to one policy of construction to maintain superiority over Germany, revised its plans and pressed its case.

On 19 April 1908, McKenna sat and listened to Fisher for three hours and then 'asked for a second dose and got it'. ${ }^{1}$ At a meeting of the Board of the Admiralty, on 4 May, Fisher told Esher, 'McKenna formally agreed to FOUR Dreadnoughts AND IF NECESSARY SIX Dreadnoughts, next year (perhaps the greatest triumph ever known!) As he says, he has to eat every word he has said of the Treasury and the Cabinet.'2 Yet Fisher too had cause for indigestion: having accommodated McKenna's calls for retrenchment the year before, he now revised his earlier estimation. Irrespective of McKenna's recantation, his former colleague at the Treasury was now prime minister, and 'growing sceptical . . . as to the whole "Dreadnought" policy'. ${ }^{3}$ His successor as chancellor had cause not only to bridle at the claim, but also at the claimant.

The implications for the revision grew more serious with the next development, which took place during one of the increasingly common cruises, the prospect of which had attracted McKenna to the post in the first place. The first was in August 1908, when the newlyweds took the Enchantress to Etrêtat, during which ' $\mathrm{R}$ is ever so much better and looked so cool and happy diving and swimming. ${ }^{4}$ On the next, a cruise around the British coast, ostensibly to inspect naval installations, Ernest, Barbara, Vinbad, the Asquiths, and Benntig accompanied them. There was much golf, as well as 'the tyranny of bridge.' They went underwater in a submarine, watched battle practice in the Channel. 'Beresford was very agreeable', Pamela found. 'I like him far better than Fisher, tho his conversation is all directed towards his own glorification.' ${ }^{6}$ Churchill joined them briefly, 'difficult and rude-not softened and changed' by his engagement to her friend Clementine Hozier.' After he left, 'In the middle of the evening, R had a telegram from Ll-G and Winston asking him to lay down a few ships to relieve the unemployment!'8

1. Fisher to Esher, 19 April 1908, Esher papers, 10/42; Esher, diary, 22 April 1908, Esher papers, 2/11/114.

2. Fisher to Esher, 5 May 1908, Fisher papers, 1/6/310.

3. HHA to RMcK, 4 July 1908, McKenna papers, 3/13/2a.

4. PMcK to [Agnes Jekyll], 18 August [1908].

5. PMcK, diary, 23 May 1910.

6. Ibid, 5 September 1908.

7. Ibid, diary, 24 August 1908.

8. Ibid, diary, 10 September 1908; Lloyd George to HHA, n.d. [September 1908], Asquith papers, 20/84. 
The episode that developed caused further loss of trust and goodwill between McKenna and his two colleagues, but was almost wholly based on suspicion and misunderstanding. Lloyd George and Churchill's request to McKenna might have been received, as it might have been intended, as a way of squaring their respective interests. Lloyd George and Churchill requested a meeting. ${ }^{1}$ Engagement prevented McKenna from attending on the day they had chosen, but he composed a lengthy reply, dictated to Pamela. McKenna told Lloyd George that though he was not averse to using construction to deal with specific pockets of unemployment, whether on the Clyde or on the Tyne, there were issues of contracts and of already overloaded contractors. ${ }^{2}$ McKenna informed Lloyd George several times that anything beyond what had already been planned would have to go through the prime minister, and McKenna suggested 'that we should arrange a convenient date to see the Prime Minister'. ${ }^{3}$ McKenna informed Asquith of Lloyd George's intervention later that day ${ }^{4}$ an act that the chancellor interpreted that as hostile. 'You have no right to suggest the possibility of such treachery', Lloyd George told McKenna. 'I rather resent being lectured on my elementary duty to my chief'. ${ }^{5}$ Lloyd George wrote to Churchill, away on his honeymoon, and Churchill then wrote to McKenna to 'confess myself a little disappointed by the result of your correspondence with LG'. Churchill told McKenna, 'And I am afraid that your suspicions have prevented you from doing justice either to the proposal or to the anxiety of your colleagues which has given rise to it. ${ }^{6}$ Churchill had gone by Lloyd George's interpretation of McKenna's letter. McKenna told both Lloyd George and Churchill that he had been quite misunderstood and repeated his original response at equal length, with a clearer explanation of the unique and complicated nature of shipbuilding, which meant that 'in ordinary circumstances nothing of the kind that you suggested as the subject of discussion could be undertaken without having a supplementary estimate in view'. ${ }^{7}$ The damage had, however, been done.

At the same time, international affairs added to the febrility. On 25 September, the French Foreign Legion forcibly reclaimed six deserters sheltering in the German consulate in Casablanca. Relations between Paris and Berlin deteriorated. Asquith, Haldane, and Grey were inclined towards British

1. Lloyd George to RMcK, n.d., McKenna papers, 3/20/3; Churchill to RMcK, 13 September 1908, McKenna papers, 3/20/5-6.

2. RMcK to Lloyd George, 12 September 1908, Lloyd George papers, C/5/12/1; draft, McKenna papers, 3/20/4-5.

3. Ibid.

4. RMcK to HHA, 12 September 1908, Asquith papers, 20/81.

5. Lloyd George to RMcK, 16 September 1908, Lloyd George papers, C/5/12/2.

6. Churchill to RMcK, 19 September 1908 , McKenna papers, 3/20/8; and also Churchill to RMcK, 2 August 1910, [copy], Churchill papers, CHAR 1/95/36; RMcK to Churchill, 4 August 1910, Churchill papers, CHAR 1/95/38.

7. RMcK to Churchill, 24 September 1908, Churchill papers, CHAR 21/1/16; RMcK notes to HHA, November 1908, McKenna papers, 3/3/4a. 


\section{Reginald McKenna}

intervention. ${ }^{1}$ Fisher told Knollys that 'McKenna came to me and said for the very first time in his life he had been awake all night.' ${ }^{2}$ Franco-German tension in the Casablanca Crisis was followed by Austro-Russian tension in the Bosnian Crisis. The repercussions for defence spending were obvious. After a summer of attempts by Churchill and Lloyd George at arms reductions, and with growing public suspicions as to German intentions, McKenna recommended to Cabinet on 8 December a new programme of six dreadnoughts for 1909-10, two more than Lloyd George wanted, although two fewer than Fisher was now advocating. ${ }^{3}$ To McKenna Asquith deprecated 'the propaganda of extravagance'. ${ }^{4}$

Cabinet discussed the proposals at a two-day meeting on 18 and 19 December. The division inside was mirrored outside. The Unionists and the right-wing press wanted eight; radicals and the left-wing press felt that, given the Royal Navy's supremacy in predreadnought ships, four would be sufficient. After prolonged discussion, Asquith proposed approving the four dreadnoughts and considering the contingent two after Christmas. Lloyd George pledged himself, he told Churchill, to 'smashing McKenna's fatuous estimates'. ${ }^{5}$ Murray, McKenna's old permanent secretary, thought the government would break up. 'It is impossible for LI.G and McKenna to continue to hold the posts they now occupy, as neither can give way over Navy estimates. ${ }^{6}$ The chancellor had already told his brother 'we have won'?

\section{LAWS OF WAR}

As the estimates row developed through the autumn of 1908, a less apparently illiberal issue also arose. The relationship between Liberalism and navalism was felt most profoundly over the issue of the laws of war at sea. The prospects of war and the likely effect on merchant shipping and the immunities of neutrals alarmed the Americans, and had already led to war with Britain, a century earlier. Within Whitehall, the potential for disagreement lay in reconciling the Admiralty's plans for economic war with the

1. Esher, diary, 5 November 1908, Esher papers, 2/11/187.

2. Fisher to Knollys, 22 December 1908, Fisher, Correspondence, 2:204-5; Grey to RMcK, 5 November 1908, Grey papers, FO800/87.

3. Fisher to RMcK, 28 July 1908, McKenna papers, 3/4/7; Fisher to RMcK, 22 December 1908, McKenna papers, 3/4/23.

4. HHA to RMcK, 14 November 1908 , McKenna papers, 3/13/4b.

5. Lloyd George to Churchill, 21 December 1908, in Winston S. Churchill, vol. 2, Companion II: Documents, 1907-1911, ed. Randolph Churchill (1969), 937.

6. Esher to Maurice Brett, 30 December 1909, Esher papers, 7/22.

7. Lloyd George to William George, 19 December 1908, in William George, $M y$ Brother and I (1958), 222. 
Foreign Office's plans for maritime law. ${ }^{1}$ To a free trader like McKenna, the rights of neutrals ought to have been axiomatic, but the Admiralty pressed for the right to stop and search the vessels of neutral states. For a besieged island, the free importation of food was vital, as was its conveyance in neutral vessels, yet the advocacy of blockade in the event of war with Germany brought McKenna and Grey into disagreement, each in his way presenting departmental but also personal preoccupations. The maintenance of successful blockade was not consistent with Britain observing maritime law under the 1856 Declaration of Paris, which ensured that 'free ships make free goods', and that enemy goods in neutral vessels were not liable to capture. Grey, conscious of the disciplines of diplomacy, regarded maritime law as being in Britain's interests; McKenna, promoting the supremacy of naval concerns within government, thought such laws constituted unconscionable restrictions on the waging of hostilities. ${ }^{2}$ As Fisher put it, "All is fair in war!'3

The International Naval Conference was held in London from December 1908 to February 1909. The Admiralty's opposition to a prize court, which could contest the legality of seizures, would only be neutralised by the enshrining of the rights of belligerent nations. McKenna had to defend the interests of the Admiralty, but he was also a lawyer and, as a free trader, regarded the legal immunity of food as a given. Moreover, as an island, Britain could only benefit from the wider recognition of rights, particularly as the United States would recognise them, and it would be Britain's most important supplier in the event of war. The first lord of the Admiralty met the foreign secretary, to be told, firmly, that 'continuous voyage'- the ability to travel without let or hindrance, and particularly the hindrance of checks by the navies of competitors, across the seas-was not important enough to risk jeopardising an agreement over blockade during the conference. ${ }^{4}$ The resultant Declaration of London, of February 1909, was highly selective, but still not sufficiently so for it to be passed by the Lords, and it was not ratified. ${ }^{5}$

In any event, the Admiralty had no intention of observing whatever decisions were arrived $a t^{6}{ }^{6}$ indeed the ambiguities inherent in the declaration

1. Record of a meeting between Grey and RMcK, 15 December 1908, Foreign Office papers, FO371/794/143.

2. RMcK to Grey, 1 January 1909, Foreign Office 800/87/180.

3. Fisher, 20 April 1904, Admiralty papers, ADM 116/942. See Aver Offer, 'Morality and Admiralty: "Jacky" Fisher, Economic Warfare and the Laws of War', Journal of Contemporary History 23 (1988): 99-119.

4. Hankey, memorandum, 23 February 1911, Cabinet papers, CAB17/87/22.

5. Stephen Neff, The Rights and Duties of Nations, A General History (Manchester, 2002), 136-41; Bernard Semmel, Liberalism and Naval Strategy: Ideology, Interest and Sea Power During the Pax Britannica (1986), 100.

6. Churchill to George V, 20 June 1911, in Companion, 2:2, 1095. 


\section{Reginald McKenna}

provided for its ultimate acceptance. ${ }^{1}$ That was both the private position and the only way to explain support for the declaration in the light of the prevailing Admiralty view. McKenna adopted a more sophisticated approach to the same ends: legality had value where conventions were contradictory. If Germany was at war and had centralised command of food, any food en route to Germany was therefore contraband; moreover, McKenna felt that if Germany did not infringe the declaration an infringement ought to be created. ${ }^{2}$ While British prize law required proof before the seizure of food as contraband, the declaration provided for the capture of any contraband destined to 'a Government department of the enemy state. ${ }^{3}$ If the Germans would do what McKenna in the end would not, and take over all food imports, any imports could then be considered enemy goods. Thus, the declaration permitted capture under traditional British law, while national prize law could then apply continuous voyage to contraband. Selective observance of two legal codes would provide effective grounds for the blockade, 'meanwhile, however, we should benefit from these declarations while we were neutral'. ${ }^{4}$ It was certainly not a position of moral steadfastness, but nor did it need to be if 'Salus Civitatis, Suprema Lex'. ${ }^{5}$ The shift from morality to cynicism could be interpreted as opportunism; the view that maintained British rights as being fundamental went beyond morality. Navalists were no more warlike in taking that view: rather, in the event of war occurring, its prosecution would be as quick and bloodless as possible. ${ }^{6}$

Nevertheless, McKenna had abrogated a central, historic, moral position, albeit in what he took to be the national interest. For McKenna to justify the policy of selective observance of laws to himself, it had to be that it was moral because it was in the national interest. 'In dealing with a formidable opponent such as Germany, every legitimate weapon would have to be used', he told Grey. ${ }^{7}$ The only conceivable problem, and it was a significant one, was that the Admiralty policy under McKenna could constitute a casus belli; the position of the United States in a likely war had hitherto not been expected to be one hostile to the United Kingdom.

1. RMcK to George V, 26 January 1911, Royal Archives, RA PS/GV/M 261/4; John Leyland, 'Declaration of London: Points and Considerations', in Naval Annual 1911, ed. T. A. Brassey (1911), 163-72.

2. Offer, First World War, 280.

3. RMcK, 19 August 1914, Foreign Office papers, FO372/588.

4. RMcK, in Semmel, Liberalism, 88, 114.

5. 'The safety of the state is the highest law'.

6. However erroneous it proved to be. See Page, Letters, 2:53-80.

7. RMcK, 15 December 1908, in Offer, First World War, 277. 


\section{ESTIMATES: PART II}

McKenna had been distracted throughout the International Naval Conference by the estimates. 'The outlook is very ominous,' Fisher told the king, 'so much so that McKenna who was when he came here an extreme "Little Navy" man is now an ultra "Big Navy" man'. ${ }^{1}$ Arms manufacturers had hastened the process. According to the private warnings of Trevor Dawson and the public warnings of H. H. Mulliner, acceleration in German shipbuilding meant that construction would exceed that of the official schedule. 'We are bound therefore to look at the German capacity to build, and we can best judge what they can do by what they are doing', McKenna told Grey on 30 December. 'Speaking for myself I have no doubt whatever that Germany means to build up to the full extent of her capacity."

McKenna thereupon wrote Asquith 'a worrying New Year's letter.'

I am anxious to avoid alarmist language but 1) Germany is anticipating the shipbuilding programme laid down by the law of $1901 ; 2$ ) she is doing it secretly; 3) she will certainly have 13 big ships in commission by the spring of $1911 ; 4$ ) she will probably have 21 big ships in commission by the spring of 1912 ; 5) German capacity to build dreadnoughts is at this moment equal to ours. This last conclusion is the most alarming, and if justified would give the public a rude awakening should it become known. ${ }^{3}$

Fisher told the king, 'your majesty would be astonished by his memorandum to Grey and to the Prime Minister as to building more Dreadnoughts next year than intended and we shall certainly get them! ... ${ }^{4}$ The conclusion was that now eight, rather than six, dreadnoughts were necessary. 'I feared all along this would happen', Lloyd George told Churchill. From their confident belief that six had been rejected, they were now faced with eight, because 'something more panicky was required' to ensure that 'the Admiralty mean to get their 6 Dreadnoughts'. ${ }^{5}$ 'I believe the admirals are procuring false information to frighten us', Lloyd George went on. 'McK feels his personal position and prestige is at stake. ${ }^{6}$

Two Cabinets took place during which, Morley told Esher, 'McKenna stood alone, without support'. ' On 24 January, in Grey's room in the

1. Fisher to Edward VII, 3 January 1909, Royal Archives, RA VIC/W 59/69.

2. RMcK to Grey, 30 December 1908 , in $R M c K, 72$; HHA to RMcK, 1 January 1909, McKenna papers, 3/3/4c; RMcK to HHA, 2 February 1909, Asquith papers, $21 / 68$.

3. RMcK to HHA, 3 January 1909, Asquith papers, 21/24.

4. Fisher to Edward VII, 3 January 1909, Royal Archives, RA VIC/W 59/69.

5. Lloyd George to Churchill, 3 January 1909, Churchill papers, CHAR 21/1/2.

6. Lloyd George to Churchill, 3 January 1909, Churchill papers, CHAR21/1/2.

7. Esher, diary, 6 January 1909, Esher papers, 2/12. 


\section{Reginald McKenna}

Commons, Lloyd George met McKenna and the sea lords. After the testimony of each, the chancellor not only reversed his opinion of the situation, but also implied that the first lord had been complacent, demanded that Beresford replace Fisher, and asked why no one had told him of the German acceleration before. Jellicoe quoted McKenna as replying 'you know perfectly well that these facts were communicated to the Cabinet at the time we knew of them, and your remark was, "It's all contractor's gossip", or words to that effect'. ${ }^{1}$

'McKenna will win,' Runciman told his wife two days later, but, while Grey and Haldane backed McKenna, 'Asquith is impartial. Fancy being impartial over this!' ${ }^{2}$ Churchill nevertheless presented a Cabinet paper to contradict McKenna's prognostications and recommended that four dreadnoughts be announced, though he told the prime minister he was prepared to accept a compromise of six. ${ }^{3}$ McKenna duly replied, and Churchill responded by recirculating McKenna's memorandum with his own marginal comments. ${ }^{4}$ The debate spilled out of the Cabinet room. Asquith denounced Lloyd George and Churchill's 'combined machinations' in the press, ${ }^{5}$ and admitted to Haldane that " $\mathrm{McK}$ has just been in, much perturbed over the organised "revolutions" in the D[aily]. N[ews]. and D[aily]. C[hronicle].; a great scandal, but what can be done?'

The chancellor gave his support to a staggered programme of four immediate and four contingent ships to the prime minister on 2 February, though he couched it in the terms of long-term construction that had led to the row with McKenna in September. ${ }^{7}$ As McKenna had then pointed out, the time it took to build ships with the necessary technological advances meant that the cost would not fall on a single budget. Lloyd George presented his compromises to Cabinet on 15 February, and won the reluctant support of Asquith and Grey. The foreign secretary visited McKenna on 20 February with the compromise, which McKenna rejected and countered by presenting his own, which, he told an unconvinced Fisher, 'is no compromise but it 'saves their faces'!' 'I'm not doubting the First Lord', Fisher told Jellicoe, 101

1. Jellicoe to RMcK, memorandum, 24 January 1909; O’Brien, 'Admiralty',

2. Runciman to Hilda Runciman, 26 January 1909, Runciman papers, 303/1; HHA to Haldane, 27 February 1909, Haldane papers, 5908/90.

3. Churchill to HHA, 3 February 1909, Companion, 2:2, 942.

4. Asquith papers, $21 / 78$.

5. HHA to MA, 20 February 1909, in Life of Herbert Henry Asquith, Lord Oxford and Asquith, 2 vols., by J. A. Spender and Cyril Asquith (1932), 1:254.

6. HHA to Haldane, 5 February 1909 , Haldane papers, 5908/88.

7. Lloyd George to HHA, 2 February 1909, Lloyd George papers, C/6/11/2.

8. Fisher to Jellicoe, 21 February 1909, Jellicoe papers, 49006/1-2; Churchill to Grey, 16 February 1909, Companion, 2:2, 954. 
'but he is inclined to compromise through Grey's solicitations not to break up the party."

McKenna made it clear that he would not remain in his office if Cabinet refused to accept his recommendations. 'The fight seemed over when a new and powerful ally appeared on the scene', McKenna later recalled. When he heard of the first lord's threatened 'resignation Sir Edward Grey realised at once that the matter must be of more urgent import than the Cabinet had recognised'. Grey 'requested a reconsideration of the case. The Prime Minister accordingly called another meeting of the Cabinet', ${ }^{2}$ during which, as he put it, 'a sudden curve developed itself of which I took immediate advantage, with the result that strangely enough we came to a conclusion which satisfied McKenna \& Grey, \& also Ll. George \& Winston'. ${ }^{3}$ The government would commit to the laying down of four dreadnoughts, with the recommendation that a forward contract be issued for four further ships by April 1910 , if they were deemed necessary.

This left the form of words with which to present the estimates to Parliament. The first sea lord told the first lord of the Admiralty that 'the compromise should be that neither four or eight are named and six in the estimates without any doubts whatever as an irreducible minimum. No qualifying statements. ${ }^{4}$ The sea lords, McKenna told Asquith, remained anxious:

They expressed grave anxiety as to the nature of the assurance of an adequate programme which is to be given them by a Bill the terms of which they have not seen. They feel that their responsibility for the Estimates, which they sign, is direct and personal, whereas they can have no similar responsibility for a Bill. I recognise the force of their objections, but I have done my best to remove them and I think with success. I have explained to them that I have the assurance of the Cabinet that a Bill embodying the decision of the Government will be passed during the present session, and further that the ordinary form in which the Estimates are presented would of itself justify their signatures being appended. I have explained to them that the Estimates must disclose the programme in contemplation at the time of their presentment and must upon the face of them give notice to Parliament of any liability which may be incurred during the year whether this liability is to be discharged in the course of the financial year or at a later time. The programme which is issued with the Estimates must therefore include 8 armoured ships in regard to which the usual details will be given. ${ }^{5}$

1. Fisher to Jellicoe, 21 February 1909, Jellicoe papers, 49006/1-2.

2. RMcK to Bacon, 27 November 1928.

3. HHA to MA, 25 February 1909, MA papers, c.6690/185-86.

4. Fisher to Jellicoe, transcription of meeting, Jellicoe papers, 49006/3; Fisher to RMcK, 21 February 1909, McKenna papers, 6/2/9.

5. RMcK to HHA, 25 February 1909. 
McKenna promised he would make an explicit commitment to the contingent four to Parliament. He told Asquith that "clear notice in the Estimates, though it has no force in the way of a vote or appropriation of money, pledges the credit of Parliament to pay at some future time for such specific materials as may be ordered by the Government'. ${ }^{1}$ Fisher replied that 'I am perfectly content to leave it to you to so deal with these jugglers that we shan't be swindled'. ${ }^{2}$ McKenna, with a view to the prime minister's own suspicions, admitted to Asquith, 'I think the fears of the Sea Lords exaggerated. ${ }^{3}$ Asquith condemned the 'reprehensible campaign in the press', and assured McKenna that 'I am absolutely at one with you'. The first lord could have the contingent four. The prime minister concluded,

It has been most painful and repugnant to me, in view of our long and close personal intimacy and (I may say) affection, even to appear to exert any kind of pressure. But you know me so well (I hope) that, in a matter like this, you will give some weight to my judgement, and believe that my one predominant desire is to attain the end which we both have in view. I have never before made-as I make to you now-so clear and direct an appeal for trust and confidence. ${ }^{4}$

'I will not say anything as to the difficulty I have had in obtaining the assent of the whole Board', McKenna told Asquith two days later. 'Perhaps it has helped me that the Sea Lords know I share their conviction as to the gravity of the situation."

The remaining issue-and it was one with which Fisher was concerned all along ${ }^{6}$ - was whether the programme would eat into the 1910 estimates. On 4 March, Fisher went to see Grey, at McKenna's request. The foreign secretary was able to offer the assurances Fisher wanted and made it a resignation issue for himself. ${ }^{7}$ The outcome was that a footnote to the estimates approved by Cabinet on 5 March requested Parliament to commit to provide for the rapid construction of a further four by March 1912. 'Though I have been a troublesome opponent', Loulou told Pamela afterwards, 'I should like to congratulate you on the way R. has "fought his corner" under severe temptations (to which he has never yielded) to employ methods which would be undesirable and undignified. I am glad it is all over and that we

1. RMcK to HHA, $1909, R M c K, 180$.

2. Fisher to RMcK, 5 March 1909 , McKenna papers, 6/2/51; Fisher to RMcK, n.d., McKenna papers, 6/12/3.

3. RMcK to HHA, 1909, RMcK, 180.

4. HHA to RMcK, 2 March 1909, McKenna papers, 3/19/8.

5. RMcK to HHA, 4 March 1909, Asquith papers, 21/161; McKenna papers, 3/19; HHA to Edward VII, 5 March 1908, Cabinet papers, CAB41/32/5.

6. Fisher to Esher, 5 May 1908, Fisher, Correspondence, 2:175-76.

7. Grey to Fisher, 5 March 1909 (enclosed Grey's record of meeting with Fisher, 4 March 1909), Fisher papers, 1/7/360. 
are able to remain together. ${ }^{1}$ Even after he had received his assurances from Grey, Fisher still suspected that the Cabinet was trying to find a way out of committing at a later date to the final four, and that only 'an emphatic declaration in your speech' would remove doubt. ${ }^{2}$

A return to the status quo ante was not yet certain, however. Immediately after Cabinet, Fisher told McKenna, 'I sincerely hope you are going to vanish for a week'. ${ }^{3}$ McKenna went off to Munstead. 'The First Lord of the Admiralty', The Times reported on 8 March, 'is indisposed, owing to a chill, and will be prevented from attending to his parliamentary duties for a few days' ${ }^{4}$ The cold front did not stand for long. 'I understand that $\mathrm{Mr}$ McKenna is suffering from no "chill", Knollys told the king, "but he wanted to resign and a friend of his advised him to go into the country for a week and consider his position. ${ }^{5}$ Rumours already had it that he had resigned. The first captain of HMS Dreadnought, and later Fisher's biographer, Admiral Sir Reginald Bacon, recalled that McKenna was 'out of the Cabinet for 24 hours because of the opposition he met to this programme. ${ }^{6}$ Fisher claimed he resigned twice. ${ }^{7}$ Indeed, as Admiral King-Hall heard, 'on two occasions Mr McKenna attended Cabinet meetings with his resignation in his pocket should his demands be ignored'. ${ }^{8}$ McKenna later claimed that had his 'resignation taken effect the whole Board of Admiralty would most certainly have declined to serve on a new board. ${ }^{9}$ It was not necessary. 'Mr McKenna,' The Times reported on 10 March, 'has recovered from his recent indisposition and hopes to be back in the House of Commons to-day'. ${ }^{10}$

\section{HYSTERIA NAVALIS}

McKenna issued the estimates on 12 March. Fisher had sought to consolidate the Admiralty's success by going to see Grey and drawing up a memorandum between them, which he sent to McKenna on 13 March. The first sea lord drew the first lord of the Admiralty's attention to the postscript: 'Sir E. Grey added that these 4 additional ships to be laid down on April 1st

1. Lewis Harcourt to PMcK, 5 March 1909.

2. Fisher to RMcK, 5 March 1909, McKenna papers, 6/2/51.

3. Ibid.

4. Times, 8 March 1909.

5. Knollys to Edward VII, 10 March 1909, Royal Archives, RA VIC/W 66/68.

6. Bacon, Minutes of the Royal Commission on the Private Manufacture of and Trading in Arms (1935), 311.

7. Fisher to Northcliffe, 24 January 1917, in Fear God and Dread Nought, The Correspondence of Admiral of the Fleet Lord Fisher of Kilverstone, vol. 3, Restoration, Abdication, and Last Years, 1914-1920, ed. Arthur Marder (1959), 422-23.

8. King-Hall, Memories, 197.

9. RMcK to Bacon, 27 November 1928.

10. Times, 10 March 1909. 
1910 did not in any way imply that only 4 ships were to be ordered for the financial year 1910-11 -that would be considered when the time came to deal with the Estimates for that year.'

McKenna then made the speech Fisher had asked for in the Commons on 16 March. $^{2}$ It was, for him, a rare coup d'theatre. He spoke without interruption for around ninety minutes, and without any rhetorical assertions or threats, appeared to transfix the Commons. The only altercation was inevitably with Balfour, who, rather as Lloyd George had done on 24 January, now accused McKenna of complacency. ${ }^{3}$ The four ships for 1909 were confirmed - two in July and two in November-with, McKenna said, four more laid down by April 1910 'for which the Admiralty could make preliminary provision without further reference to Parliament and could consequently commit Parliament to the cost of building. ${ }^{4}$ As he later recalled, 'the point of building them in orderly succession lay in the fact that they cost less if built in this way.' ${ }^{5}$ On 18 March, the Commons approved the estimates.

That was not the end of the affair, as hysteria navalis then spread via the press. Newspapers and patriots took up the cause in the country after George Wyndham, the Unionist MP for Dover, had demanded, 'we want eight, and we won't wait'. 'In the end a curious and characteristic solution was reached', Churchill recalled. 'The Admiralty had demanded six ships: the economists offered four: and we finally compromised on eight'. The first lord and first sea lord spent the spring working to make the contingent definite, while Lloyd George introduced his budget on 29 April. The political circumstances thus provided for the contingent four, even if the chancellor was reluctant, without their counting as part of the 1910-11 programme. It was clear to those outside Cabinet that they would be built. ${ }^{8}$ On 26 July, after new claims of fresh construction by Italy and Austria, and a by-election defeat in Bermondsey, McKenna confirmed to the Committee on Navy Estimates that the contingent four-variously called 'phantom ships', 'hypothetical ships', and 'mythical ships'-would be laid down and completed by March 1912, so that twenty dreadnoughts would be in commission. 'Admiral McKenna breathes again', reported Henry Lucy, in Punch.

1. Fisher to RMcK, 13 March [1909]. [Enclosed: Grey to Fisher, 9 March 1909 [copy].]

2. RMcK, 16 March 1909, Parliamentary Debates, 930-44.

3. Balfour, Parliamentary Debates, 16 March 1909, 954; Austen Chamberlain, 16 March 1909, in Politics from Inside, 159.

4. RMcK to Spender, 11 July 1935 [copy]; HHA to Haldane, 27 February 1909, Haldane papers, 5908/90.

5. RMcK, 11 July 1935; RMcK to Spender, 3 July 1935.

6. Times, 29 March 1909; Northcliffe to RMcK, 14 June 1909, McKenna papers, 3/14/23.

7. Winston Churchill, The World Crisis, 5 vols. (1923-27), $i: 37$.

8. L. T. Hobhouse to Scott, 7 April 1909, Scott papers (Manchester), 132/150.

9. RMcK, Parliamentary Debates, 26 July 1909, 855-58. 
'All is over now. The secret is out. We shall have the eight without undue wait. After four months' fitful fever the Admiral sleeps well.'

\section{COLLEAGUES}

Although the government subsequently risked being broken by the Lords, at the time of the estimates crisis the standoff between McKenna and Lloyd George threatened to have the same effect. ${ }^{2}$ If the worst had been avoided, McKenna had still suffered. 'He has made himself so unpopular with his colleagues that it is thought he will have to leave a few months hence', Knollys told the king. ' 3 cKenna is very sore with his colleagues about the way he has been treated' and was suspicious of Cabinet leaks and collusion between the chancellor of the Exchequer and Beresford. ${ }^{4}$ Esher found McKenna 'very bitter against Lloyd George and Winston Churchill. He spoke of Asquith's "weakness", 5 a weakness exploited by indulgent colleagues. 'Today's cabinet gave the usual opportunity for an exhibition of Winston's rhetoric', McKenna told Pamela. 'Cabinet rule is impossible unless the driver holds the reins with an iron wrist.' ${ }^{9}$ He told Pamela in September that 'My work is a trial. An all night sitting is impending. Hours accumulate.'7

'The rows in the Cabinet were violent,' Margot agreed. 'McKenna disappointed Henry by his want of tact \& taste \& temper-he $(\mathrm{H})$ was obliged to speak to him seriously. ${ }^{8}$ The debates produced unprecedented Cabinet intrigue. ${ }^{9}$ Garvin sought to persuade Unionist MPs that by supporting Fisher they would be undermining Lloyd George and Churchill. ${ }^{10}$ Fitzroy, at the Privy Council, thought that Lloyd George and Churchill had intended their opposition to divert the Cabinet from the great controversies portended by the chancellor's budget proposals. ${ }^{11}$ Fitzroy felt that it was as 'a countermove to his opposition, with the hope of bringing about his removal from the Cabinet', that Lloyd George and Churchill had opposed his estimates. ${ }^{12}$

1. 'Essence of Parliament', 26 July 1909, Punch, 4 August 1909, 85.

2. Esher to Maurice Brett, 4 January 1910, Esher papers, 7/23.

3. Knollys to Edward VII, 10 March 1909, Royal Archives, RA VIC/W 66/68.

4. Knollys to Edward VII, 27 March 1909, Royal Archives, RA VIC/W 66/71.

5. Esher, 20 March 1909, Journals, ii:378.

6. RMcK to PMcK, 1 September 1909.

7. Ibid.

8. MA, diary, April 1909, MA papers, d.3207/181.

9. Churchill to Fisher, 4 March 1909, Churchill papers, CHAR 2/32/30.

10. RMcK to Garvin, 2 June 1915, in Garvin of the Observer, by David Ayerst (1985), 82-84.

11. Fitzroy, diary, 1 May 1909, Fitzroy, Memoirs, $i: 377$.

12. Ibid. 


\section{Reginald McKenna}

The effects were long-term. Churchill claimed that 'McKenna and I were great friends until this miserable difference arose."

Service ministers in Liberal administrations traditionally risked becoming isolated figures, and the issue made allies of those otherwise least likely to collude, such as Lloyd George and Loulou. McKenna did not calculate his response to enhance his own or the government's position, but it did. 'For a young Minister still in the first flush of power, with an assured future ahead of him, this was no light sacrifice', as Henry Lucy described McKenna's threatened resignation. 'Mr McKenna dared everything and won.'2

McKenna also had begun to understand the importance of press opinion. On taking office, McKenna had made the unexceptionable remark to Garvin that he believed in naval supremacy, before adding 'while those are my views I should not like to be quoted as having expressed them.' He concluded, 'nor do I understand you to mean that you wish to write as one who has been in communication with me. Expressions of opinion by ministers for communication to the press are against all precedent in this department. ${ }^{3}$ It may have been because Garvin was a Unionist; within the year, however, he had used both Garvin and George Buckle at The Times as devices in his struggle.

By enveloping the Exchequer and the principal spending department in mutual distrust, the ill will surrounding the 1909 estimates soured many other aspects of the government's programme and activities. The first issue was the land tax, another central tenet of Liberalism. The tax reflected the peculiarly Liberal tension between social reform and free trade in land, and between radical and wealthy Liberal interests. ${ }^{4}$ Josiah Wedgwood, the Liberal MP and president of the English League for the Taxation of Land Values, recalled that

a desperate fight took place in the Cabinet in the winter of 1908-9 between the straight tax and anything else which could be called 'land taxation', but which would avoid 'the terrible results' to the property market. Mr Lloyd George, never an economist, did not fully understand the implications. Above all, he wanted revenue. Reginald McKenna did understand too well, and defeated the straight tax. ${ }^{5}$

McKenna's own inclinations may have been less important than the thwarting of Lloyd George's. Fitzroy noted that 'McKenna, who, whatever his

1. Churchill to Morley, 23 December 1909 [copy], Churchill papers, CHAR 2/39/121; but cf. Edward Marsh to Lady Gladstone, 30 November 1911, in Edward Marsh, Patron of the Arts, a Biography, by Christopher Hassall (1959), 175.

2. Sir Henry Lucy, Punch, 29 October 1911.

3. RMcK to Garvin, 28 May 1908, McKenna papers, 3/13/4a.

4. H. V. Emy, 'The Land Campaign', in Lloyd George: Twelve Essays, ed. A. J. P. Taylor (1971), 35-41; Cabinet papers, CAB37/97/10.

5. Josiah C. Wedgwood, Memoirs of a Fighting Life (1941), 69, and see Wedgwood, 14 April 1909, Times, 23 April 1909. 
defects as a naval administrator, is an accomplished financier, was one of the most strenuous in exposing the hollowness of Lloyd George's views on the taxation of land values and the predatory tendencies they barely concealed.'1 One result was further enmity with Lloyd George, and the further fracturing of McKenna's radical reputation. Josiah Wedgwood recalled,

I even went down to his constituency to denounce him in public meeting. But the Cabinet was converted by him and instead of a tax on land values, we had a tax on any increase in land value to be levied when the land was sold. Such a tax made it more difficult and more expensive to buy. The exact reverse of what we wanted!2

The tax had nevertheless provided for valuation and registration. The formerly predatory financial secretary to the Treasury now sought to moderate redistribution of wealth. It was not clear whether McKenna's motives were fiscal, in consideration of the efficacy of taxing inflation, or personal, in consideration of the chancellor of the Exchequer. That could have been suspected during the second reading of the Insurance Bill, in May 1911, when McKenna devised a scheme that placated both Lloyd George and the employers. Having worked on the land tax proposals with him, William Braithwaite, of the Inland Revenue, found McKenna taking 'a friendly interest in helping with deputations. He was first rate on any financial pointand so precise!' ${ }^{3}$

There was also the resolution of old age pensions. While Asquith introduced his final budget in 1908, Lloyd George managed the Old Age Pensions Bill through the Commons. The chancellor of the Exchequer was again more trenchant on the politics of the measure than on the economics. McKenna questioned the principle: 'Those who called for pensions did not say how they would be paid for, and if pensions were delivered critics would decry the money spent on it. ${ }^{4}$ An episode then took place that rather characterised McKenna's ministerial experience and his growing disenchantment. When Lloyd George found himself struggling to manage his brief, 'the Government gave him help', Henry Lucy observed. 'They gave him the help of Mr Reginald McKenna. That extremely confident minister 'assisted' $\mathrm{Mr}$ Lloyd George one evening, by refusing to take out of the Bill the clause that

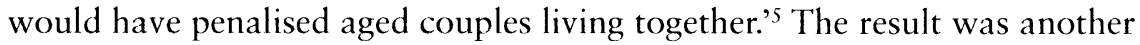

1. Fitzroy, diary, 1 May 1909, Memoirs, $i: 377$; and later, Bentley Brinkerhoff Gilbert, David Lloyd George: A Political Life, 2 vols., (1987-1992), i:373; Murray, People's Budget, 134.

2. Wedgwood, Memoirs, 69.

3. William Braithwaite, in Lloyd George's Ambulance Wagon: Being the Memoirs of William J. Braithwaite, 1911-1912, ed. Sir Henry Bunbury (1957), 180, 164, $169,171,184-87$.

4. RMcK, speech in North Monmouth, 12 October 1907.

5. King, Parliament, 256. 


\section{Reginald McKenna}

row between McKenna and the Commons, as he had with one statement managed to unite Unionists with Liberal critics. It was also the case that McKenna, presiding suddenly and temporarily in committee, was not able to commit the government to concessions as soon as the rebellion flared. When Lloyd George realised the extent of the revolt, he made the commitment, so that everyone was satisfied, 'except perhaps the luckless $\mathrm{Mr}$ McKenna', E. T. Raymond observed, 'who received no compliments'.

Although, through his estimates and his work on pensions, he was, with Lloyd George, the principal reason for it, McKenna was regarded as being more doubtful of the People's Budget than were many Liberals. ${ }^{2}$ His ambivalence was as much personal as political, as was his ultimate support. As Violet Asquith told Venetia Stanley, "his only reason for wishing the budget to go through was that Lloyd George would be a hero if it did not. ${ }^{3}$ The cause of the split with Lloyd George, while being principally personal, was also founded on policy and the formulation of policy. McKenna said that he disliked Lloyd George because 'he has no respect for the truth.4 Moreover, Lloyd George was responsible for that element of government of which McKenna was most knowledgeable, which meant that he sat on the Finance Committee of the Cabinet. McKenna also remained in touch with Treasury civil servants, where complaints about the chancellor were consistent with McKenna's own feelings. 'I wonder if Ll.G will hang himself over the Treasury. I have heard from various sources that he doesn't understand the work at all.'5

While Lloyd George located the irreversible breakdown in his relations with McKenna to the battle over the estimates ${ }^{6}$ the crisis brought McKenna closer than ever to Sir Edward Grey, indeed, 'but for him I should have been

1. E. T. Raymond, Mr Lloyd George (1922), 107-8.

2. Ayerst, Garvin, 87; RMcK, 14 December 1913, Riddell, diary, Riddell papers, 62973; Riddell, 14 June 1914, Riddell papers, 62974.

3. Violet Asquith to Venetia Stanley, 15 October 1909, in Violet Asquith, Diaries, 186-87.

4. DMcK, in conversation with the author; Violet Bonham Carter to Mark Bonham Carter, 31 December 1915, in Champion Redoubtable: The Diaries and Letters of Violet Bonham Carter, 1914-45, ed. Mark Pottle (1998), 90; Ernest Benn, Happier Days: Recollections and Reflections (1949), 107; Joseph Gourney Pease, A Wealth of Happiness and Many Bitter Trials: The Journals of Sir Alfred Edward Pease, a Restless Man (York, 1992), 329.

5. PMcK to Agnes Jekyll, 9 August 1908. Bradbury told McKenna how, at one meeting between Lloyd George and a delegation, the chancellor was holding forth and began quoting some figures. While he was talking, Lloyd George noticed that Bradbury was displaying some disquiet. Eventually Bradbury scribbled a note on a napkin-'the figures you are quoting are incorrect and do not support your argument'-and handed it to Lloyd George. Lloyd George read the note with the audience watching, then looked up and said, 'and my point is supported by my honourable friend Sir John Bradbury.' IMcK, in conversation with the author.

6. Jellicoe to RMcK, 24 February 1909, Jellicoe papers, 48990/21. 
beaten'. ${ }^{1}$ For Lloyd George, Grey was merely a 'blue funk'; ${ }^{2}$ for McKenna 'I have always had it in mind that if Grey could argue, it is not for me to be squeamish. He has been in some sort my political conscience.' ${ }^{3}$

The foreign secretary came to share with McKenna a similar sense of weariness at the experience of holding high office. Each on several occasions was to back the other to the point of resignation. ${ }^{4}$ Grey embodied much that was spiritual to Liberalism, and McKenna saw him as in some way providing a sensibility that he recognised as being absent in himself. 'I have an enormous belief in Edward', McKenna told Margot. 'I do respect his judgement far more than my own.'

McKenna made light of the fact that at the same time he was being attacked by Liberals for profligacy, by Labour for jingoism, and by Unionists for parsimony. ${ }^{6} \mathrm{He}$ had grown used to hostility outside government, but the 1909 crisis, though a personal triumph, had a greatly dispiriting effect on the first lord of the Admiralty. 'I have had enough, I don't mind telling my darling Pamski, of being any kind of minister, and the sooner you and I have our own quiet lives the better." "McKenna has been a good deal overwrought, and I think his nerves are out of gear', Asquith told Margot. 'On the whole-between ourselves-he has rather disappointed me: he is apt to be out of perspective, and to get febrile $\&$ even touchy: not a big man'. ${ }^{8}$ On the same day the prime minister described the first lord as 'touchy', Churchill was denigrating him to the first sea lord in the Athenaeum. ${ }^{9}$ McKenna then referred to the incident in Cabinet, so that it 'produced a very unpleasant effect so far as he was concerned upon those who heard him', Churchill wrote-to Fisher. ${ }^{10}$ 'McK is a bad judge of character $\&$ when his heroes disappoint him he is unforgiving \& provincial in believing every silly tale against them', Margot thought. ${ }^{11}$ Even, apparently, when they were true. $\mathrm{He}$ told Pamela, 'I hate my colleagues. ${ }^{12}$

1. RMcK to Runciman, 28 March 1910, Runciman papers, 35.

2. Lloyd George to William George, 28 May 1933, George, Brother, 234.

3. RMcK to Runciman, 28 March 1910, Runciman papers, 35.

4. Charles Hardinge to Knollys, 27 January 1910, Royal Archives, RA VIC/W $55 / 89$.

5. MA, diary, 12 February 1910, MA papers, d.3208.

6. RMcK, 28 October 1910, speech at Abersychan, Times, 29 October 1910; George Roberts, Parliamentary Debates, 16 March 1911, 2483-94.

7. RMcK to PJ, n.d. [c. 1908].

8. HHA to MA, 28 February 1909, MA papers, c.6690/187-88; PMcK to Archibald Hurd, 4 August 1914, Hurd papers, 1/35.

9. Fisher to RMcK, 28 February 1909, Fisher papers, 1/7/356.

10. Churchill to Fisher, 4 March 1909, Churchill papers, CHAR 2/32/30.

11. MA, diary, 12 December 1909, MA papers, d.3207/210.

12. RMcK to PMcK, 1 September 1909. 


\section{PAMELA}

On returning from their honeymoon, the McKennae-as the prime minister was now wont to call them-joined a then voguish Saturday-to-Monday party at Munstead. They spent weekends there, but had been living in town at Hanover Square. Soon after their marriage, the Office of Works had extensively renovated Admiralty House and it was ready for them-and Ernest-and their new role. 'The young and charming wife of the First Lord of the Admiralty makes her debut as a Liberal hostess next Monday week', the Daily Mirror reported. 'Had Mrs Asquith been in town, this duty would, of course, have fallen to her ... There are few entertainments in the course of the London season so largely attended as are these political receptions

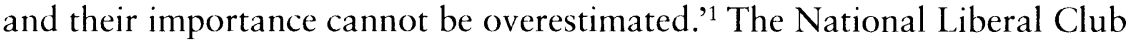
reception on 3 July 1908 was Pamela's formal induction into the role of political wife. In that role, the doyenne welcomed her. 'He will always be in any Liberal Cabinet and I know enough of Pamela to know she will take up her position with seriousness and unselfishness', Margot wrote. 'She will be an immense help to me! Which is selfish but true as we have hard times ahead.' ${ }^{2}$ Office amused Pamela. She enjoyed travelling on land and sea in great pomp, staying in suites of rooms, and attending great dinners. She told her mother, 'I think that being married is even more fun than being engaged.' Once, when Reggie could not attend lunch during a cruise on the Enchantress, Pamela stepped in, and followed dessert by inviting the prime minister and foreign secretary on a trip round the Needles in a torpedo boat. $^{4}$

Pamela's enjoyment was not wholly, or even largely, hedonistic, however. 'Mrs McKenna, one of the youngest of the ministerial brides, used to come down to the room of the First Lord of the Admiralty at the House of Commons and stay until her husband had finished his work, even when it was a very late hour', Charles King recorded. 'Sometimes she would come into the gallery in the House of Lords to see their Lordships'.5 When not launching ships, touring naval facilities, attending balls, or hosting receptions, there were also the responsibilities that derived by virtue of being a Jekyll woman: of concerts, and exhibitions, and private viewings. The load did not appear to be lightened by an addition to the family. Despite Fisher's attempts to set Bar up with his friend Hedworth Williamson, ${ }^{6}$ on 20 July 1911, Bar married Francis McLaren, Liberal member for Spalding-at twenty-five, the

1. Daily Mirror, n.d. [c. 1909].

2. MA to Agnes Jekyll, 19 March 1908.

3. PMcK to Agnes Jekyll, n.d. [7 July 1909].

4. PMcK to RMcK, n.d. [4 August 1909]; HHA to MA, 4 August 1909, MA papers, c.6690/192-93.

5. King, Parliament, 322.

6. Fisher to PMcK, 6 March 1910. 
youngest MP. Reggie gave Admiralty House for the reception, the guests at which included, in addition to the inevitable Asquiths and Harcourts, Philip Burne Jones and Ellen Terry.

Pamela's unspoken, but most politically important role, was as an antidote to her husband, while at the same time serving his interests. Where he spurned social ritual-'Mr and Mrs McKenna are not standing by Lord Carrington to receive the Prime Minister at the National Liberal Club. Bed is too short to curtail it by unnecessary ceremony. I am tired and I am going home to bed at once" - Pamela, through her upbringing, station, and disposition, endured them. She hosted 'duty lunches' for groups of MPs and their wives. He dictated his speeches to her, and she wrote them down and made suggestions. Pamela became involved with the National Women's Liberal Association and the Eighty Club. Her new friends served to alienate the old, and the more conventional. For Venetia, Pamela had very soon become 'a cabinet bore.' ${ }^{2}$ Her political interests meant that keen observation of her husband's activities inevitably embraced actual participation, and theirs became a political partnership as well as a marriage. 'Discretion (to say a very flat thing) is the most important of all', Margot told Aggie, Pamela's mother, without apparent irony, 'and to be xtra nice to the M.P.s one does not like and that one's husband's dislikes; but no advice from me is at all necessary'. ${ }^{3}$ Pamela smoothed Reggie's usually awkward and always reluctant passage through 'society'. His friends became her friends, particularly three B's: Birrell, Burns, and Benn. ${ }^{4}$ His enemies became hers. She made Lloyd George 'very apprehensive'; ${ }^{5}$ of Churchill she wrote, 'It must be a thorn in the President of the Board of Trade's horrid flesh when he remembers how Pitt became P.M. after he had been in the house three years. ${ }^{6}$ She was infuriated, daily, by the Daily Mail. Admiral Madden found her 'a very clever woman'. ${ }^{7}$ It was rumoured that Fisher had employed her to secure the appointment of Ottley as secretary of the Committee of Imperial Defence (CID),${ }^{8}$ and to pass on to the press intimations that Jack Seely would be the next chief whip. ${ }^{9}$ She withstood the Lord Chancellor Loreburn, "who comes and sits with us for hours sucking down gossip which he never hears

1. RMcK to PJ, n.d.

2. Venetia Stanley to Violet Asquith, 16 August 1908, in Violet Asquith, Diaries, 162.

3. MA to Agnes Jekyll, 19 March 1908.

4. PMcK to Archibald Hurd, 4 August 1914, Hurd papers, 1/35; Cynthia Asquith, 29 December 1915, Diaries, 117; PMcK to Balfour, 28 May 1915, Balfour papers, $49865 / 55$.

5. Riddell, diary, 22 August 1915, Riddell papers, 62959.

6. PMcK to RMcK, 14 May 1909.

7. Fisher to PMcK, 17 March 1910, McKenna papers, 6/3/48.

8. Stephen Roskill, Hankey: Man of Secrets, 3 vols. (1970-74), i:109.

9. Riddell, diary, 5 January 1915, Riddell papers, 62959. John Gulland was appointed. 
anywhere else and pretends to disdain though anything more apparent than his delight at any little personal thing I never saw.' ${ }^{1}$ Even she was beaten by Dilke, however, who 'talks all the time and won't listen to anyone else for a moment. You make a remark to him he says hastily, "I know, I know" and goes on with his own conversation."

Her other role was as a confidante of the prime minister. It in part accounted for Asquith describing his relations with McKenna as becoming very close very quickly. ${ }^{3}$ The McKenna residence became a favoured venue for Asquithian scratch dinner and bridge parties, and on those evenings when Asquith was not with Pamela, he wrote to her. Their correspondence, which spanned twenty years, was most frequent in the period before her marriage. Unlike his correspondence with another young muse, Venetia, which stopped when she married Montagu, Asquith's with Pamela continued after her marriage, albeit at a reduced rate, until the war, when it increased and exceeded its old regularity. In fact, their marriage served to bring both McKennas closer to the prime minister. ${ }^{4}$ Fisher provided Pamela with another correspondent almost as regular, and certainly more rustic, than the prime minister. However fleeting her acquaintances, there was a common response. At one of her luncheon parties, to impress a Turkish delegation shopping for dreadnoughts, Colonel Ali Risa Bay sat next to her. 'He thought I was R's daughter.'

\section{HYSTERIA GERMANICA: PART I}

The estimate crisis had contradictory consequences for McKenna's standing in the party. He had been elected to the Executive Committee of the Eighty Club in 1907, and in 1908 became a vice chairman, but the very nature of his successes antagonised those sections of the party of which he could until quite recently have included himself. McKenna's triumph had been tactical, in that he was quite determined to resign if he did not prevail, but arguably also strategic, in that the connexions between Liberalism and navalism were being strengthened. Yet there were grounds for misgivings. The former 'advanced radical' had diverted government expenditure from social investment into war machines. It did not help that the evidence for German capabilities and capacity, as luridly expressed by the Daily Mail and the Unionists, was based on evidence of often questionable veracity. ${ }^{6}$

1. PMcK, diary, 4 December 1910.

2. PMcK to Agnes Jekyll, [n.d.] 5 October.

3. HHA to MA, 3 August 1909, MA papers, c.6690/190-91.

4. Spender and Asquith, Asquith, $i: 201$.

5. PMcK, diary, 24 March 1911.

6. Jellicoe to RMcK, 24 February 1909 , Jellicoe papers, 48990/21. 'We were anxious that the case for new construction should not be overstated in a single detail', RMcK to Spender, 27 June 1935. 
Damage enough was done to his radical reputation by his reprioritising Greater Britain over Social England. It compounded the problem when McKenna later admitted in the House of Commons that, owing to delays in German manufacture, his 1909 predictions had been proved inaccurate. ${ }^{1}$ Not only did German shipbuilding not accelerate, it did not even keep to its schedule. ${ }^{2}$ However great the personal victory of the 1909 estimates, it tarnished McKenna's reputation in the party. He shared responsibility with two interested parties whose ultimate influence went far beyond their stations: Dawson and Mulliner.

The munitions contractor H. H. Mulliner was responsible for much of the hysteria Germanica. 'Balfour made at least one very alarmist speech the material for which I believe had been supplied by Mulliner', ${ }^{3}$ which was noticeable since McKenna had publicly applauded Balfour at the time for keeping the navy out of party politics. ${ }^{4}$ From May 1906 to June 1908, Mulliner had warned the Admiralty of the expansion of production at Krupp's works in Germany. Mulliner also happened to own Coventry Ordnance, a munitions firm that was in financial difficulties, and to which Reginald Bacon had moved as managing director from his post as director of Naval Ordnance at the Admiralty. ${ }^{5}$ The Admiralty demanded verification of Mulliner's claims, and much was derived from secret reports by Commander Sir Trevor Dawson, who also wrote personally to McKenna. ${ }^{6}$ Dawson visited the continent at the request of first lord of the Admiralty from 1906 to 1914, and sailed covertly around the coast in much the same way, and with much the same effect, as did Carruthers in Erskine Childers' The Riddle of the Sands. Dawson's reports concerned every available detail of the German naval programme, from plans to trials, and the information that, in June 1909, Germany ceased exporting nickel and started importing 'excessive quantities from France', the final plans for German mines to be laid in the navigable waterways of southern England, and the 'new German naval tactic' of combining battleships, submarines, and mines 'in such a manner as to form a trap for the British Fleet. ${ }^{7}$ The Foreign Office contested some of Dawson's claims, with the Admiralty tending to split the difference. ${ }^{8}$

1. RMcK, Parliamentary Debates, 16 February 1911, 1411-12.

2. Marder, Fear God, ii:208.

3. RMcK to Spender, 27 June 1935; McKenna papers, 3/12/8; Charles McLaren to RMcK, 26 March 1909, and enc., McKenna papers, 3/12/8-8(2).

4. RMcK, speech in Abersychan, 13 January 1910, Manchester Guardian, 14 January 1910.

5. Admiral Sir Reginald Bacon, From 1900 Onward, (1940), 179-203.

6. Sir Trevor Dawson to RMcK, 13 February 1909, 6 August 1909, 10 January 1910, 14 January 1910.

7. Secret Reports by Commander Sir A. Trevor Dawson R.N. to Admiralty, 1906-1914, as a 'Result of Visits made to Continent at Request of First Lord of the Admiralty and as Collected through Special Agencies', 7.

8. RMcK to HHA, 30 July 1910 , Asquith papers, 12/80. 
McKenna could therefore claim that he could only base his judgement on the evidence presented to him. The secretary of the CID, Sir Charles Ottley, told McKenna on 25 February 1909 that Mulliner was important, 'if reliable', which rather became the issue. ${ }^{1}$

Two days earlier, Pamela had launched HMS Vanguard at Vickers works, Barrow-in-Furness, and her husband had made a speech that would be cited twenty-six years later as evidence of his and the government's collusion in an arms race that led to a world war. Relations between the government and, he said, 'another firm of similar magnitude'-meaning Armstrong Whitworth-were "far more cordial than the ordinary relations of commerce.'2 McKenna's own secret weapon was at such times less effective than usual. Having left hungry contractors and foreign naval ministers in Pamela's care, and with Trevor Dawson in attendance, 'they drifted away after I had tried in vain to get clinching promises for their orders and they were off to Krupp at Essen the next day. ${ }^{3}$

For all the proximity suggested at Barrow, McKenna could also claim that the hysterical reaction of opponents required some sort of response, with a general election imminent. Basil Zaharoff, a future, and controversial, friend, was at that time working for Vickers and thought the public controversy caused by Mulliner was a distraction. Since, 'Zed' believed, Lloyd George had to be either won over or discredited, Zaharoff was said to have told him, 'You must convince McKenna that he is not helping our cause by giving way to this pressure from the men of Coventry'. ${ }^{4}$ Having been in contact with the CID throughout 1909, Mulliner wrote a letter for publication in The Times to the effect that the Admiralty was not serious in its response to the German threat. The precise nature of relations between McKenna and Mulliner was questioned both at the time and subsequently. ${ }^{5}$ At the time, and insofar as he did marginalise Mulliner's effect on the debate, McKenna's was a moderating influence. He emphasised the nature of 'capacity' - of what could reasonably be expected to be fulfilled-and that guns could not be made if the companies were operating at the limits of their capacity. ${ }^{6}$ To go beyond capacity was merely a rhetorical indulgence, a prominent symptom of the hysteria.

1. Ottley to RMcK, 25 February 1909, McKenna papers, 3/14/14.

2. Times, 23 February 1909; Philip Noel-Baker, The Private Manufacture of Armaments, 3 vols. (1936), 62; Admiral Sir Reginald Bacon, From 1900 Onward (1940), 164-65.

3. PMcK, diary, 24 March 1911.

4. T. O'Connor to Mr H McGuire, 29 November 1909, in Peddler of Death: The Life of Sir Basil Zaharoff, by Donald McCormick (1965), 98.

5. Duke, Parliamentary Debates, 16 March 1910, 418, 420-28, 456. Royal Commission on the Private Manufacture of and Trading in Arms 1936 ed. 5292, Appen$\operatorname{dix} 5$.

6. RMcK, 23 February 1909, evidence in Conference, Asquith papers, $21 / 130-7$. 
McKenna was eventually proved right-by the failure of his policy. Germany had only nine dreadnoughts at sea by 1912, and Britain fifteen; by January 1915, and with the war that had not been deterred, Britain had a superiority of only five ships. Winston Churchill later attested that such advantage as Britain did ultimately possess in 1914 was based largely on the 1909 settlement. ${ }^{1}$ A royal commission after the war found that, while the Germans had not yet been inclined to escalate their programme in the manner at first feared, the Admiralty felt it had to act on the assumption that they might, 'since it would be impossible or very difficult to correct an under-estimate of the German output, whereas an over-estimate would be a mistake on the safe side which could be adjusted in future programmes'. ${ }^{2}$

The gravest charge, particularly to an internationalist free trader, was that McKenna had presided over if not the inception, then certainly the escalation, of the stereotypical arms race that fostered a climate that made war more, not less, likely. ${ }^{3}$ He had certainly enraged the Germans, whose chancellor highlighted McKenna as an example of a statesman whose public statements were contributing to the distrust of Germany and the worsening of international relations. ${ }^{4}$

\section{EMPIRE}

Three days after McKenna confirmed his commitment to the contingent four, in May 1909, he declared, as chairman of the second day of the first Imperial Press Conference, that 'we at home make no distinction between the naval defence of one part of the empire and of another. ${ }^{5}$ The Imperial Press Conference, convened for the benefit of the pressmen of the empire, presaged the Imperial Defence Conference, also in London, two months later, and that was how McKenna used his address. He spoke of 'partnership', and how 'in the development of what you may call the naval idea in every dominion it is essential that the mainspring should come from the dominion itself.' ${ }^{6}$ The empire, and the extent to which dominions provided

1. Churchill World Crisis 1911-1914 (1923) 36-38; Admiral Viscount Jellicoe, The Grand Fleet 1914-16: Its Creation, Development and Work (1919), 35; Charles à Court Repington, Vestigia (1919), 292.

2. Royal Commission on the Private Manufacture of and Trading in Arms, 99.

3. Brockway, Labour, 72-73. See Holger H. Herwig, 'The German Reaction to the Dreadnaught Revolution', International History Review 13 (1991): 221-440.

4. Goschen to Grey, 2 December 1910, Documents, vi. 558; Goschen, diary, 22 March 1910, in The Diary of Edward Goschen, 1900-1914, ed. Christopher Howard (1980), 202; Hugh Watson to Edward Marsh, 12 March 1913, Churchill papers, CHAR 13/19/44-46; Goschen to Grey, 21 July 1909, and Grey to Goschen, 28 July 1909, in Great Britain and the German Navy, by E. L. Woodward (1964), 486-88.

5. RMcK, 8 June 1909, Times, 9 June 1909.

6. RMcK, 8 June 1909, Hardman, Parliament, 154; RMcK, memorandum, 20 July 1909, Royal Archives, RA VIC/X 10/6. 


\section{Reginald McKenna}

for their own defence requirements, were pressing, and sensitive, issues at the Admiralty. It was another area of his brief where McKenna was forced to acquire the necessary knowledge, sensibilities, and eloquence. He assured the imperial family, 'Over the waters our borders touch."

McKenna's 'one sea' imperialism confronted the quite different 'imperial overstretch' analysis of Joseph Chamberlain, who, in another expressive announcement, had proclaimed that 'the weary Titan staggers under the too vast orb of its fate." With a view to sharing the load, naval devolution could be employed to reinforce the centre: by assuming greater responsibility for their navies, the dominions would both be saving Britain money, while reinforcing the idea of imperial defence. Whether from an imperialist's perspective-that a disproportionate burden was falling on Britain-or that of an agnostic - that the empire was a distraction-the uniform remedy would include greater collective responsibility. What Chamberlain had failed to do at the 1902 Imperial Conference, McKenna sought to effect seven years later. In that, he was assisted by both external threats, which brought the navy closer home, and internal outlook of dominions growing in self-confidence. To that extent, the advocacy of partnership was as disingenuous as the real motive was financial. ${ }^{3}$

One of the first representations McKenna received on taking office was from the Australian prime minister Alfred Deakin. ${ }^{4}$ Conditioned to think about the issue by the military unpreparedness that characterised the South African war, the dominions had not been unmoved by the hysteria in Britain, which prompted the Imperial Defence Conference. McKenna's plans for the dominion navies marked a broadening of his outlook and a development of his attitudes to empire. Naval devolution was far from what the Admiralty wanted, given a natural preference for strategic unity, but there were forty-four battleships in the home or Atlantic fleets, six in the Mediterranean, and none anywhere else by the time McKenna took over. Moreover, the Atlanticist conception to which McKenna was wedded required that the fleet would be in the Atlantic; other theatres were secondary. The naval race added to this, and the dominions made representations to which McKenna was receptive, as was Crewe, who told him, 'You will have seen the New Zealand telegram offering a Dreadnought, so to speak, over the counter, and another later on if required. It is uncommonly handsome of them.'

A subcommittee of the CID, chaired by Crewe, and including Esher, Morley, Haldane, Hardinge, and McKenna, was formed, charged with

1. Ibid.

2. Chamberlain, 16 May 1888, Times 15 May 1888.

3. RMcK to Crewe, 18 August 1909, Crewe papers, M/8(1).

4. Deakin to RMcK, 21 April 1908, McKenna papers, 3/13/1; RMcK to Deakin, 21 June 1908, Deakin papers, 1540/15/3638.

5. Lord Crewe to RMcK, 22 March 1909. 
reconciling dominion control with imperial defence. ${ }^{1}$ The nationalist Deakin had already pressed McKenna to approve the construction of an Australian navy, but with a growing sense of greater Australian jurisdiction. ${ }^{2}$ Just before the conference, on 20 July 1909 , McKenna presented a plan 'upon which the growth of Colonial naval forces should be fostered', ${ }^{3}$ while at the same time providing for central Admiralty command in the event of war. His preference was for distinct fleet units, 'the smallest unit is one which while manageable in time of peace, is capable of being used in its component parts in time of war. ${ }^{4}$ Only the Canadians demurred from this view. ${ }^{5}$ He was receptive and conciliatory to dominion concerns, much more so than were many in the ministry, and managed to allay concerns, particularly of the Canadians. ${ }^{6} \mathrm{He}$ could call his policy retrenchment, and mollify belligerent interests at home, whilst at the same time effectively increase the size of the navy. By 1914, one quarter of the advantage the Royal Navy had over that of Germany was due to HMS New Zealand and HMS Australia.?

\section{ARCHER-SHEE AND BERESFORD}

More than in any other office, as first lord of the Admiralty McKenna was preoccupied with matters of personnel. On one level, he displayed his usual attention to detail in forms which, in other ministers, might have been regarded as populism. He personally recommended medals for the sailors who helped with the aftermath of the earthquake that virtually destroyed Messina in $1908,{ }^{8}$ and generally sought to improve the conditions of ordinary sailors, at 'a time when Boards of Admiralty thought it was infra dig to accept or even listen to suggestions for reform', an acquaintance wrote in The Fleet, a navy journal. The author knew how 'keenly and sympathetically interested' the first lord was 'in all matters affecting the lower-deck, and how ready he always is to give ear to suggestions for reform'. The extract was additionally published as a leaflet. ${ }^{9}$

1. Admiralty papers, ADM 116/1043b.

2. Deakin to RMcK, 28 July 1908, Deakin papers, 1540/15/3640; 22 October 1908, McKenna papers, 3/13; 14 June 1909, McKenna papers, 3/14/24a.

3. RMcK, memorandum, 20 July 1909, Publications of the Naval Record Society, vol.136, 102.

4. Ibid, vol. 131, 755-56.

5. Deakin to RMcK, 18 August 1909, Deakin papers, 1540/15/3803; F. F. G. Foxton to Sir Joseph Ward, 13 August 1909, Deakin papers, 1540/15/3803; RMcK, memorandum, 20 August 1909, Publications of the Naval Record Society, vol. 136, $105-11 ; 151,157-59$.

6. Gordon, Partnership, 239-41, 259-61.

7. Marder, Dreadnought, i:439-42.

8. RMcK to Sir Arthur Wilson, 7 October 1909, Royal Archives, RA VIC/W $59 / 88$.

9. 'Mr McKenna and the Navy', leaflet, n.d. 


\section{Reginald McKenna}

Against the will of most of the sea lords, McKenna asked Fisher's friend Lionel Yexley to send him proposals for reform. Through his Naval Discipline Act of October 1909, navy prisons were brought into line with those of the army, and many degrading practices ended. ${ }^{1}$ In 1910, he told the Commons that he wanted poorer boys to enter the Navy as officers, and sought lower fees at Osborne College, or Osborne scholarships to board school boys. 'The service was utterly astounded', Yexley reported, at proposals that 'raised a storm of criticism in naval circles.' Moreover, given that McKenna was widely thought to be in thrall to his first sea lord, Commander Barry Domvile recalled that Fisher, who did not like him, refused him a promotion on the grounds of poor hearing. McKenna told the board he would examine Domvile himself. He called Domvile to his office and, as if on the Chertsey Mead behind Dockett Eddy, spoke to him at various distances and at different pitches. 'This kind little man told me that he was surprised how well I could hear', the later Admiral Domvile recalled. ${ }^{3}$ The promotion was approved. 'Not many men would have taken the trouble he did to prevent an injustice to a junior officer'. ${ }^{4}$

One case Yexley made much of demonstrated the converse: McKenna's statement institutionalised insensitivity. The case of George Archer-Shee was dramatised by Terence Rattigan as The Winslow Boy two years late, and filmed, by McKenna's wedding page Anthony Asquith, in 1948..$^{5}$ ArcherShee, a thirteen-year-old cadet at Osborne, was accused of stealing a 5 shilling postal order. After a summary enquiry, in October 1908, Archer-Shee was dismissed from the college. Having had no success in appealing to either Osborne or the Admiralty, the boy's father, convinced of his son's innocence, hired Sir Edward Carson, the leading Unionist MP, who was also a leading barrister. After over a year pressing for a judicial inquiry, Carson sought to sue the Admiralty for breach of contract. Sir Rufus Isaacs, the solicitor general, obstructed the case, prompting Carson to proclaim a public scandal. At the eventual trial, in July 1910, Carson thoroughly and dramatically refuted the case against Archer-Shee, and Isaacs accepted the boy's innocence. The greatest damage to the Admiralty, however, occurred when McKenna became involved. His technically defensible but politically insensitive refusal to offer either apology or compensation renewed public sympathy for the boy and outrage at the government, particularly in the Commons, where Archer-Shee's half-brother, newly elected himself as a Unionist MP, was enthusiastically abetted by F. E. Smith and Admiral Lord Charles Beresford. Having resisted compensation, in far from conciliatory

1. The Fleet, n.d.; Anthony Carew, The Lower Deck of the Royal Navy 1900-39 (Manchester, 1981), 16, 35-7.

2. Lionel Yexley, Our Fighting Sea Men [1911], 321.

3. Domvile, 10 October 1950, in Marder, Dreadnought, 1:86-87.

4. Domvile, By and Large, 39.

5. Broad, Advocates, 129-39; Yexley, Fighting, 195-201. 
terms, McKenna then referred the matter of compensation to arbitration, with $£ 7,120$ subsequently awarded to the boy. No formal apology was ever issued, however, and McKenna, in common with the college authorities, privately remained convinced that Archer-Shee was guilty. ${ }^{1}$ The scandal was taken up by Churchill, Spender told Esher, to embarrass McKenna, aware of the fact that Archer-Shee was 'entirely the kind of affair in which with all his qualities [McKenna] does not shine'. ${ }^{2}$ The most noticeable consequence, Esher told Balfour, was Lloyd George and Churchill's 'joy over the bungling.' 3

More generally, however, personnel meant appointments. It was through one such that McKenna made one of his most enduring friendships, that with Jellicoe, which arose from a relatively uncontroversial promotion to the Board of Admiralty as third sea lord, in July $1908 .{ }^{4}$ It was an indication of the man, and of his appeal to McKenna, who similarly accepted promotion through a sense of duty rather than personal ambition, that Jellicoe accepted the post only reluctantly. Indeed, some time later, when McKenna tried to promote Jellicoe to command of the Atlantic Fleet, McKenna's then first sea lord, Arthur Wilson agreed, but only reluctantly. When Jellicoe discovered, he initially respectfully declined a promotion that was not unanimously supported by the sea lords. ${ }^{5}$ Of all McKenna's naval friends, it was with Jellicoe that he had the most in common. Similar in stature and appearance, from similarly modest backgrounds, both had married late to much younger, more extroverted women and had succeeded in their careers through a combination of mathematical expertise, attention to detail, and general dedication. Jellicoe, and his relationship with his first lord, contrasted with that of the other leading sailor of the age, Beatty, whose personal relations with McKenna were dreadful. ${ }^{6}$ Nor did Beatty get on with Jellicoe; indeed, Jellicoe was almost the McKenna to Beatty's Lloyd George. McKenna's preference for the former was pronounced and predictable; indeed, Jellicoe was his 'most intimate friend in the service'?

1. DMcK to Rodney Bennett, 31 March 1971 [copy].

2. Spender to Esher, 16 August 1910, Balfour papers, 49719/153.

3. Esher to Balfour, 8 August 1910, Balfour papers, 49719/151.

4. RMcK to Jellicoe, 2 July 1908, Jellicoe papers, 49035/4; Captain Eldward] Altham, Jellicoe (1938), 46-47.

5. RMcK to Knollys, 29 January 1910, Royal Archives, RA VIC/W 59/102.

6. RMcK to Knollys, 29 January 1910, Royal Archives, RA VIC/W 59/102; Jellicoe to RMcK, 18 July 1908, Jellicoe Papers, 1:11; Beatty to RMcK, 25 July 1911, Beatty Papers, 1:33; Chalmers, Beatty, 107.

7. Dickson, interview with RMcK, 1935, Dickson papers, 13586/117-18; Jellicoe to RMcK, 18 July 1908 , extract from autobiographical notes, Jellicoe papers, 49038/203-27; Jellicoe Papers, 1:11. 
McKenna recalled years later that 'the years before the war gave us two admirals of genius'. ${ }^{1}$ One was Jellicoe, the other was Fisher. McKenna wrote to him on Christmas Day, 1909:

I have been settling my accounts with the year and going over in my mind many tough and victorious fights in which we have been comrades. I think our most powerful weapon has been our perfect unanimity. It means so much to have absolute confidence that you will not be left in the lurch, and for my part I have never had the smallest hesitation or doubt. I recall with feelings of the most affectionate friendship how firmly you stood by me in my Cabinet troubles. The victory was due to you, and I owe it to myself to testify how ready you have always been for the sake of the immediate duty to fling away office and all its rewards. The political future has no alarms for me, for I have no desire to remain at the Admiralty without you. ${ }^{2}$

It was as a direct consequence of his closeness to Fisher that McKenna became embroiled with Beresford.

Asquith was well aware of 'the old tale'. ${ }^{3}$ Admiral Lord Charles William de la Poer Beresford, commander in chief of the Channel Fleet, was a sailor exceeded in seniority and ego only by the first sea lord himself. It followed that Fisher and Beresford hated each other, their hostility rooted in personal similarities and exacerbated by strategic dissimilarities. ${ }^{4}$ The new development was that Beresford had come to regard himself as Fisher's nemesis and made public claims to that effect. Fisher suggested a response for the first lord: 'Tell Beresford, in Burns's words "The Quarterdeck and silence, or Westminster and Gas!"' Beresford chose, volubly, the latter. One issue over which they clashed was the innovation, increasingly demanded by politicians, soldiers, and sailors alike, of a naval general staff, to mirror that of the army, and that through Fisher's opposition to the extension of centralised command the navy was unprepared for war. Fisher immediately briefed his first lord of the Admiralty. ${ }^{6}$

1. RMcK to Bacon, 27 August 1936, Jellicoe papers, 49044/29-31.

2. RMcK to Fisher, 25 December 1909, Fisher papers, 1/9/447; RMcK to Fisher, 20 November 1909, Fisher papers, 1/9/438.

3. MA, diary, 13 April 1908, MA papers, d.3206/67; HHA to MA, 27 October 1909, MA papers, c.6690/201-2. The fullest account is: Geoffrey Penn, Infighting Admirals: Fisher's Fend with Beresford and the Reactionaries (2000).

4. Fisher to RMcK, 26 May 1908, McKenna papers, 3/4/10-11; Fisher to RMcK, 28 July 1908, McKenna papers, 3/4/17; Fisher to RMcK, 31 March 1909, McKenna papers, 6/2/64; Fisher to RMcK, 19 August 1909, McKenna papers, 6/2/112; J. R. Thursfield to RMcK, 14 August 1908, 3/13/6. See Bennett, Charlie B, chs. 7-12.

5. Fisher to RMcK, 16 April 1908, Fisher papers, 1/6/306; Fisher to RMcK, 15 June 1908, McKenna papers, 3/4/14.

6. Fisher to RMcK, 11 May 1908, Admiralty papers, ADM 1/7992; Fisher to RMcK, 23 November 1909, McKenna papers, 3/4/34. 
As with the 1909 estimates, the Beresford affair was bound to become more than an internal matter. An aristocratic Unionist ultra, 'Charlie B' was a willing spokesman for service opposition to the government, and his complaints were amplified by what Fisher called the 'Syndicate of Discontent': a collection of right-wing politicians, journalists, and fellow-travellers that included the Prince of Wales, Leo Maxse, Horatio Bottomley, most Unionist MPs and newspapers, as well as for tacticaly reasons Haldane, Churchill, and Lloyd George, with his determination to effect economies, and the additional benefit of undermining the first lord of the Admiralty. ${ }^{1}$ McKenna and the 'Fishpond' of Fisher supporters had the less numerous but more exalted sympathies of the king, Balfour, and, of a fashion, Asquith. ${ }^{2}$ As early as January 1908, the Board of Admiralty had considered sacrificing Beresford; indeed, the Spectator acclaimed McKenna as the 'strong man', who should demonstrate who was in charge by dismissing both Beresford and Fisher. ${ }^{3} \mathrm{~A}$ letter by Arthur Lee in The Times on 6 July asked what McKenna was going to do about what was both 'a grave scandal' and 'a menace to our national security'. ${ }^{4}$

McKenna at first tried conciliation, which alarmed Fisher, and which was by then too late to be effective; ${ }^{5}$ then, though he resisted instituting a court martial, on 16 December 1908 McKenna ordered Beresford to strike down his flag a year early, when the fleet reorganisation took place in March 1909. Reginald Bacon, who was on his staff, was apprising Fisher and McKenna of Beresford's actions when Beresford went public with his criticisms, 'obviously a gross breach of duty,' McKenna complained to the prime minister. ${ }^{6}$ Quite apart from considerations of personnel and money, the strategic plans would be compromised by Beresford, whose removal from post, McKenna told Asquith, was 'really an integral part of the scheme. The friction between him and Sir John Fisher is too great to permit of any reorganisation being undertaken. ${ }^{7}$ Fisher told the king,

McKenna and the Prime Minister without any reference to me at all came to the conclusion that they could not trust Beresford in case of war ... McKenna told me he did not sleep for two nights thinking of Beresford.... He said he formed his opinion of Beresford from his

1. Jellicoe to RMcK, 24 February 1909 , Jellicoe papers, 48990/21.

2. Fisher to Edward VII, 3 January 1909, Royal Archives, KEVII W59/69; Bennett, Charlie B, 297-300; HHA to MA, 27 October 1909, MA papers, c.6690.

3. St. Loe Strachey to Sir William White, 10 July 1908, Strachey papers, $16 / 2 / 32$.

4. Arthur Lee, 4 July 1908, Times, 6 July 1908.

5. Fisher to Esher, 12 July 1908 , Esher papers, $10 / 42$.

6. RMcK to HHA, 19 October 1909, Asquith papers, 12/63.

7. RMcK to HHA, December 1908, Asquith papers, 21/8. 
interview with him-so he and Asquith had long consultation and decided it. ${ }^{1}$

Admiral King-Hall heard separately that 'McKenna demanded the Inquiry that neither Fisher, or Beresford did'. ${ }^{2}$ On 19 April 1909, Asquith undertook what would become an increasing feature of his premiership, the asphyxiation of a contentious matter by committee. ${ }^{3}$ It was in this instance an initiative fraught with risk. In the light of the mobilisation of the syndicate, Esher, for one, doubted that McKenna could prevail. ${ }^{4}$

The prime minister chaired the subcommittee of the CID, 'Appointed to Inquire into Certain Questions of Naval Policy raised by Lord Charles Beresford'. The other members were Grey, Crewe, Haldane, and Morley. The subcommittee met on sixteen occasions through the spring and summer of 1909, when over 2,600 questions were put to Beresford and McKenna, and forty-eight papers and dozens of witnesses were presented. The subcommittee witnessed an effective reversal of procedure as McKenna took the role of prosecuting counsel against Beresford, who had made the charges. ${ }^{5}$ McKenna obtained the not inconsiderable pledge from Fisher that he would remain silent, and the meetings consisted in large part of a running duel between McKenna and Beresford, with the former asking curt questions, and the latter replying, at length the exchange often engaging the personal. 'I am only a simple seaman and you are a very clever lawyer', Beresford said at one point. 'I am a lawyer of a very remote period', McKenna replied. 'You are less of a simple seaman than I am of a lawyer'. ${ }^{6}$

' $\mathrm{CB}$ made a tremendous hash of it all', George King-Hall noted. While Fisher 'hardly said anything, Beresford floundered tremendously, shewed much ignorance'? McKenna's approach was at times so enthusiastic that he found himself restrained by the prime minister. The restraint was significant, in light of subsequent strategic deliberation. Esher noted the prime minister's 'bias', intending as he was, in the interests of expediency, to force Fisher out of office and undermine McKenna's advocacy of increased naval

1. Fisher to Edward VII, 3 January 1909, Royal Archives, RA VIC/W 59/69.

2. George King-Hall, diary, 23 September 1909, King-Hall papers, Royal Naval Museum (hereafter RNM), Manuscript 2000/53 (18).

3. RMcK to HHA [draft], n.d., McKenna papers, 3/17/3.

4. Nicholas A. Lambert, Sir John Fisher's Naval Revolution (Columbia, 1999), 184-94.

5. Beresford subcommittee notes by first lord of the Admiralty, 23 April 1909 [copies of documents from June 1907], Royal Archives, RA VIC/X 729-32.

6. Report and Proceedings of a Sub-Committee of the Committee of Imperial Defence appointed to Inquire into Certain Questions of Naval Policy raised by Lord Charles Beresford, 1909, Cabinet papers, CAB16/9/1, 105.

7. George King-Hall, diary, 23 September 1909, King-Hall papers, RNM Manuscript $2000 / 53(18)$. 
estimates. ${ }^{1}$ McKenna enjoyed himself and impressed those present. ${ }^{2}$ It was, after several years of often disagreeable experience, exactly the type of situation in which he excelled.

Beresford had been unable to sustain a serious argument, but such was the sensitive nature of the episode that the report of 12 August 1909 amounted to the also increasingly apparent Asquithian casuistry: it was, as Fisher told McKenna, 'a cowardly document'. ${ }^{3}$ Knollys was 'disgusted' and explained that the king had invited McKenna to stay with him at Balmoral by way of compensation and approval. ${ }^{4}$ The final spasms were witnessed on the letters page of The Times, where Beresford went public with further allegations of 'intimidation and favouritism', and McKenna supplied 'specific contradiction proved by indisputable records' to each of 'the baseless and discreditable imputations which could only have been made by one who had forgotten his duty to the great service. ${ }^{5}$

The effect was a de facto victory for Beresford, a victory achieved in part by the committee being constituted at all, and its preoccupying the Admiralty for six months while producing no evidence of mismanagement. ${ }^{6}$ It did mean that Beresford, free from service ties could allege years of intimidation and favouritism, and the syndicate's discontent was unabated. ${ }^{7}$ McKenna told Asquith, 'imputations intimidation and favouritism, unless they can be established by unassailable evidence, are the most odious, the most cruel and the most subversive of the discipline of the Navy, of any that can be made. ${ }^{8}$

McKenna sought to deflect pressure in the Commons, and to discourage a sacrifice on the part of his friend, but Fisher knew he had to go. ${ }^{9}$ He resigned on 25 January 1910. The old adversaries had in fact managed to terminate the command of the other. Fisher retired, but remained in constant contact with the McKennas. Beresford was elected to acclaim as Unionist MP for Portsmouth, and, from across the floor of the chamber proceeded to attack 'that impudent scoundrel', the first lord of the Admiralty. ${ }^{10}$ The Westminster

1. Esher, diary, 14 May 1909, Esher papers, 2/12.

2. Hurd, Who Goes There?, 96.

3. Fisher to RMcK, 19 August 1909, McKenna papers, 6/2/112.

4. Knollys to Fisher, 19 September 1909 , Fisher papers $1 / 8 / 411$.

5. RMcK to HHA, 29 October 1909, Asquith papers, 23/18; McKenna papers, 3/18/56; Times, 1 November 1909.

6. Nicholas A. Lambert, Sir John Fisher's Naval Revolution (Columbia, 1999), 184-85; Bennett, Charlie B, 305; Morgan, Churchill, 243.

7. Hedworth Lambton to RMcK, 18 June 1909, Royal Archives, RA PS/GV/A 11b/3; Hedworth Lambton to Prince of Wales, 23 June 1909, Royal Archives, RA PS/GV/A $11 \mathrm{~b} / 1$.

8. RMcK to HHA, 27 October 1909, [RMcK, 88].

9. RMcK to Sir Arthur Wilson, 20 October 1909, Royal Archives, KEVII WR59/89.

10. In Bennett, Charlie, 308. Curiously, in Beresford's memoirs, the dramatic years of 1907-9 occupy five pages out of 576 (Beresford, Memoirs, vol. 2). 
Gazette depicted the clash as one of ego. More substantively, the subcommittee had implicitly criticised the Admiralty for its entrenched resistance to a naval staff, however rational the resistance to 'the general staff obsession' may have been. ${ }^{1}$ The matter remained unresolved, but not forgotten.

McKenna was convinced that Lloyd George, Churchill, and Haldane, three whom Fisher called 'The New Trinity', ${ }^{2}$ wanted him out. McKenna felt Asquith 'and the rest of them dead against him now', as Fisher told Esher. 'The whole Cabinet want to get rid of him.' ${ }^{3}$ The cumulative effect was further to demoralise an already demoralised man particularly when, as Pamela told him, it was at least partly his own fault,

The impression about you which seems to be current is that you are actually anxious to leave the Admiralty and get out of the Government altogether, and that you don't care for the work there. I am all for this being nipped in the bud as I think the P.M. would mind rather if he heard it on substantial evidence. It may partly account for the wirepullings of Admiralty aspirants and would excuse them to a certain extent. ${ }^{4}$

\section{COURT}

Having flirted with republican sentiment, or at least with republicans, in his advanced radical days McKenna now found himself one of the ministers with the closest contact with the court. At Balmoral and Windsor, royal misgivings as to his appointment were soon revised. Knollys told Asquith, in a note he forwarded to Pamela, that 'I believe you think highly of $\mathrm{Mr}$ McKenna, and I think therefore you may like to know that he made a most excellent impression on the King when he saw him today. ${ }^{5}$ McKenna could not reciprocate.

Staying at Windsor is not as pleasant as at Balmoral or Sandringham. We have our own retired quarters, but directly we emerge into the state rooms there are crowds of footmen, court officials and guests standing about somewhat aimlessly, and for about twenty minutes before each meal and for an hour after there is an interchange of banalities which I find most exhausting. ${ }^{6}$

1. Bridge, 'Staffs', 85.

2. Fisher to Goulding, 15 January 1910, Fisher, Correspondence, 2:285.

3. Fisher to Esher, 27 August 1909, Esher papers, 10/43.

4. PMcK to RMcK, [13 January 1910].

5. HHA to PJ, 18 May 1908.

6. RMcK to PJ, n.d. [c. 1908]. 
He pleaded to Pamela to 'take me away from Courts and never let me see them again."

It was to his disadvantage therefore that McKenna's Cabinet differences appeared to work in his favour. 'Beauchamp said Lloyd George had been left out of the Castle invitations on purpose', Margot noted in December 1909, 'and when I asked him why McKenna's shares were up in Royal circles he said he thought it was because the K[ing Edward VII] knew McKenna hated L. George.'2 There were some breaches of royal protocol. ${ }^{3}$ In June 1908, the king made the tsar of Russia an honorary admiral of the fleet, with the result, Knollys admitted, that McKenna 'had been much "put out", which elicited a letter of explanation. ${ }^{4}$ McKenna reciprocated in April 1909, when the king, cruising from Biarritz, decided to call on the Duke of Connaught at Malta. Once there, he discovered that, rather than awaiting his arrival, the fleet had been ordered away on manoeuvres. "King Edward was perfectly furious and in his rage became most unreasonable", recalled his equerry, Frederick Ponsonby. The king complained to Asquith, who 'sent ample apologies, but McKenna showed fight', and said that it was not always possible to acquaint His Majesty immediately of changes to plans and did not apologise. $^{5}$

In May 1910, the Asquiths and McKennas went off on another cruise on the Enchantress, to Portugal. It was a comfortable cruise, though Asquith's ear was as ever sensitive to Ernest, 'leading the hymns, in the absence of any other instrument, with cool courage and gusto, ${ }^{7}$ while 'McKenna is in his usual form, quite unassuaged by the Session, full of high spirits \& slapbang judgements, and crude nursery pleasantries' ${ }^{7}$ They reached Lisbon on 4 May and dined with King Emanuel II. By the time McKenna and Asquith had reached Gibraltar, Knollys had wired from London that King Edward had fallen critically ill. The Enchantress immediately turned and headed for Plymouth, but during the voyage the passengers were informed that the king had died. After dinner that night, McKenna and Asquith sat on deck and

1. RMcK to PJ, n.d.; but see RMcK to Edward VII, 8 November 1909 , McKenna papers, $1 / 3 / 2$.

2. MA, diary, 12 December 1909 , MA papers, d.3207/210; HHA to MA, 3 August 1909, MA papers, c 6690/190-1.

3. Unsigned note, telegram copy/draft [private secretary] to RMcK, 20 April 1909 , RA VIC/X 5/31; copy of telegram sent in reply to RMcK from private secretary, 21 April 1909, H. M. Yacht Victoria and Albert, Malta; RA VIC/X 5/32; RMcK to [Edward VII], 21 April 1909, Malta, RA VIC/X 5/33; F. E. G. Ponsonby to RMcK, 24 April 1909, Malta, RA VIC/X 5/36; RMcK to Knollys, 27 January 1909, RA VIC/W 59/70; RMcK to Edward VII, 17 January 1909, RA VIC/W 59/71. HHA to MA, 4 May 1910, MA papers, c.6690/224-25.

4. Knollys to HHA, 15 June 1908, Spender, Asquith, 1:250; Fisher to RMcK, 12 June 1908, McKenna papers, 3/4/13.

5. Ponsonby, Recollections, 260-61.

6. HHA to MA, 1 May 1910, MA papers, c.6690/222-23.

7. Ibid. 
watched Halley's Comet crossing the sky. Spender thought, 'McKenna has lost a good and powerful friend', ${ }^{1}$ others blamed him for the king's demise. On their return, one story went, they were taken by the queen mother to the lying in state on 11 May and told, 'Look at your work!!!'2

With Edward's passing and George's accession, McKenna was appointed to a coronation committee of thirty-nine members, which also included the archbishop of Canterbury, the prime minister, Balfour, Austen Chamberlain, Lloyd George, Grey, Haldane, and Churchill, though he had rather more to do, since the vaunted naval review fell under his purview. ${ }^{3}$ On 22 June, McKenna and Pamela attended the coronation at Westminster Abbey. Afterwards they watched the procession from Admiralty House with an improbable party of Indian Nationalists in Emily Lutyens, Annie Besant, and Besant's imported stars of Indian spiritualism, Nitya Murti, and Jiddu Krishnamurti, crippled by his wearing of shoes for the first time. ${ }^{4}$ A no less uncomfortable trio of McKenna, Churchill, and Lloyd George, in his capacity as constable of Caernarvon Castle, processed together at the investiture of the new Prince of Wales in July 1911. McKenna was already wellacquainted with his younger brother, as keeping the new George $V$ informed of the progress of the future George VI through Osborne and beyond was one of his responsibilities. ${ }^{5}$ After the Archer-Shee scandal, the queen told McKenna, 'I have no doubt that the boy was guilty. I do not wish my sons to associate with a thief!' 6

Relations with the new sovereign began well. One evening at Balmoral, McKenna was playing bridge with the king and two other European heads of state. 'I doubt that you often play with three Kings, Mr McKenna', said His Majesty. 'No, sir', the first lord of the Admiralty replied, 'I usually play with four'. ' They soon floundered. 'The King,' Asquith told McKenna, 'at our interview the other day, begged hard that in February next C. Beresford might be made an Admiral of the Fleet - of course on the understanding that his career was at an end'. 'My answer will be a clear and unqualified negative', he told Pamela. 'I do not conceive that I should be acting in accordance

1. Spender, in Wilson Harris, J. A. Spender (1946), 119.

2. Edward Marsh to Dorothy Gladstone, 20 May 1910, in Hassall, Marsh, 156.

3. RMcK to Stamfordham, 16 June 1911, RA PS/GV/PS 56078/15/758; Stamfordham to RMcK, 17 June 1911, RA PS/GV/PS 56078/15/759; RMcK to Stamfordham, 19 June 1911, RA PS/GV/PS 56078/15/761/COR. There had been some practice: RMcK to Stamfordham, 5 April 1911, RA PS/GV/PS 04248/4/205; RMcK to Stamfordham, 27 April 1911, Royal Archives, RA PS/GV/PS 04248/4/209/VISUK; Fitzroy to RMcK, 19 July 1910.

4. Lady Emily Lutyens, Candles in the Sun (1957), 33.

5. RMcK to Prince of Wales, 17 December 1908, RA VIC/W 77/135; RMcK to Prince of Wales, 20 November 1908, RA PS/GV/O 2573/16; RMcK to Prince of Wales, 7 August 1908, RA VIC/W 77/125.

6. PMcK, diary, 5 October 1910.

7. DMcK in conversation with the author.

8. RMcK to HHA, 26 December 1910. 
with my duty to make the recommendation. My reply to the P.M. will be built up by careful and slow degrees, and I shall probably not send it off till after my return home.' It was, and he did. The grounds he gave were that the king did not fully understand the regulations over promotions; moreover, unlike Wilson, Beresford was no longer at sea. ${ }^{2}$ Beresford received the Grand Cross of the Bath instead. 'Even supposing McKenna had any faults', Fisher told Churchill, '(and I do not admit that he had any) ${ }^{3}$ his 'dead body stood in the way. ${ }^{4}$

McKenna soon dreaded his royal visits. He found 'the Court atmosphere that of Rehoboam and the young bloods gave him the cold shoulder'. ${ }^{5} \mathrm{He}$ told Pamela that he had 'done my best to make myself agreeable to both King and Queen. I have spared no pains also with the Duke of Connaught, who is here, but I do not feel confident that the bread I have cast on the waters of Trinity House will come home to me. ${ }^{6}$ When the elder brethren of Trinity House unanimously elected McKenna to be made an elder brother, 'The king scratched out McKenna's name + inserted Lord Crewe's name!', Fisher told Jellicoe. 'So you see how the wind blows!?

\section{0}

\section{A General Election}

On or about 1910, a great deal happened. In between two general elections and a new head of state, McKenna became a father, and almost died. In addition to that of Peckham, for which McKenna was personally blamed, the Liberal Party had lost seventeen by-elections since the 1906 general election. Already weakened by the strains of office, the government chose to confront the Unionists in the Lords on the central constitutional issue of the century: the primacy of the elected house of Parliament over the nonelected. The latest of a series of challenges, of which the education bills were earlier examples, Lloyd George's budget, which developed the fiscal reforms of the Asquith-McKenna Treasury, had been rejected by the House of Lords, which claimed that the electorate had first to be consulted. 'If we get the election for which L.G. and Winston are working it will be an easy one.

1. RMcK to PMcK, 29 December 1910.

2. RMcK to HHA, n.d., McKenna papers, 3/18/1-5.

3. Fisher to Churchill, 22 April 1912, Churchill papers, CHAR 13/14/99-107.

4. Fisher to Hankey, 29 January 1911, Hankey papers, 5/2a/6; RMcK to HHA, 7 January 1911, Asquith papers, 24/3-10.

5. Fisher to John Leyland, 1 February 1911, Fisher papers, 3/5/2126; PMcK, diary, 22 October 1911.

6. RMcK to PMcK, n.d. [October 1910].

7. Fisher to Jellicoe, 9 May 1911, Jellicoe papers, 49006/11; Baddeley to RMcK, 6 May 1911, McKenna papers, 3/17/16; RMcK to Knollys, 29 January 1910, RA VIC/W 59/102; Fisher to PMcK, 30 March 1914, in Fisher, Correspondence, 2:501. 
But who could wish for ease on such terms? I can't help feeling gloomy', McKenna told Pamela in September 1909. ${ }^{1}$ During his post-Beresford stay at Balmoral, he discussed the crisis with Knollys, the King's Private Secretary, and in so doing briefed tutoring.

It is not too much to say that the rejection of the Finance Bill by the Lords would be a violent breach of the established constitutional practice, and would call for an immediate definition and limitation of their powers by statute. No two principles are more firmly settled in the constitution than that the House of Commons is alone responsible for taxation, and that it is only by a vote in that House that the life of the Government of the day can be terminated. Yet the action of the Lords in rejecting a Finance Bill would amount to a denial of both these principles, and no government could remain in office unless it were guaranteed against similar action by the Lords in future. ${ }^{2}$

Since a Finance Bill - the budget-had to be passed every year for the administration of national services to be maintained, the Lords could force an election any year they chose. 'But as it happens, in the actual circumstances of our financial procedure, the country never could give its verdict in advance upon the fiscal proposals of the Government. Taxation must be levied according to the actual requirements at the time.' If the Lords rejected the present Finance Bill, a budget deficit would soon accrue, forcing the chancellor to propose more severe taxation in the subsequent budget to compensate, which the Lords could again claim had not been sanctioned by the public. 'A Finance Bill has never been thrown out by the Lords. To reject the present one would be the first step in a revolution', McKenna went on. A Commons returned after an election on the issue "will not be of a mild temper, and the most moderate of its members will be convinced that the destruction of the House of Lords is inevitable'. ${ }^{3}$

While McKenna was at Balmoral, Pamela took Haldane to Mells for the weekend. 'He seems quite convinced that the Lords will throw it out and that there will be an early election and that we shall lose about 150 seats but I hope he prophesies vainly', she told her husband. ${ }^{4}$ Haldane did not prophesy above. 'Secret-the Chief Conservative Agent told a friend of mine they expected a majority of seven', Fisher told Pamela. 'Neither he nor anyone else knows which way the great silent vote is going to be cast. The ominous

1. RMcK to PMcK, 1 September 1909.

2. RMcK, 28 September 1909, 'Notes of a conversation with Lord Knollys on Sep 27th 1909', RA VIC/W 66/90.

3. Ibid.

4. PMcK to RMcK, n.d. 
thing-more rats than ever before known from the Liberal ship! No rat has left the other!'1

After forty-two days' debate, the Commons passed the budget on 4 November. On 30 November, it was debated in the Lords. 'All vestige of eloquence, if they ever possessed any, seem to forsake these men when they rise to defend their unearned monopolies against the claims of the poor', Pamela wrote from the ladies' gallery as the bill was rejected. 'Invective and exaggeration are their only substitute and of these they partake freely.'

Out in the streets crowds were booing and howling out insults as we went home. This act of the Lords had been in no sense unimpressive to the onlookers in spite of the overcrowded benches weighed down by the burden of unknown peers, and the gallery of huddled rows of peeresses. It left only a feeling that they had taken a step leading to something quite unrealised and had deliberately opened the flood-gates upon their own preserves. ${ }^{2}$

'Feeling is very strong, I find, in the country', McKenna told Knollys in December. ${ }^{3}$ The contesting of democracy, as represented by Liberal, Labour, and Irish Nationalist MPs, by the aristocracy, specifically Unionist peers, suitably, would be a constitutional crisis, and a constitutional conference to resolve it, and produce two general elections in 1910 by way of arbitration. 'There is a real interest in the constitutional question quite unlike the apathy in London,' McKenna went on. 'I want to see the question settled in favour of the Commons, but I don't want to see a triumph for the irrational section with its inevitable sequel of violent reaction.' ${ }^{4}$ On 2 December, from the ladies' gallery in the Commons, Pamela witnessed 'the last division of what was perhaps the most remarkable House of Commons there has ever been.'

Starting its work with such promise and an almost unprecedented majority it seems cruel looking back on the four years of arduous toil that so little has been accomplished and that only one of our really important legislative measures should have been placed upon the Statute Book. It is a great pride and happiness to me to know that $\mathrm{R}$ was largely responsible for hurrying on the Old Age Pensions Act in spite of considerable opposition in the Cabinet. The debate ended early and the members streamed away. There was something sad about this leavetaking, meaning as it must a shut door to so many lives, but I do not

\footnotetext{
1. Fisher to PMcK, 28 December 1909.

2. PMcK, diary, 30 November 1909.

3. RMcK to Knollys, 3 December 1909, RA VIC/W $59 / 94$.

4. Ibid.
} 
doubt that everyone felt assured as to the result of the coming election and well-equipped for the struggle with the weapons of justice. ${ }^{1}$

Asquith announced an election, and on 10 January, the Parliament elected in 1906 was dissolved. The campaign was ostensibly fought on the issue of the budget and, as the government presented it, over the democratic settlement. To that end, McKenna was unusually strident and inflated in his rhetoric and, equally unusually, personally supportive of Lloyd George in the 'end v. mend' controversy. 'I cannot believe that the electorate of this country will endorse the pretensions of the Peers to control taxation,' he told his constituents, 'or will tamely acquiesce in this violent usurpation of the Commons' rights'. ${ }^{3}$ It was also, for McKenna, an election contested against Lloyd George's overt resistance to McKenna's naval programme, and his own covert receptiveness to the idea of coalition.

The characteristics of his constituency required McKenna to accommodate the concerns of labour. In Llanhilleth, he declared that there was no subject more worthy of legislative time than the Mines Regulation Bill, providing for greater safety underground. Free trade was presented to an audience at Abergavenny as the means by which Monmouthshire coal was exported, and at Upper Cwmbran as underpinning the tinplate industry. Another issue was more recent, and more sensitive. 'The Osborne judgement is disturbing me', McKenna confided to Vinbad. 'I shall be questioned hotly at my meetings in Monmouthshire, and I must get up my case with some care. ${ }^{34}$ In 1908, W. V. Osborne, a railway porter and an active Liberal, won an action against his union using its funds, to which he contributed, to support the Labour Party. McKenna advocated the payment of MPs as an alternative to a strict political levy, and that, although nothing should be done to discourage trades union representation in Parliament, a single party so charged was politically unhealthy and subject to the same principles as the repudiation of church rates: 'religious doctrine, a man's faith, and a man's political views were not to be subject to the decision of the majority ... it was therefore for them to decide the case under consideration on its merits. ${ }^{5}$ In private, Pamela noted, 'Reggie and the Prime Minister are of the same opinion that a reversal is out of the question, though some solution must be found. ${ }^{6}$

McKenna began his campaign at Pontenewydd, proclaiming 'that the issue of the election was, in a word, the abolition of the veto of the House

1. PMcK, diary, 2 December 1909.

2. Don Cregier, Bounder from Wales: Lloyd George's Career Before the First World War, Columbia, 1976, 144.

3. RMcK, 4 January 1910 , election address.

4. RMcK to Baddeley, n.d.

5. RMcK, 11, 18, 25 October 1910.

6. PMcK, diary, 4 October 1910. 
of Lords'. ${ }^{1}$ The meetings were excellent, particularly since they involved an element of reeducation. 'The drum is still reverberating from the rigorous thumps. The doubts about my being in earnest had to be cleared up, and cleared they are. I wish you had been there', he told Pamela. 'A small deputation of three came to see me in the afternoon to tell me that it would be a good thing if I made an unmistakable statement about the veto of the Lords. They did not ask for their abolition', and nor did he offer it. Instead, he displayed a grasp of the technique that came so easily to some of his colleagues. 'Would you believe it, I did not abuse a single Lord, and I did not say in substance one word more than I had said at Pontypool. The whole difference lies in thumping the table and squaring your shoulders and declaiming that the People must prevail.'2 He nevertheless remained without his greatest electioneering asset. When she had been able to attend preelection rallies, Pamela transformed her husband's reception. She addressed meetings herself, with supportive but noncommittal observations on female suffrage, and became a greatly popular visitor to the constituency. Pamela had also been learning Welsh. ${ }^{3}$ Often the pair would address meetings in tandem, allowing for a rapport with each other and with the audience that was enthusiastically received and effectively reproduced in the following day's newspapers, the appeal of Pamela's contribution the more marked after another disquisition on free trade by her husband. 'Three cheers for Mrs McKenna! This is the popular cry at all my meetings."

The election approached. Pamela had also fallen pregnant. 'It is rather hard upon you to be kept out of the fray, but do not imagine that I pity you', Birrell told her from the hustings. 'Oh daughter of Jerusalem! It is for myself and my likes that I weep copious tears. ${ }^{5}$ McKenna set off, driven by Ernest, on his first full campaign for ten years. At each meeting, the crowds shouted 'we want Dreadnoughts' ${ }^{6}$ For once, both his office and his outlook corresponded with those of the yellow press. He received supportive coverage from the Daily Mail and The Times. 'Is fairness beginning to oust party prejudice from the arena of controversy?' Pamela, cloistered but engaged, asked him. 'Did you see that in Benn's constituency his opponent's sister-inlaw was stoned while on a round of canvassing? Isn't it splendid. I couldn't help being pleased."

Unable to take part in her first campaign, Pamela was also confined to Admiralty House, reading about how even the naturally gifted appeared to struggle with the extent of the thumping, squaring, and declaiming. ' $I$

1. Manchester Guardian, 7 October 1910.

2. RMcK to PMcK, n.d. [c. January 1910].

3. Times, 7 August 1913.

4. Ibid, 14 January 1910.

5. Birrell to PMcK, 15 January 1910; PMcK to RMcK, McKenna papers, 1/3/4.

6. Western Mail, 19 January 1910.

7. Ibid., n.d. [7 January 1910]. 
glanced at Winston's speech this morning', Pamela told her husband, 'and gathered that he had had the same difficulties and brain-wrecking over suitable subjects as others and I did not think his utterance a very exciting one.' While, on occasion, she tolerated 'Ll-G's burlesque style', ${ }^{2}$ repeated exposure 'makes me sick ... Isn't it disgusting and unseemly and unfit. Greeted I observe with "great cheer and laughter"' ${ }^{3}$ When she was in Downing Street she realized that 'George is getting more and more drivelly and can't talk about anything except what the newspapers say about himself.' ${ }^{4}$

However positive the feeling in South Wales appeared to be, nationally there was little sense of the 1906 procession. 'I have a sort of feeling that things aren't going quite so well for us', Pamela reported from London. 'Not so personally but the party as a whole. Perhaps this is owing to the gap made by the silence of the muzzled peerage-for certainly the sound of those voices, not stilled, gave one a sense of elation and of coming triumph'. ${ }^{5}$

One positive feature of the campaign for the party was that for which McKenna was responsible. Notwithstanding his preference that 'it is most desirable that the Navy should, so far as is possible, be set above party differences' ${ }^{6}$ during both elections, the Admiralty became, effectively, a party political institution. Naval matters required McKenna and his private staff to engage-to an extent recognisable at the end of the century-in briefing Liberal candidates and rebutting allegations in 1910 on the part, most notably, of Duke of Marlborough and F. E. Smith, as well as more predictably of Mulliner and Beresford. ${ }^{7}$ Moreover, McKenna could also respond favourably to entreaties from Liberal candidates that ships remained in dock until the ballots were closed to maximise bell-bottomed support. ${ }^{8}$ Still, such was his confidence in the Liberal message on the navy-or at least that for which he as first lord of the Admiralty was responsible-that he publicly gave credit to Balfour for his regime at the Admiralty during the campaign. ${ }^{9}$

It did not seem to be enough. 'Everyone I love miserable and fresh calamities every day', Pamela told Vinbad, 'but the interest and excitement of the G[eneral] E[lection] is bound to dwarf one's private feelings and we are

1. Ibid., n.d.

2. Ibid., n.d. [7 January 1910].

3. Ibid., n.d. [13 January 1910].

4. Ibid., n.d. [11 January 1910].

5. PMcK to RMcK, n.d. [11 January 1910].

6. RMcK, 8 June 1909, Hardman, Parliament, 154; Birkenhead, Sunday Times, 1 June 1923; RMcK to Northcliffe, 14 October 1911, Northcliffe papers, 62157/8687; Duke of Connaught to Princess Louise, 8 November 1911, Companion, 2:2, 1325. Nunburnholme to RMcK, 7 April 1909, McKenna papers, 3/14/18; RMcK to Nunburnholme, 20 April 1909, McKenna papers, 3/14/18(2).

7. Arthur Crosfield to RMcK, 17 December 1909, 20 December 1909; RMcK to Robert Skinner, 23 December 1909.

8. J. W. Benn to RMcK, 30 December 1909.

9. Manchester Guardian, 14 January 1910. 
wonderfully blessed in our constituency.' "I believe I shall have a good majority, but like you I am conscious of an impression, springing from no clear or defined source, that things are not quite as well with us as meetings indicate', her husband confirmed. 'If there is a liberal majority at all in the next House of Commons, I shall be satisfied. I have heard of no defections here, but one or two people have shaken their heads over L1.-G., and if our stalwart active politicians do this, what is the fireside man saying?'? Nevertheless, 'I feel in such good spirits that even Miss Megan cannot depress me', McKenna told Pamela, after a visit from Lloyd George's daughter. 'So far as I can judge we shall do well at the election, but I cannot hope for a majority like the last.' ${ }^{3}$ Indeed, ' $[\mathrm{I}]$ am not sanguine enough but my prophecy is ten more for us', he told Margot. 'I hope to get at least 8000 promises and if this expectation is realised my majority will hardly be less than in 1900 . However, I don't build on this but am prepared to see what has happened everywhere else, a moderate reduction.' ${ }^{5}$ Two days before the vote, he told Pamela:

My opinion of the elections is that they are entirely satisfactory. We must not let our judgement be carried away by the spirit of the fight. Before the elections began we decided that tariff reform must be defeated and that George must not have a victory. The big towns have smashed tariff reform, the little towns have knocked George over. I want the Government to have a very small majority over Conservatives and Irish, and if the Counties show the same temper as the Boroughs we shall just achieve this result. I am sure this solution would be best for the permanent interests of the country; and as you said, the electors are showing "divine taste". ${ }^{6}$

It was for that reason that he also told her, 'The next election, which can't be far off, we shall fight together, and then you will see how popular you are in North Mon."

\footnotetext{
1. PMcK to Baddeley, n.d.

2. RMcK to PMcK, 12 January 1910.

3. Ibid., 14 January 1910.

4. RMcK to MA, 14 January 1910 , MA papers, c. $6679 / 95$.

5. RMcK to PMcK, 18 January 1910.

6. Ibid., 19 January 1910.

7. Ibid., 18 January 1910.
} 
Polling day was 21 January. ${ }^{1}$ At least three different results were recorded in the next day's press, but the majority remained over 4000 votes-reduced, but on a higher turnout. Afterwards, with Ernest and Theo in attendance, he was carried shoulder high from Abergavenny Town Hall to the Angel Hotel. In the meantime, McKenna immediately went off with Ernest and the Birrells on a short golfing holiday in Sussex, where "we have gossiped on the old familiar themes-what Grey will do, and how Lloyd George has come down in value and all the personal topics you know by heart'. ${ }^{2}$

Haldane had predicted a loss of 150 seats-the Liberals lost 125 . More of the electorate had endorsed the 'pretensions of the Peers' than McKenna had expected. The Liberals had two more seats than the Unionists, who had gained 116. The Liberals now depended on the 122 Labour and Irish MPs for their majority. The king opened the new Parliament on 21 February. "We are swimming in calmer waters, a little battered by the storm, but at least with our heads topping the waves', the first lord of the Admiralty concluded.

If our honour is not quite unsmirched at any rate we shall be in a position to lay some sort of intelligible policy before the country. The more I consider our course during the last three weeks the more convinced I am that we made a great mistake not to face up at once to the budget:- carry out the P.M.'s pledge that our first act would be to legalise the taxes, and leave who would vote against us. However the opportunity is gone, and for a second best I think we are now doing the right thing. If we manage well the crisis will be averted till June whereby we gain two great advantages, time to table our House of Lords policy and the use of the Enchantress in the spring recess. ${ }^{3}$

\section{A Hoax}

McKenna's warnings about German naval expansion were soon rubbished. He was held, in his way, of having provided an official imprimatur to the alarms that Erskine Childers had summoned at sea, William Le Queux on

1. General election, Monmouthshire, North, 21 January 1910.

\begin{tabular}{lrl}
\hline Total electors & 15,711 & Share \\
Rt. Hon R. McKenna (L) & 8596 & $66.5 \%$ \\
E. G. M. Carmichael (U) & 4335 & $33.5 \%$ \\
Liberal majority & 4261 & $33.0 \%$ \\
\hline
\end{tabular}

2. RMcK to PMcK, n.d. [c. February 1910]; RMcK to PMcK, 22 January 1910.

3. RMcK to PMcK, 1 March 1910. 
land, and H. G. Wells in the air. ${ }^{1}$ To the general conflation of the literary and the military, in February 1910, a small party, all friends of Pamela, including the future Virginia Woolf, her brother Adrian Stephen, and Duncan Grant, and organised by Neville Chamberlain's brother-in-law Horace Cole, pretended to be the emperor of Abyssinia and party and procured a tour of HMS Dreadnought moored off Weymouth. They declined the offer of an eighteen-gun salute. After varying expressions of amusement and indignation by the press, McKenna had to answer in Parliament about the breach of security, and to deny that Admiral Sir William May, commander-in-chief Home Fleet, had asked him for permission to wear the Royal Abyssinian Order. ${ }^{2}$ Pamela made it known to Adrian that an apology might mean the Admiral escaped censure. They agreed to confess to the first lord of the Admiralty, who called them into his room at the Admiralty. When 'Adrian and Mr Grant saw McKenna[, hel merely laughed at them, and advised us not to do it again', Virginia told Violet Dickinson the following day. ${ }^{3}$ Adrian claimed when they revealed their reason for calling on him-to save the admiral-McKenna 'would have none of it, and bundled us out'. ${ }^{4}$ Either way, as Virginia put it, 'the whole affair is at an end; and without a scratch.' The whole affair saw the latent intention to ridicule masculine pomposity deflated. Moreover, Woolf recalled, 'I think that Mr McKenna was secretly a good deal amused, and liked the hoax, but didn't want it repeated. At any rate, he treated them as if they were schoolboys, and told them not to do it again'. 5

The first lord had been in a good mood. On 31 January 1910, in the great high room at Admiralty House, Whitehall, Pamela gave birth to their first child. Nurse Keithie ushered Michael McKenna into his first day, and the dean of Westminster, in Westminster Abbey, in the presence of Bar, Michael's godmother, and Fisher and Asquith, his godfathers, christened him on Pamela's birthday, 10 March. The prime minister and company 'lustily renounced all the works of the devil on behalf of the infant Michael-a nice well mannered little thing' ${ }^{6}$

1. Erskine Childers, The Riddle of the Sands (1903); William Ie Queux, The Invasion of 1910 (1906); H. G. Wells, The War in the Air (1908). See Christopher Lane, 'The Unrest Cure According to Lawrence, Saki, and Lewis', Modernism/Modernity 11 (2004): 769-96.

2. Parliamentary Debates, 24 February 1910, 339-40; Parliamentary Debates, 2 March 1910, 832.

3. Virginia Stephen to Violet Dickinson, n.d. [27 February 1910], in The Flight of the Mind: The Letters of Virginia Woolf, vol. 1, 1888-1912, ed. Nigel Nicolson (1975), 59; ADM 1/8792. See Peter Stansky, On or About December 1910: Early Bloomsbury and Its Intimate World (Cambridge, MA, 1996), 17-46.

4. Adrian Stephen, The 'Dreadnought Hoax' (1936), 44.

5. Virginia Woolf, 'Summer 1940', in Virginia Woolf, a Biography, by Quentin Bell, 2 vols. (1972), 1:214-15.

6. HHA to MA, 11 March 1910, MA papers, c.6690/213-14. 


\section{Reginald McKenna}

\section{A Crisis}

As the constitutional crisis grew in intensity, McKenna was concerned about the prospects of compromise. In the spring, Grey told the prime minister that in the absence of a commitment for reform of the House of Lords, he would resign, which prompted McKenna to declare, 'I have but one clear view and settled determination, that if Grey goes out I go too.' ${ }^{1}$ McKenna privately pressed for 'a full reform by the establishment of a second House based on democratic election only ... Cardinal importance attaches to the declaration that there must be two chamber government and that the second chamber must be based on election ... and that the hereditary principle is doomed.'

By the summer and the constitutional conference with the Unionists, McKenna had become thoroughly depressed at the prime minister's 'weakness', which he described as being 'worse than ever'. 'The political situation is clouding over again and it looks as if we were about to be wrecked on the Irish rocks', Pamela wrote in her diary. 'A conference is almost decided upon between the leaders of both parties to settle the question of the $\mathrm{H}$ of $\mathrm{L}$. How any agreement can be reached is almost incredible and the idea is very unpopular with our people. ${ }^{4}$

Three days later, they stayed with Fisher at Kilverstone in Norfolk. 'It is a little sad to see this man of boundless energy and initiative planted out in a backwater where he is not even his own master', Pamela admitted.

He spends his time writing letters and patiently mowing the lawn and counting how many strawberries are ripe and seems to take kindly to an almost unmitigated vegetable existence. His children are very good to him and he seems perfectly contented though I can't help feeling that deep down his spirit must surge and beat against the prison bars. ${ }^{5}$

They left Norfolk for a tour of the constituency. "We walked about among constituents talking about our "beloved King", and the prospects of the Liberal Cause and how much Michael weighed. They are always touchingly enthusiastic and interested and I love seeing them', Pamela wrote. 'All of the people we talked to were violently opposed to the idea of a conference and assumed that the King had specially requested it. ${ }^{6}$ She had not talked to Lloyd George. According to Hobhouse, by the chancellor's plan McKenna

1. RMcK to Runciman, 28 March 1910, Runciman papers, 35; Runciman to RMcK, 27 March 1910, McKenna papers, 3/22; Grey to HHA, 25 March 1910, in C. F. G. Masterman, a Biography, by Lucy Masterman (1939), 158.

2. RMcK to Runciman, 28 March 1910, Runciman papers, 35.

3. Hilda Runciman, diary, 12 May 1910, Runciman papers, ADD/3.

4. PMcK, diary, 7 June 1910.

5. Ibid., 10 June 1910.

6. Ibid., 13 June 1910. 
was to have been sacrificed to Balfour, ${ }^{1}$ while F. E. Smith told Chamberlain, 'I believe they mean to shunt our friend McKenna whom they hate'. ${ }^{2}$ Since January, even the foreign press had been predicting 'a joint Cabinet be chosen from the most moderate men of both parties', and which would therefore exclude McKenna. ${ }^{34}$

He wrote to Pamela from Balmoral.

L.-G., who made the happiest impression on both King and Queen, told the former that he was prepared to find five millions for the navy next year. Not content even with this expression of goodwill towards national defence he went on to declare himself in favour of universal compulsory military training. He put it on the ground of discipline and of the good physical results obtained. But neither the King nor the Conservatives will trouble about his reasons so long as he helps in getting them what they want. Perhaps L.-G means to make this his bridge for crossing over. ${ }^{5}$

Amid such suspicions, the resolution of the constitutional crisis was haltering, and McKenna resented the continual leaks to the press. ${ }^{6}$ He later recalled:

I don't think the proposal in the summer of 1910 went as far as a Coalition, although it would have led to a Coalition. Outstanding questions under four principal heads, I think Home Rule, the House of Lords, Colonial Preference, and one other which I forget, were to be settled on the basis of compromise. The Tory members of the Conference were naturally very much taken with the project, as it would invariably have led to a Coalition Government in which they would have shared. Those outside to whom the facts became known were incensed?

Outside, the McKennas spent August with the Ernests at Etrêtat, and in October went to stay with the Asquiths at Archerfield. ' $\mathrm{R}$ actually had a long talk with Henry about politics and came away very happy at seven and

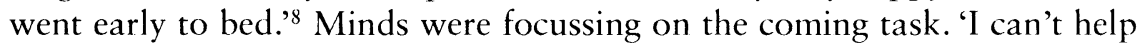

1. Charles Hobhouse, diary, 4 November 1910, in Inside Asquith's Cabinet: From the Diaries of Charles Hobhouse, ed. Edward David (1977), 98.

2. F. E. Smith to Austen Chamberlain, 21 October 1910, in Frederick Edwin, Earl of Birkenhead, by 2 nd Earl Birkenhead, 2 vols., 1:208.

3. New York Times, 31 January 1910.

4. RMcK to Runciman, 28 March 1910, Runciman papers, 35.

5. RMcK to PMcK, n.d. [1910].

6. RMcK, 22 July 1910 , McKenna papers, $3 / 17 / 8$.

7. RMcK to Bernard Mallet, 18 May 1920; Spender, Journalism, 1:159.

8. PMcK diary, 8 October 1910. 
feeling we shall have an election after Xmas and Margot talked of it as a probability.'

$\mathrm{R}$ and I went for a four mile walk along the lanes and came to the conclusion that we both suffered from mental laziness-so appalling was the prospect of two weeks of campaigning with the nightly effort of a 'rousing' speech. However we agreed that it is a healthy stimulus for our spiritual welfare. ${ }^{2}$

It was. A meeting in Blaenavon was 'much the most exciting so far', Pamela told Aggie. 'A band came out to meet us with a crowd of cheering children and men carrying torches. All the time little children who can hardly speak scream out, "Dozah for Kenna" which is rather sweet." Pamela described the campaigning of 18 October 1910.

People of all sorts came to see us from 9.30 onwards. $\mathrm{R}$ held a large deputation of coal mine representatives, and they asked us to lunch after. A long and rather tiring meal beginning with soup and ending with bread and jam. Then a blessed hour of comparative isolation darkened by speech-writing before we dressed for dinner at 4.45 . Then swallowed some undesired eggs and bacon and marched over to Pontypool in the rain where we met Rhys Stephens and Mr White of Blaenavon and proceeded with them up the mountain. We waited at Mr White's house where two rival bands came down to meet us and played alternatively which was grimly reminiscent of the King's funeral procession. They were supplanted by an enormous crowd of children like the Pied Piper of Hamelin, who cheered and sang the familiar strain of [notation] 'Vote boys, Vote for our McKenna, Vote for Reggie and re-form' which warmed the cockles of my heart. The whole town turned out with torches which I always love and walked with us for a good half mile to the hall, where we were given what's called a 'rousing reception'. It is a fine hall and holds over 2,000 people and was crammed. R spoke on the Osborne Judgement which is skating on thinnish ice, then on the Navy which never moves our people in the least, and then on free trade which they always love. He spoke extremely well and everyone was delighted. At the end of the meeting I was called upon for those usual torturing words and felt terrified and the boards sinking beneath my feet. However I got out a sentence in the Limehouse style about the evils of tariff reform and a reference to Michael which was greeted with great enthusiasm and a cry of 'Fetch him out' and a joke and a compliment

1. Ibid., 7 October 1910.

2. Ibid., 17 October 1910.

3. PMcK to Agnes Jekyll, 5 October [1910]. 
about the chairman after which I could do no more and felt dejected for the rest of evening...

'My meetings are going well, but I find them very exhausting', McKenna told Vinbad, who remained at the Admiralty in London. 'With the taboo on the House of Lords and the Osborne judgement, there is so little to say'.2

'The greatest marvel is that to-day the Radical press is eloquent with condemnation of George and Winston in contrast to $\mathrm{R}$ and Mr Asquith.' ${ }^{3}$ It mattered little in South Wales. 'Our people were very bored by the Navy and you can't make them care. They only really glow over dreary things like Welsh Disestablishment." 'Our electors despise the conservatives and distrust the socialists', Pamela told Vinbad, 'only they will not tolerate neglect as they have such inflated opinions of their own importance and R lost a lot of votes at the last Election by not visiting the rural districts.' ${ }^{5}$ To that end, McKenna held constituency surgeries. 'All the morning constituents came and went, all wanting golden appointments and impossible remedies to nonexistent grievance and $\mathrm{R}$ like patience in a monument entering with boundless sympathy into every complaint..6

As to the Conference I am quite at sea though I think the end is near and that end will mean war not peace. R saw H. H. A. who seemed hopeful and tonight A. B[irrell]. came in and talked for two hours and seemed hopeless. They each had possible solutions but neither had even heard of the other's. A. B. is burning over Home Rule but said that whenever he mentioned it seven pairs of eyes glared at him and said how easy it was to break up a conference. I think LI-G has a new wilder flight of imagination every day. Yesterday it was a Coalition Government and he was to get rid of H. H. A-R-R. B. H[aldane] and A. B. Then he may go over and make his bridge conscription and Colonial Preference and Social Reforms unhampered by expenditure on armaments which would be lubricated by a naval loan.

But I think the voice of Limehouse calls him even when he is orating on the Balmoral platform and who knows where it will end. Chamberlain over again in almost every detail. I long for an Election and to get it all settled-we should win triumphantly and disaffection is rife on the other side. They have no leader, no funds, no organisation and we have all three praise Allah.?

1. PMcK, diary, 18 October 1910.

2. RMcK to Baddeley, n.d. [October 1910].

3. Ibid., 21 October 1910.

4. Ibid., 20 October 1910.

5. PMcK to Baddeley, 21 October 1910.

6. PMcK, diary, 25 October 1910.

7. Ibid., 4 November 1910. 


\section{Reginald McKenna}

McKenna faced the second campaign, as he had the first, without Pamela. 'I find I like it less and less to come away without you. I feel at a loose end if I haven't my Pamski near me, so pray that we don't have an election this winter, at any rate until you are able to be with me. ${ }^{11}$ As it happened, in the autumn, the newly pregnant Pamela was ill, and so 'I pray Heaven for peace till after I am re-established in health.'

\section{Appendicitis}

In July, at Trevor Dawson's garden party in Dorking, 'we indulged in a fortune teller' who 'did Reggie very well but to our combined dismay said that he suffered from a nervous complaint and that in three years time unless he was very careful he would not survive it. ${ }^{3}$ On 9 November, Reggie fell violently ill, was diagnosed with an inflamed appendix, and, at the insistence of Asquith, who had come to his bedside, was operated on by Sir Watson Cheyne in the first lord's dressing room at Admiralty House the next day. ${ }^{4}$ Pamela helped overcome his resistance to the procedure.

At one o' clock a procession of frock coated serious faced doctors trooped in and we moved the victim into the room. He behaved with marvellous restraint and only said 'I believe you are wrong but I can't set my opinion up against three experts'. He was a little cheered at being asked by the anaesthetist to remove his false teeth and responded to the insult with boastful glee. ${ }^{5}$

After half an hour, Sir Watson came out brandishing the by now certainly non-functioning organ.

He was gloating over his extract and Ernest watched him cut it in half which I couldn't bear to see. It was slightly inflamed but the real awful danger was that in the middle an abscess had formed full of gangrene and it was only a question of a few hours for the poison to work its way through which would have immediately set up acute peritonitis and we should have been struggling with the odds against us to save his life. ${ }^{6}$

Fisher was the first to visit the patient, followed by Haldane, Montagu, and Grey, whom Reggie said 'was a tiring bedside companion and did not

1. Ibid., 1 October 1910.

2. Ibid., 6 October 1910.

3. Ibid., 2 July 1910.

4. Ibid., 9 November 1910.

5. Ibid., 10 November 1910.

6. Ibid. 
contribute much to the amusements of the sickroom.' ${ }^{1}$ On his second day of convalescence, the constitutional conference broke down. Pamela had lunch at 10 Downing Street on the sixteenth, in the midst of great commotion, and was struck how Asquith was

all unconcerned talking to a governess about Chaucer and going to the wedding of a tariff reformer on his way to the King. He looked wonderfully self-possessed with no trace of anxiety or nerves. I never knew anyone with such a successful system of water-tight compartments. I believe it saved him and don't think he could go on if it weren't for that. ${ }^{2}$

At Cabinet that evening, the election was announced, and all were sworn to secrecy by Asquith, who would not allow Runciman even to tell Pamela. Runciman nevertheless told Pamela. ${ }^{3}$ Few were enthusiastic about the election, Pamela observed. 'The Whips are cheerful about our prospects but all the individuals who I see despondent.' ${ }^{4}$ Nor was the king. 'He went down to Hall Barn for a day's shooting last week and was said to be in a state of profound gloom about the election!'s

That evening, prior to a big rally at Mile End to be addressed by Lloyd George, she went to 11 Downing Street.

Dinner was very like an Ibsen play. At seven o' clock Lloyd George was summoned from his bed where he was sound asleep and he came down rather late. The rest of the party consisted of Clemmie, Kitty Somerset, Sir Frank Newnes, Harold Spender and various Welsh speaking secretaries. We sat down to a frugal meal and after pecking at a fillet of plaice Ll-G said peevishly 'I am feeling very cold' and leaving the table he stretched himself at full length in a basket chair by the fire and never uttered to any of us till it was time to go. Winston appeared from nowhere in the middle and said 'Goodnight David, good luck dear fellow' and then vanished. ${ }^{6}$

In Reggie's absence, Ernest took Pamela past protesting suffragettes, to the hall, where "George was a very good hearing but he only really roused them with his vile coarse jokes.'

I could have cried with misery that a man with so divine a voice such expressive gestures and perfect delivery should have been given so much

1. Ibid., 18 November 1910.

2. Ibid., 16 November 1910.

3. Ibid.

4. Ibid., 21 November 1910.

5. PMcK to RMcK, n.d. [December 1910].

6. PMcK, diary, 21 November 1910. 
and yet had so much withheld. His speech was appalling stuff-merely a conceited review of his own attainments, and torrents of invective showered at the aristocracy. ${ }^{1}$

Asquith tried to call in on the meeting, but

he had a narrow escape from the women too for they recognised him when he was walking up Whitehall from the House and rushed towards him. Luckily they were warded off by some stalwart detectives who bundled him in the first motor which came along. They broke the window at the back and sent the glass in a shower down his neck but he was not even scratched. It turned out afterwards to be the motor of a distinguished surgeon in Harley Street and Henry now feels under the obligation of summoning him to perform a serious and costly operation in order to compensate for the damage. ${ }^{2}$

\section{Another General Election}

Parliament was prorogued on 28 November. The campaign would be crucial, but in his own words McKenna was 'bors de combat until after Christmas'. ${ }^{3}$ Despite the efforts of the chief whip, the Master of Elibank, to avoid it, North Monmouthshire was contested. ${ }^{4}$ McKenna, squaring his shoulders and thumping his pillow declaimed,

The issues on which this election will turn have an importance far transcending anything we have seen in our time. It is the final and decisive assault of representative and democratic institutions upon the entrenched and fortified privileges of the peers. Victory now will clear the way for the political and social reforms which for years have been our hope and inspiration but have been barred to us by the obstructive veto of the Lords. Victory is now within our grasp, and who would not be sad at lying in hospital whilst his comrades are winning deathless laurels on the field of battle? God speed to you all in the fight for the people. The food of the poor shall not be taxed to bolster up the fortunes of great capitalist monopolies and trusts. The voice of the people speaking through their chosen representatives, shall not be overborne and silenced by the veto of a privileged castle. Blaenavon has ever been in the forefront of

1. Ibid.

2. Ibid., 24 November 1910.

3. RMcK to Spender, 9 April 1930.

4. PMcK, diary, 18 November 1910. 
the fight for popular rights. Quit ye now like men, and our wanderings will be over and with our own eyes we shall see the promised land. ${ }^{1}$

He was not convinced in what form, however, and incapacity served further to heighten his suspicions. 'I went to see McKenna on a sofa after his operation,' Margot wrote.

He was full of this story (he sees in L. George the Devil himself \& has never understood his own extremely difficult nature): L.G. fearing a dead-lock \& knowing that only a sudden emergency wd. make a coalition possible saw a good way of getting rid of his only rival on the front bench Henry (!) . . . McK lay back on the sofa in a dressing-gown firm pale $\&$ intensely convinced of his own insight another word for his prejudices. Oh! the bargain was to be this: L.G. wd. give Col. Preference Conscription \& a big naval Loan ... I told $\mathrm{H}$ all this when I got back to Downing St. He was much amused. ${ }^{2}$

Even Pamela admitted, 'I think Reggie sees too many dark intentions. ${ }^{3}$ Yet, shortly afterwards she recorded:

A propos of Ll-G I fear there is a serious storm brewing. Margot in a foolish moment of impetuous desire to remedy existing evils wrote to him reproving him for his Mile End speech and saying that he really must not do it again as he was losing us so many supporters. He wrote her a letter in reply that no gentleman could have written and for which he deserved nothing short of a horse-whipping. He said among other unveiled insults that she would not have been in Downing Street at that moment if it had not been for his Budget. $M$ has not shown it to Henry yet but sought for advice elsewhere and will I hope show it to him as soon as the anxiety of the Election is safely over. He certainly ought to know as I am never sure whether he is blind about Ll-G or only pretends not to notice. But he hates being told disagreeable things about him and makes it almost impossible even for his best friend to tell him what is really going on. ${ }^{4}$

In his absence, McKenna's martial opponent in North Monmouthshire offered a 'plucky attack, ${ }^{5}$ albeit one without a visible target. Quite completely excited by the campaign and the results, Pamela wanted to go to

1. RMcK to Samuel Godfrey, 26 November 1910. Published as 'A Message to the Electors', 30 November 1910.

2. MA, diary, November 1910, MA papers, d.3208/89-90.

3. Ibid.

4. PMcK, diary, 4 December 1910.

5. Times, 2 December 1910. 
Monmouth to campaign instead of him, but McKenna sent Ernest in his place. Pamela watched the first night's results announced in torrential rain in Trafalgar Square. North Monmouthshire voted on 9 December. The following day,

we heard our own result early. R's majority down to 3,136 which I must admit was a disappointment to me as it is a drop of over 1,000 votes. However Ernest seemed so overwhelmingly satisfied with it that I thought perhaps I was taking a morbid view and as $\mathrm{R}$ was not there and we had as strong a candidate out against us as we have had weak ones before and he only polled 250 votes more than the carpet-bagger last year $[$ sic $]$ I feel we did not really come out of it so badly. When we are both well again I should like to go and work at the organisation which I am sure leaves much to be desired. ${ }^{1}$

A further reduction in his majority and his share of the vote could be attributed to his not campaigning. ${ }^{2}$

The national result was an almost exact duplication of the previous election, and Liberals and Unionists both had 272 MPs. Promised reforms were therefore compromised by the absence of a mandate, but consolidated by the parliamentary partnership of British socialists and Irish Nationalists, which ensured a working majority. Out of bed, but exhausted and stricken with rheumatism and neuralgia, McKenna was immediately sent off with Ernest to the south of France. Having 'wandered through our old garden', he wrote to Pamela after visiting Roquebrune,

Old memories and feelings too deep and sad to be lightly borne came over me and I longed to have you with me for you would have been a solace for all. Away from you I feel so much, much older. I look back over five years and cannot understand that I am the same person; and yet when I am with you life has a new beginning, and though I know myself to be different from what I was then, the door of life is not closed upon me. I say life, because we only live in our affections; all the rest is routine or excitement, the distractions of life, but not living itself. I cling

1. PMcK, diary, 10 December 1910.

2. General election, Monmouthshire, North, 9 December 1910.

\begin{tabular}{lrl}
\hline Total electors & 15,711 & Share \\
R. McKenna (L) & 7722 & $62.7 \%$ \\
Lt. Col. D. Ellis Williams (U) & 4586 & $37.3 \%$ \\
Liberal majority & 3136 & $25.4 \%$ \\
\hline
\end{tabular}


to you, my own dearest, brave and tender and true, and it is not by my own will that I am away from you one single day. ${ }^{1}$

Benntig and Spender went to visit him, but 'I have seen nothing of Ll.G., for which I am thankful. His absurdities in the French press are painful to a colleague.'2 McKenna did not return until the New Year, which Pamela saw in at Munstead. She looked back on 1910.

My thoughts ran along the inevitable New Years Eve groove to this time a year ago when Michael was only thought of-a whole world of imagination and hope. The old King alive, the House of Lords prevailing, then the sudden death, two elections fought and won, R's life in danger and a new life coming towards reality. ${ }^{3}$

\section{MINISTER}

Another problem with McKenna's conduct in the 'acceleration' debate over naval construction was that it was too effective, and made sceptics denounce his complacency to that point. It was another reason to bemoan his conduct as a minister. Charles King felt "his sharp, perky, "No, sir", when a Unionist asked a question which seemed to require a lengthy explanation or a clever defence, was one of the institutions of the middle portion of his term of office as First Lord of the Admiralty'. ${ }^{4}$ Nor was there any cross-party support for the man, as distinct from his measures. A Unionist backbencher heard the rumour 'that McKenna owes his present position to the fact that he is an illegitimate son of Sir C. Dilke. Probably a mere fable, but it is difficult to explain advancement of such a very third rate man. ${ }^{5}$

The greatest compensation for McKenna, as for any first lord, remained the Enchantress, the Admiralty yacht. ${ }^{6}$ McKenna, the lifelong hydrophile, delighted in hosting cruises that deftly combined work and pleasure, assisted, as Henry Lucy had it, 'what is perhaps the completest installation of wireless telegraphy in the world, whereby the First Lord, if a family man, is able when cruising to be in hourly communication with the domestic circle." 7 Ned thought it 'great fun. Pamela is the only woman and a lot of men all in

1. RMcK to PMcK, 23 December 1910.

2. RMcK to PMcK, 29 December 1910; HHA to RMcK, 26 December 1910, McKenna papers, 3/18/57.

3. PMcK, diary, 31 December 1910.

4. King, Parliament, 46.

5. Robert Sanders, 8 June 1910, Diaries, 20.

6. HHA to MA, 3 August 1909 , MA papers, c.6690/190-1; HHA to MA, 25 May 1910, MA papers, c.6690/228-29; HHA to MA, 31 May 1910, MA papers, c.6690/230-31; HHA to MA, 26 January 1911, MA papers, c.6690/247-48.

7. Henry Lucy, Punch, 29 October 1911. 
uniform all calling each other "Sir" and a general feeling of Gilbert \& Sullivan ... My jokes have had an enormous success with these green sea side minds' - a modest evaluation, which was not Pamela's experience. For her, Ned was 'a little embarrassing at first as he would make such awful jokes and say "Luff you fool" to the Captain." It meant they spent even more time with the prime minister. The cruises were more social than political in content, particularly for Asquith and his favourite 'blue-eye'. 'I had a thrilling conversation with him at dinner of an intimate and too personal kind for reproduction,' Pamela recorded, 'but I found the springs of human interest as fresh and unplumbed as ever though I think the circle is decreasing in numbers."

McKenna's nautical exploits had the effect of keeping him from the Commons, which was no great privation either for him or for other MPs. Grey told Churchill on perusing the list of most diligent voting ministers, 'while you have ascended McKenna has descended to save me from the wooden spoon'. ${ }^{3}$ Though the lists were published, it did not follow that the public was aware. 'I object to men like Mr. McKenna attempting to control the Navy without having either sea-legs or a sea-stomach', Major W. H. Edwards told the Empire Club of Canada in December 1910. 'He made one trip on the Admiralty Yacht and has never been afloat since!'4

In fact, personal courage was one quality no one could gainsay. On 12 May 1911, McKenna became the first minister of the crown to take to the air. To demonstrate the military significance of aircraft the Parliamentary Aerial Defence Committee organised a flying display at Hendon aerodrome, an event that attracted thousands, including Asquith, Lloyd George, Churchill, and Fisher, who was horrified to glimpse the future, when a model dreadnought was hit a dozen times with sandbags from two thousand feet. At the invitation of Claude Grahame-White, Britain's leading pilot, Balfour went up first, to 100 feet. Then McKenna climbed into the wicker passenger's seat, with no floor, and only a foot rail beneath, and Grahame-White took him up much higher, across country, and 'brought him down in this flimsy apparatus in a very steep nose-dive, to the alarm of the whole concourse', Churchill observed. ${ }^{5}$ McKenna was photographed, grinning, and was delighted with the experience. 'Then two flights were made, both of

1. PMcK, diary, 9 September 1910; Lutyens to Emily Lutyens, 10 September 1910, in The Letters of Edwin Lutyens to His Wife Lady Emily, eds. Jane Ridley and Clayre Percy (1988), 205.

2. PMcK, diary, 30 May 1910.

3. Grey to Churchill, n.d., votes of ministers session 1909 memo, Churchill papers, CHAR 2/39/129.

4. Major W. H. Edwards, 22 December 1910, in 'Empire Club'.

5. Londoner's Diary, 20 September 1938, in Winston S Churchill, vol. 5, Companion III: Documents 1936-1939, ed. Martin Gilbert, 1168. 
which ended in accidents, ${ }^{1}$ the press reported. When the pilot applied a lever intended to ascend, 'the reverse effect was gained'. ${ }^{2}$

\section{FURTHER ESTIMATION}

Navy estimates were not only exhausting, they were also annual. Early in the reign of George V, "The King said to R "You come to me if you have any difficulty over the Navy Estimates next year". 3 The implications were felt in the following estimates. Notwithstanding the attacks 'from the economists behind you and the scaremongers in front of you', and his reluctance to take a 'shylock attitude', in March 1911 Lloyd George expected McKenna to reduce the estimates for the following two years. ${ }^{4}$ That, in part, was the reason for the king's support. 'He can hardly have mentioned Winston's name for hatred and told $\mathrm{R}$ that he gathered that he was not a favourite with the Prime Minister either.' 5 The resultant compromise was duly attacked by both 'economists' and 'scaremongers'. In the Commons debate to reduce expenditure, McKenna moved the motion for the naval estimates, beating off Ponsonby and Beresford, 'The Master of Elybank [sic] and Sir Edward Grey implored R not to speak as they were terrified lest he should open up the Cabinet controversy over the four contingent dreadnoughts and expose LI-G and Winston', Pamela wrote.

But $\mathrm{R}$ was determined to speak and after thoroughly frightening them, to his inward joy and their intense discomfort, he got up and made what they all said was the finest speech they had ever heard from him. He came home directly after looking very excited and overstrained and prepared to give me the usual account of his failings but I was already armed with documentary evidence to the contrary as Walter and Montagu and Benn all wrote to me at once saying how splendid he had been. I was drunk with pride and joy and we had a glorious hour together both happy to the bottom of our hearts. I felt it one of the great moments of my life, but he was very tired and said that for the first time he felt real physical pain in his wound. ${ }^{6}$

McKenna concluded his speech by saying that 'for the first time I do anticipate a reduction of expenditure will take place in the ensuing year'. ' $\mathrm{He}$

1. Times, 13 May 1911; Wallace, Grahame-White, 135-38.

2. Daily Graphic, 13 May 1911.

3. PMcK, diary, 5 October 1910.

4. Lloyd George to RMcK, 3 March 1911, McKenna papers, 3/20/14-15.

5. PMcK, diary, 5 October 1910.

6. Ibid., 13 March 1911.

7. RMcK, Parliamentary Debates, 13 March 1911, 1921. 


\section{Reginald McKenna}

has just made the most splendid speech, perfect', Benn told her. 'Very courageous, every word perfect, easily the best thing he has done. I heard WSC just remark "a very fine speech", and Chief Whip delighted. ${ }^{1}$ Most importantly for the government, the backbencher Spencer Hughes told him 'Your speech has settled me and I vote with the Government.'2

McKenna announced the programme on 16 March $1911 .^{3}$ Amid general confusion about German intentions, and with the experience of parliamentary and press hostility, McKenna offered a defence policy predicated on attacks from within the United Kingdom. It took its toll. 'After he had spoken for an hour he turned very pale and said there were many other points he had hoped to deal with but he did not feel strong enough to go on-and then he sat down.'

Where the first estimates row had irrevocably divided McKenna and Lloyd George, the latest clash led to the estrangement of Lloyd George and Grey. ${ }^{5}$ A year after the first confrontation, both McKenna and Lloyd George were both threatening to resign unless they had their way. ${ }^{6}$ The board had originally decided on four capital ships for the 1910-11 estimates, and six for 1911-12. The similarities were striking. Further Dawsonian Mediterranean intelligence that Austria had laid down two dreadnoughts meant that once again McKenna faced Cabinet, in January 1910, with an increased programme of six ships. ${ }^{7}$

The proposal produced a very similar division to that of a year before, and with a very similar outcome, if one reached without quite so much bitterness. The Admiralty compromised with a programme of five in 1910 and five in $1911 .{ }^{8}$ The Foreign Office and the right-wing press were underwhelmed, Liberal MPs and the radical press exercised, but no party was animated to the extent that they had been a year before. Thus rather than another coup d'theatre to a full house, McKenna faced a half-empty Commons on 14 March. The debate passed unremarkably, but for constant interruption from Beresford, who had to be silenced by the Speaker.' 'I believe I feel more for the honour of the navy than the naval officers themselves', McKenna told Pamela. 'To think of this man having command of our largest

1. William Wedgwood Benn to PMcK, n.d.; Runciman to PMcK, 13 March 1911.

2. Spencer Leigh Hughes to RMcK, 13 March 1911.

3. RMcK, Parliamentary Debates, 16 March 1911, 2457-71; RMcK, Navy estimates 1911-12, Cd.5547.

4. PMcK, diary, 16 March 1911.

5. Lloyd George to William George, 28 May 1933, in George, Brother, 238.

6. Runciman to Hilda Runciman, 16 December 1909, Runciman papers, 303/1.

7. Sir Trevor Dawson to RMcK, 10 January 1910.

8. RMcK, Navy estimates 1910-11, Cd.5003.

9. Parliamentary Debates, 2 March 1910, Parliamentary Debates, 920-23. 
fleet, and that he should be regarded as a fine specimen of the service. The best day's work I ever did was when I made him haul down his flag.'

That autumn, however, there was another outbreak of hysteria, with Balfour again condemning governmental complacency. The Liberals were now more concerned about the dissent amongst their own members and the antiarms campaigning of the Labour Party. The effect was familiar. 'I hear that McKenna is to be forced out in November over next year's estimates', Esher told Balfour in August 1910. 'That is the mot d'ordre.'2 On the same day he told Spender, 'A section of the Cabinet are said to be anxious to bring about McKenna's fall.'

The 'intrigue afoot', Esher claimed, was to ensure 'that next year there may be an arrest of construction on a big scale' ${ }^{4}$ Economists were incensed at the continued escalation, particularly by one formerly held to be an economist. Hirst's attacks in the Economist, McKenna told Stead, were not a cause for concern, but their effect on public opinion might be. ${ }^{5}$ Rather, the effect in Cabinet was more significant. Fisher feared that after the second 1910 election, McKenna could be replaced with impunity if the Liberals won, and by one of the syndicate if the Unionist peers did. The confrontation with the Lords had meant that McKenna's position had been, relatively, weakened. C. P. Scott felt that the reason Asquith would let McKenna resign, rather than Lloyd George, was that without the latter the Parliament Bill would be lost. ${ }^{6}$ By April 1911, Fisher was convinced McKenna was safe, through his friendship with the prime minister. ${ }^{7}$ The need to replace Fisher led to the penultimate act of McKenna's time at the Admiralty, the appointment of Sir Arthur Wilson. ${ }^{8}$

\section{PAMELA}

Just over a year after Michael's birth, on 16 February 1911, Reggie's and Pamela's second son was born. 'I was so afraid that his arrival would be looked upon by my friends-like the last General Election-merely as a monotonous repetition of January 1910', Pamela told Vinbad. .' David McKenna was christened in the crypt of the House of Commons on 31

1. RMcK to PMcK, 2 March 1910.

2. Esher to Balfour, 8 August 1910, Balfour papers, 49719/151; Esher to Maurice Brett, 30 December 1909, Esher papers, 7/22.

3. Esher to Spender, 8 August [1910], Esher, Journals, 3:13.

4. Esher to Balfour, 16 August 1910, Balfour papers, 17919/153.

5. RMcK to W. T. Stead, 18 January 1911 , Stead papers, $1 / 53$.

6. Scott, diary, 17 February 1911, Scott papers, 50901.

7. Fisher to Hankey, 3 April 1911, Hankey papers, 5/2/a/9.

8. Fisher to RMcK, 23 November 1909 , McKenna papers, 3/4/34; Fisher to Yexley, 13 January 1910, Fisher papers, 3/3/2023.

9. PMcK to Baddeley, n.d. 


\section{Reginald McKenna}

March by Archbishop Wilberforce, with Spender and Benntig as godparents, in the presence of, among others, Loulou, Pease, and Birrell. 'When Reggie told Lloyd George that the baby was to be called David he looked up quickly and said, "they'll take that as a compliment in Wales!".'1

At yet another dinner Pamela hosted, she told one guest she had two sons. He looked shocked and replied, 'vous êtes très bien conserve'. ${ }^{2}$ Within two months, she was pregnant once again. It was too much for her to bear. 'The whole season has been spoilt for me', Margot wrote in her diary, by 'Pamela McKenna's nervous breakdown'. ${ }^{3}$ Still only twenty-one, and slight in build, in June Pamela miscarried. 'I felt dreadfully unhappy at seeing Pamela my beloved little friend so very very ill', Margot, who had herself lost a baby five years earlier, wrote. 'She has had 3 babies in 3 years \& Mr McKenna doesn't really understand quite what a very young woman can stand' ${ }^{4}$ 'That frail body of hers isn't equal to the gigantic spirit', Fisher told Reggie. 'I hope her mother will keep her caged at Munstead'.

Pamela convalesced at St Leonard's, on the south coast; 'an unutterable place', she told Vinbad, 'and we are living in the utmost squalor'. ${ }^{6}$ Her days, she told her husband, consisted of her being 'rolled up and down the parade alive with mumpsy measely convalescing children and lunatics and senile adults in other bath chairs'. ${ }^{7}$ Her health, never strong, never fully recovered, and the rest of her life was a struggle between her frail physical condition and the demands made of her by the roles she naturally assumed. 'I know the black days are done now', Bar assured her in the autumn. After all, 'you have got the best playthings in the world in $\mathrm{M}$ and $\mathrm{D}^{\prime}{ }^{8}$ Nor was her husband fully restored. The effects of the appendectomy lasted well over a year. 'McKenna much shaken by that operation', Fisher told Jellicoe, after they had holidayed together in Florence. 'He gets tired very soon. ${ }^{9}$ As well as emotional. Lloyd George found him 'almost in tears with the announcement that his baby was just born'. ${ }^{10}$

All increased the attractions of a life outside Parliament and raised the appeal of an almost incredible change of position, which Pamela appeared to have transmitted to Asquith. The Prime Minister wrote to McKenna

1. PMcK, diary, 21 March 1911.

2. Ibid., 24 March 1911.

3. MA, diary, 20 July 1911, MA papers, d.3209/29.

4. Ibid.; HHA to MA, 3 February 1910 , MA papers, c.6690/177; HHA to MA, 5 February 1910, MA papers, c.6690/179-80.

5. Fisher to RMcK, 24 May [1911], McKenna papers, 6/4/31.

6. PMcK to Baddeley, n.d.

7. PMcK to RMcK, n.d.

8. Barbara McLaren to PMcK, 14 September 1911.

9. Fisher to Jellicoe, 9 May 1911, Jellicoe papers, 49006/11.

10. Lloyd George, in Masterman, Masterman, 186. 
I have heard indirectly, what I did not know at the time, that you would have been willing in the summer to take Sir G Murray's post [as Permanent Secretary at the Treasury]. I need not tell you that, much as I should have deplored your loss as a colleague, the office would have been altogether at your disposal. ${ }^{1}$

Asquith was clear in expressing his hope that McKenna would not abandon parliamentary life, but the "health and other considerations" ${ }^{2}$ of the McKennae was something of which all three were conscious, as was the fact that they now had a young family, and that McKenna could earn much more, in the City with his brothers; or he could earn a little less, but at much less personal cost, in the Treasury. ${ }^{3}$

\section{STRATEGY}

For all the ambivalence McKenna felt personally by the spring of 1911, politically the effects of the constitutional crisis and talk of coalition appeared to steady his position. Fisher, out of office but not out of contact, felt disposed to tell Hankey that McKenna was safe through his closeness to Asquith, and, only a month later, to Jellicoe, 'McKenna is looking up again in the Cabinet!' and even 'Lloyd George has embraced him and dined him and breakfasted Mrs McKenna' ${ }^{4}$ His performance at the Imperial Conference in May went well, and the Admiralty generally garnered support. ${ }^{5}$ 'McKenna is absolutely indispensable!' ${ }^{\prime}$ Fisher rejoiced that 'He's a born fighter and a good hater'. 'McKenna in a ringed fence is very good. He improves in temper $\&$ manners as he goes on. He has no imagination whatever $\&$ a shocking sense of humour. He has very little insight into character but strong affection \& great loyalty. ${ }^{8}$ Most importantly, he could measure his success in relative terms. 'R saw H. H. A. in the morning', Pamela noted. 'He alluded to LI-G once as 'that little ruffian'. The disillusionment seems to be complete. ' 'What a man Ll.G!' Margot told her, 'what an ass. ${ }^{10}$

1. HHA to RMcK, 10 October 1911, McKenna papers, 4/1/3.

2. Ibid.

3. $R M c K, 120-21$.

4. Fisher to Hankey, 3 April 1911, Hankey papers, 5/2/9; Fisher to Jellicoe, 9 May 1911, Jellicoe papers, 49006/11.

5. Sir Henry Wilson, n.d. [31 May 1911], Diaries, 95; Fisher to RMcK, 19 June 1911, Fisher papers, 1/10/528.

6. Fisher to Hankey, 13 April 1911, Hankey papers, 5/2a/13. 195.

7. Fisher to Esher, 18 February 1910, Esher papers, 10/43; Fisher, Memories,

8. MA, diary, n.d. [March 1911], MA papers, d.3208/124.

9. PMcK, diary, 14 January 1911.

10. MA to PMcK, n.d. 


\section{Reginald McKenna}

McKenna's improved standing was important, as the most important issue concerning the Admiralty had to be resolved. As early as May 1909, he said privately he "was sure war with Germany could not be staved off for four years, far less for twelve as someone had suggested." By then he had attended the three meetings of the subcommittee of the Committee of Imperial Defence that was charged with considering 'the Military Needs of the Empire', and which explicitly considered sending troops across the channel in the event of war. ${ }^{2}$ Before he left on his May cruise on the Enchantress, McKenna read Archibald Hurd's article, "England's Peril." Hurd maintained that the only comfort against the 'invasion fears' was a strong navy and found it extraordinary that German naval expansion had 'prompted a movement to turn England into a military power' by 'compulsory service'. ${ }^{3}$ 'England's Peril is not invasion, but starvation, and against that peril there is one, and only one, safeguard-a supreme Fleet' ${ }^{4}$ McKenna wrote to the author to congratulate him on 'the most complete and pointed argument against conscription which I have read. You are doing a real service to naval defence'. 5

On the cruise, in between golfing trips with Asquith, McKenna inspected naval institutions. At Campbeltown, Captain Herbert Richmond 'had a yarn with McKenna.' 'He was very glib and assured me about the war plans $\&$ talked as though the whole thing were the easiest matter in the world ... He talked with easy assurance but obviously had no idea-as indeed how can he have? - of the practical difficulties of his paper ideas. ${ }^{6}$ Richmond then pressed upon Asquith the necessity of naval staff, as the Beresford inquiry had suggested; what Hurd elsewhere called 'a brain'?

The direct consequence of the Beresford crisis was a change of personnel by the first lord himself. Fisher's successor had to be someone who would not reverse the Fisher reforms, ruling out the sailors in the syndicate of discontent: Admirals Sir Reginald Custance, Sir Lewis Beaumont, Sir Arthur Moore, and Beresford, who by now blamed McKenna for undermining the discipline of the fleet, and the collective responsibility of the board, as well as the size of the German navy. ${ }^{8}$ In a quandary, with a paucity of candidates, and fearing a recrudescence of the discontents, McKenna decided on

1. Bailey, diary, 13 May 1909, in Letters, 116.

2. Cabinet papers, CAB16/5.

3. Hurd, Archibald, 'England's Peril: Invasion or Starvation', Fortnightly Review (1910): 679 .

4. Hurd, Archibald, 'England's Peril: Invasion or Starvation, II', Fortnightly Review (1910): 873.

5. RMcK to Archibald Hurd, 18 May 1910, Hurd papers, 1/35.

6. Richmond p. 335.

7. Hurd, Who Goes There?, 102; Captain Herbert Richmond, diary, 29 May [1910]; Esher to Sanders, 26 August 1909, Esher, Journals, ii:402.

8. Lord Charles Beresford, The Betrayal (1912), 23-25, 97-98, 116-124. 
appointing Admiral A. K. Wilson to succeed Fisher. ${ }^{1}$ With the marginalization of Beresford, it should have proved a harmless promotion, and Wilson indeed was intended as a stopgap, as a post-Fisher emollient. That was how it felt, at first. 'I am getting on admirably with Wilson, but I grieve daily to have lost my dear Lord Fisher'. ${ }^{2}$ McKenna was assuaging Fisher; he admitted privately to finding 'Wilson very difficult', ${ }^{3}$ and regularly visited Fisher at Kilverstone Hall with secret documents for private consultations. ${ }^{4}$ Preeminent as a fleet commander, Wilson was unsuited to Whitehall life. By the end of the year, McKenna confessed to Pamela of being 'in terror' of his first sea lord. ${ }^{5}$ Despite his being told by Fisher that he 'must stick close to Wilson', as late as October 1911 Fisher claimed that McKenna had been 'at me hammer and tongs' to return. 'The moment I come home I should be in McKenna's pocket', he told Hankey. ${ }^{7}$ Fisher's private view was that, with Wilson 'unassailable', and Fisher silent, after a year he would be back in office. ${ }^{8}$ In the meantime, not only did Wilson have limitations of imagination and expression, he did not actually agree with McKenna's Admiralty policy of blockade. The effect was that the navy case found itself marginalised at precisely the moment that the Cabinet came to recognise the probability of war with Germany and had to decide on strategy. 'He is a good fellow and is having a devillish time', Esher commented, trying to stir opposition in the Northcliffe press. 'If he is strongly attacked for neglecting to make us safe, which his own 1st Sea Lord has shown can be done, it will help him against those, who in spite of A Wilson want to eject him from the Government."

The greatest threat to the government could be said to have come not from the very public constitutional question within Parliament, but from the very private defence question within Cabinet, over whether in the event of European war Britain should intervene, and, if so, in what way. While the estimates crisis had strengthened McKenna in the short term, it also served to make him a bigger obstacle to the reconsideration of strategy. Developments in the international situation made matters more pressing. Nor had his earlier success done much for his popularity, and, when combined with Beresford and Archer-Shee, could be presented-by Lloyd George and

1. RMcK to HHA, [draft], n.d., McKenna papers, 3/17/3; Lambert, Revolution, 202-5.

2. RMcK to Knollys, 29 January 1910, RA VIC/W 59/102.

3. Esher to Maurice Brett, 4 January 1910, Esher, Joumals, 2:433; Fisher to Ottley, 25 February 1910, Fisher papers, 1/9/474.

4. Fisher to Esher, 5 August 1910, Esher papers, 10/43.

5. RMcK to PMcK, 23 December 1910.

6. Fisher to Ottley, 8 October 1911, Hankey papers, 5/2A/32; Fisher to Jellicoe, 9 May 1911, Jellicoe papers, 49006/11; Fisher to Esher, 10 October 1911, Esher papers, $10 / 43$.

7. Fisher to Hankey, 21 October 1911, Hankey papers, 5/2a/32.

8. Fisher to Hankey, 5 February 1911, Hankey papers, 5/2a/9; Fisher to Hankey, 29 September 1911, Hankey papers, 5/2a/31.

9. Esher to 'Jack' [J. S. Sandars], 7 February 1911, Balfour papers, 49719/188. 
Churchill, most obviously ${ }^{1}$-as evidence against him. In his reluctance to replace the old-fashioned board of the Admiralty with a modern general staff, as Haldane had done at the War Office, but which Fisher did not want at the Admiralty, McKenna proceeded to lose his remaining supporters in Cabinet. Agadir and Haldane did the rest.

In July 1911, a crisis erupted in the Moroccan port of Agadir, leading to mounting diplomatic tensions between France and Germany, for the second time in five years. It produced Lloyd George's uncharacteristically belligerent Mansion House speech on 21 July, which had been drafted with Asquith and Grey. Liberal reaction gave cause for some ministers to suspect that a 'continentalist' foreign policy was being forced on the Cabinet. The German reaction to the speech was so great that on 25 July Grey again advised McKenna to prepare the fleet for mobilisation. The German feeling was that a British continental commitment, as expressed by a bigger army, would be regarded as an aggressive move. ${ }^{2}$ During the Anglo-German naval talks, Germany demanded British neutrality as a condition for withdrawing the new Navy Law, which McKenna supported. ${ }^{3}$ It would achieve all that he had sought from his years at the Admiralty: peace through strength, and no embroilment in a continental war.

The reaction to Agadir, from Unionists in general and Beresford in particular, was that the navy was not ready for war. Hankey admitted to apathy in the Admiralty during the crisis. ${ }^{4}$ Operational matters were Wilson's responsibility, but he, like apparently everybody else in July, was on holiday. Even if the crews had not been on leave, the ships could not sail owing to a coal strike at Cardiff. The War Office gave notice to McKenna that the CID would be meeting to extrapolate the British reaction from the latest Moroccan dispute, a crisis that nearly brought Germany and France to war. Agadir raised further concerns that without a naval staff the fleet would not be able to respond in kind or in time. There was also McKenna's opposition to the creation of a naval staff on the model Haldane had constructed for the army. Critics cited Agadir as a pretext. The affair was not a glorious one for the navy. Asquith upbraided McKenna for the Admiralty not replying to inquiries by the War Office, and for the admirals being on holiday when the general staff was in Paris and Europe on the brink of war. ${ }^{5}$

1. Churchill to Lloyd George, 14 February 1911, Companion, 2:2, 1041; Lloyd George to RMcK, 3 March 1911, Lloyd George papers, C/5/12/7; MA, diary, 8 May 1915, in Winston S. Churchill, vol. 2, Companion 11I: Documents, 1911-1914, ed. Randolph Churchill (1969), 850; RMcK to Spender, 9 April 1930.

2. G. P. Gooch and Harold Temperley, eds., British Documents on the Origins of the War 1898-1914, vol. 6, Anglo-German Tension, Armaments and Negotiation, 1907-12 (1930), xxxviii, 102-37.

3. Keith Wilson, The Policy of the Entente: Essays on the Determinants of British Foreign Policy, 1904-1914 (Cambridge, 1985), 27.

4. Hankey to Esher, 5 October 1911, Esher papers, 4/3.

5. HHA to RMcK, 18 September 1911, McKenna papers, 4/1/2. 
On 14 August, at dinner with Asquith, Grey, Churchill, and McKenna, Haldane proposed a meeting of the CID. Admiralty opposition to the Declaration of London and its effect on contraband had irritated the Foreign Office, which was turning increasingly continentalist, as marked by the 'accord' with the French on 20 July, which committed seven divisions across the channel in the event of war. ${ }^{1}$ Haldane recognised the opportunity and pressed his case, citing the absence of a naval staff: he based his own success at the War Office upon administrative reforms that, he maintained, rendered the army more modern and responsive. The general staff was the most visible and successful such innovation. The recalcitrance of the navy in this respect served as grist to the CID mill. Haldane thought, therefore, 'in perfect sincerity but with complete ignorance of the facts', as McKenna later put it,

that the Admiralty was an incompetent office in consequence of having no war staff. He was obsessed with the idea of establishing a war staff at the Admiralty on the model of his own at the War Office, entirely oblivious of the fundamental distinction between land and sea warfare. ${ }^{2}$

The Admiralty maintained that the greater deterrence to a German attack on France would be their recognition of overwhelming British naval supremacy, rather than the sending of a relatively insignificant seven divisions of troops. Moreover, if British interests rested upon one foundation it was on financial interests rather than military. Insurers and acceptance houses in London would suffer in the event of war: it was Norman Angellism writ large. Unfortunately, for Angell, the advocate was unfit.

Haldane's forum, where continentalists opposed Atlanticists, was a subcommittee of the CID that met secretly on 23 August $1911 .^{3}$ It did not help the navy case that membership had been weighted heavily in favour of the army - 'packed' as Esher put it, and as Hankey had warned McKenna. ${ }^{4}$ As with the Mansion House speech, it was a continentalist conspiracy. The Cabinet's five continentalists were present, faced with McKenna, who was representing, in effect, he felt, the remaining fourteen Cabinet ministers. Harcourt thought it had been called when other members, and most ministers, would be out of London. In its exclusivity — and personnel—it recalled the rumours of coalition the previous summer. Fisher warned McKenna 'that if the Government land a single British soldier in France there will be an upheaval in

1. Offer, First World War, 290.

2. RMcK to T. Lloyd Humberstone, 28 January 1943 [copy].

3. CID, meeting, 23 August 1911 minutes, Cabinet papers, CAB2/2.

4. Esher, diary, 24 November 1911, Esher papers, 2/12; Hankey to RMcK, 15 August 1911, Hankey papers, 7/3. 


\section{Reginald McKenna}

England that will cast them out of office!' ${ }^{1}$ In fact, not only was the subcommittee packed, it was also rigged: Asquith's opening remarks directed them to find the best way of 'giving armed aid to the French. ${ }^{2}$ Contrary to Archibald Hurd's concerns, the issue was not invasion, but intervention.

Primed with a memorandum from Hankey, whom Fisher had successfully recommended McKenna promote as secretary of the CID, McKenna presented his case against Haldane - to some effect, it was felt by observers; he was, Runciman's wife was told, 'calm dignified and pitiless'. ${ }^{3}$

I was asked if the Admiralty would have all the arrangements necessary for the immediate transport of the expeditionary force ready ... My reply was an uncompromising No. Haldane's private explanation to Asquith was that the Admiralty transport department was wholly unorganised and that my refusal was due to the Admiralty inability ... $[\mathrm{H}]$ ad either Asquith or Haldane understood the elements of transport, they would have known that the task could present no difficulties of any kind except the one over-whelming fact that it could not be kept secret. $^{4}$

It was the case that McKenna felt that there might well be circumstances where British troops ought to be engaged, but not in the first instance, and nor should war be encouraged by such a promise. 'That there were conversations at all encouraged the French in the belief that we should fight on their side and led them to provoke Germany. ${ }^{5}$ McKenna's objection to Haldane's proposals in the end was fixed on an issue at the centre of the debate: the encouragement of the French. 'In no case should our troops be employed in the first instance and the French should never be encouraged by such a promise,' McKenna told Asquith later. 'The à Berlin temper ought never to be encouraged'. ${ }^{6}$ It was born of similar concerns to those that justified increased naval expenditure: it would discourage war. 'I declined to be a party to an overt act which could not be interpreted as other than naval mobilisation. ${ }^{7}$

1. Fisher to RMcK, 20 August 1911, McKenna papers, 6/4/47; Fisher to Hankey, 13 April 1911, Hankey papers, 5/2a/13.

2. CID minute, 23 August 1911, Cabinet papers, CAB2/2.

3. Hilda Runciman, diary, 1 November 1911, Runciman papers, add/4.

4. RMcK to Spender, 9 April 1930; Hobhouse, diary, 20 February 1912, 111-12; Riddell, diary, 29 September 1913, Riddell papers, 62973, 15 August 1914, Riddell papers, 62974.

5. RMcK to Spender, 9 April 1930 [copy].

6. RMcK, 'Minutes of a conversation at Archerfield, 20 October 1911', McKenna papers, $4 / 2 / 1$.

7. RMcK to Spender, 9 April 1930 [copy]; MA, diary, 7 August 1914, MA papers, d. $3210 / 248$. 
Their scheme was a mad one, and I did what was right. The idea of smashing the German navy was absurd. In a few years they could have replaced their ships. The cut and loss to us would have been enormous and we have nothing to gain by making France the strongest power in Europe. ${ }^{1}$

McKenna claimed to have been hearing of the 'scheme' for the first time, but Asquith reminded him of the subcommittees of December 1908 and March 1909. ${ }^{2}$ That oversight apart, 'McKenna was altogether admirable', Hankey told Fisher, 'and redressed the balance of argument', which entailed 'sharp passages' with Haldane. ${ }^{3}$

'I hope that McKenna is not as full of cocksureness,' Churchill told Lloyd George, 'as his admiral is deficient in imagination'. ${ }^{4}$ Wilson was at once the weak link and the central character. In a generally muddled performance, Admiral Wilson explained that one of the strengths of naval operations was that they would relieve military pressure in France by drawing German forces away to coastal defence. Forearmed by forewarning, General Wilson, Admiral Wilson's opposite number, 'delivered his war lecture to the 1911 fire-eaters, led by Ll.G. and Winston', as McKenna put it. ${ }^{5}$ The Admiralty was nevertheless confident, Fisher most of all. ${ }^{6}$

No decision was reached on 23 August; no decision could have been reached, given that only six members of the Cabinet were present, and it did not necessarily follow that the War Office line was supported, insofar as it required the dispatch of all six divisions to France; rather, the importance was that it further impaired confidence in the Admiralty. Asquith passed on the accusations. ${ }^{7}$ 'Some hours spent in investigation have left me quite bewildered as to the meaning of the W. O. complaints', McKenna told the prime minister, rather proving the point. ${ }^{8}$ Nevertheless, Asquith replied, 'your letter ... seems to dispose completely of the War Office complaints'. ${ }^{9}$ The issue appeared resolved. 'Neither the Prime Minister or McKenna will ever leave you in the lurch!' Fisher told Hankey. ${ }^{10} \mathrm{He}$ was half right.

1. RMcK, 29 September 1913, Riddell, diary, Riddell papers, 62973.

2. CID, Subcommittee on the Military Needs of Empire, 23 March 1909, Cabinet papers, $\mathrm{CAB} 4 / 3$.

3. Hankey to Fisher, 24 August 1911, Fisher papers, 1/10/530a.

4. Churchill to Lloyd George, 5 September 1911, Companion, 2:2, 1121.

5. RMcK to Spender, 9 April 1930; Henry Wilson, in Gilbert, Lloyd George, $1: 460$.

6. Fisher to Ottley, 8 October 1911 , Hankey papers, $5 / 2 \mathrm{a} / 32$.

7. HHA to RMcK, 18 September 1911, McKenna papers, 4/1/2.

8. RMcK to HHA, 19 September 1911, Asquith papers, 13/43.

9. HHA to RMcK, 20 September 1911, McKenna papers, 3/17/18.

10. Fisher to Hankey, 21 September 1911, Hankey papers, 5/2a/26. 


\section{Reginald McKenna}

\section{ARCHERFIELD}

With matters apparently settled, that autumn McKenna was enjoying his work more than for some time; by contrast, and to reinforce the point Runciman, his successor, felt that 'going on at the Board of Education is a waste of time'. ${ }^{1}$ The liberated former President went on another tour of naval stations on the Enchantress, and found night firing exercises on HMS Inflexible 'sensational enough for any Drury Lane melodrama.'

Steaming fifteen knots with lights out we are told at a given moment that we are in a destroyer infested sea. The night was clear with a moon behind clouds. Everyone on the bridge was on the look out. Directly a target is seen, probably at about 1000 yards, a searchlight is flashed on to it and the guns open fire. Fortunately for us the target cannot fire back. ${ }^{2}$

He felt able to plan ahead, and with enthusiasm. 'I feel very happy when I think of the men coming on in the future', he told Pamela. 'Already now we are nearly through with our bad time; by next year I shall begin to have a good choice of men for the top posts. ${ }^{3}$ The international situation also ensured greater focus. 'The German news looks so bad that I am glad to have this opportunity of some conversation with our admirals', McKenna wrote from Invergordon. 'Although war is, I believe, remote, still there is a possibility of it, and this chance makes all the exercises so real as to give one almost an emotion. ${ }^{4}$

He went on to conduct a tour of his constituency. At Aberyschan on 26 September 1911, McKenna gave a dovish address during a 'very long meeting.'

Forty minutes of hostile Labour questions, chiefly about the employment of the soldiers, after I had finished my speech. I dealt faithfully with them, which is the only course to take. The local labour leaders influence their men by fear, and I break their power if I show that I am not afraid of them. I don't think they have much following. ${ }^{5}$

He repeated his pledge to reduce naval expenditure, provided the expenditure of other countries made it possible. 'Nobody recognises more fully than I do the economic waste of expenditure upon armaments'. ${ }^{6}$ Moreover,

1. Runciman to RMcK, 1 October 1911 , McKenna papers, 3/22/79.

2. RMcK to PMcK, 15 September 1911.

3. Ibid., 11 September 1911.

4. Ibid.

5. Ibid., 27 September 1911.

6. RMcK, speech at Abersychan, 26 September 1911, Times, 27 September 1911. 
with Britain's maritime trading interests, it had nothing to gain from war. The speech aroused great alarm in Germany, owing to the fact that the Kreuz-Zeitung added a belligerent coda that was reproduced all over the country. McKenna's comments: 'Peace is not only the highest human good, but is in the greatest material interest of the British Empire', were translated in the German press as: 'Peace is not the most necessary human good. In the first place stands the material interests of the British Empire." The alarm brought contingencies for war still closer. 'Sir A Wilson's "plan" can only be regarded as puerile and I have dismissed it at once', Asquith informed Haldane, the recipient and the sentiment underlining the prime minister's own preference. ${ }^{2}$ The Admiral, Fisher told Churchill, 'is magnificent at sea but he has wrecked McKenna ashore.' ${ }^{3}$

'All well and happy', McKenna told Pamela on 4 October. 'I have cleared up all papers and letters at the Admiralty and am quite free for the week. ${ }^{4}$ The same evening he upbraided Runciman.

You horrify me. I have heard nothing whatever of any changes and I can scarcely believe that anything of the kind you mention is in prospect. You don't ask for advice and I don't presume to offer it, but it is worth remembering that so long as a man retains office he retains the power to resign at his own time and for his own reasons. ${ }^{5}$

McKenna carried on with his tour. At Upper Cwmbran on 4 October, he criticised trades unionists for whom strikes and lock-outs were 'a short cut to an industrial millennium.' They were 'the jingoes of industry'. ${ }^{6}$ At Abergavenny the following day, he criticised the connexion between church and state. 'The Church of England in Wales is not the national Church of the people.' Worse, endowments 'were not being administered by the Church for the benefit of the nation; they were used to supply the spiritual needs of a section only, and that section, it so happened, the richest and the least in want of State aid. ${ }^{7}$ It would shortly be remedied. Most worryingly, McKenna on disestablishment struck some people as akin to McKenna on denominational education, and his idea of 'bloodless administration' ${ }^{8}$

On McKenna's return to London on 10 October, he received a letter from Asquith.

1. Kreuz-Zeitung, 27 September 1911, in Gooch, Documents, vii:648-52.

2. HHA to Haldane, 31 September 1911, Haldane papers, 5909/140.

3. Fisher to Churchill, 26 October 1911, Churchill papers, CHAR 13/2/1; Selborne to Balfour, 20 May 1915, Balfour papers, 49708/251.

4. RMcK to PMcK, 2 October 1911.

5. RMcK to Runciman, 2 October 1911, Runciman papers, 44/94.

6. RMcK, speech at Upper Cwmbran, 4 October 1911, Times, 5 October 1911.

7. RMcK, speech at Abergavenny, 5 October 1911, Times, 6 January 1911.

8. J. St. Davids, Times, 9 October 1911. 


\section{Reginald McKenna}

As we are on the eve of completing our sixth year of office I am contemplating a certain amount of reconstruction both inside and outside the Cabinet ... I am going to ask you to undertake what is undoubtedly one of the most difficult and responsible places in the Government-the Home Office. Your legal training and your large and tried administrative experience and capacity give you special qualifications for its duties, and I am very confident in the wisdom of my selection. ${ }^{1}$

McKenna's immediate inclination was to refuse, and to resign. Though he had been offered a promotion, it was at the expense of the policy he had spent three and a half years promoting. He also meant exchanging offices with Churchill. Asquith permitted McKenna to seek Spender's counsel. ${ }^{2}$ McKenna also spoke to Grey. 'I think it would be an awful pity if you chucked office altogether. I have learnt nothing from Asquith. I am as much in the dark as to what is really in his mind and that is why I should like to talk it all over with him before coming to a decision to refuse the H.O.' ${ }^{3}$ Spender and Elibank also urged him to remain. ${ }^{4}$ Given the legislative load he would inherit at the Home Office, McKenna asked to delay the move for two months until his health had fully recovered. Asquith agreed. It was a qualified success for McKenna. The news was immediately leaked to Northcliffe. 'Yours is an eye from which no secrets are hid', McKenna confessed, not entirely disapproving of the fact.

Much comfort have I received from the notices which have appeared in The Times and the Daily Mail, your personal letter is of much greater value to me. Some day perhaps it may interest you to hear the story from my point of view of the circumstances which led to the change. ${ }^{5}$

Asquith then changed his mind, fearful of further destabilising leaks, and the king's objection of seals being transferred in his absence-'not very reasonable, but it is well to humour him in such matters'-and told McKenna on 15 October that the move was to be immediate. ${ }^{6}$ McKenna replied, 'It is repugnant to me not to acquiesce in any proposal made by you, ${ }^{7}$ but he would not. Asquith was 'much disappointed', ${ }^{8}$ and 'I feel bound to appeal

1. HHA to RMcK, 10 October 1911, McKenna papers, 4/1/3. Robert Sanders, 29 October 1911, Diaries, 34.

2. Spender, Journalism, $i: 242$.

3. Grey to RMcK, 11 October 1911 , McKenna papers, 4/4/5.

4. Hobhouse, diary, 16 November 1911, Diary, 108.

5. RMcK to Northcliffe, 14 October 1911, Northcliffe papers, 62157/86-87.

6. HHA to RMcK, 15 October 1911, McKenna papers, 4/1/5; Vaughan Nash to RMcK, 19 October 1911, McKenna papers, 4/1/14.

7. RMcK to HHA, 17 October 1911 , McKenna papers, 4/1/8.

8. HHA to RMcK, 18 October 1911, McKenna papers, 4/1/9. 
to you to reconsider your position'. ${ }^{1}$ McKenna would only go so far as to request a private meeting, 'to tell him all that was on my mind', ${ }^{2}$ and went up to Asquith, who was on holiday in Scotland. McKenna arrived at Archerfield on 20 October.

The conversation between the two was marked by McKenna making an extensive, handwritten record on his return, a unique act on his part, and one revealing the seriousness of the situation. ${ }^{3}$ The confrontation centred on McKenna's feeling that only he could resist the continental drift, and Asquith's implicit conviction that McKenna was therefore an obstacle. During the meeting, McKenna maintained that without him at the Admiralty in the short term, when international tensions were high, the Admiralty might not be able to resist a move to send troops to France. Asquith said 'no danger so long as he was P.M., as he was opposed to the scheme.'

I objected that he had missed my point. Particular scheme of no consequence. The fact that there were conversations at all encouraged the French in the belief that we should fight on their side and led them to provoke Germany. If we failed to join them we should be charged with bad faith. If we joined in fact we should be plunged into war on their quarrel. ${ }^{4}$

McKenna pressed his case several times, and Asquith resisted, with increasing indignation. ' $\mathrm{H}$. at Archerfield had asked McK very pertinently if he really thought he was the only person who stood between us \& a great European war', Margot wrote. ${ }^{5}$ Asquith did not mention the naval staff. ${ }^{6}$

Reluctantly, McKenna relented. ${ }^{7}$ Asquith attempted, or affected, to impress upon him the good sense of the move while misleading others as to the reason. ${ }^{8}$ He flatly denied strategic reasons and told Esher that McKenna 'had been entirely dominated (a) by Jackie, (b) by Wilson, and that he would never be inclined or able to reorganize the internal naval policy of the department'. ${ }^{9}$ The almost desperate trip to Archerfield and the variety of pleas made to support his case was, and remained, the greatest trauma of McKenna's

1. Ibid., 4/9/11.

2. RMcK, 'Minutes of a conversation at Archerfield, Friday, 20 Oct. 1911', McKenna papers, $4 / 2 / 1$.

3. Ibid.

4. Ibid., $4 / 2 / 5$.

5. MA, diary, 29 November 1911, MA papers, d.3209, 194.

6. Marder maintained that HHA sacked RMcK over the naval staff, and that strategy was just a front; it could be said that the two were in fact one, or, indeed, that the naval staff was the front.

7. HHA to RMcK, 21 October 1911, McKenna papers, 4/1/15.

8. Hilda Runciman, diary, 17 October 1911 , Runciman papers, add/4.

9. Esher, diary, 4 October 1911, Esher papers, 2/12. 


\section{Reginald McKenna}

career. 'I had the greatest difficulty in explaining it was not from rumour gossip or want of efficiency that this change was made', Asquith said of the Archerfield meeting. 'He took an excited trouble to tell me how he thought the best admiral was the one who obeyed his orders at once therefore he wd. obey his chief but he minded terribly \& was rather pathetic over it'. ${ }^{2}$ A year earlier, McKenna admitted, albeit to Margot, that Asquith could 'hurt' him through the prime minister's 'personal hold over me'. ${ }^{3}$ Twenty years later, McKenna admitted to Spender, 'My subsequent conversations with Asquith belong to the real sorrows of my life'. ${ }^{4}$

Lloyd George said that McKenna 'wept' before leaving like a 'chastened dog'. For Churchill, swapping posts with McKenna felt both right and convenient; he had, after all, allowed McKenna an earlier preferment, and had not himself been a success at the Home Office. ${ }^{6}$ He had also explicitly been campaigning for McKenna's job throughout October, petitioning the chief whip and the king. ${ }^{7}$ Fisher admitted, 'It will greatly please the King for someone else to take McKenna's place. ${ }^{9}$ McKenna discounted royal pressure, however.

There was no bargain about me at Balmoral. The change was settled at Archerfield on September 18th, certainly before September 25th, and therefore before Asquith saw the King. I know this absolutely, and, further, that the King did not relish Churchill at the Admiralty. ${ }^{9}$

The changes were announced on 24 October, the day the Commons returned for the autumn session. Those who did not know the details expected McKenna to be pleased at his elevation. 'I cannot let this occasion pass without congratulating you on your promotion', as Northcliffe tactfully put it. ${ }^{10}$ Those who knew McKenna's actual reaction were bewildered. 'I don't

1. HHA to RMcK, 15 October 1911, McKenna papers, 4/1/5; HHA to RMcK, 18 October 1911, McKenna papers, 4/1/10; RMcK, 20 October 1911, Archerfield notes, McKenna papers, 4/1/8.

2. MA, diary, 13 November 1911, MA papers, d.3209, 172-74.

3. MA, diary, 12 February 1910 , MA papers, d.3208.

4. RMcK to Spender, 9 April 1930.

5. Riddell, diary, 22 May 1915, Riddell papers, 62959.

6. Churchill to Morley, 23 December 1909 [copy], Churchill papers, CHAR 2/39/121; J. S. Sandars to Balfour, 14 December 1911, Companion, ii:2, 1357-58.

7. Churchill to Elibank, 14 October 1911 [draft], Churchill papers, CHAR 12/10/105-6; (RMcK to PMcK, 4 October 1911); RMcK to Churchill, 6 September 1911, Churchill papers, CHAR 12/12/47; Churchill to RMcK, 13 September 1911, McKenna papers, 3/21/10; Knollys to Vaughan Nash, 18 October 1911, Companion, 2:2, 1296; Churchill to George V, 14 March 1911, Companion, 2:2, 1058; Arthur Duke of Connaught to Sister Louise, 8 November 1911, VIC ADDL/MSS/A17.

8. Fisher to Hankey, 21 October 1911 , Hankey papers, $5 / 2 \mathrm{a} / 32$.

9. RMcK to Fisher, 5 November 1911, Fisher papers, 1/10/539.

10. Northcliffe to RMcK, 23 October 1911. 
know why McK should have minded so very much', Edward Marsh told Dorothy Gladstone, wife of Churchill's predecessor, 'as he admitted that he had wanted to leave the Admiralty anyhow early next year, and specially wished for the H.O.'1

More than Churchill, McKenna blamed the secretary for war. 'Undoubtedly Haldane was the instigator of my transfer to the Home Office' ${ }^{2}$ indeed, he 'doomed me'. ${ }^{3}$ Haldane wanted the job himself, but, in Churchill, had a competitor, and one, moreover, whose success would free a suitable office for McKenna. At Archerfield later that month, Asquith shut Haldane and Churchill in a room, allowed them to make their claims, and deemed Churchill's the more compelling. ${ }^{4}$ The substantive damage as far as McKenna was concerned was his relationship with Asquith. Loreburn told C. P. Scott, 'It is the way A does these things that hurts, more than the things themselves.' McKenna later recalled: 'Even after nearly twenty years the story fills me with infinite disgust when I think of it.'

A number of McKenna's colleagues had criticised his performance. Sir Francis Bridgeman, second sea lord, described his chief as being not only uncooperative but having "shown a growing indisposition to go into details concerning the manning of the Fleet and questions relating thereto.' ${ }^{7}$ The naval staff was not, in effect, a dramatic break with the recent past. ${ }^{8}$ Beresford's original claims that there were no Admiralty war plans and that it needed a general staff were taken up by the CID as a means of getting rid of McKenna and enabling a continentalist strategy. Thus McKenna's repeated private refrain: 'that is why I was sacked!'

In fact, McKenna was in the process of being persuaded of its merits, only to be obstructed by Wilson. ${ }^{10}$ The more important, though largely unspoken, 175.

1. Edward Marsh to Dorothy Gladstone, 30 November 1911, Hassall, Marsh,

2. RMcK to Spender, 9 April 1930. Others agreed. Riddell, diary, 7 March 1915, Riddell papers, 62959; Morley to Churchill, 27 December 1909, Churchill papers, CHAR2/39/124.

3. RMcK, 29 September 1913, Riddell, diary, Riddell papers, 62973.

4. $R M c K, 175$.

5. Loreburn, 7 January 1912, Scott diary, Scott papers (Manchester).

6. RMcK to Spender, 9 April 1930 [copy].

7. John Sandars to Balfour, 14 December 1911, Companion, 2:2, 1357.

8. John Leyland, in 'Naval War Staffs', Naval Annual 1912, ed. Viscount Hythe (1912), 112-23.

9. Hilda Runciman, diary, 1 November 1911, Runciman papers, add/4. See Paul Kennedy, The Rise of the Anglo-German Antagonism, 1869-1914 (1980), 448-49; Samuel R. Williamson Jr., The Politics of Grand Strategy-Britain and France Prepare for War, 1904-1914 (Cambridge, MA, 1969), 186-98; Keith Wilson, 'Hankey's Appendix: Some Admiralty Manoeuvres During and After the Agadir Crisis, 1911', War in History 1 (1994): 81-97. Lambert, Revolution, 236.

10. Esher to Balfour, 24 December 1909, Esher, Journals, 428. 
cause was therefore continentalism. McKenna's conception of the war plans was that the fleet would remain static in the North Sea, untouchable. ${ }^{1}$ McKenna could offer mitigating circumstances for Wilson, and for the precipitant timing of the meeting, and could say that he was not opposed in principle to a naval staff. ${ }^{2}$ Over the wider strategic question, however, the disagreement could not in honesty be resolved, even when it was reduced to means rather than ends. The immediate consequence of the Moroccan crisis had been that McKenna, at Grey's suggestion, had placed the Royal Navy on heightened alert; the longer term effect was that preparations were made for a possible European war, and, specifically, that the navy prepare itself to transport the British Expeditionary Force to France. McKenna felt that his refusal to do so until Cabinet had been consulted was, for the prime minister, 'a great impertinence. ${ }^{3}$ Such was his strength of feeling, that McKenna privately made it known to the 'pacifists' excluded from the debate, such as Crewe, Harcourt, and Morley. It was a step McKenna at the time denied taking, though not subsequently. ${ }^{4}$ It meant, as he told Fisher, 'I am hard on the attack on joint operations and have the Cabinet with me so far.'

'I am only anxious about McKenna!' Fisher told his son on the day McKenna left the Admiralty. 'He has pretty nearly wrecked himself for the Navy's good!' Relations with Haldane and Lloyd George were irrecoverable; they were now also joined by Churchill. ${ }^{7}$ The secretary for war was, McKenna thought, 'greatly disappointed at not getting the Admiralty. ${ }^{18}$ Twenty years later, sarcasm revealed the continuing bitterness: 'poor Haldane was done out of his reward'. ${ }^{110}$ 'Some day I will tell you the whole story,' McKenna told Jellicoe,

1. Captain Herbert Richmond, diary, 29 May [1910], in Bacon, Portrait, 70-71.

2. 'Admiral Sir Arthur Knyvett-Wilson V.C.', in The First Sea Lords: From Fisher to Mountbatten, ed. Malcolm H. Murfett (Westport, 1995), 48.

3. Loreburn, 23 October 1914, Scott diary, Scott papers, 50901/173.

4. Ibid.

5. RMcK to Fisher, 5 November 1911, Fisher papers, 1/10/539.

6. Fisher to Cecil Fisher, 24 October 1911, Fisher, Correspondence, 2:396.

7. Sir Francis Hopwood to Stamfordham, 11 January 1914, Companion, 2:3, 1845; Riddell, diary, 13 December 1913, Riddell papers, 62973; Riddell, diary, 6 January 1914, Riddell papers, 62974; RMcK, Runciman, Beauchamp, Simon, and Hobhouse to HHA, 29 January 1914, Asquith papers, 25/170; RMcK to Runciman, 6 February 1914, Runciman papers, 135; RMcK to Churchill, 27 February [1907], Churchill papers, CHAR 2/29/44; J. Moore Bayley to Churchill, 30 December 1903, Companion, 2:1, 278; RMcK to Churchill, 27 March 1907, Churchill papers, CHAR 2/29/65.

8. RMcK to Spender, 9 April 1930.

9. RMcK to Spender, 9 April 1930. See Haldane, Autobiography, 229. HHA told Haldane that the first lord should be in the Commons. HHA to Haldane, 10 October 1911, Haldane papers, 5909/157; HHA to Haldane, 15 October 1911, Haldane papers, 5909/159.

10. RMcK to Fisher, 5 November 1911, Fisher papers, 1/10/539. 
but you may be sure that I have not deserted my post. I leave the admiralty with the deepest of regret and not my own wish ... For the moment War Office ideas are having their day. But it will not last ... My leaving the admiralty, however, turned on something more vital than naval politics, but for the moment I can say no more about it. ${ }^{1}$

It was pointed out that the Royal Navy of 1911 was the navy McKenna had promised in $1909 .{ }^{2}$ During his time as first lord, McKenna was responsible for the laying down of, amongst other vessels, eighteen capital ships, fifteen cruisers, and sixty destroyers. "It might well have been called the "McKenna Fleet", Archibald Hurd observed, 'for it was a well-balanced force, complete in every detail'. ${ }^{3}$ As the backbone of Jellicoe's Grand Fleet, 'it was "McKenna's Fleet", Hurd concluded, 'that turned the scales against Germany'. ${ }^{4}$ Even Bridgeman, who resented McKenna for not promoting him to replace Fisher, admitted that, while he had not the weight in Cabinet of Churchill, he achieved more for the navy. ${ }^{5}$ Churchill later thought 'the greatest credit' was due McKenna, 'for the resolute and courageous manner in which he fought his case and withstood his Party. ${ }^{6}$ Churchill was better at getting the limelight, Viscount Sandhurst concluded, but did less. ${ }^{7}$

For the Daily Graphic, 'Mr McKenna has at last fallen a victim to the fury of the economists and pacifists to whom his fine stand for the maintenance of British naval supremacy has made him obnoxious', though it also admitted the 'falsification of his prophecies', which gave his enemies a handle. ${ }^{8}$ Hankey told him,

Only quite a few can have any real idea of the extraordinary difficulties, which you have had to contend with-not least being those connected with the personal equation. I think I can claim to be one of those few and I have often marvelled at the manner in which you have overcome the obstacles which confronted you. ${ }^{9}$

'No officer will I am sure view it with more profound feelings of sorrow than myself', Jellicoe told him, adopting the Sir George Murray position. 'The news only came to us at sea yesterday by wireless and as I was totally unprepared for it, it appeared to be impossible of belief. Confirmation has come

1. RMcK to Jellicoe, 31 October 1911, Jellicoe papers, 49035/24.

2. Times, 24 October 1911.

3. Hurd, Who Goes There?, 105.

4. Ibid., 106.

5. Stewart Ross, Admiral Sir Francis Bridgeman: The Life and Times of an Officer and a Gentleman (Cambridge, 1998), 259.

6. Churchill, World Crisis, 1911-1914, 38.

7. Viscount Sandhurst, From Day to Day, 2 vols. (1928-29), 1:341.

8. Daily Graphic, 28 October 1911.

9. Hankey to RMcK, 24 October 1911. 


\section{Reginald McKenna}

to-day but even now it seemed almost incredible. ${ }^{11}$ McKenna had emerged with his reputation enhanced-his successor admitted the navy had 'never been in a more efficient state than at the present time"2-but therein lay the problem. Fisher, for one, concluded, 'He twice walked out of the Cabinet for the sake of the navy and they asked him to walk in again but they never forgot and they have got even with him!'3

1. Jellicoe to RMcK, 25 October 1911.

2. Churchill, 21 January 1912, Riddell, diary, Riddell papers, 62970.

3. Fisher to Annie Goulding, 24 November 1911, Wargrave papers, 2/43. 


\section{Home Secretary, October 1911 to May 1915}

If you want to ruin a man send him to the Home Office.

-McKenna, $1913^{1}$

\section{A PROMOTION}

In a Commons corridor the new home secretary, fresh from being sworn in at Buckingham Palace, was congratulated on his appointment. 'Do you really think it is a matter for congratulation?' he replied. ${ }^{2}$ McKenna made no attempt to disguise his displeasure. Almeric Fitzroy saw him that day at the Privy Council. 'McKenna was clearly very sore and spoke to me very bitterly of the sudden and unexpected character of the move.' ${ }^{3}$ The loss of Admiralty House, and the Enchantress, Henry Lucy sympathised, 'cannot fail to add a pang of regret to the meditations of the new Home Secretary as he makes his way to unfamiliar quarters' ${ }^{4}$ It was, nevertheless, a promotion, as McKenna was now the principal secretary of state rather than merely a member of the Board of Lords Commissioners, and his salary rose from $£ 4,500$ to $£ 5,000$. Indeed, Fitzroy noted, 'He took a sardonic pleasure in the reflection that some days must elapse before the new Admiralty warrant was ready, during which he would draw two salaries, and I suppose Winston be without any'.5

1. RMcK, 29 September 1913, Riddell, diary, Riddell papers, 62973.

2. RMcK, 24 October 1911, AMD/P 8814/42; RMcK to Evan-Thomas, 27 October 1911, Evan-Thomas papers, 52504/94; RMcK to Jellicoe, 31 October 1911, Jellicoe papers 49035/24-25; RMcK to Archibald Hurd, 26 October 1911, Hurd papers, 1/35; MA, diary, 13 November 1911, MA papers, d.3209/172-74.

3. Fitzroy, 24 October 1911, in Memoirs, by Sir Almeric Fitzroy, 2 vols. [1925], 2:467; McKenna to Evan Thomas, 27 October 1911, Evan Thomas papers, $52504 / 94$.

4. Henry Lucy, Punch, 29 October 1912.

5. Fitzroy, diary, 24 October 1911, in Memoirs, by Sir Almeric Fitzroy, 2 vols. [1925], 2:467. 


\section{Reginald McKenna}

'He admitted that he had wanted to leave the Admiralty anyhow,' Edward Marsh said, trying to make sense of McKenna's mood, 'and specially wished for the H.O.' ${ }^{1}$ It made sense to Admiral Sir George King-Hall, who heard that 'the Govt. wished a trained lawyer at the Home Office.'2 Others heard differently. Arnold Rowntree thought McKenna was going to the Local Government Board, ${ }^{3}$ which would most certainly have been grounds for his resignation from the government, while Montagu also told Asquith that McKenna would be happy to return as financial secretary - a demotion, and one with the pleasure of working under Lloyd George. As Margot put it, 'McK was sounded as to this to his amazement'. ${ }^{4}$

'Personally it's good for McKenna', Fisher conceded, 'for his health was giving way.' It was certainly good for Runciman, who was moved from the Board of Education in the reshuffle. It appeared to be good for the Home Office, shaken by a year of Churchill, who recalled how the two "changed guard with strict punctilio'. ${ }^{6}$ On 25 October 1911, McKenna introduced Churchill to his new officials at the Admiralty, and Churchill introduced McKenna to his new officials at the Home Office. 'I hear he is settling down there very well,' Edward Marsh told Dorothy Gladstone, 'and [T]roup tells me he is quite happy with the change, though before it happened he looked on the change with consternation'? Fortunately for McKenna, Sir Edward Troup was a permanent secretary in the Murray rather than the Morant mould, and the two got on well. As his ministerial junior, McKenna had Pamela's friend Charlie Masterman, and then Northcliffe's brother Cecil Harmsworth. Nevertheless, the supportive words of Admiral Denison that 'I trust that your work at the Home Office will be easier than it has been at the Admiralty', were wildly optimistic. ' 'The Home Secretary is perhaps the minister who comes into closest touch with the public', Robert Donald told McKenna, 'and is therefore most liable to be attacked.'

The reasons were the nature of the office, and the time. By the sixth year of Liberal government, the state was being expanded as dramatically in civil society as it had been in national security. Together, Ireland, Germany, labour,

1. Edward Marsh to Lady Gladstone, 30 November 1911, in Edward Marsh, Patron of the Arts, a Biography, by Christopher Hassall (1959), 175.

2. George King-Hall, 28 November 1911, diary, King-Hall papers, Royal Naval Museum Manuscript 2000/53 (20); but cf. Sir Alexander Mackintosh, Echoes of Big Ben (1945), 61.

3. Arnold Rowntree to Mary Rowntree, 24 October 1911, in The Letters of Arnold Stephenson Rowntree to Mary Katherine Rowntree, 1910-18, ed. Ian Packer (2002), 65 .

4. MA, diary, 13 November 1911, MA papers, d.3209/172-74; cf. Edward Marsh to Lady Gladstone, 30 November 1911, Hassall, Marsh, 175.

5. Fisher to John Leyland, 7 November 1911, Fisher papers 3/5/2164.

6. Churchill, World Crisis, 1911-1914, 70.

7. Edward Marsh to Lady Gladstone, 30 November 1911, Hassall, Marsh, 175.

8. John Denison to RMcK, 24 October 1911.

9. Robert Donald to RMcK, 24 October 1911. 
women, and heredity -in several forms-posed a challenge with which the Edwardian state struggled to deal. His role in the external deterrent completed-if not to his satisfaction-McKenna now found himself charged with aspects of the domestic agenda: suffragette activity was reaching a climax, the Church of England was similarly overdue in its disestablishment in Wales, and the burgeoning of organised labour strained its accommodations with Liberalism, however much New Liberalism was transforming the condition of the nation. With Home Rule for Ireland, disestablishment for Wales, and plural voting for Labour, the government was acceding to the interests on which, since the 1910 general elections, it was dependent.

Even if McKenna was not naturally as dynamic as had been his predecessor, there was still much to do. He was immediately granted two private secretaries to take account of an apparently ever-expanding workload, and the number subsequently doubled. ${ }^{1}$ Within two months, he had been petitioned about, amongst other things, special constables, the theatre, lunatics, mines, shops, female workers, London transport, explosives storage, street criers, Jews, rail workers, use of the military during strikes, an explosion at a Liverpool seed-mill, the trades disputes act, trades unions and the law, public morality, 'white slave traffic', Welsh disestablishment, London rates increases, cotton weaving, the deportation of aliens, Lake Windermere, demoralizing literature, miners' sentences, electricity, cinema censorship, and Beresford. Friends could also urge their pet preoccupations on him. St Loe Strachey wanted to know about gypsies, ${ }^{2}$ while W. B. Yeats wanted to know about ghosts. ${ }^{3}$ McKenna told Jellicoe, "most reluctantly, and acting only upon what I conceive to be my duty, I have taken up my present post. ${ }^{4}$ It was, in effect, as a lightning conductor for the government.

\section{DISESTABLISHMENT}

The first and most substantial of McKenna's legislative initiatives was the Welsh Church Bill; the fifth since 1870. As a lawyer and a Welsh MP, armed with the Parliament Act, he was expected to deliver on another element of the Liberal mandate, as symbolic and controversial in its way as Home Rule, and seen similarly as essential to a sense of nation. ${ }^{5}$ Disestablishment of the Church of England in Wales-in effect, of the four Welsh dioceses in the 75 .

1. Jill Pellew, The Home Office, 1848-1914: From Clerks to Bureaucrats (1982),

2. John St. Loe Strachey to RMcK, 16 November 1911, Strachey papers, 10/3/1; St. Loe Strachey to RMcK, 17 May 1912, Strachey papers, 10/3/3; RMcK to St. Loe Strachey, 21 May 1912, Strachey papers, 10/3/3.

3. R. F. Foster, W. B. Yeats, 2 vols. (Oxford, 1997), $i: 502$.

4. RMcK to Jellicoe, 31 October 1911, Jellicoe papers, 49035/24.

5. HHA to RMcK, 10 October 1911, McKenna papers, 4/1/3; Morgan, Wales, 231-40, 259-74. 


\section{Reginald McKenna}

province of Canterbury - was another Free Church totem, and one around which the home secretary was required to dance, as Gladstone had done over Ireland in 1869. While the popular will within Wales was clear, it was in Westminster that opposition had to be overcome. While there may have been a Parliament Act, there was no longer a great Liberal majority, which had in any event failed to provide for the passage of three Education Bills.

McKenna began the campaign at the Queen's Hall on 25 January 1912, armed with a message from Lloyd George, and accompanied by policemen. Suffragettes nevertheless managed to interrupt almost every other word, and the meeting soon descended into chaos. ${ }^{1}$ After more public meetings, and interruptions, McKenna introduced the bill in the Commons on 23 April. ${ }^{2}$ Recognising the marginalisation of Anglicanism by nonconformity within Wales, it also intended to remove the political status of the Anglican establishment, and, of greater practical effect, secularise its endowments. McKenna claimed that the net income from endowments of the Church was $£ 268,550$, of which he would take $£ 173,000$, which would be transferred via the Church commissioners to the Welsh people, in the forms of tithes and charitable trusts. It was a pointed speech. 'The great asset which he has and which was never better shown than yesterday', Edwin Montagu told Pamela the following day, 'is pluck.'

The bill was based on the inconclusive report of a protracted and unpopular Royal Commission, and involved myriad compromises over endowments and grants the calculation of which even the commission admitted was 'almost impossible and very controversial' ${ }^{4}$ Moreover, the nonconformist revival of 1904 that had inspired McKenna's efforts at the Board of Education had by then abated, and the crusade for disestablishment had lost its momentum. It was perhaps appropriate, then, that, as The Times put it, the home secretary 'failed to impart any Celtic fire'. 'From any point of view', Bishop Edwards thought, it was 'an unworthy performance'. ${ }^{6}$ Even Herbert Lewis, sitting next to him, found the speech 'careful but lifeless'? McKenna thundered from the dispatch box, 'Those who have opposed this measure have never directed their minds to the case of Wales ... In Wales it will make the outer appearance of things correspond with the inner reality of things'. ${ }^{8}$ What the Daily Graphic called McKenna's 'characteristic lack

1. Times, 26 January 1912.

2. RMcK, Parliamentary Debates, 23 April 1912, 944-60.

3. Edwin Montagu to PMcK, 24 April 1912.

4. Report of the Royal Commission Appointed to Inquire into the Church and Other Religious Bodies in Wales, Cd.5432, 5433-35, 5436-39, 7; J. Scott Lidgett, Reminiscences [1928], 73; Elibank, diary, 1 November 1912, Elibank papers, 8814/92.

5. Times, 30 April 1912.

6. Alfred George Edwards, Bishop of St Asaph, Landmarks in the History of the Welsh Church (1912), 257.

7. Herbert Lewis, diary, 23 April 1912, Lewis papers.

8. RMcK, Times, 17 May 1912. 
of humour' elevated the bathos. ${ }^{1}$ F. E. Smith recalled how McKenna's dry observations were met with 'laughter and ridicule', ${ }^{2}$ while Balfour asked to general hilarity whether the new church 'is to look back to the right hon. Gentleman as its founder, and just as we talk now of St. Augustine and St. Columba, so posterity will talk then of St. McKenna'. ${ }^{3}$

Beatified or not, McKenna, as Violet Asquith put it, 'is a bad lubricator for a really unpopular measure, whatever his other virtues'. ${ }^{4} \mathrm{He}$ had by then thoroughly outgrown his youthful religiosity, which was perhaps why for William Robertson Nicoll, who remembered the Education Bills, he 'does not carry weight for some reason.' ${ }^{5}$ Disestablishment brought together many of the issues, individuals, and practices of his days in Education. Alfred Edwards, bishop of St. Asaph, who had mediated McKenna's difficulties at Education, now assumed a stance of implacable resistance. The Daily Graphic depicted a fraught home secretary, with his head in a history of the church in Wales in the twelfth century. Noting the performance of Gladstone in 1870 and Balfour in 1895, Edwards thought McKenna in 1912 'was less conversant with history than his predecessors' ${ }^{6}$ One particularly arcane dispute centred on McKenna's citation of Giraldus Cambrensis, to the effect that there were no tithes in Wales in 1172. Bishop Edwards questioned his honour, ${ }^{7}$ and Bishop Owen, echoing Morant, equally accusatory, suspected he had no more than an academic interest in the issue in the first place. ${ }^{8}$ The contrast when Lloyd George involved himself was marked, though at least in part because to settle the matter he proposed more generous terms than the Church itself had suggested..$^{9}$ For Unionists, the bill was another attack on religion in general, and the established church in particular, from a minister with a record of vandalism. Even without the involvement of Austen Chamberlain and Bonar Law, who were themselves nonconformists, the opposition was pointed and personal. After another confrontation, concerning the relative extent of Anglican and Calvinist slum clearance in Cardiff, Unionists shouted him down, yelling 'McKenna! McKenna!'10 When they heard of McKenna's concessions, his own Welsh members did so. ${ }^{11}$ Austen

1. Daily Graphic, 14 May 1912.

2. Birkenhead, Sunday Times, 1 June 1924.

3. Balfour, Parliamentary Debates, 14 May 1912, 1016.

4. Violet Asquith to Montagu, 15 December 1912, Violet Asquith, Diaries, 347.

5. W. R. Nicoll, 16 November 1913, Riddell, diary, 62973; Stephen Koss, Nonconformity in Modern British Politics (1975), 10, 88.

6. Edwards, Landmarks, 256.

7. Times, 17 June 1912.

8. Western Mail, 7 September 1943.

9. Robert Sanders, 26 April 1912, Diaries, 46; Herbert Lewis, diary, 25 April 1912, Lewis papers; Lloyd George, Parliamentary Debates, 29 April 1912, 1265-86.

10. Punch, 17 June 1912.

11. Bridgeman, diary, 18 December 1912, in The Modernisation of Conservative Politics: Diaries and Letters of William Bridgeman, 1904-1935, ed. Philip Williamson (1988), 63. 


\section{Reginald McKenna}

Chamberlain commented McKenna 'is as much disliked on his own side as on ours-which is saying a great deal'. ${ }^{1}$

Others accepted the political case for the bill, but deprecated the severity of the disendowments, as over 5,000 petitions and a million and a half signatories against, and two petitions and four signatories in support of the bill, suggested. ${ }^{2}$ Given that McKenna had based his case more on what passed for audit than on the reasons for wishing for disestablishment, it was the audit that preoccupied opponents. 'The figures quoted were untrue', Bishop Edwards went on, 'and the knowledge displayed of the whole problem was elementary'. 'Tithes in Wales were not the offspring of piety; they were the creation of law', McKenna declared, which caused another row with Unionists who, if not exercised by piety, certainly were by property and the challenge of his 'Welsh spoliation bill'. ${ }^{4}$ While not affecting the rest of Britain, it had symbolic resonance, which weakened the support of English Anglican MPs. What could be called disestablishment could also be called disendowment. Cartoonists could as easily depict him delivering on a progressive agenda, as they could have him mugging the Welsh church of its assets because he had been paid by the nonconformist vote to do so. One had 'the man with the pick' hacking away at the buttresses of a church, carting away the stone for secular construction. McKenna, as Asquith put it, 'did not feel able to call himself a member of the Church of England', ${ }^{5}$ which the archbishop of York may have surmised when he defended the principle of establishment in the face of 'the commonplaces of Mr McKenna's oldfashioned individualism'. ${ }^{6}$ The Lords vetoed the bill on 13 February 1913.

\section{SUFFRAGISM}

The inevitable continuance of the Welsh Church controversy joined the equally inevitable continuance of the female emancipation controversy, and, more specifically, acts of militancy by women to that end. The acts were hard to avoid. Asquith, possibly with conciliation in mind, had holidayed with the McKennae at Dornoch, in the Highlands, where they had taken a house. Out on the links one day, McKenna and Asquith were ambushed by two suffragettes, who started hitting them with umbrellas. The home secretary and prime minister parried with golf clubs until they were rescued. ${ }^{7}$

1. Chamberlain, 16 November 1912, in Politics from Inside, an Epistolary Chronicle, by Austen Chamberlain (1936), 492.

2. Times, 7 December 1912.

3. Edwards, Landmarks, 257.

4. Arthur Griffith to Boscawen, Times, 18 June 1912; RMcK, 25 January 1912, Times, 26 January 1912.

5. HHA to Simon, 26 July 1915, Simon papers, 51/76.

6. Archbishop of York, 12 June 1912, Times, 13 June 1912.

7. Yorkshire Post, 10 September 1943. 
On another occasion, a suffragette jumped on McKenna as he talked with the king during a tour of Wales, sending them both tumbling down a hill. ${ }^{1}$ 'McKenna is a very courageous man', observed Riddell. 'He does not seem to know what fear is. Notwithstanding the violence of the suffragettes, he never bothers about police protection.'2

Just as the militants provoked obduracy in McKenna, he 'did more than most of the Government to turn the movement into a well-organised party', Lady Frances Balfour claimed. 'He was a complete "Epicier", and had no knowledge of women or of Society in any of its graded shades'. ${ }^{3}$ F. E. Smith finally found common ground in thinking McKenna was one of the 'sincere opponents in principle', ${ }^{4}$ as did Lloyd George. ${ }^{5}$ Yet McKenna was as ambivalent as the Cabinet was divided. With Henry Labouchere, he had supported Charles McLaren's 1904 resolution to repeal the 'doctrine of inherent incapacity of women', ${ }^{6}$ and ensured parliamentary time, and with it much criticism, for Arthur Lee's June 1912 White Slave Traffic Bill. ${ }^{7}$ McKenna was of radical tutelage and liberal marriage. Pamela told her husband towards the end of the January 1910 campaign that 'It is glorious to be a man and have a brain and make History and speeches and be the tool of a large constituency and miserable to be a woman and sit at home and do no good. ${ }^{8}$ At the Horticultural Hall on 16 December 1911, a meeting of the Women's Liberal Federation 'to inaugurate the women's suffrage campaign' heard speeches from Lloyd George and Grey, alongside whom on the platform were Aggie and Pamela. Ned's wife Emily was active in the Women's Social and Political Union (WSPU), and Frances Horner lobbied McKenna through Pamela. ${ }^{9}$ McKenna admired the activists, of whom the most notable were

1. Times, 27 June 1912; Washington Post, 19 July 1912; George V, diary, 23 January 1913; Clive Wigram to PMcK, 7 September 1943.

2. Riddell, diary, 29 September 1913, Riddell papers, 62973; Brian Harrison, Separate Spheres: The Opposition to Women's Suffrage in Britain (1978), 38; Runciman to Churchill, 13 December 1907, Churchill papers, CHAR 2/30/92.

3. Lady Frances Balfour, Ne Obliviscaris: Dinna Forget, 2 vols. (1930), ii:161.

4. F. E. Smith to Bonar Law, 27 December 1911, Bonar Law papers, 24/5/157; David Morgan, Suffragists and Liberals, The Politics of Woman Suffrage in England (Oxford, 1975), 41; Leslie Parker Hume, The National Union of Women's Suffrage Societies, 1897-1914 (New York, 1982), 128, n. 128; but see Cregier, Bounder, 191.

5. Scott, diary, 15 June 1911, Scott papers (Manchester).

6. Sir Charles McLaren, Parliamentary Debates, 16 March 1904, 1333; Constance Rover, Women's Suffrage and Party Politics in Britain, 1866-1914 (1967), 135.

7. RMcK, 10 June 1912, Parliamentary Debates, 607-14; Troup, Home Office, 203-4.

8. PMcK to RMcK, n.d. [January 1910].

9. Lutyens to Emily Lutyens, 9 August 1909, in The Letters of Edwin Lutyens to His Wife Lady Emily, eds. Jane Ridley and Clayre Percy (1988), 173. 
the Pankhursts. He told Keir Hardie, 'Sylvia is a plucky girl!' He had also said, during the January 1910 election campaign: 'I have always hitherto supported the extension of the franchise to women.'

As with Pamela, it was not the measure so much as the method that he opposed; violence had to be resisted. 'One could wish that those who take part', he told another interrupted meeting, 'realize that at every meeting at which a demonstration of this kind takes place they make a large number of enemies to their cause'. ${ }^{3}$ As home secretary, his primary consideration had to be public order. Opposition to suffragism may not have been liberal, but nor were the actions of suffragettes. As well as being physically attacked in public, he was assaulted at home, and at work, and so felt justified in comparing 'fanatical and hysterical women' to the followers of the Mahdi in Sudan. ${ }^{4}$ In November 1912, when he presided at Spender's lecture on 'The Influence of the Press on Public Morals' at Holborn Hall, McKenna was shouted down by a suffragette who had tied herself to her chair, prompting him to abandon his comments until after his friend had finished, whereupon over a dozen women ran to the stage, shouting and gesticulating, while sympathetic members of the audience formed a bodyguard, and, to avoid a still larger group waiting at the entrance, bundled McKenna and Pamela through a side door and into a car. ${ }^{5}$

Militancy met with a response similar in kind but the opposite of that intended: it transformed McKenna into 'decidedly an anti-suffragist'. ${ }^{6} \mathrm{He}$ explained his position to a suffragette who approached him at a public meeting. 'The majority of women don't want it, but if they did I should be prepared to put aside my own prejudice and vote for the measure.' 'But how do you suggest our obtaining this majority', the suffragette asked. 'Educate the country, not smash windows'? As he also said, during the January 1910 election campaign, 'as long as the present methods are pursued, I absolutely decline to give any pledge'.

The obstruction of each conciliation bill-which offered female suffrage based on a property qualification, and which McKenna told Elizabeth Haldane the government could not support, as it would be defeated in the

1. RMcK, in E. Sylvia Pankhurst, The Suffragette Movement: An Intimate Account of Persons and Ideals (1931), 451.

2. Manchester Guardian, 8 October 1910.

3. RMcK, 25 January 1912, Times, 26 January 1912.

4. RMcK Parliamentary Debates, 18 March 1913, 906; New York Times, 15 March 1914; Yorkshire Post, 10 September 1943; Times, 11 April 1914; Manchester Guardian, 8 May 1913.

5. Times, 5 November 1912.

6. Times, 25 November 1911.

7. The suffragist replied they had been doing that for forty-six years. 'EM', Suffragette, 8 November 1912.

8. Manchester Guardian, 8 October 1910. 
Commons, never mind the Lords 1 - produced more fervent protest, and by the spring of 1912 there were increased levels of militancy. The most traumatic issue, for ministers as well as for suffragettes, was hunger strikers. Churchill had felt compelled to introduce forcible feeding, which even the Daily Mail and the king found repugnant. The measure stood thereafter as a stain on the reputation of the Liberals as a progressive party. ' $I$ am sure that but for forcible feeding the hunger strike would be adopted by many other prisoners who are now serving their sentence without trouble', he told Stamfordham, the King's Private Secretary who had passed on the king's desire that it be ended, ${ }^{3}$ but it 'is as repugnant to the prison authorities as it is to me. In fact, it is one of the most unpleasant public duties that can fall to anyone's lot. ${ }^{4}$

The matter was potentially as divisive within the Cabinet as it was in the country. It was another issue that divided McKenna and Lloyd George. "So long as the "pros" take action, what are the "antis" to do?' McKenna asked Margot.

They have a choice of evils. They can remain quiet and allow suffrage to become part of the recognised policy of the Liberal Party, a situation that would be intolerable for the Prime Minister; or they can take action themselves, with the risk of breaking up the Cabinet. Total abstention was the right and the agreed policy, but it can only be pursued if it is loyally accepted on both sides. The only colleagues I have seen to talk to are Grey, Harcourt, and Runciman. They all feel some anxiety about the future, but I don't think any one of them takes quite so serious a view as you and I do of the danger of public disagreement on any prominent political question. ${ }^{5}$

McKenna sought to mitigate prison conditions by freeing prisoners from uniform and leaving their cell doors unlocked, except in the case of hard labour prisoners and those convicted of serious violence. ${ }^{6}$ 'It was never my practice or intention to treat window smashing or other acts of real violence as offences involving no disgraceful consequences', he told Churchill. 'The

1. Elizabeth Haldane, From One Century to Another (1937), 270-71.

2. F. W. Pethick-Lawrence, Fate Has Been Kind (1942), 83; Pankhurst, Suffragette, 453; Rover, Suffrage, 134-35; David Mitchell, Queen Christabel (1977), 191; Stamfordham to RMcK, 27 March 1913, RA PS/GV/O 459/1; Henry Morris, Times, 11 March 1918.

3. RMcK to Stamfordham, 31 March 1913, RA PS/GV/O 459/4.

4. RMcK to Stamfordham, 28 March 1913, RA PS/GV/O 459/2.

5. RMcK to MA, 31 January 1912, MA papers, c. 6679/96-98.

6. RMcK, Parliamentary Debates, 21 March 1912, 2068; RMcK, 21 May 1912, Times, 24 May 1912. 


\section{Reginald McKenna}

privileges of the new rule were always intended for purely technical illegalities which did not involve injury to pursue a destruction of property. ${ }^{1}$

'The effect of this is to give them nearly all the advantages of imprisonment in the first division except that they will have no facilities for carrying on their propaganda from within the prison.' ${ }^{2}$ Under him, Sylvia Pankhurst thought Holloway prison had become 'a jolly place indeed'. ${ }^{3}$ He continued to be criticised by the Royal College of Surgeons, ${ }^{4}$ and had to refute the allegation that prison officers administered hypnotic drugs to hunger-strikers. McKenna defended such measures by citing the example of a prisoner who had sponged herself over with warm water before going to bed without any clothes on, in order to 'catch her death of cold in order to die in prison'. ${ }^{5}$ "Mrs Pankhurst is still surviving in health but in a worse temper than ever. She threatens to walk about her cell without clothes in order to force us to let her out,' he told Pamela. 'I am not disturbed however.'

Unionists again questioned McKenna's honour, accusing him of practising differential treatment of suffragette prisoners and arbitrarily of selecting the divisions in which they served their sentence. McKenna had already explicitly refused such treatment for suffragette leaders, ${ }^{7}$ but Lord Robert Cecil moved a reduction of McKenna's salary by $£ .100$ in an attempt to mount a House of Commons censure, questioning the home secretary's personal integrity. ${ }^{8}$ Sir Frederick Banbury, an MP long preoccupied with parliamentary propriety, said McKenna is not a capable person to occupy the position' of home secretary. ${ }^{9}$ Where for some it was merely a matter of competence, for others it was a matter of morality. Emily Hobhouse compared Emmeline Pankhurst and McKenna to Gandhi and Smuts. ${ }^{10}$ At the next election, the Election Fighting Fund of the women's movement announced it would contest North Monmouthshire.

1. Churchill to RMcK, 2 March 1912.

2. RMcK to Scott, 25 May 1912, Scott papers (Manchester), 332/115.

3. Pankhurst, Suffragette, 376-77; Fulford, Votes, 263; Mitchell, Christabel, 186-87.

4. John and Eustace, 'Shared Histories', 13.

5. Pankhurst, Suffragette, 559-60; RMcK, Parliamentary Debates, 18 March $1913,898$.

6. RMcK to PMcK, n.d. [c. 1913].

7. RMcK to Scott, 27 March 1912, Scott papers (Manchester), 332/90; RMcK to Scott, 30 July 1913, Scott papers (Manchester), 333/29.

8. I.ord Robert Cecil, Parliamentary Debates, 28 June 1912, 653-55; Sir Frederick Banbury, 28 June 1912, Parliamentary Debates, 655-56; RMcK, 28 June 1912, Parliamentary Debates, 702, 694.

9. Sir Frederick Banbury, Parliamentary Debates, 28 June 1912, 655.

10. Emily Hobhouse to J. C. Smuts, 29 December 1913, in Selections from the Smuts Papers, vol. 3, June 1910-November 1918, eds. W. R. Hancock and Jean Van Der Poel (Cambridge, 1966), 154. 


\section{TRADES UNIONISM}

McKenna may have admitted -in private-that 'the Liberals would never have to fear the Labour party, for the Labour party had no brains', ${ }^{1}$ but labour provided the third militant threat to the Liberal state with which he had simultaneously to deal. Whether of hunger, mines, or docks, strikes came to characterise 1912. Reflective of the government's parliamentary dependency, the principal response had been concession. The first of McKenna's tenure, by coal miners, came on 29 February 1912. Loreburn warned him of impending breakdown. 'It is not only police etc but also reserves of food, transport, etc which may soon be needed. I do hope you are now equipped for this contingency.' ${ }^{2}$ McKenna was confident he could 'keep London fed'. ${ }^{3}$

The home secretary convened a conference at the Board of Trade. 'The feeling is very strong indeed', the chief industrial commissioner Sir George Askwith told Knollys, 'and somewhat astonished McKenna who started gaily ... and then found himself "grassed" in 10 minutes. ${ }^{4}$ In fact, McKenna was more critical of the failure of the owners to attend, accusing them of showing 'great determination not to take the men back except on the owners' terms, and if this resolve is insisted upon, the strike cannot be otherwise than protracted.' As over the Welsh Church, Lloyd George was co-opted as an emollient, and he duly acceded to the miners' demands; McKenna was for statutory resolution and threatened to resign unless a bill was brought in. ${ }^{6}$ The Coal Miners (Minimum Wage) Bill established both the principle of the minimum wage and the machinery for settlement, with the threat of force if the strike continued after the act, which became law on 29 March 1912. The twin effects were that the strike was ended and Labour amendments were defeated, but it still appeared to critics that industrial peace was being purchased, rather than commanded. ${ }^{7}$

McKenna was much less inclined than his predecessor to use troops and was content to station forces in Darlington and Newport in case of disorder in Durham or South Wales. Nevertheless, trades unionists had complained during the coal strike that the home secretary had prolonged the dispute by

1. William Braithwaite, in Lloyd George's Ambulance Wagon: Being the Memoirs of William J. Braithwaite, 1911-1912, ed. Sir Henry Bunbury (1957), 180.

2. Earl Loreburn to RMcK, 24 March 1912, RMcK, 151.

3. Mark Bonham Carter to Violet Asquith, 24 May 1912, Violet Asquith, Diaries, 315 .

4. G. R. Askwith to Knollys, 29 May 1912, RA PS/GV/B 348/10.

5. RMcK to George V, 29 May 1912, RA PS/GV/B 348/12.

6. Charles Hobhouse, diary, 27 March 1912, in Inside Asquith's Cabinet: From the Diaries of Charles Hobhouse ed. Edward David (1977), 112-13.

7. Times, 4 March 1912. 


\section{Reginald McKenna}

policing of 'undue severity', ${ }^{1}$ while during the subsequent dock strike, businessmen complained that he was not doing enough to protect free labour and food supplies. ${ }^{2}$ Having declared that the government would not be 'taking sides', McKenna promptly infuriated Labour leaders by preventing vessels from docking. He did the same to Unionists by referring to free labour as 'strike breakers', in a speech that shook both the stock market and merchants who proclaimed a 'state of terrorism' at home, and threatened to take their business to 'a free country.'

McKenna appeared finally to take sides by refusing police protection for strike-breakers whose actions he regarded as 'provocative'. For that decision, on 12 June, he was arraigned and the subject of a vote of censure in the Commons moved by Chamberlain, perhaps with the scars of stripped tobacco still smarting, who described McKenna's actions as 'unconstitutional and contrary to law'. ${ }^{4}$ The debate was long and the House disorderly. The right to work was contested against the right to strike, and Asquith was forced to defend the actions of his home secretary. ${ }^{5}$ With the support of Labour MPs, the motion was defeated.

The national transport strike did not affect the labour that was being transported from Monmouth to London to break the dock strike, or the police being transported from London to Monmouth to break the coal strike. ${ }^{6}$ No one made the connection at the time-and McKenna denied sending 'an expeditionary force to wild Wales" Monmouth, had refused to offer protection to his own constituents freely engaged in work for ratepayers who had paid for the Metropolitan police, which were policing his own constituents in his constituency. ${ }^{8}$ It may have been coincidental, but it would have been embarrassing had anyone noticed it. Conscious of rising union militancy, the political interests of the Liberal Party, and indeed the demands of coalition government, in October 1910, McKenna stated that payment of MPs was insufficient. He also pressed for the reversal of the Osborne judgement and helped introduce the Trades Union (No. 2) Bill on 9 May 1912, which, as the Trade Union Act 1913, in

1. RMcK to George V, 31 May 1912, RA PS/GV/O B 348/17; Tom Mann, Tom Mann's Memoirs (1923), 265-81.

2. Times, passim, 17 June 1912, Parliamentary Debates, 1317-21; RMcK to George V, 29 May 1912, Royal Archives, GV/B/348/12; Robert Sanders, diary, 19 June 1912, Diaries, 47; Austen Chamberlain, 9 June 1912, in Politics from Inside, an Epistolary Chronicle (1936), 490.

3. Letters, Times, 8, 10, 11, 17 June 1912; Parliamentary Debates, 6 June 1912, $423-24$.

4. Austen Chamberlain, Parliamentary Debates, 12 June 1912, 872.

5. HHA, Parliamentary Debates, 12 June 1912, 913-17.

6. RMcK, Parliamentary Debates, 6 June 1912, 426-27.

7. Sir J. D. Rees, 6 June 1912, Parliamentary Debates, 281.

8. Austen Chamberlain, Parliamentary Debates, 12 June 1912, 878; Times, 22 December 1911; Letters, Times, 8, 10 June 1912. 
large part, did. ${ }^{1}$ Despite these measures, and almost unnoticed, the Labour Party decided, a month earlier, that, like the women's movement, it would contest North Monmouthshire in the next election.

\section{PAMELA}

In autumn 1911, Reggie endured the lowest point of his career at the same time as being, in Margot's words, 'ill with anxiety over Pamela'. ${ }^{2}$ They were both physically infirm. The consequences of his appendectomy continued through 1912, and he was often too ill even to golf. There were no more children, and her health improved, assisted by the replacement of Nanny Gibson with the Asquiths' Nanny Lavinia Harris, to Margot's subsequent chagrin. ${ }^{3}$ Reggie, Pamela, Michael, and David spent their summers at Dornoch and their winters at Munstead.

Intimate observers of $\mathrm{Mr}$ and $\mathrm{Mrs}$ McKenna noticed the differences in outlook that their ages and backgrounds suggested. ${ }^{4}$ Asquith found Pamela one afternoon in the Commons tearoom with her husband, 'inclined to bouder [sulk] because the latter had absorbed himself in Land \& Water', the journal for which Hilaire Belloc wrote. 'Pamela was much younger than Reginald, and they had not an easy sharing of tastes', recalled their friend, the publisher Francis Meynell. 'She made their houses in London and Somerset party-centres more for young artists and writers than for the smart world of politicians. Reggie's political interests had to be served, but for Pamela this was duty more than interest. ${ }^{6}$ That was not how it appeared to everyone at the time. Riddell increasingly came to think 'Mrs McKenna is a very clever little woman'. ${ }^{7}$ Fisher agreed. 'A clever little woman-full of brains' ${ }^{8}$ Margot thought, 'She takes her husband's point of view politically always, not socially.' Certainly, it was because 'you never faltered when your Reggie's political life was at stake' ${ }^{10}$ that Fisher wanted her to edit his memoirs. He then changed his mind. 'There's too much about both of you!'11

1. Times, 19 October 1910.

2. MA, diary, 13 November 1911, MA papers, d.3209/172-74.

3. MA, diary, 13 October 1912, MA papers, d.3210/170.

4. Compton Mackenzie, My Life and Times, 147-48.

5. HHA to Venetia Stanley, 27 February 1915, in Letters, 453.

6. Meynell, Lives, 68.

7. Riddell, diary, 28-29 September 1913, Riddell papers, 62973.

8. Fisher, 3 February 1915, Riddell, diary, Riddell papers, 62959.

9. MA, diary, 15 May 1915, MA papers, d.3212/8-9.

10. Fisher to PMcK, 2 March 1912, McKenna papers, 6/5/2.

11. Fisher to PMcK, 20 April 1912, McKenna papers, 6/5/7-8; Fisher to Churchill, 22 April 1912, Hankey papers, 5/2/A; Fisher to Kitchener, 11 March 1915, Kitchener papers, PRO 30/57/80/39; PMcK to Baddeley, n.d. [1912]. 
Pamela's political interests had started to diverge from those of her husband. In addition to the suffrage, Pamela displayed what Reggie privately regarded as the Jekylls' naively romanticised views of the class struggle ('mother wants you to produce a thrilling socialist and bring him to dine'1). From 1912, she became friendly with J. A. Pease, who had succeeded Runciman at Education. Pease holidayed with the McKennas in Dornoch in the summer of 1912, and the two swapped and discussed socialist tracts. They appeared to become too friendly, and Pease was 'expelled by McKenna from his house in the country where he was staying because he was seen holding Pamela's hand.'2 That with Pease became one of Pamela's 'soul friendships', but her likely appeal to men remained a sensitive issue. ${ }^{3}$ Pamela had asked Arnold Bennett to introduce her to H. G. Wells, but then made excuses for each luncheon Bennett organised. Then she said 'she would like to see me for a moment, if possible, as she didn't care to write what she wanted to say'. When Bennett went to see her, 'she was nervous, and turned away to a table as she told me that Reginald didn't want her to meet Wells, and indeed told her that she 'couldn't' meet Wells'. ${ }^{4}$

Many of her friends were socialists. Francis Meynell designed, and the Daily Herald published, The March of the Workers and Other Songs, edited by Pamela, and she even composed a tune for William Morris's 'The Voice of Toil', among others. 'The songs are a delightful surprise', C. Hubert Parry told her. 'One gets such an appalling lot of rubbish sent one with the problem of devising something that will convey the facts or name them, without causing acute disappointment; and when something so rare as your songs come along it is quite a joy and wonder.'

Her public role had also been growing, as her health improved and her confidence grew. On 19 March 1914, she gave evidence to a Parliamentary committee about the infrastructure of the Palace of Westminster, and in particular of the ladies' gallery, which was now less agreeable than the speakers' gallery. Her interest was personal, as she spent so much time there. It was there that she would meet Asquith: she was with him when he was attacked by a suffragette and, according to Riddell, promptly 'pounced upon [the woman,] seized her by the neck and dragged [her] away'.

In November, Margot 'saw little Pamela the 1 st time to talk alone since his change. I gave her a good talking to in a friendly way in joining \& encour-

1. PJ to RMcK, 10 February 1908.

2. Cynthia Asquith, diary, 5 June 1915, Diaries, 38.

3. Cameron Hazlehurst and Christine Woodland, eds., A Liberal Chronicle: Journal and Papers of J. A. Pease, 1st Lord Gainford, 1908-10 (1994), 30, n. 24.

4. PMcK, [24 March 1916], in Reginald Pound, Arnold Bennett: A Biography (1952), 261; Newman Flower, ed., The Journals of Arnold Bennett, vol. 2, 19111921 (1932), 158.

5. Meynell, Lives, 81.

6. Sir C. Hubert H. Parry to PMcK, 5 November 1912.

7. Riddell, diary, 29 September 1913, Riddell papers, 62973. 
aging her husbands indiscreet grousing. ${ }^{1}$ Nevertheless, Pamela combined to moderate the effect of her husband, and was herself a means of influencing him. Their differences complemented each other, and, for Asquith, 'on the whole I think they have kept up attachment \& its outward forms better than most married couples'. ${ }^{2}$ It was a more notable achievement when the husband was not one of whom romantic gestures would have ever been expected, and who did not disappoint, ending one longing missive, 'I miss you dreadfully for no intelligible reason. ${ }^{3}$

\section{SOCIAL REFORM}

At the same time as withstanding an unprecedented coincidence of militancies, McKenna was back in a domestic department, which gave him another opportunity to advance social reform. Poor Law guardians had for some time been seeking powers to deal with the 66,000 'mental defectives' in the country, 46,000 of whom were released into society at the age of sixteen, but over whom no supervisory powers existed beyond the Idiots Act of 1886 and the Lunacy Acts $1890-1911 .{ }^{4}$ On 16 May 1912, on the same day as the second reading of his Welsh Church bill, McKenna introduced his sixty-eight-clause Mental Deficiency and Lunacy Bill. On its second reading the following day, McKenna offered a sympathetic assessment of the problem. ${ }^{5}$ Product of another Royal Commission, wider welfare reforms, and contemporary eugenicist thinking, the mental defectives bill required Local Education Authorities to identify mentally defective children who would henceforth receive special education, and allowed the courts to certify, rather than send to prison, those deemed 'mentally defective'. ${ }^{6}$ Much more extensive information would be kept on each person by local authorities, Poor Law officials, and medical and police officers, and much greater authority, again, would accrue to the home secretary.

Despite being criticised from the left by Josiah Wedgwood, and from the right by Lord Robert Cecil, each objecting in their way to the further emboldening of the state and the wider implications on government, the measure did not attract serious opposition. ${ }^{7}$ McKenna's claims as to the

1. MA, diary, 29 November 1911, MA papers, d.3209, 194.

2. HHA to Venetia Stanley, 27 February 1915, in Letters, 453.

3. RMcK to PMcK, 20 October 1912.

4. Edward Percy Everest, The Public Authorities' Guide to the Mental Deficiency Act 1913 (1914); James Greig and William Gattie, Archbold's Lunacy and Mental Deficiency, 5th ed. (1915), 737.

5. RMcK, Parliamentary Debates, 17 May 1912, 1458-62.

6. Parliamentary Papers, (1912-13), vol. 3; Everest, 'Mental', 28-91. See G. R. Searle, Eugenics and Politics in Britain (Leyden, 1976).

7. Greig, 'Lunacy', 793; Viscount Ullswater, (James William Lowther), A Speaker's Commentaries, 2 vols. (1925), ii:149. 
measure's innate humanitarianism appeared to convince, and compared to some of McKenna's legislative experiences, the bill was a model of considered scrutiny, and concessions were offered where they were sought. It was therefore a great frustration that after the government's defeat on the Home Rule bill, lack of parliamentary time meant that it had to be sacrificed, on 19 November. ${ }^{1}$ McKenna found himself in the unfamiliar position of being criticised by the bishops for not pushing through his legislation, and the abandonment brought widespread frustration that the government could not find the little time it needed to complete its process. ${ }^{2}$ His reintroduced bill of 25 March 1913 was successful. Of his time at the Home Office he years later regarded it as 'his most important Bill', which was 'hotly contested in the House of Commons by the champions of personal liberty'. ${ }^{3}$

\section{CAT AND MICE}

In October 1913, Mill House, Theo's sixteen-room Hampshire property, was destroyed by fire. Police found a note: 'Mr McKenna, coward; very brave in torturing women, but afraid to touch men. A protest against forcible feeding. Votes for women. ${ }^{4}$ By the spring of 1913, the suffragette militancy appeared to have exhausted the patience of the public and was having the effect on the cause McKenna had predicted and for which he hoped. The king asked him to close museums and art galleries as protection against the 'monstrous action of these misguided women'. ${ }^{5}$ McKenna refused. 'I am glad to say, however, that the information I have points to a weakening on the part of the militant women, and I doubt whether in their present spirit they will be prepared to carry their excesses very far'. ${ }^{6}$ Shortly after, houses owned by other prominent businessmen were destroyed by arson, and numerous cases of public disorder were encouraged by the likes of Zelie Emerson, for whom 'there is no better object to practise your strength upon than some of McKenna's pups ... they are large and fat and you cannot miss them if you aim right'. 7 There was therefore implicit public support for the twin strategy

1. HHA, Parliamentary Debates, 2 December 1912, 1877.

2. Letters, Times: 22 November 1912, 23 November 1912, 25 November 1912, 28 November 1912, 29 November 1912, 2 December 1912.

3. 'Reggie's own notes dictated to me [Pamela McKenna] on his early years', n.d. [c. 1943]. In the notes, RMcK, or PMcK, misremembers it as a bill originating from his period at Education.

4. Times, 28 October 1913.

5. Stamfordham to RMcK, 28 January 1913, RA PS/GV/O 417/1; Stamfordham to RMcK, 31 January 1913, RA PS/GV/O 417/3.

6. RMcK to Stamfordham, 29 January 1913, Royal Archives, GV/ O 417/2.

7. Zelie Emerson, in Rise Up Women! The Militant Campaign of the Women's Social and Political Union, 1903-1911 by Andrew Rosen (1974), 218; Pankhurst, Suffragette, 509. 
McKenna adopted at this stage: the suppression of the Pankhursts' WSPU and the release of hunger strikers.

While it was likely that the movement would be hampered if the printers and publishers of its papers were targeted, McKenna was sufficiently concerned as to the legality of his actions that he consulted the attorney general. ${ }^{1}$ In a little over a year, having attacked the message, he sought to undermine the messenger and ordered the raiding of the offices of the union in May 1914 to reveal the names of subscribers and open them up to civil proceedings from those whose property had been damaged; this time he ignored the attorney general by retaining a police presence, tapping phone lines, and diverting mail. ${ }^{2}$ The revenue of the movement thus impeded, McKenna reasoned, the activities of activists would be curtailed. For that reason, he attempted also to suppress the Suffragette on grounds of incitement by arresting members of the editorial board. Critics deplored unheralded levels of authoritarianism. 'McKenna should be examined at once by two doctors', George Bernard Shaw demanded. 'He apparently believes himself to be the Tsar of Russia, a very common form of delusion. ${ }^{3}$

McKenna's second strategy dealt with the most emotive issue and produced the single most controversial measure of the suffrage struggle. Most of the criticism he had attracted concerned forcible feeding. C. P. Scott petitioned the home secretary with his concerns as a Liberal, and the Suffragette was preoccupied with the issue, publishing graphic illustrations of the "torture'. ${ }^{4}$ The alternatives, given that granting suffrage under prevailing conditions was politically impossible, were allowing prisoners to die, deporting them, or letting them out on licence. The home secretary defended himself in the Commons.

There are some people who say, 'Let them die'-(An Hon. Member: 'Hear, hear')—and because I absolutely decline to let them die, I am subjected to attacks on the grounds of want of courage. The usual statement is, 'If he had courage, he would let them die.' I wonder if it requires more courage to let some helpless woman die because she has broken a window, or to refuse to do that, and face the obloquy showered upon my head. ${ }^{5}$

1. Samuel to RMcK, 3 March 1913, Home Office papers, HO 45/2.31366/31; 'JW' to RMcK, 23 March 1913, Home Office papers, HO 45/1070()/236973.

2. Times, 10 June 1914; RMcK, Parliamentary Debates, 11 June 1914, 532; RMcK, 30 May 1914, Home Office papers, HO 144/1318/252288.

3. In Barbara Winslow, Sylvia Pankhurst: Sexual Politics and Political Activism (1996), 49.

4. RMcK to Scott, 21 November 1911, Scott papers (Manchester), 332/51; RMcK to Scott, 14 March 1912, Scott papers (Manchester), 332/85; RMcK to Scott, 8 July 1914 , Scott papers, M/332/95.

5. RMcK, Parliamentary Debates, 18 March 191.3, 904-5. 
'A tragedy is wanted', Emily Wilding Davison had admitted, after one of her suicide attempts at Holloway Prison. ${ }^{1}$ McKenna told MPs 'What is proposed is that the Home Secretary should take the risk-at whose expense? At his own? Not at all, but that he should take the risk at the expense of somebody else's life'.2

McKenna introduced his Prisoners (Temporary Discharge for Ill-Health) Bill on 25 March. As the 'Cat and Mouse Act', it saw the 'mouse' released when undernourished and then recaptured by the 'cat' after its health had improved. 'The objects of my Bill for dealing with these women are twofold', McKenna told Stamfordham. '(1) to get rid of the necessity for forcible feeding; (2) to enable me to discharge suffragist prisoners from prison without remitting their sentences. ${ }^{3}$ McKenna told Cabinet of one paralytic epileptic who had starved in the preceding week; his colleagues unanimously supported his proposal, and within a month the measure was law. ${ }^{4}$ However insidious the measure, it was clearly preferable to forcible feeding, and was one on which McKenna and Lloyd George agreed, even if Asquith had doubts as to its effectiveness. ${ }^{5}$ For McKenna, 'No amount of provocation shall induce me by any executive action to undermine the respect of women which men observe in their treatment of them as the physically weaker sex' ${ }^{6}$

'He would not let us die, you see, humane man,' commented Emmeline Pankhurst, 'but will bring us to death's door as often as he can, and so hopes to make us permanent invalids. ${ }^{7}$ Edith Rigby would have to be arrested at least fifty times for her sentence to have been carried out. Her husband complained: 'Mr McKenna must be greatly pleased at this success. ${ }^{8}$ What was attacked by progressives as draconian was attacked by conservatives as defeatist. McKenna did nothing to accommodate the women, or their supporters, ${ }^{9}$ but by removing 'torture' from public discourse he went some way to neutralising the force as an issue and starvation as a weapon.

1. PRO PCOM/8/174 [Pugh, Rise, 204].

2. RMcK, Times, 3 April 1913.

3. RMcK to Stamfordham, 28 March 1913, RA PS/GV/O 459/2.

4. RMcK, 2 April 1913, Parliamentary Debates, 404-10; HHA to George V, 13 March 1913, Rosen, Women!, 191. See Pankhurst, Suffragette, 471-91.

5. Earl of Oxford and Asquith, Fifty Years of Parliament, 2 vols. (1926), 2:126; Martin Pugh, The Pankbursts (2001), 291-94; Hobhouse, diary, 13 March 1913, Diary, 133.

6. RMcK, diary, 1913, memoranda.

7. Emmeline Pankhurst to Ethel Smyth, 13 June 1914, in Emmeline Pankburst, a Biography by June Purvis (2002), 261.

8. Charles Rigby, 11 September 1913, in My Aunt Edith, by Phoebe Hesketh (1966), 76-77.

9. Emmeline Pethick-Lawrence, My Part in a Changing World, 1938, 296-98; RMcK, Parliamentary Debates, 11 June 1914, 521-22; Pankhurst, Life, 151; Harold Smith, 18 March 1913, Parliamentary Debates, 877, 882; Sir F. Banbury, Parliamentary Debates, 18 March 1913, 923; Pankhurst, Suffragette, 452-53, 569. 
In the first four months of 1913, six women were released after forcible feeding, of whom three had finished their sentence. Among them was the leading 'mouse'. 'If Mrs Pankhurst starves herself,' McKenna said, 'the Secretary of State wishes her to be kept constantly supplied with suitable and appetising food'. ${ }^{1}$ A fortnight later, she was released on grounds of health, before another of her eight arrests. 'When he attempts to arrest me again he will require a regiment of soldiers,' Emmeline Pankhurst said; 'I am a Prisoner of War'. ${ }^{3}$ McKenna told Pamela, 'Mrs P. is still under lock and key, emotional, i.e. in a bad temper, and nervous about her health. It looks as if we should keep her over. ${ }^{4}$

Once more Lloyd George mediated, through a similarly imprisoned George Lansbury, with the intention of dividing constitutionalists from militants. ${ }^{5}$ McKenna accepted the advice, released Lansbury, as he was unlikely to incite criminal behaviour, and would have remitted the entire sentence had a firm promise been forthcoming. ${ }^{6}$ Indeed, if any prisoners signed an undertaking not to commit militant actions in the future, they would be released without threat of recommittal. On 11 June, as a bomb was discovered across the road in Westminster Abbey, McKenna told the Commons that no further legislation would be required. In the words of one activist, 'McKenna's speech was to me remarkably significant: and every politician I have talked to about it thinks so too." 'I don't see what is possible as long as they insist on militant methods', the Liberal backbencher Arnold Rowntree sympathised. 'McKenna is willing to release them all tomorrow if they will promise to desist from such methods."

The Suffragette disparaged the measure as a bluff. 'If it ever becomes law it will, of course, be a dead letter.' Three months later it demanded 'Repeal the act!!'" C. P. Scott told him, it was 'not ideal-nothing can be-but it seems fairly adequate' and certainly more effective than any other conceivable method. ${ }^{11}$ In 1909 , there were 156 commitments to prison; in 1911, the numbers rose to 188 , and in 1912 to 290 . In the first year of the act, the

1. RMcK, 4 April 1913, Pugh, Pankhursts, 262.

2. RMcK to Stamfordham, 12 April 1913, RA PS/GV/O 459/6.

3. Emmeline Pankhurst, 10 March 1914, in Purvis, Pankhurst, 255.

4. RMcK to PMcK, 9 April 1913.

5. Lloyd George to RMcK, 6 July 1914 , Lloyd George papers, C/5/12/9. Though Lloyd George supported RMcK's denying additional time to the Women's Suffrage Bill in May 1911. Morgan, Suffragists, 75-76; Hume, National Union, 107.

6. Pugh, Pankhursts, 294.

7. Laurence Housman to Sarah Clark, 21 June 1914, in Holton, Suffrage, 208.

8. Arnold Rowntree to Mary Rowntree, 24 June 1913, Rowntree, Letters, 123; Earl of Oxford and Asquith, Memories and Reflections, 1852-1927, 2 vols. (1928), $i: 221$.

9. Suffragette, 28 March 1913.

10. Times, 4 July 1913.

11. Scott to RMcK, 9 July 1914 [copy], Scott papers (Manchester), 333/96. 


\section{Reginald McKenna}

number fell to $183 .{ }^{1}$ From January 1913 to March 1914, 186 suffragettes were imprisoned, of whom 42 were released under the act. Of the minority that was released and rearrested, most undertook to abandon militancy in return for remission of their sentences, or were released as no longer being a threat.

\section{COLLEAGUES}

With McKenna now out of a spending department, and both eliciting and receiving abuse on behalf of the government, Riddell even thought ' McKenna and Lloyd George now close allies'. ${ }^{2}$ When the Marconi scandal broke in the autumn of 1912, and Lloyd George, with Masterman, was implicated in career-threatening allegations of insider dealing, McKenna was instinctively tribal, being averse to flying a 'white sheet', and political, claiming Lloyd George was 'the greatest platform asset the Liberal Party possessed'; 'his value as a demagogue was retrievable, and it was the business of the party to pull that out of the mire'. ${ }^{3}$ Lloyd George admitted, 'McKenna has acted like a brick all the time. ${ }^{4}$

Where that relationship appeared to have steadied, another worsened still further. McKenna and Churchill 'hate each other like poison', in Fisher's words, ${ }^{5}$ while the latter actually wished McKenna was 'dead', Margot noted privately, 'his expression several times to me this year.' 'I was rash enough once to mention Winston in his house', Lucy Masterman recalled. 'I was never received with a more chilling silence in my life." The Admiralty, and strategy, remained emotive issues. At one CID meeting, Fisher recorded, 'McKenna and Winston were tearing each other's eyes out the whole time.' Churchill blamed his predecessor for the navy being too weak, yet, Margot admitted, 'owes it entirely to McKenna that he is not two ships shorter than he is-He opposed McK when he was 1st sea lord [sic] in a disgraceful way ... intrigued with the Press against him ... etc etc. ${ }^{.9}$ Most significantly, for the accusations of subterfuge on McKenna's part, as Fisher told Esher, 'He

1. RMcK, Parliamentary Debates, 11 June 1914, 519.

2. RMcK, 26 April 1913, Riddell, diary, Riddell papers, 62972; Lloyd George, 18 April 1913, Riddell, diary, Riddell papers, 62972.

3. RMck, Hobhouse diary, 13 June 1913, Diary, 138.

4. Lloyd George, Riddell diary, 28 March 1913, Riddell papers, 62972.

5. Fisher to Annie Goulding, 24 November 1911, Wargrave papers, 2/43; Riddell, diary, 14 January 1914, Riddell papers, 62959.

6. MA, diary, 21 May 1912, MA papers, d./3210/32.

7. Lucy Masterman, diary, 26 June 1912, in C. F. G. Masterman, a Biography, by Lucy Masterman (1939), 234.

8. Fisher to Cecil Fisher, 5 July 1912, Fisher, Correspondence, ii:470.

9. MA, diary, 21 May 1912, MA papers, d.3210/32-34. 
hates Winston justly, yet he encourages me to help him all I can'. ${ }^{1}$ Fisher felt 'as if I have condoned the d_d dirty trick played McKenna!', ${ }^{2}$ but McKenna told him, 'I believe the time is not far off when you will have to take a strong line, and it is essential that there should not be the slightest appearance of anything personal in your action. ${ }^{3}$

There was also an ability to take personal slights, perceived or real, and act on them with prejudice. It happened to Montagu, whom McKenna had suspected, along with many others, of having helped engineer his removal from the Admiralty. It prompted a pained response from the younger man. 'I have never surrendered my loyalty to you and never will'. It upset him that 'you have no longer any use for my friendship', a friendship that was 'almost inestimable'. 'I am very emotional and ... need you more than ever'. ${ }^{4}$

\section{MINISTER}

For 'St. McKenna', Asquith told the Commons to loud laughter during the Welsh Church debate, canonisation was unlikely, though 'I am very reluctant to tarnish or bedim the contingent halo which would so becomingly encircle the brow of my right hon. friend'. ${ }^{5}$ What was calculated to be supportive only served to highlight McKenna's predicament. Six months after the previous low, the summer of 1912 was perhaps the nadir of McKenna's ministerial career. Publicly he admitted to 'circumstances of unparalleled difficulty'. ${ }^{6} \mathrm{He}$ meant for the country, but it also applied to him. Throughout that summer, a large, professional, anonymous advertisement appeared in the press. 'CITIZENS OF THE BRITISH EMPIRE', it began, before quoting Beresford that what many regarded as McKenna's naval scaremongering was in fact complacency, and concluding:

That a Minister whose administration, when at the Admiralty, has been so severely censured by so high a Naval Authority, should be entrusted with the control of the Home Office at a critical time in the Nation's history, when such questions have to be dealt with as the Present Industrial Unrest, Labour Troubles, and the Treatment of Suffragist Prisoners

1. Fisher to Esher, 2 April 1912, Esher papers, 10/43.

2. Fisher to Spender, 31 October 1911, Fisher, Correspondence, 2:409; Fitzroy, 19 May 1915, Memoirs, ii:594.

3. RMcK to Fisher, 5 November 1911.

4. Montagu to RMcK, 8 November 1911 , McKenna papers, 4/4/7; RMcK replied cursorily, to the effect that there were no hard feelings, McKenna papers, $4 / 4 / 8$. See HHA to Sylvia Henley, 23 August 1916, Asquith papers, 542/4/726; HHA to Sylvia Henley, 6 January 1917, Asquith papers, 542/4/834.

5. HHA, Parliamentary Debates, 15 May 1912, 1153.

6. RMcK, Parliamentary Debates, 28 June 1912, 703. 


\section{Reginald McKenna}

who are now suffering in a manner considered by so many as Grossly Unjust. ${ }^{1}$

Political cartoons, which had hitherto presented an accurate representation of McKenna's features, now moved into caricature, and his naturally unsympathetic features were wrought into as much cold intensity as the artist could muster. ${ }^{2}$

Once again, there was a disjunction between opinion in Whitehall and in the country. At the worst moment of the summer, the chief whip admitted he had 'a really high opinion of McK's values and abilities', ${ }^{3}$ while Lloyd George felt 'he is really a very capable man for this sort of job'. ${ }^{4}$ Charles Hobhouse praised 'a wonderful quickness of mind and a remarkable memory. ${ }^{5}$ Riddell heard from civil servants how McKenna 'is a first-class critic and administrator, narrow but logical, accurate, industrious and methodical, deals with all his official papers immediately they arrive. ${ }^{6}$ The cost was, McKenna told Pamela, that 'I am overwhelmed with work. On Tuesday I did not get to bed till 4.30 and every day Committees, Deputations and Papers keep me hard at it from morning till night. ${ }^{37}$ The home secretary's deputy, and Lloyd George's and Churchill's associate, Charlie Masterman, having hitherto been critical, found McKenna 'loyal and generous' and a 'chief who always endeavoured to give me my fair share of the limelight, which is more than can be said for many heads of Department'. ${ }^{8}$ Masterton Smith was so enamoured of working with McKenna that he sought a transfer from the Admiralty: he 'loved McKenna $\&$ hesitated a long time before continuing his secretarial work under Winston,' Margot noted. 'The affection McK inspired in this man is enormously to McKenna's credit-we ended by his telling me of McK's excellent brain-courage, self-effacement."

Comparisons between McKenna and Churchill were striking. Masterton Smith said, "take away that something which men call genius \& brain for brain McKenna's is as good as [Churchill] I personally think. ${ }^{10}$ Lloyd George even claimed, 'McKenna's judgement is 1000 times better than Winston's!'11 Maurice Hankey put it more charitably: while Churchill, 'is a really great

1. Times, 22 June 1912, 24 June 1912.

2. For example, H. R. Westwood, Modern Caricaturists (1932), 126-27.

3. Maurice Bonham Carter to Violet Asquith, 24 May 1912, Violet Asquith, Diaries, 315 .

4. Lloyd George, Riddell diary, 28 June 1912, Riddell papers, 62970.

5. Hobhouse, diary, 13 August 1912, Diary, 121.

6. Riddell, diary, 26 September 1913, Riddell papers, 62973; Edward Marsh to Lady Gladstone 30 November 1911, Hassall, Marsh, 175.

7. RMcK to PMcK, 24 October 1912.

8. Masterman, Riddell diary, 3 May 1913, Riddell papers, 62972.

9. MA, diary, n.d. [1913], MA papers, d.3210/100.

10. Ibid.

11. MA, diary, 23 January 1915, MA papers, d.3211/149. 
man ... he is far more brilliant than McKenna, but probably has not such solid qualities'. ${ }^{1}$ Élan was another matter. 'It may be that I don't attach enough value to the flow and balance of words', McKenna told Pamela after reading one of Churchill's speeches, 'but I could not help thinking it almost meaningless in its oversighted rhetoric." At the back of each of his appointment diaries, McKenna attempted pithy observations on political issues, very rarely achieving the oratorical trenchancy of those of his more prominent colleagues. More successful were the protracted mathematical formulae, devised and worked out for pleasure. At least Margot preferred 'an honest outsider even tho' provincial \& limited like McKenna to a little treacherous gutter genius like Winston. ${ }^{3}$

Such prosaic talents meant the home secretary had multiple ministerial uses. 'I have been playing second fiddle, somewhat rustily and scrapily, to Ll.G on his Revenue Bill, and I have not enjoyed the performance', ${ }^{4}$ he told Pamela in March 1913. As home secretary he had little to do with financial matters, but what Montagu called McKenna's 'wonderful financial brain's ensured he was engaged with and critical of those who did. He complained to Riddell: 'economic principles are their fetish and they are always opposed to any innovation unless it is forced upon them at the point of a bayonet. ${ }^{3}$ Where there was innovation, as when the 1914 budget employed fiscal devices as measures of policy rather than as means of revenue, he deplored it and predicted difficulties, which, to the embarrassment of the government, were immediately realised. On 22 June, the Speaker compelled the government to drop several tendentious clauses; Riddell agreed. 'The whole thing has been a shocking muddle."

McKenna's relations with Fleet Street hike at the Admiralty had been unprecedented. There he had been espousing the agenda of the right-wing press. At the Home Office, normal relations were resumed. Other than Spender, whom Fisher described as being 'on the most intimate terms' with McKenna, ${ }^{8}$ Scott, and Donald, McKenna deprecated newspapermen and their works. ${ }^{9}$ Nevertheless, while Pamela said that 'he felt he could not do so', ${ }^{10}$ McKenna was trying to develop his political sensibilities in the way he

1. Hankey to Fisher, 24 March 1912, Fisher papers, 1/11/563.

2. RMcK to PMcK, 4 October 1911.

3. MA, diary, April 1909, MA papers, d.3207/181.

4. RMcK to PMcK, 15 April 1913.

5. MA, diary, 7 August 1914, MA papers, d.3210/269.

6. RMcK, 26 September 1913, Riddell, diary, Riddell papers, 62973.

7. Riddell, diary, 23 June 1914, More Pages, 215.

8. Fisher to Hankey, 14 March 1912, Hankey papers, 5/2a/67; Kennedy Jones, Fleet Street and Downing Street (1919), 6; Northcliffe to Elibank, 8 November 1915, Elibank papers, 8803/258.

9. RMcK to Stamfordham, 28 March 1913, RA PS/GV/O 459/2.

10. PMcK, Riddell diary, 18 December 1913, Riddell papers, 62973; Riddell, diary, 16 December 1913, Riddell papers, 62973. 
attempted to rectify any failings. That was easier when the failing concerned inanimate objects or measurable goals. As Lloyd George put it, though McKenna 'is performing a most difficult and troublesome task in a most able way, he has a bad manner which prevents him from doing himself justice." 'His faults are all on the surface, you don't have to dig them up', Elizabeth Asquith felt. 'McKenna is a calico man. You can measure him out by the yard all the same. He is like the small boxes of paints we had when we were children - the red, the green and the blue, all the same size, each in its little compartment.'2

He took pleasure in his pedantry. One evening in the Commons, when McKenna told a Unionist 'the question of the Honourable Member is impertinent,' Henry Lucy, watching from the press gallery, reported that 'roar expressive of outraged sense of decency hurtled from Opposition benches.'

Half-a-dozen Members sprang to their feet to ask Speaker's ruling if it was in order to accuse an Honourable Member of putting an impertinent question. For them the word had nothing beyond its meaning in colloquial use, defined in New English (Oxford) Dictionary ... as "meddling, abusive, presumptuous, insolent in speech or behaviour".

"I use the word," McKenna quietly added, "in its older sense."

This reminded the House that it originally had another meaning. In usage of the law, "impertinent" still means "not pertaining to the subject or matter in hand, irrelevant." That, it seems, was what McKenna had in mind.

Just as well to have it explained. This done, the storm blew over as rapidly as it had arisen. But the badgered, provokingly smiling Home Secretary had his retort courteous. In skilful hands, more blessed than "Mesopotamia" is the word "impertinent". ${ }^{3}$

The opposition applied their 'new tactics' on him, which were a more personalised and vituperative application of his own under the gangway exploits of ten years before. Lord Robert Cecil was as diligent a persecutor of McKenna as McKenna had been of the Chamberlains, while his colleagues sat opposite the government front bench and shouted at the home secretary. One declared, 'we have cowed Asquith, and we have cowed McKenna'. ${ }^{4}$

McKenna was also yoked with Asquith in terms of patronage, and the prime minister knew it. ${ }^{5}$ As the Liberal government went on, McKenna's

1. Lloyd George, Riddell diary, 28 June 1912, Riddell papers, 62970.

2. Riddell, diary, 2 July 1912 , Riddell papers, 62971 (alluded to by Lloyd George, Memoirs, 447).

3. 'Essence of Parliament', [Henry Lucy], Punch, 17 July 1912.

4. Lucy Masterman, diary, n.d. [1911], in C. F. G. Masterman, a Biography, by Lucy Masterman (1939), 219.

5. HA to Venetia Stanley, 12 January 1915, in Letters, 372. 
position was more dependent on Asquith than was that of any other minister, since no other minister of comparable prominence had so little standing in the party. Asquith did not write to him as often as he did Crewe or Grey, or bemoan him as he did Lloyd George and Churchill. Instead, the prime minister retained and promoted him in spite of more compelling reasons not to. Unlike the position of Lloyd George or Grey, that of McKenna did not represent a strong personal or political following. For a prime minister he represented something more; not only efficiency, but also a shelter. As politicians they therefore complemented each other: abrasion and emollience. ${ }^{1}$

So the minister could concentrate on his strengths, which, unlike for some colleagues, did not require being 'always in the limelight'. 'I don't pretend to be a good speaker', McKenna admitted. 'I am not able to do the big bow-wow like Asquith. I confine myself to explaining a proposal or to defend a Departmental position'. ${ }^{3}$ Lloyd George admitted McKenna 'could make the best departmental defence speech of any man in the House of Commons'. ${ }^{4}$ The problem was that there was often more offence than defence. McKenna's often deliberate antagonism of opponents in the Commons regularly led to disorder. After the near-riot in the chamber during the debate on Cardiff slum clearance, one Unionist MP claimed it 'the first time that a Minister of the Crown has deliberately refused to meet a charge made face to face in the House of Commons. ${ }^{5}$ The result was that hostility from the opposition became organised. 'The personal relations of opposing political parties in the House of Commons are, as a rule, of the friendliest character', Henry Lucy explained to foreign visitors. 'If there be an exception it is found in the case of the Home Secretary. For reasons incomprehensible to a wide circle of personal friends, the Opposition have, to use an expressive phrase, got their knife into Mr McKenna. ${ }^{6}$ Mr McKenna confessed that he

1. With McKenna possessing no personal or political following, and being the focal point of opposition and vitriol, the claim (Jenkins, Chutchill, 229) that he owed his position to the fact that, as with Crewe, he never caused his prime minister any trouble is scarcely plausible.

2. RMcK, in Charles à Court Repington, The First World War, 1914-18, 2 vols. (1920), i:350.

3. RMcK, Riddell diary, 3 May 1913, Riddell papers, 62972; RMcK to MMcK, 14 October 1924; RMcK to PMcK, 4 October 1911, 16 April 1921, 24 August 1921.

4. Lloyd George, Riddell diary, 9 October 1913, Riddell papers, 62973; Violet Asquith to Churchill, 12 June 1912, Churchill papers, CHAR 1/103/6.

5. Arthur Griffith Boscawen, Times, 18 June 1912.

6. Henry Lucy, From the Crossbenches, [June 1912]; John Gardiner to Bonar Law, 24 April 1912, Bonar Law papers, 26/2/4; Selborne to Bonar Law, 8 June 1912, Bonar Law papers, 26/4/13; Beresford to Bonar Law, n.d., Bonar Law papers, 33/21; Bishop of St. David's to Bonar Law, 13 November 1912, Bonar Law papers, $27 / 4 / 25$. 


\section{Reginald McKenna}

was 'sick of the whole thing. The worry and anxiety are sometimes almost intolerable.'

'I don't know why we always go on with it, considering its worries and terribly hard work,' McKenna complained to Riddell, before explaining why, and in so doing why he could never have been a civil servant: 'I should not mind going out, but I hate to see them come in. I should hate to see them on the front bench.' ${ }^{2}$

\section{RADICAL PLUTOCRAT}

While reactionaries hated McKenna, it did not follow that he retained his reputation as a radical. Bernard Shaw had begun to 'despair' of Beatrice Webb, for her tendency to 'swallow McKenna'. It was merely 'inveterate idolatry of ambitious and successful plutocrats.' ${ }^{3}$ The distinction between plutocrat and radical was admittedly fine. In January 1912, Labouchere died; Dilke had gone a year earlier. ${ }^{4}$ Neither had the chance to pass judgement on their disciple as home secretary. One of his civil servants, Harold Butler, considered him both 'able and liberal', 5 though there was much that was far from liberal, even if the worst blemishes were as much due to the fabric of society as to any particular intolerance on McKenna's part. He claimed his Mental Deficiency Bill 'exists for the protection of individual sufferers', and sought to strip from it any reference to 'what might be regarded as the eugenic idea', ${ }^{6}$ which was not what the Eugenics Review thought, claiming approvingly that heredity had at last become a practical consideration, ${ }^{7}$ as did Bernard Shaw.

In his 'examination of the Government's record from a working-class standpoint', the editor of the Labour Leader, Fenner Brockway, included open letters to Lloyd George and to McKenna. ${ }^{8}$ He was particularly exercised by the home secretary.

The determination of the organised workers of North Monmouth to nominate a Labour candidate at the next election is evidently disturbing you. You have recently been touring your constituency and in every speech you have indulged in haughty and very childish denunciation of the Labour Party. It is easy to see you have fears for your seat, but you

1. RMcK, 15 June 1913, Riddell, diary, Riddell papers, 62972; RMcK to PMcK, 21 October 1912.

2. RMcK, 26 April 1913, Riddell, diary, Riddell papers, 62972.

3. Bernard Shaw to Webb, 26 August 1914, Shaw, Letters, 247.

4. RMcK to Stephen Gwynn, 24 September 1916, Dilke papers, 43967/289.

5. Harold Butler, Confident Morning (1950), 76.

6. RMcK, Parliamentary Debates, 28 May 1913, 221.

7. Eugenics Review 6 (1914): 52, and 5 (1914): 166.

8. Brockway, Labour, 103-9. 
will defeat your own purpose if you continue in your present strain. If you will permit me to say so, you are only succeeding in making yourself look ridiculous ...

Brockway disparaged McKenna's claims to represent labour. He was not supported by their subscriptions; instead, he was 'a nominee and servant of the capitalists'. The New Liberal measures of labour interest were not Liberal initiatives at all. 'Your record is blacker than that of almost any man in the Cabinet,' Brockway went on, citing lukewarm drafting of the Coal Mines Act, increased naval expenditure, opposition to female suffrage. 'And you claim to be a Labour representative! It won't do, Sir. It is no use your trying to gain support by sailing under false colours. Your record is too damning. ${ }^{2}$

McKenna was sympathetic to Leopold Amery's demands for national treatment of syphilis ${ }^{3}$ and was so determined to make the Deficiency Act work that in April 1913 he offered several inducements to poach Webb's friend George Newman from where he had put him the year before at Education to chair its Board of Control; ${ }^{4}$ when C. P. Scott urged the appointment as a commissioner of Mary Dendy, an innovative campaigner who held social considerations as being more important than heredity, McKenna duly appointed her. ${ }^{5}$ McKenna's pronouncements on criminal justice and prison reform, by the standards of the period, were liberal and lucid. ${ }^{6}$ His Criminal Justice Administration Act allowed for fines to be paid as an alternative to summary imprisonment for young offenders and liberalised borstal. ${ }^{7}$

The tension between radical and plutocrat, loosely defined, continued in Cabinet. McKenna had opposed Haldane's suggested compulsory training for the Territorial Army, a central tenet of continentalism, for the same reason that he rejected continentalism. ${ }^{8}$ In September 1913, McKenna and Haldane once again clashed, when the former refused to support the latter's attempt to employ troops on strikers. ${ }^{9}$ Where McKenna did intervene, as at the Admiralty, was over working conditions, such as instigating better workplace inspection-the number of inspectors rose from thirty-eight to

1. Ibid., 103.

2. Ibid., 108-9.

3. Leo Amery, diary, 17 July 1911, in The Leo Amery Diaries, vol. 1, 1896-1929, eds. John Barnes and David Nicholson (1980), 79.

4. Newman to RMcK, 12 August 1913, McKenna papers, 4/4/20.

5. RMcK to Scott, 21 August 1912, Scott papers (Manchester) 332/151; Times, 1 November 1913.

6. On borstal, Times, 27 December 1911; corporal punishment, Times, 13 January 1912; prison labour, Times, 16 February 1912.

7. Holmes, 'Criminal'.

8. Hobhouse, diary, 10 April 1913, 133.

9. Riddell, diary, 29 September 1913, Riddell papers, 62973. 
one hundred in his time ${ }^{1}$-independent of the employers, in the Factory and Workshop Act. McKenna instigated the first prosecution of a mine owner for breaking the Eight Hour Act, in January 1912, ${ }^{2}$ and in December 1913 established an inquiry into the explosion at Senghenydd colliery, in which 430 died, with a view to improving safety in an industry where over one thousand workers were killed every year. ${ }^{3}$ The mining engineer who chaired the inquiry, Richard Redmayne recalled that McKenna's 'visit to the colliery and homes of the bereaved was a characteristic action'. ${ }^{4}$

McKenna's relations with the head of state remained awkward for a plutocrat. During the coal strike, McKenna sought to placate George V, but merely soured relations with him, as he had with his father, by failing to inform him of executive actions, such as the commuting of the radical trades unionist Tom Mann's sentence for sedition, and the remission of hard labour for others. ${ }^{6}$ When reprimanded, McKenna apologised but cited the demands of his duties, while maintaining his privilege, as he had over Malta, and continued to do in other areas. ${ }^{7}$ In addition to his erratic observance of protocol, the king feared McKenna's attitude to strikers 'will be regarded as a sign of weakness and of yielding to the clamour of the Labour Party'. All of which may have explained why McKenna's efforts to gain honours for social reformers were notably unsuccessful, as were his efforts to secure royal visits to now better-inspected factories. ${ }^{9}$

For all the vocal misgivings of radicals, regulation could be in the interests of liberalisation. That was the reasoning behind the Mental Deficiency Bill, just as it was behind the Inebriates Bill, by which special institutions would be created to treat alcoholics, with incarceration replacing fines. ${ }^{10}$ After a deputation from the Cinematograph Exhibitors Association asked for an official film censor, McKenna admitted, 'it is a project which smiles upon me', ${ }^{11}$ and approved the creation of the British Board of Film Censors

1. Times, 5 February 1914; Troup, Home Office, 164-65.

2. Times, 12 January 1912 .

3. Times, 28 October 1913, 3 January 1914; J. S. Middleton to RMcK, 9 November 1914, Labour papers, WNC 1/1/4; S. W. Harris to Middleton, 12 November 1914, Labour papers, WNC 1/1/5.

4. Richard Redmayne, Men, Mines and Memories (1942), 157.

5. RMcK to George V, 25 May 1912, RA PS/GV/B 348/4; RMcK to George V, 30 May 1912, RA PS/GV/B 348/15.

6. RMcK, 20 May 1912, Parliamentary Debates, 1567; RMcK to Stamfordham, 21 May 1912, RA PS/GV/O 353/2; Stamfordham to RMcK, 22[20] May 1912, RA PS/GV/O 353/1; Mann, Memoirs, 313-14.

7. RMcK to George V, 9 February 1912, RA PS/GV/PS 4392/18/MAIN; RMcK to Stamfordham, 27 May 1912, RA PS/GV/O 353/1.

8. Stamfordham to RMcK, 23 May 1912, RA PS/GV/O 353/3.

9. RMcK to Churchill, 1 May 1912, Churchill papers, CHAR2/56/81.

10. Times, 4 December 1911, 15 December 1913.

11. RMcK, 22 February 1912, Home Office papers, HO 45/10551/163175/26. 
in 1913, because he would not support state censorship. ${ }^{1}$ A similarly indulgent approach to theatre censorship had the immediate consequence of his being lampooned in George Grossmith's Kill That Fly! at the Alhambra. The twisted loyalties and sympathies of his political roots were further entangled with those of the society into which he had married. As the police arrested Pamela's friend the designer and publisher Francis Meynell for participating in a suffragette protest, he shouted to the gathering crowd that he was a friend of the home secretary. ' $\mathrm{Mr}$ McKenna and the Suffs have always had very different versions of the temper and character of the police', Meynell told Pamela afterwards. 'In my little story I find a reconciliation of both views'. ${ }^{3}$ Meanwhile, Saki's Louise, 'mooning about' Westminster Abbey, was in danger of being 'seized under the Cat and Mouse Act and sent to Reginald McKenna'. 'That would be extremely awkward', said Jane. 'We hardly know the McKennas. ${ }^{4}$

\section{SMITH SQUARE}

'I hope we shall never be rich enough to have a large house', Pamela told her mother after a weekend at Loulou's Nuneham Park, which was a very large house. ${ }^{5}$ In fact, the final conventional statement of status for the couple was not necessary while they resided at Admiralty House. Even if his removal from the Admiralty had come as a surprise, Reggie had already made provision. Throughout the early summer of 1910 , 'R continued our Smith Square negotiations', Pamela recorded. 'I think the land is ours as he went up to $1 / 3$ [one shilling and threepence] a foot for $3000 \mathrm{sq} \mathrm{ft}^{36}$ Smith Square was a sequestered spot behind Westminster Abbey, between Millbank and Victoria Street. Partially developed, the site had the characteristics of a country town; not long before it had been a thoroughfare flanked by slum property. ${ }^{7}$ The central feature of the square was St. John's Church, described by Disraeli as 'ponderous', and by Dickens as 'very hideous'. The square went on to spend most of the twentieth century housing the headquarters of the Labour and Conservative parties. 'I am very excited about it as it is wonderful to think of building a London house tho' I can't imagine how we shall be able to afford it."8

By August, Ned Lutyens had heard through Aggie that 'McKenna has bought a site in London and I do hope he asks me to build it for him. Pamela

1. RMcK, 22 April 1912, Parliamentary Debates, 751.

2. Meynell, My Lives, 72 .

3. Francis Meynell to PMcK, 2 March 1914.

4. H. H. Munro, The Toys of Peace and Other Papers (1919), 16.

5. PMcK to Agnes Jekyll, 18 July [1910].

6. PMcK, diary, 17 June 1910.

7. See Frederick J. Froom, A Site in Poultry (1950).

8. PMcK, diary, 17 June 1910. 


\section{Reginald McKenna}

is for me, and the whole Jekyll family.' ${ }^{1}$ That was enough. Ned soon found himself en route with Reggie, Pamela, and Ernest to Venice on the Enchantress, where 'after dinner we settled down to House plans and he drew us a wonderful one for Smith Square-such lovely rooms and good staircase and full of nice ideas' ${ }^{2}$ Ned drew up the plans in little over a month, costed at $£ 7,325,1 \mathrm{~s}, 8 \mathrm{~d} .{ }^{3}$ Large for a London townhouse, the heavily neo-Georgian 36 Smith Square came replete with night nursery, day nursery, pram room, Pamela's and Reggie's individual dressing rooms, individual bedrooms, butler's room, four maid's bedrooms, servants' quarters, division bell, and coffered ceiling designed by Sir Herbert Jekyll. The house required three floors and an attic. 'McKenna thinks my staircase a miracle,' Ned told Emily. 'He has spent months at it himself.' ${ }^{4}$ Preparatory work involved Pamela engaging with the locals. One included W. T. Stead, who "came to lunch and I disliked him. Thought him a busy-body, self-important, unstraight and wrong-headed, no glamour like Garvin. We talked for hours but he is not a good talker and said nothing in the least memorable. I regret to say that he will be one of our nearest neighbours.'

Though Reginald McKenna became Lutyens' best-known and most faithful client, the buildings that resulted were, to varying degrees, the product of creative partnership. Reggie's natural proclivities ensured a fascination on his part with the intricacies of design and the practicalities of construction. His Jekyll-inspired interest in the creative arts and his innate utilitarianism could be married pre-eminently in architecture. Ned's design for Smith Square attempted to retain something of the country in this part of the city, and it shared many qualities with the 'Wrennaissance' country houses he also built. At the turn of modernism, Lutyens had returned to classicism. ${ }^{6}$ It was through his working relationship with Pamela's aunt Gertrude Jekyll, the most prestigious garden designer of the day, and his friendship with her brother Herbert and Aggie at Munstead House, that the most prestigious architect of the day came to acquire many of his clients, and McKenna extended his reach. At Smith Square, Reggie introduced Ned to Crewe, who was to invite Ned to the Delhi Planning Committee, charged with designing the capital of India.?

'Ned was here yesterday and was very cheerful about the house', Pamela told Reggie in September. 'He says they have only had to go down eighteen

1. Lutyens to Emily Lutyens, 22 August 1910, Letters, 202.

2. PMcK, diary, 9 September 1910.

3. See A. S. G., Butler, The Architecture of Sir Edwin Lutyens, 3 vols. (1950), 3:15, plates I, 1-3; Lutyens to Emily Lutyens, 9 September 1910, Letters, 203; Nicholas Taylor to DMcK, 19 May 1969.

4. Lutyens to Emily Lutyens, 10 September 1910, Letters, 205.

5. PMcK, diary, 16 January 1911.

6. Jane Ridley, 'Architect for the Metropolis', City Journal, Spring (1998).

7. Christopher Hussey, The Life of Sir Edwin Lutyens (1953), 246. 
feet'. ${ }^{1}$ It did nothing for relations with Stead, who, faced with 'this new and barbaric method', threatened an injunction.

I am sure you are not aware that the builders whom you employ have adopted a new style of building that necessitates continual pile driving which is rendering the houses in your vicinity uninhabitable ... Now Smith Square in which you are about to live is composed of houses about three hundred years old. They are very well built but they are old houses, and if this pile driving goes on they will be shaken to pieces ... My next neighbour, who is nearer to the house than I am, finds his crockery smashed and the whole house dancing. I am sure nothing could be further from your wish than that the putting up of your house should necessitate the pulling down of mine. ${ }^{2}$

McKenna's legal advisor, Theo, interceded.

Construction began in the New Year, with the family having decamped from Admiralty House to 28 Old Queen Street. In October 1912, Pamela took Michael and David to Scotland, while Reggie moved in at Smith Square, with Henry, his butler. 'The top floor is now finished. Blinds up, cork lino down and all fires lit,' he wrote to her. 'I have instructed Harrods to deliver our furniture from the workhouse on Tuesday next, and tomorrow midday Cohens are sending in all the servants' things', revealing on a number of levels the social nuances of the exercise. ${ }^{3}$ The move offered Reggie no respite from his other responsibilities, as the following day 'the P.M. would not hear of my crying off from the Wharf week end.' ${ }^{4}$ Such was the size of the plot Reggie had acquired, and the burgeoning of the related families, that building grew to accommodate a new political dynasty. When the $f 8,622,9 \mathrm{~s}, 1 \mathrm{~d}$ construction was completed in February 1913, three houses had been built: 36 Smith Square for Reggie and Pamela, 8 Little College Street for Francis and Bar, and the Corner House, Cowley Street, for Francis' sister, Lady Norman. ${ }^{5}$ It was another mark of a rising minister, as it was for a still rising architect: Ned had just moved his office to 17 Queen Anne's Gate; within two years there would be another, in Delhi.

1. PMcK to RMcK, n.d. [11 September 1911].

2. W. T. Stead to RMcK, 7 November 1911.

3. RMcK to PMcK, 20 October 1912.

4. Ibid., 21 October 1912.

5. Jane Brown, Lutyens and the Edwardians: An English Architect and His Clients (1996), 130-33. 


\section{Reginald McKenna}

\section{FORMER NAVAL PERSON}

McKenna's removal from the Admiralty was designed to distance if not remove him from strategic deliberation, just as it distanced those who were similarly opposed to the shape war preparations were taking. Consequently, 'When I left the Admiralty in October 1911 I insisted upon the whole French negotiations up to that date being disclosed in the Cabinet and fully discussed', McKenna told Spender years later. The effect was that 'discussion took place and from that date onwards every negotiation with the French was reported to the Cabinet'. ${ }^{1}$ At the cost of souring relations with the prime minister, McKenna had made the 'packing' of the secret CID subcommittee with continentalists on 23 August 1911 an issue to those excluded, with the result that two Cabinet meetings in November 1911 were forced to resolve that no mobilisation would take place without Cabinet approval.

When McKenna had raised the 1909 estimates with the news of Austrian naval building, he warned the prime minister that the development would require dreadnoughts to be sent to the Mediterranean, 'and thus reduce our advantage over Germany in this type of ship'. ${ }^{2}$ His commitment to a British presence in the Mediterranean occasioned the next row with Churchill, who advocated a withdrawal in the summer of 1912. The Court opposed this view, and supported his predecessor. 'Winston's reply to McKenna is the weakest thing I ever read', Esher told Knollys. 'McKenna was splendid. ${ }^{4}$ McKenna took the far from unprecedented measure of briefing the king, which irritated Churchill, who might have been flattered by imitation. ${ }^{5}$ McKenna's concern remained that commitments to the French-whether of a troops in France or a fleet in the Mediterranean-served to make war more likely and, in that eventuality, commit Britain to a conscripted continental army. ${ }^{6}$ On 4 July 1912, the policy of a one-power Mediterranean standard, with more provision in home waters, was adopted. A consistent account soon surfaced. 'It was a hard fight', Esher told the king. 'McKenna, Harcourt and L. George were all very staunch." McKenna was 'absolutely first class', Elibank told Spender. 'At all points. Fine in temper, and in the presentment of his case.' It was a compensation of sorts for 23 August 1911. 'McKenna excellent', Esher told Knollys. 'Crammed with facts and replies on all points. Haldane feeble and tricky'.'

1. RMcK to Spender, 8 May 1929.

2. RMcK to HHA, 30 January 1910 , McKenna papers, 3/17/3.

3. Louis Battenberg to Churchill, 1 July 1912, Churchill papers, CHAR 13/9/97.

4. Esher to Knollys, 27 June 1912, RA PS/GV/Q 724/12.

5. Churchill to George V, 2 July 1912, RA PS/GV/G 405a/1; naval position Cabinet papers, RA PS/GV/G 405/a/2, 3, 4.

6. Churchill, memorandum, 25 June 1912, Churchill papers, CHAR 13/17/10.

7. Esher to George V, 4 July 1912, RA PS/GV/Q 724/15.

8. Elibank to Spender, 5 July 1912 [encl. in Spender to RMcK, 7 July 1912].

9. Esher to Knollys, 5 July 1912, RA PS/GV/Q 724/16. 
Churchill's response, after being 'most abusive and insulting to McKenna' in Cabinet, ${ }^{1}$ was to present increased naval estimates for $1914-15 .{ }^{2}$ Further complications were provided by the general election that would have to be held the following year. 'The Government had absolutely nothing to fear' in general, McKenna told Scott, 'but the real danger point was in the Estimates. ${ }^{3}$ The radical press was roused by the first lord's encouragement of the 'armour press,' and the home secretary became the focal point for Cabinet opposition. McKenna thought the estimates 'really indefensible' and said that to persevere would lose radical support 'and put the Government in a minority.'4 The obvious, if unflattering, interpretation was harder than usual to make. 'No doubt McKenna bears Winston no good will', Riddell noted, 'it would be strange if he did. But to me he has not spoken in any bitter or spiteful manner regarding the present controversy'. 'You know I am a big navy man,' McKenna told Scott, 'but I am against waste'. ${ }^{6}$ Lloyd George felt McKenna 'acted very cleverly' by, as Riddell put it, taking 'no active part but supply[ing] other people with powder and shot in the shape of technical information'. The chancellor agreed. 'It is the cleverest thing he has done. I did not think he could have shown so much shrewdness'.?

McKenna told Riddell that 'the Government may break on the question.' At a time of international calm, he, Lloyd George, Runciman, Harcourt, and Simon would only agree to finance two capital ships; Churchill proposed four, which were required, he claimed, to fulfil the policies of his predecessor. ' 'One naval difference has only been composed to give place to another', McKenna explained to Margot.

Before the holidays we differed about the programme-two dreadnoughts or four. Now it is agreed on all hands that whatever the merits the Cabinet are committed to Winston's proposal of four ships and

1. Hobhouse, 17 July 1912, and 28 June 1912, Diary, 118 and 116.

2. Arthur Marder, From the Dreadnought to Scapa Flow: The Royal Navy in the Fisher Era, 1904-1919, 5 vols. (1961-70), 1:316; RMcK to Fisher, 10 August 1912, Fisher papers, 1/12/598. See F. W. Wiemann, 'Lloyd George and the Struggle for the Navy Estimates of 1914', in Lloyd George: Twelve Essays, ed. A. J. P. Taylor (1971), 71-91.

3. RMcK, 8 February 1914, Scott diary, Scott papers, 50901/106.

4. Ibid.

5. Riddell, diary, 6 January 1914, Riddell papers, 62974. Cf. Wiemann, 'Lloyd George', 78, 86.

6. RMcK, 8 February 1914, Scott diary, 50901/106; Maurice Bonham Carter to Violet Asquith, 28 January 1914, Diaries, 411.

7. Riddell, diary, 19 December 1913, Riddell papers, 62973; Fisher to Hankey, 6 March 1912, Hankey papers, 5/2a/64.

8. RMcK, 6 January 1914, Riddell, diary, Riddell papers, 62974.

9. Churchill, memorandum, 5 December 1913, Churchill papers, CHAR 13/23/34; Churchill to Lloyd George, 19 January 1914, Churchill papers, CHAR $13 / 29 / 25-27$. 
must accept it. So far for peace; but now a new question has arisen on the total of the money asked for. It appears that the previous estimates were incomplete and consequently the arrangement as to an agreed figure has gone by the board. How this controversy will develop I cannot say. It is certainly serious. ${ }^{1}$

The dispute threatened to be as damaging to the Cabinet as that of 1909 had been, but with more pressing distractions, such as rebellion in Ulster. Some ministers preferred that Churchill resign over the navy than over Ireland. McKenna wanted to suppress both Ulster and the estimates, which meant another confrontation with Churchill. In Cabinet on 27 January, 'McKenna took him to task over details', Hobhouse recorded, 'but he got no effective help from Ll.G'. ${ }^{2}$ The chancellor remained noncommittal. 'Ll.G. by this time was aware which way the cat would jump', McKenna told Runciman. 'Winston raged and talked about not going on, but as it was 1.30 the company quietly dwindled away. So much for the first round. We had all the merits and victory is assured provided we stick to our guns. I anticipate not less success in cutting down the total.' 'The success was measured on 11 February with a reduced programme, which an unusually measured Churchill then announced to the Commons. Lloyd George had, McKenna told Scott, become "Churchill's man", but compromised over estimates for the sake of Ulster. $^{4}$

\section{IRELAND}

While Ireland had never been a subject about which McKenna had ever been particularly animated, his sympathies were pronounced, and he had upset Unionists by referring to 'the Irish government'. ${ }^{5}$ For him the cause was best yoked to the practical, and especially, to the fiscal. Echoing Uncle Joseph, who had made a similar point thirty years before, McKenna wanted to prevent Irish members from voting on British taxation. Irish votes could be manipulated on matters for which Ireland would not be taxed. ${ }^{6} \mathrm{He}$ had, perhaps, asked the 'East Limerick Question'.

Over Home Rule and Ulster, McKenna was more emphatic. That which alliance with Nationalists since 1910 had made necessary, the 1911 Parliament Act made possible. McKenna, presaging Johns Redmond and Dillon,

1. RMcK to MA, 19 January 1914 , MA papers, c.6679/99.

2. Hobhouse, diary, 27 January 1914, Diary, 158.

3. RMcK to Runciman, 6 February 1914, Runciman papers, 135.

4. RMcK, 6 February 1914, Scott diary, Scott papers, 50901/81.

5. Felix Cassel, 17 June 1912, Parliamentary Debates, 1314.

6. RMcK, 11 December 1911, Home Rule bill Cabinet paper, Churchill papers, CHAR21/29a. 
opposed Lloyd George's original 'Grand Committee' proposal, by which he framed-and, they felt, diluted-Home Rule by placing it within a federal conception of United Kingdom devolution. ${ }^{1}$ The proposal was dropped from the final, Gladstonian, bill. The third Home Rule Bill was introduced in 1912, and reintroduced, after its rejection in the Lords, in 1913. Rising tension in the four counties and opposition from Unionists inclined Asquith, Lloyd George, and Churchill to compromise on some form of exclusion for Ulster; McKenna was regarded as the leading united Ireland 'die-hard'.

Cabinet discussion on 17 July 1913 produced, according to Margot, 'an awful row between Churchill and McKenna. ${ }^{3}$ Churchill wanted to accept a Lords amendment that Ulster be excluded, while McKenna pressed, as he had consistently, for putting the bill on the statute book before arranging a settlement. ${ }^{4}$ He then chose to conclude the debate by quoting Churchill back at him such that 'Winston-who loathes McKenna-lost his temper completely called him every name under Heaven! $\mathrm{H}$. had to make peace- $\mathrm{McK}$ is aggravating to a degree.' "We know that the exclusion of Ulster is absolutely impossible in practice,' McKenna told Runciman, 'and that to attempt it is to kill Home Rule. Carson knows it too, and it is merely playing into his hands to talk about it as a feasible solution. I remember that the suggestion was emphatically vetoed in the Cabinet a year ago. Has anything unexpected happened since ${ }^{6}$ Rising tension across Ulster had happened since, but when Redmond publicly rejected exclusion in November, McKenna told Riddell: 'That shuts the door'.'

When the situation worsened with the New Year, with Asquith advocating compromise and Lloyd George declaring it would 'fizzle out', McKenna wanted publicly to procrastinate until 'the patience of the hooligan element in Belfast is exhausted and they begin to riot', whereupon troops would be sent in to quell the rioters and the mutineers. ${ }^{8}$ Though Lloyd George's temporary exclusion scheme for Ulster was supported in Cabinet, Asquith told the king its 'many difficulties, financial and administrative, were dwelt upon by Mr McKenna." Fears that the act would be imposed encouraged protestant paramilitary organisations armed by Germany, and near-mutiny at the Curragh on 20 March, when British army officers threatened to disobey orders to enforce Home Rule on Ulster. Rumours had it that McKenna

1. RMcK, memorandum, 'Home Rule Bill', 11 December 1911, Cabinet papers, CAB37/108/176.

2. Patricia Jalland, The Liberals and Ireland: The Ulster Question in British Politics to 1914 (Brighton, 1980), 159.

3. MA, diary, 18 July 1913 , MA papers, d.3210/235.

4. Riddell 13 December 1913, Riddell, diary, Riddell papers, 62973.

5. MA, diary, 18 July 1913, MA papers, d.3210/235.

6. RMcK to Runciman, 12 October 1913 , Runciman papers, 82/75.

7. Riddell, diary, 13-14 December 1913, More Pages, 189, 186.

8. Anon, in Ian Colvin, The Life of Lord Carson, 3 vols. (1932-36), 1:320-1.

9. HHA to George V, 5 March 1914, Asquith papers, 7/101. 
wanted to issue warrants for the arrest of the Ulster leaders, including Carson, but was restrained by Asquith and Grey. ${ }^{1}$ When McKenna did not prosecute Ulster Volunteer gunrunners and thereby undermined support for the Government of Ireland Bill, the prime minister told the king that, of the senior ministers, the home secretary 'is the most opposed to settlement." He relented on 17 July, by which time Seely, the secretary for war, had been forced to resign. McKenna agreed with Lloyd George that the only course left was an Amending Bill, providing that any Ulster county could vote itself out of Home Rule for six years. ${ }^{3}$

The latest stage of the Welsh Bill gave McKenna reason to bemoan 'our small but somewhat critical Party. ${ }^{4}$ Church protests having produced concessions, those concessions in turn produced further protests from nonconformists. F. E. Smith called on 'the methods by which Mr Lloyd George and $\mathrm{Mr}$ McKenna rose to notoriety', 5 namely the disobedience against the 1902 Education Act, to be used against the bill. Yet for all the opposition provoked, with Home Rule and the Osborne judgement at the forefront of public and parliamentary concerns, outside the chamber of the Commons, the salience was minimal, while inside the passion was spent. The committee stage began on 29 November 1912 and was concluded on 4 February 1913. There were more petitions, of often questionable veracity, and further squabbling over endowments, which McKenna was still defending years later. ${ }^{6}$ After the third reading, the bill was rejected by the House of Lords. Under the terms of the Parliament Act the bill would require a full threesession passage, and McKenna duly reintroduced the bill on 16 June 1913. The same process was repeated, summoning even less attention, passing all three readings by May 1914 in debates that Speaker Lowther regarded as 'quiet, not to say dull', ${ }^{8}$ and going off to the Lords. The measure that Smith said 'has shocked the conscience of every Christian community in Europe', prompted Chesterton to ask,

If the voice of Cecil falters, If McKenna's point has pith,

1. Colvin, Carson, 309-10. Brigadier General H. Gough to Brigadier General J. E. Gough, 1 April 1914, and Major General L. B. Friend, in memorandum by Clive Wigram, 14 April 1914, in The Army and the Curragh Incident, 1914, ed. Ian Beckett (1986), 166 and 359; Robert Sanders, 28 April 1914, Diaries, 76.

2. Stamfordham, 17 May 1914, RA PS/GV/K 2553(5)/28.

3. Hobhouse, diary, 18 July 1914, Diary, 173.

4. RMcK to Herbert Lewis, 15 October 1914, Lewis papers. 321.

5. F. E. Smith, in F. E. Smith, First Earl of Birkenhead, by John Campbell (1983),

6. RMcK to Rev. John Roberts, 20 July 1917; J. Scott Lidgett, My Guided Life (1936), 236-37.

7. RMcK, 16 June 1913, Parliamentary Debates, 59-66.

8. Ullswater, Commentaries, 2:46. 
Do they tremble for their altars?

Do they, Smith?'1

\section{AUGUST 1914}

Notwithstanding his longstanding concerns about making apparent commitments to France, McKenna recalled, 'I never had the slightest doubt during the cabinet discussions that we should be fully engaged in the war.' 2 The worsening international situation made the subject even more pressing than it had been. By Asquith's reckoning, the pro-war party consisted of himself, Grey, Haldane, and Churchill; the anti-war party included Lloyd George, Runciman, and Simon, while McKenna, with Crewe and Samuel, and as over the South African war, and much else, constituted a 'moderating intermediate body'. ${ }^{3}$ The question, as it was increasingly to be, was over the type of war. 'McKenna was for war if Belgian territory was violated', Hobhouse wrote after one August Cabinet, but 'against the dispatch of an expeditionary force. ${ }^{4}$ McKenna later explained to Spender:

When the issue of our intervention was first raised I had no doubt that we were committed to France and that in the event of war being declared between France and Germany we should join in. There was unanimity of opinion that we ought not definitely to commit ourselves in advance of actual hostilities, lest by doing so we should precipitate war. I took little part in the discussions because of my firm conviction of the inevitable outcome in the event of war being declared. ${ }^{5}$

'Much that passes for doubt and hesitation in the later stories was nothing more than tactical manoeuvres by one or two inveterate tacticians, ${ }^{6}$ McKenna later maintained.

There were one or two members of the Cabinet who were opposed to war in any circumstances and two or three more who would have been opposed if they had felt confident that public opinion was with them.

1. G. K. Chesterton, Antichrist, or the Reunion of Christendom: An Ode.

2. RMcK to Spender, 6 February 1929.

3. HHA to Venetia Stanley, 2 August 1914, in Letters, 146; Harold Temperley to Spender, 1 January 1928, Spender papers, 46386/41; Morley, memo on resignation, 26; Asquith, Memories, 1:8; RMcK to Spender, 8 May 1929.

4. Hobhouse, diary, n.d. [August 1914], Diary, 179.

5. RMcK to Spender, 8 May 1929, Spender papers, 46386/60.

6. RMcK to Spender, 6 February 1929 [copy]; Spender to RMcK, 3 February 1929. 
On Sunday, August 2nd, it was quite evident that public opinion was not opposed to our entering the war. ${ }^{1}$

So it was that 'Lloyd George came over to Asquith as the result of his observation of public opinion', ${ }^{2}$ and the government set out on war with internal distrust already evident.

The prime minister summoned the German ambassador, 'who broke down and burst into tears,' Asquith told Pamela, before 'the all-day Cabinet, and the resignations; and the infinite kaleidoscopic chaos of opinion + characters. ${ }^{3}$ At the moment of war, 'I found McKenna and Grey in the Cabinet Room, with the P.M.,' Margot wrote, 'we were all very serious, very anxious'. They sat for a full ten minutes after the declaration of war came into effect in complete silence, before Churchill burst in, 'grinning'. ${ }^{4}$ Privately McKenna was, as the prime minister put it, 'full of blood and thunder' with Lloyd George and Churchill, ${ }^{5}$ who 'is fighting with my ships-the ships he endeavoured to prevent me from building,' McKenna complained. 'What a comedy it all is! Where would the nation have been if I had not insisted upon my programme?'6

One immediate consequence of war was the abandonment of domestic hostilities. On 10 August, Asquith suggested in Cabinet that the Welsh Bill be dropped. After general assent was forthcoming and the ministers filed out, McKenna remained behind to protest. Lloyd George then also stayed. The two '(quite properly \& with good temper)', Asquith recorded, 'took up the Nationalist and Welsh cudgels', ${ }^{7}$ before agreeing on the prudent course of action on disestablishment; on 9 September, McKenna and Lloyd George were back, with Redmond and Dillon, and it was decided that the same would apply to Wales as to Ireland; ${ }^{8}$ on 15 September, Asquith proposed that 'The Government of Ireland Bill and the Established Church (Wales) Bill shall not be proceeded with further during the continuance of the present War'. ${ }^{9}$ That left the Unionists. McKenna was sceptical. 'The war

1. RMcK to Spender, 8 May 1929 , Spender papers, $46386 / 60$.

2. RMcK to G. M. Trevelyan, 30 April 1936 [copy].

3. HHA to PMcK, 1 August 1915.

4. MA, diary, 4 August 1914, MA papers, d.3211/263; Riddell, diary, 14 January 1915, Riddell papers, 62959; Stevenson, Diary, 29 March 1915, 37; Lloyd George, Memoirs, 1:45.

5. HHA to Venetia Stanley, 18 February 1915, in Winston S. Churchill, vol. 3, 1914-16, Companion I: Documents, August 1914-May 1915, ed. Martin Gilbert (1972), 52.

6. RMcK, 15 August 1914, Riddell, diary, Riddell papers, 62974.

7. HHA to Venetia Stanley, 10 August 1914, Letters, 163; E. T. Raymond, $\mathrm{Mr}$ Lloyd George (1922), 148; B. Nicholas to RMcK, 29 October 1922; Riddell, diary, 4 January 1913, Riddell papers, 62972.

8. HHA to Venetia Stanley, 9 September 1914, in Letters, 228.

9. HHA, Times, 16 September 1914. 
has not softened them,' he told Asquith, 'and they look upon Nationalist Ireland $\&$ its cause and claim as a second Belgium'. ${ }^{1}$ McKenna found Bonar Law's speech in reply, in which the leader of the opposition claimed that the government 'took advantage of our patriotism to betray us', ${ }^{2}$ so offensive, Asquith noted, that he 'left the bench \& (as he told me) lay down on his sofa upstairs, lest he should succumb to the temptation of going for him physically and muscularly'. ${ }^{3}$ On 17 September, McKenna and Lloyd George combined again to overcome Asquith and Simon to resist the Lords' amendments to the Suspensory Bills, and the following day both the Welsh Disestablishment Bill and its attendant Suspensory Bill were passed to receive Royal Assent, ${ }^{4}$ and that of Irish Nationalists. 'I can assure you that I fully appreciate the loyalty of your husband to our cause through all the vicissitudes of the past few years', Redmond told Pamela three days later. 'I shall be delighted to meet you both at the Dublin meeting. ${ }^{5}$ He did meet them, and the prime minister and Redmond spoke on a platform with Unionists and Nationalists to call for recruits to fight, 'since Ireland's highest material interests were at stake.'

The other peacetime imbroglio the new warriors would rather was now resolved was broached by Pamela's uncle. 'I wonder if it is any use for me to intercede through you for Sylvia Pankhurst?' Sir John Horner asked her. 'She is really broken by her last hunger-strike; and dreads re-arrest. Yet she herself will give no undertaking. She does not know, of course, that I am making this appeal.' Sir John pledged that Pankhurst would only 'conduct a constitutional campaign in peace ... I beg you to help. ${ }^{7}$ A month later, the cat released the mice for good, initially in return for undertakings 'not to commit further crimes or outrages', ${ }^{8}$ then, three days after that, 'the remainder of the sentences of all persons now undergoing terms of imprisonment for crimes connected with the suffrage agitation'. ${ }^{9}$ McKenna was 'confident that the prisoners ... will respond to the feelings of their countrymen and women in this time of emergency and that they may be trusted not to stain the causes they have at heart by any further crime or disorder. ${ }^{30}$ Emmeline Pankhurst thought him 'half-heartedly ... begrudging', ${ }^{11}$ though, she did agree with his denying passports to a delegation of women to attend the

1. HHA to Venetia Stanley, 26 August 1914, in Letters, 198.

2. Bonar Law, Parliamentary Debates, 15 September 1914, 894.

3. HHA to Venetia Stanley, 15 September 1914, in Letters, 240, 239; HHA to MA, 16 September 1914, MA papers, c.6691/173-74.

4. RMcK, Parliamentary Debates, 17 September 1914, 992-96.

5. John Redmond to PMcK, 22 September 1914.

6. HHA, 25 September 1914, Times, 26 September 1914.

7. Frances Horner to PMcK, n.d. [4 July 1914].

8. RMcK, Parliamentary Debates, 7 August 1914, 2158.

9. Ibid., 10 August 1914, 2265; Riddell, War Diary, 7.

10. RMcK, Parliamentary Debates, 10 August 1914, 2265.

11. Purvis, Pankhurst, 267. 


\section{Reginald McKenna}

International Congress of Women at the Hague in April 1915. ${ }^{1}$ Shortly after, he walked up to Sylvia Pankhurst and said, 'I must shake hands with you. You are the pluckiest girl I ever knew'. She refused his hand.'

However bathetic it had been in its final stages, the muddle of war provided the Welsh Bill with a more apt conclusion than a suspensory bill would have allowed. Church commissioners had continued with their plans for disendowment, prompting the Duke of Devonshire on 9 March to move a Postponement Bill, by which the act would not come into effect until six months after the end of the war. With Unionist assurances that they would not prevent the act from taking effect, they reached a compromise. At which point 'McKenna (of all people) has let us in for a terrible mess', ${ }^{3}$ Asquith complained, 'through not keeping the little gang of Welsh members, who are as touchy as they are stupid, well in hand, and nobbling them in advance'. ${ }^{4}$ Welsh members held daily 'indignation' meetings, and in the Commons rounded on the home secretary and 'nearly tore him to pieces', in the prime minister's words. 'They believe, (not altogether without reason) that they have been both flouted and hoodwinked by McK'. ${ }^{5}$ The postponement was withdrawn on 26 July, and the suspension remained. The Welsh Church was eventually disestablished, with the bishop of St Asaph becoming the archbishop of Wales (and refusing to mention McKenna by name in his account of the saga) on 1 June 1920.

\section{CONTROLS}

The war provided an entirely new set of prejudices with which to target the home secretary. 'I am afraid it is that ruffian McKenna who is at the head of the Home Office and I fancy he is obstructing every suggestion put forward', Rear Admiral David Beatty complained. ${ }^{6}$ The impression of doctrinal indolence became the orthodoxy, but it was only an impression. The obvious home front in the war concerned public order. The security and intelligence services effectively had been invented in the years before the war and were subject to a summary and rapid expansion. In July, McKenna had chaired a CID subcommittee on an Emergency Powers Bill, dealing with the jurisdiction of the state over the individual in time of war, which concluded common law would suffice. On 7 August, he introduced an 'emergency Bill, which, while it is very important, is extremely simple', preventing persons

1. Pankhurst, Home, 151.

2. Pankhurst, Suffragette, 451; Fulford, Votes, 301.

3. HHA, in Jenkins, Asquith, 344.

4. HHA to Venetia Stanley, 10 March 1915, in Letters to Venetia Stanley, 469; HHA to Lord Robert Cecil, 9 March 1915, Cecil papers, 51073/14.

5. HHA to Venetia Stanley, 12 March 1915, in Letters, 474; Times, 12 March 1915.

6. David Beatty to Ethel Beatty, 10 November 1914, in Beatty, Papers, 1:160. 
obtaining or communicating information to the enemy, and securing means of transport and communication, with persons contravening it to be tried by court-martial. ${ }^{1}$ It provided for further extensions as required. There was no debate, McKenna did not even have the bill printed, and by the end of the afternoon the Defence of the Realm Act had been passed. ${ }^{2}$

Though there had been planning for war, as McKenna knew to his cost, improvisation was the dominant impression. When an MP complained that his mail was being tampered with by officials of MO5, the precursor to MI5, McKenna summoned to his office Captain William 'Blinker' Hall, head of naval intelligence, and Colonel George Cockerill, head of MO5. McKenna asked Hall directly if he had been tampering with mail, and with Hall's admission of guilt informed him that the prison term for such an act was two years. After listening to Hall's case for the use of censorship in facilitating an economic blockade of Germany, McKenna established the War Trade Intelligence Department, reconstituted the Office of Postal Censors, and thereby immediately produced processions of protesting American journalists. ${ }^{3}$ The latter became a constant concern, and McKenna sought to keep 'American correspondents in as good humour as the circumstances will allow', ${ }^{4}$ but the balance between freedom and controls-in that as in other areas-was a difficult one for Liberals. After an alert from Sir Cecil Spring Rice, who had succeeded James Bryce as ambassador to the United States, concerning a spy ring based in the Ritz Carlton hotel in New York, Asquith 'put it in the trusty hands of McKenna', who duly issued warrants for the opening of all mail sacks from Holland to the USA, and the opening of any letters therein addressed to the Ritz. ${ }^{6}$

McKenna suppressed newspaper billboards that might by association undermine confidence in the fragile Yorkshire Penny Bank, whose continued existence Sir Edward Holden, the chairman of Midland Bank, was overseeing, ${ }^{7}$ and he assumed parliamentary responsibility for the Press Bureau, which was installed in the United Services Institution with the Central Telegraph Office, which censored cables. ${ }^{8}$ F. E. Smith was put in operational control, and on 10 September the two found themselves on the same side of the chamber defending the withholding of news. When Smith decided to join the army, McKenna proposed Stanley Buckmaster as his replacement, who

1. RMcK, 7 August 1914, Parliamentary Debates, 2191-93; Home Office papers, HO 45/10690/228849.

2. Michael MacDonagh, diary, 7 August 1914, in Michael MacDonagh, In London During the Great War: The Diary of a Journalist (1935), 13

3. HHA to Venetia Stanley, 16 September 1914, in Letters, 242; Andrew, Secret Service, 177.

4. RMcK to John St. Loe Strachey, 24 September 1914, Strachey papers, 10/3/4.

5. HHA to Venetia Stanley, 26 February 1915, in Letters, 450.

6. Hobhouse, diary, 5 March 1915, Diary, 226-27.

7. $R M c K, 127$; Holmes and Green, Midland, 145-46.

8. Troup, Home Office, 244-45. 


\section{Reginald McKenna}

thereafter had to confront angry press interests. ${ }^{1}$ Public dissent was not a problem, and given the extent of public support for the war, communication was more efficacious than coercion, elevating the likes of Hedley Le Bas, the publisher and publicist, who came up with 'Your Country Needs You.'

Another initiative that further extended the remit of the state came from the uncommon circumstances. Having discovered the extent of drunkenness on shipbuilding and munitions production, McKenna and Lloyd George agreed on the need to nationalize the liquor trade, Asquith being delighted to see the duo on harmonious and 'even intimate terms', though within a fortnight McKenna had come to the view that the policy was 'for practical purposes a chimera'. ${ }^{3}$ With Haldane, McKenna backed the use of compulsory powers to control munitions workers and supported the total prohibition of spirits. ${ }^{4}$ When McKenna did follow police recommendations, as over a curfew order in January 1915, it was rejected by the Cabinet; ${ }^{5}$ when he remonstrated with Claude Grahame-White for flying over Greenwich, the Daily Mail condemned his restrictions. ${ }^{6}$ Privately, McKenna maintained, 'in the present state of public feeling trial by court martial was likely to be more just than trial by jury', which Riddell found 'a curious opinion by a radical minister. ${ }^{7}$ Yet he ensured that conscientious objectors would be held under civilian authority and were not sent to France. Arnold Rowntree thought, 'McKenna is the one member who has really done his level best to stop the scandals." ${ }^{8}$

Britain's principal wartime enemy had been its principal peacetime customer, and where at the Admiralty McKenna's preoccupation was the trading of neutrals with the enemy in time of war, at the Home Office he was concerned with British subjects trading with the enemy through neutral countries. Yet trade was also the area where the Atlanticists felt Britain's belligerency would best be served. So it was with those often conflicting interests that McKenna called a conference at the CID in March 1915 of all the departments with an interest in economic warfare. The Declaration of London provided for the regulation of trade in war, and the conference decided

1. HHA to Venetia Stanley, 21 September 1914, in Letters, 251.

2. Northcliffe papers, 62176b/4-5; Riddell, diary, 26 June 1915, Riddell papers, 62959; Benn, Side Shows, 2-3. Le Bas offered to help Northcliffe with his circulations (Northcliffe papers, 62170/139) and took out full-page advertisements. Isaac F. Marcosson, Adventures in Interviewing (1919), 131; Skidelsky, Keynes, ii:134-39.

3. HHA to Venetia Stanley, 14 April 1915, Letters, in 541; RMcK, n.d., 'Drinking in the Shipbuilding Trades', Cabinet papers, CAB37/127/23; HHA to Venetia Stanley, 1 April 1915, in Letters, 527.

4. Hobhouse, 22 April 1915, Diary, 238-39; Churchill to RMcK, 13 September 1911, McKenna papers, 3/21/10.

5. Home Office 45/16782/278944.

6. Wallace, Grahame-White, 188.

7. RMcK, 14 February 1915, Riddell, diary, Riddell papers, 62959.

8. Arnold Rowntree to Mary Rowntree, 30 May 1915, Letters, 218; ibid, 23 May 1915, 217. 
to adopt a much more stringent attitude to traders, with the Royal Navy intercepting all cargoes. ${ }^{1}$ What had been theoretical discussions between McKenna and Grey five years earlier were now real, particularly with free trade a given. 'Importance to us-dependent on imports of food and raw materials 47,000,000 on small island, U.S. nature produces all needed', McKenna noted in his diary. 'F. T. essential. We must import largely and we must export to pay for imports."

McKenna cooperated with Lloyd George to restrict discussion of the blockade, ${ }^{3}$ and with Churchill over contraband, and the pledge of indemnity for importers of supplies sunk en route. ${ }^{4}$ McKenna professed no interference in trade, but tried to ban the importation of German-grown sugar into the British empire, ${ }^{5}$ and he established the Royal Commission on Sugar Supplies, through which merchants were shocked to find McKenna buying stocks at half the market value. ${ }^{6}$ When he was attacked for rejecting pricefixing, McKenna pointed out that it was not in fact wise to fix prices lower than they were elsewhere when one depended on imported food. ${ }^{7}$ It was the first of a series of subtle positions that would irritate more than they convinced. He rejected an Admiralty suggestion that rather than stabilising the market within which it operated, the state should simply take control of all shipping. McKenna, with Runciman, believed that if merchant ships were compelled to bring goods only to and from Britain, with no trading with neutrals, currency would be lost to support the balance of payments. That position may also have explained why he and Lloyd George opposed Asquith and Grey over supplying the Belgian population with food. ${ }^{8}$ With his support for compulsory powers over munitions workers, ${ }^{9}$ it made McKenna's position less straightforward than his critics implied.

\section{HYSTERIA GERMANICA: PART II}

Britain's principal wartime enemy had also provided its second largest foreign population, and consequently, the biggest domestic issue of the first

1. See McDermott, 'Trading'.

2. RMcK, note, n.d. c. Aug 1914.

3. Memorandum on restriction of enemy trade, 12 August 1914, Churchill papers, CHAR 13/27b/10-11.

4. Churchill to RMcK, 13 September 1911, McKenna papers, 3/21/10; Churchill to HHA, 23 October 1911, in Companion, ii:2, 1296-97; Admiralty announcement, 6 February 1915, in Companion, iii:1, 490-1.

5. Fitzroy, 26 October 1914, Memoirs, 2:574.

6. Fitzroy, 19 August 1914, Memoirs, 2:567; Times, 9 October 1914.

7. RMcK, 8 August 1914, Parliamentary Debates, 2217.

8. HHA to Venetia Stanley, 21 October 1914, Letters, 281.

9. Pease, diary, 4 March 1915, and Emmott, diary, 7 March 1915, both in Hazlehurst, Politicians, 303. 
year of the war. ${ }^{1}$ It was another example of Liberal instinct clashing with populist wartime exigencies. McKenna had campaigned on the alien issue, as had Dilke, as the human concomitant of free trade. Given the conditions of wartime, free trade in this area at least would have to be supplanted by protection. At the Admiralty, McKenna had considered the threat of foreign espionage, and at the Home Office had charged the Special Intelligence Department with evaluating German espionage. He had also been a member of the Aliens subcommittees of the CID to consider the treatment of aliens in time of war. ${ }^{2}$ McKenna adopted its conclusions as the basis for the Aliens Restriction Act of 5 August, an Order in Council, 'restricting the movements of alien enemies from, to, and in the United Kingdom. ${ }^{3}$ The Aliens Restriction (No 4) Order of 20 August banned German language publications without his permission; and the Aliens Restriction (Consolidation) Order of 9 September restricted the possession of communication equipment. The Aliens Restriction (Change of Name) Order of 8 October forbade aliens from changing their name without McKenna's permission. After anti-German rioting in Deptford on 18 and 19 October, McKenna responded with the arrest on 20 October of every German and Austrian of military age. His Defence of the Realm (Consolidation) Regulations of 28 November stipulated that any enemy alien could be removed if the military desired it.

The Defence of the Realm Act, the Official Secrets Act, and the Aliens Restriction Act summarily transformed the role of the state, both in terms of what it did and how it did it: they took the place of legislation and allowed for new powers on a day-to-day basis. ${ }^{4}$ By 13 August 1,980 enemy aliens had been interned; by 28 August, 4,300, by 7 September, 6,600; by 16 September, 11,000; which meant that by 20 September all available facilities were full. Police stations were overwhelmed with Germans trying to register. $^{5}$ Within a month of the outbreak of the war, 9,000 cases of espionage had been reported, of which 90 were considered worthy of investigation. By November, McKenna told the Commons, 120,000 cases had been investigated, 342 persons interned without charge, and 'no less than 6,000 houses have been ransacked'. ${ }^{6}$ London's Olympia was filled with bedding, and then by two shiploads of Austrians whose vessel had docked in London without their realising war had broken out.?

1. See Panayi, 'Enemy', 49-76, Bird, 'Control', 14-88; Troup, Home Office, $242-43$.

2. Aliens Sub Committee WO/5368/0103/37571; 'Foreign Espionage' CID Subcommittee, 30 March 1909, Cabinet papers, CAB16/8.

3. RMcK, Parliamentary Debates, 9 September 1914, 563-67.

4. Troup, Home Office, 239-40.

5. Times, 10 August 1914.

6. RMcK, Parliamentary Debates, 26 November 1914, 1390.

7. Basil Thomson, Queer People [1922], 59. 
While the latitude Parliament had granted the government in general and the home secretary in particular was deprecated by Liberals further alarmed at the accretion of centralised power, ${ }^{1}$ the dominant reaction in the press was that too little was being done. At least one newspaper claimed there were 250,000 armed Germans in the country, ${ }^{2}$ while St Loe Strachey warned McKenna that Germans were planting mines in the Midlands, before himself admitting, 'I fully agree that anyone could get the spy mania'. 'When a Ssssssssspy is reported to the Home Office nowadays-by which I mean the Home Office supplemented by its wife', Montagu told McKenna, 'it puts its nose to the clue, it silently, grimly, determinably ferrets and investigates, and criticises and then conclusively, undeniably, indisputably, infallibly, unfalteringly, unerringly, etc, etc, etc, etc, proves that HE DOES NOT EXIST. ${ }^{4}$

There were real spies, hunted down by Vernon Kell, and executions at the Tower of London, ${ }^{5}$ but the main constituent was hysteria, to which Kell himself contributed. ${ }^{6}$ McKenna gave Cabinet what Asquith described as an 'amusing commentary on the ridiculous spy fever', ' and while no attacks on dachshunds were reported, 'guttural persons' were rumoured to be scouring the West Country for suitable stable accommodation, pigeon-dealers were hounded, Russian landings were reported near Aberdeen, and whole salonsfull of hairdressers and café-loads of waiters were bundled into furniture vans and driven off to Olympia. ${ }^{8}$ The home secretary was unmoved by the clamour. Having found personal meetings with McKenna fruitful before, Admiral Domvile went to see him with a War Office request to shoot two spies caught wiretapping on the East Coast. This time 'he gave me a pitying look when I made my bloodthirsty proposal, and putting his hand on my shoulder said: "My dear Domvile, do you think I am going to have innocent civilians placed at the mercy of an irascible major?"' After complaints of a Home Office official's inaction over special constables who were aliens, McKenna thought that, since he was 'very humanely disposed in his

1. Sir William Byles, Parliamentary Debates, 5 August 1914, 65, 1990; Troup, Home Office, 144.

2. RMcK, Parliamentary Debates, 9 September 1914, 565.

3. St. Loe Strachey to RMcK, 19 October 1914, Strachey papers, 10/3/5; St. Loe Strachey to RMcK, 15 October 1914, Strachey papers, 10/3/5; RMcK to St. Loe Strachey, 20 October 1914, Strachey papers, 10/3/5. Raymond to Katherine Asquith, 10 September 1914, in Raymond Asquith, Life and Letters, ed. John Jolliffe (1980), 194.

4. Montagu to RMcK, 11 September 1914.

5. Thomson, People, 117-73; Viscount Sandhurst, From Day to Day, 2 vols. (1928-29), 1:29.

6. Nicholas Hiley, 'The Failure of British Counter-Espionage Against Germany, 1907-1914', The Historical Journal 28 (1985): 835-62.

7. HHA to Venetia Stanley, 27 January 1915, in Letters, 400.

8. Thomson, People, 14, 34, 37, 60 .

9. Domvile, Large, 50-51; Riddell, diary, 29 October 1914, Riddell papers, 62974. 
treatment of aliens I have been content to leave him a free hand'. ${ }^{1}$ As Riddell put it, that 'he cannot view with much sympathy the execution of a policy which he so strongly opposed'.2

Latent dissatisfaction began to grow more pronounced with what Lloyd George later called McKenna's 'indulgent regime'. ${ }^{3}$ The home secretary issued a press release stating that 'The public may rest assured that a great majority of the Germans remaining in this country are peaceful and innocent persons from whom no danger is to be feared. ${ }^{4}$ After publishing a lengthy statement summarising the steps already taken, The Times condemned what it regarded as McKenna's latest 'tranquil assertion. ${ }^{5}$ In so doing, it demonstrated a clear failure of the home secretary. No one "can question the ability or the ceaseless industry', Montagu told Asquith, but McKenna's 'presentation of the case seems to me to be very unsatisfactory'. ${ }^{6}$ Had McKenna been at all concerned with cultivating publicity and newspaper opinion, such allegations could not have been made. Instead of issuing his own rhetoric, he attacked that of his accusers. On 12 November, McKenna asked the Commons whether, being at war with Germany, 'we are to treat every individual German in this country now as we should treat an enemy on the battlefield?' Bad tempered exchanges with Bonar Law were a feature of the debates, and McKenna's distaste was not mitigated by personal experience. After one Munstead Sunday, the Asquiths went with the McKennae and Ernest to Deepcut, a tented prison camp of 4,500 men 'of whom nearly $1 / 2$ are the civilians who have been herded there during the last week under McKenna's orders' ${ }^{8}$ The home secretary 'said he was quite horrified at the hideous discomfort \& wd. see that it was altered."

McKenna's visceral distaste at the clamour was also practical. He pointed out that by turning waiters out of jobs they 'were likely to become dangerous because they were starving ${ }^{10}{ }^{10}$ Moreover, thousands of army recruits were vying for accommodation at the same time as thousands of internees, for whom there were no longer enough soldiers left in the country to serve as guards. McKenna tried to use the limitations of capacity as a caution, which was optimistic when 'Intern them All' became as pervasive a cry as wanting

1. RMcK to Rufus Isaacs, 28 September 1914, Reading papers, 54/51.

2. Riddell, diary, 30 January 1915, Riddell papers, 62959; Riddell, n.d. [October 1914], Riddell papers, 62974.

3. Lloyd George, Memoirs, 1:132; Walter Long to Balfour, 15 November 1914, Balfour papers, 49777/127; French, 'Spy Fever'; Bryce to HHA, 23 November 1914, Kitchener papers, PRO 30/57/75; Riddell, diary, 29 October 1914, Riddell papers, 62974; MA to HHA, 7 December 1914, Montagu papers, AS6/9/19.

4. RMcK, Times, 10 August 1914.

5. Times, 9 October 1914, 15 October 1914.

6. Montagu to Asquith, 7 December 1914 [copy], Montagu papers, AS6/9/19.

7. RMcK, Parliamentary Debates, 12 November 1914, 92.

8. HHA to Venetia Stanley, 25 October 1914, in Letters, 286.

9. MA, diary, 27 October 1914, MA papers, d.3211/8.

10. RMcK, Parliamentary Debates, 12 November 1914, 95. 
eight, and being reluctant to wait. The War Office asked the Home Office to suspend the policy. 'I know your difficulties,' McKenna told Kitchener, 'but the public is being worked up to a state of frenzy and I fear we may have disturbance'. ${ }^{1}$ Having originally advocated the measure, Kitchener replied that there was not enough accommodation for a more general internment. ${ }^{2}$ With the Home Office responsible for policy, but the War Office with its application, confusion was inevitable, as was the effect that the Home Office was blamed, to its frustration. Kitchener had expressly requested the internment of enemy aliens of military age in September, suspending the measure in October through lack of facilities, before renewing it later in October, and then suspending it again in November. ' 'It is all K's fault!' McKenna told Margot. ' 6 weeks ago I asked him to let me at the Home Office take over the civilians $\&$ leave him the soldiers but he refused $\&$ this is what we see!' $B y$ December, Kitchener asked McKenna to release internees once again. ${ }^{5}$

The issue changed in complexion when McKenna went from being criticised for general complacency to actual pro-Germanism, notwithstanding that he had been condemned abroad for 'violent Germanophobia. ${ }^{6}$ The latest first sea lord, Battenberg, had to resign because his name sounded foreign. Beresford had led the baiting, but his success was rewarded by the return of Fisher.' Conversely, it was because of the 'embarrassing family associations' to a Liberal government of his brother Northcliffe, that Cecil Harmsworth, under secretary at the Home Office, was forced to resign. ${ }^{8}$ Attention then turned to the Cabinet itself. 'Anyone more dissimilar from McKenna', Archibald Hurd said of Haldane, 'it would be difficult to imagine', ${ }^{9}$ but the two were as one to their enemies, including Beatty, who thought, 'He and old Haldane should be locked up and removed from any responsible position'..$^{10}$ Though McKenna had never said in public, as it was claimed Haldane did, that Germany was his 'spiritual home', ${ }^{11}$ some perhaps remembered reading about the Home Secretary's early years and the devotion of Herr Freytag, or even of Herr Wurms' band playing from the Minstrels' gallery at his wedding reception. As with Haldane, who suffered similarly

1. RMcK to Kitchener, 16 October 1914, Kitchener papers, PRO 30/57/75/WT-1.

2. Kitchener to RMcK, 17 October 1914, Home Office papers, HO 45/10760/ $269116 / 7$.

3. Troup to B. B. Cubbitt, 6 November 1914 , Home Office papers, HO 45/10760/ $269116 / 27$.

4. MA, diary, 27 October 1914, MA papers, d.3211/8.

5. Kitchener to RMcK, 10 December 1914, Home Office papers, HO 45/10760/ 269116/89.

6. Kreuz-Zeitung, 27 September 1911, in Gooch, Documents, vii:648

7. Beresford to Bonar Law, 3 January 1912, Bonar Law papers, 25/1/6; Riddell, diary, 25 January 1914, Riddell papers, 62974.

8. Cecil Harmsworth to RMcK, n.d. c. May 1915.

9. Sir Archibald Hurd, Who Goes There? [1942], 98.

10. David Beatty to Ethel Beatty, 10 November 1914, Beatty, Papers, i:160.

11. New Age, 23 January 1919; Times, 31 May 1918. 
having strengthened an armed service, McKenna spoke German and knew Germany. In 1912, he signed a pledge of goodwill to Germany in the journal of the Official Arbitration League. ${ }^{1}$ His sensitivities to the nation extended to the person. 'My crippled sister had a German maid, and I had a German governess', Margot recalled. 'By a stroke of the pen and in spite of the raised eyebrows of our thoughtful press, Reggie McKenna allowed them their freedom'. ${ }^{2}$ After representations from Walter Cunliffe, governor of the Bank of England, McKenna granted British citizenship to Bruno Schröder, whose merchant bank was one of London's largest acceptance houses, and essential to weathering the financial crisis brought about by the war, though that did not prevent some MPs calling for Schröder's internment rather than his naturalisation. ${ }^{3}$

'McKenna has had a bad time in regard to the alien question', Riddell admitted.

He is too self-opinionated and does not pay sufficient regard to the views of the public. He wants the Cabinet to be popular but at the same time he wants to govern in his own way. There is no doubt that he hates the anti-German agitation. He is always talking of 'fighting like gentlemen' of 'not losing our heads' of 'lack of evidence of German machinations' and of 'the absence of danger' etc etc. ${ }^{4}$

McKenna's 'rigid and fretful answers, though always technically complete, were provocative', Lloyd George recalled, and 'whilst administering the letter of his trust, he showed too clearly that he had no sympathy with its spirit. ${ }^{5}$ It was because McKenna 'is quite ignorant of the popular view', that Riddell 'gave him G. H. Lewes's Robespierre the other day. I hope it may educate him in the right direction. He is one of those people who want a democratic form of government but fear the mob. ${ }^{6}$ In May, the hysteria reached its peak, with the sinking of the Lusitania and the publication of the Bryce report on German atrocities in France and Belgium. Riots flared around the country, fanned by the likes of William Le Queux, Horatio Bottomley, and Leo Maxse and what McKenna described to Burns as 'the maniac press'. ${ }^{7}$ The public concern implanted before the war by the likes of Le Queux, Erskine Childers, and H. G. Wells had assisted McKenna's earlier departmental concerns; with the war they presupposed, McKenna

1. Stephen Koss, Lord Haldane: Scapegoat for Liberalism (New York, 1969), 66; Times, 29 April 1911; Martin Landy to DMcK, 9 September 1967.

2. Asquith, Record, 101, fn.

3. RMcK, Parliamentary Debates, 26 November 1914, 1391.

4. Riddell, diary, 'End of October' 1914, Riddell papers, 62974.

5. Lloyd George, Memoirs, 1:132.

6. Riddell, diary, 14 January 1915, Riddell papers, 62959; Donald Munro to Ferguson to Rosebery, 15 July 1915, Rosebery papers, 10020/112.

7. RMcK to Burns, 26 October 1914, Burns papers, 46282/127. 
soon became its principal political victim. That his earlier commitment had no taint of anti-German agitation offered no protection when the cause was taken up more widely. As Riddell observed, it was a liability: 'He and Mrs McKenna are too sympathetic to the Germans. They are always preaching tolerance.'

He, Mrs McKenna, and their children, spent the first weekend of the war with Ned and Emily at Munstead. With the war, and her improved health, Pamela was restored to political duties. There were 'jolly little flowers' 2 and a 'delightful motoring scarf' 3 for her husband's sworn enemy, a 'magnificent shawl' for Birrell ('I am reserving it for my shroud'4), books for Pease, and lunches at Smith Square-for everyone. 'It's I who feel a universal spongee at your lunches', Charlie Masterman told her, 'but they are so much jollier than anyone else's-and cheer one up in what is-behind all laughter-a subject of "duty and terror" tragedy'. ${ }^{5}$ Not that guests necessarily regarded them as merely jolly. 'I wonder if Mrs McKenna's courtesies and attentions to me in the past two years have not been made partly with the object of detaching me from Winston', Riddell wondered. ${ }^{6}$

In October, the McKennae hosted lunch for Masterman, Francis Meynell, George Lansbury, and Violet Markham. While Riddell was convinced of Pamela's 'curious mental twist' which meant that 'for some reason she is pro-German', dinner revealed that McKenna and Markham were pro-war, Lansbury and Meynell against, and Pamela and Masterman neutral. ${ }^{8}$ As if to press the point, as a subsequent dinner party at Smith Square that included Ernest, Basil Thomson, Simon, Buckmaster, Troup, and Cecil Harmsworth was breaking up, 'McKenna ran in from his telephone room, crying "Zeppelins! Zeppelins!"' Pamela said, 'What about my babies? Shall we take them to the cellar?' The party stood in a semicircle around the telephone waiting for news, Simon said, 'like the scene in the second act of a melodrama'. News came through that Whitechapel and Stoke Newington had been bombed, with dead reported. Sir William Byrne ran upstairs with Pamela to carry the boys down to the cellar, while, instead of the drawing room,

1. Riddell, diary, 30 January 1915, Riddell papers, 62959; Riddell, diary, 31 October 1914, Riddell papers, 62974; French, 'Spy Fever', 78.

2. Lloyd George to PMcK, 20 February 1914.

3. Lloyd George to PMcK, 12 January 1915.

4. Birrell to PMcK, 18 February 1912.

5. Masterman to PMcK, 17 November 1914.

6. Riddell, diary, 1 May 1915, Riddell papers, 62959; PMcK to Burns, 11 February 1909, Burns papers, 46300/193; PMcK to Burns, 4 October 1910, Burns papers, 46301/176; PMcK to Burns, 11 October 1910, Burns papers, 46301/180.

7. Riddell, diary, 14 November 1914, Riddell papers, 62974; Meynell, Lives, 82-83.

8. Violet Markham to RMcK, 26 May 1915.

9. Simon to PMcK, 1 June 1915. 


\section{Reginald McKenna}

the gentlemen repaired to Scotland Yard. 'Such a pleasant evening', Simon thanked her, '(with the proper entremets-Bombes à la Zeppelin)'.'

After that, Michael and David went off to Munstead and remained there for the duration, with Aggie adapting the cottage to their needs. In London, Pamela and Bar became the 'impresarios' of the Voluntary Aid Detachment, constituted by a number of London wives, run by the St. John's ambulance, and meeting at Smith Square. ${ }^{3}$ Pamela was moved by the experience to be one of the first to provide an ambulance service after air raids. Such excitement continued alongside more conventional political activities that blurred the public and the private. On 9 November 1914, McKenna received a deputation at the Home Office concerned with women and drinking, one member of which was his wife.

The war did nothing to separate the personal and the political, other than that, like the king, and Lloyd George, McKenna 'knocked off wine and alcohol' for the duration. ${ }^{4}$ Whether at Downing Street, Munstead, Dornoch, or Walmer, the Asquiths and 'McKennae' were closer than ever; she would cut the prime minister's hair at Smith Square, ${ }^{5}$ and he would 'spend Sunday at Munstead in an atmosphere more or less permeated ... by the McKennae'. ${ }^{6}$ It became too much for some. Though 'I myself am devoted to McKenna \& so is Henry,' Margot confessed, 'the family can't appreciate him'; ' Violet and Venetia 'never have a good word to say for him-to be ugly $\&$ have spots is quite enough for superficial idle young females to be put off any one!'s It was reciprocated, and this time their subject had an excuse. One evening in January Asquith 'and his ladies', including Pamela, 'had just gone in to a "Jolly" (new names for cards, frolic, and frivolity)' at Francis and Bar's, Runciman told his wife. 'Reggie, who disapproves of frivolities during the war refused to go'. 9

1. Basil Thomson, 31 May 1915, in The Scene Changes (1939), 244-45.

2. Simon to PMcK, 1 June 1915.

3. Viola Parsons, ed., Alan Parsons' Book:A Study in Anthology (1937), 57; Frances Horner, Time Remembered (1933); Horner, Time, 206.

4. MA to Arthur Asquith, 12 April 1915, in Command in the Royal Naval Divisions-a Military Biography of Brigadier General A. M. Asquith, DSO, by Christopher Page (Staplehurst, 1999), 5.

5. HHA to Sylvia Henley, 8 October 1916, Asquith papers, 542/4/759.

6. HHA to Venetia Stanley, 24 October 1914, in Letters, 284.

7. MA, diary, 23 January 1915, MA papers, d.3211/148; HHA to MA, 15 August 1914, MA papers, c.6691/157-58; HHA to MA, 17 August 1914, MA papers, c.6691/159-60, 165-66.

8. MA, diary, 15 June 1915, MA papers, d.3211/207.

9. Runciman to Hilda Runciman, 12 January 1915, Runciman papers, 303/2; RMcK to PMcK, 18 August 1915; Runciman to Hilda Runciman, 3 March 1917, Runciman papers, 303/2. 


\section{HOSTILITIES}

The war had occasioned a mild reshuffle of ministers, and a change in the hue of the ministry that would betoken greater change. John Burns and John Morley immediately resigned from the government, and Burns's presidency of the Board of Trade passed to Runciman, liberating him from the Board of Education. As secretary of state for war, Asquith appointed Earl Kitchener, as a politically neutral figurehead, to add martial authority to a far from conventionally warlike Cabinet the day after war had been declared. The appointment was at least in part necessary gives the likes of the home secretary sitting around the Cabinet table. Riddell thought that 'he is very half-hearted I always think about the war.'

That did not mean McKenna was not belligerent. His rapprochement with Lloyd George, the 'intimacy' of which Asquith had spoken, came to a sudden end with the war. The deterioration in relations between the two thenceforth became the greatest source of internal Cabinet frustration for Asquith. As Spender put it, 'the inner history of those times was in no small degree the record of their battles'. ${ }^{2}$ In March, McKenna told Asquith that Northcliffe was colluding with Lloyd George to replace him as prime minister. Asquith summoned McKenna and Lloyd George. The chancellor denied the accusation and accused the home secretary of colluding with Robert Donald, of the Daily Chronicle. McKenna denied that and blamed Churchill for colluding with Balfour, whom he called 'a poisonous snake in the grass', ${ }^{3}$ which produced agreement from all three. Nevertheless, Asquith threatened to resign unless they stopped squabbling and in so doing managed to produce a ceasefire. ${ }^{4}$

It was far from an armistice. On 15 April, McKenna and Lloyd George fell out again in a Cabinet Asquith described as 'the saddest $\&$ most disagreeable' he had ever experienced. ${ }^{5}$ The ostensible subject was the Munitions Committee, over which Lloyd George had fallen out with Kitchener. 'Ll. George lost his head \& temper-Winston was foolish, McK who ought to have helped sat silent \& unhelpful \& gloating over the situation', Margot wrote. 'No doubt McK has a provincial mind \& likes small quarrels \& seeing his (boring!) suspicions come true. ${ }^{\prime 6}$ Asquith blamed both McKenna and Lloyd George, the home secretary having 'played the part of a wrecker, pure

1. Riddell, diary, 31 October 1914, Riddell papers, 62974.

2. Spender, Journalism, 1:165; Frances Lloyd George, The Years That are Past (1967), 122.

3. HHA to Venetia Stanley, 24 March 1915, in Letters, 505.

4. Ibid., 29 March 1915, in Companion, iii:1, 760; HHA to Venetia Stanley, 30 March 1915, Letters, 522; RMcK, 29 June 1913, Riddell, diary, Riddell papers, 62972.

5. HHA, in MA, diary, [c.16] April 1915, MA papers, d.3211/240.

6. MA, diary, [c.16] April 1915, MA papers, d.3211/241. 
and simple. It will take me a long time to forget and forgive their attitude'. ${ }^{1}$ 'None of you came out of that Cabinet well', Margot scolded the home secretary afterwards. 'He got quite pink but said nothing'. ${ }^{2}$ According to Asquith, Simon was by now 'rather anti-McK, whom he suspects as a mischief maker'. ${ }^{3}$ Margot confessed 'I feel a little nervous as to his future unless he controls this pleasure in seeing his enemy in a hole' ${ }^{4}$

The parties being duly chastened, it was almost a week before the next row, when, to Asquith, Lloyd George "cursed McKenna (one of his henchmen told him that McK \& Donald had been seen together)', Margot recorded. 'He was in a state of despair-absolutely genuine despair. H calmed him down but cd. not move him about McK, \& fearing serious break in the cabinet said he wd. see them both together that afternoon', ${ }^{5}$ when the allegations were accepted as being untrue, and another cessation was negotiated. ${ }^{6}$

It was because McKenna's suspicions about Lloyd George and Churchill were often accurate that they were just as often exaggerated. 'There is all the difference between insight $\&$ suspicions but $\mathrm{Mr}$ McK slightly confounds the 2, ${ }^{7}$ Margot thought, just after McKenna had told Violet at length that it was in fact the Master of Elibank who had 'intrigued' him out of the Admiralty. ${ }^{8}$ To McKenna's legitimate grounds for suspicion was added his personal insecurity, which, given the experiences of the previous seven years, was not groundless. While relations were worsening once again with Lloyd George, McKenna's suspicions revolved on one man. 'I have been impressed by the way in which the McKenna vendetta haunts the scene in all sorts of strange ways', Riddell reflected in January. ' $\mathrm{H}$ is hatred of Winston amounts to an obsession'. ${ }^{10}$ It was 'one of the most virulent and persistent hatreds I have ever known', ${ }^{11}$ the 'the intensity and continuity' of which 'is difficult to believe'. ${ }^{12}$

Fisher's return brought further discord. Once back, Fisher immediately fell out with his first lord, Churchill, in part through Fisher's relations with

1. HHA to Venetia Stanley, 16 April 1915, in Letters, 546.

2. MA, diary, [c.16] April 1915, MA papers, d.3211/241.

3. HHA to Venetia Stanley, 29 March 1915, in Companion, iii:1, 760.

4. MA, diary, 21 April 1915, MA papers, d.3211/240-41.

5. Ibid., d.3211/244.

6. Riddell, diary, 29 March 1915, Riddell papers, 62959; MA, diary, 21 April 1915, MA papers, d.3211/247.

7. MA, diary, April 1915, MA papers, d.3211/24()-41.

8. HHA to Venetia Stanley, 30 January 1915, in Letters, 410.

9. Riddell, diary, 1 May 1915, 62959; PMcK to Burns, 11 February 1909, Burns papers, 46300/193; PMcK to Burns, 4 October 1910, Burns papers, 46301/176; PMcK to Burns, 11 October 1910, Burns papers, 46301/180.

10. Riddell, diary, 14 April 1915, Riddell papers, 62959.

11. Ibid., 31 October 1914, Riddell papers, 62974; MA, diary, 15 May 1915, MA papers, d.3212/6.

12. Riddell, diary, 1 May 1915, Riddell papers, 62959. 
McKenna, ${ }^{1}$ but most substantively over the Dardanelles, and Churchill's high-risk plan to take Constantinople by amphibious assault. Fisher and McKenna felt the risk too high, and their misgivings were reinforced by the mission's troubled lack of progress. ${ }^{2}$ McKenna felt that though six ships might get through, twenty ships would be lost. More ships and men would then be required 'till we are bled white', and the war lengthened. ${ }^{3}$ The endeavour brought about the complete breakdown of relations between first lord and first sea lord. Lloyd George felt McKenna's 'pet aversion' to Churchill meant that he did nothing to assuage Fisher's concerns. ${ }^{4}$ Fisher told Spender and Jellicoe, 'I would only serve under Bonar Law or McKenna-with either of these I required no guarantees'. 'At Fisher's request [I] saw McKenna $\&$ told him the whole story', Hankey wrote. 'McK promised to stick to Fisher through thick and thin'. ${ }^{6}$ The following day, 13 May, Fisher showed his resignation letter to McKenna, which the home secretary could not dissuade Fisher from then sending to Asquith. ${ }^{7}$ Fisher felt he could not continue in office and demanded what should be done with 'such a determined mad Gambler' as Churchill, before suggesting that Hankey 'ask McKenna! Secretly'.

The prime minister ordered Fisher back to his post. Fisher instead went to Margot and 'asked if he cd. see McKenna before deciding, ${ }^{9}$ Stamfordham telling the king that their 'most intimate relations' might resolve the crisis. ${ }^{10}$ McKenna went to Kilverstone Hall, in Norfolk, and sat up with Fisher into the small hours. ${ }^{11}$ The next day, the McKennae went to The Wharf, in Oxfordshire, where 'he went to H's room \& remained there'. ${ }^{12}$ The following day Fisher wrote to McKenna: 'I want you kindly to tell the Prime Minister distinctly and definitely that I am no longer First Sea Lord. ${ }^{13}$ McKenna replied, 'The P.M. holds the opinion that your resignation is void until he

1. Ibid., 16 November 1913, Riddell papers, 62973; Riddell, diary, 5 November 1914, Riddell papers, 62974.

2. Fisher to Churchill, 16 May 1915, McKenna papers, 6/8/1; Hobhouse, diary, 7 April 1915, Diary, 234.

3. MA, diary, 15 May 1915, MA papers, d./3212/11.

4. Lloyd George, Memoirs, $i: 135$.

5. Fisher to Jellicoe, 22 May 1915; Fisher to Bonar Law, 22 May 1915, Bonar Law papers, 50/3/31; Fisher to RMcK, 22 May 1915, McKenna papers, 6/8/3.

6. Hankey, diary, 12 May 1915, Hankey papers, 1/1/29.

7. Hobhouse, diary, 17 May 1915, Diary, 243.

8. Fisher to Hankey, 14 May 1915 , Hankey papers, $5 / 2 \mathrm{~b} / 2$.

9. MA, diary, 15 May 1915, MA papers, d.3212/6.

10. Stamfordham to George V, 19 May 1915, in Winston S. Churchill, vol. 3, 1914-16, Companion II: Documents May 1915-December 1916, ed. Martin Gilbert (1972), 873, 911.

11. Lord (Cecil) Fisher to PMcK, 18 September 1943; Fisher to HHA, 17 May 1915, Fisher papers, 1/19/1015.

12. MA, diary, 15 May 1915, MA papers, d.3212/8-9.

13. Fisher to RMcK, 16 May 1915 , McKenna papers, 16/5/15. 
accepts, ${ }^{1}$ despite the fact 'the Home Secretary reported', Stamfordham told the king, 'that Lord Fisher's decision was evidently irrevocable'. ${ }^{2}$ It was desertion, Asquith told Balfour. 'Strictly speaking he ought to be shot'. ${ }^{3}$ On reflection, McKenna acknowledged his mistake in urging Fisher to return to the Admiralty in the first place. ${ }^{4}$ The fact 'that Fisher had stuck to his guns' and resigned, and in so doing helped seal Churchill's fate, would have been only a minor comfort. ${ }^{5}$ That evening, McKenna smuggled Fisher out of London on the last train to Glasgow. Even he had to agree that his friend was 'a bit off his balance.'

\section{MINISTER}

That did not mean that Fisher had been misguided a year earlier when he proclaimed, after 'a long tête-à-tête' with McKenna, that 'his star is rising again!'7 After the traumas of Archerfield, relations between McKenna and Asquith had been restored, and with six months of the war gone, Asquith thought 'Crewe K[itchener] \& McKenna are far the best now', ${ }^{8}$ with the latter in particular being 'invaluable'. ${ }^{9}$ In a private classification of ministers, Asquith had McKenna third, behind Crewe and Grey, and ahead of Lloyd George, Churchill, Harcourt, Simon, Haldane, Runciman, Samuel, and the 'beagles'. ${ }^{10}$ 'McKenna and I had a walk and talk, about persons and particularly about courage (of which, with all his limitations, he is a shining example). I found that we didn't differ much, both marking L. George rather low in this respect, and E Grey too nervy to be put really high. ${ }^{11}$ Margot agreed. 'After Grey Crewe \& Haldane, McKenna is Henry's most loyal \& devoted colleague-haven't you all laughed at me-except Henry \& I'll say more he has got the best of heads. ${ }^{12}$ On the relative contributions of ministers, Asquith said, 'I think McKenna is the most remarkable of the lot in what he

1. RMcK to Fisher, 16 May 1915, in Fear God and Dread Nought, The Correspondence of Admiral of the Fleet Lord Fisher of Kilverstone, vol. 3, Restoration, Abdication, and Last Years, 1914-1920, ed. Arthur Marder (1959), 232.

2. Stamfordham to George V, 19 May 1915, Companion, iii:2, 911.

3. HHA to Balfour, 20 May 1915, Balfour papers, 49692/149.

4. RMcK, Scott diary, 7 February 1916 , Scott papers, 50902/125.

5. MA, diary, 15 May 1915, MA papers, d.3212/9.

6. Hankey, diary, 21 May 1915, Hankey papers, 1/1/34; 'a little mad', Balfour to Selborne, 20 May 1915, Balfour papers, 49708/249-50.

7. Fisher to Hankey, 8 April 1914, Hankey papers, 5/2a/38.

8. MA, diary, 7 March 1915, MA papers, d.3211/201.

9. Ibid., 23 January 1915, MA papers, d.3211/205.

10. HHA to Venetia Stanley, 26 February 1915 , in Letters, 452.

11. HHA to Venetia Stanley, 28 November 1914, in Letters, 321.

12. MA, diary, 7 August 1914, MA papers, d.3210/249; ibid, 15 June 1915, d. $3211 / 206-7$. 
has done'. ${ }^{1}$ Despite their disagreements, Montagu also thought him 'the best of the lot'. ${ }^{2}$ Margot maintained, 'He is a most loyal courageous \& capable person $\&$ with the exception of the muddle over the Welsh Church Poll has done everything well. ${ }^{3}$ Even Lloyd George was impressed. 'I was rather surprised to hear him praise McKenna highly', Margot wrote after seeing him. ${ }^{4}$ 'I always like to hear his opinion \& he has always got one', Lloyd George went on. 'He is often prejudiced \& wrong but he has wonderful courage \& quite excellent brains'.

Lloyd George also had to admit that 'he is extraordinarily unpopular ... I suppose it's his cocky manner.' ${ }^{6}$ The McKenna problem was summed up by Masterman: 'a very capable man with a bad manner'? 7 Margot agreed. 'Tho he is not arrogant he is a little too sharp \& a trifle insolent. ${ }^{8}$ Despite having the 'courage of a lion', for Riddell he was 'a most unfortunate man. He is too cocksure'. ${ }^{9}$ Asquith sent Pamela a newspaper profile of her husband, 'The Unpopular Mr McKenna'. 'I read this with much interest: it is the work of a clever devil-I wonder who? And it contains a good many half-truths, as well as some things which are really true. ${ }^{10}$

There is something mysterious about the word 'McKenna'; for some reason it seems impossible to pronounce it like other words or names; it cannot pass the lips without an added weight of pity, derision, or contempt ... Mr McKenna is, in fact, unpopular, in excelsis, and to say a good word for him is like calling for the police ... McKenna, of course, will never go, because his colleagues, though they no doubt enjoy his unpopularity, could not get by without him ... McKenna has gone through a gigantic bombardment for years without the artillery once having gained an ascendancy over the enemy. At the hottest moment he preserves his composure-not because it is the thing to do, but because he simply doesn't care. He just wraps his frock-coat round his knees, lights another cigar, cocks a bright and unconcerned eye on the world around him, and goes on as if the political weather were 'set fair'. ${ }^{11}$

1. Ibid., 28 October 1914, MA papers, d.3211/22-23.

2. Ibid., 7 August 1914, MA papers, d.3210/249.

3. Ibid., 15 May 1915, MA papers, d.3212/8.

4. Ibid., 23 January 1915, MA papers, d.3211/148; MA, diary, 25 January 1915, MA papers, d.3211/150.

5. Ibid., 23 January 1915, MA papers, d.3211/149.

6. Ibid., 23 January 1915, MA papers, d.3211/149.

7. Masterman to Riddell, 3 May 1915, Riddell papers, 62972.

8. MA, diary, 2.3 January 1915 , MA papers, d. $3211 / 149$.

9. Riddell 12 May 1915, Riddell papers, 62959; Riddell, diary, 7 April 1915, Riddell papers, 62959 .

10. HHA to PMcK, 28 June 1915.

11. Illustrated Sunday Herald, 18 April 1915. 
Nevertheless, extreme measures had been considered. Where the permanent secretaryship of the Treasury had been on offer in 1911, in 1915 it was the viceroyship of India. As in 1911, McKenna had expressed an interest in the post, but 'wd. hate it to be known so don't breathe it to a soul,' Asquith told Margot. ' 'He would do anything well. He would sit on an elephant just as well as any-one else', Asquith went on two months later. 'We want a man of business out there. It is like being the head of 3 huge departments. McKenna wd. do it admirably.' 'Apart from looks and manners', Asquith told Venetia Stanley, 'he would do the job with his characteristic efficiency, \& probably, poor man, not be more unpopular there than he is here. I have a very genuine respect for him'. ${ }^{3}$

'Poor man!' Riddell exclaimed. 'He is always in the wars'. ${ }^{4}$ Arnold Bennett's opinion, that one 'so slayed in the Northcliffian papers must be superexcellently the right soul', was a minority view. 'He possesses an unhappy genius for being misunderstood', the Fortnightly Review wrote. 'When he does well, he rarely gets credit for it; when things go ill he is made the scapegoat not only for his own shortcomings but for the sins of others' ${ }^{6}$ McKenna 'has never been a popular Minister. He has faults of manner which undoubtedly invite attack [but] it is due to him as much as to any living man that this country does not now stand in a position of supreme danger', the Pall Mall Gazette admitted in an article entitled 'Fair Play': 'This man saved the Navy, and the country owes him a debt of gratitude that cannot easily be measured. ${ }^{7}$ Loulou read it. 'It is not as much as you deserve, but it is something. You have been abominably treated.8

Margot's thought that McKenna 'is a man of affairs but not a man of the world', 9 was illustrated by the home secretary's use of the press. The Daily Express was a frequent baiter. 'I think the charges of ignorance and apathy directly against me by you and another newspaper', McKenna sarcastically told Blumenfeld, editor of the Daily Express, in September, 'have materially contributed to the success of the operations by lulling the enemy in our midst into a false sense of security'..$^{10}$ The sarcasm was lost on William Le Queux, who proclaimed that McKenna was engaged in misleading the public 'to hide the true state of affairs ... and to lull them into a false sense

1. MA, diary, 23 January 1915, MA papers, d.3211/205.

2. MA, diary, 7 March 1915, MA papers, d.3211/201; Churchill to Clementine, 2 November 1909, in Companion, 2:2, 917.

3. HHA to Venetia Stanley, 7 March 1915, in Letters, 464.

4. Riddell, diary, 20 March 1915, Riddell papers, 62959.

5. Arnold Bennett to PMcK, 7 April 1915.

6. Fortnightly Review, January 1915, 25.

7. Pall Mall Gazette, 25 November 1914; Fisher to Annie Goulding, 24 November 1911, Wargrave papers, $2 / 43$.

8. Lewis Harcourt to RMcK, 25 November 1914.

9. MA, diary, 15 May 1915, MA papers, d.3212/8.

10. RMcK to R. D. Blumenfeld, 29 September 1914, Blumenfeld papers, McK 1. 
of security'. ${ }^{1}$ Such misrepresentations were thought not to matter. The Illustrated Sunday Herald drew the conclusion that he

does not care a curse (if the phrase is permitted) for the public, runs the Home Office as he did the Admiralty, exactly as though it were situated near the Mansion House and had nothing to do with Parliament at all, works very hard, does not golf in public, and is quite terribly efficient at his job. ${ }^{2}$

'Poor McKenna,' thought the prime minister, 'who gets lots of kicks \& rarely a halfpenny worth of praise.' 'I don't think you like McKenna and some people loathe him but he is one of the very best fellows in the world and the ablest', Margot attempted to convince Balfour.

If only I could give him a new appearance, clear off that cockiness of manner I would show you a man without vanity of any kind-a forgiving, unrancorous, resolute fire-fighting man. He would have made a wonderful soldier. Of course, he is one of those of whom one can say if you think it worth saying; he is not quite a gentleman ... 4

Three years had etched their effect. 'He has aged during the past month', Riddell thought in January. 'He has been bitterly attacked and has not managed well. Just now he is the most unpopular man in the country'; 'more unpopular in and out of the $\mathrm{H}$, of C. than all the rest of the Gov', Hobhouse agreed. ${ }^{6}$ If Margot was right that McKenna was 'dumb when he is praised \& clamorous when he is abused'? As Bonar Law told Lloyd George, 'We all dislike him more than anyone in the Cabinet."

1. William Le Queux, in Andrew, Secret Service, 179; William Ie Queux, Things I Know about Kings, Celebrities, and Crooks (1923), 256.

2. Illustrated Sunday Herald, 18 April 1915 [encl. in H. H. Asquith to Pamela McKenna, 28 June 1915].

3. HHA to Venetia Stanley, 26 January 1915, Letters to Venetia Stanley, 398.

4. MA to Balfour, 16 April 1915, Balfour papers, 49794/146.

5. Riddell, diary, 30 January 1915, Riddell papers, 62959.

6. Hobhouse, Diary, 2.3 March 1915, 230.

7. MA, diary, 15 June 1915, MA papers, d.3211/207.

8. Bonar Law to Lloyd George, 20 November 1914, Riddell papers, 62974; Leo Amery to Bonar Law, 3 April 1914, Bonar Law papers, 32/2/10; James Campbell to Bonar Law, 3 April 1914, Bonar Law papers, 32/2/11. 


\section{COALITION}

The pre-war unity of the Cabinet had been illusory. Privately, McKenna thought Lloyd George and Masterman should have resigned over Marconi, and had told Asquith as much. ${ }^{1}$ The episode did nothing to alter McKenna's view both of Asquith's indecisiveness and Lloyd George's dishonesty, and his frustration that the latter continually benefited from it. Where McKenna once observed, half-admiringly, Asquith's ability to be won over by an argument and then attack the position he had previously adopted, ${ }^{2}$ the war gave McKenna cause to despair. 'The Prime Minister, is really too easy'. ${ }^{3}$ Fisher's resignation, the alien hysteria, and a Northcliffe-driven scandal of alleged shell shortages in the army, portrayed a government that was not in control of events. There were already concerns about manpower. Kitchener asked McKenna whether the police might "unearth any fitters, millwrights, machine hands, and skilled or unskilled labour that we could use to increase the output of munitions?'4 A reconstruction of the ministry was as desirable politically as it was necessary constitutionally, another consequence of the 1911 Parliament Act. Avoiding an election was both in the broader national, as well as in the narrowly political, interest, and could only be done by the creation of a national government, as had been predicted in 1910. As in 1910, McKenna's omission was expected to be a condition of the enterprise. He had already felt Masterman had been sacrificed, and thought his letter of resignation from the Cabinet 'extraordinarily generous'.

Coalition would have the advantage of silencing by implication the leading critics of the conduct of the war, and for Lloyd George was another opportunity to get rid of McKenna. ${ }^{6}$ Asquith made soundings as to the participation of Unionists in government. As the price of their participation, they wanted offices, and the replacing of Liberals. Bonar Law said Asquith could not retain both McKenna and Haldane, while Fitzroy expressed a common view when he expected both to be sacrificed. ${ }^{7}$ Walter Long told McKenna, 'Our sole desire is to be of service in this great crisis and to see

1. RMcK, 178 .

2. Riddell, diary, 19 January 1913, Riddell papers, 62972.

3. RMcK, 13 October 1913, Riddell, diary, Riddell papers, 62973.

4. Kitchener to RMcK, 31 March 1915.

5. RMcK, 3 February 1915, in Masterman, Masterman, 271.

6. Riddell, diary, 19 May 1915, Riddell papers, 62959; MA, diary, 23 January 1915, MA papers, d.3211/148; Riddell, diary, 29 March 1915, Riddell papers, 62959.

7. Fitzroy, 18 May 1915, Memoirs, ii:593. 'M.J.L.', Birmingham Gazette, 7 September 1943, Yorkshire Observer, 7 September 1943; Robert Rhodes James, ed., Memoirs of a Conservative: J. C. C. Davidson's Memoirs and Papers, 1910-37 (1969), 24-25. Long did not want either: Long to Bonar Law, 20 May 1915, Bonar Law papers, 117/1/12. Haldane said he would have resigned anyway, Haldane to Rosebery, 9 June 1915, Rosebery papers, 10030/167. 
our enemies defeated whether they are at home or abroad.' ${ }^{11}$ Long then told Law that 'if McKenna remains in the Government the great majority of our men will bitterly resent it and will be scandalised if any of our leaders consent to serve with him'. ${ }^{2}$ McKenna claimed he had offered to resign, and serve without salary, in any capacity. 'You see, I don't want the money'. ${ }^{3}$

'McKenna will be retained,' Stamfordham told the king. ${ }^{4}$ Indeed, as Riddell put it, "he has become one of the 4 chief actors in the Cabinet drama." The construction of the coalition was as confusing as it was surprising for most observers. 'McKenna, whom every man in the street would like to expel', Cynthia wrote, 'is the one fixture about whom there has been no doubt', which was not quite accurate. 'I see you are everywhere named as First Lord', Arnold Bennett told McKenna; ${ }^{8}$ while Crewe actually thought 'McKenna no doubt clings to his post, from the honourable wish to settle the aliens etc'. ${ }^{9}$ McKenna himself made a note, which largely reflected the actual positions in the reconstituted ministry-except that he remained at the Home Office, and Lloyd George at the Treasury. ${ }^{10}$ 'Mr McKenna', The Times reported on $25 \mathrm{May}$, 'in whom $\mathrm{Mr}$ Asquith reposes great trust, will remain Home Secretary'. ${ }^{11}$ Later that day, in a meeting with Basil Thomson, McKenna was called to Downing Street, expecting to be told to continue as home secretary. On his return, he announced to Thomson: 'You are the first person that I tell the news to. I have got to leave you and go to the Treasury.'12

1. Long to RMcK, 30 November 1914.

2. Long to Bonar Law, 21 May 1915, Bonar Law papers, 117/1/13; Long to Bonar Law, 20 May 1915, Bonar Law papers, 117/1/12; Long to Bonar Law, 23 May 1915, Bonar Law papers, 50/3/39; Rufus Isaacs, diary, 21 May 1915, Reading papers, F118/153.

3. RMcK to Basil Thomson, 27 May 1915, journal, Thomson, Scene, 244.

4. Stamfordham, 19 May 1915, memorandum, RA PS/GV/K 770/3; Riddell, diary, 19 May 1915, Riddell papers, 62959.

5. Riddell, diary, 22 May 1915 , Riddell papers, 62959.

6. Runciman to RMcK, 19 May 1915, McKenna papers, 5/8/1; Runciman to RMcK, 19 May 1915, McKenna papers, 5/8/2; Rufus Isaacs, diary, 8, 15, 18 May 1915, Reading papers, F118/153; Long to Bonar Law, 19 May 1915, Bonar Law papers, 62404/84-85; MacCallum Scott, diary, 24 May 1915, MacCallum Scott papers, 1465/6; Arnold Bennett, diary, 21 May 1915, in The Journals of Amold Bennett, vol. 2, 1911-1921, ed. Newman Flower (1932), 132.

7. Cynthia Asquith, 21 May 1915, Diaries, 25.

8. Arnold Bennett to RMcK, 21 May 1915.

9. Crewe to Lloyd George, 24 May 1915, Crewe papers, C/38.

10. RMcK, note, n.d. c. May 1915.

11. Times, 25 May 1915.

12. RMcK to Basil Thomson, 27 [sic] May 1915, journal, Thomson, Scene, $243-44$. 


\section{Reginald McKenna}

That McKenna was merely a locum tenens became the most important element in the orthodoxy regarding his subsequent chancellorship. ${ }^{1}$ It was Crewe who happened upon the idea of Lloyd George galvanising munitions production by establishing a new department expressly for that purpose before returning to the Treasury. Lloyd George said Law refused to accept the move on the grounds that he himself should have the office, ${ }^{2}$ though the Unionist leader changed his mind on the same day that 'McKenna should only hold the place temporarily - I would agree only on that condition', said Lloyd George. '[McKenna] is to come here temporarily. I am to return as soon as I place the other business on a sound footing. ${ }^{3} \mathrm{H}$. A. Gwynne, one of McKenna's most vociferous critics, conceded, 'I do not think he can do much harm at the Treasury, especially as he appears to be somewhat in the nature of a warming pan'. ${ }^{4}$

There were, in fact, several reasons for Asquith omitting McKenna from the government, no reasons for Asquith to appoint him temporarily as chancellor, and several reasons for McKenna to take over tout court. Forming a new administration and actually promoting his most unpopular minister served two functions for the prime minister: it helped to demonstrate that, while he may have been forced into coalition, he was manning it on his terms; and that, in the face of growing calls for conscription and tariffs, he was publicly restating key tenets of Liberal doctrine-voluntarism and free trade. So it was that Liberals retained the main offices of state, while Bonar Law was embarrassed, personally by accepting the Colonial Office, and politically for presiding over the discombobulation of the Unionist leadership. 'If you leave out Balfour, who does not belong to the party', McKenna told Thomson, "the Unionists have secured only two of the big offices.' As Asquith explained to Pamela, 'I prefer a Cad with Liberal ideas to a gentleman with none'. 6

In 1905, McKenna had been appointed financial secretary to the Treasury; in 1907, he regretted his promotion to the Cabinet since it meant leaving the Treasury; in 1908, the chancellor of the Exchequer became prime minister and wanted McKenna as his replacement, a promotion widely expected;

1. Crewe to Lloyd George, Lloyd George papers, C/4/1/22; Riddell, 26 May 1915, Diary, 96; A. J. Sylvester, 28 November 1931, in Life with Lloyd George: The Diary of A. J. Sylvester, 1931-45, ed. Colin Cross (1975), 59; G. C. Peden, The Treasury and British Public Policy, 1906-1959 (Oxford, 2000), 76; Horn, Britain, 100; Roy Douglas, The History of the Liberal Party, 1895-1970 (1971), 99.

2. Stamfordham to George V, 25 May 1915, Companion, iii: 2, 944; Austen Chamberlain, Down the Years [1935], 321.

3. Lloyd George to Margaret Lloyd George, 25 May 1925, in Lloyd George Family Letters, 1885-1936, ed. Kenneth O. Morgan (1973), 178.

4. H. A. Gwynne to Countess Bathurst, 26 May 1915, in The Rasp of War: The Letters of H. A. Gwynne to the Countess Bathurst 1914-18, ed. Keith Wilson (1988), 100 .

5. RMcK to Basil Thomson, 27 May 1915, journal, Thomson, Scene, 244.

6. HHA to PMcK, 28 May 1915. 
in 1911, some were convinced McKenna was to be appointed Chancellor then; ${ }^{1}$ in 1915 , McKenna finally became chancellor of the Exchequer. Yet the appointment was characterised at the time and subsequently as both unexpected and unwarranted. Yet, in placing Lloyd George at a new ministry and McKenna at the Treasury, Asquith was recognising the preeminent talents of each. If a cipher were required as chancellor, there were better candidates, Liberals with more experience of financial affairs than Lloyd George had in 1908, and with none of the infamy that McKenna had in 1915. Press and parliamentary opinion would have been appeased, and Lloyd George provided with an effortless means of return in the event of his desiring one, rather than the bitterness that would follow his returning and removing McKenna. Churchill and Haldane, whom McKenna claimed by that point 'was a wreck', ${ }^{2}$ had been sacrificed, and neither were as unpopular in the country, and both were more popular in the party, than McKenna, over whom both had prevailed on matters of substance in the recent past.

Two other pieces of evidence were adduced for the view that McKenna's was a makeshift appointment: Lloyd George's retention of 11 Downing Street, ${ }^{3}$ and Pamela's apparently shocked letter of gratitude to the prime minister. ${ }^{4}$ McKenna did not move into the chancellor's official residence because he had just built a large townhouse for his new family, at great expense, and had a division bell installed in the library, allowing him time to reach the lobbies for a vote in the Commons. 'I have the advantage of living within a short radius of all the public offices so that no great expenditure of time is needed.' 36 Smith Square was as near to the Commons as the Commons was to 11 Downing Street. Asquith had also declined to move into No. 11 when he became chancellor, preferring instead to live in his house in Cavendish Square, which was farther away than that of McKenna. ${ }^{6}$

Pamela's letter was considered by historians in isolation: there was only one in the Asquith papers, which were generally available, and it was not known that there had been a longstanding correspondence between them, or that the tone of the letter was the natural tone of the writer (who was still only twenty-five) rather than one stimulated by circumstance.

When I left the Exchequer for less congenial and in some ways more trying duties, I registered on the tablets of my mind the conviction and determination that he would make the best Chancellor of our time ... Nothing in all this upheaval, with its poignant separations, has given me

1. Fisher to Jellicoe, 9 May 1911, Jellicoe papers, 49006/11.

2. Webb, diary, 14 June [1915], Webb, Diary, 233.

3. Riddell, diary, 26 May 1915, Diary, 96.

4. PMcK to HHA, 26 May 1915, Asquith papers, 27/220: 'amazed gratitude', Jenkins, Asquith, 369; 'effusive', Hazlehurst, Politicians, 298, n. 2.

5. RMcK to J. C. Smuts, 16 May 1917, Smuts papers, $17 / 86$.

6. Horne, ed., Telling Lives, 166. 
so much consolation and happiness as that he should now be where I have always thought he ought to be. ${ }^{1}$

'The papers describe your glory as temporary', Garvin told him. 'I think of the proverb about "the permanency of the provisional".'2

'So', as Lloyd George later put it, 'Lord Haldane was driven in disgrace into the wilderness and Mr M'Kenna was promoted to the second place in the Government.' 'I wasn't so surprised as some', Garvin also told McKenna, 'for I know how near you came to the Chancellorship in 1908'. ${ }^{4}$ Riddell claimed to have predicted the move, ${ }^{5}$ while McKenna's former free trade confrère Harold Cox was relieved McKenna was 'at last ... where you ought to have been years ago, in place of other people.' 'Many of us thought you ought to have gone there when the P.M. left it,' thought the Liberal backbencher George Hay Morgan, 'but better now than not at all." For Archibald Hurd, 'The pity is that you were not at the Treasury five years ago. ${ }^{8}$ Alexander Harvey, the Liberal backbencher, told him, 'I have always thought that the Exchequer was your place and I have regretted that you did not get it long ago'. 'It's a queer company he's in!' Masterman told Pamela. 'He has triumphed over all his enemies, and is now in so large a place and one so suited to his ability. ${ }^{10}$ For the chairman of the Welsh Church Commission, Sir Henry Primrose, 'you at last come into your own. ${ }^{11}$ 'I am glad your ambition is realised', Bennett told Pamela. ${ }^{12}$ Even some of the implacables were placated. 'The right men have gone to the right places', Milner told Leo Amery, 'for McKenna, who is no good for anything else on earth, really has financial ability'. ${ }^{13}$ Riddell concluded the tale. 'An interesting metamorphosis which shows that if a man is courageous and prepared to eat enough dirt and submit to enough insults he may triumph in the end. ${ }^{14}$ Theo congratulated his brother. 'You as usual get a job at its most difficult moment.'15

1. HHA to PMcK, 25 May 1915.

2. J. L. Garvin to RMcK, 26 May 1915.

3. Lloyd George, Memoirs, 1:138.

4. Garvin to RMcK, 26 May 1915; Harold McKenna to RMcK, 26 May 1915.

5. George Riddell to RMcK, 26 May 1915.

6. Harold Cox to RMcK, 26 May 1915.

7. George Hay Morgan to RMcK, 26 May 1915.

8. Archibald Hurd to RMcK, 25 May 1915.

9. Alexander Harvey to RMcK, 27 May 1911.

10. Masterman to PMcK, 22 May 1915.

11. Sir Henry Primrose to RMcK, 26 May 1915.

12. Arnold Bennett to PMcK, 29 May 1915.

13. Milner to Amery, 23 June 1915, in Amery, Diaries, 1:118.

14. Riddell, diary, 22 May 1915 , Riddell papers, 62959.

15. Theodore McKenna to RMcK, 26 May 1915. 


\section{Chancellor of the Exchequer, May 1915 to December 1916}

Happy is the Department which has no history.

-McKenna, $1916^{1}$

\section{AGENDA}

It was not a good time to go back to the Treasury. The office that had been the engine of the Liberal government was now regarded as an ancillary weapon in the war, a war fought by a coalition. Throughout his time as chancellor, McKenna tried to impress upon protagonists the practical considerations of the economy, both in winning the war and succeeding in the peace. McKenna had arrived to find 'hopeless financial disorder at the Exchequer, so great indeed that Westminster could not have carried on for another three months, if no change had taken place. ${ }^{2}$ Having handled the initial financial crisis of August 1914 with aplomb, Lloyd George thereafter acted as if his job were done, with the war a matter for other departments, whose greater efforts he exhorted while his own department drifted; ${ }^{3}$ his war budget of 1914 was nothing like as belligerent as that of 1909 had been. The chancellor had given up on finance as a factor in the war and

1. RMcK to Walter Runciman, 4 June 1916, Runciman papers, 149/1.

2. RMcK, 17 June 1915, in Inside Asquith's Cabinet: From the Diaries of Charles Hobhouse, ed. Edward David (1977), 247; Edwin Montagu to Venetia Stanley, 11 June 1915, in Politics, Religion and Love: The Story of H. H. Asquith, Venetia Stanley and Edwin Montagu, by Naomi Levine (New York, 1991), 330; R. H. Brand to Sir John Simon, 2 June 1915, Simon papers, 51/38.

3. Lloyd George, 1 March 1921, in An Ambassador of Peace: Pages from My Diary, by Viscount D'Abernon, 3 vols. (1929-30), i:128; Lloyd George, War Memoirs, 61-74; Hartley Withers, War and Lombard Street (1915), 108-12; J. M. Keynes, 'War and the Financial System, August 1914', Economic Journal 24 (1914): 460-86; Bank of England, iii:101-69, Bank of England papers, ADM2/3; Lloyd George, Parliamentary Debates, 4 May 1915, 1000; Sir John Bradbury to HHA, 20 May 1915, Asquith papers, 14. 


\section{Reginald McKenna}

presided over the near collapse of morale amongst his officials. ${ }^{1}$ Sir Robert Chalmers, who had succeeded Sir George Murray as permanent secretary in 1911, when McKenna might have done so, had fled to Ceylon as governor two years later-ostensibly on the grounds of Lloyd George misleading the Commons-while his joint successor, Sir John Bradbury, would have resigned if Lloyd George had not been replaced as chancellor. ${ }^{2}$

'McKenna has come out best', Margot Asquith concluded of the reconstruction. 'He has shown more character \& real courage'. ${ }^{3}$ The appointment also benefited her husband, in demonstrating his authority. ${ }^{4}$ Yet some Liberals outside were as incensed by coalition politics in 1915 as McKenna had been by the thought of it in 1910. Asquith was regarded as having betrayed his party by creating a coalition, and McKenna's own brother-in-law admitted, 'I am sorry to see Reggie or Loulou in it'. 'The Coalition is a hateful thing. We loathe it and I don't believe it will solve any of the difficulties', Pamela told Fisher. ' $\mathrm{R}$ is in bad spirits but sends his fondest love.' ${ }^{6}$ Asquith complained to Pamela about 'rubbing shoulders with uncongenial unfamiliar personalities. But (as "Candide" says) "il faut cultiver notre jardin"." Stanley Buckmaster, who had done well out of the change as the new lord chancellor, told Pamela, 'I shall feel more pity even than I ever felt before for caged creatures. ${ }^{8}$

McKenna's move had the customary effect on the civil servants he had left, and on those he had joined. 'He was considerate of the time, trouble, work, and feelings of others', Richard Redmayne recalled. 'We all loved him at the Home Office'. ${ }^{9}$ The years working with McKenna at the Home Office 'were for me the happiest of my life', J. Huws Davies told him. ${ }^{10}$ 'I feel very sad about it', Sidney Harris admitted. 'I can say without hesitation that the last three and a half years have been the happiest of my official life. I am only sorry that they have come so suddenly to an end."

1. Frederick Leith Ross, Money Talks: Fifty Years of International Finance (1968), 40; Keynes to Montagu, 4 September 1914, Montagu papers, AS6/9/2(1); Thomas McKinnon Wood to Aunt Ann, 26 October 1911, McKinnon Wood papers, c 499/223; Sir Robert Chalmers, Riddell diary, 21 June 1913, Riddell papers, 62972; Keynes to Montagu, 4 September 1914, Montagu papers, AS6/9, 21; Lloyd George to Montagu, 24 June 1915, Montagu papers, AS4/3/2.

2. Chalmers, 21 June 1913, Riddell, diary, Riddell papers, 62972; Chalmers to PMcK, 8 March 1915.

3. MA, diary, 5 June 1915, MA papers, d.3211/207.

4. Manchester Guardian, 26 May 1915.

5. Francis McLaren to Barbara, 28 May 1915, McLaren papers; Burns, diary, 28 May 1915, Burns papers, 46337.

6. PMcK to Fisher, 7 June 1915.

7. HHA to PMcK, 17 June 1915.

8. Stanley Buckmaster to PMcK, 29 May 1915.

9. Richard Redmayne, Men, Mines and Memories (1942), 289.

10. J. Huws Davies to RMcK, 29 May 1915.

11. S. W. Harris to PMcK, 25 May 1915; Mary Harris to PMcK, 26 May 1915. 
even confessed, 'I wish I were in the civil service, then I could wish nothing better than to serve under you." It followed that McKenna received 'a most cordial welcome-how cordial it is you will know without my telling you,' from Bradbury. 'If ministers were elected by a plebiscite of the[ir] officials ... the results would often be curious, and as a rule unsatisfactory. In the present case, however, it would have been merely an alternative method of producing the same effect'. ${ }^{3}$

The mutual admiration was immediately suspected by their new colleagues. 'The authorities with which we are confronted', the new agriculture secretary, Selborne, capturing the collegial spirit of coalition, told his fellow Unionist and new colonial secretary Andrew Bonar Law, 'are McKenna, Sir John Bradbury, and Professor Keynes'. ${ }^{4}$ The three came close to forming a coherent whole. Bradbury, an old friend, and Keynes, a new one, worked closely together and shared a view of the war, with varying degrees of pessimism. There were suspicions at the time and subsequently that McKenna served merely as a spokesman for his officials, just as there had been when he was at the Admiralty. ${ }^{5}$ Such suspicions failed to appreciate the extent to which the minister happened to agree with his advisers, as was emphatically the case at the Treasury. McKenna, Bradbury, and Keynes were supported by the joint permanent secretary Sir Thomas Heath, and by Ralph Hawtrey, Basil Blackett, Frederick Leith Ross, and Otto Niemeyer, with Horace Hamilton and Alan Parsons as his private secretaries. It was a self-contained and confident hierarchy, which managed to sustain a coherent and exclusive departmental ethic. 'I rejoice for your sake', Chalmers told him from Nuwara Eliya. 'I rejoice still more for the sake of the Treasury, who will hail your coming with an ecstasy.' "It is so glorious to see how happy the civil servants are', Montagu told Venetia. 'They at last believe they can trust this Chancellor not to give them away and to do business instead of avoiding it." ${ }^{7}$

McKenna's ministerial team was less agreeable to him. As financial secretary, he had Montagu, to Montagu's irritation, ${ }^{8}$ and less officially, Rufus Isaacs, 'on Asquith's request. He had no special understanding of the financial

1. Archibald Hurd to RMcK, 8 June 1915.

2. Bradbury to RMcK, 26 May 1915.

3. Ibid.

4. Selborne to Bonar Law, 22 October 1915, Selborne papers, 81/202.

5. Keith Neilson, Strategy and Supply, 36, n. 20 contends that it was, Martin Horn, Britain, France, and the Financing of the First World War (Montreal, 2002), 207 n. 43 that it was not.

6. Chalmers to RMcK, 27 May 1915. 'As for Winston (of the Duchy) I remind you (and myself) of Psalm cix, verse 28, [Let them curse, but bless thou: when they arise, let them be ashamed: but let thy servant rejoice.] and do lxviii, 23 [That thy foot may be dipped in the blood of thine enemies, and the tongue of thy dogs in the same.].'

7. Montagu to Venetia Stanley, 28 May 1915, in I.evine, Politics, 328.

8. Ibid., 26 May 1915, in Levine, Politics, 327. 


\section{Reginald McKenna}

problems I had to confront. ${ }^{1}$ Where Lloyd George had been content not to interfere with his ministers, McKenna from the outset was more interventionist, and in any case marginalised both his political subordinates in favour of Bradbury and Keynes. ${ }^{2}$ More problematically, and again in contrast to his predecessor, McKenna both intervened in the business of, and subordinated, the governor of the Bank of England, Walter Cunliffe. Cunliffe shared many of Beresford's traits and had a similar relationship with McKenna, largely through seeking to resist the encroachment of government into his hitherto independent institution, having been free from such interference when Lloyd George had been chancellor. ${ }^{3}$ The McKenna regime transformed relations between the Bank and the Treasury. ${ }^{4}$ The increasing number of committees that determined the conduct of the war reflected a lack of collegial working in the coalition, and reinforced McKenna's view that the prime minister behaved as little more than an observer in the disputes. ${ }^{5}$ Such committees were nevertheless an advantage to McKenna, skilled as he was in interrogation, but they reinforced the suspicions of former opponents-now colleagues-who despaired of politicians they regarded as 'jellies', 'pacifists', and who, in McKenna, took an absurdly pessimistic view of the length the war was likely to take. ${ }^{6}$ It was for such reasons that McKenna privately admitted his 'anxiety'.

\section{THE CHALLENGE}

It is common knowledge among those who understand finance, from Mr McKenna downwards, that, from the point of view of winning the war, we run more risk of having too many soldiers than too few. Victory in the long run depends on staying power ... our greatest danger is financial exhaustion. ${ }^{8}$

It did not follow that since Bertrand Russell could understand McKenna's position it was an inherently complicated one. 'The War must be paid for,' he

1. RMcK to Beaverbrook, 24 March 1927, Beaverbrook papers, C234; cf. Rufus Isaacs to RMcK, 27 May 1915.

2. Alexandre Ribot, Letters to a Friend; Recollections of My Political Life [1926], 35; Montagu to HHA, 2 May 1916, Montagu papers, AS1/1/2/26.

3. RMcK to Beaverbrook, 24 March 1927, Beaverbrook papers, C234; Riddell, diary, 31 July 1914, Riddell papers, 62974.

4. Keynes to Montagu, 4 September 1914, Montagu papers, AS6/9/21/(2-4)/ 2072/(2-4); Niemeyer, in The Bank of England: Money, Power, and Influence, 16941994, by Richard Roberts and David Kynaston (Oxford, 1995), 25.

5. RMcK to Beaverbrook, 24 March 1927, Beaverbrook papers, C234.

6. Bernard Mallet to St. Loe Strachey, 8 November 1914, STR 10/5/41.

7. RMcK to Archibald Hurd, 29 May 1915, Hurd papers, 1/35.

8. Bertrand Russell, January 1916, in The Collected Papers of Bertrand Russell, ed. Richard Rempel (1988), xiii:320. 
told Sylvia Pankhurst, who had gone to see him at the Treasury to demand that he reject conscription, press for compulsion, reduce taxation, improve working conditions, and provide equal pay and votes for women. 'Its cost has been greatly underestimated'. ${ }^{1}$ If it could not be paid for, as Heath later pointed out, the Treasury 'stands between the country and national bankruptcy'. ${ }^{2}$ For all the resilience of the British economy, wartime expenditure inevitably outstripped income, and so borrowing was essential. Borrowing could be moderated by raising taxation and by the sale of overseas assets. However, all the means of raising revenue had disadvantages. Borrowing could be inflationary and might saddle the post-war economy with unmanageable burdens. Raising taxation might discourage enterprise and be politically unpopular. The sale of overseas assets would imperil Britain's international investments and markets. The diversion of manpower into uniform would undermine Britain's productive capacity and make imports more expensive, which would increase the trade imbalance and add pressure to the exchange. McKenna's immediate challenge was therefore 'to solve the problem of raising immediate revenue without impairing the resources on which we have to rely for future loans'. ${ }^{3}$

The bigger issue was the balance between finance and strategy. The broadly Unionist view was that no aspect of the economy was more important than military victory; the broadly Liberal view was that Britain ought to manage the war effort whilst mitigating the worst necessities of paying for it. The state of the economy did not matter if the war was lost, the former claimed; losing the war was more likely by bankruptcy, the latter maintained. According to the former, Britain's position in the world was more likely to be maintained with victory. According to the latter, victory when the pound had been replaced by the dollar was of little value. It was a fundamental division of outlook, and it became a clash: whether finance had to be a servant of strategy or was an objective of strategy. The issues became personalised by, respectively, Lloyd George as the minister of Munitions, and McKenna as the chancellor of the Exchequer.

To make matters more complicated still, Britain was not only governed by a domestic coalition, but also fought as a member of an international one. The old navalist conception was that Britain would remain predominantly a naval power, blockading the enemy and maintaining trade, while serving as the arsenal for the French and the Russians, who occupied themselves with killing Germans. It was soon clear that neither Paris nor Petrograd would consent to such a demarcation, demanding a significant British land presence, and that the British had therefore to find an equilibrium. McKenna, consequently, sought to rationalise the finances not merely of Britain, but

1. RMcK, 15 August 1915, in The Home Front: A Mirror to Life in England During the World War, by E. Sylvia Pankhurst (1932), 217.

2. Sir Thomas Heath, The Treasury (1927), 1.

3. RMcK, budget notes, n.d. [August 1915], McKenna papers, 5/3/7. 
also of the Entente. Economic relations with France and Russia became a recurring and worsening problem for him, and, because of that, for the service ministers as well. ${ }^{1}$

One international economic issue was the amount Britain would lend to the allies and the extent of supervision over disbursements. Allied purchases in Britain had been controlled from the outset, but British productive capacity soon reached its limit, not least because of the number of workers who had volunteered to enlist in the army. Purchasing had to be conducted in the United States-a neutral power, and one bent upon capitalising on a European war. Relations with the French and the Russians worsened consistently, as they then did with the Americans. Rather than evolve from arsenal to participant, Britain attempted to be both. ${ }^{2}$ In this, McKenna's concerns were consistent with those that culminated in his move from the Admiralty: the desire to limit British involvement in a European land war.

Relations with the United States were, in Hawtrey's words, 'the dominant consideration in British war finance'. ${ }^{3}$ The United Kingdom had increasingly to import supplies, and dollars were required not only for purchases of essential war materials, but also to maintain the rate of the pound on the exchange to keep prices stable. With a growing balance of payments deficit, the requirement became increasingly untenable. Sterling fell from a rate of $\$ 7.00$ to the pound in 1914, to $\$ 4.79$ in February 1915. In January 1915, the War Office contracted J. P. Morgan \& Co as sole purchasing agent in the United States for the War Office and the Admiralty. It dealt with the payment of American firms supplying Britain, and the buying and selling of exchange. Maintaining the rate of the pound was important for both purchases and prestige. It became harder because Lloyd George, in his desire to expedite matters, had waived Treasury scrutiny of War Office purchases, which ensured inflated prices and profiteering. It was made harder still by Entente purchases being conducted separately from British ones, thereby costing more. ${ }^{4}$

By May 1915, long-term damage to the economy had already been done. This did not mean the war could not be fought; indeed, the absence of forethought was due to the common expectation of a short war. The economy was a cause of concern to only a few politicians, civil servants, and philosophers, if fiscal oversights were the price to pay for winning the war and serving the national interest. It was one reason that, as F. W. Hirst put it, 'as guardian of public finance, Mr McKenna can only plead impotence'. 5

1. Treasury papers, $\mathrm{T} 171 / 110 / 14$.

2. Stamfordham, 4 January 1916, memorandum, RA PS/GV/K 869/4.

3. R. G. Hawtrey, Currency and Credit (1928), 396.

4. Kathleen Burk, Britain, America, and the Sinews of War, 1914-1918 (1985), 15; W. G. Lyddon, British War Missions to the United States, 1914-1918 (1938), 115-16; K. England, British War Missions to the United States of America (Washington, D. C., 1919), 8.

5. Francis Hirst, The Political Economy of War (1916), 326. 


\section{FIRST EXCHANGE CRISIS}

With Britain's daily revenue in May 1915 at $£ 730,000$ and expenditure at $£, 3,000,000$, Hirst had a point. McKenna decided on an immediate domestic war loan, the second. ${ }^{1}$ The objectives of the loan were deflation and propaganda, or, at least, absorbing some of the spending power of individuals at the same time as demonstrating popular support for the war effort. An initially secondary interest, which became primary, was transatlantic. A successful loan would help calm growing United States alarm at the trade imbalance, but would have to be at a high rate of interest in order to tempt American investors; a recognition both of past inadequacies and future circumstances. ${ }^{2}$ McKenna announced it on 21 June. $^{3}$ Provision was made for the conversion of past issues and for the conversion of any future long-term loans. The convertibility of existing loans became and remained a source of contention within the Treasury and rancour outside it, with bankers in particular attracting scorn. ${ }^{4}$

In the loan's targeting of the lower classes, the correspondent of the American Nation suggested that 'Mr McKenna may be able to assert that he has democratized the finances of the state'. 'McKenna's statement was very good both in substance and form', Asquith told Sylvia Henley, 'and the House generally was so pleased with the generosity of the terms offered ... that we have every prospect of an early rising'. ' $N$ Nothing could have been better', he went on to Pamela, 'for it deserved to the full what I think are the 3 most laudatory epithets (all 'c's): conciseness, cleverness, cogency.7 'I thought your speech admirable in its form, and masterly in its grasp of your

1. RMcK to Northcliffe, 22 June 1915, Northcliffe papers, 621.57/189.

2. Bradbury to Rufus Isaacs, 7 June 1915, Reading papers, F118/112A; Keynes, memorandum, 14 May 1915, Treasury papers, T170/72; Cecil Spring-Rice to Grey, 10 June 1915, Foreign Office papers, FO371/2589/81800; Hartley Withers to Keynes, 8 July 1915, Keynes papers, T/12/18; Leopold de Rothschild to Rufus Isaacs, 9 July 1915, Reading papers, F118/76/30.

3. RMcK, notes, McKenna papers, 5/3/41-42. Bonds were available at $£ 5$ and $£ 25$, with five shilling vouchers obtainable at post offices. Interest was at $4.5 \%$, issued at par, and the units were repayable in 1945. RMcK, Parliamentary Debates, 12 June $1915,949-1004$.

4. Treasury papers: Panmoure Gordon to Bradbury, 29 June 1915, T170/78; Booth to Bradbury, 30 June 1915, T170/78; Walter Leaf to RMcK, 14 June 1915, T170/58; Montagu to RMcK, 30 June 1915, T170/78.

5. Nation [US], 15 July 1915.

6. HHA to Sylvia Henley, 21 June 1915, Asquith papers, 542/1/147; Sandhurst, diary, 21 June 1915, in Viscount Sandhurst, From Day to Day, 2 vols. (1928-29), 1:247; Walter Cunliffe to Keynes, 26 June 1915, Keynes papers, T/12/75; Montagu Norman, diary, 9 July 1915, Norman papers, (323/89; Northcliffe to RMcK, 6 June 1915, Northcliffe papers, 62157/194.

7. HHA to PMcK, 21 June 1915. 
difficult problem', Haldane told him. 'Your solution is full of ingenuity, and its reception has been admirable. ${ }^{1}$

Another ' $c$ ' was confidence. Confidence was the intangible but essential factor in war finance. The loan had to be seen to be a success. McKenna had planned for $£ 1000 \mathrm{~m}$, and raised $£ 900 \mathrm{~m}$. Too much had been expected of inexperienced small investors. The labouring classes would require greater instruction in investing and a clearer sense that the privations of war were affecting classes fairly, a link with taxation the chancellor would build on. ${ }^{2}$ The conversion terms were criticised for being overgenerous, and Lloyd George in particular subsequently deplored the burden on post-war governments. ${ }^{3}$ At the time, he offered the "Warmest congratulations of the Ex Chancellor on the striking success of your great loan. ${ }^{4}$ In fact, conversion was partly a measure required to accommodate laxity in the earlier issue. ${ }^{5}$ The enduring lesson was that effectiveness had to be predicated on popular and political requirements as well as economic. McKenna sought the Labour MP George Barnes, 'one of the class to whom we are appealing', to chair the effort at attracting small investors to the loan. ${ }^{6}$ Such 'propagandist work' did not help McKenna when he refused to countenance Premium Bonds, cited vividly by Punch as another example of his doctrinaire rectitude at a time of crisis. ' It is a relief', wrote Harold Cox, 'to listen to a Ch of the Exchequer who knows the difference between business and sloppy sentiment', ${ }^{8}$ but it was not necessarily an advantage. 'So glad Reggie's loan has been such a success. He has suddenly leapt into an international reputation', Charlie Masterman told Pamela. 'Meantime the world crumbles to pieces!'?

More problematic than the loan was the dollar exchange, 'a nightmare to me from the first moment I went to the Treasury,' McKenna recalled. 'Cunliffe's obstinacy in failing to understand it was a real obstacle in our financial business. ${ }^{10}$ The exchange and the governor brought the first financial crisis of the coalition. 'I have just had a gloomy interview with [Cunliffe's

1. Haldane to RMcK, 22 June 1915.

2. RMcK, Representative Conference of Organised Labour and National Finance, 1 December 1915, sec. of Labour Party to RMcK, 3 December 1915, Labour papers, WNC 32/1/1; RMcK to J. S. Middleton, 4 December 1915, WNC 32/1/2; W. A. Appleton to RMcK, 1 December 1915; Neville Chamberlain, 28 November 1915, in The Neville Chamberlain Diary Letters, vol. 1, The Making of a Politician, 19151920), ed. Robert Self (Aldershot, 2000), 1:101.

3. Lloyd George, War Memoirs, i:74; Mason, Six Years, 114-26; Daily Chronicle, 23 February 1917; RMcK to H. Reginald Sibson, 5 March 1917 [copy].

4. Lloyd George to RMcK, n.d. c. 1915.

5. William Turpin, memorandum, 9 June 1915 , Treasury papers, T170/76.

6. RMcK to Earl Grey, 27 January 1916, Earl Grey papers, 228/11.

7. Punch, 22 March 1916.

8. Harold Cox to RMcK, 22 June 1915.

9. Masterman to PMcK, 19 July 1915.

10. RMcK to Beaverbrook, 24 March 1927, Beaverbrook papers, C234. 
cousin, and senior partner at Morgan Grenfell] Teddy Grenfell on the growingly sombre subject of the American exchange,' Asquith told Pamela on 21 July. Grenfell, who thought McKenna 'a very ignorant man ... a apt to try to appear wise', ${ }^{2}$ had told the War Office the day before that J. P. Morgan could not buy any more dollars without the exchange slipping below $\$ 4.77$, and that the Americans were demanding part prepayment of munitions orders. Cunliffe confronted the chancellor, the demarcation issue between their institutions was inflamed by McKenna's sarcasm. 'But, Mr Governor, this is what you call a matter of exchange. Is it not for you?' Cunliffe backed down; McKenna said, 'leave it to me', sent for Sir George May, secretary of the Prudential Assurance Company, and discovered that they had $\$ 40 \mathrm{~m}$ in American securities. 'Will you give them to me and let me settle later?' McKenna asked. When the directors agreed, McKenna told them to 'let the Bank of England have them by ten o'clock tomorrow morning.. ${ }^{3}$

The incident, popularised subsequently by Beaverbrook, was cited as a cornerstone of British financial policy during the war. In one respect it was, inasmuch as an extemporised gentleman's agreement had served to reinforce institutional change. In the context of the worsening situation, however, McKenna's initiative was merely a palliative. 'Sooner or later this situation was bound to arise', McKenna told Cabinet the following day. Since the allies depended on British means, 'we have therefore to treat such purchases as our own'. ${ }^{4}$ It was no longer possible to increase exports, because of labour shortages, or to reduce imports, for they were of raw materials, munitions, and food. The most viable means of redress therefore concerned the numbers of men enlisting from industry (for which reason McKenna resisted the recruitment of his own officials, ${ }^{5}$ and the volunteering of tax collectors $\left.{ }^{6}\right)$. In the long term, the problem which the declining exchange rate presented was much more than a question of labour; it concerned British strategy in its widest sense. In the short term, the unedifying manner in which the Treasury had resolved the exchange crisis with the assistance of the Prudential was the cause of recrimination. 'I found-as I generally do when I slip out at the back-door for a day or two', Asquith told Pamela, 'that something had gone awry in the kitchen. A kettle of fish simmering and diffusing an unwholesome odour, and the Cooks playing skittles. ${ }^{7}$

1. HHA to PMcK, 21 July 1915.

2. E. C. Grenfell to H. Davison, 5 August 1915, in Kathleen Burk, 'The Treasury: From Impotence to Power', in War and the State, ed. Kathleen Burk, 84-107, 105, n. 41.

3. Lord Beaverbrook, Politicians and the War,1914-1916 (1928), 147-49; RMcK to Beaverbrook, 24 March 1927, Beaverbrook papers, C234.

4. RMcK, memorandum, 29 July 1915, Cabinet papers, CAB37/131/37.

5. Long to RMcK, 25 October 1915, Asquith papers, 15/120.

6. John St. Loe Strachey to RMcK, 12 June 1916, Strachey papers, 10/3/6; RMcK to St. Loe Strachey, 4 July 1916, Strachey papers, 10/3/6.

7. HHA to PMcK, 9 July 1915. 
Asquith told McKenna of his 'disquietude' about the episode and suggested a future course of action, 'with the frankness with which I always use to you and which you never resent'. ${ }^{1}$ The future course happened to be that of the present, McKenna replied, with 'not less surprise than pain'. ${ }^{2}$ Asquith had been prodded by the co-ordinated efforts of Cunliffe, Montagu, and Isaacs, who had united in opposition to the Treasury clique. As much was admitted by Asquith's immediate and conciliatory rejoinder, both to McKenna and to his wife:

Perhaps you know that I have been in correspondence during the last 2 days with the Ch of the Ex? I have just got a very nice and characteristic letter from him which makes me wonder how he could ever have thought that I was in a reproachful or even misunderstanding mood. ${ }^{3}$

He thought it because the prime minister had implied that 'the Governor's grumblings were justified' ${ }^{4}$ In the absence of all the evidence, the chancellor was not alone in his misreading of the situation. 'I was afraid of a real and damaging rumpus, for the Governor had tendered his resignation', Asquith explained to Pamela, blaming Cunliffe in a further attempt to mollify her husband. 'In the dialect with wh. you are growing familiar, lubricants were indicated, and I feel confident now that things will go on oiled castors' ${ }^{6}$

The episode anticipated the frequent future divisions between policy makers, with McKenna preoccupied with cause and his antagonists with effect. Nevertheless, the Treasury had acquired the required levers over exchange control, though its moral authority would remain contested. ${ }^{7}$ McKenna had also established the limits of what he felt ought to be avoided even in the prosecution of the war: the prosecution of policy without regard to the economy. Three further examples occurred that July. First, over a miners' strike, Lloyd George acquiesced in the miners' demands, to the prime minister's private chagrin. ${ }^{8}$ Again, Lloyd George's espousal of controls was privately abandoned in the face of the requirements of war and complaints

1. HHA to RMcK, 25 July 1915, McKenna papers, 5/8/3; Grey to RMcK, 24 July 1915, McKenna papers, $5 / 6 / 1$.

2. RMcK to HHA, 26 July 1915 [copy], McKenna papers, 5/8/5.

3. HHA to PMcK, 26 July 1915 ; HHA to RMcK, 26 July 1915 , McKenna papers, $5 / 8 / 6$.

4. RMcK to HHA, 26 July 1915 , McKenna papers, 5/8/7.

5. RMcK to Beaverbrook, 24 March 1927, Beaverbrook papers, C234/155.

6. HHA to PMcK, 28 July 1915 . See H. Montgomery Hyde, Lord Reading: The Life of Rufus Isaacs, First Marquess of Reading (1967), 183-86.

7. RMcK to Cunliffe, 18 October 1915, McKenna papers, 5/10/10; Cunliffe to RMcK, 19 October 1915, McKenna papers, 5/10/11.

8. HHA to PMcK, 21 July 1915. 
from trades unions, while McKenna, vilified for neglecting economies, was more concerned with the ultimate effect of spiralling wage demands. ${ }^{1}$

Second, in the absence of ministerial action, two committees concerned themselves with control. The Committee on Public Retrenchment, chaired by McKenna, and the Naval Expenditure Standing Committee both attempted some scrutiny of expenditure. ${ }^{2}$ What economies McKenna did make that avoided impairing the war effort were used against him as 'attacks on the crown'. 'I am done', he told Pamela one evening. ' 3 hours a day of the Retrenchment Committee on top of everything else is more than ordinary humanity can bear. ${ }^{4}$

The third issue was allied purchasing. McKenna sought to reassert Treasury control and failed. He felt that the purchasing deal with J. P. Morgan was too generous to the Americans and had sought to restructure it, with French approval. ${ }^{5}$ Through his actions, McKenna had successfully subverted both Morgan and Cunliffe, only to find that the strictures imposed by Lloyd George's lassitude constrained him. The Entente came to crystallise everyone's resolve: most particularly that Lloyd George felt that only an acceleration in the war effort would satisfy the French, without whose cooperation the war was lost, and that McKenna could cite French demands as illustrating the impossibility of satisfactory leadership of the Entente. Relations with the allies were another source of tension. 'Not one of the Frogs could speak or understand a word of English: so you can imagine the sort of thing that went on', Asquith wrote to Pamela from GHQ in France.

I can honestly say I have never heard so much bad French talked in my life: the carpet was strewn with wrong gender, false concords, and a chaotic confusion of verbs tenses and idioms: I say nothing about pronunciation. However, we managed to understand one another, and A. J. B. declares that he finds $\mathrm{K}$ more cogent and persuasive in French than in English! 6

1. RMcK to Representative Conference of Organised Labour and National Finance, 1 December 1915; Keynes, 9 September 1915, The Financial Prospects for This Financial Year, Treasury papers, T170/90.

2. Major-General Sir C. E. Callwell, Stray Recollections (1923), 2:282; RMcK to Midleton, 15 May 1931; Asquith papers, 28/241-50; Committee on Public Retrenchment, 1915 HMSO, Cd 8068.

3. Midleton, Retrenchment Committee, 23 February 1916, Curzon papers, F112/117/47. Of other measures: R. H. Brand to Simon, 23 June 1915, Simon papers, 51/38; Montagu to HHA, 2 February 1916, Montagu papers, AS5/1/8.

4. RMcK to PMcK, 18 August 1915.

5. Horn, Britain, 101-2.

6. HHA to PMcK, 7 July 1915. 
Having waived Treasury scrutiny when chancellor, Lloyd George now ordered purchases in the United States to be conducted regardless of cost. ${ }^{1}$ The French joined the Russians, who had been purchasing independently since May 1915. ${ }^{2}$ Neither Lloyd George nor McKenna doubted the significance of France and Russia to the war effort, but where Lloyd George saw that their purpose was best served by the expediting of orders, McKenna sought to link the credits that underpinned them more closely to the prosecution of the war. ${ }^{3}$ It was obvious which policy was more easily effected. In the first instance, the French and Russian finance ministers, Alexander Ribot and Peter Bark, had to be convinced that their gold reserves were better used than hoarded, which was easier said than done when they suspected Britain of hegemonic motives. ${ }^{4}$ Whatever the proposals McKenna made for disbursement, the effect was resentment. The chancellor's manner in dealing with French and Russian finance ministers did nothing to allay their suspicions that Britain was behaving in a peremptory and supercilious manner. ${ }^{5}$ McKenna and Keynes shared a low opinion of the French. In context, the demands they made of Paris were not unreasonable, but were not expressed reasonably. As great a concern was the uncertain state of the Russian economy, indeed, of the Russian government. ${ }^{6}$ Petrograd's increased needs for provisions had to be counterbalanced with the requirements of the exchange rate. Russia's failure to restrict capital exports did not help, nor did it bring out the spirit of entente in the chancellor. Asquith noticed 'the way in which he gloated over the rise in the value of the rouble'?

The essence of the problem was gold. Petrograd reasonably, if naively, felt that any shipping of gold ought to be matched by an expansion of credit. ${ }^{8}$ In August, McKenna went to Boulogne 'whence if he returns with 40, or even 20, millions of Ribot's gold in his pouch', Asquith told Pamela, 'I have promised him (by way of first fruits) a golden statuette, to be set up (like

1. Von Donop, diary, 27 September 1915, Von Donop papers, WO 79/77, 14; Burk, Britain, America, 41.

2. Keith Neilson, Britain and the Last Tsar-British Policy and Russia, 18941917 (Oxford, 1995), 195, 363; David French, British Strategy and War Aims, 1914-1916 (1986), 121.

3. Treasury papers: Bradbury to Lloyd George, 27 August 1915, T170/73; Hanson to Bradbury, 31 August 1915, T170/73; Llewellyn Smith to Bradbury, 31 August 1915, T170/73.

4. Keynes, memorandum, Keynes papers, T/7/1-2, T9/1-34; Lloyd George to Esher, 6 February 1915, Esher papers, 2/14.

5. Cambon to Ribot, 23 June 1915, in 'External Finance in Anglo-French Relations in the First World War, 1914-1917', by Martin Horn, International History Review 17 (1995): 63; Spring-Rice to Grey, 28 August 1915, Foreign Office papers, FO371/2.589/121430; Ribot to RMcK, 27 May 1915.

6. RMcK to George Lambert, 18 October 1916, Treasury papers, T172/337.

7. HHA to Sylvia Henley, 13 August 1915, Asquith papers, 542/2/331; Sir John Hanbury-Williams to Stamfordham, 15 January 1916, RA PS/GV/Q 722/11.

8. Keynes, memorandums, Keynes papers, T/9, T/7. 
the image ordered by Nebuchadnezzar the King) in the drawing room of 36 Smith Square.' In fact, McKenna conceded ground to Ribot and Bark and announced that a joint mission to New York would be undertaken, under Lord Reading, as Rufus Isaacs had become. ${ }^{2}$

Unrestrained allied purchasing prompted the next financial crisis, when an American loan became the only course of action, despite fears that it might contravene Washington's neutrality. ${ }^{3}$ On 18 August 1915, Britain purchased $\$ 100 \mathrm{~m}$ in United States securities in London for resale in New York, and at the same time shipped a further $£ 100 \mathrm{~m}$ in gold. ${ }^{4}$ McKenna had administered another fraught corrective. Despite calls from Asquith, Cunliffe, and J. P. Morgan, McKenna took no immediate steps to address the situation for three weeks after the ad hoc Prudential episode. The reason, however, was less complacency than deliberation in lieu of precedent. ${ }^{5}$ Eventually, Reading and Edward Holden, chairman of Midland Bank, were dispatched across the Atlantic charged with borrowing $\$ 1,000 \mathrm{~m} .{ }^{6}$ The target was ambitious, particularly as the Americans had yet to sanction a loan. President Woodrow Wilson supported neutrality, and with an election in 1916, he was anxious not to alienate that body of his electorate that was averse to Entente success in the European war. McKenna was notified about the appearance of neutralists and pro-Germans in the United States, and of the divergence of interest between the Treasury and the Federal Reserve Board. ${ }^{7}$ Both institutions felt that, for the immediate future at least, American interests were

1. HHA to PMcK, 22 August 1915.

2. HHA to George V, 19 August 1915, Cabinet papers, CAB41/36/39; HHA to George V, 28 August 1915, Cabinet papers, CAB41/36/41; RMcK to Kitchener, 24 August 1915, Kitchener papers, 30/57/57; Ribot, Letters, 42.

3. James Forgan to Edward Holden, 19 August 1915, McKenna papers, 5/6/3-10; Holden to RMcK, 1 September 1915, McKenna papers, 5/6/11; Sir William Plender to Bradbury, 18 August 1915, Treasury papers, T170/62; Rothschild to Rufus Isaacs, 9 July 1915, Reading papers, F118/76/32-57.

4. HHA to George V, 19 August 1915, Cabinet papers, CAB41/36/39; Martin to Holland to RMcK, 19 August 1915, Treasury papers, T170/62; Holden to RMcK, 19 August 1915, McKenna papers, 5/6/3; Martin to Holland to Sir Thomas Elliot, 20 August 1915, T170/62; Sir George Anderson to Bradbury, 26 August 1915, Treasury papers, T170/62; Holden to RMcK, 27 August 1915, McKenna papers, 5/6/8; Holden to RMcK, 1 September 1915, McKenna papers, 5/6/11.

5. Philip Kerr to George Cave, 28 August 1915, Cave papers, 62495/145-58; Runciman, memorandum, Runciman papers, 89/23; Spring-Rice to RMcK, 14 September 1915, Foreign Office papers, FO371/2589/131217; but cf. Money Talks: Fifty Years of International Finance, by Frederick Leith Ross (1968), 45.

6. HHA and RMcK to Rufus Isaacs, 1 September 1915, Reading papers, F118/ 112b/230; HHA to George V, 27 August 1915, Cabinet papers, CAB41/36/179; Rufus Isaacs to RMcK, 8 September 1915 , McKenna papers, 5/6; Rufus Isaacs to RMcK, 25 September 1915, McKenna papers, 5/6/24.

7. Holden to RMcK, 27 August 1915, McKenna papers, 5/6/5. 


\section{Reginald McKenna}

best served by continued allied purchasing. Pointedly, Wilson only acceded to the loan issue, rather than embraced it with any enthusiasm. ${ }^{1}$

The mission failed in its primary objective, which was to win over the American public, or at least financial and political opinion. It was not helped by the exporting of the one booming part of the domestic war effort-fractiousness-with it. ${ }^{2}$ American self-interest proved as calculating as that of the allies needed to be-there was no evidence of the racial sympathy many had assumed ${ }^{3}$ - and it corresponded to diplomatic sentiment, in that the Americans did not want belligerent paper. They agreed to lend $1.100 \mathrm{~m}$ at an interest rate of more than five percent. Failure could not be entertained, and nor, therefore, risk: with the need for success, the Treasury had accepted underwriting. Culturally the loan marked progress; quantitatively it was a failure. ${ }^{4}$ Introspection and antipathy had not been factored into allied calculations. All served to reinforce the Treasury view that future commitments in the United States should be reduced to an absolute minimum, which would also sustain confidence in the war effort. ${ }^{5}$ It would need to, given the demands of the allies. 'I have just come back from the Bark orgie', Asquith told Pamela. 'There was not much to raise one's pulse. Bark made a short speech in French, whose value (in cost) was estimated by some expert among the guests at about 1 million francs a word. ${ }^{6}$

\section{COLLEAGUES}

On the creation of the coalition, the Unionist MP Leslie Scott told McKenna that 'you are one of the rare men who are likely to make it work harmoniously." It was optimistic, but for all his misgivings, McKenna attempted some leaden civility with his new colleagues. ${ }^{8}$ For them, McKenna was the embodiment of what should have been swept from office and had to be marginalised for the war to be effectively prosecuted. Unionists outside Parlia-

1. McAdoo to Wilson, 21 August 1915, in The Papers of Woodrow Wilson, ed. Arthur Link (Princeton, 1980), 34:275, 183-88.

2. Basil Blackett to Bradbury, 2 October 1915, Treasury papers, T170/62.

3. Cyrus Adler, ed., Jacob H. Schiff: His Life and Letters, 2 vols. (1929), 2:248-53; Sir Gilbert Parker to Churchill, January 1915, Churchill papers, 26/3/14; Whigham to Curzon, 28 September 1916, Curzon papers, F112/112B.

4. RMcK to Rufus Isaacs, 20 September 1915, 21 September 1915, 25 September 1915, Foreign Office papers, FO371/2589, 134637, 135252, 138211; RMcK to Rufus Isaacs, 14 October 1915, Foreign Office papers, FO371/2589, 150444; HHA to George V, 2 October 1915, Cabinet papers, CAB41/36/46.

5. Blackett to Bradbury, 2 October 1915, Treasury papers, T170/62.

6. HHA to PMcK, 28 September 1915.

7. Leslie Scott to RMcK, 27 May [1915].

8. RMcK to Curzon, 12 January 1915, Curzon papers, F112/115/113; RMcK to Curzon, 26 November 1915, Curzon papers, F112/115/122; PMcK to Long, 22 April 1915, Long papers, 62419; Long to RMcK, 30 May 1915. 
ment branded him a 'pacifist' 'pro-German' 'logician'. ${ }^{1}$ The distance between McKenna and Lloyd George grew through the latter's increasing proximity to the Unionists. For all his partisan rhetoric, Lloyd George had always been more agreeable to the idea of coalition, and in the crisis of war, felt partisan concerns to be even less important. Most significantly, they came to agree about the conduct of the war. The increasing cooperation between Lloyd George and the Unionists heightened McKenna's already strong aversion to both.

When the coalition was formed, Margot feared for the effect of the Minister of Munitions on the Chancellor of the Exchequer. She told Pamela, 'I hope he will never let Ll. George's name cross his lips'. ${ }^{2}$ Margot had been even more optimistic than Leslie Scott. From the outset, the two were barely on speaking terms. Each blamed the other for weaknesses at the centre of the administration: 'McKenna is always wrong'. ${ }^{3}$ He was always wrong, it was alleged, over his suspicions of Lloyd George's growing collusion with the Unionists. As much went for Pamela, who told Fisher that Balfour was 'thick as thieves with Lloyd George and Churchill'. ${ }^{4}$ In August, F. E. Smith sent a note to Lloyd George offering his assistance, and saying, 'Bonar Law cannot come tonight'. 5 Smith wrote the minutes and sent a copy to 'The Chancellor of the Exchequer'. The 'Chancellor' duly opened it, but the Chancellor was now McKenna. Two days later, he sent it on to Lloyd George. 'Dear Lloyd George, the enclosed was delivered to my house in a box. I opened it and have read it.' ' 'Next time a letter comes into your hands by mistake', Lloyd George told McKenna, 'put it back into the same Box and send it to the right person at once'?

Within the Treasury, however, there was Montagu, whom McKenna treated the way he had Morant, and who responded in kind. 'As undistinguished as

1. Gwynne to Sassoon, 19 October 1916, in The Rasp of War: The Letters of H. A. Gwynne to the Countess Bathurst, 1914-18, ed. Keith Wilson (1988), 122; Gwynne to Wilson, 27 March 1916, ibid., 196; Roger Keyes, in The Anvil of War: Letters Between F. S. Oliver and His Brother, 1914-18, ed. Stephen Gwynn (1936), 324.

2. MA to PMcK, 26 [May 1915].

3. Lloyd George, 31 July 1915, Riddell, diary, 62959/114. The two diarists closest to Lloyd George testified to his preoccupation with McKenna. The most serious included, from Riddell, the entries of (1915): 2, 3, 4, 31 July; 20, 29 August; 4 September; 23, 29 October; 14, 28 November; 11 December; (1916): 5, 23 January; 26 February; 12 March; 30 April; 2, 11, June; 8, 16, 21, 30 July; 14 October; 3, 5, November; 3 December; and of Frances Stevenson (1915): 2, 15, 17, September; 5 October; 15, 24, November; (1916): 18, 31 October; 21, 25, November; 6 December.

4. Fisher to Hankey, 7 June 1915, Hankey papers, 5/2b/9; Balfour to RMcK, 29 May 1915; Scott, diary, 7 February 1916, Scott papers, 50902/125.

5. Smith to Lloyd George, n.d., Lloyd George papers, D/17/12.

6. RMcK to Lloyd George, 11 August 1915, Lloyd George papers, D/17/12/1.

7. Stevenson, Diary, 2 September 1915, 56. 
any man I have ever served and I have not much respect for him as a politician,' he told Venetia. 'I feel how small he is compared with George.'2 If Montagu had not sought to undermine McKenna at the Admiralty, he did at the Treasury. McKenna's only ministerial confidant remained Runciman, who had been promoted to president of the Board of Trade, and who had become more critical of Asquith, not least for having formed the coalition in the first place. ${ }^{3}$ McKenna and Runciman came to assume a strikingly similar aspect, physically as well as politically. The Daily Mail, damning by association, commented that 'So alike are they in features and in dress that many people who were watching the members of the Cabinet arrive entirely confused the two'. ${ }^{4}$ Runciman had already succeeded McKenna in two offices, displaying many of McKenna's strengths and few of his faults. Less unpopular, but also less hardy, Runciman was probably the only colleague McKenna completely trusted. Their experience of coalition politics brought them closer together. It did the same to Grey, with whom McKenna shared a similarly besieged outlook, and about whom he felt increasingly warm. Outside, McKenna still liaised closely with Fisher, and was occupied in constantly discouraging him from making speeches in the Lords. ${ }^{5}$

The issue of personal relations became critical because of the peculiar dynamics of coalition. 'How difficult it is to run a well-constructed ménage!' Asquith told Pamela. 'You seem to do it somehow in Smith Square: I wish you wd. impart your secret to Downing St. ${ }^{6}$ Asquith's predicament brought him closer to McKenna. He told Viola Tree, who had married McKenna's private secretary Alan Parsons, that McKenna and Reading were his 'most steadfast' friends. ${ }^{7}$ McKenna, for Charles Hobhouse, was now 'the PMs only confidant'. 'I don't mind what others may say or think', McKenna told Asquith, 'but I do mind very much if you are dissatisfied with me'. Their relations were crucial because, by some accounts, they were the centre of a government of 'very serious depression and dissatisfaction', Walter

1. Montagu to Venetia Stanley, 26 May 1916, in Levine, Politics, 327.

2. Ibid., 28 May 1916, in Levine, Politics, 328.

3. Runciman to Hilda Runciman, 12 January 1915, Runciman papers, 303/2; Runciman to Lord Runciman, 20 May 1915, Runciman to Hilda Runciman, 28 December 1915, Runciman papers, 303/2.

4. Daily Mail, 29 December 1915.

5. RMcK to Fisher, 8 November 1916, Fisher papers, 3/1/3/2755; Fisher to RMcK, 16 January 1917, Fisher papers, 3/14/2853; Hankey, diary, 21 January 1916, Hankey papers, 1/1/136; Fisher to Garvin, 1 December 1916, 12 June 1917, 11 July 1917, 15 January 1918, Garvin papers, 1/13; Fisher to Hankey, 30 March 1917, Hankey papers, $5 / 2 \mathrm{~b} / 42$.

6. HHA to PMcK, 9 July 1915.

7. Alan Parsons, Alan Parsons' Book: A Study in Anthology, ed. Viola Parsons, (1937), 92.

8. Hobhouse, diary, 14 October 1915, Diary, 255; HHA to Sylvia Henley, 23 October 1915, Asquith papers, 542/2/496.

9. RMcK to HHA, 26 July 1915 , McKenna papers, 5/8/7. 
Page told President Wilson. 'Except Lloyd George and the Chancellor of the Exchequer the Cabinet seems to suffer a sort of paralysis."

One antagonist had been displaced. 'The inner conclave were PM, LG, Grey and Winston', George Riddell noted. 'Now McKenna has replaced Winston'. ${ }^{2}$ Recognising the fact, Churchill exchanged Cabinet for a commission, and had gone to France, from where it appeared to him that 'LG $\&$ McK and the old block are far away and look like mandarins of some remote province of China'. ${ }^{3}$

\section{LE BAS}

In contrast to his experience earlier in the war, as chancellor McKenna enjoyed a broadly supportive, even, at times, uncritical press. ${ }^{4}$ In personal terms, only Spender remained close; relations remained cordial with Riddell and Scott, but no more than that as they moved increasingly towards Lloyd George. To compensate, Northcliffe regarded his younger brother Cecil as being 'entirely under McKenna's influence', Northcliffe told Riddell, who thought 'McKenna has succeeded in getting at Northcliffe through the family fool'. ${ }^{5}$ Politically, McKenna still had most in common with H. W. Massingham's equivocations at the Nation, and as such for keeping 'our flag flying'. ${ }^{6}$ A. G. Gardiner was fundamentally suspicious of the ministerial mind, and it followed that after his first lordship, McKenna was one of those Liberals about whom Gardiner was most doubtful. ${ }^{7}$ His relationship with McKenna fluctuated, though he was still suspected by Lloyd George as being the recipient of leaks from the chancellor. ${ }^{8}$ Gardiner, however, at least yielded to circumstance, which could not usually be said of F. W. Hirst. ${ }^{9}$

In policy terms, McKenna's accommodation by Fleet Street was largely because finance was even less a preoccupation to pressmen than it was to politicians or soldiers. McKenna nevertheless endeavoured, for the only

1. Walter Page to Woodrow Wilson, 26 September 1915, in The Life and Letters of Walter H. Page, ed. Burton Hendrick (1922-25), ii:96.

2. Riddell, dairy, 22 May 1915, Riddell papers, 62959.

3. Churchill to Clementine, 27 November 1915, in Winston S. Churchill, vol. 3 1914-16, Companion II: Documents, May 1915-December 1916, ed. Martin Gilbert (1972), 1290.

4. RMcK to A. G. Gardiner, 19 June 1915, Gardiner papers, 1/22/4.

5. Riddell, diary, 2 July 1915, Riddell papers, 62959/108.

6. RMcK, in The Rise and Fall of the Political Press in Britain, by Stephen Koss, 2 vols. (1981-84), 2:344.

7. Stephen Koss, Fleet Street Radical: A. G. Gardner and the Daily News (1973), 121-22, 170 .

8. RMcK to Gardiner, 17 February 1914, Gardiner papers, 1/22/2; RMcK to Gardiner, 1 May 1915, Gardiner papers, 1/22/3; Stevenson, Diary, 17 September 1915, 60 .

9. MacCallum Scott, diary, 15 January 1916, MacCallum Scott papers, $1465 / 7$. 
time in his public life, actively to cultivate public opinion, and in so doing became something of a pioneer. He had adopted the habit of passing statements and information to Pamela's friend Charlie Masterman, director of Propaganda, at Wellington House, ${ }^{1}$ and McKenna was 'interviewed' by the New York Times, or, rather, sent an article written by Keynes and Blackett to the paper's London correspondent. ${ }^{2}$ Masterman duly passed it on to the Foreign Office for distribution in France, Russia, and Italy. ${ }^{3}$ McKenna's policy of resisting the recruitment of his officials allowed J. H. Curle to perform considerable savings propaganda work. ${ }^{4}$ Just as he had never enjoyed so supportive a press before, McKenna had never before employed, or even countenanced, propaganda as he would as chancellor.

Most important to him was the publisher and publicist Hedley Le Bas. After his initial recruitment triumph with the Kitchener poster, Le Bas remained frustrated at how little politicians appeared to realise the potential of the new media. ${ }^{5}$ Le Bas showed a prescient understanding that McKenna would provide some relief for his frustration when he told Pamela that her husband's appointment as chancellor 'is the only thing that reconciles me to a coalition government. ${ }^{6}$ Within a month, on the morning of 22 June 1915 , Le Bas appeared at 36 Smith Square. He had read over breakfast that the chancellor had launched his loan, but with little publicity. 'I immediately put on my hat and made tracks for Mr McKenna's private house', he recalled. 'It was rather a risky proceeding, because I did not know Mr McKenna.' Henry, McKenna's butler, answered the door. The chancellor was in the bath. Fifteen minutes later, he appeared in his dressing gown, and 'received me most politely, listened to what I had to say and invited me to the Treasury.' Two days later, Le Bas presented McKenna with a detailed scheme for a massive advertising campaign, and the chancellor pledged $£ 100,000$, making it 'the biggest advertising campaign ever carried out in this or any other country'?

Le Bas took a full page of The Times to promote the issue, while McKenna persuaded the Parliamentary Recruiting Committee to launch a poster campaign, the Royal Mail to deliver leaflets, and the National War Savings

1. Masterman to PMcK, 4 August 1915; Lucy Masterman, C. F. G. Masterman, a Biography (1939), 283-84.

2. Ernest Marshall to RMcK, 19 July 1916; H. C. Montgomery to Horace Hamilton, 20 July 1916; Dudley Ward to Hamilton, 5 August 1916; J. B. Pratt to H. Hamilton, 11 August 1916.

3. Masterman to Hamilton, 14 August 1916.

4. Sir Edgar Waterlow to RMcK, 22 January, Midland Bank papers, 192.069.

5. 'The Man Who Induced the Government to Advertise', Higham's Magazine, April 1916, 14-15.

6. Hedley Le Bas to PMcK, 26 May 1915.

7. Le Bas, in 'Sir Hedley Le Bas and the Origins of Domestic Propaganda in Britain, 1914-1917', by Nicholas Hiley, Journal of Advertising History 10 (1987): 38; Isaac F. Marcosson, The War After the War (New York, 1917), 130-34. 
Committee to concern itself with War Loan propaganda. ${ }^{1}$ In January 1916, Le Bas produced a publicity film for cinemas with music by Pamela, ${ }^{2}$ and the following month was appointed to the National Organising Committee for War Savings at the Treasury, which led to a national exhortation to economy and thrift. ${ }^{3}$ When he issued his Exchequer Bonds in February 1916, McKenna occupied, not for the first time, the whole of the front page of the Daily Mail, but this time the paper was extolling his cause. ' $M c K e n n a$ was the first Chancellor to use publicity on an extensive scale in the interests of the Treasury', Le Bas wrote after the war. 'He had what I think I may call an instinctive sense of its value'. ${ }^{5}$

Lloyd George found the scratch alliance risible, mocking Le Bas 'from whom McKenna is seeking to secure inspiration as to the views of the working-classes!', ${ }^{6}$ and Cunliffe, among others, found the development distasteful. ${ }^{7}$ As if carrying on feuds by other routes, Le Bas and Riddell had long before fallen out over a business deal. 'The Le Bas campaign of frightfulness is growing more and more spicy', Pamela told her husband. 'I long to penetrate into the dark details at which you hint. Will it mean an open exposure?'8 With Lloyd George, Riddell suggested financial impropriety between Le Bas and McKenna, for which they were censured by the Newspaper Proprietors' Association. ${ }^{9}$ For Lloyd George, Le Bas was 'a contemptible jackal,' and 'a whore. ${ }^{10}$ In October 1916, he joined the Ministry of Munitions.

Le Bas was ultimately knighted for his war work, as was another associate, Basil Zaharoff, the munitions manufacturer whom McKenna had met while at the Admiralty. In another speculative venture for a supposedly arch economist, and for another $£ 100,000$, McKenna gambled on shortening the

1. Le Bas to RMcK, 20 July 1915, Treasury papers, T1/11799/15557/1915/155 50; Times, 26 June 1915.

2. Masterman to PMcK, 4 August 1915; Lucy Masterman, C. F. G. Masterman, a Biography (1939), 283-84.

3. Hiley, 'Le Bas', 40.

4. Daily Mail, 3 February 1916; Northcliffe to RMcK, n.d., Northcliffe papers, $62157 / 192$.

5. Le Bas, 'Advertising', 245.

6. RMcK, 19 February 1916, Riddell, diary, Riddell papers, 62960.

7. Riddell, diary, 26 June 1915, Riddell papers, 62959; August 1916, Treasury papers, T172/349; 3 February 1916, Runciman papers, 149/1; Le Bas to Northcliffe, 23 July 1915, Northcliffe papers, 62170/154.

8. PMcK to RMcK, 7 September [1915].

9. By the newspaper proprietors association, Riddell, diary, 19 February 1916, 30 April 1916, 3 November 1916, Riddell papers, 62960. Riddell had been a director of Caxton but in 1915 was taken to court by Le Bas charged with fraud; in turn Riddell accused Le Bas of blackmail over his divorce. See J. M. McEwen, ed., The Riddell Diaries, 1908-1932 (1986), 10-11.

10. Riddell, diary, 15 September 1915, Riddell papers, 62959. 
war through the offices of a bigamist, embezzler, brothel tout, and arsonist. ${ }^{1}$ With his east European contacts, Zaharoff had persuaded the British government that he could convert the Greek government to join the allies for $£ 1.5 \mathrm{~m}$. McKenna and Asquith had eventually been convinced of Zaharoff's ability and chance of success, and on 11 December 1915, Asquith told Caillard, the middleman, that the government would pick up Zaharoff's bill until April. ${ }^{2}$ The initiative led to an Anglo-French news agency in Athens, but only Greek neutrality. McKenna and Asquith declined to finance Zaharoff in 'opening up' Rumania, and, more pointedly, the Dardanelles. ${ }^{3}$ The 'idea about Turkey', McKenna told Caillard, was 'worth "risking the toss" to the extent of $£ 100,000{ }^{\prime}{ }^{4567}$

\section{THE FIRST BUDGET}

While his subordinates were trying to raise money in the United States, McKenna prepared his first budget. ${ }^{8}$ There were the familiar expedients of supplementing permanent loans, further encouraged by the ease with which debt would be absorbed in the peace many still envisaged as being imminent. With added inflationary concerns, everything pointed to increases in taxation, which had been demanded from representatives of both capital and labour. Of George Lansbury's call for a forced loan on the rich, 'I do not know that a government could do anything so drastic, but war profits will be taxed. ${ }^{9}$ The interest groups, which the chancellor had met throughout the summer, nevertheless provided detailed reasons as to why increases should not apply to their particular interests. ${ }^{10}$

McKenna delivered his budget on 21 September 1915. Since Lloyd George's last budget in May, revenue had increased by $£ 5 \mathrm{~m}$, to $£ 272 \mathrm{~m}$. Expenditure, however, had risen by $£ 457 \mathrm{~m}$, to $£ 1,590 \mathrm{~m}$. McKenna offered conclusive proof of his own defeat on 23 August 1911 when he revealed expenditure on the navy of $£ 190 \mathrm{~m}$, and on the army of $£ 750 \mathrm{~m}$. It all meant

1. 'Basil Zaharoff', in H. C. G. Matthew and Brian Harrison eds., Oxford Dictionary of National Biography (Oxford, 2004).

2. HHA to Caillard, 11 December 1915, Foreign Office papers, FO1093/47.

3. Stephen Roskill, Hankey: Man of Secrets, 3 vols. (1970-74), i:239.

4. RMcK, attrib., Caillard to HHA, 9 July 1916, Foreign Office papers, FO1093/52.

5. Scott, diary, 13-20 April 1916, Scott papers, 50902.

6. RMcK, 20 November 1915, in The Scene Changes, by Basil Thomson (1939), $255-56$.

7. Basil Thomson, Queer People [1922], 74.

8. McKenna papers, 5/3/5, 6, 7; G. C. Peden, The Treasury and British Public Policy, 1906-1959 (Oxford, 2000), 91.

9. Pankhurst, Home, 217.

10. Such as deputations from millers, 5 October 1915 , Treasury papers, T172/204; and shipbuilders, 9 October 1915 , Treasury papers, T172/210. 
therefore, less than one sixth of the war was being paid for by current finance. To narrow the gap, McKenna announced an increase in income tax of 40 percent, with a reduction in the exemption limit from $£ 160$ to $£ 130$. The most striking instance of direct taxation was the supertax of an additional 3 shillings 6 pence per $£$ on all incomes over $£ 10,000$. More generally, McKenna attempted to both restrict consumption and raise revenue, and supplemented increases in both through two innovations. The first innovation was a 'special tax in respect of profits which have increased during the war period', ${ }^{1}$ an extension of the Munitions of War Act for munitions producers, and the most substantial and practical fiscal innovation of the war. ${ }^{2}$ It was, moreover, the first excess profits tax of any belligerent. Despite the complaints of the City, the Excess Profits Tax did little to dent profits, the pursuit of which encouraged firms to meet deadlines. ${ }^{3}$

The second and most dramatic innovation was announced with characteristic baldness. 'To obtain revenue is now and always the first object of taxation', he told the Commons, but 'at this time there are other objects which must not be left out of view. I am afraid that what I am going to say will satisfy neither Free Trader nor the scientific Tariff Reformer. Both of them must put for the time being their fiscal theories upon one side'. Putting fiscal theories to one side, he had now to 'tax with objects beyond revenue, with objects which are purely temporary, and without regard to the permanent effect upon trade. ${ }^{3}$ He then announced a 33.33 per cent tax on imported luxury goods. The most inveterate free trader had introduced tariffs. The economic factors were avowedly pragmatic: the reduction of imports, the raising of revenue, the freeing of freight space, and the preservation of the exchange. Indeed, the McKenna Duties were intended as a temporary expedient but were from the outset a political issue, and one which outlasted the war. It was a gamble, with no obvious potential for success. The peculiar reasons for this were that the measure was not really justified in terms of revenue, nor was it a political statement of any stridency, though it remained a controversial issue for the next ten years. McKenna adopted different explanations to different people. He claimed to free traders that they were imposed to demonstrate the futility of tariffs and were in any case merely temporary; ${ }^{5}$ to protectionists, that they were a recognition of chang-

1. Treasury papers: T170/88; T170/212.

2. Johnathan Boswell and Bruce Johns, 'Patriots or Profiteers? British Businessmen and the First World War', Journal of European Economic History 11 (1982): 426; Robertson to Lansdowne, 1 December 1916, Robertson papers, 1/21/1/1/47.

3. Sir Robert Sanders, 23 June 1920, Diary, 139; J. Hastings Duncan to RMcK, 28 June 1917, 13 May 1917; G. W. James to RMcK, 24 April 1918; George Lansbury to RMcK, 3 January 1919; RMcK to John Montgomerie, 12 June 1919; Montgomerie to RMcK, 17 June 1919.

4. RMcK, Parliamentary Debates, 21 September 1915, 351.

5. RMcK to Alfred Mond, 17 October 1915, McKenna papers, 5/10/9. 
ing circumstances. ${ }^{1}$ As with most acts of apparent apostasy, it dismayed the proponent's friends and failed to convince his enemies. It was certainly not something a Unionist chancellor would have done at that time. As McKenna announced it in Cabinet, Lloyd George passed a note to Walter Long: 'So the old system goes destroyed by its own advocates'.2

Notwithstanding some misgivings, the budget was well received, not least for its clarity and compression. ' $\mathrm{Mr}$ McKenna is generally supposed to have found his niche at last', wrote James Muirhead in the Nation, 'and there are not wanting veteran members of the House of Commons to declare that his Budget speech was the best they ever heard'. 'As you know, I am not given to flattery; but I can honestly say that I have never witnessed the better discharge of an overwhelmingly difficult task', Asquith told Pamela. 'It had every merit; clear, unprovocative, eloquent and-concise!' Those interest groups adversely affected were swift to press their cases, ${ }^{6}$ and McKenna's equanimity was often tested. Bankers 'drive a hard bargain whenever they are asked to assist', Leith Ross noted. 'McKenna was absolutely furious after the last meeting'. The exception was the chairman of the London City and Midland Bank. McKenna told Perks that 'Holden behaved like a brick. He was far and away in front of them all. ${ }^{8}$ Most significantly, to American eyes, Germany's financial laxity was cast into stark relief by McKenna's 'unsparing hand'. ${ }^{9}$ After all the struggles of its defence, bathos characterised the end of free trade. 'I think the Budget ended up as well as could be', Asquith

1. Hewins, diary, 7 September 1915, Hewins, Apologia, 2:51; MacCallum Scott, diary, 21 October 1915, MacCallum Scott papers, 1465/6; Harold Macmillan, Winds of Change, 1914-1939 (1966), 138.

2. Hewins, Apologia, ii:52.

3. Punch, 29 September 1915; Glasgow Herald, 23 September 1915; F. W. Hirst and J. E. Allen, British War Budgets (1926), 119; Bank of England, 1:101, Bank of England papers, ADM2/1; Frank McVey, The Financial History of Great Britain, 1914-1918 (New York, 1918), 35; Ernest Bogart, Direct and Indirect Costs of the Great World War (New York, 1919), 16; F. W. Hirst, The Consequences of the War to Great Britain (1934), 155; Sir Bernard Mallet and C. Oswald George, British Budgets, Second Series, 1913-14 to 1920-21 (1929), 91; Runciman to RMcK, 22 September 1915, McKenna papers, 5/3/1; Redmond to RMcK, 22 September 1915, McKenna papers, 5/3/2; Long to PMcK, 21 June 1915.

4. Nation [US], 21 October 1915.

5. HHA to PMcK, 21 September 1915.

6. Treasury papers: T172/221, 222, 225, 227; RMcK to John Montgomerie, 12 July 1919; Josiah Stamp, Taxation During the War (1932), 46-50, 155-6; Boswell and Johns, Patriots, 434-38.

7. Leith Ross to his mother, 21 November 1915, Leith Ross papers, T188/267; 22 December 1915, T170/93, 10; RMcK to Worthington-Evans, 7 October 1915, Worthington-Evans papers, 894/3.

8. R. W. Perks, 27 July 1915, Midland Bank papers, ACC558/04.

9. Nation [US], 30 September 1915. 
told Pamela, 'and even the Tariff-mongers do not seem very tearful over the untimely fate of hats and plate-glass.'

\section{THE ALTERNATIVES}

As McKenna gave his financial statement, the Battle of Loos had commenced. Where the military went, the financial had to follow. 'The figures of expenditure are appalling, and whatever I do in the way of taxation, I quake at the enormity of the prospective loan.'2 On 30 September 1915, McKenna increased advances to Petrograd, conditional on British credit in New York. A lack of military progress required a mobilisation not only of money but also of men. For Unionists, conscription was axiomatic; for most Liberals it was not only philosophically objectionable, but also ultimately impractical. That had been McKenna's position at the Admiralty. ${ }^{3}$ The War Policy Cabinet Committee interviewed the chancellor on 23 August. Faced with growing pressure for conscription, Asquith had appointed conscriptionists, including Curzon, Selborne, and Chamberlain, to the committee, the last of whom felt that McKenna's arguments necessitated compulsion, despite the chancellor's protestations. ${ }^{4}$ The committee subjected McKenna to questioning that was usually hostile and at times incredulous. In close cooperation with Keynes, McKenna endeavoured to transform the conceptual understanding of, among other things, finance and strategy. ${ }^{5}$ At times, the meeting resembled a class in elementary political economy.

For the first time McKenna made explicit what he and Keynes had long thought of as 'the Alternatives'. Britain could serve as the paymaster for the Entente or risk bankruptcy by trying to do too much: 'we have already reached the prudent limits of safety'. ${ }^{6}$ Discrimination was not only critical, but obvious. McKenna advocated a division of labour within the Entente: compared to the activities of France and Russia, Britain's 'is a more skilled effort and a more valuable output'. ${ }^{7}$ Lloyd George later described McKenna's evidence as 'ingenious but unconvincing', ${ }^{8}$ and it was rejected by the committee, which nevertheless professed to 'admiring its ingenuity'. ${ }^{9}$ Misunderstanding derived from McKenna holding no objection to conscription other

1. HHA to PMcK, 1 October 1915.

2. RMcK to PMcK, 5 September 1915.

3. RMcK to Archibald Hurd, 18 May 1910, Hurd papers, 1/35.

4. Austen Chamberlain to Churchill, 19 August 1915, Churchill papers, 21/61; HHA to MA, 26 August 1915, MA papers, c.9961.

5. War Policy Cabinet Committee, 23 August 1915, Cabinet papers, CAB27/2.

6. RMcK, 23 August 1915, Cabinet papers, CAB27/2/11.

7. Ibid., 14.

8. Lloyd George, Memoirs, 1:432.

9. Cabinet papers, CAB27/2, appendix 27, 226-28; Hirst, Political Economy, 318-19. 
than its effect on production in the absence of any countervailing economies. Insofar as Curzon believed more men could be recruited without its affecting production, McKenna agreed. The chancellor's methods of doing so were the curtailment of spending and the greater conscription of wealth, with its attendant economic benefits. Curzon's was conscription of manpower combined with an escalation in spending. McKenna thought that manpower was better employed where it was best suited: in providing for the Entente. As with other statements of intent, the conscriptionist view was, moreover, predicated upon military success, which in summer 1915 was neither apparent nor real. The view was unaffected: military failure could always be blamed on the defeatist core of the Cabinet.

The chancellor had discovered that the most beneficial control was that over spending, but it could not be applied without reference to strategy. In this, McKenna, to the military the model of a meddling politician, found two unlikely supporters: Kitchener and General Robertson. Kitchener displayed some sensitivity to McKenna's concerns, while they both opposed, for different reasons, conscription and wanted to wait on events on the Continent to secure British ascendancy after the peace. ${ }^{1}$ Though Robertson despaired at 'finance as well as politicos' being involved in the war effort, ${ }^{2}$ he nevertheless shared with McKenna a view of the war that went beyond immediacies, and was distrustful of 'decisive' actions and the verbiage that preceded them. ${ }^{3}$ Yet Robertson's growing enmity with Lloyd George clouded the message, and it was the suspicion of some that their growing distance was the reason for McKenna's increasing proximity. ${ }^{4}$

The result was that McKenna had managed to press his concerns upon the generals with rather more success than he had with the politicians. Kitchener told McKenna that of that summer's casualties, only 40 percent constituted 'irrecoverable wastage'. ${ }^{5}$ Yet both Kitchener and Robertson, in different ways, presided over the expansion of the army that was causing McKenna so many of his problems, and they differed fundamentally in the belief that everything should be subordinated to victory. For McKenna, the value of victory depended upon what was being subordinated. McKenna 'thought

1. Kitchener to RMcK, 31 March 1915; Kitchener, 'The Financial Situation', 27 July 1915; Lloyd George to Christopher Addison, 2 November 1915, in Four and a Half Years, by Christopher Addison (1934), 144. As did Runciman: Runciman to Kitchener, 12 August 1915, Kitchener papers, PRO 30/57/80/15-16; Walter Long, Memories (1923), 221-23.

2. Robertson to Murray, 5 April 1916, Sir Archibald Murray papers, 52461/125.

3. Robertson to Haig, 27 January 1916, Robertson papers, 1/22/19; Robertson to Cavan, 5 May 1916, Cavan papers, WO 79/66.

4. Robertson to Haig, 4 November 1916, Robertson papers, 1/22/7; Montagu, memorandum, n.d., Roberts papers, Mss. Eur. F170/10/8-9.

5. Kitchener to RMcK, 5 August 1915. 
that Ll.G and Law were playing for conscription or a general election'. ${ }^{1}$ It was clear which would be worse. He told Scott in September, 'There are 100 ways of winning the war and only one of losing it-conscription.'

The exigencies of war had brought inevitable social restrictions. Although Churchill, the proponent of 'war socialism', had advised Clementine 'drink a generous red wine \& buy some clothes of taste and jauntiness, to show contempt of McKenna \& his parsimony, ${ }^{3}$ Arnold Bennett was even reduced to being his own chauffeur. "The other one has at last "joined"; so we have laid up the big car, and I am now to be seen careering about in a Ford', he told Pamela. 'Yet it is said that we do not take the war seriously'. ${ }^{4}$ One party at Smith Square in September 1915 had to squeeze in Wedgwood Benn, before, like Churchill, he went off to war, Asquith, Masterton Smith, Bluey Baker, Edwin Montagu, Sylvia Henley, Lady Sheffield, Buckmaster, Clifford Carver, Lady Scott, Mrs Keppel, Viola, Aubrey Herbert, Francis McLaren, Cynthia Asquith, Beb Asquith, Lord Reading, Lord Elibank, Lady Cunard, and Bar. ${ }^{5}$ Another had Clementine fleeing in disgust at McKenna's 'tepid counter-jumping calculation ... he really is a most noxious creature' ${ }^{6}$

For Asquith, political necessity had unwelcome social consequences. "We could have done very well without Nancy, B. Law, the "Margarine King", and other disfigurements of the landscape, ${ }^{7}$ he told Pamela. The following evening, he sought redress in calling for more familiar faces, but one advantage of the exigencies of war tack for her husband was that it could be applied to civilian life.

Only the Grace of God which has kept me from Bridge at No. 10 is responsible for this or any other letter from me. I have had one unbroken rush since you left till 9.15 this evening when in the company of Hamilton, I broke out into eggs and bacon at this [Reform] club, only to be interrupted by a telephone message that I was expected to dinner by Mrs Asquith and would I come in later to play bridge. Ten minutes afterwards another telephone to say that they were 12 and if I preferred to stay away I might-and I did. ${ }^{8}$

1. Hobhouse, diary, 17 June 1915, Diary, 248; RMcK to HHA, 16 June 1916, McKenna papers, 5/8/9.

2. L. T. Hobhouse to Scott, 24 September 1915, Scott papers, 50908/125; RMcK to Scott, 15 October 1915, Scott papers, 50902/13.

3. Churchill to Clementine, 8 December 1915, Companion, iii:2, 1319.

4. Arnold Bennett to PMcK, 17 June 1915.

5. PMcK, note, 5 September 1915.

6. Clementine to Churchill, 29 January 1916, Churchill papers, CHAR $1 / 118 \mathrm{~A} / 43$.

7. HHA to PMcK, 17 August 1915.

8. RMcK to PMcK, 18 August 1915. 


\section{Reginald McKenna}

There were still occasions for bravery under fire. During one debate, the noise of explosions was heard in the chamber, followed by cries of 'Zeppelin', and the chamber rapidly emptied, except for the Speaker and McKenna, who was speaking at the time. ${ }^{1}$ He remarked the next day it was lucky he had 'taken off the duty on plate glass just in time for the air raid last night'.2

\section{CONTROLS}

With the possibility of a short war past, the gravity of resource allocation was finally being recognised in the autumn of 1915. 'This is a horrible place,' Asquith wrote to Pamela from No. 10. 'Full of cross-currents, and smouldering fires, and trimming sails, of bold bad men, and timid good men, and of men who are neither good nor bad. I might add indefinitely to the catalogue, but I will spare you. ${ }^{3}$ Division within the Cabinet hardened. McKenna suggested either a reduction of consumption or an increase in production. His conclusion was that lavish expenditure, as demanded by conscriptionists, was only possible in the short term if backed by the promise of military victory by the spring of 1916; in its absence, such expenditure would have to be met by a sudden contraction. Alternatively, a more measured approach could be conducted. ${ }^{4}$ Unionists would hear nothing of it. After one meeting, according to Leith Ross, McKenna 'used the most violent language to his secretary about Chamberlain'. ${ }^{5}$

'Amongst our resources at the present time, there is no one which is more important than our possession of American securities', ${ }^{6}$ the chancellor told one delegation. The Bank of England had, on Treasury instructions, been buying British-held American securities for sale in New York since June 1915. The Americans were happy, emulating the City of London as the world's financial centre, and creating a large acceptance market in New York. ${ }^{7}$ It was clear to McKenna that future loans had to be different. 'Americans have always been borrowers, and not lenders; and the whole system

1. Michael MacDonagh, diary, 13 October 1915, in In London During the Great War: The Diary of a Journalist, by Michael MacDonagh (1935), 82.

2. RMcK, 14 October 1915, in Thomson, Scene, 250.

3. HHA to PMcK, 10 September 1915.

4. Bradbury, Cabinet papers, CAB1/13; Keynes papers, T/7/38.

5. Leith Ross to his mother, 27 November 1915, Leith Ross papers, T188/267.

6. RMcK, 19 November 1915, Treasury papers, T172/223/4; RMcK to Worthington-Evans, 10 November 1915, Worthington-Evans papers, 894/7.

7. Strong to Norman, 1 October 1915, Norman papers, G35; Lester Chandler, Benjamin Strong, Central Banker, Washington D. C., (1958), 81-86; Carl Parrini, Heir to Empire: United States Economic Diplomacy, 1916-23 (Pittsburgh, 1969), 101. 
of American finance does not readily admit of the issue of great loans.' Americans were, moreover, accustomed to lending on security, rather than on racial pacts with distant warring tribes. McKenna thought that London institutions should lend securities in their possession to the government. 'For the purpose of raising funds in the United States we do not need anything more than the physical possession of American securities.' ${ }^{2}$ The challenge to the Treasury was in getting them. ${ }^{3}$ Still convinced that cooperation was more productive than coercion, McKenna decided to press institutions to lend their securities to the government, which would then borrow upon them in New York. They would only be sold if money could not be borrowed on them, but he did not intend selling them: 'We are not in the least anxious to sell. The fact that the power exists is primarily what is needed. ${ }^{4}$ The policy required a stable foundation, which took the form of an exchange rate pegged at $\$ 4.76$ to the pound. The peg highlighted the risks of which McKenna had warned, for on the peg hung British capacity to fight: a suspension of payments would remove the peg; credit would collapse, as would the spending of France and Russia, and the Entente war effort.

McKenna served as guarantor for institutions that realised the next step was compulsion of their resources. 'I am trustee for the state,' he said. ${ }^{5}$ For his critics, McKenna's rejection of compulsion-here as elsewhere-confirmed his weakness. Yet he wanted to avoid compulsion, not because it contravened the conventions of British financial practice, which it did, but because he felt the ends required were those best effected with the support, rather than the coercion, of the City. "If you do not trust the country it is all up, he told the Trust companies. ${ }^{6}$ The consequence of compelling financial mobilisation would be to damage confidence and prompt the withdrawal of foreign deposits from London, with settlement having to be met in gold, and resulting in the probable suspension of payments. ${ }^{7}$ Even a supporter of Lloyd George, such as C. P. Scott, realised this and commented on how Lloyd George had 'misrepresented' McKenna's attitude 'as timid and obstructive' through 'making a bogey of the adverse American exchange ... I should think McKenna has a much saner judgement than he on a question of that kind.8

1. RMcK, 19 November 1915, Treasury papers, T172/201.

2. Ibid.

3. RMcK to Cunliffe, 18 November 1915, 'Bank of England', ii:13-21, Bank of England papers, ADM2/2; Keynes to Bradbury, 13 August 1915, Treasury papers, T170/62; RMcK to Chalmers, 12 November 1915, T170/66.

4. RMcK to Whittaker, 11 December 1915, Treasury papers, T172/221/43.

5. RMcK, 11 December 1915, Treasury papers, T171/221/28.

6. RMcK, 19 November 1915, Treasury papers, T172/223/25.

7. Ibid.; Montagu to HHA, 30 December 1915, Montagu papers, AS5/1/ 5(S)1130(2); Keynes, 6 November 1915, T170/73; Norman, diary, 30 May 1916, 14 June 1916, Norman papers, ADM 34/4.

8. Scott to L. T. Hobhouse, 26 September 1915, Scott papers, M/132/214. 


\section{Reginald McKenna}

By December 1915, the French were convinced that McKenna was not determined to press for victory, while the chancellor's relations with the Russians by this point had effectively broken down. ${ }^{1}$ The compulsionist party felt that indiscriminate purchasing, if not quite desirable in itself, was only to be expected in wartime, and anything less was obstructionism. As McKenna had done with Mulliner, when he was at the Admiralty, 'capacity' was employed as his most effective form of control: what could not be produced would not be paid for and so underspending served as a safety net-and in the form of shipping, it also served to relieve the exchange. ${ }^{2}$ Otherwise, the freight question remained unanswerable. ${ }^{3}$ McKenna felt that Germany had advantages over Britain in not depending on imports and having lines of internal communication, as well as the security provided from a defensive aspect. What became increasingly clear was an unexpected consequence of blockade: it did not make Germany more efficient, McKenna told Scott, but 'by diverting so enormous a proportion of shipping to war purposes, we were in fact engaged in most effectively blockading ourselves.' Another pillar of McKenna's Admiralty policy augmented the blockade: Continuous Voyage without let or hindrance, and its infraction as a casus belli for the Americans, on whose cooperation the war effort increasingly depended. ${ }^{5}$

\section{THE FIRST DECEMBER CRISIS}

Underlining his decision not only to retain but also to promote McKenna in May 1915, Asquith continued to risk much over him that winter. In November, the Prime Minister decided to reconstruct the body charged with the higher direction of the war, and to replace the Dardanelles Committee with a smaller War Committee. The Dardanelles Committee had itself, in June 1915, replaced the War Council, which had, in November 1914, effectively replaced the Cabinet. In each, McKenna had been present. With each, the attitude of Lloyd George and Unionists that membership was still too large, and generally grew even larger, had hardened. Asquith having been persuaded

1. Bouillon to I.loyd George, 11 December 1915, Riddell, diary, Riddell papers, 62959; RMcK to HHA, 25 March 1916, McKenna papers, 5/10/18.

2. Keynes, 18 December 1915, Keynes papers, T/10/54.

3. RMcK to Jellicoe, 11 September 1915, Jellicoe papers, 49035/89; Fisher to Jellicoe, 16 April 1916, Jellicoe papers, 49007/153-54; RMcK, 29 February-3 March 1916, Scott, diary, Scott papers, 50902/178-80.

4. RMcK to Scott, 23 February 1916, Scott papers, 50902/171; Fisher to PMcK, 2 April 1916, McKenna papers, 6/9/1; Fisher to RMcK, n.d. [1916], McKenna papers, 6/12/8; Whigham to Curzon, 28 August 1916, Curzon papers, F112/112B; Spring-Rice to Balfour, 30 January 1916; R. Houston to RMcK, 23 February 1916, Runciman papers, 149/1.

5. Spring-Rice to Grey, 29 January 1916, Grey papers, FO800/86/32-33. 
to concentrate authority even further, then 'spent the week-end before the names ... were announced with the McKennas, and when he returned on Monday, he announced that he had decided to make McKenna a member of the committee!' The new committee comprised Asquith, Kitchener, Balfour, Law, McKenna, and Lloyd George. The chancellor's inclusion, The Times observed, 'was not expected by the political prophets'. ${ }^{2}$ Lloyd George was 'much annoyed that McKenna had been added', Riddell wrote. 'He says that McKenna worried the PM into appointing him and that in so doing he had not played the game'. ${ }^{3}$ Churchill was similarly disgusted, both at McKenna's manoeuvre and its potential consequences. 'He is dangerous' ${ }^{4}$ Lloyd George complained to Scott that 'we were now living under a McKenna regime.'

Though he gave the impression of confidence to backbenchers, indeed, that the war would be over by the end of $1916,{ }^{6}$ McKenna's concerns had been growing. The War Committee offered another platform to express them, and particularly the limits of available manpower. Whereas the conscriptionists demanded seventy divisions or 35,000 men per week, McKenna maintained the country could only afford fifty, or 10,000 recruits. ${ }^{7}$ With the Entente's lack of success, by the autumn of 1915 the likelihood of British troops being committed en masse increased. Kitchener's significant decision to support conscription was covert recognition of the inelasticity of manpower. The compromise between Liberals and Unionists was a scheme supervised by Lord Derby: first men would register to serve, then attest that they would. Unmarried men would be called up before those with families.

By the end of the year, however, Asquith had come to experience his own inelasticity of manpower. 'In the fullest sense of the word a Hellish week,' he told Pamela on New Year's Day. 'One of the worst even in my storm-tossed annals'. ${ }^{8}$ On 27 December, Lloyd George threatened to resign; the following day it was McKenna's turn. The complaint was conscription, but the symptoms were more general. Resolution took the form of the Derby Scheme: a national register of men, intended as an exercise in information but ostensibly a political census, "which is not to be in the hands of an incompetent War Office'. ${ }^{9}$ After what was regarded as an insufficient number of men had

1. Lloyd George, 15 November 1915, in Stevenson, Diary, 72; HHA to Sylvia Henley, 10 November 1915, Asquith papers, 542/2.

2. Times, 12 November 1915.

3. Riddell, diary, 14 November 1915, Riddell papers, 62959; Geoffrey Robinson to Sir Edward Goulding, 11 November 1915, Wargrave papers, 2/37.

4. Churchill to Clementine, 8 December 1915, Companion, 3:2, 1409.

5. Lloyd George to Scott, c. 13 November 1915, in The Political Diaries of C. P. Scott 1911-1928, ed. Trevor Wilson (1970), 157.

6. MacCallum Scott, diary, 17 November 1915, MacCallum Scott papers, $1465 / 6 / 321$.

7. Hankey, diary, 30 December 1915, Hankey papers, 1/1/126-27.

8. HHA to PMcK, 1 January 1916.

9. RMcK to PMcK, 5 September 1915. 


\section{Reginald McKenna}

attested to serve, Asquith consented to the drafting of a conscription bill, to be introduced in the New Year. Then, 'Today, alas! The sky is covered with clouds and thick darkness, and a thunderbolt has fallen', he told Pamela. ${ }^{1}$ McKenna, Runciman, and Simon announced their intention to resign. Margot then turned to Pamela's husband, from her bed, on 28 December. 'Henry always said to me, "If all my colleagues were to turn on me, McKenna never would." Not till I hear it from your own lips will I believe it.'

Earlier in the day, McKenna and Runciman went to 10 Downing Street and tendered their resignations. ${ }^{3}$ McKenna's resignation letter declared that:

In my judgement, the policy approved by the Cabinet entails the maintenance of an army of a size which will gravely embarrass the country in giving the support to our Allies in directions which are of greater importance in the common prosecution of the war to a successful conclusion. Demands have been made and are being met which I admit can only be met by compulsion, but they are demands which, however, met, are in my opinion inconsistent with other and not inferior obligations into which we have already entered ... [I]t would prejudice the policy which has been adopted if its control or execution were to remain in the hands of a minister who was not in full sympathy with it. ${ }^{4}$

The three had, Runciman told his wife, 'a most unpleasant interview, ending with not even a handshake'. 5

McKenna had 'rather surprised'6 Asquith by his position, but in form rather than substance. He did not oppose the proposed conscription bill, but the size of the army it presupposed. Asquith's dilemma was twofold: the political necessity of retaining his chancellor and principal lieutenant and his private sympathy with McKenna's objections. It would have assisted him if his chancellor could persuade others. 'Though McKenna is right on

1. HHA to PMcK, 28 December 1915; RMcK, 28 December 1915, McKenna papers, 5/9/1-4; Runciman to Hilda Runciman, 28 December 1915, Runciman papers, 303/2; Kathleen Scott, diary, 29 December 1915, Asquith papers, 52/125; HHA to RMcK, Runciman, and Simon, 28 December 1915, Simon papers, 52/26; Runciman, 1 January 1916, Runciman papers, 149/1; HHA to Violet Tree, 30 December 1915, Tree papers, 59895/34; Esher, diary, 1 March 1916, Esher papers, 2/15.

2. MA to RMcK, 28 December 1915, McKenna papers, 5/9/9.

3. HHA to Montagu, Montagu papers, AS1/1/45; HHA to Sylvia Henley, 28 December 1915, Asquith papers, 542/2/504; HHA to Sylvia Henley, 29 December 1915, Asquith papers, 542/2/509; Kathleen Scott, diary, 29 December 1915, Asquith papers, $152 / 125-26$.

4. RMcK to HHA, [draft] 28 December 1915, McKenna papers, 5/9/1.

5. Runciman to Hilda Runciman, 28 December 1915, Runciman papers 303/2.

6. HHA to Sylvia Henley, 28 December 1915, 542/2/504. 
his case', Maurice Bonham Carter told Violet, 'he almost damns himself to perdition by his animus against his opponents'.

'I am afraid that this is the climax of 6 months of discontent and protest on their part', Asquith told Montagu. 'Can you and Rufus do anything with them to-day?'2 The prime minister also set Margot to work. 'A wife can play a big part in a great crisis like this', she told Pamela.

If the Chancellor whom I love really cares for Henry and believes him necessary to our country just now he must stick to him. Thro' LI.G's treachery and baseness your husband and Mr Runciman and others feel that Henry has come down on the wrong side on Ll.G's side, and this is more than they can stand. I sympathize. . . He is a hound of the flimsiest disloyal ungrateful kind. What counts for most with Mr McKenna his love for Henry or his hate for Ll.G? That is the whole question and by this he will be tested. ${ }^{3}$

The single mitigating concession in the measure was that no married men would be taken until all single men had been recruited. McKenna knew he would better influence the debate by remaining in the Cabinet. A continued existence as martyrs was preferable to a sudden and enforced reacquaintance with the backbenches-'annihilation', as Runciman put it-followed by a " "round up the shirkers" election ... EG holds this strongly, so does Reggie'. ${ }^{4}$

'Nobody has any business to resign', Birrell told Pamela. 'To do so is to deliver over the keys of the fortress'. ${ }^{5}$ Only Simon left. ${ }^{6}$ Runciman would not leave without McKenna, and McKenna and Grey were locked into another of their compacts: given their respective perspectives, the actuarial and the haunted consciences of Liberalism. Asquith told the king he was 'disgusted' by Grey's attitude, ${ }^{7}$ but managed through private entreaties, and through those of others, to persuade McKenna to withdraw his resignation. ' 'The

1. Maurice Bonham Carter to Violet Asquith, 31 December 1915, in Lantern Slides, Diaries and Letters of Violet Asquith, eds. Mark Bonham Carter and Mark Pottle (1996), 90.

2. HHA to Montagu, 28 December 1915, Montagu papers, AS51/1/45.

3. MA to PMcK, 28 December 1915; Cynthia Asquith, diary, 29 December 1915, Diaries, 1915-1918 (1968), 117.

4. Runciman to Hilda Runciman, 30 December 1915, Runciman papers, 303/2; Elibank, diary, 17 June 1916, Elibank papers, 8814/137; New York Times, 7 January 1915 .

5. Birrell to PMcK, 15 January 1916.

6. Hankey, diary, 30 December 1915, Hankey papers, 1/1/126; Long to HHA, 2 January 1916, Asquith papers, 16/1.

7. Stamfordham, memorandum, 29 December 1915, RA PS/GV/K 869/3; HHA to Sylvia Henley, 29 December 1915, Asquith papers, 542/2/508-9.

8. Montagu to Grey, 30 December 1915, Montagu papers, AS6/10/28; J. H. Whitehouse to RMcK, 24 December 1915, McKenna papers, 5/9/6; Harcourt to 


\section{Reginald McKenna}

country cannot afford to lose its sanest elements', Hankey told him. 'As a private individual bent on his country's good, and as a friend, I implore you not to resign if you can help it. ${ }^{1}$ Even Montagu urged him to stay. ${ }^{2}$ Those who urged McKenna to leave were as strident as they were less numerous. ${ }^{3}$ The knowledge that his resignation was exactly what Lloyd George and the 'militarists and extremists' ${ }^{4}$ wanted may also have been in the chancellor's mind. The bill went ahead, McKenna remained. ${ }^{5}$ Since his doubts had always been about the precedent established rather than the principle conceded, it was the only tenable course once resignation had been resisted; or deferred. 'Liberalism is for the moment lost', Massingham told him, 'but it will revive if some hope of the future exists' ${ }^{6}$ The measure, Hankey assured McKenna, much as McKenna had assured supporters over his duties, 'is an opportunistic ad hoc arrangement'. 'By remaining, the chancellor had the chance of effecting the greater goal. 'McKenna thinks we could probably get a better peace now than later when Germany is wholly on the defensive,' Hankey noted, 'and I am inclined to agree. ${ }^{8}$ On 4 January 1916, Asquith went to the Commons to "introduce this damned Bill."

The following day, Montagu reported to Asquith, 'McKenna has been playing a noble game all day in persuading members to vote for the bill' ${ }^{10}$ Lloyd George told Churchill that McKenna 'is much weakened by his defeat', ${ }^{11}$ yet McKenna's resignation had not actually been withdrawn so much as suspended. As late as 4 January 1916, Stamfordham told the king that 'McKenna may not remain."12 Indeed, Ernest assured Arnold Bennett, 'Reginald [is] still quite determined to leave the Cabinet if it tried to outrun the constable.' ${ }^{13}$ The main consequence of Simon's resignation and bathetic resignation speech was the further attenuation of the Liberal contingent in

RMcK, 28 December 1915, McKenna papers, 5/9/7; Aga Khan to RMcK, n.d., McKenna papers, 5/9/25; Perks to RMcK, 29 December 1915, McKenna papers, 5/9/11; HHA to PMcK, 5 January 1916.

1. Hankey to RMcK, 25 December 1915 , McKenna papers, 5/9/5.

2. Montagu to RMcK, 28 December 1915, McKenna papers, 5/9/10.

3. Whitehouse to RMcK, 31 December 1915, McKenna papers, 5/9/18; Hirst to RMcK, n.d., McKenna papers, 5/9/24.

4. Hankey to RMcK, 25 December 1915, McKenna papers, 5/9/5.

5. Montagu to HHA, 6 January 1916, Asquith papers, $16 / 3$.

6. Massingham to RMcK, 1 January 1916, McKenna papers, 5/9/21.

7. Hankey to RMcK, 25 December 1915, McKenna papers, 5/9/5.

8. Hankey, diary, 22 January 1916, Hankey papers, 1/1/138.

9. HHA to PMcK, 4 January 1916.

10. Montagu to Asquith, 6 January 1916, Montagu papers, AS5/1/7.

11. Churchill to Clementine, 1 February 1916, Companion, iii:2, 1409.

12. Stamfordham, memorandum, 4 January 1916, RA PS/GV/K 869/4.

13. Arnold Bennett, diary, 15 January 1916, in The Journals of Arnold Bennett, vol. 2, 1911-1921, ed. Newman Flower (1932), 151; Hankey, diary, 3 January 1916, Hankey papers, 1/1/129; Hankey, diary, 16 January 1916, Hankey papers, 1/1/132; HHA to Sylvia Henley, 17 January 1916, Asquith papers, 542/3/539. 
the Cabinet, to his immediate regret. ${ }^{1}$ As it was, Churchill complained to Lloyd George, 'you have enthroned McKenna at the Treasury, in the War Council, and in the confidence of the Liberal Party and press. ${ }^{2}$

\section{PAMELA}

After putting the chancellor on the War Committee in November, Lloyd George complained to Riddell that Asquith had been spending the 'weekend with the Jekylls and has no doubt been subjected to much feminine influence. Mrs McK, LG thinks, has been working hard in the interests of her husband'. ${ }^{3}$ Stronger in health and confidence, Pamela reached the peak in her role as political wife during the coalition. She was suspected in a similar way to Margot as a source of intrigues and leaks, but, being a more congenial personality, caused less offence. ${ }^{4}$ At a time when McKenna was barely on speaking terms with most of the Cabinet, the painter and critic Charles Holmes attended a Smith Square dinner, where Pamela's 'charm and beauty' 'dispelled in time these rather acrid political vapours, and ended delightfully an entertainment which for a novice had been almost too exciting. ${ }^{5}$ She was capable of bearing grudges-'Mrs McKenna hates Winston with the most deadly animosity' 6 - but also of maintaining good relations at the same time. Balfour 'formed a very high opinion' of her through her work with the National Relief Fund, which led to another epistolary affair, with one her husband's chief tormentors, Walter Long.' Lloyd George admitted 'she is a very clever little person'. ${ }^{8}$ Margot used Pamela not only to influence McKenna's actions but those of her own husband. ${ }^{9}$ Margot planned social events carefully lest 'the gossip will say Mr McKenna "got at" H', because McKenna's 'well advertised hatred of Ll.G makes it highly important for us all to be silent'. ${ }^{10}$ This was particularly so for the chancellor himself. 'Beg him

1. John Simon, Retrospect (1952), 107; MacCallum Scott, diary, 5 January 1916, MacCallum Scott papers, 14657/1; C. Tilbert to Simon, 30 December 1915, Simon papers, $52 / 34$.

2. Churchill to Lloyd George, 25 January 1916, Churchill papers, CHAR 2/71/1.

3. Riddell, diary, 14 November 191.5, Riddell papers, 62959; Geoffrey Robinson to Sir Edward Goulding, 11 November 1915, Wargrave papers, 2/37.

4. Scott, diary, 8 May 1916, Scott papers, 50903/3; Philip Magnus, Kitchener: Portrait of an Imperialist (1958), 289.

5. Charles Holmes, Self and Partners (Mostly Self) (1936), 325; E. M. House to Woodrow Wilson, 15 January 1916, in Woodrow Wilson Papers, xxxv, 484.

6. Riddell, diary, 14 January 1915, 62959.

7. 2nd Earl Balfour to Agnes Jekyll, n.d; PMcK to Sir William Bull, 3 April 1916, Bull papers, $4 / 13$.

8. Lloyd George, in Riddell diary, 14 November 1915, Riddell papers, 62959.

9. MA to PMcK, n.d. [January 1912, June 1914].

10. Ibid. 
not to criticize ... if Bonar or Ll.G make bad speeches and don't let him flatter them.'1

Asquith, infamously, had a number of female correspondents-and no male equivalents. In addition to Venetia Stanley, he wrote to her sister Sylvia Henley, to Kathleen Scott, widow of the explorer, to Hilda Harrisson, Viola Parsons, Ettie Desborough, and conceivable still others. To each, to varying degrees, he recounted his political experiences and revealed his personal feelings. What made those to Pamela McKenna unique, particularly during the coalition, was that the recipient was almost a functioning part of the Cabinet. Moreover, she alone of his correspondents was married not only to a colleague, but to one of the leading members of the government. Asquith had been accused of allowing his relationship with Venetia Stanley to affect his judgement in May 1915; he has also been accused by critics, and with more justification, of allowing his relationship with Reginald McKenna to affect his judgement throughout the eighteen months of the coalition. He grew closer to McKenna-and closer to Pamela. Their correspondence grew in regularity and increased intensity from May 1915 to December 1916, when she became the most favoured member of what Margot called her husband's 'little harem'.?

'Asquith at that time was very much prejudiced in favour of Mrs McKenna', Lloyd George said years later. ${ }^{3}$ Asquith admitted it.

There is only one person along all my friends who loves me entirely for myself, not with fluid eyes, or the intoxication of a blurred ... passion; who knows me as I am, with whatever strength I possess + also with all my weaknesses + shortcomings; and yet would (I sometimes think) rather be blotted out of the book of life than that I should cease to be. That one person is you. ${ }^{4}$

The relationship between Asquith and Pamela was the more striking when considered alongside that with Venetia Stanley. Both women married one of his ministers. Where his correspondence with Pamela increased on her marriage, that with Venetia stopped. When his correspondence with Venetia ended, he wrote with greater frequency to Pamela. It followed that Pamela's husband found himself closer to Asquith, and Venetia's found himself marginalised, and closer to Lloyd George. Venetia's conversion to Montagu's Judaism confirmed the breach. "What did you think of the conspicuous announcement in the "Times" to-day?' Asquith asked Pamela. 'I thought

1. MA to PMcK, n.d. [November 1915, May 1916].

2. MA, in Letters to Venetia Stanley, 1.

3. A. J. Sylvester, 28 November 1931, in Life with Lloyd George: The Diary of A. J. Sylvester, 1931-45, ed. Colin Cross (1975), 59.

4. HHA to PMcK, 3 October 1915.

5. Times, 17 July 1915. 
it an outrage, for it is a matter in which the public have no concern. ${ }^{1}$ In contrast, his relationship with Pamela was a source of resentment for some of his other female friends. ${ }^{2}$

Asquith deplored his predicament. When one woman told Asquith that everyone envied him his fate, 'I gazed and even glared at her in a stupor of astonishment.' ${ }^{3}$ The extraordinary nature of the circumstances had made Asquith more than ever dependent on Pamela. 'I went to the House, and in a speech of portentous dry-as-dustiness moved a vote of credit for about $£ 420$ millions', the leader of the war effort told her, one evening in February.

The House emptied and the debate collapsed, and I stole away in a taxi to 36 Smith Square and asked if I might see Mrs McK. I was quite hopeful and even confident, and met the strong negation of a man in shirt-sleeves with a cheerful request that the standing veto of visitors might be suspended in my case. After an interval of waiting the minion returned with the message that the house refused to allow anyone to cross the bed-room threshold of her patient. So I returned to the Palace of Westminster, with flagging steps and cursing lips, a disappointed man. ${ }^{4}$

In March 1916, Asquith left for Paris with Kitchener, Grey, and Lloyd George. 'After that, I am bound for Rome: Ll.G refuses to go: don't you think you might snuggle in? In some capacity or other', Asquith asked her.

I am afraid that noblesse oblige-or, in bald English, that the Chancellor of the Exchequer's wife must be above and beyond suspicion. Damn! Shall we ever get to the halcyon time when (in the absent millionaire's yacht) we can say with a free heart, and a full voice, 'lorgue la galère'?

For almost the exact duration of the coalition, Asquith wrote to Pamela most days, a natural reflection of his feelings of 'Our sacred, secret, thrilling intimacy, which never fails on either side in expression and response, is to me, and as long as we both live will I believe be to both of us, a thing quite unique, and unshareable-except by us two. ${ }^{6}$ More prosaically, it served to improve the attendance of a reluctant House of Commons man. Whenever the chancellor was due in the chamber, Asquith went up to the ladies' gallery to find his wife, and wrote again, to complain, if she was not there. "I have just "climbed the steep ascent" (as the hymn says) which leads to

1. HHA to PMcK, 17 July 1915; Cynthia Asquith, 12 June 1915, Diaries, 42.

2. Cynthia Asquith, 28 May 1916, Diaries, 168.

3. HHA to PMcK, 7 December 1915.

4. HHA to PMcK, 21 February 1916.

5. HHA to PMcK, 23 March 1916.

6. HHA to PMcK, 12 October 1915. 
your accustomed lair, only to be informed by the austere Johnson that "Mrs McKenna has not arrived yet"!' Occasionally, the 'steep and disappointing

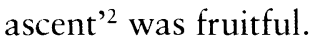

Midnight. I am sure it was an absolutely unique incident. Scene The Speaker's Ladies Gallery Personae P.M Wife of C of Ex Otherwise-untenanted twilight space Down below The intermittent hum of drones above Everything that no one could imagine From the time of Simon de Montfort there has, I am certain, been nothing like it. This memory alone-apart from others + from hopes ought to link us together for all time. You $+m e^{3}$

\section{THE THREE CHANCELLORS}

The conscription crisis over, the next 'question which has divided the Cabinet, the dispute between McKenna and Kitchener,' ${ }^{3}$ as Esher put it, was McKenna's attempt to delay the spring offensive until the summer. 'Lord Kitchener is anxious to arrive at an agreement with the Chancellor,' Stamfordham told the king. ${ }^{5}$ It was consistent with his attitude at the Admiralty that he attended the first tank trials with Asquith and Lloyd George at Hatfield Park, and promised 'all the finance necessary', ${ }^{6}$ but the main issues would be addressed in another new forum devised by Asquith to debate the conduct of the war: the Committee on the Coordination of the Military and Financial Effort.' 'Mr McKenna is to meet Sir W. Robertson ... and discuss with him the question of numbers and finance,' Asquith told the king. ${ }^{8}$ Conscription was proving to be an opportunity. Where recruiting had been unpredictable-when it had not been indiscriminate-conscription would allow for a rational allocation of resources, with obvious appeal for an 'economist'. 'On the policy as stated to me', Montagu told Asquith, 'I feel that McKenna ought to win'?

1. Ibid., 4 November 1915.

2. Ibid., 4 January 1916.

3. Ibid., 29 September 1915.

4. Esher to Stamfordham, 25 January 1916, RA PS/GV/Q 724/66.

5. Stamfordham, memorandum, 4 January 1916, RA PS/GV/Q 869/4.

6. Sir Albert Stern to PMcK, 7 September 1943.

7. Stamfordham, memorandum, 29 December 1915, RA PS/GV/Q 869/3; Robertson to Haig, 31 December 1915, Robertson papers, 1/22/4; RMcK, 1 January 1916, Cabinet papers, CAB41/37/1; Hankey, diary, 30 December 1915, Hankey papers, $1 / 1 / 126$.

8. Stamfordham, memorandum, 29 December 1915, RA PS/GV/Q 869/3.

9. Montagu to HHA, 6 January 1916, Asquith papers, 16/3. 
The committee consisted of three of Cabinet's chancellors-McKenna, Asquith, and Chamberlain —and met thirteen times in January 1916. ${ }^{1}$ This time McKenna said he was 'confident ... that the carrying on of the scheme proposed by the General Staff would force us off the gold standard', with the result that Germany would offer greater resistance and 'would not give in for mere defeat unless she was absolutely overwhelmed'. ${ }^{2}$ It was all a matter of timing, for timing introduced the element of pace, which, with capacity, gave McKenna both a framework for his concerns and constructive means of addressing them. He was "all in favour of "squeezing" the war machine', but he did not wish to break it. 'If we went on withdrawing men slowly we could last for an indefinite time.' ${ }^{3}$ The army had to give up some of its men, or the allies give up some of their money. The War Office proposals, McKenna said, were a gamble on beating Germany by August. If this were not done they would all be 'done for.' 'Unless the allies could gain some military victory before the economic pressure on them became as great as it was on Germany, the allies might make peace ... [T] he action favoured by the general staff might paralyse us in the spring. ${ }^{.4}$ It was all 'a matter of time.'s

McKenna was a source of frustration for Asquith, mainly because he agreed with him, but was also aware that few others did. ${ }^{6}$ It was a perilous position for the prime minister, which the "dizzy gyrations of the $\mathrm{C}$ of the Ex" did little to steady. In fact, Lloyd George thought, McKenna "had acquired an extraordinary influence over Asquith largely by saving him the trouble of thinking. ${ }^{8}$ Nevertheless, 'Chamberlain had been much impressed by McKenna's case, ${ }^{9}$ Montagu told Asquith, who admitted to Lady Scott, 'the Dickens is I so agree with him' ${ }^{10}$ There was much of the 1909 spirit to deliberations, and both Asquith and Hankey-who, McKenna told Fisher, 'is now the one man Asquith relies upon'11 - found themselves exhausted by the chancellor's relentless working methods. ${ }^{12}$ Nevertheless, rather as Lloyd George did in 1909, Chamberlain ended up upbraiding the chancellor for

1. Earl of Oxford and Asquith, Memories and Reflections, 1852-1927 (1928), 2:125; HHA to Sylvia Henley, 1 January 1916, Asquith papers, 542/3/576; HHA to George V, 1 January 1916, Cabinet papers, CAB41/37/1, CAB27/4, passim.

2. RMcK, 12 December 1916, Cabinet papers, CAB27/4/8/184.

3. RMcK, 20 January 1916, Cabinet papers, CAB27/4/11/258.

4. RMcK, 14 January 1916, Cabinet papers, CAB17/4/9/200.

5. Ibid.

6. HHA to Kathleen Scott, 11 February 1916, Asquith papers, 152/130.

7. HHA to Sylvia Henley, 6 February 1916, Asquith papers, 543/3/562.

8. Lloyd George, 13-15 November 1915, Scott, Diaries, 157.

9. Montagu to HHA, 3 January 1915 [sic: 1916], Montagu papers, AS1/1/48(1).

10. HHA, 13 January 1916, Kathleen Scott, diary, Asquith papers, 152/129.

11. Fisher to Jellicoe, 8 February 1916 , Jellicoe papers, $49007 / 89$.

12. HHA to Sylvia Henley, 12 January 1916, Asquith papers, 542/3/582; Hankey, diary, 20 January 1916, Hankey papers, 1/1/136. 


\section{Reginald McKenna}

being 'over-sanguine'. ${ }^{1}$ The final report decided on sixty-two divisions, more than McKenna intended, but a compromise nevertheless, and one reinforced by another committee in April to consider the course of events. ${ }^{2}$ The report, rather like that of Beresford in 1909, was a pyrrhic victory. ${ }^{3}$ McKenna had secured much that was purely financial in effect, though the wider meaning was lost. 'There can be no guarantee worth having which permits 67 or 70 divisions now', said Runciman, who was less inclined to remain in office at the end of January than he had been a month earlier. "We must decline to be swindled with our eyes open'. 'McKenna and Co. waste their time fighting colleagues over this', Esher told Balfour; if the French were unable to maintain the war effort much longer, 'McKenna need not fuss, and every available recruit should commence training at once for the Armageddon this summer.'

\section{THE SECOND BUDGET}

There were signs that the situation had upset the chancellor. 'McKenna's behaviour is very mysterious just now', his private secretary Alan Parsons told Duff Cooper in February. 'He writes long letters with his own hand to Northcliffe and often disappears for an hour without saying where he is going to'. 7 He had 'proved himself unstable mentally and morally', Lady Scott recorded Asquith as saying the following day. 'Moreover he hadn't the excuse of a stupid man, nor the excuse of artistic temperament or any such thing. It saddened him' ${ }^{8}$ In March, McKenna told Fisher that the government was in crisis and 'can't last many weeks longer!'; 9 the following day Hankey found him 'very jubilant about his budget and his revenue was coming in extraordinarily well, while his expenditure was below the

1. Austen Chamberlain, 20 January 1916, Cabinet papers, CAB27/4/11.

2. Report, 4 February 1916, Cabinet papers, CAB27/4/10.

3. Montagu to HHA, 5 February 1916, Asquith papers, 16/48; Hankey, diary, 1 February 1916, Hankey papers, 1/1/142; Robertson to Haig, 22 March 1916, Haig papers, 3155/105/36a; Runciman to Hilda Runciman, 11 January 1916, Runciman papers, 303/2; Bonar Law, 10-11 January 1916, Scott diary, Scott papers, $50902 / 91$.

4. Robertson to Haig, 27 January 1916, Robertson papers, 1/22/19.

5. Runciman to RMcK, 23 January 1916 , McKenna papers, 5/9/23.

6. Esher to Balfour, 25 January 1916, Balfour papers, 49719/278; Esher to Stamfordham, 25 January 1916, Esher papers, 2/15.

7. Duff Cooper, diary, 12 February 1916, in The Duff Cooper Diaries, 19151951, ed. John Julius Norwich (2005), 24; Tom Clarke, diary, 29 December 1915, My Northcliffe Diary (1931), 87. However many Parsons claimed RMcK wrote, only one survived, and that concerned the excess profits tax (RMcK to Northcliffe, 9 February 1916, Northcliffe papers, 62157/202).

8. HHA, 11 February 1916, Kathleen Scott, diary, Asquith papers, 152/130.

9. Fisher to Jellicoe, 16 March 1916, Fisher, Correspondence, 3:331. 
estimate'. ${ }^{1}$ One explanation for the chancellor's gyrations was a nervous indisposition. Another was that his warnings, if not having produced the desired effect, had at least predicted what would happen. Capacity, as he had hoped, had provided its own control.

McKenna delivered his second budget on 4 April 1916. It reflected the realisation of the limitations of fiscal policy, and deepened rather than broadened the tax take. Total revenue, expected to be $£ 502 \mathrm{~m}$, was three times the total for the last financial year before the war. Income tax was raised to a maximum of five shillings in the pound on incomes over $£ 2,500$, thereby raising an extra $£ 44 \mathrm{~m}$ a year. Partly in consequence, the supertax was not increased. McKenna's attempted resolution of the fiscal disparity between his Excess Profits Tax and Lloyd George's Munitions Levy produced another row between the two and another threatened resignation from the latter. ${ }^{2}$ It was raised from 50 to 60 percent. There were increases to the taxes he had imposed in September on cocoa, coffee, and chicory, and new taxes on entertainment, railway tickets, and matches.

Such measures failed to compensate for the budget's relative lack of substance- and the general lack of progress in the war-and, though applauded, the response was less positive than before. ${ }^{3}$ Not only were there no ostentatious breaches with hitherto sacrosanct principles, McKenna maintained that nothing had happened to change the realities of fiscal questions. ${ }^{4}$ There was one innovation. Where before there had been the McKenna Duties, there was now the 'McKenna Rule': taxation would be sufficient to cover interest charges on new borrowing. The rule implicitly admitted that the war could only be financed by borrowing, but was a measure unprecedented in any belligerent: 'to fulfil that principle is the minimum duty of the Chancellor of the Exchequer.' It was also another example of how effective McKenna's

1. Hankey, 17 March 1916, Hankey papers, 1/1/167; Keynes, 15 March 1916, in The Collected Writings of John Maynard Keynes, vol. 16, Activities, 1914-1919: The Treasury and Versailles, ed. Elizabeth Johnson (1971), 184-88; Scott, diary, 8 February 1916, Scott papers, 50901/132.

2. Crewe to George V, 1 January 1916, Cabinet papers, CAB41/37/1; Scott to Lloyd George, 29 February 1916, Lloyd George papers, D18/15/9; Lloyd George to RMcK, 1 April 1916, Lloyd George papers, D/17/12/4; RMcK to Lloyd George, 3 April 1916, Lloyd George papers, D17/12/5; Lloyd George to RMcK, 13 May 1916, Lloyd George papers, D/17/12/6.

3. RMcK, Parliamentary Debates, 4 April 1916, 1049-65; Selborne to RMcK, January 1916, Selborne papers, 82/86; HHA to George V, 23 March 1916, Cabinet papers, CAB41/37/12, 55-58; Hirst, Political Economy, 316; Hirst and Allen, Budgets, 135; Nation, 8 April 1916; Glasgow Herald, 5 April 1916; Times, 6 April 1916; Hewins, diary, 14 April 1916, Hewins, Apologia, 68.

4. Chamberlain to Samuel, 9 April 1916, Samuel papers, 155/151-52.

5. RMcK, 22 April 1918, Parliamentary Debates, 721; but cf. Bruce Kent, The Spoils of War: The Politics, Economics and Diplomacy of Reparations 1918-32 (Oxford, 1991), 33. It was a principle McKenna also applied to the Royal Commission on Sugar Supply, which he chaired. Royal Commission on Sugar Supply HMSO, 1917, Cd.8728. See: 'Distribution of Sugar from July to Dec. 1916', R. Com. Memo.; 


\section{Reginald McKenna}

parliamentary manner could be. His speech, 'a marvel of lucidity, telling everything within the space of an hour, marked a striking revolution in a particular field of Parliamentary procedure', Sir Henry Lucy maintained. 'Beginning without exordium, it finished without a peroration'. ${ }^{1}$ The only drama came from Michael, seated in the gallery, who dropped his teddy bear on the rapt members below.

\section{COLLEAGUES}

'Thank heavens the worst of my labours are now over', ${ }^{2}$ McKenna told Pamela's friend the Duchess of Hamilton four days later. The chancellor's second budget consolidated his first and provided the framework for taxation during the war. Alfred Mond thought he spoke for free traders when he told McKenna that 'you have enormously damaged your position in the party', ${ }^{3}$ but, more generally, McKenna's reputation had rarely been higher. The master of Elibank had 'the greatest confidence in his judgement. My City friends think highly of him, and I believe one day he will be Prime Minister' ${ }^{4}$ Northcliffe told Massingham that McKenna 'was the best member of the Government!' For the first time, opinion of him improved with exposure. His Unionist colleagues gave grudging respect. Though he may have been 'a bigoted Cobdenite radical, with a narrow technical mind, a manner singularly devoid of charm and the appearance of a cock-sparrow', according to Selborne, "he has done his tremendous task pluckily and efficiently and with as small a proportion of blunders as anyone could expect. ${ }^{6}$ Crawford thought McKenna a 'radical wretch' who 'improved on acquaintance'?

With his nominal allies, however, old complaints resurfaced with greater frequency. Reading left at the end of July $1916 .^{8}$ A week later, from the Ministry of Munitions, where he had replaced Lloyd George, Montagu expressed his feelings in a letter to Margot.

It is not only tha[t] McKenna has found difficulties with Rufus, and with Lord Cunliffe-difficulties which I believe are irretrievable ... It is tragic to think that it is not really a question of ability; it is a question

1916, Cd.8395, xxiv, 537; 'Financing the Purchase of Sugar and Meat Abroad on behalf of H. M. Government', Treasury minute, 20 July 1916, Cd.8326, xxiv, 533.

1. Lucy, diary, 5 April 1916, Diary, iii: 245

2. RMcK to Duchess of Hamilton, 9 April 1916, Fisher papers, 4/1/16.

3. Mond to RMcK, 14 October 1915 , McKenna papers, 5/10/7.

4. Elibank to Spender, 7 June 1916, Elibank papers, 8804/28.

5. Massingham to RMcK, n.d., McKenna papers, 5/10/28.

6. Selborne memorandum, June 1916, Selborne papers, 80/289.

7. Crawford, Cabinet memorandum, 18 August 1916, Papers, 360.

8. RMcK to Rufus Isaacs, 29 July 1916, McKenna papers, 5/10/20; Rufus Isaacs to RMcK, 2 August 1916, McKenna papers, 5/10/21. 
of method and of manner ... Great resentment will inevitably be felt if public discussion ensues upon a situation which has been incurred by one Minister who has not chosen by reason of his own self-confidence, to seek support either from his colleagues or from his clientele ... The fact emerges that despite efficiency and ability of great value to the Government, McKenna is a bad colleague. ${ }^{1}$

Montagu had had to mediate between them when they fell out again over press collusion, ${ }^{2}$ a row that caused Asquith to despair of the 'the Lloyd GeorgeMcKenna feud,' ${ }^{3}$ when he was not 'pacifying Cunliffe and McKenna, ${ }^{4}$ or having 'fresh trouble with McKenna'. ${ }^{5}$ Montagu and Cunliffe resented not having 'the honour of being consulted or being present at or being invited to attend deliberations. ${ }^{6}$ He had, however, lobbied for McKenna's dismissal, or his appointment as secretary for war, first lord of the Admiralty, or even viceroy of India. ${ }^{7}$ The vision of McKenna on an elephant had again been reported in the press just before the first December crisis. ${ }^{8}$ Instead, Montagu 'almost at daggers drawn' with McKenna, ${ }^{9}$ was moved out, as was Reading, who had been similarly isolated. ${ }^{10}$

McKenna was 'fussed about who is going to replace E.M. ${ }^{11}$ Asquith offered 'little Jack Tennant', ${ }^{12}$ who was then at the War Office and who happened to be the prime minister's brother-in-law, and who also happened to have married McKenna's Clapham campaign worker May Abraham, but 'McKenna would not have him at the Treasury at any price' ${ }^{13}$ With a view to

1. Montagu to MA, 8 August 1916, Montagu papers, AS5/1/15/(1)1140(1) 'Not sent'.

2. Montagu to Lloyd George, 26 April 1916, Lloyd George papers, D/17/16/1.

3. Kathleen Scott, diary, 28 April 1916, Asquith papers, 152/134.

4. Ibid., 17 August 1916, Asquith papers, 153/19.

5. Ibid., 27 August 1916, Asquith papers, 153/20.

6. Montagu to RMcK, 5 May 1916, Montagu papers, AS6/9/2; HHA to Sylvia Henley, 23 August 916, Asquith papers, 542/4/126; Montagu to HHA, 2 May 1916, Montagu papers, AS1/1/2/26; Churchill to Rufus Isaacs, 7 September 1916, Reading papers, F118/13/87; RMcK to Cunliffe, 18 October 1915, McKenna papers, 5/10/10. 'A clear hour saved by not having the Jews', RMcK to PMcK, 4 August 1916.

7. Montagu to RMcK, 8 November 1911 , McKenna papers, 4/4/7; Montagu to MA, 8 August 1916, Montagu papers, AS5/T/15(1)1140(1); Montagu to HHA, 1 October 1914, Montagu papers, AS1/7/32; Montagu to HHA, 3 January 1915 [sic: 3 January 1916], Montagu papers, AS1/1/48(2).

8. New York Times, 18 December 1915.

9. HHA to Sylvia Henley, 23 August 1916, Asquith papers, 542/4/726.

10. RMcK to Rufus Isaacs, 29 July 1916, Reading papers, 54/58-59; HHA to RMcK, 6 August 1916, McKenna papers, 5/10/22; Rufus Isaacs to RMcK, 2 August 1916, Reading papers, 54/60; Rufus Isaacs to RMcK, 2 August 1916, McKenna papers, 5/10/21; Lord Beaverbrook, Men and Power 1917-1918 (1956), 93, 99.

11. HHA, 4 July 1916, Kathleen Scott, diary, Asquith papers, 153/16.

12. HHA to Sylvia Henley, 7 July 1916, Asquith papers, 683.

13. Ibid., 6 July 1916, Asquith papers, 678. 


\section{Reginald McKenna}

'the future of the party', the chancellor asked the prime minister for Simon. 'He didn't think the Tories would stand it and so I asked for McKinnon Wood', ${ }^{1}$ as mild a deputy as could be imagined. ${ }^{2}$ The salient point was that McKenna was absolutely at one with his Treasury civil servants, of whom he could easily have been one himself, and the devotion was mutual. The moment McKenna asked him, Chalmers returned to the Treasury from the governor-generalship of Ceylon, his 'pestilential' tropical refuge from Lloyd George. ${ }^{3}$ For Keynes, another Inner Temple Cambridge mathematician, the 'McKennae' between them traversed his private and public interests. Through his Treasury work with McKenna, he privately admitted 'I am on very intimate terms now and I have got extremely fond of him'. ${ }^{4}$

McKenna's poor manner had always been made worse by his grasp of detail and inclination to demonstrate it; as chancellor, he was expert. F. E. Smith, thought McKenna 'in Cabinet prolix to a degree'. ${ }^{5}$ There were concerns, moreover, that decision making in wartime required different practice. Ribot told Esher of 'the different methods of Lloyd George and McKenna'.

Both surrounded themselves with experts, but Lloyd George was conscious of, and showed complete ignorance of financial detail. He would invite discussion saying very little himself, but when the talking was over, he would give a decision there and then, and this was final. McKenna, on the other hand, did most of the talking himself, and after consulting all the experts all round, would try to get some formula, invariably a compromise agreed to, and if he failed, the question would be hung up. ${ }^{6}$

When Laurie Brock invited McKenna to a National Relief Fund meeting, the chancellor immediately got into a row with Walter Long. 'McKenna kept his temper admirably but somehow always seemed a little too glib, a little too plausible and too convincing. ${ }^{7}$ It was the more frustrating for

1. RMcK to Runciman, 10 July 1916, Runciman papers, 149/1.

2. Selborne, memorandum, Selborne papers, $80 / 287$; RMcK to Thomas McKinnon Wood, 6 July 1916, McKinnon Wood papers, c.499/199; Thomas McKinnon Wood to his aunt, n.d., Thomas McKinnon Wood papers, c.499/225-26.

3. Earl Grey to Bonar Law, 3 December 1915, Earl Grey papers, 228/11; RMcK to Chalmers, 12 November 1915, Treasury papers, T170/66; Leith Ross to his mother, 21 November 1915, Leith Ross papers, T188/267.

4. Keynes, 10 September 1916, in John Maynard Keynes, by D. E. Moggridge (1993), 249.

5. F. E. Smith to Churchill, 25 February 1916, Churchill papers, CHAR 1/118A/ 43-44.

6. Ribot, in Esher, diary, 18 April 1916, Esher papers, 15/2; Sir John HanburyWilliams to Stamfordham, 29 October 1916, RA PS/GV/Q 722/31.

7. Laurence Brock to Violet Markham, 19 July 1915, in Duty and Citizenship: The Correspondence and Political Papers of Violet Markham, 1896-1953, ed. Helen Jones (1994), 75-76. 
the prime minister that McKenna 'tho' generally right, is singularly rasping and unpersuasive in manner'. ${ }^{1}$ One MP about to give evidence to the War Contracts Committee met him before the meeting, to be reassured 'you can tell me anything you like but remember that I will hold myself free to use it against you as in your favour'. ${ }^{2}$

Yet, while never professing to be an orator, through his labours McKenna turned himself into an accomplished speaker. In 1916, Cecil Hepworth, who had lobbied McKenna in 1912 for the British Board of Film Censors, prevailed on Asquith, Lloyd George, other members of the Cabinet, and public figures to speak to the cinema audience. Each man would address Hepworth's camera and issue a public announcement, which the audience would follow periodically on speech cards. ${ }^{3}$ Of the twenty men filmed, McKenna was among the most engaging, varying his physical pose and facial expression as he spoke, but without the theatricality that characterised some of his more exalted colleagues. What was successful in front of one man and his camera remained less so in front of an audience. Neville Chamberlain was in a meeting addressed by the chancellor, whom he found 'singularly tactless' and 'pig-headed', in addressing a sensitive meeting where 'if he had the gumption of a mussel' he could have avoided eliciting 'jeers and derision'. ${ }^{4}$

McKenna's manner was less damaging at the Treasury than it had been in earlier departments. It was largely a reflection of the war. In whatever forum, financial matters were flattered to find themselves on even the periphery of discussion, while the tactical tended to displace the strategic. ${ }^{5}$ It explained, partly, the pressure to omit McKenna from the War Committee, and Unionist exasperation that in Asquith's absence, as Long put it, 'leadership devolves upon Lloyd George, or failing him, upon McKenna [who] has no claim on it save that he is Chancellor. ${ }^{6}$ McKenna had to be persistent, and as such was a constant in Asquith's convocational preoccupations, and as such managed to cause further irritation, most of all to Lloyd George. 'McKenna enters upon the scene. Conceited, self-confident, persistent, he cannot conceive of any War Committee on which he is not represented. ${ }^{7}$ His

1. HHA to Sylvia Henley, 23 July 1915 , Asquith papers, 542/1.

2. RMcK to Caradoc Rees, in MacCallum Scott diary, 23 October 1916, MacCallum Scott papers, 1465/7; cf. Lloyd George, ibid., 23 January 1916. 1921.

3. Hepworth Cinema interviews 1916, I, II, III, Accession 135, Title 1212, Reel

4. Neville Chamberlain, 22 July 1916, Diary, $i: 148$.

5. Fitzroy, diary, 8 September 1916, Fitzroy, Memoirs, 51; Hankey, diary, 28 December 1915, Hankey papers, 1/1/127; Hankey, diary, 1 March 1916, Hankey papers, $1 / 1 / 127$. 198.

6. Long to Bonar Law, in Walter Long and his Times, by Charles Petrie (1936),

7. Lloyd George, 15 November 1915, in Stevenson, Diary, 72; HHA, July 1916; Finance Committee, 3 July 1916, Cabinet papers, CAB17/145. 
opponents suspected a more pervasive influence, which might require much more substantive change in the Cabinet.

\section{'A BETTER PEACE NOW'}

Refusing to countenance the gamble of a dramatic acceleration in the war, McKenna had come to the view that the choice was between 'an indefinite war [or] a reasonable peace." While preparing for the former, he wanted the latter, and recognised that the Americans were central, just as they were to the financing of the war, as mediators or as participants. President Wilson had sent his emissary E. M. House to Europe, and both Elibank and Hankey knew 'that Grey and Balfour together, and McKenna and Lloyd George secretly and separately have discussed peace with House'. ${ }^{2}$ McKenna admitted in Cabinet from the beginning of the year that he supported negotiations, particularly as an alternative to a great summer offensive. ${ }^{3}$ In February, at lunch with Lloyd George, McKenna advocated American mediation to produce a negotiated peace. Grey agreed. ${ }^{4}$ The discussions with the Americans led to the House-Grey Memorandum concerning American mediation, which was rejected in Cabinet in March. Renewed discussions took place in May, where Massingham felt McKenna's 'mind is harking back to push negotiations and that he is feeling his way to a Pro-English settlement.' Given 'the black financial outlook,' McKenna told Hankey, and the fact that, within the War Committee, McKenna, Asquith, Grey, and Balfour were in favour and only Lloyd George and Law against, he 'thought there was every prospect of the proposal being accepted'. ${ }^{6}$

The memorandum went no further, for a second time, and for the same convoluted reasons as decision making in 1916 produced few decisive decisions. It failed also because, as McKenna and Grey knew, Asquith still believed in military success, as promised by that summer's planned offensive. It was the last time McKenna's preference took a realisable form. A compromise peace-peace without the unconditional surrender of Germany-would preserve Britain's great power status and concomitant financial prestige and reinforce Liberalism at the expense of increasingly strident Unionism, as well as ending the waste on the other side of the Channel.

1. RMcK, 2-3 October 1916, Scott diary, Scott papers, 50903/74.

2. Hankey, diary, 22 January 1916, Hankey papers, 1/1/138; Elibank to Spender, 7 June 1916, Elibank papers, 8804/27-28; Montagu to HHA, 18 March 1916, Asquith papers, 16/100.

3. RMcK, 13 January 1916, Curzon papers, F112/128/9.

4. Stevenson, Diary, 23 February 1916, 101.

5. Massingham to Haldane, 10 June 1916, Haldane papers, 5913/20; W. H. Butler to E. M. House, 30 November 1917, Wilson, Papers, 45:175.

6. Hankey, 24 May 1916, Hankey papers, 1/1/194; see Carson memorandum, Carson papers, $10 / 16$. 
McKenna told Scott that those in the Army 'have no desire needlessly to sacrifice their lives or the lives of those dear to them. As for Lloyd George himself, he risks very little. His sons are well-sheltered'. ${ }^{1}$

On 5 June, the secretary of state for war was killed. A week later, McKenna confided to Runciman,

The gloom of Kitchener's death is still hanging over me. Needless to say that the news was not 24 hours old before claims to the succession were put in by a prominent person. Austen Chamberlain is regarded as the most probable man. Reading and Montagu are sturdy beggars for Ll-G. but so far the P.M. has stood out ... If past experience is followed, $\mathrm{Ll}-\mathrm{G}$. will threaten him into acquiescence, but I know he recognises how unsuited Ll-G. is for the office. ${ }^{2}$

'Be of good cheer', McKenna told Runciman a week after that, 'Ll-G is not yet at the War Office'. ${ }^{3}$ A week after that, McKenna claimed that Asquith "knows the appointment is a bad one but he has not the strength to resist." On 6 July, Lloyd George succeeded to the post. The implications for strategy and for the chances of a negotiated settlement were transformed. 'To get rid of LI-G from the Munitions is such a relief that I am quite reconciled to his going to the War Office. ${ }^{5}$ Montagu thereafter soon attempted to 'introduce order and rationality, and the result is bound to be reflected in the expenditure'. ${ }^{6}$

As at the Home Office, and with similar discretion for fear of similar vituperation, McKenna risked obloquy by accommodating 'pacifists'. ' He was strikingly warm towards Lansbury ${ }^{8}$ and told Gilbert Murray, 'It is a slow business dealing with conscientious objectors, but I think we are making distinct headway. ${ }^{9}$ Supporters included friends of Pamela, such as John Galsworthy, and 'conchies' included friends of Keynes, whom McKenna promised to support. ${ }^{10}$ It was entirely consistent with McKenna's attitude

1. RMcK, 2-3 October 1916, Scott, diary, Scott papers, 50903/74. The editor omitted this observation from the published version, commenting 'McKenna went on to make a rather cruel and slighting remark about LG which it has not been thought necessary to reproduce here'. Op cit, 228, n. 3.

2. RMcK to Runciman, 11 June 1916, Runciman papers, 1/1/6.

3. Ibid., 19 June 1916, Runciman papers, 149/1.

4. Ibid., 26 June 1916, Runciman papers, 149/1.

5. Ibid., 10 July 1916, Runciman papers, $149 / 1$.

6. Ibid., 21 July 1916, Runciman papers, 149/1.

7. Lord Bertie, diary, 7 June 1916, in The Diary of Lord Bertie, 1914-18, ed. Lady Algernon Gordon Lennox, 2 vols. (1924), ii:69-70, 1:359.

8. Pankhurst, Home, 216.

9. RMcK to Gilbert Murray, 27 May 1916, Gilbert Murray papers, 30/87.

10. Keynes to Duncan Grant, 14 January 1917, Grant papers, 57931/III/98; Keynes to Duncan Grant, 20 May 1916, in Moggridge, Keynes, 259; David Garnett, The Flowers of the Forest (1955), 104-7, 149-51. 


\section{Reginald McKenna}

during the war, as it had been in the peace. Arnold Bennett noticed at one Smith Square dinner in April 1916 that 'McKenna didn't seem to believe in a smashing of Germany', though others did. ${ }^{1} \mathrm{~A}$ knock-out blow was not desirable either in terms of the destabilising effect of a crippled Germany, which would be the intended effect, or a crippled Britain, which McKenna suspected would be the unintended consequence. As much went for the execution of Roger Casement, which he also opposed. ${ }^{2}$ That, and his desire to retain Birrell after the Easter Rebellion in Dublin had been suppressed, ensured Nationalists retained faith in him. ${ }^{3}$ The execution of the leaders of the rebellion, like so much else in the context of war, produced a sense of detachment similar to that which McKenna had felt periodically throughout his ministerial career. C. P. Scott noted that 'he could not understand the mentality of his colleagues who could not see these things which to him seemed elementary and self-evident. He thought "private life" was the place for him. ${ }^{4}$

\section{AMERICAN RELATIONS}

'It is a most valuable success from more points of view than one', Haldane told Pamela after her husband's second budget, 'for it will influence Continental and American opinion much. The tone of recent letters I have had from numerous persons in the U. States shows me how useful this resolute Budget will be as an illustration.' ${ }^{5}$ The United States had grown in importance, despite remaining officially neutral. McKenna told Repington 'if the U.S. came in, all his difficulties would be removed'. ${ }^{6}$

In his New York Times interview, he sought to reaffirm British credit.? McKenna's attention to American opinion was significant. One self-evident observation that few made was that, when the war ended, 'America would have all the money', McKenna told Repington, 'and would be the greatest power in the world. ${ }^{8}$ They 'had learnt a lot about finance, and were now less provincial. ${ }^{9}$ Underspending notwithstanding, McKenna told the Cabinet in May, orders placed in the United States were placing financial relations near

1. Arnold Bennett, 11 March 1916, Journals, ii:156.

2. Duff Cooper, Diary, 30 April 1916, 28.

3. Tim Healy to Maurice Healy, 17 September 1916, in Letters and Leaders of My Day, by T. M. Healy, 2 vols. [1928], ii:576.

4. Scott, diary, 23 February 1916, Scott papers, 50902/171.

5. Haldane to PMcK, 23 September 1915.

6. RMcK, 19 October 1916, in The First World War, 1914-18, by Charles à Court Repington, 2 vols. (1920), i:369.

7. Ernest Marshall to RMcK, 19 July 1916; New York Times, 13 August 1916.

8. RMcK, 19 October 1916, in Repington First World War, i:369.

9. Ibid. Spring-Rice to Grey, 1 June 1916, FO 731/2851/454; Spring-Rice to Lloyd George, 16 June 1916, Lloyd George papers, E/9/1/14. 
breaking point in both New York and London. ' 'I foolishly went into the City', Asquith told Pamela, 'and was caught by the Governor and Deputy Governor, with whom I spent a dolorous hour at the Bank!'2 Esher's summer 'Armageddon', Haig's June offensive on the Somme, further undermined credit, and confidence, as did Jellicoe's equally indecisive Battle of Jutland. ${ }^{3}$ 'I am afraid that I cannot think I deserve all you say, but we did our best', Jellicoe told to Pamela from the Iron Duke immediately afterwards. 'For a complete victory we should want a good deal more time than we had that afternoon. Let us hope we shall get it next time'. ${ }^{4}$ The attitude of the Americans led to further skirmishing between McKenna and Lloyd George. Lloyd George maintained that businessmen would never turn down business, and that Wilson would protect the investments. McKenna said that, quite apart from the ability of American manufacturers to deal with still indiscriminate purchasing, American businessmen were themselves concerned with Britain's creditworthiness in the absence of military success. ${ }^{5}$

Above all, the extent of Britain's indebtedness meant that the Americans now had the ability to dictate terms, which demonstrated the folly of antagonising American public opinion with cable and mail censorship, the principle of Continuous Voyage, blacklisting American companies, and the execution of Irish rebels. All damaged British credit as a presidential election approached, and Irish, Jewish, and German American voters considered their position. ${ }^{6}$ For McKenna, it was not even whether Britain could borrow; 'the real question is: is America prepared to lend?? The worst possible scenarios of Wilson's defeat by an even less Anglophile candidate, and American war with Mexico, were narrowly avoided. Nevertheless, the failure of the American harvest meant that Britain would have to turn to Australian wheat, with the additional burden on shipping already being decimated by U-boats. ${ }^{8}$ The most inveterate compulsionists in the Cabinet now recognised

1. RMcK, 19 May 1916, Cabinet papers, CAB37/148/6; RMcK, 3 July 1916, Cabinet papers, CAB17/145/10; Midleton to Cromer, 3 November 1915, Cromer papers, FO633/24/212.

2. HHA to PMcK, 4 May 1916.

3. Blackett to Keynes, 9 June 1916, Treasury papers, T170/102.

4. Jellicoe to PMcK, 18 June 1916.

5. Lloyd George, 29 June 1916, Cabinet papers, CAB17/145; RMcK, 6 July 1916 , Cabinet papers, CAB17/145/24-28; Long to HHA, 11 November 1916, Asquith papers, $16 / 195$.

6. Cleveland Hadley Dodge to Woodrow Wilson, 26 June 1915, Wilson, Papers, 34:28; E. M. House to Wilson, 11 January 1916, in The Intimate Papers of Colonel House, ed. Charles Seymour, 2 vols. (1926), ii:123, and 2 June 1915, 1:468; SpringRice to Balfour, 30 January 1916, Balfour papers, 49740/5-6; Spring-Rice to Grey, 2 August 1916, Grey papers, FO800/86/729; HHA to George V, 3 August 1916, Cabinet papers, CAB41/37/29/136.

7. RMcK, 6 July 1916, Cabinet papers, CAB17/145/4.

8. Fisher to Jellicoe, 6 April 1916, Fisher, Correspondence, 3:338. 


\section{Reginald McKenna}

the pressures on shipping, ${ }^{1}$ just as McKenna now admitted to accepting rationing as 'inevitable.'

The exchange rate made intangible concerns real. Each increase in the bank rate to retain foreign balances in London was at the expense of confidence; the higher the rate the more imperilled was the state of British credit. ${ }^{3}$ By the end of July, 'I have now no immediate cause for financial alarm', McKenna told Runciman. 'I am indeed in a much stronger position now than two months ago'. ${ }^{4}$ His small 'substantial reserve' built up in advance of the autumn demands, however, came at cost expressed in the exchange. On 1 August, Cunliffe and Montagu called on McKenna. The chancellor refused to countenance higher rates. ${ }^{5}$ They nevertheless left, the chancellor told his wife, 'best of friends-talked of our American arrangements as if nothing had happened'. ${ }^{6}$ After they left, they went to the prime minister and left him with 'much disquietude'. 'I am a good deal worried about City matters, but I am hoping to-morrow to devise something', Asquith told Pamela. "Do you know the real meaning of the word "Pontifex"?"8 The bridge the prime minister sought to construct between the Bank and the Treasury took the form of 'a small and secret committee', consisting of himself, McKenna, Reading, and McKinnon Wood to work with the Bank and the City. ${ }^{9}$ It was little more than a token to Cunliffe, who had recently been to Downing Street for a meeting with McKenna and Asquith, ${ }^{10}$ and who had another with them the following day. ${ }^{11}$ In addition to the prime minister's intervention, another loan was agreed to but, against McKenna's wishes, it had to be secured by collateral. The loan's only partial success further undermined confidence, upsetting Ribot and Cunliffe, while having established the undesired precedent of collateral. ${ }^{12}$

1. Runciman, 9 November 1916, Cabinet papers, CAB22/66/55; Robertson to Cavan, 5 May 1916, Cavan papers, WO79/66; William G. McAdoo, Crowded Years (Port Washington, 1931), 392.

2. Crawford, Cabinet memorandum, 13 November 1916, 28 November 1916, Crawford papers, 9769/97/4/3.

3. RMcK, 24 January 1916, Cabinet papers, CAB27/4/291; Montagu to HHA, 30 December 1915, Montagu papers, AS5/5(3)1130(3).

4. RMcK to Runciman, 21 July 1916, Runciman papers, 149/1.

5. Norman, diary, 7 July 1916, Norman papers, ADM34/4; Cunliffe to HHA, 14 August 1916, Reading papers, F118/11-13,85.

6. RMcK to PMcK, 4 August 1916.

7. HHA to RMcK, 15 August 1916, McKenna papers, 5/8/10.

8. Ibid.; HHA to Sylvia Henley, 16 August 1916, Asquith papers, 542/4/715.

9. HHA to RMcK, 15 August 1916 , McKenna papers, 5/8/10.

10. HHA to Sylvia Henley, 17 July 1916, Asquith papers, 542/3/689.

11. Ibid., 17 August 1916, Asquith papers, 542/4/717.

12. Churchill to RMcK, 15 August 1916, Bank of England, i:110, Bank of England papers, ADM2/1; Churchill to HHA, 14 August 1916, Reading papers, F118/7/85; Churchill to Rufus Isaacs, 7 September 1916, Reading papers, F118/13/87; Norman, diary, 7 June 1916, Norman papers, ADM34/4. 
Entente requirements continued to press upon the Treasury; Asquith thought the French and the Russians 'the villains of the piece," while they in turn deplored what they regarded as parsimonious actions on the part of the chancellor, with their grievances meeting a ready champion in Lloyd George, who encouraged French suspicions that McKenna had 'pacifist tendencies' and pro-German sympathies. ${ }^{2}$ McKenna for his part prepared a memorandum on the actual state of affairs for French public consumption, and employed Masterman for further dissemination at home. ${ }^{3}$ Arbitration at the London Conference in July produced a host of conclusions, most of which were obvious beforehand, but the predictable effect of the chancellor lecturing his allies was more resentment. ${ }^{4}$ The third issue was the continued vocal dissatisfaction of the Bank of England with McKenna's policies in general. 'A high old row has developed between McKenna \& Ribot in regard to an American loan \& other financial troubles between ourselves \& the French,' Asquith told Margot. 'The result is that the Frogs demand an immediate Conference. ${ }^{6}$ There, at Calais, Cunliffe and Ribot were placated with McKenna relenting at the margins of British disbursements. ${ }^{7}$ Tsar Nicholas II was assured of 'the anxiety of Mr McKenna to help in every possible way', and King George $\mathrm{V}$ that the Russians were 'probably somewhat uneasy after the Chancellor's firmness. ${ }^{9}$ It seemed to impress the Italians, one of whose delegation asked for a signed photograph 'as a personal souvenir of the guiding character in the unparalleled financial struggle of the British Treasury in this historic moment'. ${ }^{9}$ The previous day, McKenna had had to defend the high rate of interest on the latest bond issue, which the German press immediately derided as proof of the failure of British finance. ${ }^{10}$

1. HHA, 24 January 1916, Cabinet papers, CAB27/4/12/293.

2. Horn, Britain, 118.

3. RMcK to Masterman, 22 May 1916; Masterman to RMcK, 25 May 1916; Masterman to RMcK, 25 May 1916.

4. Llewellyn Smith to Runciman, 7 June 1916, Runciman papers, 143; Treasury conference minutes, 14 July 1916, Ministry of Munitions papers, MUN 4/3007/5; RMcK, 3 July 1916, Cabinet papers, CAB17/145/17; Hardinge to Buchanan, 21 July 1916, Hardinge papers, 30.

5. RMcK to PMcK, 4 August 1916; Churchill to RMcK, 15 August 1916, Bank of England papers, ADMR/1/1; Churchill to HHA, 14 August 1916, Reading papers, F118/7/85.

6. HHA to MA, 22 August 1916; HHA to Sylvia Henley, 23 August 1916, Asquith papers, 542/4/726.

7. Kathleen Scott, diary, 27 August 1916, Asquith papers, 153/20; Treasury papers, T172/344; HHA to Sylvia Henley, 25 August 1916, Asquith papers, 542/4/728; Hankey, diary, 24 August 1917, Hankey papers, 1/1/229.

8. Brigadier General W. Walters to George V, 22 August 1916, RA PS/GV/Q 832/288; Carson to HHA, n.d., McKenna papers, 5/10/23; HHA to RMcK, 6 August 1916, McKenna papers, 5/10/22.

9. Paolo Coudy to Horace Hamilton, 21 October 1916; Hamilton to PMcK, 23 October 1916.

10. New York Times, 22 October 1916. 


\section{Reginald McKenna}

\section{THE SECOND DECEMBER CRISIS}

As the third winter of the war and the second of the coalition approached, and political crises were 'so much a condition of our life that I have ceased to be greatly interested in them', ${ }^{1}$ McKenna informed the Cabinet that Britishowned securities were now almost exhausted and that the country might be a fortnight from insolvency. ${ }^{2}$ McKenna revealed to Robertson Nicoll his concern at "how dependent we are on the United States and the need for sympathetic treatment from that country, particularly while the presidential election is keeping their nerves on edge'. ${ }^{3}$ Later that week, it was Lloyd George's turn to speak to the New York Times, in which he announced, 'the fight must be to a finish-to a knock-out'. 'I need not tell you', McKenna told Scott, 'that for my department his action is most injurious. ${ }^{5}$

'It is well known that they dislike one another personally', Montagu told Margot, and 'it is well known that they make the fatal error of doing their work surrounded by their own particular choice of press-men. ${ }^{6}$ Lloyd George, McKenna told Repington, 'honestly thought himself appointed by heaven to win the war'. ${ }^{7}$ Cabinet opposition was harder to muster from colleagues symbolically incapacitated. Exhausted and losing his sight, Asquith moved the foreign secretary to the Lords. 'Grey's going made me very unhappy', ${ }^{8}$ while Runciman was recovering from a nervous breakdown. ${ }^{9}$ 'I want you back,' McKenna told him. 'Only this morning I was thinking how much I miss you and how lonely your absence leaves me in the political world. ${ }^{10}$ McKenna visited him and 'discussed politics and agreed time has come for Govt. to go out', before going 'home to lunch with Le Bas who also agreed Govt. should go out. ${ }^{\prime 11}$ Fisher felt zeppelins and submarines between them would occasion the fall of the country. ${ }^{12}$ McKenna was

1. RMcK to Runciman, 21 July 1916, Runciman papers, 149/1.

2. Report of the Joint Anglo-French Financial Committee, Cabinet papers, CAB37/157/40; Interdepartmental Committee to Consider Dependence of the British Empire on the United States, Treasury papers, T170/95.

3. RMcK to Robertson Nicoll, 22 September 1916, Treasury papers, T172/358; RMcK, MUN 4/3007/9; Whigham to Curzon, 28 September 1916, Curzon papers, F112/112A.

4. Lloyd George, in Lloyd George: From Peace to War, 1912-1916, by John Grigg (1985), 425.

5. RMcK, 2-3 October 1916, Scott, diary, Scott papers, 50903/74; Ponsonby to Trevelyan, 6 October 1916, Trevelyan papers, CPT 60. sent'.

6. Montagu to MA, 8 August 1916 , Montagu papers, AS5/1/15/(1)1140(1) 'Not

7. RMcK, 12 October 1916, Repington, First World War, $i: 360$.

8. RMcK to Runciman, 10 July 1916 , Runciman papers, $149 / 1$.

9. Birrell to PMcK, 1 June 1916; MacCallum Scott, diary, 4 February 1917, MacCallum Scott papers, 36; Viscount Cecil, All the Way (1949), 136.

10. RMcK to Runciman, 21 July 1916, Runciman papers, 149/1.

11. RMcK to PMcK, 4 August 1916.

12. Fisher to PMcK, 29 August 1916. 
becoming impatient with his chief. He complained to Robertson Nicoll of Asquith's 'failure to come to decisions', and that 'he would favour a change in the head of the Government if he could see an alternative'. ${ }^{1}$

Since the late summer, Pamela had been exhausted. Benntig, who had worked with her on the National Relief Fund, invited her to recover in Egypt, where he was stationed in the Royal Flying Corps. ${ }^{2}$ She was needed at home, and by the autumn, was also bedridden, to Asquith's further consternation.

I was more distressed than I can say to hear this morning, that, tho' you have escaped from the mildew of jaundice, you are still far from well, and that your weight is ridiculously and perilously light. You must without delay put a stop to all this, which is due to you over-taxing your strength with your damned Committee, and probably other extraneous cares, of which I know nothing ... for my sake dearest, do at once contract your outside cares and responsibilities. ${ }^{3}$

In August, McKenna retired for a fortnight with exhaustion. 'My work of late has been rather too much for me and I have been forced to rest and do nothing'. ${ }^{4} \mathrm{He}$ went to see his closest Cabinet invalid. 'Reggie and I lunched together and talked of all the possibilities in case of Asquith's sudden collapse', Runciman told his wife. ${ }^{5}$ Their concerns as to the prime minister's resilience were heightened by Raymond Asquith's death in action. 'I suppose the blind and insatiable Fury had already marked him down', Asquith told Pamela, 'and now I feel, for the first time at any rate, bankrupt in pride and life.' 6

As the days shortened, there was an almost palpable sense of Liberal collapse, most importantly, on the part of Asquith. 'In case I do not see you again,' he wrote to Pamela at midnight on 13 November 1916,

this is to assure you of my deep + everlasting gratitude for your unceasing + always understanding love. It is to me a priceless possession + will (whatever happens) be a life long + death surviving memory. You have been an angel to me, ever since I first really knew you. Whatever may happen come, your ever loving + wholly devoted, $\mathrm{HHA}^{7}$

1. Riddell, 13 April 1916, War Diary, 172.

2. Benn to PMcK, 23 July 1916.

3. HHA to PMcK, 2 October 1916.

4. RMcK to Gertrude Tuckwell, 1 September 1916, Dilke papers, 43967/285; RMcK to Fisher, n.d. [1916], Fisher papers, 3/13/2827.

5. Runciman to Hilda Runciman, 6 September 1916, Runciman papers, 303/2.

6. HHA to PMcK, 20 September 1916.

7. Ibid., 13 November 1916. 


\section{Reginald McKenna}

The financial crisis predicted by the Cassandra of the Treasury had arrived. Asquith told the king on 30 November, in what would be his final Cabinet report:

Mr McKenna reported a very serious communication from New York to the effect that the federal board of reserve had issued a warning to the banks not to give any further borrowing to the allied Governments. The Exchequer committee of the London bankers took so grave a view of the matter as to recommend that we should at once suspend specie payments. ${ }^{1}$

President Wilson by now regarded relations with Britain as being worse than those with Germany ${ }^{2}$ and not only issued a general warning against investment in British securities, but insisted on 'stronger and more explicit' language. ${ }^{3}$ The Cabinet was divided between those who recognised the seriousness of the episode and those who thought their bluff was being called. ${ }^{4}$ Meanwhile, allied bonds and American war stocks plummeted, and gold was sold to shore the exchange. ${ }^{5}$ Warburg, the German-American banker, was said to be 'in the seventh heaven of delight'. 'Another ten days of this', Keynes said, 'and we should have been finished'.

The resultant financial crisis, as with that of 1911 , concerned the machinery of government; as with the first December crisis, the affair hinged on

1. HHA to George V, 30 November 1916, Cabinet papers, CAB1/20/23/42; George V, diary, 5 December 1916; RMcK, in Lamont, Davison, 208; Crawford, Cabinet memorandum, 29 November 1916, Crawford papers, 9769/97/4/3; Bertie, diary, 30 November 1916, Diary, ii:69-70. 112.

2. Charles Heath, diary, 30 November 1916, in Papers of Woodrow Wilson, xl,

3. Wilson to Harding, 26 November 1916, in Papers of Woodrow Wilson, 40:77, 87-88;. For an underemphasised episode, see: W. P. G. Harding, The Formative Period of the Federal Reserve System (1925), 65-70; Carl Moore, The Federal Reserve System: A History of the First Seventy-Five Years (Jefferson, 1990), 53; Chandler, Benjamin Strong, 87-88; Thomas W. Lamont, Henry P. Davison: The Record of a Useful Life (New York, 1933), 206-9; Charles Tansill, America Goes to War (Boston, 1938), 125; Patrick Devlin, Too Proud to Fight: Woodrow Wilson's Neutrality (1974), 586.

4. War Committee, 28 November 1916, CAB 22/77; Bonar Law, 3 July 1916, Cabinet papers, CAB17/14514-17.

5. Lamont to Morgan, in 'Strange Bedfellows: J. P. Morgan and Co., Whitehall and the Wilson Administration During World War I', by Roberta Dayer, Business History 28 (1976): 132; Woodrow Wilson in Woodrow Wilson: Life and Letters, vol. 6, 1915-1917, Facing War, ed. Ray Stannard Baker (1939), 375; Bonar Law, Parliamentary Debates, 14 December 1922, 3233.

6. Charles Sumner Heath, diary, 25 November 1916, in The Papers of Woodrow Wilson, ed. Arthur Link, 40:77.

7. Keynes, 15 February 1917, in The Collected Writings of John Maynard Keynes, vol. 16, Activities, 1914-1919: The Treasury and Versailles, ed. Elizabeth Johnson, 210 . 
Robertson and McKenna. 'Robertson is a first-rate man', McKenna thought, after their work together after the first December crisis, because he 'had put his finger unerringly on all the points' of McKenna's case, and had also fallen out with Lloyd George over resisting the latter's demands at the War Office. McKenna said 'he knew Lloyd George well, and thought that he would never forgive this defeat'. ${ }^{1}$ The occasion was the 'Kitchener Dodge', Lloyd George's seasoned ruse for dispatching dissenting warriors on spurious missions far away, about which Robertson was becoming increasingly concerned. ${ }^{2}$ In November, McKenna visited Haig at the Front and made supportive noises. ${ }^{3}$ On McKenna's return, Robertson went to see him, and, he told Haig, left convinced that McKenna was 'a friend of ours' in Robertson's struggles against Lloyd George. ${ }^{4}$ At a climactic Cabinet meeting on 21 November Lloyd George, without any evidence, accused McKenna of fomenting distrust between himself and Robertson. ${ }^{5}$ It was the final Cabinet row between McKenna and Lloyd George. ${ }^{6}$ The two had made the normal operation of the Cabinet impossible. Lloyd George's mistress and secretary Frances Stevenson wrote that evening: 'D literally hates him \& I do not think he will rest till he has utterly broken him'?

The breaking took the form of a new war committee, a 'civilian General Staff', the demand for which Lloyd George circulated four days later. It would achieve what the War Council, the Dardanelles Committee, and the War Committee had failed to achieve. As it would omit the service chiefs, it would exclude Robertson; as it would omit portfolios secondary to the prosecution of the war, as Lloyd George saw the Treasury, it would omit McKenna. 'George among Government officials is a byword for neglect and inefficiency', Leonard Hobhouse told Scott. 'The capable man is McKenna whom they won't have because he knows too much of our real condition to push conscription hard'. ${ }^{8}$ Asquith duly rejected the proposal on 26 November. The following day came the Federal Reserve Board warning. 'Alas! The whirlwinds are blowing, and the windmills are whirling', Asquith told

1. RMcK, 29 September 1916, in Repington, First World War, ii:351, 350.

2. Hankey, diary, 17 November 1916, Hankey papers, 1/1/273; Esher, diary, 17 October 1916, Esher 2/17; Robertson to HHA, 13 November 1916, Robertson papers, $1 / 13 / 21 \mathrm{a}$.

3. Haig, diary, 2 November 1916, Haig papers, 3155/109; RMcK to Haig, 6 November 1916, Haig papers, 3155/109/21; Rawlinson to Clive, 7 November 1916, RA PS/GV/Q 2522/81.

4. Robertson to Haig, 8 November 1916, Haig papers, 3155/109; Montagu, memorandum, Roberts papers, Mss. Eur. F170/10/9.

5. Stevenson, Diary, 21 November 1916, 126, cf. Runciman to Hilda Runciman, 16 December 1909, Runciman papers, 303/1.

6. Hankey, 21 November 1916, Hankey papers, 1/1/275; Esher to Haig, 25 November 1916, Esher papers, 4/7.

7. Stevenson, Diary, 21 November 1916, 126.

8. L. T. Hobhouse to Scott, 3 December 1916, Scott papers, 50909/44. 


\section{Reginald McKenna}

Pamela that evening. 'I am in the centre of an aerial tornado, from which I cannot escape'. ${ }^{1}$

Making explicit that which had been apparent for at least seven years, Lloyd George made it clear that no Cabinet was big enough for both himself and McKenna-that he would not sit in any Cabinet that included McKenna. ${ }^{2}$ The prime minister explained to the king 'the difficulties which arose from the personal dislike of Mr Lloyd George and Mr McKenna for one another', with the latter being 'somewhat pessimistic, whereas Mr Lloyd George was an optimist but was devoid of financial knowledge'. ${ }^{3}$ Lloyd George considered McKenna's influence on Asquith to be the determining factor, and so, unable to sideline the chancellor, Lloyd George sought to sideline the prime minister. ${ }^{4}$ Frances Stevenson felt that Asquith would delay his decision because 'McKenna would fight very hard against it, and he must be given time. That means that Mrs McKenna will oppose it and that is what will weigh with the P.M.'.

On 1 December, in Balfour's words, Lloyd George 'put a pistol to the head of the PM', and proposed a war committee of three, chaired by himself. ${ }^{6}$ Asquith initially accepted the proposal, then, in the familiar way, saw McKenna and changed his mind. He rejected the proposal, though he did concede to the reconstitution of the existing war committee. ${ }^{7}$ There could not have been room for McKenna on that committee. McKenna, alarmed at Northcliffe's actions through The Times, persuaded the failing Grey and Runciman to see Asquith, while he mobilised his own pressmen. ${ }^{8}$ Le Bas was spotted around Westminster on 3 December, pressing McKenna's case in person, and Riddell heard that '[Robert] Donald has received a message from the poisonous Le Bas stating that McKenna would resign unless he is included in the war council'. ${ }^{9}$ It was through his being seen with the McKennas one evening that even Repington was suspected as intriguing on behalf of Asquith. ${ }^{10}$

1. HHA to PMcK, 27 November 1916.

2. Thomas Jones to Eirene Theodora, 6 December 1916, in Thomas JonesWhitehall Diary, vol. 1, 1916-2.5, ed. Keith Middlemas (1969), 7.

3. HHA to George V, attrib., Lord Errington, memorandum, December 1916, RA PS/GV/K 1048a/2.

4. Riddell diary, 16 October 1916, Riddell papers, 62959.

5. Stevenson, Diary, 25 November 1916, 128.

6. Balfour, memorandum, 7 December 1916, Balfour papers, 49692/182; Balfour to HHA, 5 December 1916 [copy], Balfour papers, 49692/193.

7. HHA to LG, 4 December 1916 [copy], Balfour papers, 49692/190-2; RMcK to Bacon, 28 June 1929.

8. MacCallum Scott diary, 4 February 1917, MacCallum Scott Papers, 36.

9. Riddell, diary, 3 December 1916, Riddell papers, 62960; Montagu, memorandum, Roberts papers, Mss. Eur. F170/10/9/5.

10. Charles Repington, in The Letters of Lieutenant-Colonel Charles à Court Repington CMG, Military Correspondent of The Times, 1903-1918, ed. A. J. A. Morris (Stroud, 1999), 41. 
Asquith told Pamela he had

to grapple with a 'Crisis' - this time with a very big capital C. The result is that I have spent much of the afternoon in colloguing with messrs Ll. George and Bonar Law, and one or two minor worthies. The 'Crisis' shows every sign of following its many predecessors to an early and unmourned grave. But there were many Wigs very nearly on the green. ${ }^{1}$

The arrangement they had agreed to was that the prime minister would not sit on the reconstructed War Council, but would retain the right of veto and the supreme authority for decisions. After he had written to Pamela on Sunday 3, Asquith dined with his wife she recorded and 'begged me not to believe all the stories McKenna was spreading about that he [Lloyd George] wanted to take my place, and was disloyal etc'. ${ }^{2}$

On the morning of Monday 4, Asquith read what he regarded as a humiliating account of the arrangements in The Times. ${ }^{3}$ Lloyd George had personally briefed Northcliffe. That provided the final evidence for the chancellor that the prime minister must resist what he claimed was an attempted coup. Asquith spent the rest of the day in No. 10 with McKenna ${ }^{4}$ Northcliffe told Lloyd George 'that in every step the P.M. has taken in the crisis he has acted on McKenna's instructions as to what he should do'. told Asquith to refuse a subservient position. Convinced now that Lloyd George wanted to take his place, Asquith rescinded his support for the new War Council and, Lloyd George claimed, thereafter avoided seeing him. ${ }^{6}$ In the Commons that afternoon, journalists were surprised to see Asquith, McKenna, and Runciman sitting alone on the Treasury bench. ${ }^{7}$ The prime minister had already announced the reconstruction of the government.

On Tuesday 5, 'R. had an early morning letter from Margot saying the P.M. had written to Ll.G. refusing his terms', Pamela later told Beaverbrook. 'Violet lunched with me and seemed to think a modus vivendi would be reached. ${ }^{8}$ On being told that Asquith would not consent to a new War Committee without the prime minister as its chairman, Lloyd George immediately tendered his resignation. That evening, the Cabinet Liberals met. The ostensible purpose was to consider a government without Lloyd George, but the occasion brought McKenna and Montagu out into open confrontation. Montagu proposed an ad hoc constitutional conference. 'My suggestion was derided, and McKenna most helpfully asked me if I wanted four Prime

1. HHA to PMcK, 3 December 1916.

2. MA, diary, 3 December 1916, MA papers, d.3215/141.

3. Times, 4 December 1916.

4. L. T. Hobhouse to Scott, 3 December 1916, Scott papers, 50909/44.

5. Stevenson, Diary, 6 December 1916, 133.

6. Riddell, diary, 1 September 1919, Intimate Diary, 121.

7. Michael MacDonagh, Diary, 4 December 1916, 153-54.

8. PMcK to Beaverbrook, 5 July [1928], Beaverbrook papers, BBK/G/2/17. 
Ministers, or, if not, which one I wanted. ${ }^{1}$ They also tried to determine what they would do if their efforts failed, and 'if they were invited to join a Bonar Law and Lloyd George Government. McKenna said he would have no difficulty in deciding as he was not likely to receive an invitation.'2 The consensus, with McKenna the most vehement, was for Asquith to refuse any subordinate position, and, implicitly, to accept Lloyd George's resignation. Montagu thought that, as usual, the foreign secretary was the key and 'had tried to get hold of Grey but had failed. McKenna had succeeded in capturing him. ${ }^{3}$ McKenna then embarked on a midnight mission between Donald, Bonham-Carter, and Asquith, to clarify the prime minister's position. ${ }^{4}$

Asquith had already sent his letter of resignation to the king, apparently expecting the Unionists to prefer him as prime minister over Lloyd George. ${ }^{5}$ When no such assurance was forthcoming, the king invited Bonar Law to form a government. Asquith made clear his disinclination to serve under him, with the support of the Cabinet Liberals. There was little optimism. At the Treasury, Alan Parsons had been packing up for McKenna. ${ }^{6}$ On Thursday 7, Lloyd George kissed hands as prime minister. ${ }^{7}$ McKenna sent a telegram to Benntig, far from hostilities at the front:

Asquith and all his late liberal colleagues in Cabinet are absent from new government. McKenna. ${ }^{8}$

1. Montagu, in Edwin Montagu-a Memoir and an Account of His Visit to India, ed. S. D. Waley, 964, 110; Elibank, diary, 6 December 1916, Elibank papers, $8815 / 16$.

2. Montagu's account of his part in December 1916, Beaverbrook papers, $\mathrm{BBK} / \mathrm{G} / 2 / 21$.

3. Ibid.; Elibank, diary, 6 December 1916, Elibank papers, 8815/17.

4. [Typescript, n.d., no author], Donald papers, DON/2/20.

5. Crewe, memorandum, 20 December 1916, in Lord Crewe: 1858-1945: The Likeness of a Liberal, by James Pope-Hennessy (1955), 181-90; HHA to Lloyd George, 4 December 1916, Balfour papers, 49692/190-2; Balfour to HHA, 5 December 1916, Balfour papers, 49692/193; Elibank diary, 6 December 1916, Elibank papers, $8815 / 16-17$.

6. Duff Cooper, 5 December 1916, Diary, 41.

7. Ruth Longford, Frances: Countess Lloyd George: More Than a Mistress (Leominster, 1996), 40-41.

8. RMcK to Wedgwood Benn, 10 December 1916, Stansgate papers, ST 24/1/2. 


\section{Bibliography ${ }^{1}$}

\section{PRIMARY SOURCES}

\section{Unpublished}

\section{Individuals}

Allen, C. P., Modern Records Centre, University of Warwick.

Asquith, H. H., Bodleian Library, Oxford.

Asquith, Margot, Bodleian Library, Oxford.

Balfour, A. J., British Library, London.

Balcarres and Crawford, Earl of, National Library of Scotland, Edinburgh.

Beaverbrook, Lord, Parliamentary Archives, London.

Blumenfeld, R. D., Parliamentary Archives, London.

Bonar Law, Andrew, Parliamentary Archives, London.

Bull, Sir William, Churchill Archives Centre, Cambridge.

Burns, John, British Library, London.

Campbell-Bannerman, Sir Henry, British Library, London.

Cavan, Earl of, National Archives, Kew.

Cave, Sir George, British Library, London.

Cecil, Lord Robert, British Library, London.

Chandos, Viscount, Churchill Archives Centre, Cambridge.

Churchill, Winston Spencer, Churchill Archives Centre, Cambridge.

Crewe, Marquess of, Cambridge University Library.

Cromer, Earl of, National Archives, Kew.

Crook, William, Bodleian Library, Oxford.

Curzon, Earl of, Oriental and India Office Collection, London.

Deakin, Alfred, University of Adelaide Library.

Desborough, Ettie, Hertfordshire Archives and Local Studies, Hertford.

Dickson, Robert, National Library of Scotland, Edinburgh.

Dilke, Sir Charles, British Library, London.

Edward VII, Royal Archives, Windsor.

Elibank, Master of, National Library of Scotland, Edinburgh.

Esher, Viscount, Churchill Archives Centre, Cambridge.

Evan-Thomas, Sir Hugh, British Library, London.

Fisher, Lord, Churchill Archives Centre, Cambridge.

1. Only sources cited have been included. Unless otherwise stated, all books were published in London. 


\section{Bibliography}

Gardiner, A. G., British Library of Political and Economic Science, London.

George V, Royal Archives, Windsor.

Gladstone, Herbert, British Library, London.

Gladstone, W. E., British Library, London.

Grant, Duncan, British Library, London.

Grey, Viscount Edward, National Archives, Kew.

Grey, Albert, 4th Earl, Durham University Library.

Haig, Lord, National Library of Scotland, Edinburgh.

Haldane, Viscount, National Library of Scotland, Edinburgh.

Hamilton, Sir Edward, British Library, London.

Hankey, M. P. A., Churchill Archives Centre, Cambridge.

Harcourt, Viscount, Bodleian Library, Oxford.

Hardinge, Lord, Cambridge University Library.

Hurd, Sir Archibald, Churchill Archives Centre, Cambridge.

Jellicoe, Earl, British Library, London.

Keynes, John Maynard, Kings College, Cambridge.

King-Hall, George, Royal Naval Museum, Portsmouth.

Kitchener, Earl, National Archives, Kew.

I.eith-Ross, Frederick, National Archives, Kew.

Lewis, Herbert, National Library of Wales, Aberystwyth.

Liddell Hart, Sir Basil, Kings College London, London.

Lloyd George, David, Parliamentary Archives, London.

Lodge, Oliver, Birmingham University Library.

Long, Walter, British Library, London.

McLaren, Francis, Papers in the possession of Mrs Nancy McLaren.

McKenna, Reginald, Churchill Archives Centre, Cambridge.

McKenna, Stephen, British Library, London.

Montagu, Edwin, Trinity College, Cambridge.

Murray, Sir Archibald, British Library, London.

Murray, Gilbert, Bodleian Library, Oxford.

Norman, Montagu, Bank of England Archive, London.

Northcliffe, Lord, British Library, London.

Passfield, Lord, British Library of Political and Economic Science, London.

Reading, Viscount, Oriental and India Office Collection, London.

Riddell, Lord, British Library, London.

Ripon, 1st Marquess of, British Library, London.

Roberts, Charles, Oriental and India Office Collection, London.

Robertson, Sir William, Kings College, London.

Rosebery, Earl of, National Library of Scotland, Edinburgh.

Runciman, Sir Walter, Newcastle University Library.

Samuel, Sir Herbert, Parliamentary Archives, London.

Scott, Alexander MacCallum, Glasgow University Library.

Scott, C. P., British Library, London.

Scott C. P., Papers (Manchester). University of Manchester Library.

Selborne, Earl of, Bodleian Library, Oxford.

Simon, Sir John, Bodleian Library, Oxford.

Smuts, J. C., Cambridge University Library.

Spender, J. A., British Library, London.

Stansgate, Viscount, Parliamentary Archives, London.

Stead, W. T., Churchill Archives Centre, Cambridge.

Strachey, Giles Lytton, British Library, London.

Strachey, John St. Loe, Parliamentary Archives, London.

Tree, Violet, British Library, London. 
Trevelyan, Charles Philips, Newcastle University Library.

Von Donop, Sir Stanley, National Archives, Kew.

Wargrave, Viscount, Parliamentary Archives, London.

Webb, Beatrice, Cambridge University Library.

Wigg, George, British Library of Political and Economic Science, London.

Wood, Thomas McKinnon, Bodleian Library, Oxford.

Worthington-Evans, Sir Laming, Bodleian Library, Oxford.

\section{Institutions}

Bank of England, Bank of England, London

Board of Education, National Archives, Kew.

Cabinet, National Archives, Kew

Eighty Club, Bodleian Library, Oxford.

Foreign Office, National Archives, Kew.

Home Office, National Archives, Kew.

Labour Party, Labour History Centre, Manchester.

Midland Bank, HSBC Head Office, London.

Ministry of Munitions, National Archives, Kew.

Treasury, National Archives, Kew.

Trinity Hall, Trinity Hall, Cambridge.

War Office, National Archives, Kew.

\section{Other}

Hepworth Cinema interviews. National Screen and Sound Archive of Wales, National Library of Wales, Aberystwyth.

\section{Published}

\section{Diaries and Papers}

Addison, Christopher. Four and a Half Years. 2 vols., 1934.

Asquith, Lady Cynthia. Diaries, 1915-1918. 1968.

Asquith, H. H. HHA: Letters of the Earl of Oxford and Asquith to a Friend. First Series 1915-1922. Edited by Desmond MacCarthy. 1933.

- H. H. Asquith Letters to Venetia Stanley. Edited by Michael Brock and Eleanor Brock. Oxford, 1982.

Asquith, Raymond. Raymond Asquith, Life and Letters. Edited by John Jolliffe. 1980.

Asquith, Violet. Lantern Slides, Diaries and Letters of Violet Asquith. Edited by Mark Bonham Carter and Mark Pottle. 1996.

Amery, Leo. The Leo Amery Diaries. Vol. 1, 1896-1929. Edited by John Barnes and David Nicholson. 1980.

Bailey, John. John Bailey, 1864-19.31, Letters and Diaries. Edited by Sarah Bailey. 1935.

Beatty, Earl. Life and Letters of David, Earl Beatty. Edited by W. S. Chalmers. 1951.

The Beatty Papers: Selections from the Private and Official Correspondence of Admiral of the Fleet Earl Beatty. Vol. 1, 1902-1918, vol. 2, 1916-1927. Edited by B. McL. Ranft. Aldershot, 1989-93. 


\section{Bibliography}

Belloc, Hilaire. Letters from Hilaire Belloc. Edited by Robert Speaight. 1958.

Bennett, Arnold. The Journals of Arnold Bennett. Vol. 2, 1911-1921, vol. 3, 19211928. Edited by Newman Flower. 1932-33.

Bertie, Lord. The Diary of Lord Bertie, 1914-18. Edited by Lady Algernon Gordon Lennox. 2 vols. 1924.

Bonham Carter, Violet. Champion Redoubtable: The Diaries and Letters of Violet Bonham Carter, 1914-45. Edited by Mark Pottle. 1998.

Chamberlain, Austen. Politics from Inside, an Epistolary Chronicle. 1936.

Chamberlain, Neville. The Neville Chamberlain Diary Letters. Vol. 1, The Making of a Politician, 1915-1920. Edited by Robert Self. Aldershot, 2000.

Churchill, Winston Spencer. Winston S. Churchill, Vol. 2, Companion I: Documents, 1901-1907, Companion II: Documents, 1907-1911, Companion III: Documents, 1911-1914. Edited by Randolph Churchill. Vol. 3, Companion I: Documents, August 1914-May 1915, Companion II: Documents, May 1915December 1916. Vol. 5, Companion III: Documents, 1936-1939. Edited by Martin Gilbert. 1969-72.

Clarke, Tom. My Northcliffe Diary. 1931.

Clifford, John. Dr John Clifford, C. H., Life, Letters and Reminiscences. Edited by Sir James Marchant. 1924.

Cooper, Duff. A Durable Fire: The Letters of Duff and Diana Cooper, 1913-1950. Edited by Artemis Cooper. 1983.

- The Duff Cooper Diaries, 1915-1951. Edited by John Julius Norwich. 2005.

Craigmyle, Lord. Letters to Isabel. 1936.

Crawford, Earl of. The Crawford Papers: The Journals of David Lindsay, Twentyseventh Earl of Crawford and Tenth Earl of Balcarres (1871-1940), During the Years 1892 to 1940. Edited by John Vincent. Manchester, 1984.

D’Abernon, Viscount. An Ambassador of Peace: Pages From My Diary. 3 vols. 1929-30.

Davidson, J. C. C. Memoirs of a Conservative: J. C. C. Davidson's Memoirs and Papers, 1910-37. Edited by Robert Rhodes James. 1969.

Denney, James. Letters of Principal James Denney to W. Robertson Nicoll, 18931917. [1920].

Esher, Reginald Viscount. Journals and Letters of Reginald, Viscount Esher, Vol. 2, 1903-1910. Edited by Maurice Brett. Vol. 3, 1910-1915, Vol. 4, 1916-1930. Edited by Oliver, Viscount Esher. 1934-38.

Fisher, Lord. Fear God and Dread Nought, The Correspondence of Admiral of the Fleet Lord Fisher of Kilverstone. Vol. 2, Years of Power, 1904-1914, vol. 3, Restoration, Abdication, and Last Years, 1914-1920. Edited by Arthur Marder. 1956-59.

Goschen, Edward. The Diary of Edward Goschen, 1900-1914. Edited by Christopher Howard. 1980.

Gwynne, H. A. The Rasp of War: The Letters of H. A. Gwynne to the Countess Bathurst, 1914-18. Edited by Keith Wilson. 1988.

Hamilton, Edward. The Diary of Sir Edward Walter Hamilton, 1885-1906. Edited by Dudley Bahlman. Hull, 1993.

Healy, T. M. Letters and Leaders of My Day. 2 vols. [1928].

Hobhouse, Charles. Inside Asquith's Cabinet: From the Diaries of Charles Hobhouse. Edited by Edward David. 1977.

House, E. M. The Intimate Papers of Colonel House. Edited by Charles Seymour. 2 vols. 1926.

Jellicoe, Earl. The Jellicoe Papers. Vol. 1, 1893-1916. Edited by A. Temple Patterson. 1966. 
Jones, Thomas. Thomas Jones-Whitehall Diary. Vol. 1, 1916-25. Edited by Keith Middlemas. 1969.

Keynes, John Maynard. The Collected Writings of John Maynard Keynes. Vol. 16, Activities 1914-1919: The Treasury and Versailles. Edited by Elizabeth Johnson. 1971.

King-Hall, Sir Herbert. Naval Memories and Traditions. [1926].

Lee, Viscount. A Good Innings: The Private Papers of Viscount Lee of Fareham. Edited by Alan Clark. 1974.

Lloyd George, David. Lloyd George Family Letters, 188.5-19.36, Edited by Kenneth Morgan. 1973.

—. Lloyd George: A Diary by Frances Stevenson. Edited by A. J. P. Taylor. 1971. . My Darling Pussy: The Letters of Lloyd George and Frances Stevenson, 1913-1941. Edited by A. J. P. Taylor. 1975.

Lockhart, Robert Bruce. The Diaries of Sir Robert Bruce Lockhart. Vol. 1, 19151939. Edited by Kenneth Young. 1973.

Lucy, Sir Henry. Later Peeps at Parliament from Behind the Speaker's Chair. 1905.

- The Diary of a Journalist, Later Entries. Vol. 2. 1922.

The Diary of a Journalist, Fresh Extracts. Vol. 3. 1923.

I utyens, Edwin. The Letters of Edwin Lutyens to his Wife Lady Emily. Fdited by Jane Ridley and Clayre Percy. 1988.

MacDonagh, Michael. In London During the Great War: The Diary of a Journalist. 1935.

Markham, Violet. Duty and Citizenship: The Correspondence and Political Papers of Violet Markham, 1896-1953. Edited by Helen Jones. 1994.

Milner, Viscountess. My Picture Gallery, 1886-1901. 1951.

Munro, H. H. The Toys of Peace and Other Papers. 1919.

Nevill, Dorothy. The Life and Letters of Lady Dorothy Nevill. Edited by Ralph Nevill. 1919.

Nicoll, William Robertson. Life and Letters. Edited by T. H. Darlow. 1925.

Oliver, F. S. The Anvil of War: Letters Between F. S. Oliver and His Brother, 191418. Edited by Stephen Gwynn. 1936.

Page, Walter. The Life and Letters of Walter H. Page. Edited by Burton Hendrick. 3 vols. 1922-25.

Parsons, Alan. Alan Parsons' Book: A Study in Anthology. Edited by Viola Parsons. 1937.

Pease, J. A. A Liberal Chronicle: Journal and Papers of J. A. Pease, 1st Lord Gainford, 1908-10. Edited by Cameron Hazlehurst and Christine Woodland. 1995.

Pease, Joseph Gourney. A Wealth of Happiness and Many Bitter Trials: The Journals of Sir Alfred Edward Pease, a Restless Man. York, 1992.

Redmayne, Richard. Men, Mines and Memories. 1942.

Repington, Charles à Court. The First World War, 1914-18. 2 vols. 1920.

- The Letters of Lieutenant-Colonel Charles à Court Repington CMG, Military Correspondent of The Times, 1903-1918. Edited by A. J. A. Morris. Stroud, 1999.

Richmond, Sir Herbert. Portrait of an Admiral: The Life and Papers of Sir Herbert Richmond. Edited by Arthur Marder. 1952.

Riddell, George. Lord Riddell's War Diary, 1914-1918. [1933].

Lord Riddell's Intimate Diary of the Peace Conference and After, 19181923. 1933.

- More Pages from My Diary, 1908-1914. 1934.

- The Riddell Diaries, 1908-1932. Edited by J. M. McEwen. 1986.

Robertson, Sir William. The Military Correspondence of Field Marshal Sir William Robertson. Edited by David Woodward. 1989. 


\section{Bibliography}

Rowntree, Arnold. The Letters of Arnold Stephenson Rowntree to Mary Katherine Rowntree 1910-18. Edited by Ian Packer. 2002.

Russell, Bertrand. The Collected Papers of Bertrand Russell. Vol. 13. Edited by Richard Rempel. 1988.

- The Selected Letters of Bertrand Russell. Vol. 1, The Private Years, 18821914. Edited by Nicholas Griffin. 1992.

Sanders, Robert. Real Old Tory Politics: The Political Diaries of Sir Robert Sanders, Lord Bayford, 1910-35. Edited by John Ramsden. 1984.

Sasson, Siegfried. Siegfried Sassoon Diaries: 1915-1918. Edited by Rupert HartDavis). 1983.

Selborne, Lord. The Crisis of British Unionism: Lord Selborne's Domestic Political Papers 1885-1922. Edited by George Boyce. 1987.

Schiff, Jacob. Jacob H. Schiff: His Life and Letters. 2 vols. Edited by Cyrus Adler. 1929.

Scott, C. P. The Political Diaries of C. P. Scott, 1911-1928. Edited by Trevor Wilson. 1970.

Shaw, George Bernard. Collected Letters, 1911-1925. Edited by Dan H. Stone. 1985.

Shaw, Lord. Letters to Isabel. 1921.

Smuts, J. C. Selections from the Smuts Papers. Vol. 3, June 1910-November 1918. Edited by W. R. Hancock and Jean Van Der Poel. Cambridge, 1966.

Spencer, Earl. The Red Earl: The Papers of the Fifth Earl Spencer, 1835-1910. Vol. 2, 188.5-1910. Edited by Peter Gordon. Northampton, 1986.

Spender, J. A. A Modern Journal: Being the Diary of Greville Minor for the Year of Agitation, 1903-1904. 1904.

Sylvester, A. J. Life with Lloyd George: The Diary of A. J. Sylvester, 1931-45. Edited by Colin Cross. 1975.

Tree, Viola. Can I Help You? 1937.

Vansittart, Lord. The Mist Procession. 1958.

Webb, Beatrice. The Diary of Beatrice Webb. Vol. 3, 1905-1924: The Power to Alter Things. Edited by Norman Mackenzie and Jeanne Norman. 1984.

West, Algernon. Private Diaries of the Rt. Hon. Sir Algernon West, G.C.B. Edited by Horace Hutchinson. 1922.

Wilson, Sir Henry. Field Marshal Sir Henry Wilson, His Life and Diaries. Edited by Sir C. E. Callwell. 1927.

Wilson, Keith. 'Hankey's Appendix: Some Admiralty Manoeuvres During and After the Agadir Crisis, 1911.' War in History by Woodrow Wilson. Vol. 1, 81-97. 1994.

Wilson, Woodrow. Woodrow Wilson: Life and Letters. Vol. 4, 1915-1917, Facing War. Edited by Ray Stannard Baker. 1939.

- The Papers of Woodrow Wilson. Vol. 35, October 1915-January 27, 1916; Vol. 40, November 20, 1916-January 23, 1917. Edited by Arthur S. Link. Princeton, 1980-82.

Woolf, Virginia. The Flight of the Mind: The Letters of Virginia Woolf. Vol. 1, 18881912. Edited by Nigel Nicolson. 1975 .

\section{Institutions}

Army Records Society. The Army and the Curragh Incident, 1914. Edited by Ian Beckett. 1986.

British Documents on the Origins of the War, 1898-1914. Vol. 4, Anglo-German Tension, Armaments and Negotiation, 1907-12; vol. 7, The Agadir Crisis. Edited by G. P. Gooch and Harold Temperley. 1930-32. 
Navy Records Society. Vol. 113, Documents Relating to the Naval Air Service. Vol. 1, 1908-18. Edited by S. W. Roskill. Aldershot, 1969.

- Vol. 131, British Naval Documents, 1904-1960. Edited by John Hattendorf, R. J. B. Knight, A. W. H. Pearsall, N. A. M. Roger, and Geoffrey Till. Aldershot, 1993.

Vol. 136, The Collective Naval Defence of the Empire, 1900-1940. Edited by Nicholas Tracy. Aldershot, 1997.

\section{Memoirs}

Addison, Christopher. Politics from Within. 2 vols. 1929.

Amery, L. S. My Political Life. 3 vols. 1952-55.

Asquith, Cynthia. Remember and be Glad. 1952.

Asquith, Herbert. Moments of Memory: Recollections and Impressions. 1937.

Asquith, Margot. The Autobiography of Margot Asquith. 1962.

Atkins, J. B. Incidents and Reflections. 1947.

Bacon, Admiral Sir Reginald. From 1900 Onward. 1940.

Balfour, Lady Frances. Ne Obliviscaris: Dinna Forget. 2 vols. 1930.

Beaverbrook, Lord. Success. 1922.

- Men and Power, 1917-1918. 1928.

- Politicians and the War, 1914-1916. 1960.

- The Decline and Fall of Lloyd George, 1963.

Benn, Ernest. Happier Days: Recollections and Reflections. 1949.

Benn, William Wedgwood. In the Side Shows. 1919.

Bennett, Arnold. Arnold Bennett's Letters To His Nephew. 1936.

Beresford, Lord Charles. The Betrayal. 1912.

Birrell, Augustine. Things Past Redress. 1937.

Boulton, A. C. Forster. Adventures, Travels and Politics. 1939.

Braithwaite, William. Lloyd George's Ambulance Wagon: Being the Memoirs of William J. Braithwaite, 1911-1912. Edited by Sir Henry Bunbury. [1957].

Browning, Oscar. Memories of Later Years. 1923.

Butler, Harold. Confident Morning. 1950.

Callwell, Major-General Sir C. E. Stray Recollections. 2 vols. 1923.

Cecil, Viscount. All The Way. 1949.

Chamberlain, Austen. Down the Years. [1935].

Churchill, Winston S. The World Crisis. 5 vols. 1923-27.

Clynes, J. R. Memoirs. 2 vols. 1937.

Colville, Lady Cynthia. Crowded Life. 1963.

Croft, Brigadier General The Lord. My Life of Strife. [1948].

Dixon, Ella Hepworth. As I Knew Them. [1930].

Domvile, Admiral Sir Barry. By and Large. 1936.

Edwards, Alfred George, Archbishop of Wales. Memories. 1927.

Fisher, Lord. Memories. 1919.

Fitzroy, Sir Almeric. Memoirs. 2 vols. [1925].

Garnett, David. The Flowers of the Forest. 1955.

George, William. My Brother and I. 1958.

Gray, George ['The Fighting Parson']. Vagaries of a Vagabond. 1930.

Grey, Sir Edward. Twenty-Five Years. 3 vols. 1928.

Haldane, Elizabeth. From One Century to Another. 1937.

Haldane, R. B. Autobiography. 1929.

Hardinge, Lord. Old Diplomacy. 1947.

Hesketh, Phoebe. My Aunt Edith. 1966.

Hewins, W. A. S. Apologia of an Imperialist. 2 vols. 1929. 
Holmes, Sir Charles. Self and Partners (Mostly Self). 1936.

Horner, Frances. Time Remembered. 1933.

Hume-Williams, Sir Ellis. The World, the House, and the Bar. 1930.

Hurd, Sir Archibald. Who Goes There? [1942].

Jekyll, Agnes. Ne Oublie. Edited by Barbara Freyberg and Pamela McKenna. [1937].

Memoirs of Sir Herbert Jekyll. Privately printed from the Royal Engineers Journal, March 1933.

Jellicoe, Admiral Viscount. The Grand Fleet 1914-16: Its Creation, Development and Work. 1919.

Keynes, J. M. Essays in Biography. Edited by Geoffrey Keynes. 1957.

Leith Ross, Frederick. Money Talks: Fifty Years of International Finance. 1968.

Le Queux, William. Things I Know about Kings, Celebrities, and Crooks. 1923.

Leslie, Shane. The End of a Chapter. 1929.

- Long Shadows. [1966].

Liddell Hart, Basil Henry. The Memoirs of Captain Liddell Hart. 2 vols. 1965.

Lidgett, J. Scott. Reminiscences. [1928].

- My Guided Life. 1936.

Lloyd George, David. War Memoirs. 2 vols. 1938.

Lloyd George, Frances. The Years that are Past. 1967.

Long, Walter. Memories. 1923.

Lucy, Sir Henry. Sixty Years in the Wilderness. 1912.

Lutyens, Lady Emily. Candles in the Sun. 1957.

Mackenzie, Compton. My Life and Times, Octave Four, 1907-1915. 1965.

Mackintosh, Sir Alexander. Echoes of Big Ben. 1945.

Macmillan, Harold. Winds of Change, 1914-1939. 1966.

Mallet, Sir Charles. Herbert Gladstone: A Memoir. 1932.

Mann, Tom. Tom Mann's Memoirs. 1923.

Marcosson, Isaac F. Adventures in Interviewing. 1919.

Markham, Violet. Return Passage, The Autobiography of Violet R. Markham, 1953.

Martin, Kingsley. Father Figures, Autobiography, 1897-1931, 1966.

Mason, D. M. Six Years of Politics. 1917.

Maugham, The Right Honourable Viscount. At the End of the Day. 1954.

McAdoo, William G. Crowded Years. Port Washington, 1931.

McFadyean, Andrew. Recollected in Tranquillity. 1964.

McKenna, Stephen. Reginald McKenna 1863-1943: A Memoir. 1948.

—. 'Reginald McKenna, 1863-1943'. A preprint of the life written for the Dictionary of National Biography, 1941-1950. Aspley Guise, 1946.

- 'Reginald McKenna'. In The Dictionary of National Biography, 1941-1950. Edited by L. G. Wickham Legg and E. T. Williams. 1959.

W. While I Remember. 1921.

Meynell, Francis. My Lives. 1971.

Montagu, Edwin. Edwin Montagu-A Memoir and an Account of His Visit to India. Edited by S. D. Waley. 1964.

Murray, Arthur C. Master and Brother-Murrays of Elibank. 1945.

Murray, Gilbert. An Unfinished Autobiography. 1960.

Oxford and Asquith, Countess of. Off the Record. 1944.

Oxford and Asquith, Earl of. Fifty Years of Parliament. 2 vols. 1926. Memories and Reflections, 1852-1927. 2 vols. 1928.

Pankhurst, E. Sylvia. The Suffragette Movement:An Intimate Account of Persons and Ideals. 1931.

- The Home Front: A Mirror to Life in England During the World War. 1932. 
Pethick-Lawrence, Emmeline. My Part in a Changing World. 1938.

Pethick-Lawrence, F. W. Fate Has Been Kind. 1942.

Ponsonby, Sir Frederick. Recollections of Three Reigns. 1951.

Repington, Charles à Court. Vestigia. 1919.

Ribot, Alexandre. Letters to a Friend; Recollections of My Political Life. [1926].

Samuel, Herbert, Viscount. Memoirs. 1945.

Sandhurst, Viscount. From Day to Day. 2 vols. 1928-29.

Sassoon, Siegfried. Siegfried's Journey. 1945, 1982.

Seely, J. E. B. Adventure. 1930.

Simon, John, Viscount. Retrospect. 1952.

Snowden, Philip, Viscount. An Autobiography. 2 vols. 1934.

Spender, J. A. Life, Journalism and Politics. 2 vols. 1927.

Stephen, Adrian. The 'Dreadnought Hoax'. 1936.

Swinton, Earl of. Sixty Years of Power. 1966.

Tennyson, Hallam. The Haunted Mind, An Autobiography. 1984.

Thomson, Basil. Queer People. [1922].

. The Scene Changes. 1939.

Ullswater, Viscount (James William Lowther). A Speaker's Commentaries. 2 vols. 1925.

Warner, Sir Pelham. Long Innings. 1951.

Wedgwood, Josiah C. Memoirs of a Fighting Life. 1941.

\section{Contemporary Works}

Angell, Norman. The Great Illusion: A Study of the Relation of Military Power to National Advantage. 1913.

Bacon, Admiral Sir R. H. The Life of Lord Fisher of Kilverstone. 2 vols. 1929.

The Life of John Rushworth, Earl Jellicoe. 1936.

Bagehot, Walter. Lombard Street: A Description of the Money Market. 5th ed. 1874.

The Bank of England, 1914-1921. Many uncited authors, published privately. 4 vols. 1926.

Bigge, Sir Lewis Amherst Selby-. The Board of Education. 1927.

Birkenhead, Rt. Hon. Earl of. Contemporary Personalities. 1924.

Bloch, I. S. Is War Now Impossible? 1899.

Bogart, Ernest L. Direct and Indirect Costs of the Great World War. New York, 1919.

Bond, Henry. A History of the Trinity Hall Boat Club. Cambridge, 1930.

Bridge, Admiral Sir Cyprian. 'Navy War Councils and General Staffs'. In Naval Annual 1910. Edited by T. A. Brassey, 80-90. 1910.

Brockway, A. Fenner. Labour and Liberalism. 1913.

Doyle, Sir Arthur Conan, The Memoirs of Sherlock Holmes, 1894.

Childers, Erskine. The Riddle of the Sands. 1903.

Dilke, Sir Charles Wentworth, and Spenser Wilkinson. Imperial Defence. 1892.

Edwards, Alfred George, Bishop of St Asaph. Landmarks in the History of the Welsh Church. 1912.

Everest, Edward Percy. The Public Authorities' Guide to the Mental Deficiency Act 1913. 1914.

Fairlie, John A. British War Administration. New York, 1919.

Fox, Frank. Ramparts of Empire. 1910.

Greig, James, and William Gattie. Archbold's Lunacy and Mental Deficiency. 5th ed. 1915. 


\section{Bibliography}

Gwynn, Stephen, and Gertrude Tuckwell. The Life of the Right Honourable Sir Charles W. Dilke. 2 vols. 1917.

Harding, W. P. G. The Formative Period of the Federal Reserve System. 1925.

Hardman, Thomas, ed. A Parliament of the Press: The First Imperial Press Conference, 1909.

Harris, S. E. Monetary Problems of the British Empire. New York, 1931.

Hawtrey, R. G. Currency and Credit. 1928.

Heath, Sir Thomas Lyttle. The Treasury. 1927.

Hirst, F. W. The Political Economy of War. 1916.

. The Consequences of the War to Great Britain. 1934.

Hirst, F. W., and J. E. Allen. British War Budgets. 1926.

Holmes, Thomas. 'The Home Secretary's Criminal Administration Bill'. Contemporary Review 106 (1914): 91-100.

Hurd, Archibald. 'England's Peril: Invasion or Starvation'. Fortnightly Review 87 (1910): 679-92.

. 'England's Peril: Invasion or Starvation, II'. Fortnightly Review 87 (1910): $862-73$.

Jones, J. H. The Economics of War and Conquest: An Examination of Mr. Norman Angell's Economic Doctrines. 1915.

Keynes, J. M. 'War and the Financial System, August 1914'. Economic Journal 24 (1914): 460-86.

King, Charles. The Asquith Parliament (1906-1909): A Popular History of Its Men and Its Measures. 1910.

Le Bas, Hedley. 'How Advertising Helped to Win the War'. Ways and Means 26 (1919): 245-46.

Le Queux, William. The Invasion of 1910. 1906.

Leyland, John, 'Declaration of London: Points and Considerations'. Naval Annual, 1911. Edited by T. A. Brassey, 163-72. 1911.

- 'Naval War Staffs'. Naval Annual 1912. Edited by Viscount Hythe, 112-23. 1912

Marcosson, Isaac F. The War after the War. New York, 1917.

Masterman, Lucy. C. F. G. Masterman, A Biography. 1939.

McKenna, Sir Joseph Neale, Imperial Taxation: The Case of Ireland Plainly Stated for the Information of the English People and of Those Others Whom it May Concern. 1883.

- The Irish Land Question Where the Requisite Funds for its Solution are to be Found Without Trenching on or Imperilling the Proceeds of British Taxes the Question Considered and Answered in Connection with Mr Gladstone's Taxation of Ireland from 1853 to the Present Time. n.d.

Monro (p. 306. n. 229.).

Noel-Baker, Philip. The Private Manufacture of Armaments. 3 vols. 1936.

Pankhurst, E. Sylvia. The Life of Emmeline Pankhurst. 1935.

Raymond, E. T. (M. Thompson). Lloyd George. 1922.

- Portraits of the New Century. 1928.

Salter, Arthur. Personality in Politics: Studies of Contemporary Statesmen. 1947.

Spender, Harold. Herbert Henry Asquith. 1915.

Spender, J. A. The Life of Sir Henry Campbell-Bannerman, GCB. 2 vols. 1923.

-. Sir Robert Hudson, A Memoir. 1930.

- Great Britain and Commonwealth, 1886-1935. 1936.

Spender, J. A., and Cyril Asquith. Life of Herbert Henry Asquith, Lord Oxford and Asquith. 2 vols. 1932.

Stamp, Josiah. Taxation During the War. 1932. 
Thornton, Percy M. 'Battersea and Clapham'. In Bygone Surrey. Edited by George Clinch and S. W. Kershaw. 1895.

Troup, Sir Edward. The Home Office. 1925.

Wells, H. G. The War in the Air. 1908.

Westwood, H. R. Modern Caricaturists. 1932.

Withers, Hartley. War and Lombard Street. 1915.

Yexley, Lionel. Our Fighting Sea Men. [1911].

\title{
Reference Works
}

Alumni Cantabrigieneses.

Burke's Peerage, Baronetage and Knightage.

Constitutional Yearbook.

Debrett's Peerage, Baronetage, and Knightage.

Dictionary of Business Biography.

Dictionary of National Biography.

Dod's Parliamentary Companion.

Eighty Club Yearbook.

A Guide to the Papers of British Cabinet Ministers. Compiled by Cameron Hazlehurst, Sally Whitehead, and Christine Woodland. 1996.

King's College School Register. Vol. 2. 1985.

Ladies' Who's Who.

Law List.

Liberal Yearbook.

National Register.

O'Hart, John. Irish Pedigrees, 3rd ed. Dublin, 1881.

Oxford Dictionary of National Biography.

Whittaker's Almanack.

Who Was Who.

Who Was Who in America.

Who's Who.

\section{Newspapers and Periodicals}

\author{
Aborigines' Protection Society Yearbook \\ Birmingham Gazette \\ Birmingham Post \\ Daily Chronicle \\ Daily Graphic \\ Daily Mail \\ Daily Mirror \\ Daily News \\ Echo \\ Economist \\ Evening Standard \\ Financial News \\ Glasgow Herald \\ Globe \\ Higham's Magazine \\ Illustrated Sunday Herald \\ Morning Post
}




\section{Bibliography}

Nation [UK]

Nation [US]

New Age

New Statesman

New York Times

Pall Mall Gazette

Pontypool Free Press

Punch

Queen

Scotsman

South Wales Argus

South Wales Daily News

South Wales Daily Press

Spectator

Suffragette

Sunday Times

Time

Times

Times Literary Supplement

Truth

Washington Post

Week

Westminster Gazette

World

Yorkshire Observer

Yorkshire Post

\section{Official Publications}

England Census Records.

History of the Ministry of Munitions. 8 vols. London: HMSO, 1918-1922.

House of Commons Debates, 4th and 5th series.

Parliamentary Debates, 4th series.

Parliamentary Debates, 5 th series.

Report from the Select Committee on War Office Contracts. London: HMSO, 1900. Report on the State of Employment in the United Kingdom in February 1915. Cd. 7939.

Report of a Sub-Committee of the Committee of Imperial Defence. Cd. 256. 12 September 1909.

Retrenchment in the Public Expenditure, 1st Report ICMD. Cd. 8608. London: HMSO, 1915.

Royal Commission on the Private Manufacture of and Trading in Arms, 1936, Cd. 5292.

Statistics of the Military Effort of the British Empire During the Great War, 19141920. London: HMSO, 1922.

\section{SECONDARY SOURCES}

\section{Unpublished Works}

Farr, Martin. 'Reginald McKenna as Chancellor of the Exchequer 1915-1916'. PhD thesis, University of Glasgow, 1998. 
Hammer, Margaret. "The Building of the Nation's Health"; the Life and Work of George Newman to 1921'. PhI) thesis, University of Cambridge, 1995.

Hemery, John Anthony. 'The Emergence of Treasury Influence in British Foreign Policy 1914-1921'. PhD thesis, University of Cambridge, 1988.

O'Brien, Phillips Payson. 'The Cabinet, the Admiralty, and the Perceptions Governing the Formation of British Naval Policy 1909, 1921-1922, 1927-1936'. PhD thesis, University of Cambridge, 1992.

Wallace, Johnathan. 'The Political Career of Walter Runciman, 1st Viscount Runciman of Doxford'. PhD thesis, University of Newcastle, 1995.

\section{Published Works}

Adams, R. J. Q. 'Asquith's Choice: The May Coalition and the Coming of Conscription, 1915-1916'. Journal of British Studies 25 (1986): 243-63.

Addison, Paul. Churchill on the Home Front, 1900-1955. 1992.

Allen, Bernard M. Sir Robert Morant-A Great Public Servant. 1934.

Altham, Captain E[dward]. Jellicoe. 1938.

Andrew, Christopher. Secret Service: The Making of the British Intelligence Community. 1985.

Ayerst, David. Garvin of the Observer. 1985.

Bell, G. K. A. Randall Davidson, Archbishop of Canterbury. 2 vols. 1935.

Bell, Quentin. Virginia Woolf, a Biography. 2 vols. 1972.

Bentley, Michael. The Liberal Mind, 1914-1929. Cambridge, 1977.

Betts, Robin S. 'Winston Churchill and the Presidency of the Board of Education, 1906-1907'. History of Education 15 (1986): 89-93.

Bird, J. C. Control of Enemy Aliens in Great Britain, 1914-1918. New York, 1986.

Birkenhead, 2nd Earl. Frederick Edwin, Earl of Birkenhead. 2 vols. 1933.

Boswell, Johnathan S., and Bruce R. Johns. 'Patriots or Profiteers? British

Businessmen and the First World War'. Journal of European Economic History 11 (1982): 423-45.

Broad, Lewis. Advocates of the Golden Age: Their Lives and Cases. 1958.

Brown, Jane. Lutyens and the Edwardians: An English Architect and His Clients. 1996.

Burk, Kathleen. Britain, America, and the Sinews of War, 1914-1918. 1985.

.'The Treasury: From Impotence to Power'. In War and the State: The Transformation of British Government, 1914-1919, edited by Kathleen Burk, 84-107. 1982.

Butler, A. S. G. The Architecture of Sir Edwin Lutyens. 3 vols. 1950.

Campbell, John. F. E. Smith, First Earl of Birkenhead. 1983.

Cannadine, David. 'Writer and Biographer'. In Roy Jenkins: A Retrospective, edited by Andrew Adonis and Keith Thomas, 271-306. Oxford, 2004.

Carew, Anthony. The Lower Deck of the Royal Navy, 1900-39. Manchester, 1981.

Cashman, John. 'The 1906 Education Bill: Catholic Peers and Irish Nationalists'. Recusant History 18 (1987): 422-39.

Cassar, George H. Asquith as War Leader. 1994.

Chandler, Lester V. Benjamin Strong, Central Banker. Washington D. C., 1958.

Clarke, Peter. A Question of Leadership. 1991.

Colley, Robert. 'Railways and the Mid-Victorian Income-Tax'. Journal of Transport History 24 (2003): 78-102.

- 'The Shoreditch Tax Frauds: A Study of the Relationship Between the State and Civil Society in 1860'. Historical Research 78 (2005): 540-62.

Colvin, Ian. The Life of Lord Carson. 3 vols. 1932-36. 


\section{Bibliography}

Coogan, John W. The End of Neutrality-The United States, Britain, and Maritime Rights, 1899-1915. Ithaca, 1981.

Cregier, Don M. Bounder from Wales: Lloyd George's Career Before the First World War. Columbia, 1976.

- 'Reginald McKenna'. In the Oxford Dictionary of National Biography, edited by H. C. G. Matthew and Brian Harrison. Oxford, 2004.

Cross, Colin. The Liberals in Power, 1905-1914. 1963.

Daglish, Neil. Education Policy-Making in England and Wales. 1996.

_A "Difficult and Somewhat Thankless Task": Politics, Religion, and the Education Bill of 1908'. Journal of Educational Administration and History 31 (1999): 19-35.

Dale, H. E. The Higher Civil Service of Great Britain. Oxford, 1942.

Daunton, Martin. Trusting Leviathan: The Politics of Taxation in Britain, 17991914. Cambridge, 2001.

David, Edward. 'The Liberal Party Divided, 1916-1918'. Historical Journal 13 (1970): 509-33.

Dayer, Roberta. 'Strange Bedfellows: J. P. Morgan and Co., Whitehall and the Wilson Administration During World War I'. Business History 28 (1976): 127-51.

Devlin, Patrick. Too Proud to Fight: Woodrow Wilson's Neutrality. 1974.

Dimsdale, N. H. 'Keynes and the Finance of the First World War'. In Essays on Maynard Keynes, edited by Milo Keynes, 142-61. Cambridge: Cambridge University Press, 1975.

Douglas, Roy. The History of the Liberal Party, 1895-1970. 1971.

Emy, H. V. 'The Land Campaign'. In Lloyd George: Twelve Essays, edited by A. J. P. Taylor, 35-41. 1971.

Farr, Martin. 'A Compelling Case for Voluntarism: Britain's Alternative Strategy, 1915-1916'. War in History 9 (2002): 279-306.

- 'Clann MacKenna's Edwardian Exile'. Sydney Series in Celtic Studies 8 (2005): 207-24.

- "Squiff", "Lliar George", and "the McKennae": The Unpersuasive Politics of Personality in the Asquith Coalition, 1915-16'. In Making Reputations: Power, Persuasion and the Individual in Modern British Politics, edited by Julie Gottlieb and Richard Toye, 29-42. 2005.

_ 'Left, Right: The Forward March of Liberals Halted'. Journal of Liberal History 47 (2005): 30-35.

Ferguson, Niall. The Pity of War. 1998.

Fergusson, Sir James. The Curragh Incident. 1964.

Foster, R. F. W. B. Yeats. 2 vols. Oxford 1997.

Francis Birrell and Others. [No author cited.] Heywood Hill, 1991.

Fraser, Peter. 'British War Policy and the Crisis of Liberalism in May 1915'. Journal of Modern History 54 (1982): 1-26.

French, David. British Economic and Strategic Planning, 1905-1915. 1982.

- 'The Meaning of Attrition, 1914-1916'. English Historical Review 103 (1988): 385-405.

.'Spy Fever in Britain, 1900-1915'. Historical Journal 21 (1978): 355-70.

Froom, Frederick J. A Site in Poultry. 1950.

Fry, Michael. 'Political Change in Britain, August 1914 to December 1916: Lloyd George Replaces Asquith: The Issues Underlying the Drama'. Historical Journal 31 (1988): 609-27.

Fulford, Roger. 'Jacob's Ladder', Times Literary Supplement. 19 June 1948, 339.

. Votes for Women: The Story of a Struggle. 1957.

Gilbert, Bentley Brinkerhoff. The Evolution of National Insurance in Britain, the Origins of the Welfare State. 1973. 
David Lloyd George: A Political Life. 2 vols. 1987-1992.

Gordon, Peter, Richard Aldrich, and Dennis Dean. Education and Policy in England in the Twentieth Century. 1991.

Gradidge, Roderick. Edwin Lutyens: Architect Laureate. 1981.

Grigg, John. Lloyd George: From Peace to War, 1912-1916. 1985.

Guttsman, W. L. The British Political Elite. 1963.

Harris, José, and Cameron Hazlehurst. 'Campbell-Bannerman as Prime Minister', History 55, (1970): 360-83.

Harris, Seymour E. John Maynard Keynes. New York, 1955.

Harris, Wilson. J. A. Spender. 1946.

Harrison, Brian. Separate Spheres: The Opposition to Women's Suffrage in Britain. 1978.

Hassall, Christopher. Edward Marsh, Patron of the Arts, a Biography. 1959.

Haste, Cate. Keep the Home Fires Burning. 1977.

Hazlehurst, Cameron. Politicians at War: July 1914 to May 1915. A Prologue to the Triumph of Lloyd George. 1971.

Hearnshaw, F. J. C. The Centenary History of King's College, London, 1828-1928. 1929.

Hession, Charles H. Jobn Maynard Keynes. New York, 1984.

Hiley, N. 'The Failure of British Counter-Espionage Against Germany, 1907-1914'. Historical Journal 28 (1985): 835-62.

- 'Sir Hedley Le Bas and the Origins of Domestic Propaganda in Britain, 1914-1917'. Journal of Advertising History 10 (1987): 30-46.

Holmes, A. R., and Edwin Green. Midland: 150 Years of Banking Business. 1986.

Horn, Martin. 'External Finance in Anglo-French Relations in the First World War, 1914-1917'. International History Review 17 (1995): 51-77.

. Britain, France, and the Financing of the First World War. Montreal, 2002.

Horne, Alistair, ed. Telling Lives. 2000.

Howe, Anthony. Free Trade and Liberal England, 1846-1946. Oxford, 1997.

Hume, Leslie Parker. The National Union of Women's Suffrage Societies, 1897-1914. New York, 1982.

Hussey, Christopher. The Life of Sir Edwin Lutyens. 1953.

Hyde, H. Montgomery. Lord Reading: The Life of Rufus Isaacs, First Marquess of Reading. 1967.

Jackson, Robert. The Chief, the Biography of Gordon Hewart, Lord Chief Justice of England, 1922-40. 1959.

Jalland, Patricia. The Liberals and Ireland: The Ulster Question in British Politics to 1914. Brighton, 1980.

James, Robert Rhodes. Churchill: A Study in Failure, 1900-1939. 1970.

Jenkins, Roy. Asquith. 1964.

. Baldwin. 1987.

- The Chancellors. 1998.

Jones, Thomas. Lloyd George. 1951.

Kennedy, Paul. The Rise of the Anglo-German Antagonism, 1869-1914. 1980.

Kent, Bruce. The Spoils of War: The Politics, Economics, and Diplomacy of Reparations, 1918-32. Oxford, 1991.

Kettle, Michael. Salome's Last Veil: The Libel Case of the Century. 1977.

Koss, Stephen. 'The Destruction of Britain's Last Liberal Government'. Journal of Modern History 40 (1968): 257-77.

Lord Haldane: Scapegoat for Liberalism. New York, 1969.

- Fleet Street Radical: A. G. G. Gardner and the Daily News. 1973.

. Nonconformity in Modern British Politics. 1975.

Asquith. 1976. 


\section{Bibliography}

The Rise and Fall of the Political Press in Britain. 2 vols. 1981-84.

Kynaston, David. The Chancellor of the Exchequer. Lavenham, 1980.

Lambert, Nicholas A. Sir John Fisher's Naval Revolution. Columbia, 1999.

Lamont, Thomas W. Henry P. Davison: The Record of a Useful Life. New York, 1933.

Lane, Christopher. 'The Unrest Cure According to Lawrence, Saki, and Lewis'. Modernism/Modernity 11 (2004): 769-96.

Leslie, Shane. Mark Sykes: His Life and Letters. 1923.

Levine, Naomi B. Politics, Religion and Love: The Story of H. H. Asquith, Venetia Stanley and Edwin Montagu, Based on the Life and Letters of Edwin Samuel Montagu. New York, 1991.

Lloyd George, Earl. Lloyd George. 1960.

Longford, Ruth. Frances: Countess Lloyd George: More than a Mistress. Leominster, 1996.

Lowe, Peter. 'The Rise to the Premiership, 1914-16'. In Lloyd George: Twelve Essays, edited by A. J. P. Taylor, 95-136. 1971.

Lyons, F. S. John Dillon: A Biography. 1968.

MacLysaght, Edward. Irish Families. Dublin, 1957.

Marder, Arthur. From the Dreadnought to Scapa Flow: The Royal Navy in the Fisher Era, 1904-1919. 5 vols. 1961-70.

McCormick, Donald. Peddler of Death: The Life of Sir Basil Zaharoff. 1965.

McDermott, John. 'Trading with the Enemy: British Business and the Law During the First World War'. Canadian Journal of History 22 (1997): 201-19.

McEwen, J. M. 'The Press and the Fall of Asquith'. Historical Journal 21 (1978): $863-83$.

— 'The Struggle for Mastery in Britain: I loyd George Versus Asquith, December 1916'. Journal of British Studies 18 (1978): 131-56.

McGill, Barry. 'Asquith's Predicament, 1914-1918'. Journal of Modern History 39 (1967): 283-303.

McKenna and Co. [Solicitors], 1882-1982. Privately published, 1982.

McNicholl, Vincent. 'Reginald McKenna, Statesman and Financier'. Clann MacKenna 4 (1994): 55-63.

Miles, Frank, and Graeme Cranch. Kings College School, The First 150 Years. 1979.

Miller, J. D. B. Norman Angell and the Futility of War: Peace and the Public Mind. 1986.

Mitchell, David. Queen Christabel. 1977.

Moggridge, Donald Edward. Maynard Keynes: An Economist's Biography. 1992.

Moore, Carl H. The Federal Reserve System: A History of the First Seventy-Five Years. Jefferson, 1990.

Morgan, David. Suffragists and Liberals: The Politics of Woman Suffrage in England. Oxford, 1975.

Morgan, Edward Victor. Studies in British Financial Policy, 1914-25. 1952.

Morgan, Kenneth O. Wales in British Politics, 1868-1922. Cardiff, 1980.

Morris, A. J. A. The Scaremongers: The Advocacy of War and Rearmament, 18961914. 1984.

Murfett, Malcolm H., ed. The First Sea Lords: From Fisher to Mountbatten. Westport, 1995.

Murphy, Richard. 'Walter Long, the Unionist Ministers, and the Formation of I.loyd George's Government in December 1916'. Historical Journal 29 (1986): 735-45.

Murray, Bruce K. The People's Budget 1909-10: Lloyd George and Liberal Politics. Oxford, 1980 . 
Neff, Stephen. The Rights and Duties of Nations, A General History. Manchester, 2002.

Neilson, Keith. Strategy and Supply: The Anglo-Russian Alliance, 1914-17. 1984.

. Britain and the Last Tsar-British Policy and Russia 1894-1917. Oxford, 1995.

Offer, Avner. "Morality and Admiralty: "Jacky" Fisher, Economic Warfare and the Laws of War'. Journal of Contemporary History 23 (1988): 99-119.

. The First World War-An Agrarian Interpretation. Oxford, 1989.

Owen, Frank. Tempestuous Journey: Lloyd George, His Life and Times. 1954.

Page, Arnot, R. South Wales Miners: A History of the South Wales Mining Federation, 1898-1914. 1967.

Page, Christopher. Command in the Royal Naval Divisions-A Military Biography of Brigadier General A. M. Asquith, DSO. Staplehurst, 1999.

Panayi, Panikos. The Enemy in Our Midst: Germans in Britain During the First World War. New York, 1991.

Parrini, Carl P. Heir to Empire: United States Economic Diplomacy, 1916-2.3. Pittsburgh, 1969.

Patterson, A. Temple. Jellicoe-A Biography.1969.

Peden, G. C. British Economic and Social Policy. Oxford, 1985.

. The Treasury and British Public Policy, 1906-1959. Oxford, 2000.

Pellew, Jill. The Home Office 1848-1914:From Clerks to Bureaucrats. 1982.

Penn, Geoffrey. Infighting Admirals: Fisher's Feud with Beresford and the Reactionaries. 2000.

Petrie, Charles. Walter Long and His Times. 1936.

Pope-Hennessy, James. Lord Crewe: 1858-1945: The Likeness of a Liberal. 1955.

Pound, Reginald. Arnold Bennett: A Biography. 1952.

Pugh, Martin. 'Asquith, Bonar Law and the First Coalition'. Historical Journal 17 (1974): 813-36.

. The Pankhursts. 2001.

Purvis, June. Emmeline Pankhurst: A Biography. 2002.

Reid, Michaela. Ask Sir James. 1987.

Richards, Noel. 'The Education Bill of 1906 and the Decline of Political Nonconformity'. Journal of Ecclesiastical History 23 (1972): 49-63.

Rosen, Andrew. Rise Up Women!: The Militant Campaign of the Women's Social and Political Union, 1903-1911. 1974.

Roseveare, Henry. The Treasury: The Evolution of a British Institution. 1969.

Roskill, Stephen. Hankey: Man of Secrets. 3 vols. 1970-74.

Ross, Stewart. Admiral Sir Francis Bridgeman: The Life and Times of an Officer and a Gentleman. Cambridge, 1998.

Rover, Constance. Women's Suffrage and Party Politics in Britain, 1866-1914. 1967.

Rowland, Peter. The Last Liberal Governments. 2 vols. 1968-71.

Sacks, Benjamin. The Religious Issue in the State Schools of England and Wales, 1902-1914. Albuquerque, 1961.

Searle, G. R. The Liberal Party: Triumph and Disintegration, 1886-1929. 1992.

. Corruption in British Politics, 1895-1930. Oxford, 1987.

- Eugenics and Politics in Britain. Leyden, 1976.

Semmel, Bernard. Liberalism and Naval Strategy: Ideology, Interest and Sea Power During the Pax Britannica. 1986.

Seymour-Jones, Carole. Beatrice Webb, Woman of Conflict. 1992.

Skidelsky, Robert. John Maynard Keynes. 3 vols. 1983-2000.

Stansky, Peter. On or About December 1910: Early Bloomsbury and Its Intimate World. Cambridge, MA, 1996. 


\section{Bibliography}

Strachan, Hew. The First World War. Oxford, 2001.

Swezey III, C. Eugene. The Mackennas of Truagh. Privately printed, 2nd ed. 1977.

Tansill, Charles Callan. America Goes to War. Boston, 1938.

Taylor, A. J. P. 'Politics in the First World War'. Raleigh Lecture on History, 1959. Proceedings of the British Academy 45 (1959): 67-95.

- Beaverbrook. 1972.

Thirlwell, A. P., ed. Keynes as Policy Adviser. 1982.

Thomas, J. A. The House of Commons, 1906-1911; An Analysis of Its Economic and Social Character. Cardiff, 1958.

Thomson, Malcolm. David Lloyd George: The Official Biography. [c. 1950].

Tooley, M. J., and P. Arnander, eds. Gertrude Jekyll: Essays on the Life of a Working Amateur. Witton-le-Wear, 1995.

Trevelyan, G. M. Grey of Fallodon. 1937.

Turner, John. British Politics and the Great War: Coalition and Conflict, 1915-1918. 1992.

Vogeler, Martha. Frederic Harrison: The Vocations of a Positivist. Oxford, 1984.

Wallace, Graham. Claude Grahame-White, a Biography. 1960.

Wiemann, F. W. 'Lloyd George and the Struggle for the Navy Estimates of 1914'. In The Politics of Grand Strategy-Britain and France Prepare for War, 1904-1914, edited by Samuel R. Williamson, Jr. Cambridge, MA, 1969.

Wilson, John. CB: A Life of Sir Henry Campbell-Bannerman. 1973.

Wilson, Keith M. The Policy of the Entente: Essays on the Determinants of British Foreign Policy, 1904-1914. Cambridge, 1985.

Wilson, Trevor. The Downfall of the Liberal Party, 1914-1935. 1966.

Winslow, Barbara. Sylvia Pankhurst: Sexual Politics and Political Activism. 1996.

Woodward, E. L. Great Britain and the German Navy. 1964.

Ziegler, Philip, and Desmond Seward. Brooks's: A Social History. 1991. 


\section{Index}

Compiled by the author. Titles of individuals are given for the time when $\mathrm{RMcK}$ had the most contact with them in the period covered by this volume; subsequent and highest titles are in parenthesis. Numerals in bold face indicate a chapter/section devoted to a subject entry. Entries are broadly chronological in sequence, except where no chronology is present.

Abergavenny 45, 47, 63, 64, 186, 190, 215

Aberyschan 45, 214

Aborigines' Protection League (APS) $56-7,73,76$

Abraham, Margery Mary (May) (later Tennant) 41,325

Abyssinia 53

Addison, Christopher (1st Viscount Addison) 7,8 n. 2

Admiralty 7, 13, 14, 129, 132-222, 249, 279, 307; 'atlanticists' and 'continentalists' 135-136; naval staff $180,208,210$, 217; war planning 212-213, 254-256

Agadir (Second Morocco Crisis, 1911) 210,220

Agricultural Land Rating Bill (1896) 54

Aitken, William Maxwell see Beaverbrook, 1st Baron

Albert, Prince, Duke of York (King George VI) 28, 182

Alexandra, Queen: blames RMcK for death of Edward VII 182

Allen, William 60

Aliens 46, 225; wartime hysteria concerning 265-271

Aliens Restriction Act (1914) 266

Amery, Rt. Hon. Leopold, MP (Unionist) 8 n. 2, 249

Angell, Norman 136, 211
Antichrist, or the Reunion of Christendom: An Ode 258-259

Archer-Shee, George 164-165, 182

Archer-Shee, Major Martin, MP (Unionist) 164

Archer-Shee affair 164-165, 182, 209

Archerfield 217, 276

Aristotle 110

Armstrong Whitworth 160

Arnander, Mrs Primrose (RMcK's granddaughter) xiv, 72 n. 2 , 95 n. 6,97 n. 5

Arthur, Prince, first duke of Connaught and Strathearn 181, 183

Askwith, Sir George (Baron) 233

Asquith, Anthony 164

Asquith, Cynthia 71, 98, 281, 309

Asquith, Elizabeth 71, 246

Asquith, Herbert ('Beb') (2nd Earl of Oxford and Asquith) 309

Asquith, Rt. Hon. Herbert Henry, MP (1st Earl of Oxford and Asquith) ('Henry')

1, 7,8 n.6, 40, 50, 70, 74, 95, 138, 140, 182, 195, 202, 208, 327; and RMcK 13, 14, 65, 196; and Beresford affair 166-169, 180; as Chancellor 82, 87-90, 92, 111, 112, 183; and Horners 98; and Jekylls 98; and Venetia Stanley, 99, 318-319; and PMcK 98, 99, 236; 
Asquith, Rt. Hon. Herbert Henry, MP (1st Earl of Oxford and Asquith) ('Henry') (continued) correspondence with $\mathrm{PMcK}$, 5,6 n. $4,99,100,121,158$, 282, 306-307, 318-320, 331, 335, 337-338, 339; and Party leadership 61; and Boer War 65; and Labour 113; RMcK's admiration of 117 ; becomes Prime Minister, 127-128; and the McKennae 127, 181, 193, 268, 272, 309; and naval expenditure 137; mediates rows concerning RMcK 141, 147; and war 141 ; tensions with RMcK 148; critical of RMcK 151, 155; godfather to MMcK 191; PMcK on 197; on Winston 203; offers RMcK Permanent Secretaryship of the Treasury 207; and RMcK's removal from the Admiralty 207, 210, 212-213, 215-222; on Lloyd George 207; and Welsh Church 228; and suffragism 228; forced to defend RMcK 234, 243; dependence on RMcK 246-247, 300, 321; and Lloyd George 247; and Ulster 255-258; and declaration of war 259-260; mediates RMcK-inspired rows 273-274, 293, 325, 332-333; high opinion of RMcK 276, 306; and RMcK as Chancellor 294, 297; and coalition 310, 313; and RMcK's resignation 314-315; and Committee on the Co-Ordination of the Military and Financial Effort 321-322; low opinion of RMcK 322; put Lloyd George in the War Office 329; increasing preoccupation with PMcK 318-320; forced to pacify Bank and City 332 ; on Entente 333; Raymond's death 335-336; and second December crisis 336-339; resigns 339

Asquith, Katharine see Horner, Katharine
Asquith, Margaret Emma Alice, (Countess of Oxford and Asquith) ('Margot')

5, 138, 140, 194, 216, 231, 255, $269,275,309,321$; and RMcK 90, 122; on RMcK 93, 94-95, 116, 121, 133, 155, 181, 199, 207, 224, 244, 270, 272, 273, 276-277, 279, 286; on the McKennae 157; on Lloyd George 199, 207, 315; on PMcK 235, 236-237, 315; on Winston 242; and first December crisis 315; on wartime war between Lloyd George and RMcK 299; and second December crisis 339

Asquith, Raymond: marries Katharine Horner 98; killed in action 335

Asquith, Violet (Violet Bonham Carter) 71, 123, 274, 315; and RMcK 116; on RMcK 121, 154, 227, 272; and PMcK, 99; and second December crisis 339

Astor, Nancy 309

Athenaeum 155

Athens 304

Atkins, John 30, 44

Australia 162-163

Austria: naval construction 150, 204

Bacon, Sir Reginald (Admiral) 11, 149, 159,167

Bach, J. S. 138

Baddeley, (Sir) Vincent ('Vinbad') 137, 140, 186, 188, 195, 205, 206

Bagehot, Walter 20

Baker, Harold ('Bluey') 309

Balcarres and Crawford, Earl of see Crawford, David Alexander Edward Lindsay

Baldwin, Stanley (1st Earl) 7

Balfour, Rt. Hon. Arthur James MP (Unionist) (1 st Earl)

$57,58,66,75,76,94,165,167$, 193, 322; and religion 69; 72; as Prime Minister 77, 80, 81, 83; on RMcK 91, 110, 126, 227; and Lloyd George 115; 117; and education 125, 126 ; and naval expenditure 159; and flight 202; and Welsh 
Church 227; and war 273; appointed to Government 1915 282; on Kitchener 295; wartime intrigues 299; appreciation of PMcK 317; and a negotiated peace 328 ; and Lloyd George's coup 338

Balfour, Lady Frances 79, 229

Balliol College Oxford 97

Balmoral 180, 184, 218

Banbury, Sir Frederick (1st Baron Banbury) 232

Bank of England 15, 288, 310, 333

Bar see Jekyll, Barbara

Bark, Peter (Russian finance minister) 296; orgy 298

Barnes, Rt. Hon George, MP (Labour): RMcK recruits 292

Barrie, (Sir) James Matthew 138

Barrow in Furness 160

Bathurst, Charles (1st Viscount Bledisloe) 7

Battenburg, Prince Louis of (1st Marquess of Milford Haven)

forced to resign as First Lord of the Admiralty 896

Bay, Ali Risa (Colonel) 158

Beach, Michael Hicks (1st Earl St Aldwyn) 67,84

Beatty, Rear Admiral David (1st Earl) and RMcK 165; believes RMcK an unsuitable minister for wartime 262, 269

Beauchamp, William Lygon, 7th Earl 181

Beaumont, Sir Lewis 208

Beaverbrook, William Maxwell Aitken, 1 st Baron

8 n.2; and PMcK 6; and 1915 exchange crisis 293; and second December crisis 339

Beb see Asquith, Herbert

Belfast 257

Belgium 76

Belloc, (Joseph) Hilaire 96, 99, 235

Belmont Castle 65

Benn, William Wedgwood (1st Viscount Stansgate) ('Benntig')

7, 138, 140, 187, 201, 203; and PMcK 157, 335; on RMcK 203-204; godfather to DMcK 206; and war 309; informed by RMcK of the end 340
Bennett, Enoch Arnold

$21,96,99,236,281,316$; and

PMcK 309; on RMcK 278;

on RMcK as Chancellor 284;

wartime privations of 309 ;

and RMcK on the war 330

Benntig see Benn, William

Wedgwood

Beresford, Admiral Lord Charles William de la Poer

114, 137, 140, 151, 182, 184;

on RMcK 208; and RMcK

166-169, 180, 188; as MP

204; RMcK on 205; policy

problem at Home Office 225 , 243; and war 268, 288

Beresford, Dorothy 99

Beresford Inquiry, 166-169, 180, 208, 322

Berlin 141

Besant, Annie 182

Biarritz 127, 181

Birrell, Rt. Hon Augustine MP

40, 71, 92, 99, 138, 190, 195, 206; and APS 56; and FTU 73; and education $86,90,102-103$, 108; and PMcK, 121, 157, 187, 271; and coalition 315 ; and Easter rebellion 330

Birmingham Post 130

Blackett, (Sir) Basil Phillott 287, 302

Blackley, Reverend William Lewery 36, 55

Blaenavon 45, 46, 76, 194, 198

Bloch, Ivan Stanislavovic 136

Blockade, naval 143-144, 209

Bloomsbury 96

Blumenfeld, Ralph David (editor of the Daily Express) 278

Boer War see wars, 1899-1902

Board of Education 11, 224, 249

Board of Trade 78, 129, 232, 273

Bond, Henry 30, 32

Borwick, Leonard 98

Bottomley, Horatio MP 167, 270

Boulogne 296

Bourne, Francis Alphonsus, Archbishop of Westminster 104

Bracken, Brendan Rendall (Viscount Bracken) 7

Bradbury, Sir John (1st Baron Bradbury) (Permanent Secretary, HM Treasury) 


\section{Index}

Bradbury, Sir John (1st Baron Bradbury) (Permanent Secretary, HM Treasury) (continued) 154, 287, 288; on Lloyd George (attrib.) 154 n. 5

Bradlaugh, Charles MP 20

Braithwaite, William 153

Bridgeman, Vice Admiral Sir Francis Charles (Second Sea Lord) 219,221

Bridgeman, William Clive (1st Viscount Bridgeman) 7,10 n. 2

Bright, John 96

Brighton 113

Bristol 20

British Board of Film Censors 250-251, 327

British Empire 53, 56, 161-163, 215

British Expeditionary Force (BEF) 220

British Weekly 105

Brixton 37

Brock, Laurie 326

Brockway, Fenner 248-249

Brooks's Club 94

Bryanston Square 21

Bryce, James (Viscount Bryce) 91, 263

Buchanan, Sir George 9 n. 1

Buckle, George Earle 128, 152

Buckle, Henry Thomas 29

Budgets

1906: 88; 1907: 89; 1908 112, $153 ; 1909,151,183-184$, 199; $1913245 ; 1914,245$; 1915 (May) 304 (September) 304-307; 1916 322-324

Buckingham Palace 223

Buckmaster, Rt. Hon. Stanley Owen MP, Baron (1st Viscount)

7, 263, 271, 309; on Coalition 286

Bucknill, Thomas 31

Bulgars 20, 53

Bull, John 111

Bunyan, John 29

Burke, Edmund 28

Burne-Jones, Philip 96, 97, 156

Burns, Rt. Hon John Elliott MP

42, 43, 44, 50, 68, 138; and APS 56; and FTU 73; and pensions 111-112; and naval expenditure 114; and education 118; and PMcK 157; resigns over war 273

Butler, (Sir) Harold Beresford 248
Butler, Samuel 29

Butt, Isaac 19

Byrne, Sir William 271

Cabinet 13, 86, 91, 142, 209

Caenarvon Castle 182

Caillard, Sir Vincent Henry Penalver 304

Calais 333

Cambridge Union 28

Campbell, Rear Admiral Sir Charles 85

Campbell-Bannerman, Rt. Hon Sir Henry MP

$61,132,137$; irritation at Radicals 53,60 ; and leadership of Liberal Party 61, 66; and Boer War 61; and RMcK 65-7, 81; and Premiership 80-81; appoints RMcK to government 82, 83-84; calls election 85 ; considers calling election 103; promotes RMcK 91-92; and Labour 113; illness 117, 127; irritation at denominational educationalists 118 119; resigns as Prime Minister 127; death 127 , n. 5 ; posthumous wish that RMcK succeed HHA as Chancellor 128

Campbeltown 208

Cameron McKenna 21

Canada 162-163

Candide, ou l'Optimisme (Voltaire) 286

Canterbury, Archbishop of see Davidson, Randall Thomas

Cardiff 227, 247

Carlyle, Thomas 29

Carter, (Sir) Maurice Bonham-(Government Chief Whip and HHA's son in law)

on RMcK 244, 314-315, 340

Carnarvon, Henry Howard Herbert, 4th Earl of 96

Carrington, 3rd Baron (Marquess of Lincolnshire) 157

Carruthers, Charles 159

Carson, Rt. Hon Sir Edward, MP (Baron Carson) 164, 257

Carver, Clifford 309

Casablanca 141

Casement, (Sir) Roger 330 
'Cat and Mouse Act' see Prisoners (Temporary Discharge for IllHealth) Bill

Cawley, Frederick 66

Cecil, Lord Robert (Viscount Cecil of Chelwood) 126, 232; attacks RMcK 237, 246

Ceylon 286, 326

Chalmers, Sir Robert (Permanent Secretary, HM Treasury) (Baron Chalmers)

84; flees from Lloyd George 286; returns for RMcK 326; ecstatic 287

Chamberlain, Arthur 63

Chamberlain, Rt. Hon. (Sir) (Joseph) Austen, MP

62, 66, 182, 193; RMcK attacks, 76-78; attacks RMcK 90, 234; and naval 'acceleration' 139; and Welsh Church 227; and war 307, 310; and Committee on the Co-Ordination of the Military and Financial Effort 321-322; and replacing Kitchener 329

Chamberlain, Rt., Hon. Joseph ('Joe') $\mathrm{MP}$

$7,14,36,40,50,56,66,73,75$, 86; RMcK attacks 62,64 , 76-78, 80; attacks RMcK 66; and Liberal Party 57; and Tariff Reform 57, 72, 74 ; on the 'weary titan' 162;

Chamberlain, Rt. Hon. (Arthur) Neville 191,327

Charing Cross Station 127

Chaucer, Geoffrey 197

Chesterton, G. K. 258-259

Cheyne, Sir (William) Watson 196

Childers, Erskine 159, 190, 270

Church of England 46, 69, 102-103, 110, 215, 225, 228; Catholic 54, 93, 110; of Wales 78; Free 110,125

Churchill, Clementine (née Hozier) 140, 197, 309

Churchill, Randolph Frederick Edward Spencer 3

Churchill, Lord Randolph Henry Spencer 52
Churchill, Rt., Hon. (Sir) Winston Leonard Spencer, MP 70, 76, 79, 82, 87, 101, 138, 182, 183, 195, 202, 309, 316; manner, 15 , reputation 8 n.2, 38 ; and FTU 73; first tensions with RMcK 84, 91-92; contrasts with RMcK, 115 , 188, 221, 244; deterioration of relations with $\mathrm{RMcK}$, 127-128, 141, 145, 151-154, 165, 167, 180, 183, 209-210; unsuccessfully presses $\mathrm{HA}$ for Admiralty ahead of RMcK, 129, 140-141; and naval expenditure 139-142, 145-150; concedes RMcK was correct over naval expenditure 161, but c.f. 242; collapse of relations with RMcK 220 , 255; essential differences with RMcK 116, 151; and education 125 ; use of press 128 , 146; and PMcK 157; opposes RMcK on war planning 212-213, 254-255; exchanges Home Office for Admiralty 216, 219; at Home Office 223, 231; hates RMcK 242, 257; and HHA 247; and Ulster 256-257; and declaration of war 259-260; rows with RMcK 273-274; rows with Fisher 274-275; on coalition 301; complains of RMcK's enthronement 317

Clapham 35, 36-45, 50, 55, 56, 74, 111,125

Clapham Parliament 40

Clare 97

Clergy Mutual Insurance Company 36

Clifford, Dr John 37, 69, 118, 123, 125

Cinematograph Exhibitors Association 250

Coal Mine Regulation Bill (1896) 54

Coal Miners (Minimum Wage) Act 233

Coal Mines Act (1911) 249

Coalition: (1910) 193, 195; (1915) 280-284, 286

Cobden, Richard, MP 133

Cockerill, George 263

Cole, Horace 191

Colonial Office 83 


\section{Index}

Colonial Preference 193, 199

Colville, Sir John Rupert 3, 5

Committee for Church Defence 126

Committee of Imperial Defence (CID)

$133,160,162,208,219,242,254$, 264; 23 August 1911 meeting 211-213

Committee on the Co-Ordination of the Military and Financial Effort $320-322$

Committee on Public Retrenchment (1915) 295

Congregationalism 41

Cork 97

Connaught, Duke of see Arthur, Prince, first duke of Connaught and Strathearn

Conscription 193, 199, 208, 249, 254, 309, 313-317

Constitutional Conference (1910) 195

Coventry 45

Coventry Ordnance 159

Cooper, (Alfred) Duff (1st Viscount Norwich) 7, 322

Coudy, Paolo 333 n. 9

Courbet, Gustave 22

Courtauld, Kaiser von 129

Cox, Harold 129; on RMcK as Chancellor 284,292

Craigmyle, Thomas Shaw, 1st Baron 79

Crawford, Lady 72, 97

Crawford, David Alexander Edward Lindsay, twenty-seventh earl of Crawford and tenth

earl of Balcarres, 10 n. 2; on RMcK 324

Crete 53

Crewe, Robert Crewe-Milnes, 1st Marquess of

7, 70, 96, 132, 162, 168, 183, 247; and war planning 220; and New Delhi 252; and declaration of war 259-260; and war 276,282

Criminal Justice Administration Act (1914)

Crook, William 79

Cunard, Lady Nancy Clara 309

Cunliffe, 1st Baron (Walter) (Governor of the Bank of England)

270; and RMcK 288, 292, 325; concerted action against $\mathrm{RMcK}$ 294, 331, 332; threatens
Cupid 127

resignation 294; RMcK subverts 295, 324; unhappy with

RMcK's policies $331,332-333$

Curle, J. H. 302

Curragh mutiny 257-258

Curzon, Rt. Hon George MP (Marquess Curzon of Kedleston) 53, 57; and war 307, 308

Custance, Admiral Sir Reginald 208

Daily Chronicle 116, 128, 146, 273

Daily Express 58, 278

Daily Graphic 43, 221, 226, 227, 231

Daily Herald 236

Daily Mail 157, 158, 300; supports RMcK 187, 216; condemns RMcK 264

Daily Mirror 156

Daily News 41, 80, 146

Daily Telegraph 134; on 'McKennaism' 127

Dalziel, James Henry, MP 60

Dante 110

Dardanelles 275, 304

Dardanelles Committee (1915) 312, 337

Darlington 233

Darwin, Charles, 29, 39

Davey, Sir Horace (Baron Davey) 45, 48

Davidson, John Colin Campbell (1st Viscount Davidson) 7, 10 n. 2,

Davidson, Randall Thomas (1st Baron Davidson) (Archbishop of Canterbury)

$110,123,130,182$

Davis, John 41

Davison, Emily Wilding 240

Davies, J. Huws on RMcK 286

Davies, Lewis 46

Dawson, Sir (Arthur) Trevor 159, 196, 204

Deakin, Alfred 162-163

Declaration of London (1909) 143, 264

Declaration of Paris (1856) 143

Defence of the Realm Act (1914) 263, 266

Dendy, Mary 249

Denison, Rear Admiral John 224

Denmark 112

Derby 50

Derby, Lord see Stanley, Edward George Villiers, 17th earl of Derby 
Derby scheme 313

Desborough, Ethel, Lady ('Ettie'), cor-

Devonport 33 respondence with HHA 318

Diamond Jubilee (1897) 54, 55

'Diary of Greville Minor', The 75

Dickens 29, 34, 251, 321

Dickinson, Violet 191

Dilke, Rt. Hon. Sir Charles Wentworth MP

$14,36,40,41,45,50,67,68,70,82$, $84,93,95,266$; and RMcK, 44, 58, 66; ensures RMcK's nomination for North Monmouthshire 46, 48; patronage 50,83 ; parliamentary tutelage of RMcK 51-2, 201; and Labour, 54, 55; and APS 56; RMcK splits from 83; and Select Committee on Taxation (1907) 88; and PMcK, $100,120,138$; and RMcK as Chancellor 128; and navalism 136; death 248

Dillon, John, MP 9 n.1, 256, 260; on RMcK 134

Disestablishment of the Welsh Church

195, 215, 225-228, 260-262 see also Welsh Church Bill

Disraeli, Rt. Hon. Benjamin, MP (Earl of Beaconsfield) 251

Docket Eddy 44, 90, 164

Domville, Admiral Sir Barry 164, 267

Donald, Robert (editor, Daily' Chronicle)

116, 128, 224; and RMcK 245, 273, 274; and second December Crisis 338,340

Donegal 96

Donnelly, Lucy 71

Dorking 196

Dornoch 228, 235, 272

Dorset 80

Dreadnought, 139-142, 161

'Dreadnought Hoax', The 190-191

Dublin 19, 96, 330

Duke of York see Albert, Prince 182

East Limerick Question 256

Echo 41, 42

Economist, The 205

Edward VII, King
$81,227,138,145,167,201$; and RMcK 181-182; death 181; RMcK blamed for by Queen mother 182

Edwards, Alfred George, Bishop of St Asaph (Archbishop of Wales)

and education 101, 126, 127, 131; and the Welsh Church 226-227, 262

Edwards, Major W. H. 202

Education Act (1870) 69, 110, 118

Education Act (1891)

Education Act (1902) 69, 78, 84, 86, $90,101,258$

Education (Special Religious Instruction) Act (1907)

Education Bill (1906) 91, 102-103, 125

Education Bill (1908) 117-120, 123-127, 130-131.

Education (Administrative Provisions)

Egypt 335 Act (1907) 107-10

Eight Hours Bill (1892) 46, 54

Eighty Club 39, 157, 158

Einzig, Paul 4

Elections

general: 1886,$45 ; 1892,41-45$; $1895,46-48 ; 1900,63-65$, 67; 1906, 84-86, 102, 183; February $1910184-190$; December 1910 198-201

by: 130, 183; North Monmouthshire (1907) 101; Peckham (1908) 126, 183;

Elgin, Victor Alexander, 9th Earl of 83, 84

Elibank, Master of (1st Baron Murray) 198, 203, 309; on RMcK 204, 254, 324; on RMcK's sacking from Admiralty 216; blamed by $\mathrm{RMcK}$ for his sacking from Admiralty 274; and a negoti-

Elion, G. 31 ated peace 328

Eliot, George 29

Ellis, Thomas Edward MP (Liberal) 46

Emerson, Zelie 238

Emmot, Alfred MP (Baron Emmot)

(Liberal) 56

Emmanuel II, King 181

Enchantress 129, 140, 156, 181, 190, 208, 214, 223 


\section{Index}

Entente

290, 295, 307, 311; doubts as to

RMcK's commitment to the war 312; demands 333

Esher, William Brett, 2nd Viscount

3, 10, 133 and n.7., 145, 151, 162, $165,168,180,242$; on RMcK 205, 209, 254; on Coalition divisions 320; and Armageddon 322,331

Eton College 25, 97

Etrêtat 22, 49, 95, 140, 193

Eugenics Review 248

Evans, (Sir) Samuel Thomas 69

Evicted Tenants' Bill (1894) 55

Excess Profits Tax (1915) 305, 323

Exchequer see Treasury, HM

Factory and Workshop Act (1895) 250

Federal Reserve Board 297, 336-338

Finlay, Robert Bannatyne (1st Viscount Finlay) 35

First World War see wars, 1914-18

Fisher, Admiral Sir John Arbuthnot (1st Baron Fisher) ('Jacky')

11, 114, 139, 184; initial misgivings as to RMcK, 114, 133; and naval strategy 136 ; relationship with RMcK 137, 196, 216; and estimates 140-142, 145-150, 151; and PMcK, 140, 206; and Beresford affair 166-167, 180, 183; RMcK's esteem for 166, 209; resigns (1909) 169; godfather to MMcK 191; and the McKennae 192; on RMcK's position 205, 207; on RMcK 206; consulted by RMcK after resignation, 209; and naval staff 210; and war planning 211, 213; and RMcK's sacking from Admiralty 218, 220, 222, 224; on PMcK 235; on working with Winston after RMcK, 242-243; returns as First Sea Lord 274; resigns again as First Sea Lord 275, 280; RMcK seeks to mollify 276 , 300; fears effect of U-boats and zeppelins 334

Fitzroy, Sir Almeric (clerk of the Privy Council)
$10,78,106,128,223$; on RMcK's position in 1915280

Fletcher, Alfred 56

Florence 206

Foreign Office 129, 204, 302

Forest of Dean 45, 50, 52

Forsyte, Cosmo: and Theo 21

Forsyte Saga, The (Galsworthy) 21

Fortnightly Review 73, 278

Fourth Party 52, 58

Foxe, John 20

France 12, 22, 53, 70, 210, 254; government 289, 295, 296; war $289,302,307$

Frederick III, Emperor 21

Free Food Union 79

Free Trade 305-307

Free Trade Union (FTU) 57, 71, 72-75, $77,79,86,113$

French Foreign Legion 141

Frewen, Moreton 74-75

Freyberg, Bernard (General) ('Ber') xvii

Freytag, August 24, 269

Friday, Man 51, 101

Froude, James Anthony 29

Fry (née Pease), Sophia (Lady Fry) 37

Fulford, Sir Roger Thomas Baldwin 10 n. 6

Gallipoli see Dardanelles

Galsworthy, John 21; and conscientious

Galway 97 objection 329

Gandhi, Mohandas Karamchand 232

Gardiner, Alfred George (editor Daily News) 80; and RMcK 301

Garvin, James Louis (editor Observer)

$73,132,151,152$; PMcK on 252; on RMcK as Chancellor 284

George V, King

167, 190, 193, 197, 224, 281; and RMcK 182-183, 250; coronation 182; and Beresford 182; and navy 203, 254; on Winston 203, 218; and war 333; and second December crisis 338,340

George VI see Albert, Prince

George, William 8 n. 2, 142 n. 7

General Headquarters (GHQ) 295

General Staff 321 
Germany

23-4, 37, 74, 89, 210, 257, 269; and education 107; navy 139-140, 158-159, 160-161, 190, 208; and war 144, 208, 215, 263, 265, 312; RMcK against smashing 330

Gibraltar 96, 181

Gladstone, Dorothy 219, 224

Gladstone, Rt. Hon. Herbert, MP (Viscount Gladstone) 7, 113, 125 , 129, 138, 219

Gladstone, Rt. Hon. William Ewart MP $19,36,41,46,90,96,132$,

Glasgow 276 226,227

Globe, The 132

Great Illusion, The 136

Goole 123

Gold Standard 321

Goschen, George Joachim, 1st Viscount Goschen 90

Graham, William 96

Grahame-White, Claude 202, 264

Grant, Duncan 191

Granville, Granville George LevesonGower, 2nd Earl Granville 40

Greece 53

Greenwood, Hamar Greenwood, 1 st Viscount Greenwood: on RMcK 105

Greece 304

Greek Interpreter, The (Conan Doyle) 60

Grenfell, Edward (1st Baron St Just) 293

Grey, Rt. Hon. Sir Edward MP (Viscount Grey of Falloden)

1, 4, 7, 8 n. 6, 50, 62, 73, 129, 168, 182, 202, 319; and RMcK $147,196,300$; and war 141, 276; and laws of war 143; and naval expenditure 145, 148, 149-150, 203; as RMcK's political lodestar 190, 192; and war planning 210; and RMcK's sacking from Admiralty 216; and suffragism 229, 231; and HHA 247; and Ulster 258; and declaration of war 259-260; and a negotiated peace 328 ; ennobled 334 ; and second December crisis 338,340

Grey Club 39

Grossmith, George 251

Guthrie, Sir James 1, 16

Gywnne, Howell Arthur (editor Morning Post) 10 n. 2, 282

Gypsies 225

Hague Tribunal 76

Haig, General Sir Douglas 331, 337

Hardy, Herbert Hardy Cozens-(1st Baron Cozens-Hardy) 35

Hardy, Thomas 96

Haldane, Elizabeth 230

Haldane, Rt. Hon. Richard Burden MP (1st Viscount Haldane of Cloan)

7, 40, 50, 61, 72, 83, 99, 162, 168, 182, 190, 196; and naval expenditure 114; and war 141, 249, 264, 269, 277; and Beresford 167; deterioration of relations with $\mathrm{RMcK}$ 180; and PMcK 138, 184; and naval staff 210,211; and war planning 212-213, 254; and RMcK's sacking from Admiralty 219; RMcK on by May 1915 220; and declaration of war 259-260; sacrificed rather than RMcK 280 , 283; on RMcK as Chancellor 291-292; and second December crisis 340

Hall, Albert 78

Hall, (Sir) William Reginald ('Blinker') 263

Halleys Comet 182

Hamilton, Lord Claude 24

Hamilton, Sir Edward Walter 84, 88; and RMcK 91

Hamilton, (Sir) Horace Perkins 287, 309

Hamilton, General Sir Ian 99, 121

Hannay, James (Canon) (George Birmingham) 27

Hankey, Lt. Col. (Sir) Maurice Pascal Alers (1st Baron Hankey)

3, 10; and naval strategy 136, 207, 210; and war planning 212; and RMcK at Admiralty 221; on RMcK 244; on RMcK and 
Hankey, Lt. Col. (Sir) Maurice Pascal Alers (1st Baron Hankey) (continued)

Fisher 275; urges RMcK not to resign 315-316; HHA's dependence on 321 ; and a negotiated peace 328

Harcourt, Sir William George Granville Venables Vernon

25, 36, 40, 50; leadership of Liberal Party 53, 60; offers RMcK promotion 60,93

Harcourt, Rt. Hon. Lewis Vernon MP (1st Viscount Harcourt) ('Loulou')

$7,50,61,70,73,83,138,206,251$; and naval expenditure 114 , $148,152,255$; and war planning 211,220, 254; and suffragism 231; and coalition 286

Hardinge, Sir Arthur Henry 57

Hardinge, Charles, 1st Baron Hardinge of Penshurst 9 n. 1, 162

Hardie, Keir 68, 113; works with RMcK 54; and APS 56; and suffragism 230

Hardy, Thomas 96

Harmsworth, Cecil, MP (RMcK's private secretary; Northcliffe's brother) $224,269,271$

Harris, Iavinia 235

Harris, (Sir) Sidney West: on RMcK 286

Harrison, Frederic 71

Harrison, May 138

Harrisson, Hilda 6 n. 1,318

Hart, Sir Basil Liddell, 8 and n. 2

Harvey, Alexander 284

Haslam, Lewis 85

Hatfield Park 320

Hawtrey, Sir Ralph George 287, 290

Heath, Sir Thomas Little (Permanent

Secretary, HM Treasury) 287, 289

Henley 33

Henley, Sylvia (née Stanley], 291, 309

Henry (RMcK's butler) 253, 302

Hepworth, Cecil Milton: films RMcK 327

Herbert, Aubrey 309

Hill, James 37

Hirst, Francis Wrigley (editor, The Economist) 136, 205, 290, 291, 301
Hoare, Samuel (Viscount Templewood) 7

Hobhouse, Rt. Hon (Sir) Charles Edward MP

$50,70,73$; on RMcK 95, 244, 279; sees RMcK as orthodox Liberal 86; claims I.loyd George wanted RMcK sacked 193; and Ulster 256; and declaration of war 259

Hobhouse, Emily 71, 232

Hobhouse, Leonard Trelawny 73, 337

Hobson, John Atkinson 136

Hogg, James MP 96

Holden, Sir Edward Tompkinson (chairman, Midland Bank)

263, 297; RMcK described as 'a brick' 306

Holland 263

Holloway Prison 240

Holmes, Charles 317

Holmes, Mycroft 60

Holmes, Sherlock 60

Home Office, 12-13, 269, 279

Home Rule

for Ireland 19, 36, 42, 43, 57, 72, 193, 225, 226; for London 42; for Wales 225; for United Kingdom 53, 257

Home Rule Bill (1912) 257

Horne, Sir Robert Stevenson (Viscount) 7

Horner, Lady Frances Jane 96, 98; and suffragism 229

Horner, Katharine (Katherine Asquith) 98

Horner, Jack 96

Horner, Sir John 98; and Sylvia Pankhurst 261

House of Commons 49, 51, 56, 60, 76, $91,114,164,184$

House of Lords

$46,55,87,91,102,143,156$; орроsition to Liberal programme $103,183,258$; constitutional crisis 184-188, 190, 192-196; reform of 193 ;

House, Edward Mandell 328

House-Grey Memorandum (1916) 328

Hozier, Clementine see Churchill, Clementine

Hudson, Sir Robert Arundell 70, 137

Hughes, Spencer 204 
Hume-Williams, Ellis 47

Hurd, Archibald (naval correspondent, Daily Telegraph)

134, 208, 221; and war planning 212; and war 269; on RMcK 286-287

Hyde Park 33, 70

Ibsen, Henrik 197

Idiots Act (1886) 237

Illustrated Sunday Herald 279

Imperial College London 107

Imperial Conference (1902) 162

Imperial Defence (Dilke) 1.36

Imperial Defence Act (1888) 54

Imperial Defence Conference (1902) 162

Imperial Defence Conference (1909) 161,162

Imperial Defence Conference (1911) 207

Imperial Press Conference (1909) 161-162

Independent Labour Party (ILP) 79, 113

India 252

India Office, RMcK mooted as Viceroy 278

Inebriates Bill (1911)

Inner Temple 31-2, 35, 40, 45, 50, 326

Inter-Parliamentary Union Conference (1903)

International Congress of Women (1915) 262

International Naval Conference

Invergordon 214 (1908-09) 143, 144

Inverness 35

Ireland, 17-19, 42, 56, 91, 93, 224, 256-259 see also Dublin and Home Rule

Iron Duke, HMS 331

Irving, (Sir) Henry 96

Is War Now Impossible? (Bloch) 136

Isaacs, Rt. Hon. Sir Rufus MP and see Reading, Lord 40, 164

Italy: naval construction 150; and war

Ivy, The 21 302,333

J. P. Morgan \& Co 290, 295

James, Gwilyan 46

Jellicoe, Admiral Sir John Rushworth (1st Earl Jellicoe)
3, 7, 8, 11, 136, 146, 183, 206, 207; and RMcK 137, 165; RMcK's esteem for 166; and RMcK's sacking from Admiralty 220221, 225; and Jutland 331

Jekylls (Family) 95-98, 138, 252; RMcK's suspicion of political naivety 236

Jekyll, Dame Agnes ('Aggie') (RMcK's mother in law)

xvii, 95, 96, 97, 98, 138, 157, 206, 251; and suffragism 229

Jekyll, Barbara ('Bar') (RMcK's sister in law)

xvii, 95, 97, 98, 138, 139, 140, 191, 206, 253, 272, 309

Jekyll, Francis ('Timmy') (RMcK's brother in law) xvii, 95, 97, 98

Jekyll, Gertrude xvii, 95, 97, 98, 252

Jekyll, Colonel Sir Herbert (RMcK's father in law) 95, 96-97, 98, 252

Jekyll, Pamela, see McKenna, Pamela

Jekyll, Walter 96

Jones, (William) Kennedy 8 n. 2

Jutland, Battle of 33

Kell, (Sir) Vernon George 267

Keppel, Alice 309

Kerry 97

Kettle, Thomas Michael 71

Keynes, John Maynard (Baron Keynes)

8 ; on RMcK 8 n. 5, 326; and RMcK 9; during war 287, 302; and the French 296; and strategy 307 ; and conscientious objection 329; and final financial crisis 336

Kilverstone Hall 192, 275

Kill That Fly! (Grossmith) 251

King's College School 25

King's Lynn 20, 21

King, Charles (Parliamentary reporter) $58,59,60,70,90,156,201$

King-Hall, Sir George (Admiral) 168, 224

Kitchener, Horatio Herbert, 1st Earl Kitchener of Khartoum

319 ; as a poster $1,264,302$; and aliens 269; at War Office 273, 276, 280; and strategy 308, 320 ; and War Committee 313; 'dodge', 337; death 329. 
Knollys, Francis, 1st Viscount Knollys (Private Secretary to Edward VII, and George V)

$151,169,180,181,184,185,254$

Knox, Edmund Arbuthnott, Bishop of Manchester: measured judgement of 127

Kreuz-Zeitung: misrepresents RMcK speech on defence 215

Krishnamurti, Jiddu 182

Labouchere, Rt. Hon. Henry, MP (Liberal)

67; leader of the radical caucus 52 , $58,66,229$; death 248

Labour Leader 248

Labour Party 45, 85, 108, 113, 186, $205,248-250,251$

I.ake Windemere 225

Lambeth Baths 30

Lancet, The 21

Land \& Water 235

Lang, (William) Cosmo Gordon, Archbishop of York (Baron Lang of Lambeth) 228

Lansbury, George 304; and RMcK 329 ; and suffragism 241; and PMcK 271

Lascelles, Alan 97

Law, Rt. Hon. Andrew Bonar, MP

8; and Welsh Church 227; RMcK tempted physically to attack 261 ; believes RMcK an unsuitable minister for wartime 268 ; demands RMcK's sacrifice 280; appointed to Government 1915 282; and coalition 287; wartime intrigues 299; and conscription 309; and War Committee 313; and a negotiated peace 328

Le Queux, William Tufnell 190, 270, 278

Lee, Arthur Hamilton (Viscount Lee of Fareham) 7, 167, 229

Lewes, George Henry 270

Le Bas, (Sir) Hedley

264, 3(2)-304; thinks coalition should resign 334; during second December Crisis 338

Lewis, (John ) Herbert, MP 226

Lewisham 24

Liberal Central Office 52
Liberal Party

$45,50,55,57,79,81,234,242$; and religion 69; and Boer War 65; and Labour 113, 119; and suffragism 231

Liberal Unionists 36, 40, 41, 50

Liberalism

$10,13,53,58,87,142$; and navalism 131-136; actuarial and haunted 315; and war 329

Life of Gladstone (Morley) 138

Lidgett, John Scott (Reverend) 130

Lisbon 181

Llanhilleth 186

Llewelyn, Leonard 85

Lloyd George, Rt. Hon. David, MP (1st Earl Lloyd-George of Dwyfor)

13, 182, 190, 195, 202, 319, 327; and RMcK 2, 13; on RMcK $244,247,255$; reputation 8 , $10,38,71$; manner 15 ; preeminence 51; friendship and co-operation with RMcK 52, 54, 56, 62, 76, 78, 79, 82, 126, 243; and Boer War 61; conflict with 66 ; RMcK promotes into government 83-84; first tensions with 84,87 ; and pensions 112; as Chancellor 89, 224, 245, 285, 287-288; contrasts with RMcK 101 , $107,225,165,181,188$, 197-198, 227, 233, 242, 300, 326 ; and naval expenditure 114, 139-142, 145-150, 160; disagreements with 115 , 231 ; deterioration of relations with RMcK, 115, 118 , 127-128, 140-141, 151-154, 165, 167, 180, 183, 209-210; successfully presses HHA for Exchequer ahead of RMcK 128; collapse of relations with RMcK, 220; and education 118, 126, 130; essential differences with RMcK 115, 132, 153-154; use of press 128 , 146; Prime Minister 340; and PMcK 157; on PMcK 317; supported by RMcK 186; seeks RMcK's sacking 193; rhetoric 197; threatened resignations 204, 313; on DMcK 
206; on Agadir 210; opposes RMcK on war planning 212213; supports RMcK on war planning 254; and the Welsh Church 226; and suffragism 229; and Marconi 242, 280; and HHA 247; HHA on 276; and Ulster 256-258; and declaration of war 259-260; wartime cooperation with $\mathrm{RMcK}$ 260-262, 264-265; resolves Welsh and Irish Home Rule with RMcK 260-262; believes $\mathrm{RMcK}$ an unsuitable minister for wartime 268, 333; rows with RMcK 273-274; praises RMcK 277; and RMcK's appointment as Chancellor 283; at Ministry of Munitions 289 ; wartime war of attrition with 294-295, 299 n. 3, 307, 312-313, 311, 316, 331; wartime intrigues 299 ; and conscription 307; complains of government by RMcK 313, 321,327 ; and a negotiated peace 328 ; RMcK accuses of bloodlust and hypocrisy 329 and n. 1, 334; replaces Kitchener 329; on American neutrality 331 ; 'knock out blow' interview 334; 'hates' RMcK 337; becomes prime minister 340

Lloyd George, Megan 189

Local Authority Default Act (1905) 110 Local Education Authority (LEA) 69, 102, 104, 108, 109, 110, 118, 237

Local Government Board 224

London, 21, 36

London City and Midland Bank see Midland Bank

Long, Walter Hume (1st Viscount Long) 7, 306; on RMcK 280-281, 327; and PMcK 317; and RMcK 326

Loos, Battle of 307

Lord Mayor of London 24

Loreburn, Robert Threshie Reid, Earl (Lord Chancellor)

157; on RMcK's sacking from Admiralty 219; on industrial disruption 233
Louise (Saki) 251

Loulou see Harcourt, Lewis

Lowther, Rt. Hon James William (1st Viscount Ullswater) (House of Commons Speaker)

$58,258,309$

Lucy, Sir Henry William (parliamentary journalist)

52, 58, 66, 151, 153, 201, 223, 246, 247,324

Lunacy Acts (1890-1911) 237

Lutyens, (Sir) Edwin Landseer ('Ned')

138, 229, 271; collaborations with Gertrude Jekyll 97; collaborations with RMcK 97, 251253; on Enchantress 201-202, 252

Lutyens, Emily 182, 252, 271; and suffragism 229

Lutyens, Robert 138

Lyttelton, Alfred 123, 138

MacDonald, Ramsay 13; and APS 56

Mackarness, Frederic, 133

Mackenzie, Ethel 21

Mackenzie, (Sir) Morell 21

Mackenzie, Muir 96, 138

Macaulay, Thomas Babington 29

Madden, Captain (Sir) Charles Edward 136

Malians, Sir Richard 24

Mallet, Charles 40

Malta 181, 250

Manchester, Bishop of see Knox, Edmund Arbuthnott

Manchester Guardian, The 75, 84-85, 116

Mann, Tom 250

March of the Workers, and Other Songs, The (PMcK) 236

Marconi 242, 280

Marder, Arthur Jacob 5, 11

Markham, Violet Rosa 271

Marlborough, Charles SpencerChurchill, 9th Duke of Marlborough 188

Marsh, (Sir) Edward Howard 219, 224

Massingham, Henry William (editor, The Nation [UK])

70, 75, 324; and RMcK 301; urges RMcK not to resign 316; and a negotiated peace 328 
Masterman, Rt. Hon Charles Frederick Gurney, MP

138; PMcK's friend and RMcK's junior 224; and Marconi 242, 280; on RMcK 244, 277; and PMcK 271; resigns from Cabinet 280; on RMcK as Chancellor 284, 292; RMcK and Wellington House 302

Masterman, Lucy 242

Masterton Smith, James 309; on RMcK 244

Matabeleland 53

May, Sir George (1st Baron May) 293

May, Sir William Henry 191

Mayo 97

Maxse, Leopold James (editor, National Review) 167, 270

McKenna, Agnes (RMcK's sister in law) 193

McKenna, Alice (RMcK's sister) 21, 24

McKenna, Lady Cecilia (RMcK's daughter in law), 4

McKenna, David (RMcK's younger son)

xi, xv, xvii, 32, 154 n 4 and n. 5, 196, 235, 253; and McKenna papers, $3-5$; birth 205 ; christening 205-206; Lloyd George on 206; and war 271-272

McKenna, Emma (RMcK's mother) xvii; marriage 20; RMcK and 22 , 72; moves to France, 22, 35, 95; death 95.

McKenna, Ernest (RMcK's brother)

Xvii, 21, 23, 31, 35, 38, 48, 49, 72, $85,140,187,190,200), 252$, 268; RMcK and 22, 46, 60, 70, 196; and Spender 75; and France, 75, 95, 99, 193; musical proclivities of 99,100 , 181 ; and war 316

McKenna, Gerald (RMcK's brother) $21,22,23,31$

McKenna, Sir Joseph Neale MP (RMcK's uncle) xvii, 18-19, 49, 52,257

McKenna, Leopold ('Poldy') (RMcK's brother) xvii, 21, 23, 24, 38

McKenna, Mary (RMcK's sister) 21, 70

McKenna, Michael (RMcK's paternal grandfather) 19
McKenna, Michael (RMcK's elder son) xvii, 192, 194, 206, 235, 253; birth 191, 205; christening 191; and war 271-272; intervenes in 1916 budget statement 324

McKenna, Pamela (RMcK's wife) xvii, 95, 156-158, 182, 193, 205-207, 235-237, 271-272, 317-320; correspondence with HHA 7, 277, 282, 283, 291, 300, 306-307, 310, 313, 331, 335; on Mells and Munstead 96; birth, 97; appearance 97, 100, 317; health 196, 206, $235,271,317,335$; personality 97,100 ; opinions of 98 ; intelligence 100, 235; and RMcK 100, 121; and suffragism 113, 229, 236, 251; diary entries 113, 139, 140, 158, 185-186, 192, 193-194, 202, 203, 251; RMcK proposes to 121; marriage 138; and Fisher, 140, 184, 209, 286; on Dilke 158; political role of 141,148 , 156-158, 160, 184, 186-188, 193-195, 206, 235-236, 309, 271, 272, 303, 315, 317-319, 326; on Beresford 140; on Fisher 140, 192; on Loreburn 157; on Winston 140, $157,188,197,317$; on Lloyd George 188, 197-198, 199; on RMcK, 199, 203; on HHA 197, 198; role in the naval crisis, 160; counsels RMcK on political career 180; miscarriage 206; differences with RMcK 235; accused of proGermanism during wartime 271; war work 272; and HHA during war 272, 318-320; and first December crisis 315; and Le Bas 302, 303; Balfour on 317; and second December crisis 338, 339

McKENNA, REGINALD

PRIVATE LIFE

Background: Ancestors, xvii, 17-19; birth 17; childhood 21-16; family life 19-22

Education: Afton House College, 23; St Malo 23; Ebersdorf 
23-4, 25; King's College School 25-6; Trinity Hall Cambridge 26-31; Inner Temple, 31-33, 35

Personal: 70-2; appearance 70, 100, 116, 121, 244, 272, 279, 300, 305, 274, 327; depression, 151 ; health 183 , 196-197, 200-201, 203, 206, 216,224 ; intellect $25 ; 121$; finances $23,25,29,31,33$, 38

Courtships: 70-1, 95-101, 120-123

And PMcK, 100, 120-123; age disparity $121,122,138,158$; correspondence with 122,123 , 129, 151, 180, 182-183, 184, 188, 189, 190, 204, 241, 244, 245 ; proposes to 121 ; marriage 138 ; love of 138 ; counselled by 180 ; confides in 181 , 209; jealousy 236; contrasts with 235, 236-237

Character: arithmetical skills $22,25,26,32,59$; awkwardness 95 ; dislike of big social events 40, 157, 180; dislike of small social events 94 , 253,309 ; dislike of any social events 272; emotionality 206, 218 ; fascination with process 32 ; humour 207,226 , 310 ; linguistic skills 24,25 ; loneliness 122,155 ; meticulousness 58; modesty 2, 3, 16, 203; religious beliefs 26-31; romanticism 237; self-confidence 196, 277; seriousness 32; self-consciousness 34,94 , 100 ; stammer 28,44 ; sarcasm 278, 293, 339

Family: 19-23; parenthood 183, 206 see also PMcK

Homes: 2 Cheyne Walk 22; Villa McKenna 22; 6 Ravensbourne Park 24; 2 Sheffield Terrace 31; 10 Clarence Terrace 40; 123 Sloane Street 70; 2 Whitehall Court 99, 129; Admiralty House 129, 134, 157, 182, 196, 223, 251; 36 Smith Square 251-253, 271-272
Recreations: architecture 252253; billiards 32; diary 26; golf 90,139 ; reading 29,94 ; rowing 30-1, 32, 33; bridge 90, 309; seafaring 129, 201; swimming 22, 140

PUBLIC LIFE

Character: 37 ; anxiety 142,155 , 322-323; blackballed 94, 183; charmlessness 121, 277, 324; considerateness 163-164; suspicious of conspiracy 193 , 199, 243, 274; accused of conspiracy 273-274; courage 202, $229,244,277,310$; desire to leave politics $155,277,330$; dislike of public meetings 74 , 79; dislike of ostentation 245 ; rhetorical qualities, $28,40,44$, $59,74,150,126,203,324$, 327; partisanship 49, 59, 207, 242, 248, 298-299; coldness 165; debating manner 59, 106 , 201, 227, 247; exhaustion 244, 295, 335; humanitarianism 250, 267-268, 270, 329330 ; lack of personal ambition 91, 93; love of Treasury 83 , 93, 101-102, 111, 282-283, 326; meticulousness 105, 153, $168,245,254$; insecurity 274 ; intelligence 277; industry 321 ; isolation 114-115, 155, 334; tenacity $148-149,169,181$, 207 ; modesty 155,244 ; misery 243,248 ; unpopularity 60 , 114-115, 228, 246-247, 277, 278, 279, 280-281

Reputation: 1-16; press opinions of: $46,60,70,74,77,90$, 93, 103, 105, 221, 226, 244, 276-277, 278; individuals opinions of: $78,91,92,93$, $101,105,148,151,155,181$, 207, 209, 228, 244-246, 277, 324-325

Ideas and attitudes: traditional liberalism 36-37, 49-50; New Liberalism, 37, 86-87, 154-155; social conscientious $36-8$; radical $52,158,248-$ 251; reformer $87,111-114$, 237-238; rights of man 
McKENNA, REGINALD (continued) PUBLIC LIFE (continued)

Ideas and attitudes: (continued) 56-57; free trade 57, 72-75, $77,107,115,143,189,305-$ 307 ; education $64,69,103$, 107; monarchy 67 ; retrenchment 86, 133; reform 87; sport 107; pensions 111-112; suffrage 113-114; taxation 88-89; fiscal orthodoxy 111 , 152-153; fiscal unorthodoxy 90, 245; naval expenditure 114; navalism 132-134; expediency, 144; female emancipation 229-230

Election campaigns: Clapham (1892) 41-44; North Monmouthshire (1895) 45-47; (1900) 63-65; (1906) 84-86; (1910) 186-190, 194-196, 198-200

Backbencher: 49-81, interventions 53; and APS 56; conduct 58-63; declines promotion 60; and Boer War 64; and Sir William Harcourt 50; and Sir Henry Campbell-Bannerman 65; attacks on Chamberlains 62, 76-78; and Free Trade Union, 72-5; and tobacco, $76-78$; and religion 227

Minister: 105-107, 201-203, 243-248, 276-279; and civil servants $91,92,94,120,130$, 136-137, 207, 224, 244, 248, 286-288, 326; and press 117 , $128,146,152,245,270$, 273-274, 301-304, 334, 338; and departmentalitis, 134135,137 ; threatened resignations 147, 148-149, 204, 216, 313; disenchantment 180 ; and court 180-183; considers retiring 207; shouted down in Commons 227

And colleagues: 114-117, 151-155, 242-243, 298-301, 324-330; and Grey 155, 196; moral compact with 315 ; and HHA 13, 14, 65, 90, 193, 196; critical of 151 , 280,$335 ; 218$; admiration of
117; relationship damaged 219; dependent on 246-247, 300,321 ; and Lloyd George 2, 13, 52, 54, 56, 62, 76, $78,79,82,115,118,126$, 127-128, 140-141, 151-154, $165,167,180,183,189,199$, 209-210, 220, 243, 260-262, 264-265; suspects of preparing to abandon Liberal Party 192-193; and Spender 73-74, 115,245 ; assessment of 242 , 280; accuses of bloodlust and hypocrisy 328-329, 334; and Winston 84, 91-92, 127-128, 141, 145, 151-154, 165, 167, 180, 183, 209-210, 220, 255, 273-274

And parties: Labour: 68, 85, 248-249; Liberal: 11; Grey Club, 39; Eighty Club 39, 40; tensions with 158; Unionist: $41,44,46,58,72,251$

Financial Secretary to the Treasury: 11, 82-4, 87-94; qualities as 84,88 ; instincts $88-89$; colleagues 114-117

President of the Board of Education: 11, 101-131; promotion to 91-94; misgivings 93; agenda, 101-103; legislation 103-104, 107-110; Special Religious Instruction Bill (1907); Education Bill (1908) 117-120, 123-127, 130-131

First Lord of the Admiralty: 132-222; circumstances of appointment, 128-129; 1909 estimates 139-142, 145-151; laws of war 142-145; and war 142, 207-213, 214; and imperial defence 161-163; and Archer Shee 164-165; and Beresford 166-169, 180; 1911 estimates 203-205; love of the service 204-205, 214; replaces Fisher with Wilson, 205, 208-209; sacked 216; resists sacking 217-218; legacy 221-222

Home Secretary: 223-284; 12; attitude on appointment 223-224; and Welsh Church 
225-228; and suffragism 228-232, 238-242; and trades union militancy, 233-237; and mental health legislation 237-238; Prisoners (Temporary Discharge for Ill-Health) Bill (1913) 240-242; social reform 248-251; war planning 254-256; and Ulster 256-259; resolves Welsh and Irish Home Rule with Lloyd George 260-262; releases remaining suffragist prisoners 261-262; wartime controls 262-265; espionage 265-271; accused of pro-Germanism 269-270, 299

First World War: 12; pre-war strategic deliberations 133 , $135,162-163$; on the declaration 259-260; criticised 262; on Dardanelles 275; on coalition 286; on peace $328-330$; and conscientious objection 329-330

Chancellor of the Exchequer: 128-129, 285-340; appointed 281-284; condition of the Treasury in 1915 285-286; problems of war finance 288-290; the dollar exchange 292-298, 310-312; wartime intrigues 299 ; and propaganda 301-304; budgets 304-307, 322-324; and bankers 306; and strategy 307-310; and conscription 309; first December crisis 312-317; and War Committee 312-313; resigns 314 ; anxiety $322-323$; and ministers 324-326; and Casement and the Easter rebellion 330; and American ambitions 330-331; on Robertson 336-337; second December crisis 334-340

After 1916: Midland Bank 15, subsequent offers of Exchequer 15; Post War Banking Policy 7

McKenna, Stephen (RMcK's nephew) xvii, 3, 4-5; and RMcK, xi-xii, 3, $6-7,59,100,115$
McKenna, Theodore ('Theo') (RMcK's brother)

xvii, 23, 35, 40, 46, 70, 85, 138, 190, 252; career 21; and Cosmo Forsyte 21; house destroyed by suffragettes 238; on RMcK as Chancellor 284

McKenna, William Columban (RMcK's father)

xvii, 31; birth 19; work 19-20, 24; marriage 20; death 35

McKenna Duties (1915) 305-307, 323

McKenna Rule (1916) 323

McLaren, Charles 229

McLaren, Francis (RMcK's brother in law) 156-157, 253, 272, 309; on Coalition 286

Mells (home of the Horners) 27, 95, 98,184

Mells Park 96

Mellands (family) 96

Mental Deficiency and Lunacy Bill (1912) 237

Mental Deficiency and Lunacy Bill (1913) 238, 248, 249

Mentone 70

Messina 163

Methodist Times 130

Mexico 331

Meynell, (Sir) Francis Meredith Wilfrid $235,251,271$

Midland Bank 2, 4, 5, 15, 263, 297, 306

Mill on the Floss, The (Eliot) 29

Military Service Act (January 1916) 313-316

Military Works Bill (1897) 57

Milner, Alfred, 1st Viscount: on RMcK 284

Mines 225, 250

Ministry of Munitions 289, 303, 324

MO5 263

Mond, Rt. Hon Sir Alfred Moritz (1st Baron Melchett): and McKenna Duties 324

Monet, Claude 22

Monmouth Burghs 85

Montagu, Rt. Hon Edwin Samuel, MP 99, 119, 158, 196, 309, 321; supportive of RMcK 203, 226, $277,287,320$; critical of RMcK 299; intrigues against RMcK 224, 243, 300, 324; 
Montagu, Rt. Hon Edwin Samuel, MP (continued) needs RMcK 243 n. 4; breakdown in relations with $\mathrm{RMcK}$ 243; on RMcK 245; and conduct of the war 267; critical of Lloyd George 287; supports Lloyd George 318, 329; opposes RMcK 332; under RMcK 287; urges RMcK not to resign 316; marriage and marginalisation 318-319, 325; and second December crisis 339-340

Monte Carlo 70

Montfort, Simon de 320

Moore, Sir Arthur 208

Morant, Sir Robert Laurie 94, 119-120, 130, 138, 227; on RMcK, 101-102, 120

Morgan, George Hay 284

Morgan Grenfell 293

Morley, John, Viscount Morley of Blackburn

40, 50, 91, 96, 128, 138; and APS 56 ; on RMcK 92, 116; and naval expenditure 145 ; and war planning 220; resigns over war 273

Morris, William 236

Moulton, John Fletcher (Baron Moulton) 35, 40, 41, 82

Muirhead, James 306

Mulliner, H. H. 159-160, 188, 312

Munitions Levy (1915) 323

Munitions of War Act (1915) 305

Munro, H. H. see Saki

Munstead 95, 98, 148, 206, 235, 252, 268,272

Munstead Wood 97

Murray, Sir George Herbert (Permanent Secretary, HM Treasury)

91, 92, 94, 142, 221, 286; RMcK mooted to replace 207

Murray, (George) Gilbert 1.34; RMcK and conscientious objectors 329

Murti, Nitya 182

Napier, Albert 71

Nation, The (UK) 75, 301

Nation, The (US) 291, 306

National Health Service 111
National Liberal Club 103, 156

National Liberal Federation 52

National Union of Teachers 105

National Relief Fund 317, 326, 335

National War Savings Committee 303

National War Organising Committee 303

Naval Discipline Act (1909) 164

Naval Expenditure Standing Committee (1915) 295

Ned see Lutyens, Edwin

New Liberalism 49, 55, 58, 225

New York Times 193; RMcK interviewed by 302; Lloyd George interviewed by 334

New Zealand 112, 162

New York 263, 311

News of the World 59, 116

Newspaper Proprietors' Association 303

Newman, (Sir) George 111, 249

Newnes, Sir Frank 197

Newport 233

Nicholas II, Tsar 181, 333

Nicoll, (Sir) William Robertson 105, 227,335

Niemeyer, (Sir) Otto Ernst 287

Nonconformists 61, 124-125

Nonconformist Parliamentary Committee 61

Norfolk 35

Norfolk, Henry Fitzalan-Howard, 15th duke of 104

North Monmouthshire, 49, 52, 86, 198, 199, 232, 235; RMcK's description 45

Northcliffe, Alfred Harmsworth, Viscount Northcliffe (Proprietor of The Times and

The Daily Mail)

138, 209, 216, 218, 269, 273, 278, 280; and RMcK 322 and n. 7; on RMcK 324; on RMcK and his brother 301 ; and second December Crisis 338, 339

Norman, Lady 253

Norman, Montagu Collett (Baron Nor-

Norfolk 192 man) 15,331

Norwich, Viscount see Cooper, Alfred Duff

Nuneham Park 251 
O'Connell, Daniel, 18-19

O'Connor, T. P. 72

Official Arbitration League 270

Official Secrets Act (1914) 263266

Olympia 266

Orme, Eliza 56

Osborne College 164, 182

Osborne judgement (1911) 186, 194-195, 234, 258

Ottley, Sir Charles Langdale (Director of Naval Intelligence) 160

Overend Gurney 20, 22

Owen, Bishop 227

Paderewski, Ignacy Jan 96

Page, Walter 300-301

Pall Mall Club 38

Pall Mall Gazette 43, 278

Pankhursts (family) 230, 139

Pankhurst, Emmeline 240, 241, 261-262

Pankhurst, Sylvia 230, 232, 261; and war finance 289

Paris 95, 141, 210, 319

Paris International Exhibition (1900) 97, 98

Parker, Sir (Horatio) Gilbert George 94

Parliament 49, 50, 57, 101, 183-186, 209

Parliament Act (1911) 205, 226, 258, 280

Parliamentary Cycle Union 71

Parliamentary Recruiting Committee 302

Parnell, Charles Stewart 19, 43

Parry, Sir Charles Hubert Hastings 236

Parsons, Alan 287, 300, 322, 340

Parsons, Viola 300, 309

Pease, Rt. Hon. Joseph Albert, MP (1st Baron Gainford) ('Jack')

138, 206; and PMcK 271; RMcK ejects 236

Pennefather, Sir John 63, 64, 85

Pennsylvania 19

Pensions, 185

Perks, Sir Robert William 61, 123, 306

Phoenix Park Murders 96

Pretious, Ivy Gladys 71

Police and Sanitary Committee (House of Commons) 61

Ponsonby, (Sir) Frederick Edward Grey, (1st Baron Sysonby) 181

Pontenewydd 64, 186
Pontypool 45, 47, 68, 79, 187, 194

Pontypool Free Press 64, 85

Portland Place 21

Portugal 181

Press Bureau 263

Premium Bonds 292

Price, Thomas Philips, MP: resigns North Monmouthshire 45

Primrose, Sir Henry William 284

Primrose League 78

Prince of Wales see George V

Prince of Wales (King Edward VIII) 182

Prisoners (Temporary Discharge for IllHealth) Bill (1913) 240-242

Privy Council 78, 101, 223

Prudential Assurance Company 293, 297

Public Bodies Corrupt Practices Act (1889) 62

Punch 51, 103, 151, 292

Purser, Sarah 96

Queen's Speech (1897) 55

Queen's Hall 226

Radclyffe-Hall, Margueritte 137 n. 1.

Raddeford, W. 113

Radical Committee 52

Rattigan, Terence 164

Raymond, E. T. (E. R. Thompson) 154

Rea, Walter 108 n. 3

Reading, Lord (Baron Reading of Erleigh) and see Isaacs, Rufus (1st Marquess of

Reading)

309; under RMcK 287-288, 315, 324-325; concerted action against RMcK 294; loan mission to US 297-300; leaves Treasury 324; supports Lloyd George 329; helps pacify Bank and City 332

Redmayne, (Sir) Richard Augustine: on RMcK 250, 286

Redmond, John Edwards MP 61, 104, 256, 257, 260; and McKennae 261

Reid, Thomas Wemyss 29

Reform Club 61, 78, 94

Reginald McKenna 1863-194.3 A Life, xi, 1, 3, 4, 6-7, 18, 20 n. 5, 26, 59,115 , 
Repington, Charles A Court 8 n. 2, 10 n. $2,330,334$, and second December crisis 338

Reynold's News 138

Ribot, Alexander (French Finance Minister)

296; on RMcK and Lloyd George 326; unhappy with RMcK 332-333

Richmond, Herbert 208

Riddell, George Allardice (Baron Riddell) (Proprietor of The News of the World)

9, 10 n. 1, 83, 116, 245, 248, 255, 301 ; on RMcK 59, 229, 274, 278; on PMcK 235, 236; on RMcK and Lloyd George 242; believes RMcK an unsuitable minister for wartime 264,268 , 270,273 ; on RMcK's appointment to the Exchequer 281; on RMcK as Chancellor 284, 301; and Le Bas 303, and n. 9

Riddle of the Sands, The (Childers) 159

Rigby, Charles 240

Rigby, Edith 240

Ripon, George Frederick Samuel Robinson, 1 st marquess of 93,104 , 108,119

Robertson, General Sir William and strategy 308, 310; and Lloyd George 308; and RMcK 308, 336-337

Rogers, James Guinness (Reverend) 41, $46,48,125$

Robespierre (Lewes) 270

Roquebrune 70

Routledge: qualities as a publisher 37

Routledge, Edmund 37

Rosebery, Archibald Philip Primrose, 5 th earl of 50, 66, 80

Ross, (Sir) Frederick William Leith$287,306,310$

Routledge: qualities as a publisher 57

Rowntree, Arnold 224, 241

Royal College of Surgeons 21, 232

Royal Commission on Poor Law and Unemployment (1905) 87

Royal Commission on Sugar Supplies (1914) 265

Royal Commission on the Private Manufacture and Trading in Arms (1936) 161
Royal Commission Appointed to Inquire into the Church and Other Religious Bodies

in Wales (1910)

Royal Flying Corps 335

Royal Navy 135, 265

Rumania 304

Runciman, Hilda 5, 212, 272, 335

Runciman, Rt. Hon. Walter, MP (1st Viscount Runciman of Doxford)

7, 22, 50, 70, 74, 79, 80, 82, 83, 138; and RMcK 75-76, 203; political sympathies with RMcK 86; correspondent 90, 257; President of the Board of Education 131, 214, 236; and PMcK 197; warns RMcK of intrigue 215; at Board of Agriculture 224; and suffragism 231; and naval expenditure 255; and Ulster 256; and declaration of war 259-260; and the conduct of war 265,272, 322; at Board of Trade 273; critical of HHA 300 ; increasing closeness to 300,332 , 334; resigns over conscription 314-315; prepares for the fall 335

Ruskin, John 29

Russell, A. E. (George William Russell) 96

Russell, Bertrand

calls RMcK a 'blackguard' 71; RMcK refutes accusation 122; blames RMcK for First World War 134; agrees with RMcK 288

Russell, Charles 70

Russia 12, 74; war 289; government 289, 296, 307

Saki 251

Salisbury, Robert Arthur Talbot Gascoyne-Cecil, $3 \mathrm{rd}$ marquess of 3641

St Asaph, Bishop of see Edwards, Alfred George

St. David's, Bishop of 78

St. James the Less 36

St. Leonards 206

St. Margaret's Church, Westminster 138 
Sambourne, (Edward) Linley 103

Samuel, Sir Herbert Lewis (1st Viscount Samuel)

7, 8 n.6, 70 138; and APS 56; and declaration of war 259-260

Sandringham 180

Sargent, John Singer 98

Sandhurst, Viscount 105; on RMcK 221

Scotland 46

Scott, Charles Prestwych (editor, Manchester Guardian)

9, 10 n. 1, 115, 219; and RMcK 245, 301; and APS 56; and FTU 75 ; and naval expenditure 205,255 ; and suffragism 239, 241; and conscription 307; and RMcK as Chancellor 311, 312 ; and a negotiated peace 328-329

Scott, Kathleen (Lady) 309, 321; correspondence with $\mathrm{HHA} 318$

Scott, Sir Leslie Frederic 298, 299

Second Morocco Crisis see Agadir

Second World War see wars, 1939-45

Seely, John Fdward Bernard (1st Baron Mottistone)

82, 138; resigns as Secretary for War 258

Selborne, William Waldegrave Palmer, 2nd Earl of 10 n. 2, 287, 307; on RMcK 324

Senghenydd colliery 250

Shaw, George Bernard 138, 239, 248

Shaw, Thomas 113

Sheffield 20

Sheffield, Mary Katharine, Lady 309

Siam 53

Simon, Sir John Allsebrook (1st Viscount Simon)

7, 8 n. 6, 70; on RMcK 274; on naval expenditure 255; and declaration of war 259-260; and war 271; resigns over conscription 314

Sinclair, John 113

Smith, Frederick Edwin (1st Earl of Birkenhead)

$106,133,188,263$; on RMcK 227, 229, 258, 326; claims Lloyd George wanted RMcK sacked 193; wartime intrigues 299

Smith Square 251-253

Smuts, J. C. 232
Snowden, Philip (Viscount Snowden)

$$
7,82
$$

Socialists 42

Somerset, Lady Kitty 197

Souls 96

South Africa 53, 56

South Wales Argus 46

South Wales Daily Press 85

South Wales Miners' Federation 85

Spectator, The 167

Spender, Harold 58, 197

Spender, John Alfred (editor Westminster Gazette)

$70,79,100,104,111-112,165$, $182,230,254$; and RMcK 73-74, 115, 116-117, 201, 245, 301; and FTU 73-74; on RMcK and Lloyd George 115-116; godfather to DMcK 206; and RMcK's sacking from Admiralty 216

Spring-Rice, Sir Cecil Arthur 263

Stamfordham, Arthur John Bigge, Baron Stamfordham (Private Secretary to George V)

230, 240, 275, 276, 281, 320; and RMcK's threatened resignation 316

Stanley, Edward George Villiers, 17th earl of Derby 313

Stanley, Percy 26

Stanley, Venetia (later, Montagu)

154,287 ; on RMcK 123, 272; correspondence with HHA 6, 158, 318; on PMcK 157; HHA's comments on her conversion to Judaism 318-319

Stead, William Thomas 136, 205, 252

Stephen, Adrian 191

Stephen, Virginia (later, Woolf) 191

Stephens, Rhys 194

Stevenson, Frances Louise (Countess Lloyd-George of Dwyfor) 8 n. 2,8 n. $8,337,338$

Stevenson, Robert Louis 96

Stock Exchange 21

Stockton on Tees 45

Stoke upon Trent 20, 21

Stokoe, Reverend Dr Thomas Henry: saves RMcK's education 2.5

Strachey, Lytton: on Agnes Jekyll 96

Strachey, John St Loe 138, 225

Strikes 225 
Stubbs Mercantile Agency 24, 35

Sudan 53

Suffragette 239, 241

Suffragettes 198, 225

Suffragism 228-232

Sunday Times, The 138

Swann, Sidney 26

Sykes, Sir John 105

Taff Vale case, 68,87

Tait, Donald 26

Talbot, Lord Edward 126

Tank, RMcK and first trial of 320

Tariff Reform 72, 107, 305-307

Tariff Reform League 73

Taxation

Land Tax, 88, 152-153; Supertax, 88; Select Committee (1907) 88; Excess Profits Tax (1915) 305,323

Tennant, John 325

Tennant, Lilian 99

Tenniel, John 103,

Tennyson, Charles 71

Territorial Army 249

Terry, (Dame) Ellen Alice 96, 157

Times, The

68, 76, 78, 89, 90, 110, 113, 126, $132,149,160,187,216$; and

Beresford affair 167, 160;

believes RMcK an unsuitable minister for wartime 268 ; and second December crisis 338, 339

Thackery, William Makepeace 29

Theatre 225

Theo see McKenna, Theodore

Thomas, Alfred 51

Thomson, (Sir) Basil Home 271, 281

Thornton, Percy 41, 42, 48

Tobacco 56, 76-78

Trades Disputes Bill (1905) 87, 102, 225

Trades Union Bill (1912) 234

Trades Union Act (1913) 234-235

Trades Union Congress 68, 111

Traill, Henry 52

Treasury, HM

$13,84,85,87-90,91$; and war 285-290; and scrutiny of War Office purchases 290

Tree, Viola 28 n. 3, 99 and see Parsons, Viola
Treveylan, Charles Philips 68

Treveylan, George Macaulay 4

Trinity College Dublin

Trinity Hall Cambridge 26-31, 40, 47

Trinity House 183

Troubridge, Commodore (Sir) Ernest Charles Thomas 136-137

Troup, Sir (Charles) Edward 224, 271

Truck Bill (1896) 54

Tuckwell, Gertrude Mary 41

Turkey 52

Tweedmouth, Edward Marjoribanks, 2nd Baron Tweedmouth

$115,132,133$, nervous breakdown as First Lord of the Admiralty 134.

U-boats 331

Uganda 53

Ulster see Ireland

United States of America

$12,91,263$; and neutrality in the event of war 143, 144; and neutrality during war 290 , 297, 330-333; mission to (1915) 297-298; financial ambitions $310-311$; presidential election 1916331

Unionist Party (Conservative party) 41, 44, 46, 58, 72, 251; Salisbury's hegemony 36 ; opposition to Liberal programme 102-103; conception of war strategy 289

Upper Cwmbran 186, 215

Victoria, Queen, death of 67

Vickers 160

Vienna 76

Villiers, Mrs Miranda (RMcK's granddaughter) xiv, 6 n. 5 ,

Vinbad see Baddeley, Vincent

Vivisection 55

'Voice of Toil', The (Morris) 236

Voltaire 286

Voluntary Aid Detachment 272

Wales 51, 53, 65, 80, 234

Walmer 272

Wandsworth 41

War: 1899-1902 61, 65, 108, 111, 259; 1914-18 12, 208, 209, 239-340; declaration of 259- 
260; peace moves $328-330$; $1939-457$

War Cabinet Contracts Committee 327

War Committee (1915-16) 313, 317;

RMcK's membership of 327-328, 337

War Council (1914-15) 312, 337

War Council (1916) 338, 339

War Office Contracts Committee 61

War Office 62, 80, 83, 114, 213, 273, 321,325 ; and purchasing 290

War Office Contracts Committee 61

War Policy Cabinet Committee (1915)

War Trade Intelligence Department 263

Warburg, Paul 336

Watson, Dr 60

Waverley, John Anderson (1st Viscount Waverley) 7

Wedgwood, Josiah Clement (1st Baron Wedgwood) 2, 152; criticises RMcK 237

Webb, Beatrice

101, 138; and RMcK 248; on RMcK $87,95,106,111,115$; and pensions 111-112; and education $118,119,130$

Webb, Sidney $111,130,138$

Wellington House 302

Wells, Herbert George 191, 270; and PMcK 236

Welsh Church Bill (1870) 225, 227

Welsh Church Bill (1912) 226

Welsh Church Commission 284

Welsh Disestablishment see Disestablishment of the Welsh Church

Westminster, Archbishop of see Bourne, Francis Alphonsus

Westminster Abbey 182, 241, 250, 251

Westminster Gazette, The $107,138,169,180$; and RMcK 73, 75; on RMcK 69-70, 105, 106,127

Weymouth 191

Wharf, The 90, 98

White Slave Traffic Bill (1912)

Whiteley, George 73

Wholesale Tobacconists' Protection Association 77

Wilberforce, Archbishop 206

Wilhelm II, Kaiser 21, 134

Williams, Joseph Powell 62

Wills, Sir William Henry (1st Baron Winterstoke) $40,45,48$
Wilson, Admiral Sir Arthur Knyvet

165, 183; and RMcK 217; replaces Fisher 205, 208; and 'puerile' war plan 213; and naval staff 219

Wilson, General Sir Arthur 213

Wilson, President Woodrow

Neutrality 297; lukewarm support of Britain 298; informed that Lloyd George and RMcK alone work in Cabinet 300-301; sends emissary 328; impartial between Britain and Germany 336

Wimborne 80

Windsor 180

Winslow Boy, The (Rattigan) 164

Winterton, Edward Turnour, 6th earl of 94

Women's Liberal Federation 229

Women's Social and Political Union (WSPU) 229, 239

Women's Suffrage Bill (1907) 113

Wood, Rt. Hon. Thomas McKinnon, MP

RMcK selects as deputy 326 ; helps pacify Bank of England and City 332

Woolf, Virginia see Stephen, Virginia

Working Men's Dwellings Bill (1896) 55

Workmen (Compensation for Accidents) Bill (1897) 55, 113

Xmas (1910) 194

Yeats, William Butler: and the Jekylls 96; and ghosts 225

Yexley, Lionel (James Woods) 164

York, Archbishop of see Lang, Cosmo Gordon

York, Duke of (George VI) 28

Zaharoff, Basil (Zacharias Basileios Zacharoff) ('Zed')

160; bigamist, embezzler, brothel tout, and arsonist 304; paid by RMcK to end the war 303

Zanzibar 57

Zeppelins 271, 310, 334

Zollverein 98

Zulus 57 
